Digitized by the Internet Archive in 2007 with funding from Microsoft Corporation 




\title{
A Study of the Cognomina of Soldiers in the Roman Legions
}$$
-\overline{B Y}
$$ \\ LINDLEY RICHARD DEAN
}

\section{A DISSERTATION}

Presented to the Faculty of Princeton Univerity in Candidacy for the Degree of Doctor of Philosophy

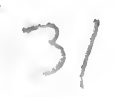

Princeton, N. J. 1916 
CS

2351

$D 43$

Accepted by the Department of Classics June, 1914

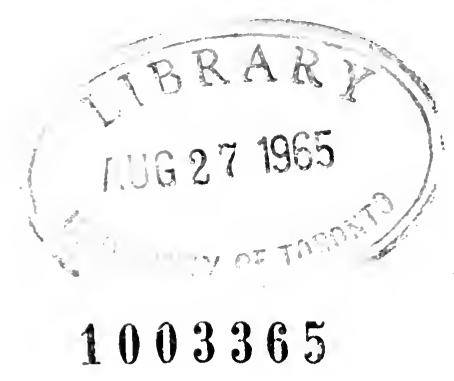

INTELLIGENCER PRINT LANCASTER, PA. 


\section{PREFACE}

I take this opportunity to express my obligation to all my teachers at Dartmouth and Princeton. Especial thanks are due to Prof. Frank Frost Abbott, whose assistance and encouragement have been generously given to me during the preparation of this dissertation. I am indebted also to Prof. Duane Reed Stuart for many helpful suggestions.

Lindley Richard Dean.

Princeton, N. J.

September, 1915. 



\section{TABLE OF CONTENTS}

INTRODUCTION .................

Chapter I-Popular Cognomina ............ 13

Chapter II-Classification of Cognomina........ 63

Chapter III-Supplementary Paragraphs........ 103

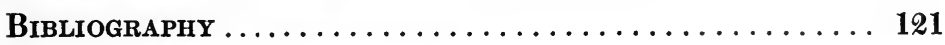

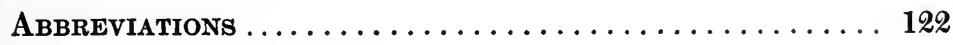

The Alphabetical List.................. 127 



\section{INTRODUCTION}

The present study of the Cognomina of Roman legionaries is an attempt to collect and to classify the cognomina of men enrolled in the legions in the time of the Empire. The cognomina of soldiers, veterans, and under-officers, up to and including primi pili, who served in the legions only are considered. These men have as a common bond Roman citizenship and may properly be brought together for a study of this kind.

Cognomina which occur with any frequency are assembled in the first chapter. A brief summary of the evidence supporting the name is given, together with the data showing its distribution among the provinces, its chronological development, and the homes of the men who bear the name.

The second chapter contains a detailed classification of all the cognomina, arranged alphabetically under several headings, e. g., according to form, endings, or derivation. The table of divisions indicated at the beginning of the chapter will explain further the classification.

The third chapter is devoted to a brief discussion of some problems which grow out of the investigation of the cognomina. Altogether about 5700 names are published in the alphabetical list which is placed at the end of this study. This list is arranged primarily to meet the needs of this investigation, but it is hoped that the material in it will prove useful to those who may wish to study the legionaries for some other reason.

The desirability of making a study of the cognomina of soldiers was suggested by a statement of Eugen Bormann (Der roemische Limes in Oesterreich, Heft IV, 1903, p. 132). In this passage an inscription found at Carnuntum and containing the names of two soldiers is under discussion. At the conclusion of the comment on the names of these men it is said, "die beiden anderen haben die gleichartigen Cognomina, Firmus und Severus, erhalten, vielleicht, da es für Soldaten passende sind, (Fest, Streng) als sie zum Soldatendienst bestimmt waren." Furthermore no exhaustive collection of cognomina in Roman 
names has as yet been made, although such a work would prove a valuable contribution to classical study. Schulze, Lat. Eigennamen p. 497, observes, "Eine mit allen Künsten und Mitteln der Epigraphik vorgehende Untersuchung, die auch für die Interessen des Grammatikers dringed erwünscht wäre," etc.

That enrollment in a legion presupposed Roman citizenship is a fact too well-known to need a repeated demonstration. And further, toward the end of the first century, when the legions began to be recruited outside of Italy, it seems beyond question that many men were becoming legionaries who had not been Roman citizens for a very long period before their enlistment. Note the formation of the legions I and II Adiutrices from the fleet in the year 68. This admission into citizenship was probably accompanied by a change of name. (Inscriptions of the II Adiutrix in England during the next two decades, 71-85, may be searched in vain for any men who appear to be non-Romans. Practically all the men named in these inscriptions indicate their tribe and father's name, usually considered definite testimony to Roman citizenship, vid. Mommsen's comment on an inscription cited below. A soldier born at Lugudunum has the Celtic cognomen Salica, Eph. Epigr. IX p. 557).

Some information, meager but precise, about the change of name which took place when a man entered the Roman army or the fleet has come down to us. Unfortunately the references in this ancient testimony do not concern legionaries, but, inasmuch as Roman citizenship was a sine qua non for service in this part of the army and since the recruiting was going on in all sections of the Empire, there is every reason for believing that the practice of name-changing here mentioned took place in the case of the soldiers of the legions as well as in that of men in other bodies of troops.

A description of the evidence upon which this conclusion depends may be properly brought in here, although it has already received considerable attention in the discussions cited below. A letter written to his father by a lad who had just joined the fleet has been found in Egypt on a papyrus of the first half of the second century. (Berliner griechische Urkunden 423, Deissmann, Licht vom Osten, 1909, pp. 120ff, Milligan, Greek Papyri, pp. 90-92, Cambridge, 1910.) The young man, Apion, from Philadelphia in Egypt, writes to his father, Epimachos, that he 
has reached his station at Misenum safely after a stormy voyage. He rejoices over three gold pieces paid to him at the outset of his new duties and adds this sentence important for our

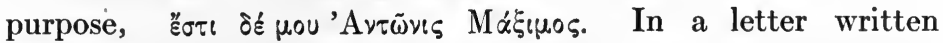
some years later to his sister Sabina this "soldier" calls himself only by his new name, Antonius Maximus. In this second communication he mentions his son Maximus and nephew Maximus. (Deissmann, op. cit. p. 125f, Lambertz, Glotta, V, 1913, p. 108.) In several other instances men who entered the fleet have recorded their native and adopted names on stones (Mommsen, Hermes, 16, 1881, p. 466, Lambertz, Glotta, IV, p. 130f). From another papyrus (Pap. Cattaoui 3) we learn of an $\alpha \sigma \tau \delta$

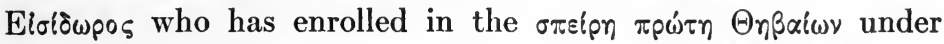
the name 'Ioú afforded by still another papyrus from the Fayoum, now in the Berlin collection (B. G. U. 888). This document is dated in the years 159-160 and reads as follows: Гáios 'Ioú $\cos ^{\prime} A \pi 0 \lambda_{l}-$

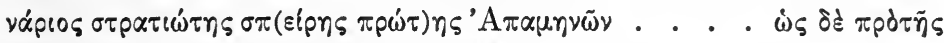

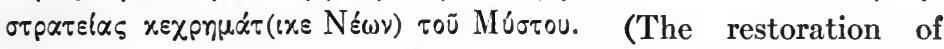
this last name is adopted from Lambertz, op. cit., V, p. 153.) The new names chosen in place of the old are in these cases Maximus, Martianus, and Apollinaris. In the instances of the men in the fleet that are referred to above, the newly acquired cognomina are Celer, Silvanus, Albanus, Paulus, Valens, and Victor. Many parallels to these names, which may be regarded as "typical," may be found among the names of the legionaries in this collection. If then we feel sure that the greater part of the names of soldiers in the legions were taken by them at the time of their enlistment, that is, about the age of twenty (vid. Cagnat, "legio," Daremberg-Saglio) the examination of these cognomina may not prove an unprofitable exercise.

It is possible, however, to derive some information concerning the names of legionaries from the inscriptions now existing. Mommsen has made a very significant observation in commenting on a list of soldiers found on a stone in Egypt. This inscription (CIL III 6627 = Eph. Epigr. V, p. 5-17) is dated by the editor as early as the reign of Augustus. In regard to the soldiers' names and particularly concerning those of men belonging to the tribe Pollia, Mommsen remarks, "Cives hos civitate Romana donatos patrem cire omnes tantum abest, ut offendat, ut adeo 
coniecturam confirmet; nam, ut bene monuit Huelsenus noster, nullus eorum patrem habet praenomine diverso, id quod praesertim in titulo eius aetatis qua praenominum usus adhuc plene vigebat, indicat patres ex bona parte ficticios esse et una cum tribu et civitate adsumptos." None of the soldiers whose names are recorded on this stone bears a cognomen. It is important for our purpose, however, to note that the name was subjected to certain changes. Later, when cognomina were in use, it is not unreasonable to suppose that this part of the name una cum tribu et civitate was assumed. The conclusion of Schulze, Lat. Eigennamen, p. 496, points in this direction: "Die Fremden, die erst durch die Einreihung in die Legion das Bürgerrecht und der roemischen Namen empfingen, haben also aus diesen Anlass ihren alten Individualnamen, wenigstens für die amtliche Sprache, ablegen müssen." The words of Lambertz, Glotta, V, p. 108, apply only to a particular part of the army, but this may not be an overstatement for the majority of the legionaries. The passage referred to reads," dass.... der Eintritt ins römische Heer für den Aegypter ein Grund war, einen seiner neuen Umgebung angepaszten Namen anzunehmen."

The same conclusion has been reached by Rudolf Herzog (Namensübersetzungen und Verwandtes, Philologus, LXI, 1897, pp. 33-70), "Wer römisches Gewand annahm, römische Bürger wurde, muszte sich dazu bequemen, den Vornamen und Namen einer bestehenden römischen gens anzunehmen, die durch äuszere Verhältnisse für ihn bestimmt wurde. Seine Nationalität konnte er nur durch eine Hinterthür, das cognomen, das keine integrierenden Bestandtheil des Namens bildete, hereinschmuggeln, wenn er wollte. Wollte er sie verleugnen, konnte er allerdings durch die drei von uns aufgestellten Namensänderungen auch sein Cognomen latinisieren."

Since new names were chosen by the legionary recruits, it is a proper question to ask what these names were. It is idle to speculate on the fitness of names or the reason for selecting this or that one until some investigation is made of the available ev dence regarding the names. The two parts of the Roman name where any large measure of variety was possible were the nomen and cognomen. The history of the nomen has been treated exhaustively by Wilhelm Schulze, Zur Geschichte lateinscher Eigennamen, and the frequency with which the nomen 
of an Emperor is employed by soldiers has already been observed by Mommsen (Hermes, 19, 1884, p. 3) “.... etwa seit Marcus, da von da an die Kaisergentilicien bei den Legionaren in auffallender Häufigkeit sich einstellen." $C f$. A. von Premerstein, Klio, III, 1903, p. 4, and Cagnat, L'Armée Romaine, 2nd. ed. p. 293, vid. Chap. III. below. The cognomen is the most variable part of the name and the present classification throws some light on its use in an important unit of society under the Empire.

Beyond the application to an individual of a nomen and cognomen a further step in the development of the name is the practice of using nicknames. At first sight it would seem natural to investigate nicknames, if one wished to ascertain whether the soldiers possessed some appellation peculiarly suited to men in the military calling. And, indeed, such a study would be entered upon with great eagerness were material abundant enough to warrant it. That there were nicknames among the soldiers one can hardly deny, but on account of their ephemeral nature they have almost entirely perished. To speak of a name of this kind reminds one at once of the famous Fabius Cunctator, but other examples are few. Names of this nature which are known in literature are collected by Kampf, Romanorum sermonis castrensis reliquiae collectae et illustratae, Jarhb. f. klass. Phil. Suppl. XXVI, pp. 340-400.

The existence of the supernomen and cases of its occurrence have been excellently discussed by Lambertz in an article referred to above. (Zur Ausbreitung des Supernomen oder Signum im roemischen Reiche, Glotta, 1913, IV, pp. 78-143, and $\mathrm{V}$, pp. 99-169) Amid the material which is collected in these two articles the names of legionaries which show double cognomina are few. In the absence of any index to the work of Lambertz and for convenient reference these cases are assembled on another page, vid. Chap. III, Double Cognomina.

We can scarcely hope then for many humorous side-lights on camp life from the nicknames which were applied by the soldiers to each other. Such names as Cicatricula, Lugudunolus, or Sterceius may actually have been bestowed in jest, but one must resist the temptation to theorize on the appropriateness of many names because of the slender supply of information which has been preserved. And, while a large number of names may have been chosen or applied with full understanding of 
what the word meant, it would be folly to maintain the literalness of Rufus or the probable fitness of Maximus in every instance. The object of this study is simply to ascertain what the facts are in regard to the use of cognomina among Roman citizens, below the equestrian rank in this particular walk of life.

The evidence which has been considered here comes to us wholly on stones and on papyri. The limits placed have been the rank of the person and the indication of some legion. Men who are not assigned to any legion but are certainly members of one have been included as far as possible. Care has been taken to make the alphabetical list of cognomina given at the end as complete as the material which has been published thus far will permit. It must be admitted, however, that omissions may be detected, and the constant appearance of new material prevents a work of this kind from being actually complete. 


\section{CHAPTER ONE}

\section{POPULAR COGNOMINA}

\section{Foreword}

Chapter One is composed of brief paragraphs which summarize the evidence concerning those cognomina found most frequently in the names of legionary soldiers. The number twenty has been adopted as a standard for admission to this list of "popular" cognomina. Such cognomina as are represented by twenty or more examples are here discussed. These are:

$\begin{array}{llll}\text { Alexander } & \text { Festus } & \text { Marcianus } & \text { Saturninus } \\ \text { Antoninus } & \text { Firmus } & \text { Martialis } & \text { Secundus } \\ \text { Bassus } & \text { Fortunatus } & \text { Maximus } & \text { Severus } \\ \text { Candidus } & \text { Fronto } & \text { Niger } & \text { Silvanus } \\ \text { Castus } & \text { Fuscus } & \text { Optatus } & \text { Tertius } \\ \text { Celer } & \text { Germanus } & \text { Primus } & \text { Urbanus } \\ \text { Clemens } & \text { Honoratus } & \text { Priscus } & \text { Valens } \\ \text { Crescens } & \text { Ianuarius } & \text { Proculus } & \text { Valentinus } \\ \text { Crispus } & \text { Ingenuus } & \text { Pudens } & \text { Valerianus } \\ \text { Datus } & \text { Iulianus } & \text { Rogatianus } & \text { Verecundus } \\ \text { Donatus } & \text { Iustus } & \text { Rogatus } & \text { Verus } \\ \text { Emeritus } & \text { Longinus } & \text { Rufinus } & \text { Victor } \\ \text { Faustus } & \text { Marcellinus } & \text { Rufus } & \text { Victorinus } \\ \text { Felix } & \text { Marcellus } & \text { Sabinus } & \text { Vitalis }\end{array}$

Attention is called particularly to the geographical distribution and chronological development of the use of the cognomina. Any cognate forms of names in the list given above are also mentioned, if these occur in the names of soldiers. In many cases the home of the soldier who has a given cognomen will be far removed from the place where the stone itself was found. The majority of such cases as these can be assigned to the first or early part of the second century. The inscriptional evidence is divided according to the provinces in which the stones were found. The general distribution of the evidence showing the use of cognomina in the legions is as follows: From the province of Africa slightly over one-third of the whole number of names 
has been taken; from provinces the inscriptions of which are published in CIL, vol. III, about one-third; and from other parts of the Roman Empire, the remainder, something less than one-third. In discussing "popular" cognomina, then, it will be necessary to bear in mind this proportional division of the inscriptions, and contrast the frequency of names from Lambaesis, which was the camp of the III Augusta in Africa for a long period, with that of the names found in the Danube provinces. The table added at the end of the chapter indicates in convenient form the distribution of the several cognomina here mentioned. Constant reference to the alphabetical list at the back will be found helpful and necessary for a full understanding of these brief statements.

The date of an inscription is always important but not always easy to determine. For the majority of the cognomina in this chapter, a number of the examples sufficient to indicate the general chronological development can be dated. A knowledge of the movements of the legions in the several provinces is very helpful in dating these inscriptions. This, however, must be used with great care, because not all the detailed movements of legionary detachments are known beyond question.

In this chapter when a name is noted as found in Pannonia or Germany the legion to which the bearer of this name belongs is not always given. To state the legion in such instances does not seem an essential factor in the study of the cognomina. This relative unimportance of the name of the legion in which a man is enrolled is due to the scantiness of the material available for present examination. Had we as many names of the members of every legion as of those who served in the III Augusta at Lambaesis, it is very probable that more cognomina which enjoyed popularity in particular legions or provinces could be discovered.

If we turn to the consideration of the nature of the cognomina which appear in this chapter our attention is drawn to the large number of them which are adjectives in origin. In anticipation of the classification of Chapter II, these popular cognomina may be grouped in the following manner: Adjectives denoting qualities suited to men in military service are Celer, Faustus, Felix, Festus, Firmus, Fortunatus, Martialis, Severus, Valens, and Victor. Adjectives with reference to physical character- 
istics are Candidus, Crispus, Fuscus, Niger, Rufus, and Vitalis. Adjectives containing a reference to mental or moral characteristics are Castus, Clemens, Iustus, Pudens, Verecundus, and Verus. Germanus and Sabinus possess some geographical or racial significance. Silvanus and Urbanus originally had a local coloring. Primus, Secundus, and Tertius are numeral adjectives. Ianuarius and Saturninus, perhaps also Martialis, are connected with names of deities and may in addition relate to birthdays. Participial adjectives are frequent in African names, vid. Chap. III, The Cognomina of African Legionaries. In this chapter one finds Crescens, Datus, Donatus, Emeritus, Honoratus, Optatus, and Rogatus. Ingenuus, Priscus, and Maximus are the remaining adjectives in this chapter. It will be noted that adjectives form almost three-fourths of the popular cognomina. The following end in -ianus: Iulianus, Marcianus, Rogatianus, and Valerianus. Those ending in -inus are Antoninus, Longinus, Marcellinus, Rufinus, Sabinus, Saturninus, Valentinus, and Victorinus. Bassus, Fronto, and Proculus are well-known Roman names. The same may be said of Marcellus, which is in form, however, a diminutive. Antoninus is connected with an Emperor's name. Alexander is the only cognomen not of Roman origin.

\section{Alexander}

This cognomen, which is the first, alphabetically, to be found with any frequency, and the only name of Greek origin in this chapter, is represented by forty-eight examples in the list given below. Alexsander and Alexandrus have been found once each. These fifty instances are distributed among the provinces of the Roman Empire as follows: Thirty-one examples have been found in the scattered territory the inscriptions of which are published in CIL III; from Lambaesis and its camp in Africa eleven examples have been collected; at Mainz four cases were found; at Rome three; and in England one. The earliest instance of the use of Alexander as a soldier's cognomen appears on a papyrus from Egypt. The soldier, whose name is Ulpius Alexander, is enrolled in the III Cyrenaica legion which was stationed in Egypt before the year 108. (For the use of the nomen Ulpius in this period, vid. Chap. III, Imperial Nomina.) Two other examples of Alexander have been found in Egypt, 
both belonging to the second century. The cognomen Alexander was in use in the Danube provinces throughout the second and early part of the third century. At Lambaesis the earliest case of Alexander is in the name of a petty officer in service in the reign of Antoninus Pius. The other dated examples at this camp belong to the first decades of the third century. At Mainz the cognomen Alexander is found in the name of a centurion, Valerius Alexander, serving in the XXII Primigenia, twice on a stone cut in the year 204 and again in the year following. The centurion of the year 205 is probably the same as one of those of the previous year. The legionaries at Rome who bear this cognomen belong to the late second or third century.

Alexandrus, due to Greek influence, is found in the name of a signifer serving in Egypt later than the year 214, who adds natione Macedon.

The nomina used with Alexander are to be noticed because they appear over and over again with the various cognomina in this collection. Some of these are Aurelius (in nine names), Claudius (two), Domitius (three), Flavius (two), Iulius (nine), Septimius (two), Valerius (five), Ulpius (three). All except Valerius are imperial nomina and may often assist in determining the approximate date of inscriptions. (Mommsen, Hermes XIX, p. 3, and Chap. III, Imperial Nomina.)

\section{Antoninus}

Antoninus has been found as a cognomen among the legionaries in twenty names. These are distributed in the following provinces: In the territory the inscriptions of which are published in CIL III ten examples have been noted. Nine instances are listed from Africa, and one is found in Italy.

The last mentioned is perhaps the first in point of time. The person who bears the name Flavius Antoninus was a primus pilus of the I Adiutrix promoted from service in the fleet, and may belong to the close of the first century. Claudius Antoninus enrolled as a soldier in the III Cyrenaica in Egypt cannot be later than the year 108. In the Danube provinces Antoninus is noted first in the year 134. Other examples range in date through nearly a century following this. One instance of the name M. Aurelius Antoninus to designate a soldier appears on a stone in Dacia. This inscription is certainly later than the 
reign of Trajan and probably is later than the principate of Marcus Aurelius. Among the number from Lambaesis a centurion bears the name M. Aurelius Antoninus. This man, like the one just mentioned, may reasonably be assigned to the latter part of the second century. The earliest example of Antoninus at the African camp belongs to a veteran (?) who was born in camp, serving during the reign of Hadrian. The other dated instances fall in the interval between the years 198 and 253.

The cognomen Antonianus is found twice in the inscriptions from Lambaesis. One instance belongs to the reign of Gallienus (253-268); the other is not dated. Antonianus is the cognomen of a centurion in England; the inscription is later than the reign of Hadrian.

Antonius is found as the cognomen of a soldier in Moesia in the year 155 .

\section{Bassus}

Forty-two examples of the cognomen Bassus have been collected. Cognomina related to Bassus are Bassinus and Bassianus, each represented by one inscription. Basus is probably a variant spelling. Bassilas seems to be connected with Bassus. The origin and meaning of the name Bassus is a problem with which the present study is not concerned.

The geographical distribution of the inscriptions containing the names of legionaries who bear the cognomen Bassus is as follows: The provinces covered by CIL III furnish sixteen; Africa yields fourteen; Italy contributes six; Germany, four; and England, two.

The earliest instances belong to the period before the reign of Claudius. These are C. Apidius Bassus, whose home is Amiternum, serving in the XIth legion as primus pilus; Q. Marcius Bassus, whose home is Beneventum, serving in the VIIth legion in Dalmatia; and L. Refidius Bassus, whose home is Venafrum, serving as centurion in the XVIth legion at Mainz. Several men with this cognomen were enrolled during the latter part of the first century. One was stationed in Germany; three have been recorded on stones and a papyrus from Egypt. Of these, one, a miles, of the year 80 indicates Damascus as his home. Two others of the years 90 and 94 were born in camp. Still 
another first century instance of Bassus is noted as the cognomen of a veteran whose home is Pisaurum, of the VII Claudia in Dalmatia.

Bassus is found as the cognomen of legionaries in the Danube region in inscriptions of the second and third centuries. Two examples belonging to the second century have been found in Egypt. The series of legionary inscriptions from Africa which contain this cognomen begins with the names of two veterans (?), whose native town is Apamea, in service during the reign of Hadrian. Other examples extend well into the third century. Hadrumetum and the camp are the birth-places of two men who bear the cognomen Bassus. All the variant forms relating to Bassus have been found in inscriptions from Africa.

\section{Candidus}

There are twenty-three examples of the cognomen Candidus in the present list. Candidinus and Candidianus are cognomina related to Candidus which appear among the names of soldiers. The geographical distribution of the inscriptions which furnish Candidus as a cognomen of men who belong to the legions is as follows: From the provinces embraced by CIL III come twelve of the number; from Africa five have been taken; from England and Germany, two each.

The earliest legionary, as far as we know, to bear this cognomen is a member of the IIII Macedonica. Consequently this man was enrolled before the reign of Vespasian. A centurion at Theveste in Numidia has been assigned to the second half of the first century. If this date is correct, we have in addition to an early use of Candidus an early employment of the nomen Aurelius. (For Aurelius, vid. Chap. III, Imperial Nomina.) All the other dated examples of the cognomen Candidus are later than the first century. Theveste is given as the home of a centurion with this cognomen at Lambaesis about the year 215. Examples of Candidinus and Candidianus are also later than the first century.

\section{Castus}

Twenty-three instances of Castus as a cognomen of legionaries have been found. The related form Castinus appears on one stone recording the name of a soldier. The examples of Castus 
are divided among the provinces as follows: From the territory covered by CIL III, four; from Africa, fifteen; from Germany, two; from England and Gallia Narbonensis, one each.

By far the earliest of this group and, in fact, one of the very early instances of the use of a cognomen among the legionaries is that found in Egypt on a stone dated by Mommsen in the reign of Augustus (CIL III 6627. A centurion mentioned on this stone has the cognomen Castus. Other cognomina from this inscription are noted later, and these are collected in Chapter III under "The Earliest Cognomina.") No other first century use of Castus has been noted. In Africa Castus appears first in a list of centurions of the year 162. Other examples extend the use of Castus into the third century. The homes of men who possess this cognomen are indicated in some inscriptions. Two were born in camp. Theveste and Cirta are also mentioned. The Danube provinces yield three examples of Castus. One can be dated in the year 195, belonging to a veteran whose home is Ratiaria in Moesia.

\section{Celer}

Celer has been found as the cognomen of thirty-eight legionaries. Cognomina related to Celer are Celerinus, Celerianus, and Celeris. Celeris, though clearly the reading of the stone, is perhaps an error on the part of the engraver. The examples of Celer as a cognomen are distributed among the provinces as follows: From the territories covered epigraphically by CIL III twenty-four have been taken; from Africa (Lambaesis), five; from England and Spain, three each; from Italy, two; and from Gallia Narbonensis, one.

The earliest use of Celer by a legionary is in the name of a man enrolled in the VI Ferrata at Beneventum probably not long after $31 \mathrm{~B}$. C. This is the only inscription of a group found at Beneventum to preserve a name with a cognomen and to add the name Ferrata to the number of the legion. Eleven names with the cognomen Celer can be dated in the first century, an unusually large proportion of the whole number of examples. Two of these have been found in Dalmatia. One belongs to a centurion whose home is Verona. Two others were preserved at Carnuntum. One soldier with this cognomen indicates Ara (Agrippinensium) as his home. Celer is the cognomen of a 
soldier and of a veteran enrolled in the II Adiutrix and found in inscriptions in England and Spain respectively. The home of the soldier is Aprum and that of the veteran is Brixia. A soldier of the IIII Macedonia with the cognomen Celer adds ex Ispania after his name. The four remaining of this first century group are the names of legionaries in Egypt toward the close of the century. One of these men was born in camp. Possibly of the first century are men named Celer from Cremona, Florentia, and Ticinum, serving in Pannonia. Pessenuntum and Clunia are indicated as the homes of men bearing this cognomen in service in Rome and Spain respectively.

Celer continues to be used as a cognomen in the Danube region throughout the second and into the third century. At Lambaesis the earliest use of Celer belongs to the reign of Hadrian. In this instance the veteran (?) who bears the cognomen indicates Nicomedia as his home. Three other examples of Celer belong to the third century. The last instance, undated, of Celer is as the cognomen of a man born in camp. Carthage is given as the home of Ravillius Celer, a veteran at Alexandria in the year 194 .

Celerinus is found as a cognomen twice during the first century. Six other examples belong to a later period. Four are certainly dated in the third century. Six instances were found in the Danube provinces; two were recovered in Germany together with Celerianus. It will be noted that during the third century the cognomen Celer occurs more frequently in Africa than in the Danube region, where Celerinus appears to have gained in popularity.

\section{Clemens}

This cognomen appears both as Clemens and Clemes. The examples of Clemens and Clemes number thirty-eight. The form Clementinus is found in three names. The distribution of the uses of Clemens is as follows: The provinces covered by CIL III furnish nineteen cases; Africa yields seven; Germany, six; England, four; and Italy, two.

The earliest instance of the use of Clemens is as the cognomen of a centurion in Egypt in the reign of Augustus. (Vid. Castus above and Chap. III, The Earliest Cognomina.) Two centurions in England toward the close of the first century have 
the cognomen Clemens. Another centurion in Belgica belongs to this same period, and two soldiers in Germany were in service about this time. One gives as his home Aequm. It is not improbable that Aulus Baebius Clemens, whose home is Faesula, a soldier at Mainz, may belong to this early period. A group of four men with the cognomen Clemens or Clemes are noted on papyri from Egypt. One belongs to the year 90, the others are earlier than the year 108.

The cognomen Clemens continued in use throughout the second century in the Danube provinces. Third century examples are lacking. Clementinus, however, appears in Pannonia in the year 228.

Five of the instances of Clemens from Africa, $i$. e. Lambaesis, are before the year 200. The other two are not certainly dated. Gabala and Napoca are the homes of two men who bear the name Clemens and a third was born in camp. C. Sulpicius Clementinus in service at this camp gives Sicca as his home. (Note: Caecilius Clemens found on two stones in England appears twice in the present list. Without doubt both names refer to the same person.)

\section{Crescens}

Like Clemens, the cognomen Crescens appears also as Cresces on several stones and these have been separated in the alphabetical list. Crescens has been found in fifty names and Cresces is represented by six examples. The related forms of Crescentinus and Crescentianus are also preserved. The distribution of the fifty-six instances of the use of Crescens and Cresces among the provinces is as follows: The territory the inscriptions from which are published in CIL III yields eleven; Africa contributes thirty-two; Germany, seven; Italy and England, three each. The four examples of Crescentianus are all from Africa. Crescentinus is recorded on three stones from Africa and on as many from the Danube provinces.

The earliest uses of Crescens as a cognomen for legionaries have been found in Germany. These are in the following names: L. Aemilius L. f. Cla(udia) Crescens Ara, belonging to a soldier about the year 62, Q. Bruttius Q. f. Sergia Crescens domo Tucci and - Pollia Crescens Fano Fortunae, belonging to men in service before the reign of Vespasian. 
Names containing this cognomen from the Danube provinces are all later than the first century. Vercellae and Carsulae are the homes of two men stationed in these provinces. A military list of the year 195 found at Viminacium contains three names with Crescens as the cognomen. Brixia and Augusta Vindelicum are the homes of two soldiers in Britain who bearthe cognomen Crescens. The instances of Crescens (Cresces) in Africa range in date from the year 162 to 275 . The following towns in Africa are given as the homes of men who possess this cognomen: Carthage, Cirta (3), Cuiculum, Hippo, Theveste, and the camp itself.

\section{Crispus}

The instances of Crispus as a legionary cognomen number twenty-four. Crispinus is represented by two inscriptions. The examples of Crispus are distributed as follows: The regions covered by CIL III furnish twelve; Africa contributes seven; Germany adds four; and England yields one. The last mentioned instance is the earliest one: viz., in the name of a veteran of the II Adiutrix when that legion was at Chester shortly after 71 A. D. An example of Crispus in a military inscription at Mainz is not wholly certain. If this be the correct restoration then the inscription belongs to the period before the principate of Vespasian, because the IIII Macedonica is the legion named therein. The home of the soldier (?) here named is Valentia. Crispus is found on a stone at Mainz as the cognomen of a soldier, whose home is Savaria, enrolled in the I Adiutrix toward the end of the first century. Crispus appears in the names of three legionaries in Egypt. Two of the men with this cognomen were in service in the year 90 and the third, born in camp, was a veteran in the year 94. The cases of Crispus in the Danube provinces extend through the second century.

Crispus in Africa is noted first as the cognomen of a veteran (?), whose home is Sidonia, in the reign of Hadrian. The latest inscription with Crispus belongs to the reign of Alexander Severus (222-235). Hadrumetum is the home of Ottacilius Crispus and C. Aelius Crispus was born in camp. Crispinus as a cognomen has been found in Africa. One instance of its use belongs perhaps to the latter part of the first century and another was found in a military list which is dated in the year 202. 


\section{Datus}

This cognomen, it may be said quite properly, is peculiar to Africa. Only two of the twenty-two examples are found outside that province. The two exceptions are M. Granius Datus, the name of a veteran of the II Adiutrix in Pannonia who indicates his African origin, domo Africa Sufetla, and M. Iulius Datus, the name of a soldier of the same legion at Carnuntum. The date of the first mentioned inscription is probably later than the middle of the second century when the II Adiutrix was in Africa for a time. The date of the second is not certain, but can not be earlier than the second century when this legion came into Pannonia.

The earliest inscription from Africa bearing this cognomen is earlier than the year 147. Thirteen others can be dated. They extend from the year 198 to the reign of Alexander Severus (222-235). Two stones record the names of men born in camp and these can not be far removed from the same period. Iulius Datus and Pompeus Datus of the year 202 have been identified with men bearing the same names of the year 218. Sextilius Datus, a cornicen of the year 203, it has been assumed, is the same Sextilius Datus who appears on a military list of the year 218. There is little to be said in one way or the other, so far as the nomina are concerned, because they are frequently found, but, inasmuch as the offices are the same in the case of each pair, this fact may be enough to make their identification probable. It has seemed wise, however, to print each name separately.

Attention may be called to the fact that no centurion with this cognomen is found in this list. Datus would seem then to be pre-eminently a soldier's name. (For the significance of this name and others peculiar to Africa vid. Chap. III, The Cognomina of African Legionaries.) It is also noticeable that Aelius is the only imperial nomen found with Datus. L. Fabius Dadatus has been regarded as a stone-cutter's error. Cognomina related to Datus are Dativus (218), Datullus (in the reign of Alexander Severus), Datianus (date uncertain); all found at Lambaesis.

\section{Donatus}

Of the sixty-eight inscriptions which contain the cognomen Donatus four were found in the Danube provinces, two in 
England, and the remaining sixty-two in Africa. The surprisingly large proportion from Africa has been noticed so far only in the case of Datus treated above. A similar state of things may be observed in connection with several names which follow. (For all the cognomina popular in Africa vid. Chap. III, The Cognomina of African Legionaries.) The evidence supporting the use of Donatus is sufficient in quantity and of a character to afford a general idea of what is meant by a "popular" cognomen. The "typical" nomina are found in use with it. By glancing through the alphabetical list the frequency of these nomina may be noted under every cognomen which is used commonly in the later period. Among the familiar nomina are Aelius, Caecilius, Flavius, Iulius, and Valerius. As might have been expected Aurelius is not found with Donatus. Septimius and Ulpius are not represented in this group.

The earliest instance of the use of Donatus as a legionary cognomen belongs to the reign of Antoninus Pius. From this time until the year 275 all the dated military lists at Lambaesis contain one or more examples of Donatus. All the lower military grades are represented, but Donatus does not seem to have been much used as the cognomen of centurions before the year 253. Nine of the men bearing this cognomen were born in camp. Bagai, Cirta, Thamugadi, Theveste, and Thysdrus are African towns from which men named Donatus came. Napoca is the home of a tubicen in the principate of Antoninus Pius. A single instance of the cognomen Donatianus is found in the camp at Lambaesis. (Note: Following the general practice no attempt is made to determine the relations between the men bearing the name Iulius Donatus, but the names have been kept separate in the alphabetical list.)

\section{EMERItus}

The instances of Emeritus as a cognomen for soldiers number twenty-three. Six of this group have been found in Pannonia, sixteen in Africa, and one example was recovered at Mainz. Of those from Pannonia none is earlier than the second century, and the earliest known date is 195, while the latest is 228. A centurion bearing this cognomen indicates Carnuntum as his home; a soldier gives Vicus Gallorum. The earliest use of this cognomen in Africa is placed in the year 162. The latest date 
for the appearance of an Emeritus is in the year 218. Two of the men who bear this cognomen were born in camp. No other homes are known. The single instance of Emeritus at Mainz is dated in the year 223. Aemeritus is the spelling of the cognomen in a military inscription at Lambaesis.

\section{Faustus}

Faustus has been found as a cognomen in thirty names. Cognomina related to Faustus are Faustianus, three examples, Faustinus, fourteen, Faustinianus and Faustiolus, one example of each. Of the thirty examples of Faustus all except four are found in the names of members of the III Augusta in Africa. The four exceptions are scattered as follows: From Mainz an inscription belonging to the last third of the first century contains the name of a soldier whose cognomen is Faustus and whose home is Polentia; from Moesia a centurion whose service was later than the reign of Hadrian bears this cognomen; P. Porcius Faustus was a primus pilus at Aquileia in the reign of Septimius Severus; a veteran in Moesia recorded in an undated inscription has the cognomen Faustus.

In Africa Faustus appears in military inscriptions from the year 162 until the close of the reign of Alexander Severus. The following homes of men possessing this cognomen are preserved, Ammaedara (2), Capsa, Carthage, Cilium, and Tipasa. Two men were born in camp.

Of the fourteen examples of the use of Faustinus as a cognomen eleven are found in Lambaesis and its camp. These extend from the year 166 to 275 . Carthage is the home of four men bearing this cognomen. Cirta is the home of one and another was born in camp. Outside of Africa the use of Faustinus as a cognomen belongs to the late second or third century. Faustianus is found twice at Lambaesis, once in Pannonia. Faustiolus appears on a stone at Lambaesis. Faustinianus is recorded in Moesia.

\section{Felix}

In Felix we have what seems to be the most popular cognomen among the soldiers of Africa. The evidence showing the use of this cognomen is so abundant that it leaves little room for doubting that it was a name liked by the Africans. Cognomina in this list related to Felix are Felicianus and Felicissimus. 
The examples of Felix used as a cognomen in the names of legionaries number two hundred and ten, and of these one hundred and eighty-one have been found in Africa. The provinces covered by CIL III afford fourteen instances, England contributes seven, Germany yields four, Italy furnishes three, and Spain is represented by one.

The earliest use of the cognomen Felix seems to be recorded on a papyrus from Egypt which gives the names of two soldiers in service in the year 90. Another instance of the use of Felix on a stone in Egypt belongs perhaps to the third century. Outside of Africa the cases of Felix as a cognomen are scattering. They extend through the second and third centuries, but so far as these occasional examples go there is little to distinguish Felix from other little used cognomina.

The moment one turns to a military list from Lambaesis or its camp, one is impressed by the very frequent use of this cognomen. A stone found at Thamugadi which records a veteran's name, Aufidius Felix, may belong to the close of the first century, before the III Augusta took its new quarters at Lambaesis. Soon after its arrival at this camp an inscription was cut in the reign of Hadrian preserving the name of a veteran (?), L. Gellius Felix, whose home was Carthage. The use of Felix extends as late as the year 275 , after which date the epigraphical evidence is generally small in quantity. A list of legionaries cut in the year 218 contains no less than twenty-three instances of the use of the cognomen Felix. The homes of men bearing this cognomen are all African towns. The camp itself was the birthplace of eleven men. Carthage is given as the home of twelve legionaries. The name of one was recovered from a stone at Rome, of another in Moesia. Thamugadi and Cirta are indicated four times each as the home of men named Felix. Ten other towns are mentioned in inscriptions which preserve the name Felix.

In Africa Felix is not often found as the cognomen of a centurion. Four such cases have been noted. Among the inscriptions containing Felix from other provinces, seven record the names of men who were centurions. (L. Antonius Felix, whose home is Carthage, is recorded on a stone found in Moesia as a centurion of the III Augusta, X Gemina, and I Italica legions. Antonius Felix, the name of a man who was also a centurion of 
the III Augusta, is found on a stone at Lambaesis. It is possible to suppose that these two inscriptions refer to the same man and this suggestion has already been made. Cagnat, however, (L'Armée Romaine 1st ed. p. 204) has printed the two names separately and his practice has been followed here.)

The same name is often found more than once in a single military list (e. g. Valerius Felix, A. E. 1902: 10, and CIL VIII 2564), but is used to designate different persons. Iulius Felix with or without a praenomen has been found as the name of twenty-five men enrolled in the III Augusta. Any attempt to prove through repetition of name that men recorded on different stones are identical is almost futile unless other strong indications are found to warrant such an hypothesis. Thus, for example, Aufidius Felix, a duplarius, in VIII 2816 may be one of the men bearing this name mentioned in VIII 2564, but there is no apparent reason for identifying him with one or the other. It is not unreasonable to suppose that he may be a different person altogether. In this case and elsewhere it has been thought preferable to print the names separately in the alphabetical list.

One soldier bears a supernomen: viz., C. Tannonius Felix qui et Aquensis. For a collection and discussion of similar cases vid. Chap. III, Double Cognomina. For what appears to be a Punic equivalent of the Latin Felix, vid. Namphamo, Chap. II, Cognomina of Punic Origin, and Chap. III, Cognomina of African Legionaries. (Note: C. Domitius Felix (VIII 3097) was assigned by Van der Weerd (Études sur trois Legions romaines du Bas-Danube, p. 100) to the V Macedonica, following the index of CIL VIII, owing to what would appear to be an incorrect reading of the stone. The letters there are MILLEGVAXLV. The first " $\mathrm{V}$ " is undoubtedly for "vixit" and not for "quintae," cf. VIII 2827, 3020, and 3141 for a similar use.) For Felicianus and Felicissimus consult the alphabetical list.

\section{Festus}

Inscriptions bearing the cognomen Festus have been found in sufficient numbers to give the name a place in this chapter. Festianus and Festivus are cognomina related to Festus. The examples of Festus are distributed among the provinces as fol- 
lows: The Danube provinces contribute three cases; Africa affords ten instances; Italy, Germany, and Spain yield two each; and one was found in Gallia Narbonensis. The last mentioned example is the first in point of time. The cognomen belongs to a man who served in the XVIth legion during the reign of Tiberius. Later instances of Festus are scattered from the close of the first to the early part of the third century. In Africa, Simitthus, Bulla, Carthage, and Madaura are indicated as homes of soldiers bearing the cognomen Festus. Calagurris is the birthplace of M. Aurelius Festus serving in Germany probably about the year 100 . Siscia is the native town of $\mathbf{L}$. Lucanius Festus, a soldier in Pannonia later than the first century.

\section{Firmus}

The examination of the cognomen Firmus was undertaken with great interest, inasmuch as it had been selected with Severus by Bormann (vid. Introduction.) as a name "zum Soldatendienst bestimmt." (Der roemische Limes in Oesterreich, Heft IV, 1903, p. 132.) The results are disappointing in that the cognomen falls far short of the popularity which some others enjoy, as far as one may judge from the number of the instances preserved. The cognomen Firmus has been found forty-three times. Cognomina related to Firmus are Firminus, Firmianus, Firmanus, Firminianus, and Firmidius. The examples of Firmus are distributed as follows: Frominscriptionsin CILIII the cognomen is taken twenty-two times; in Africa eleven instances have been found; in Germany and Italy, four each; in England and at Lyons, one each. The related cognomina follow this division: From the Danube provinces six instances are taken, Africa contributes Firmianus, Germany yields four, and Spain though not represented in the examples under Firmus furnishes instances of Firmanus and Firminus.

The earliest appearance of the cognomen is in a military list from Egypt belonging to the reign of Augustus. Here it is in the name of a centurion. A considerable number of names containing Firmus can be dated in the first century. Arelate and Verona are the homes of two soldiers during this period bearing the cognomen Firmus. In the Danube provinces this cognomen was in common use during the second century. No dated ex- 
amples in the third century have been found. In Africa the uses of Firmus extend from the year 147 to 218. Picenum and Aspendus are the homes of two men who bear this cognomen. The camp itself was the birth-place of two others. Salona is given as the native town of a primus pilus in service in the year 147. While the name was current in Lambaesis it does not seem to have been a popular one. The form Firminus appears in Spain as a soldier's cognomen probably before the year 70 . Other dated instances of its use belong to the late second century or first half of the third. Firmanus is the cognomen of a veteran whose home is Verona and whose service seems to be earlier than the reign of Hadrian. For the remaining related forms vid. alphabetical list.

\section{Fortunatus}

The cognomen Fortunatus has been listed fifty-nine times with this distribution among the provinces. The regions covered by CIL III offer four examples; Africa, forty-nine; Italy, three; England, Germany, and Lyons, one each. Fortunatianus is found twice at Lambaesis. Of the ten outside of Africa the earliest instance is that in the name of a soldier of the V Alauda before the year 87, L. Vidius Fortunatus at Tergeste. Other instances of Fortunatus are noted in the second and third centuries scattered among several provinces.

The large number found in Africa comes from Lambaesis or belong to the III Augusta, with one exception, M. Petronius Fortunatus (VIII $217 q . v$.), a centurion of two legions about the year 215. Besides this centurion there are four others with this cognomen, all outside of Africa. None of the forty-eight examples from men of the III Augusta are men of so high a rank. It is distinctly a cognomen for soldiers and petty officers. Instances of the cognomen Fortunatus are found from the first arrival of the legion at Lambaesis during ther eign of Hadrian, down to the year 275. The homes of several men who bear this cognomen are known, three being from Carthage, from Hadrumetum two, from Cirta and Lamigus one each. Four men were born in camp and one gives Lambaesis as his birth-place. The two cases of Fortunatianus are undated, but the domus is given with both, Carthage and Caralis. 


\section{Fronto}

Fronto is used as a cognomen in military circles in thirty-two names. Of these instances nineteen have been found in the provinces included in CIL III, six appear in inscriptions from Africa, three from Italy, and two each from England and Germany. Cognomina related to Fronto are Frontinus, Frontinianus, and Frontonianus.

Aquilius Fronto, a centurion in Dalmatia before the reign of Vespasian, affords us perhaps the earliest instance of the use of this cognomen. L. Gerellanus Fronto, a primus pilus of the $\mathbf{X}$ Fretensis and praefectus castrorum of the XII Fulminata in Syria in the principate of Nero, possesses rather high rank, but the name has been listed on account of the early date and the nomen in -us. Other first century cases of Fronto are preserved at Carnuntum, in Germany, and England. Instances of the cognomen Fronto appear in the Danube provinces, in Egypt and Africa, and in the East throughout the second century and during the early part of the third. Brixia, Celeia, and Sidonia are the homes of men bearing this cognomen. Two men named Fronto at Lambaesis were born in camp.

\section{Fuscus}

The cognomen Fuscus is supported by the testimony of twentytwo military inscriptions. Fuscinus and Fuscianus also appear as cognomina for legionaries. The geographical distribution of the examples of Fuscus is as follows: From Egypt four instances are taken; from other provinces covered by CIL III, three; from Africa, ten; from Germany, three; from England and Rome, one each.

The earliest use of Fuscus is in the name of a soldier, whose home is Aprum, enrolled in the II Adiutrix in England about the year 71. Other first century cases are found at Mainzin the name of a soldier whose home is Savaria-and in Egypt. In the latter province names containing Fuscus can be dated in the years 90 and 94. Another must be placed earlier than the year 108, and a fourth can not be later than the principate of Hadrian. The dated examples in Africa range from the first century (?) to the year 218. Carthage and Theveste are homes of men who bear the cognomen Fuscus. Lugus is the 
home of T. Riburinnius Fuscus, a soldier in the Spanish legion, VII Gemina. L. Fadienus Fuscus, a veteran in Dalmatia, indicates Dertona as his native town. For Fuscinus and Fuscianus vid. alphabetical list.

\section{Germanus}

The cognomen Germanus has been found twenty-nine times in names of legionary soldiers. The geographical distribution is as follows: From the provinces covered by CIL III sixteen instances have been taken; Africa contributed twelve examples; Germany, four; and Spain, one.

The earliest use of Germanus in this group belongs to the name of a soldier, whose home is Tyre, serving in Egypt in the year 81. Other instances from Egypt can be dated in the years 90, 94, and in the period before the year 108. Another of the year 194 belongs to a veteran born in camp. Three cases in Moesia are dated in the second century. Scupi and Pessenuntum are the homes of two men who bear this cognomen. Four inscriptions found in Arabia record names with the cognomen Germanus. Two of these inscriptions are dated in the latter part of the second century. The inscriptions containing Germanus which have been found on German soil are all later than the first century. The home of one legionary bearing this cognomen is Emona in Pannonia. One Germanus adds natione Dacus, another, natione Batavus.

From Lambaesis Germanus appears first in inscriptions cut during the reign of Antoninus Pius and from this time to the stormy reign of Gallienus (253-268) examples are found. One man born in camp received the cognomen Germanus. A soldier in Arabia had besides the cognomen Germanus the native name of 'Aoveĩos. For this supernomen, vid. Chap. III, Double Cognomina.

\section{Honoratus}

Thirty examples of the cognomen Honoratus are recorded in the present list. Of this number twenty-seven are found in Africa. One case has been noted from Pannonia, from Germany, and from England. None of the last three mentioned can be dated definitely. An examination of the great majority from Africa shows that all but one belong to the names of men enrolled in the III Augusta and with few exceptions are found 
in Lambaesis and its camp. Fifteen can be definitely dated and fall in the period from the year 198 to the close of the reign of Alexander Severus (222-235). None of the men in the III Augusta who bear the cognomen Honoratus are centurions. On this point one may compare the usage followed in the case of the cognomen Fortunatus. Thamugadi, Cirta, and Carthage are indicated as the homes of men named Honoratus. Honoratianus is the cognomen of two centurions in the III Augusta, M. Calpurnius Honoratianus and another whose nomen is not preserved, about the year 150 .

\section{IANUARIUS}

(Vid. Gottanka, Epigraphische Beiträge p. 39f. Augsburg, 1912.) This cognomen has been found seventy-eight times among the legionaries, with the following distribution in the provinces: From those covered by CIL III fourteen examples have been collected; from Africa, fifty-nine; from England, Germany, France, Spain, and Italy, one each. One of the earliest is in an inscription from Mainz, M'. Silius Ianuarius, a centurion of the I Adiutrix between the years 70 and 100. In the Danube provinces the cognomen is found in three military lists of the second century. On one of these cut in the year 195 the homes of two veterans named Ianuarius are known; the towns mentioned are in the province of Moesia. Another in Dalmatia belongs to the second century. Later Ianuarius is found in the reign of Alexander Severus. The example in England appears in the name M. Ulpius Ianuarius, who was born at Ulpia Traiana; legion and date are uncertain.

Of the fifty-nine from Africa, thirty-one can be dated, and practically all the dated military lists from the year 162 to 275 show one or more examples of this name. Ianuarius is another of the cognomina which are unusually popular among the soldiers of the III Augusta in their camp at Lambaesis. The homes of ten men named Ianuarius are known. These are all African towns; two persons are from Carthage; two were born in camp.

In some cases it may be that we have a name repeated, e. g., Carcopino identifies the Iulius Ianuarius of Bull. Archeol. 1904 p. 206 with one of those from VIII 2564, but such identifications are only conjectures ( id. Felix), and both names are included 
in this list. Iulius Ianuarius is such a common name that the identity of those who possess it cannot be assumed.

\section{INGENUUS}

This cognomen appears in the inscriptions in two forms: viz., Ingenuus and Ingenus. Ingenuinus and Ingenuilis are cognate forms. Eugenus would seem to be due to Greek influence. Ingenuus as a cognomen is found in twenty-two names, Ingenus in sixteen. The geographical distribution of these thirty-eight instances is as follows: The provinces the inscriptions of which are embraced in CIL III contribute sixteen; Africa supplies fourteen; Italy, three; Germany and England, two each; and Spain, one.

The earliest use of Ingenuus seems to be as the cognomen of a centurion named in the inscription from Spain just mentioned. This officer was enrolled in the Xth legion which left Spain in the year 70. Two other first century cases are noted and the cognomen continued in use throughout the second and third centuries. In Africa, Carthage, Hippo, and the camp are indicated as the birth-place of men bearing the cognomen Ingenuus or Ingenus. A soldier of the VI Victrix stationed in Africa, T. Flavius Ingenuus, adds after his name provincia Brittaniae Inferioris. Similarly Aurelius Ingenuus, a soldier of the XIII Gemina serving in Rome adds natione provincia Dacia. For M. Ingenius Ingenuinus vid. Chap. III, Similarity between Nomen and Cognomen.

\section{IULIANUS}

Before discussing Iulianus, the use of Iulius as a cognomen should be mentioned. Five examples of such use of Iulius have been collected. Four of these were found in the Danube provinces, two of the cases appearing in a list of veterans of the year 195. Sirmium and Scupi are the homes of men bearing this cognomen. Two other instances of Iulius are later than the first century. The remaining example is preserved on a stone from Africa in the name Avicius Iulius, who was a soldier in the XVIth legion.

Iulianus is listed as a cognomen fifty-one times. This number includes the cognomen Iulanus where a letter may have been omitted by the stone-cutter. Iullinus, if this reading of the 
stone is correct, seems to be related to Iulianus. The examples of Iulianus are divided among the provinces as follows: From the territory covered epigraphically by CIL III twenty-four instances have been taken; from Africa, nineteen; from Germany, four; from Italy, two; from Spain and England, one each. The earliest use is as the cognomen of a centurion at Carnuntum in the XV Apollinaris before the year 63. From Egypt we have two centurions of the III Cyrenaica named Iulianus before that legion left the province in the year 108 . T. Flavius Iulianus, a veteran of the VIII Augusta in Syria, belongs to the latter part of the first century. Examples from the Danube provinces are found for over a century following the year 134 .

In Lambaesis the earliest instances are found in the names of two veterans (?) in the reign of Hadrian. One bearing this cognomen comes from Tyre, the other from Nicomedia. Other dated inscriptions which record the name Iulianus at Lambaesis extend from the year 162 to the reign of Gallienus (253-268). The homes of nine men who bear this cognomen are known. C. Aelius Iulianus comes from Sarmizegetusa in Dacia. The two contemporary with Hadrian have already been mentioned. Two men were born in camp. Thamugadi is the birthplace of one, possibly of another legionary. Carthage and Tharsus sent men named Iulianus to the legion at Lambaesis. Hadrumetum, often mentioned as the home of soldiers of the III Augusta, is given by Iulianus, a veteran of the II Traiana in Alexandria in the year 194, as his birth-place.

A stone recently found affords another example of a supernomen, L. Decrius Iulianus qui et Numisianus, a princeps of the XI Claudia in the period from 100-150 at Naples. (Vid. Chap. III, Double Cognomina). For the many instances of the name Iulius Iulianus cf. Claudius Claudianus and for other similar names vid. Chap. III, Similarity between Nomen and Cognomen.

\section{Iustus}

Thirty examples of the use of Iustus as a cognomen have been collected. Eleven of these are found in the provinces embraced by CIL III; seven come from Africa; six from England; five from Germany; and one from Italy. The earliest instance of 
the use of Iustus is as the cognomen of a centurion in Egypt in the time of Augustus. Of the examples found in the Danube provinees, Metilius Iustus is the name of a centurion of the XV Apollinaris in Carnuntum. From this case we pass to a military list of the year $195 \mathrm{~A}$. D. before another use of Iustus in this section can be dated. At this time three veterans of the VII Claudia at Viminacium have the cognomen Iustus, L. Apuleius Iustus from Remesiana, if this restoration of the name of the town be correct, Aelius Iustus from Salonae, and another, whose nomen is lost, from Sirmium. Two examples can be dated in the first quarter of the third century. One appears in the name of M. Aurelius Iustus, whose home is Horreum Margi in Moesia Superior. Two cases from Lambaesis belong to the reign of Alexander Severus (222-235). The others are not dated. The large proportion from England is not usual. Possibly the same name is repeated in two inscriptions and in this case the number of the examples would be lessened, but there is no cogent reason for any such supposition. It might be noted that ten centurions have the cognomen Iustus, or one-third, a large proportion, of the whole number.

Iustinus is the cognomen of fourteen legionaries. All seem to be later than the first century. Eight instances appear in the Danube provinces; three of these are dated toward the end of the second century. The remaining examples are found in Italy, Germany, and England. No use of the cognomen Iustinus among African soldiers is preserved. Iustianus is represented by three cases. Two belong to the third century.

\section{LoNGINUS}

The cognomen Longinus has been found in the military inscriptions in greater numbers than Longus, which properly deserves mention first. Other related cognomina are Longinianus and Longo. For the latter vid. Chap. II, Cognomina Ending in -o. The examples of Longus as a cognomen number sixteen. The earliest uses are found in the names of two centurions serving in Egypt during the reign of Augustus. Three instances of Longus are preserved on a papyrus from Egypt of the year 90. Inscriptions in this same province which can be dated in the years 94 and 194 contain the name Longus. Paraetonium is the home of M. Furfanius Longus, a veteran in the year 194 . 
Longus is recorded as the cognomen of a centurion in Africa in the interval between the years 52 and 57. A later example in the principate of Hadrian from this province serves as the cognomen of a veteran (?) whose home is Apamea. Inscriptions from the Danube provinces containing this cognomen range through the second century. On two stones only the letters LONG are recorded and it is impossible to determine whether the cognomen was Longus or Longinus.

The cognomen Longinus has been found in thirty-four names of legionaries. Of this number twenty-seven have been taken from the provinces embraced in CIL III, three come from Africa, two each from Italy and Germany. Three examples belong to the latter half of the first century. Savaria, Philippi, and Heraclea are given as the homes of men who bear the cognomen Longinus in this period. In the Danube provinces eleven instances can be dated in the first half of the second century. A list of veterans cut about the year 134 contains Longinus six times and three of those cases preserving the letters LONG were found on this stone. Another list of the year 195 in Moesia records the cognomen Longinus in three names. The homes of the veterans bearing this cognomen are towns in that region. One third century example is preserved. In Egypt Longinus appears twice on a papyrus as the cognomen of men enrolled in the III Cyrenaica before that legion left the province in the year 108. Examples are recorded on stones also which can be dated in the second and third centuries. Longinus at Lambaesis appears once as the cognomen of a man born in camp. Neither this instance nor the other two can be dated.

Longinianus is found at Lambaesis as often as Longinus. One case is dated in the reign of Septimius Severus. This cognomen is found once in an inscription in Pannonia, and again at Aquileia, on which stone the centurion indicates his birthplace as Moesia Inferior.

\section{(Marcus) Marcellinus, Marcellus, Marcianus}

With the uses of Marcus as a cognomen there must be included Marcianus, Marculus, Marcellus, and Marcellinus. The number of examples of each cognomen are: Marcus, sixteen; Marcianus, thirty-two; Marculus, one; Marcellus, twenty-three; Marcellinus, twenty-two. The total is then ninety-three, which 
is distributed as follows among the provinces: Forty-eight from the provinces included in CIL III; nineteen from Africa; thirteen from Italy; nine from inscriptions in CII. XIII; three from England; one from Spain. CIL III affords the greater number in each single name as well as in the total.

Marcus is not found in Africa. The earliest case seems to be Iulius Marcus, the name of a soldier in Moesia Inferior in the year 155. At Alexandria in the year 194 two veterans bearing the cognomen Marcus are recorded in a military list; both were born in camp. The majority of the dated examples fall in the late second or third centuries.

Marcianus is used more than any other cognomen formed on this stem and these examples are probably all later than the first century, at least all the dated ones are. Marcianus is found in Moesia in the year 135 and in the legion VII Claudia at Viminacium, to which Aelius Marcianus of this year belongs, were enrolled in the year 195 three Marciani, coming from Scupi, Nicopolis, and Ratiaria. Nearly a century later in the year 270 Aurelius Marcianus was an officer at the same place. Others from the Danube region are dated in the early third century. T. Flavius Marcianus, a centurion in Arabia, gives Philippopolis as his home.

At Lambaesis the usage extends over a long period. Two veterans (?) during the reign of Hadrian bearing this cognomen came from Nicomedia. Others are dated in the third century. The homes of two undated legionaries are Oea and Thamugadi. The only example of a Marcianus born in camp is found in Moesia in the year 170 .

Marcellus appears earlier among the soldiers than the other cognomina in this group. M. Vibrius Marcellus, a centurion of the XVIth legion at Rome, belongs to the time of Tiberius or Gaius. Salvius Marcellus, a centurion of the XV Apollinaris at Carnuntum, is probably earlier than the year 63. Maecius Marcellus, a centurion of the XI Claudia in Italy, is dated in the year 75. A centurion Marcellus in the III Augusta at Thamugadi was in service in the latter half of the first century. Two soldiers named Marcellus came from towns outside of Africa: one in the reign of Hadrian, from Larisa, another in the reign of Antoninus Pius, from Ivenna in Noricum. (This reading for 
the name of the town is not wholly certain.) Other dated examples at Lambaesis belong to the early third century.

The homes of some men in other provinces are known: $M$. Fuficius Marcellus in Pannonia Superior comes from Aquileia; M. Seius Marcellus at Athens, from Forum Iulii; M. Valerius Marcellus, from Vercellae. None of these is dated. A very late example of Marcellus appears in the year 298 in the name of a centurion of the II Traiana in Egypt.

Marcellinus is not frequent in the first century. C. Iulius Marcellinus from Tavium was in Alexandria before the year 108. T. Aridius Marcellinus was a centurion at the same place in the year 155. And in the year 194 we find Baebius Marcellinus also at Alexandria. In Pannonia two examples are found in the early third century. At Viminacium in Moesia in the year 195 one veteran, M. Valerius Marcellinus, came from Scupi. Later than the year $\mathbf{1 7 0}$ is the name Marcellinius Marcellinus. (Vid. Chap. III, Similarity between Nomen and Cognomen.) L. Septimius Marcellinus in Germany was born in Pannonia at Ulpia Papiria Petavio and served as a centurion in three legions during the reign of Alexander Severus (222-235). Marculus is found as the cognomen of a legionary at Vienna. The nomen is lost and the date is uncertain.

\section{Martialis}

The cognomen has been found among members of the legions fifty-two times, and of this number thirty-eight were collected from African inscriptions, eight were taken from the provinces embraced by CIL III, four from Germany, one each from Rome and England.

The group of examples from Germany is worthy of note because all four are early. Iulius Martialis, a centurion of the IV Macedonica, served before the reign of Vespasian. M. Vibius Martialis, a centurion of the X Gemina, held office in the interval between the principates of Vespasian and Domitian. Aufidius Martialis, a centurion of the I Minervia, belongs to the reign of Domitian. C. Memmius Martialis, a centurion of the XI Claudia, was in service in the period from the reign of Vespasian to that of Trajan. Of the last mentioned legion a soldier of the period from the year 42 to 70 is found, L. Cassius Martialis from Aquae Statiellae, serving in Dalmatia. Ex- 
amples of Martialis in the Danube provinces belong to the second century. The home of one veteran bearing this cognomen is known and it is a town in this same region.

The earliest instance in Africa is dated in the latter half of the first century. More than half of this group of names can be dated and such examples are found throughout the second century and the first half of the third. Two men bearing the cognomen Martialis belonging to the reign of Hadrian came from Apamea and Carthage. Other places indicated as homes are Ammaedara, vicus Augusti, Cilium, Thamugadi, Thelepte, and Vaga. Two born in camp received the cognomen Martialis. Only one centurion named Martialis in Africa has been recovered. Note the early group from Germany on this point and consult also the cognomen Honoratus.

The cognomen Martis may be mentioned in this connection. One example has been found at Lambaesis.

\section{Maximus}

Besides the form Maximus, this cognomen appears as Maxsimus, Maxumus, and Maxsumus. Cognomina related to Maximus are Maximinus, Maxsiminus, Maximianus, and Maximo. (For the last mentioned see Chap. II, Cognomina Ending in -o.) The geographical distribution of the examples of Maximus (including the variant spellings) is as follows: From the provinces included in CIL III seventy have been taken; from Africa, fifty-one; from England, ten; from Germany, seven; from Italy, six; from Spain, two. (Total, one hundred and fortysix.)

It is scarcely profitable to examine each name singly; only those valuable on account of date or for other reasons can be mentioned. Perhaps the earliest use is in the name of A. Resius Maximus, a centurion of the XI Claudia in Dalmatia about the year 42. Two examples are found in Carnuntum as the cognomina of men in service possibly before the year 63. C. Attius Maxsimus, whose home is Baeterrae, was a soldier at Mainz in the period from 43-70.

The cognomen is found throughout the second and third centuries in the Danube provinces. In Moesia a military list of the year 135 contains seven examples of this cognomen and another of the year 195 has preserved eight cases of Maximus. 
The latter inscription records also the home of each veteran. For men bearing this cognomen the homes indicated are Scupi, Ratiaria, and Pautalia. In other localities legionaries with the cognomen Maximus come from Roma, Sirmium, and Mantua. A veteran serving in Alexandria gives Caesarea as his home.

In Africa Maximus is reasonably common as the cognomen of soldiers in the III Augusta legion. Military lists of the principates of Hadrian and Antoninus Pius show the name somewhat more frequently than later inscriptions, although Maximus is found as late as the second half of the third century. The soldiers enrolled when Hadrian was emperor came from Nicomedia, Tolomais, and Parethonium. The homes of men with the cognomen Maximus as recorded on later stones are Savaria, Napoca, Capsa, Hadrumetum, Tharsus, Theveste, and Thysdrus. Six men were born in camp, one in Lambaesis.

In Germany three of the seven cases of Maximus belong to legionaries enrolled in the XI Claudia in the interval between the reigns of Vespasian and Trajan. One of these men came from Forum Cornelii, another from Augustonemetum.

Maximinus and Maximianus are with one possible exception comparatively late.

Cognomina which have some connection with Maximus in meaning if not in form and consequently properly mentioned here are Maior, Magnus, Magnius, Magnianus, and Magnio. Maior has been found as a cognomen nine times. One example belongs to the first century. The other cases seem to be much later and scattered among several provinces.

The cognomen Magnus is represented by fifteen examples. One instance is extremely early: viz., C. Titius Magnus, who was a signifer of the $\mathrm{V}$ Urbana at Ateste possibly soon after 31 B. C. Two other examples belong to the first century and names of a still later date extend the series until the third century. Magnius and Magnianus are cognomina found at Lambaesis.

\section{Niger}

The cognomen Niger is supported by nineteen examples from inscriptions and papyri. Another instance is listed to make the required number, but the cognomen in question may be either Niger or Nigrinus. Besides Nigrinus, Nigrianus is also used by the soldiers. The cases of Niger are distributed as 
follows: From the provinces covered by CIL III ten examples have been taken; from Africa, three; from Italy, six; and from Germany, one.

The earliest instance of the use of Niger as a cognomen is preserved in the name of $\mathrm{M}$. Tudius Niger, a member of the $\mathrm{V}$ Urbana legion possibly soon after the year 31 B. C.; the stone was found at Ateste. A veteran in Dalmatia in the period between the year 42 and the principate of Vespasian, whose home was Forum Iulii, bears this cognomen. In Egypt the cognomen Niger appears on papyri which can be dated in the years 90 and 94 and on two stones cut before the year 108. Instances of the use of Niger are found in inscriptions from Moesia and from Africa later than the first century. Two men bearing this cognomen at Lambaesis are of African origin. In other provinces Nicopolis, Antioch, and Carcaso are indicated as the homes of men named Niger.

Nigrinus is found as the cognomen of a soldier in service before the reign of Hadrian. All the instances of its use are widely scattered. Nigrianus is preserved in one inscription at Vienna.

\section{Optatus}

Thirty-four examples of the cognomen Optatus among the legionaries have been collected. Six are found in the Danube provinces; nineteen, in Africa; five, in Germany; two, in Italy, and one each, in England and Spain.

The cognomen is noted in two early inscriptions, one in Dalmatia borne by a soldier, Q. Gavius Optatus from Brixellum, of the XIth legion, probably before the year 42, as "Claudia" is not added to the number of the legion. The other case, assigned to the early period because of the omission of the "cognomen" of the legion, belongs to C. Iulius Optatus, whose home is Lugudunum, a soldier of the XVIth legion at Mainz. Two others from Germany are earlier than the end of Vespasian's reign; T. Clodius Optatus and L. Piperacius Optatus, both born in Augusta Taurinorum. P. Aelius Optatus, a soldier of the XXth legion in Italy has been dated with a question in the reign of Tiberius, because this legion was sent to Britain under Claudius. Eporedia and Aquae Sextiae are the homes of men named Optatus who may have enrolled in the first century. 
In Africa where the cognomen Optatus is most frequently found all the men who bear it belong to the III Augusta. Ten of the names can be dated. The earliest are about the year 198 and the use continues through the reign of Alexander Severus (222-235). Optatus is the cognomen of two men born in camp. Other soldiers possessing this cognomen came from Bagai, Hippo, Milevum, and Tipasa.

\section{Primus}

The first use of Primus in the Roman name seems to have been as a praenomen, vid. CIL XIII 6885. By the middle of the first century, however, it is found in the army as a cognomen. Fifty examples have been collected. Of this number fifteen were found in the provinces embraced in CIL III; twentyseven, in Africa; six, in Germany; one each, in England and Italy.

Perhaps the earliest to bear the cognomen are two members of the XV Apollinaris at Carnuntum before the year 63, a veteran, C. Arruntius Primus from Hasta (Assta), and Ecetius Primus, a centurion. Placentia, Comum, and Utica are the homes of men named Primus during the first century. A few examples outside of Africa can be dated in the second and third centuries. Q. Iulius Primus, an imaginifer of the II Traiana after the year 214, was transferred from the III Augusta. Inasmuch as his home is Theveste this man is better joined with those named Primus from Africa. Dated cases in Africa are scattered through the military lists ranging from the year 198 to the end of the reign of Alexander Severus (222-235). Two of the soldiers were born in camp. Three give Carthage as their home. Vaga and Tubuna are also mentioned.

Several cognomina derived from this root may be noted here: Primanus, four examples, all later than the first century; Primianus, two examples; Primicianus, Primitius, Primigenius, and Primitivos are related forms from inscriptions in Africa. Primitus and Primullus are found on stones from Pannonia. Primulus appears on a stone in Germany with the nomen Primanius, vid. Chap. III, Similarity between Nomen and Cognomen. Prior is the cognomen of a soldier (?), whose home is Siscia, serving at Lambaesis. 


\section{Priscus}

Forty examples of the use of Priscus as a cognomen have been collected. Cognomina related to Priscus are Priscinus, Priscianus, and Priscillianus. The geographical distribution of the examples of Priscus is as follows: From the provinces covered by CIL III seventeen examples have been taken; from Africa, eight; from inscriptions published in CIL XIII, six; from Italy, five; from England, four. In the names from England the name Sentius Priscus appears on two stones; probably the same man is referred to in both inscriptions. Valerius Priscus and C. Valerius Priscus are recorded as centurions of the XXIId legion at Thebes, Egypt, in the year 65. These inscriptions without doubt contain the name of the same man. These names just mentioned constitute the earliest use of the cognomen Priscus. Instances of this cognomen on stones cut in the first century are noted in Dalmatia, in Egypt, in Africa, and at Mainz. One of the soldiers at Mainz who bears the cognomen Priscus names Tolosa as his home. Instances of the use of Priscus in scattered localities can be dated throughout the second century and the first half of the third. Three of the men named Priscus in African inscriptions are not natives of that province. The cases of Priscus on military lists of the years 162 and 202 probably are to be thought of as belonging to men born in Africa.

The dated examples of Priscinus and Priscianus belong to the late second century or the first half of the third. Priscillianus is the cognomen of a signifer whose home is Caesarea, stationed at Alexandria in the year 194 .

\section{Proculus}

(For this cognomen vid. Schulze, Lateinische Eigennamen, p. 460). The cognomen appears also in the form Proclus. The cognate forms, Proculinus, Proclinus, Proculeianus, Proculeanus, Proclianus, and Proclion are found among the legionary cognomina. Proculus and Proclus are represented by sixty examples and the cases of each are listed separately. Their geographical distribution is as follows: From the provinces included in CIL III twenty-two examples have been taken; from Africa, thirteen; from Germany, five; from Italy, four; from England, eight; and from Spain, one. 
First century instances of Proculus are contained in the names of C. Valerius Proculus whose home is Baeterrae, of two centurions in England, of Q. Iulius Proculus, whose home may be Damascus, of C. Cornelius Proculus, whose home is Regium, and of two with the cognomen Proclus. Several inscriptionscut in the second century preserve the cognomen Proculus or Proclus in the Danube provinces. C. Valerius Proculus indicates Calagurris as his home. At Lambaesis inscriptions with Proculus extend from the reign of Hadrian to the year 275 . Homes of men bearing this cognomen are Sidonia, Carthage, Ariminum, Adana, and Thelepte.

Worthy of mention are the following: Aurelius Proculus natione Surus domo Hemesa; P. Tarrutenius Proculus, whose home is Taurini; T. Iavennius Proculus, whose birth-place is Faventia.

All the known dates of the appearance of any cognomen related to Proculus are later than the first century. Proclion seems to be due to Greek influence. The single example appears in the name of a veteran whose home and station is Alexandria. The inscription was cut in the year 194.

\section{Pudens}

In addition to thirty-seven examples of the cognomen Pudens there are two instances of the spelling Pudes. The cognomen Pudentianus is preserved in one inscription. The distribution of the cases of Pudens and Pudes is as follows: From countries covered by CII III sixteen have been taken; from Africa, nine; from Germany and England, five each; from Italy, three; and from Spain, one.

Pudens or Pudes appear in the following names of men in service in the first century: C. Vibius Pudes, whose home is Aretium (42-70); T. Valerius Pudens, whose home is Savaria (in England about the year 71); C. Valerius Pudes, also born at Savaria (possibly of the first century); - esis Pudens (?) whose home is Augusta (also in England about the year 71); M. Blossius Pudens (serving in Rome during the reign of Vespasian), Sex. Licinius Pudens (84); L. Flavius Pudens (70-100); and Aponius Pudens (before the year 63, following Mommsen's interpretation of CIL III 14358: 21a). The cognomen is read on a papyrus of the first century from Egypt. Two inscriptions can be dated not later than the early part of the second 
century. The names on these stones are $\mathbf{Q}$. Lucilius Pudens, a soldier at Vindonissa, who was born at Bergomum, and G. Iulius Pudens, a veteran of the $\mathrm{X}$ Gemina from Emona. M. Mucius Pudens, a soldier of the XXIId legion at Mainz from Albingaunum, should perhaps be assigned to an early date an account of his Italian origin. In the Danube region Pudens continues as a cognomen through the second century and probably into the third, although none is actually dated after the year 200. In Egypt the latest date is in the year 194; Servilius Pudens, a centurion. In Africa in the principate of Antoninus Pius, a Pudens from Emona was librarius of the III Augusta. Pelagonia is the home of C. Domitius Pudens at the same camp. (It will be noted that five names found in other provinces belong to men who were born in the Danube region and thus add appreciably to the majority already given from that locality.) Other dated uses of Pudens at Lambaesis fall in the third century. One man of this name was born in camp. Pudentianus is recorded on a stone at Lambaesis.

\section{Rogatus and Rogatianus}

All except two of the forty-four examples of the cognomen Rogatus belong to men enrolled in the III Augusta legion. All except two of the instances were found in Africa. These are C. Iulius Rogatus mentioned on an inscription of the year 211 found in Pannonia, who served as a soldier in the III Augusta and later in the II Adiutrix, and C. Iulius Rogatus, a beneficiarius consularis of the XI Claudia recorded on an undated inscription found in Dalmatia.

It is reasonable to infer then that we have here a cognomen peculiarly African. (See also Chap. III, Cognomina of the African Legionaries.) The evidence in the case of Rogatianus is similarly convincing, since all of the twenty examples have been found in Africa. (A study of these two cognomina, Rogatus and Rogatianus, in the index of cognomina in CIL III and VIII, gives further testimony to their popularity in Africa.)

In point of time Rogatus appears first as a cognomen. The earliest dated instance belongs to a veteran (?) whose home is Hadrumetum, in service while Hadrian was emperor. From this time examples of Rogatus appear on inscriptions which can be dated as late as the first quarter of the third century. Be- 
sides the camp itself, Ammaedara and Carthage are mentioned as homes of men bearing this cognomen.

Rogatianus does not appear on dated inscriptions until the third century. And all of the examples which can be dated exactly belong to the first half of this century. The soldiers bearing this cognomen are probably all of African origin. The homes mentioned are the camp, Lambaesis and Thysdrus.

One inscription from Civitas Celtianensium deserves especial notice, because $\mathbf{Q}$. Oppius Rogatus who is referred to on the stone is a veteran of the I Adiutrix. Neither Juneman (De legione romana I Adiutrice) nor Cagnat (L'Armée Romaine d'Afrique 2d. ed., p. 220-1) mentions this inscription in speaking of the movements of this legion in Africa. If this inscription may be dated with the others containing the name of this legion, i. e., about the year 150, then we have an early use of the cognomen and the veteran may have come from Pannonia.

\section{Rufus and Rufinus}

Examples of Rufus to the number of ninety-six have been collected. The cognomen Rufinus is represented by thirty-one examples. The geographical distribution of the cases of Rufus is as follows: From the provinces included in CIL III forty examples have been taken; from Africa, twenty-seven; from inscriptions in CIL XIII, six; from Italy, nine; from England, eight; from Spain, five; and from Gallia Narbonensis, one.

The earliest instance of the use of the cognomen is in the name C. Aebutius Rufus, an aquilifer of the XIth legion. The inscription was found at Ateste and probably is one of a group at that place preserving the names of men sent there after the battle of Actium. Another example is in the name Vettius Rufus borne by a centurion in Egypt during the principate of Augustus. Rufus is found as a cognomen in military inscriptions of the first century no less than fifteen times. Men bearing this cognomen indicate as their homes Aprum, Aequum, Ara Agrippinensium, and Ravenna. Throughout the second century dated examples may be noted from the Danube provinces and Egypt. The homes of legionaries named Rufus in this period are Amasia, Vicetia, Heraclea, Concordia, Beneventum (?), and Cremona. In $A$ frica the series of instances extends through the second century and into the third. Men bearing this cognomen were 
enrolled from Antioch, Nicomedia, Anthedo, Iguvium, Lambaesis, and its camp, Hadrumetum, and Prusias.

The examples of Rufinus do not follow the same lines of distribution among the provinces as have been noted in the case of Rufus. It may be observed that usually related cognomina flourish in the general region where the form from which they came is common. Of the thirty-one cases collected three were found in the Danube provinces; twenty-one, in Africa; two each in Italy, Germany, and England; and one in Spain.

The earliest appearance is in the name of a signifer in England from Vienna toward the end of the first century. In Africa the use of Rufinus extends on dated inscriptions from the year 162 to the reign of Alexander Severus (222-235). Men bearing this cognomen joined the legion from Carthage, Thelepte, and the camp itself. Outside of Africa, Virunum and Aequum are the homes of men serving in Mainz and Ravenna. In Spain Q. Cumelius Rufinus set up a tombstone to his father whose home was Brixellum.

\section{SABINUS}

The cognomen Sabinus has been found in forty-two legionary names. The cognate form Sabinianus is represented in eight names. Sabius as a cognomen is possibly the error of the engraver for Sabinus. The distribution of the cases of Sabinus is as follows: Twenty-three are from provinces covered epigraphically by CIL III; ten come from Africa; five are taken from Italy; three are found in inscriptions in CIL XIII; and one, in England.

The first instances of Sabinus in point of time are not earlier than the middle of the first century. Later examples extend the use of the cognomen throughout the second century and into the third. The following cases deserve mention: L. Rutius Sabinus has recorded after his name on the stone the words $e x$ Hispania. Since this man is a soldier of the X Gemina he may have been enrolled when this legion was stationed in Spain before the year 70. L. Petronius Sabinus, who served in three legions during the reign of Antoninus Pius, gives Forum Brentanum as his home. Cornelius Sabinus, whose home was Nicomedia, saw service at Lambaesis in the reign of Hadrian. M. Antonius Sabinus was a centurion in the $\mathrm{X}$ Fretensis before being trans- 
ferred to the III Augusta. His home is Caesarea Augusta in Palestine. Q. Fabius Sabinus at the camp in Lambaesis indicates Carthage as his birth-place. C. Iulius Sabinus enrolled from Ratiaria in the VII Claudia and is recorded as a veteran in the year 195. Valerius Sabinus was born at Narbo.

Sabinianus is used as a cognomen in the later period. All the known dates are in the third century. At Lambaesis one soldier bearing this cognomen was born in camp. Another legionary at the same place came from Carthage. (For Salonius Sabinianus signo Scammatius vid. Chap. III, Double Cognomina.) Sabius appears as the cognomen in the name Aurelius Sabius nat Surus on a stone in Egypt.

\section{SATURNINUS}

Saturninus is second in popularity to Felix as a cognomen among the soldiers of the legions. The examples collected number one hundred and eighty-three. Cognate forms which appear are Saturnanus, Saturnilus, Saturnalis, Saturnus, Saturus, and Saturio. The geographical distribution of the evidence showing the use of Saturninus is as follows: From the provinces covered by CIL III, twenty-four cases; from Africa, onehundred thirty-nine; from Italy, ten; from Germany, six; from England, three; and from Spain, one.

The earliest examples are contained in the names of two signiferi in the year 65 at Alexandria. Their home is Ancyra. Two other instances belonging to the first century occur in Dalmatia and two in Egypt. A stone in Italy of the first century contains the name M. Valerius Saturninus, borne by a soldier of the IX Hispana whose home is Forum Iulii. A veteran of the XIIIth legion, M. Furius Saturninus, may have served in the first century. Dated cases of Saturninus in the Danube provinces for the second century are few in number. Scupi and Sarmizegetusa are the homes of two veterans bearing this cognomen, recorded in a military list in the year 195 .

In Africa the earliest examples of Saturninus have been found at Theveste, the camp of the III Augusta in the latter half of the first century. Examples at Lambaesis range from the time of the arrival of the legion at that camp during the principate of Hadrian until the latter part of the third century. On one military list in the year 218 , eighteen men bear the cognomen 
Saturninus. The homes of the men named Saturninus in Africa are for the most part places in that province. Eleven towns in Africa are given by several men as their birth-place. Heliopolis and Siscia are the homes outside of Africa which are named. Some examples of Saturninus in the third century have been found outside of Africa, but these are few in number.

Of the cognate forms, Saturnanus in Italy is later than the year 170. Saturnilus is found on two papyri in Egypt belonging to the first half of the second century. Saturnalis and Saturio are found on two stones in Germany. Saturnus is the cognomen of a legionary in Pannonia whose home is Cetium. Saturus is perhaps used for Saturnus. (Concerning the omission of " $n$ " after " $r$ " vid. Hoffman, De Titulis Africae Latinis, p. 32, who does not mention this case.) It is possible to derive the cognomen from the Greek Satyrus where " $y$ " becomes " $u$ " (for this phenomenon in Africa vid. Hoffmann, op. cit. p. 70.) As a soldier's cognomen Saturus is found at Lambaesis on seven stones; 166 and 200 are the only dates known. (Note: In the matter of repetition of names with the cognomen Saturninus the same practice has been followed as in other names in this chapter. For examples consult Felix.)

\section{Secundus}

Like Primus, Secundus seems to have been used first as a praenomen in the names of ordinary citizens. (Vid. CIL XIII 6899). It is found as a cognomen as early as the middle decades of the first century and was in general use among the legionaries into the third century. It is found evenly distributed among the provinces and the proportion of examples agrees, roughly speaking, with the whole number of names from the different regions of the Roman empire. One hundred and ten examples have been gathered; of these thirty-four come from the provinces embraced in CIL III, thirty-nine, from Africa, sixteen, from Germany; eleven, from Italy (including Gallia Narbonensis); six, from England; and three, from Spain.

The earliest group consists of seven members of the XV Apollinaris in Pannonia, perhaps all earlier than the year 63. Of these one was born in camp. Another came from Savaria. In Dalmatia where the XI Claudia was stationed between the year 42 and Vespasian's reign one finds two soldiers, one whose 
home was probably Iuvavum. A veteran of the VII Claudia in the same province in this period was C. Curatius Secundus from Augusta Troas. The group from Germany comprises almost wholly first century names. To the years from 70-100 belong C. Dannius Secundus from Vienna, T. Iulius Secundus from Firmum, and M. Gellius Secundus from Ara. The following soldiers were in service before the reign of Trajan: $\mathbf{Q}$. Petilius Secundus from Milan and L. Cattonius Secundus from Virunum were soldiers stationed at Mainz. M. Apronius Secundus (Vid. CIL XIII 5201 for interpretation of inscription)from Lucus Augusti, Q. Bisius Secundus from Brixia, and two others whose homes are not known were enrolled in this period. Other undated examples of this cognomen occur in the case of men from Brixia and Dertona and may well belong to the early period.

In Africa the earliest instance of Secundus is in the name of a man born at Theveste and serving at Lambaesis in the reign of Hadrian. About half of the African examples are dated and it can be seen that the cognomen was in use throughout the period which is covered by the military inscriptions from Lambaesis. The homes known are Carthage (3), Thysdrus (2), Cirta, Opitergium, Hadrumetum, and Uthinia. Three men were born in camp.

Secundus is found in the Danube region also in the second century and probably in the third where dated inscriptions are few. Emona and Falerio are the homes of two men bearing this cognomen. In England the only dated example is in the name of Iulius Secundus, a centurion about the year 71. Pollentia and Cremona are the homes of two legionaries in this province. One name from Spain is dated in the year 155 . Another name is borne by a man from Albentibilis in Italy, the province from which most of the soldiers in the early period came.

Secundinus and Secundianus are cognomina in this list related to Secundus. The examples of these cognomina are later than the first century. The Danube provinces furnish a majority of the instances. For Aurelius Secundianus qui et Itrius vid. Chap. III, Double Cognomina. The cognomen '2eanus' is the reading of Wessely of a papyrus from Egypt written before the year 108. In a more recent publication of this papyrus (Studien zur Palaeographie und Papyruskunde XIV p. 3, Leipzig, 1914.) 
the figure 2 has been omitted from the cognomen by the editor, Wessely.

\section{Severus.}

The cognomen Severus, it will be recalled, is joined to Firmus, $q . v$., by E. Bormann, as one "zum Soldatendienst bestimmt." It is not found so frequently, however, as some others in this Chapter. Eighty-four examples have been collected; thirtyfour were found in the provinces included in CIL III; sixteen, in Africa; thirteen, in Italy; eleven, in Germany; five each, in England and Spain.

The earliest instances are placed in the period before the year 42. These are M. Domitius Severus from Brixia, a soldier of the XIth legion in Dalmatia, and Babudius Severus, a centurion of the IXth legion in England. Twelve names with the cognomen Severus can be dated between the years 42 and 100 . Several of these names are accompanied by the name of the town from which the men came, e.g., Aquae Statiellae, Ticinum, Verona, Aequum, Vienna, and Antipolis. Some other soldiers who are not much later than the first century indicate as their homes Arretium, Alba Pompeia, and Lucus Augusti.

During the second century Severus is found in the Danube provinces seven times in a military list about the year 134, and later, in the third century three times in an inscription (about the year 212). Other instances are scattered. In Egypt two cases of Severus can be dated in the years 194 and 240. The group from Africa attracts attention, because it is perhaps possible to see here the waning popularity of the cognomen. One centurion, Fundanius Severus, seems to belong to the latter half of the first century, when the III Augusta was in Theveste. Five men bearing this cognomen in Africa served during the reign of Hadrian and their homes are all outside of the province, Arado, Gazza, Gen-, Nicomedia, and Tolomais. In the reign of Antonius Pius there is a case of Severus borne by a man from Naragarra. Dyrrachium is the home of another Severus; the inscription is not dated. Hadrumetum and the camp (at Lambaesis) are the only towns in Africa mentioned in this group. In the later period, C. Iulius Severus belongs to the reign of Alexander Severus (222-235). This name is found in another inscription undated. The same man may be referred to in both. 
C. Domitius Severus at Cartenna is a soldier of the XXII Primigenia; date uncertain, possibly third century. Three remain undated. In the name of Aristius Severus the cognomen is by no means certain. The province of Germany contributes examples of Severus in the first century and the name is still in use in the third. The same may be said of Italy.

Severinus is found six times in the inscriptions from the Danube provinces, probably all later than the first century. Severianus is represented by four scattered examples. Severius Severianus in Raetia (238-244) exhibits a feature of the later period; for other instances of this sort vid. Chap. III, Similarity between Nomen and Cognomen.

\section{Silvanus.}

Thirty-four examples are included under this cognomen in the alphabetical list. Ten are found in the Danube provinces; seventeen in Africa; three in Italy; one each in Arabia, Spain, Germany, and England. The related cognomina, Silvinus and Silvester, are represented by three names each. Silvanus appears in the following names of the first century: L. Pomponius Silvanus, a soldier in the XIth legion, has been placed earlier than the year 42 by Van der Weerd, Etudes sur les trois Legions romaines du Bas-Danube, p. 228. C. Gavius Silvanus was primus pilus of the VIII Augusta at Taurini in the year 65 . Several names belong to the period before the reign of Vespasian: L. Valerius Silvanus was a soldier of the VI Victrix in Spain; Titius Silvanus was a centurion of the XI Claudia in Dalmatia; and Sex. Iulius Silvanus served in the same province. Three other names can be dated in the second century and two are to be placed in the third. At Lambaesis ten of the seventeen examples can be dated in the years from 198 to the reign of Alexander Severus (222-235). Another soldier named Silvanus was born in camp. Carthage is the home of a soldier at Lambaesis and of another serving in Arabia. Iulius Silvanus on a stone at Lambaesis and Verecunda probably refers to the same man. Those undated in this and other places may be read from the alphabetical list.

Silvinus is the cognomen of two legionaries later than the principate of Septimius Severus. Silvester appears in one name of the first century and another of the third. The other examples 
can not be dated. For Silvanius Silvester vid. Chapter III, Similarity between Nomen and Cognomen.

\section{Tertius}

For the use of Tertius as a praenomen vid. CIL XIII 6939. Twenty-two examples of the use of Tertius as a cognomen have been collected. Cognomina related to Tertius are Tertinus, Tertianus, Tertiolus, Tertullus, Tertullinus, and Tertullianus. The distribution of the examples of Tertius is as follows: From the inscriptions published in CIL III eight cases are taken; from inscriptions found in Africa, three; from those in Germany, nine; from those in Italy, two. Three examples appear in the names of men who are natives of Italian towns, while one of the examples in Italy is the cognomen of a man born in Pannonia. The homes in Italy named by legionaries bearing the cognomen Tertius are Cremona, Hasta, and Placentia. Virunum is the home of a man named Tertius serving in Mainz. The earliest date in this list for the use of Tertius is before the principate of Vespasian. The latest instances belong to the third century. Lambaesis is the home of Numitorius Tertius, who was a veteran probably about the year 200 .

Of the cognate forms noted above Tertullus is the only one to appear on stones of the first century. Three of the six instances of its use as a cognomen belong to the period before the reign of Vespasian. L. Valerius Tertullus, whose home is Laus, was stationed at Mainz probably in the first century. Two names with the cognomen Tertullus at Lambaesis can be dated in the years 144 and 218. Tertullinus and Tertinus are recorded in inscriptions published in CIL III. Tertiolus is preserved in a name in Africa. Tertullianus is the cognomen of a centurion in England. Tertinus is represented by names on stones at Mainz and in Noricum.

\section{URBANUS}

Seventeen of the twenty-one examples of this cognomen come from Africa; two from Spain; one each from Pannonia and Germany. The last mentioned is the earliest; L. Cornelius Urbanus, a soldier of the XXI Rapax, was in Germany between the year 70 and the reign of Hadrian. In Africa the first dated name is Iulius Urbanus, borne by a centurion of the III Augusta 
in the year 162. Ten others can be dated from the years 198 to 218. Two men bearing this cognomen came from Cirta; one was born in camp. L. Alfidius Urbanus, from Spain, was a speculator of the VII Gemina about the year 200. Aelius Urbanus is the name in an inscription in Pannonia of the year 228.

Urbicus also appears as a legionary cognomen. An early spelling is found in the case of C. Vetienius Urbiqus, a tubicen of the firsi century in Germany. From Carnuntum a stone reads Sextus Gellius Urbicus natione Cilix. Vienna is the home of D. Capienius Urbicus in England. Two other cases are undated. Urbicinus is found in the name of P. Aelius Urbicinus, a frumentarius at Rome.

\section{Valens and Valentinus}

The cognomen Valens or Vales, which has been listed separately for convenience, has been found in one hundred and fifty-two names. Related to this cognomen are Valentinus, Valetinus, and Valentianus. The geographical distribution of the examples of Valens or Vales is as follows: From the provinces the inscriptions of which are published in CIL III one hundred and eight instances have been taken; from Africa, twenty-four; from Italy, ten; from Germany, six; one from England, and one example from Spain, if in this instance Valens is the correct restoration of the cognomen, the first letters of which appear on the stone.

The earliest uses of Valens or Vales are found in inscriptions which can be dated in the second half of the first century. Ten examples can be assigned to this period. Two soldiers bearing this cognomen were born in Heraclea and Ara Agrippinensium. Mantua is the home of M. Sulpicius Valens, whose period of service may belong to the first century. During the second century the cognomen Valens was in frequent use in the Danube provinces. In a military list which was cut on the stone about the year 134 twelve instances of Valens are preserved. In a similar inscription in the year 155 this cognomen appears in nine names. Still later in a list of veterans at Viminacium in the year 195 nineteen men bear the cognomen Valens. In the last mentioned inscription the homes of the men are recorded with the names. The towns are all in Moesia. In other inscriptions 
in this region the homes of men bearing the cognomen Valens are Heraclea, Salona, Stobi, Ancyra, Amasia, and Amastris.

In Africa we find that several of the soldiers named Valens are not natives of that province. Eight men with this name are recorded in a list cut during the reign of Hadrian. (No other list at Lambaesis contains so many instances.) Of this number five men come from the East; their homes are Sidonia, Capitolis, Heliopolis, and Tolomais. Cyrene and Hippo are also indicated on this stone as the birth-places of two men bearing the cognomen Valens. C. Iulius Valens natio Surus was transferred from the III Gallica to the III Augusta. Three men possessing the name Valens found on stones in Africa belong to legions stationed in that region only for short intervals and probably these men were not born there. Africa, in comparison with other sections, has few instances of Valens used as a soldier's cognomen. Besides the cases in the principate of Hadrian, four others can be placed in the second century and four in the third. This decline would seem to indicate that this cognomen was not a popular one among the members of the III Augusta legion. Two of the men who bear it were enrolled from Theveste and two were born in camp.

Instances of Valens in the Danube provinces during the third century are not common, but this is largely due to the small number of datable inscriptions in this period. All the evidence, however, points to its frequent and continued use in this part of the empire. The latest example is dated in the year 295 on a papyrus at Oxyrhynchus.

The thirty examples of the cognomen Valentinus follow the general distribution of the use of the name Valens. Eighteen military inscriptions published in CIL III preserve the cognomen Valentinus; five instances are found in Africa; five in Italy; two in Germany. The two inscriptions from Germany may belong to the first century, and, if so, constitute the earliest use of Valentinus among the soldiers. The name on one stone is C. Vibullius Valentinus, whose home is Milan. Along the Danube the cognomen Valentinus is in use later than the first century. Dated examples range from the years 134 to 294 . In Africa Valentinus is the cognomen of two men of native origin: viz., from Hadrumetum and Cirta. A centurion Valen- 
tinus of the secunda Flavia in Africa is later than Diocletian's reorganization of the army.

The following men deserve mention: L. Arbustius Valentinus, whose home is Cremona, and Salvinius Valentinus natus Carnunto are names of men serving in Italy. In Syria L. Philocalus Valentinus gives Gadara as his home. Valetinus and Valentianus are cognomina found once in the names of legionaries.

\section{VALERIANUS}

Before speaking of Valerianus there are several examples of Valerius as a cognomen, which must be noticed. The sixteen cases here collected are from the provinces included in CIL III, except for one each from Italy and England. Valerius was in origin a nomen and as a cognomen cannot be dated earlier than the second century. The earliest date of the appearance of this cognomen is in the year 155 in the name Flavius Valerius borne by a soldier of the XI Claudia in Moesia. One of the latest uses is in the name of a tesserarius of the same legion in Oxyrhynchus in the year 295. Another example not earlier than the reign of Diocletian is in the name Ulpius Valerius, borne by a speculator of the I Norica in Noricum. Nearly all of the instances of Valerius can be dated and these fall within the limits just mentioned. Ampelum may be the home of $\mathbf{T}$. Flavius Valerius, a veteran at Viminacium in the year 195 .

Thirty-four examples of Valerianus are presented here. Twenty-two cases come from the provinces included in CIL III; five were found in Africa; four in Italy; two in Germany; and one in Gallia Narbonensis. The earliest instance is not later than the reign of Vespasian. Other dated examples belong to the second and third centuries. The following cases deserve mention: D. Valerius Valerianus, whose home was Vienna, was a soldier at Rome. T. Flavius Valerianus, whose home was Oescus in Moesia, was a frumentarius in Rome. In the same city in the year 208, L. Domitius Valerianus was in service from Capitolias in Syria. Antioch is the home of a tubicen bearing the cognomen Valerianus, who became a veteran at Alexandria in the year 194.

Valerinus and Valerio appear also as the cognomina of legionaries on stones in Dacia and at Lyons. Balerianus is, doubtless, a variant spelling of Valerianus. 


\section{Verecundus}

The twenty-two examples of Verecundus here collected are well scattered. The Danube provinces and Germany contribute seven each; four were found on Italian soil; two at Lambaesis; one each in Spain and Syria. Several instances of the use of this cognomen belong to the first century. D. Miscenius Verecundus was a centurion of the XV Apollinaris at Carnuntum, probably before that legion left for the East in the year 63 . Caecilius Verecundus, a centurion in Dalmatia, D. Iunius Verecundus and Seionius Verecundus, centurions at Mainz, were in service in the early period. In the first century L. Valerius Verecundus is thought to have come from Vienna. Vercellae furnished a Verecundus to the XXI Rapax probably in the first century. C. Iulius Verecundus, who adds Traianensis, is dated about the year 100, a soldier at Bonn. Savaria and Sarmizegetusa are homes near the Danube of two men bearing this cognomen. C. Mettius Verecundus came from Alba Pompeia, and Q. Moneius Verecundus adds Narbonensis. L. Campanius Verecundus belongs to the tribe Pollia. At Lambaesis Iulius Verecundus was in service during the reign of Alexander Severus (222-235). (This case is by far the latest of Verecundus as a soldier's cognomen.)

\section{Verus}

The cognomen Verus has been found in thirty-three legionary names. Cognomina related to Verus are Verissumus and Verinus. The distribution of the examples of Verus is as follows: Fifteen have been taken from the provinces covered by CIL III; eight from Africa; five from inscriptions published in CIL XIII; three from Italy; and two from England.

The earliest instance is in the name Licinius Verus from an inscription in Egypt cut during the principate of Augustus. At least seven examples can be dated in the latter half of the first century. Lucus Augusti, Forum Iulii, and Vienna are the homes of men bearing the cognomen Verus not later than the year 70. Dated cases of the second and third centuries in the Danube provinces are found but not frequently. Dertona is the home of C. Cornelius Verus, who served in Pannonia later than the first century. Ammaedara is the birth-place of a soldier of the I Adiutrix. This inscription is probably to be dated later than the middle of the second century when this 
legion was in Africa. Ammaedara is also the home of two men bearing this cognomen at Lambaesis. One legionary served during the reign of Alexander Severus (222-235). The other has the same name and possibly the same man is referred to on both stones. Cirta and the camp are given as the homes of two more men at Lambaesis named Verus. Verinus has been found as a soldier's cognomen in nine inscriptions; all appear to be later than the first century. Cemenelum is the home of $\mathbf{L}$. Gratius Verinus. One example of Verissimus is noted in the name of a veteran, whose home is Ratiaria in Moesia. The inscription found in the same province was cut in the year 195.

\section{Victor AND Victorinus}

The cognomen Victor would seem to fill all the requirements of a suitable cognomen for soldiers and it causes us no surprise to find that it is one of the most frequent cognomina. One hundred and sixty-eight examples have been collected. The cognomina Victorinus, Victorianus, and Victorius are also used by the soldiers and will be mentioned later. The distribution of the evidence showing the use of Victor as a cognomen is as follows: Eighteen cases are taken from the provinces included in CIL III; one hundred and twenty-five come from Africa; fourteen are found in the provinces included in CIL XIII; and ix were recovered from inscriptions found in Italy; two each, in England and Spain.

The earliest and perhaps the only use of the first century is in the name of C. Iulius Victor from Hispalis, a soldier of the $\mathrm{X}$ Gemina. Lucius Valerius Victor, a soldier of the XXIId legion at Mainz, is not certainly of the first century because of the omission of the word "Primigenia" in citing the legion. The group of Victors from the Danube region range from about the year 134 to the third century. Three men named Victor are found in the East, and one centurion bearing the cognomen Victor was stationed in Egypt in the interval between the years 120 and 140. Aelius Victor from Trimontium is the only veteran with this cognomen in the list in the year 195 found at Viminacium which contained Valens so many times. C. Castricius Victor gives Comum as his birth-place; the inscription is undated. An eques in Dacia bearing the cognomen Victor came from Iader. The stone was cut later than the reign of Trajan. 
If we turn to the large number from Africa, an examination of the cases of Victor borne by men enrolled in the III Augusta shows that about seventy can be dated. The earliest use is perhaps in the name of a veteran preserved at Thamugadi, possibly before the legion moved its camp to Lambaesis during the reign of Hadrian. In the first military list at the new camp, when Hadrian was emperor, L. Antonius Victor from Scytopolis is recorded. From this time until the year 275 (the end of Aurelian's reign), the cognomen Victor enjoyed great popularity. In the year 218 nineteen duplarii bore this cognomen. The small number of centurions is noticeable; only three possessed this name in the III Augusta. To name the homes from which Victors came to join the legion at Lambaesis is to mention many of the towns of Africa; thirteen have been preserved. Seven men named Victor were born in camp.

For other scattered cases of Victor outside of Africa consult the alphabetical list. All except one of the dated uses of Victor in Germany belong to the third century. One name found in Italy is borne by a man of African origin- $\mathbf{Q}$. Cornelius Victor nat Afer.

Victorinus (forty-eight examples), strangely, does not follow the same development as Victor among the legions. The Danube provinces lead with twenty cases; fourteen come from Africa; eight from Germany; three from England; two from Rome; and one from Genava. Of the first century there is one instance in the name of a centurion of the VI Victrix in Germany; L. Titennius Victorinus from Bononia was a soldier in Germany between the reigns of Vespasian and Trajan. In the Danube region Victorinus appears later than the first century. Aelius Victorinus, a soldier in Moesia in the year 155, is the earliest name to which an exact date can be assigned. M. Aebutius Victorinus from Poetovio is a centurion of seven legions after the reign of Trajan at Ancyra. A stone cut in the third century at Rome records the name of a man in service there in the cohorts, formerly a legionary: viz., Aurelius Victorinus, who adds natione Dacisca regione Sardica.

In Africa one notes T. Flavius Victorinus from Damascus at Lambaesis during the reign of Hadrian as the earliest soldier to bear this cognomen here. Sex. Vettius Victorinus, born in camp, was a veteran about the year 198. Six examples can be 
dated in the third century. Besides a Victorinus born in camp, Siscia and Traianopolis, both in Europe, are mentioned as the homes of men bearing this cognomen. In Germany the dated cases of Victorinus belong to the third century.

Victorianus appears in the name C. Atilius Livius Victorianus borne by a veteran at Lambaesis. For the double nomen vid. Chap. III, Double Cognomina. Victorius is the cognomen in an inscription from Dacia and in two at Lambaesis; one of these is dated in the reign of Aurelian (270-275).

\section{Vitalis}

Sixty-nine instances of the cognomen Vitalis have been collected. One example of the spelling Vitales has been found. Vitealis affords another variant. The cognomen Vitalianus is preserved on one stone in a soldier's name. Twenty cases of Vitalis come from the Danube provinces; twenty-nine from Africa; ten from the provinces included in CIL XIII; five from England; four from Italy; and one from Spain.

The period between the years 42 and 70 is the earliest date to which any instances can be assigned. The cases in point are: C. Octavius Vitalis from Brixia, a veteran in Dalmatia, Aurelius Vitalis, a veteran in Moesia, and L. Celerinius Vitalis of the IX Hispana in England. Ti. Claudius Vitalis was a centurion of several legions at Rome during the reign of Domitian. Those who come from Italian towns are generally early and Vitalis is known from Blaera, Hasta, and Ticinum. Interamnia is the home of a primus pilus of the III Augusta, Ti. Claudius Vitalis at Lambaesis; the date is uncertain. In Moesia and Pannonia Vitalis is found throughout the second century and into the third. In the year 195 at Viminacium three veterans born in camp and one from Ratiaria bear this cognomen. In Africa Vitalis is found during the second and third centuries as a name for legionaries of African origin. Four were born in camp. Another gives Lambaesis as his home. Ammaedara, Carthage, Simitthus, Theveste, and Tipasa also furnished men bearing this cognomen to the III Augusta. The earliest date in Germany for Vitalis is in the year 186; four other cases can be assigned to the first half of the third century. One instance from England has been mentioned above. Another is dated in the year 191. Iulius Vitalis (undated) adds after his name natione Belga. 
Table Showing Distribution of Popdlar Cognomina

\begin{tabular}{|c|c|c|c|c|c|c|c|c|}
\hline \multirow[b]{2}{*}{ CogNOMEN } & \multicolumn{2}{|c|}{ CIL III } & \multicolumn{2}{|c|}{ Africa } & \multicolumn{2}{|c|}{$\begin{array}{l}\text { OTHER } \\
\text { PrOV- } \\
\text { INCES }\end{array}$} & \multirow[b]{2}{*}{ 胥 } & \\
\hline & 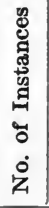 & 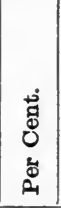 & 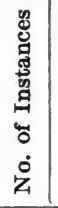 & 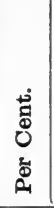 & 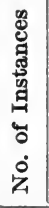 & 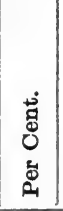 & & \\
\hline Alexander.... & 31 & 62 & 11 & 22 & 8 & 16 & 50 & Including Alexsander and Alex- \\
\hline Antoninus... . & 10 & 50 & 9 & 45 & 1 & 20 & 20 & andrus. \\
\hline Bassus....... & 16 & 38 & 14 & 34 & 12 & 28 & 42 & \\
\hline Candidus.... & 12 & 52 & 7 & 30 & 4 & 18 & 23 & \\
\hline Castus....... & 4 & 17.5 & 15 & 65 & & 17.5 & 23 & \\
\hline Celer........ & 24 & 63 & 5 & 13 & 9 & 24 & 38 & \\
\hline Clemens.... . & 19 & 50 & 7 & 18 & 12 & 32 & 38 & Including Clemens and Clemes. \\
\hline Crescens..... & 11 & 20 & 32 & 57 & 13 & 23 & 56 & Including Crescens and Cresces. \\
\hline Crispus...... & 12 & 50 & $\boldsymbol{7}$ & 29 & 5 & 21 & 24 & \\
\hline Datus....... & 2 & 9 & 22 & 91 & $\cdots$ & $\ldots$ & 22 & \\
\hline Donatus..... & 4 & 6 & 62 & 91 & 2 & 3 & 68 & \\
\hline Emeritus..... & 6 & 25 & 17 & 71 & 1 & 4 & 24 & Including Aemeritus. \\
\hline Faustus...... & 2 & 7 & 26 & 87 & 2 & 6 & 30 & \\
\hline Felix....... & 14 & 7 & 181 & 86 & 15 & 7 & 210 & \\
\hline Festus...... & 3 & 15 & 10 & 50 & 7 & 35 & 20 & \\
\hline Firmus...... & 22 & 51 & 11 & 26 & 10 & 23 & 43 & \\
\hline Fortunatus... & 4 & 7 & 49 & 83 & 6 & 10 & 59 & \\
\hline Fronto....... & 19 & 59 & 6 & 19 & 7 & 22 & 32 & - \\
\hline Fuscus....... & 7 & 33 & 10 & 45 & 5 & 22 & 22 & \\
\hline Germanus.... & 16 & 55 & 8 & 29 & 5 & 16 & 29 & 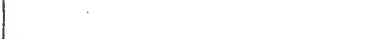 \\
\hline Honoratus. . . & 1 & 3 & 27 & 90 & 2 & 7 & 30 & \\
\hline Ianuarius... . & 14 & 18 & 59 & 76 & 5 & 6 & 78 & \\
\hline Ingenuus..... & 16 & 42 & 14 & 37 & 8 & 21 & 38 & Including Ingenuus and Ingenus. \\
\hline Iulianus. .... & 24 & 47 & 19 & 37 & 8 & 16 & 51 & Including Iulanus. \\
\hline Iustus....... & 11 & 37 & 7 & 23 & 12 & 40 & 30 & \\
\hline Longinus..... & 27 & 79 & 3 & 9 & 4 & 12 & 34 & \\
\hline Marcellinus.. & 12 & 55 & 2 & 9 & 8 & 36 & 22 & \\
\hline Marcellus.... & 10 & 43 & 7 & 30 & 6 & 27 & 23 & \\
\hline Marcianus... & 16 & 50 & 11 & 34 & 5 & 16 & 32 & \\
\hline Martialis..... & 8 & 15 & 38 & 73 & 6 & 12 & 52 & \\
\hline Maximus.... & 70 & 48 & 51 & 35 & 25 & 17 & 146 & Including Maxsimus, Maxsumus, \\
\hline Niger........ & 10 & 50 & 3 & 15 & 7 & 35 & 20 & and Maxumus. \\
\hline Optatus...... & 6 & 18 & 19 & 56 & 9 & 26 & 34 & \\
\hline Primus...... & 15 & 30 & 27 & 54 & 8 & 16 & 50 & \\
\hline Priscus...... & 17 & 42.5 & 8 & 20 & 15 & 37.5 & 40 & \\
\hline Proculus..... & 29 & 48 & 13 & 22 & 18 & 30 & 60 & Including Proclus. \\
\hline Pudens...... & 16 & 41 & 9 & 23 & 14 & 36 & 39 & Including Pudes. \\
\hline Rogatianus... & & & 20 & 100 & & $\ldots$. & 20 & \\
\hline
\end{tabular}


Table Showing Distribution of Popular Cognomina-Continued.

\begin{tabular}{|c|c|c|c|c|c|c|c|c|}
\hline \multirow[b]{2}{*}{ Cognomen } & \multicolumn{2}{|c|}{ CIL III } & \multicolumn{2}{|c|}{ Africa } & \multicolumn{2}{|c|}{$\begin{array}{l}\text { OTHER } \\
\text { Prov- } \\
\text { INCES }\end{array}$} & \multirow[b]{2}{*}{ 丞 } & \\
\hline & 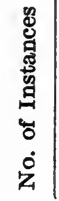 & 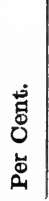 & 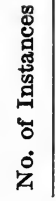 & 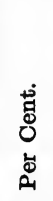 & 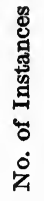 & 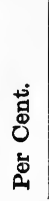 & & \\
\hline Rogatus.... & 2 & 5 & 42 & 95 & $\cdots$ & $\cdots$ & 44 & \\
\hline Rufinus...... & 3 & 9 & 21 & 68 & 7 & 23 & 31 & \\
\hline Rufus...... & 40 & 42 & 27 & 28 & 29 & 30 & 96 & \\
\hline Sabinus...... & 23 & 55 & 10 & 24 & 9 & 21 & 42 & \\
\hline Saturninus... & 24 & 13 & 139 & 75 & 20 & 12 & 183 & \\
\hline Secundus.... & 35 & 32 & 39 & 35 & 36 & 33 & 110 & \\
\hline Severus...... & 34 & 40 & 16 & 19 & 34 & 41 & 84 & \\
\hline Silvanus.... . & 11 & 32 & 17 & 50 & 6 & 18 & 34 & \\
\hline Tertius..... & 8 & 36 & 3 & 14 & 11 & 50 & 22 & \\
\hline Urbanus.... . & 1 & 5 & 17 & 81 & 3 & 14. & 21 & \\
\hline Valens....... & 108 & 71 & 24 & 16 & 20 & 13 & 152 & Including Vales. \\
\hline Valentinus... & 18 & 60 & 5 & 17 & 7 & 23 & 30 & \\
\hline Valerianus... & 22 & 64 & 5 & 14 & 7 & 22 & 34 & \\
\hline Verecundus. . & 8 & 36 & 2 & 9.5 & 12 & 4.5 & 22 & \\
\hline Verus........ & 15 & 45 & 8 & 26 & 10 & 29 & 33 & \\
\hline Victor....... & 18 & 11 & 125 & 75 & 24 & 14 & 167 & \\
\hline Victorinus... . & 20 & 42 & 14 & 29 & 14 & 29 & 48 & \\
\hline Vitalis....... & 21 & 30 & 29 & 41 & 20 & 29 & 70 & Including Vitales. \\
\hline
\end{tabular}

Note-The general proportionate distribution of the inscriptions among the provinces will be recalled from the Foreword at the beginning of this chapter: viz., about one-third from the provinces of which the inscriptions are published in CIL III, slightly over one-third from the territory of Africa except Egypt, and the reremainder from other parts of the Roman Empire. This distribution makes the normal percentage in these different regions about 33 . 


\section{CHAPTER TWO}

\section{CLASSIFICATION OF COGNOMINA}

\section{Foreword}

A few words of explanation may make clear the method which has been employed of classifying the cognomina in the present collection. There are three general classes which in turn permit of several subdivisions. In the first class will be found cognomina arranged according to form and meaning: $i$. e., adjectives, nouns, and diminutives to which sections dealing with names connected the names of divinities and the names of emperors have been added. The great majority of the words in these groups are of Roman or Italian origin. The second class is composed of those cognomina which have similar endings: e. g., -a, -ianus, etc. Here almost as many names of foreign as of Roman origin will be found. The third class is entirely devoted to words of foreign origin: $i$. e., Celtic, Greek, Thracian, etc.

It will be observed that a name may appear in more than one section of the classification. E. g., a Punic name ending in -o will be noted in two classes, a noun ending in -a will also be recorded in two classes, and so on. The cognomen Martialis offers a case in point. First, it is considered with those adjectives suitable in meaning to serve as the cognomina of soldiers. It may also refer to a birthday and at the same time must be mentioned in the group of names connected with the names of divinities. Finally it is listed with the cognomina which end in -lis.

In each section the cognomina involved are listed alphabetically and some general remarks concerning the significance of that particular group of names and the earliest names are made. The most noteworthy names receive especial mention. In each section, however, the details in regard to the individual names must be sought in the proper place in the large alphabetical 
list. It has been impossible to attempt any complete repetition of the data available there.

In the classification of adjectives considerable freedom has been exercised in the assignment of names under each heading. Further classification might be thought advisable although it is believed that the arrangement adopted is reasonable and convenient.

There are 1333 different cognomina in this collection. This number is computed on the basis that a variant spelling: $e . g$., Clemes for Clemens forms two distinct cognomina. This separation has been adhered to throughout and will be found to make the study of the names in the alphabetical list a simpler matter.

Cognomina have been arranged in the following sections.

\section{Class I}

A. Adjectives used as Cognomina.

A 1. Adjectives denoting qualities suited to men in military service.

A 2. Adjectives denoting physical characteristics.

A 3. Adjectives denoting mental or moral characteristics.

A 4. Adjectives with geographical or racial significance.

A 5. Numeral adjectives.

A 6. Adjectives relating to birthdays.

A 7. Participial adjectives.

A 8. Adjectives in the comparative and superlative forms.

A 9. Adjectives not elsewhere classified.

B. Nouns used as Cognomina.

C. Diminutives used as Cognomina.

D. Praenomina used as Cognomina.

E. Cognomina connected with the names of divinities.

F. Names of Emperors used as Cognomina.

G. Well-known cognomina at Rome which are found in the names of legionaries.

\section{Cluass II}

A. Cognomina ending in -a.

B. Cognomina ending in -anus.

C. Cognomina ending in -ianus.

D. Cognomina ending in -inus. 
E. Cognomina ending in -ius.
F. Cognomina ending in -lis.
G. Cognomina ending in -o.
H. Cognomina ending in -osus.
I. Cognomina ending in -x.

Class III

A. Cognomina of Arabic origin.

B. Cognomina of Celtic origin.

C. Cognomina of Egyptian origin.

D. Cognomina of Germanic origin.

E. Cognomina of Greek origin.

F. Cognomen of Illyrian origin.

G. Cognomen of Ligurian origin.

H. Cognomina of Persian origin.

I. Cognomina of Phrygian origin.

J. Cognomina of Punic origin.

K. Cognomina of Semitic origin.

L. Cognomina of Thracian origin.

M. Cognomina of uncertain origin.

Cognomina not elsewhere classified.

\section{Adjectives Used as Cognomina}

About four hundred, or nearly one-third of the whole number of different cognomina, are in the form of adjectives. These have been subdivided into several related groups as shown by the headings indicated in the foreword to this chapter. The practice of using an adjective as a cognomen is observed in the earliest names of soldiers which have come down to us, and it is also widespread, for fully half of the total number of names in the alphabetical list contains a cognomen in the form of an adjective.

\section{Adjectives Denoting Qualities Suited to Men in Mili- TARY Service}

Following the suggestion of Bormann ( $V i d$. Introduction), who described the cognomina Firmus and Severus as names suited to men in military service, the present section is made up of a number of cognomina which seem properly to belong under such a heading. These are: 


$\begin{array}{llll}\text { Acer } & \text { Constans } & \text { Fidus } & \text { Pervincus } \\ \text { Acutus } & \text { Costa } & \text { Fidelis } & \text { Promptus } \\ \text { Audax } & \text { Dexter } & \text { Firmus } & \text { Repentinus } \\ \text { Audeus } & \text { Efficax } & \text { Fortis } & \text { Robustus } \\ \text { Bellicus } & \text { Exupereus } & \text { Fortunatus } & \text { Severus } \\ \text { Castrensis } & \text { Faustus } & \text { Laevus } & \text { Tenax } \\ \text { Catus } & \text { Felicissimus } & \text { Martialis } & \text { Torquatus } \\ \text { Celer } & \text { Felix } & \text { Militaris } & \text { Valens } \\ \text { Certus } & \text { Ferox } & \text { Militio } & \text { Velox } \\ \text { Classicus } & \text { Festus } & \text { Pertinax } & \end{array}$

This list of suitable names may be increased by other cognomina not adjectives. The noun Victor is pre-eminently a proper cognomen for a soldier. Vindex also deserves mention here. Names of military offices appear as cognomina, Pequarius, Polio, Princeps, Tribunus, and Veteranus. Ballista and Castellus are not out of place in a soldier's name. Some names of Greek origin are suitable for use in the name of a soldier; these are Achilleus, Alexander, Anicetus, Deiotarus, and Nicomachus.

Under this heading are found several of the most popular cognomina: viz., Faustus, Felix, Festus, and Fortunatus, the names of good omen common in Africa, Celer, Firmus, Severus and Valens, the names of valor which prevail in the Danube region, Martialis and Victor, propitious names for the soldier also frequent in Africa. Some other names seem to us equally suitable for the legionary, Bellicus, Fortis, and Pervincus, but these have not come down to the present day in such large numbers as those just mentioned.

Several of the names in this group are found as cognomina in the first century. Among the earliest to be used are Celer, Firmus, Severus, and Valens. The names Castrensis, Militaris, Militio, and Torquatus are later than the first century.

The cognomen Audeus is found in an inscription from Dacia. The full name is P. Aelius Septimius Audeus qui et Maximus. (For the supernomen vid. Chap. III, Double Cognomina.) The spelling on the stone is Audeo and so Lambertz (Glotta IV p. 132) reads this form as a nominative. The Index Cognominum of CIL III adopts the form Audeus. The double nomen Aelius Septimius is not frequent (vid. Chapter III $l$. $c$. and $c f$. Mucapor and Romanus). This inscription is later than the reign of Trajan. On the use of the cognomen Fidelis among Roman citizens vid. Kubitschek, Jahres. Wien. 1899 
Beibl, 73. The name Constans appears also as Costas and the spelling Costa is restored to Constans.

\section{Adjectives Denoting Physical Characteristics}

The following cognomina are adjectives which denote physical characteristics:

$\begin{array}{llll}\text { Albus } & \text { Flaccus } & \text { Magnus } & \text { Rufus } \\ \text { Aprinus } & \text { Flacus } & \text { Maior } & \text { Salutaris } \\ \text { Aquilus } & \text { Flavus } & \text { Masculus } & \text { Silo } \\ \text { Balbus } & \text { Flaus } & \text { Masgilus } & \text { Taurinus } \\ \text { Barosus } & \text { Florus } & \text { Maximus } & \text { Tauriscus } \\ \text { Bellus } & \text { Fuscus } & \text { Mutilus } & \text { Vegetus } \\ \text { Calvus } & \text { Gracilis } & \text { Niger } & \text { Venustus } \\ \text { Candidus } & \text { Longus } & \text { Paetus } & \text { Virilis } \\ \text { Celsus } & \text { Lucidus } & \text { Paulus } & \text { Vitalis } \\ \text { Crispus } & \text { Macellus } & \text { Paullus } & \\ \text { Equinus } & \text { Macer } & \text { Piscinus } & \end{array}$

Among this number are several cognomina which appear also in Chap. I; Candidus, Crispus, Fuscus, Maximus, Niger, Rufus, and Vitalis. The prevalence of these seven names bears witness to the frequent use of cognomina of this kind in the name of men in the legions. Celsus, Florus, Longus, and Magnus have been recorded in more than ten names each. Several cognomina are formed from the names of animals, Aprinus, Equinus, Taurinus, and Tauriscus, $c f$. Caprarius. Piscinus may be mentioned in this connection. Adjectives referring to size are Celsus, Longus, Macer, Marcellus, Magnus (Maior and Maximus), and Paulus. Adjectives indicating color are Albus, Candidus, Flavus, Fuscus, Lucidus, Niger, and Rufus. Certain peculiarities of the body are denoted by the words Balbus, Calvus, Crispus, Flaccus, Mutilus, Paetus, and Silo. Bellus, Gracilis, and Venustus point to attractive qualities.

Cognomina of this kind are used in the early period by the soldiers. Among the earliest legionary cognomina which have been preserved are Celsus, Magnus, Niger, Rufus, Longus, and Flaccus. The use here of the words "physical characteristics" is not by any means intended to convey the impression that the man who bore the cognomen received it because he had the particular physical peculiarity which the cognomen indicates. Such a name as Rufus can scarcely have retained its physical significance. But at this distance it is impossible to determine 
how far these names were suited to their bearers. It seems useful, however, to have the cognomina of this kind brought together.

On Mutilus vid. comm. in CIL XIII 8591 cf. 2583. This cognomen is found also in Frontinus, Strat. 1. 5, 17 and Livy, Epit. 89. On Paulus vid. Schulze, Lat. Eigennamen p. 508. Masgilus is perhaps related to Masculus and for that reason has been listed with it.

Adjectives Denoting Mental or Moral Characteristics

The following adjectives which denote mental or moral characteristics are found as cognomina in the names of Roman soldiers:

$\begin{array}{llll}\text { Aequus } & \text { Dignissimus } & \text { Mansuetus } & \text { Securus } \\ \text { Aequos } & \text { Disertus } & \text { Melior } & \text { Sedatus } \\ \text { Amabilis } & \text { Dubius } & \text { Mellitus } & \text { Sedulus } \\ \text { Amenus } & \text { Facilis } & \text { Memor } & \text { Serenus } \\ \text { Apricosus } & \text { Festivus } & \text { Moderatus } & \text { Serranos } \\ \text { Asper } & \text { Frugi } & \text { Modestus } & \text { Simplex } \\ \text { Avidus } & \text { Garrulus } & \text { Nobilis } & \text { Sterceius } \\ \text { Bibulus } & \text { Genialis } & \text { Pius } & \text { Suavis } \\ \text { Bonus } & \text { Gratus } & \text { Placentus } & \text { Tacitus } \\ \text { Bonosus } & \text { Honestus } & \text { Placidus } & \text { Verax } \\ \text { Carus } & \text { Hospitalis } & \text { Probus } & \text { Verecundus } \\ \text { Castus } & \text { Innocens } & \text { Prudens } & \text { Verus } \\ \text { Clarus } & \text { Iucundus } & \text { Pudens } & \text { Verissimus } \\ \text { Clemens } & \text { Iustus } & \text { Quietus } & \\ \text { Clemes } & \text { Laetus } & \text { Respectus } & \\ \text { Dignus } & \text { Lepidus } & \text { Sanctus } & \end{array}$

Of the sixty-one names here listed six have been used frequently enough to come under the heading of popular cognomina: viz., Castus, Clemens, Iustus, Pudens, Verecundus, and Verus. Mansuetus, Modestus, and Probus are represented by ten or more examples.

As in the case of adjectives denoting physical characteristics the literal meaning of the adjectives under this heading can not be pressed closely in every case. In some names, however, we may feel sure that the name was in some way suited to the men who bore them. Sterceius is certainly an undesirable name and was probably applied with full knowledge of its meaning. Asper, Avidus, Bibulus, and Garrulus may well have been bestowed in disparagement of a soldier. In contrast to these 
names of an uncomplimentary nature, the adjectives indicating favorable qualities are many and widely scattered. Cognomina of this kind appear during the first century in the names of men enrolled in the legions. For these details and others consult the alphabetical list. The Greek name Asmenus, Aristo, and Hilarus should be mentioned here on account of their agreement in meaning with other names in this section. On the name Frugi it is interesting to note what Cicero (Tusc. 3, 8, $16 \mathrm{seq}$ ) has to say in regard to the application of this name to L. Piso. The cognomen Clarus has been noted in the names of African legionaries only.

\section{Adjectives with Geographical or Racial Significance}

Adjectives which contain geographical or racial indications are often used among the legionaries as cognomina. The following names have been found:

$\begin{array}{llll}\text { Africanus } & \text { Cilicianus } & \text { Italicus } & \text { Reticus } \\ \text { Africus } & \text { Cretianus } & \text { Italus } & \text { Romanus } \\ \text { Albanus } & \text { Creticus } & \text { Laco } & \text { Romulus } \\ \text { Aquileiensis } & \text { Curia } & \text { Latinus } & \text { Sabinus } \\ \text { Arabus } & \text { Curta } & \text { Laurentinus } & \text { Saloninus } \\ \text { Aretinus } & \text { Etruscus } & \text { Lavinus } & \text { Sarmatius } \\ \text { Aternus } & \text { Eufratianus } & \text { Ligus } & \text { Sausa } \\ \text { Atticus } & \text { Faventinus } & \text { Lucanus } & \text { Soranus } \\ \text { Atticinus } & \text { Florentinus } & \text { Lugudunolus } & \text { Suebus } \\ \text { Atticianus } & \text { Gaetulicus } & \text { Macedo } & \text { Surus } \\ \text { Aurassus } & \text { Getulicus } & \text { Marsus } & \text { Syriacus } \\ \text { Aventinus } & \text { Galicanus } & \text { Maurinus } & \text { Siriacus } \\ \text { Britto } & \text { Gallicus } & \text { Maurus } & \text { Tarquiniensis } \\ \text { Bruttianus } & \text { Germanus } & \text { Moesicus } & \text { Telesinus } \\ \text { Camerinus } & \text { Geta } & \text { Noricus } & \text { Teurnicus } \\ \text { Campanus } & \text { Hadrias } & \text { Panno } & \text { Thevestinus } \\ \text { Campanianus } & \text { Hispanus } & \text { Parthicus } & \text { Tevestinus } \\ \text { Capetolinus } & \text { Ispanus } & \text { Ponticus } & \text { Thubunius } \\ \text { Capitolinus } & \text { Hispelo } & \text { Praenestinus } & \text { Tuscus } \\ \text { Caudinus } & \text { Hister } & \text { Raeticus } & \text { Umbrianus } \\ \text { Celtiber } & \text { Iadestinus } & & \end{array}$

Several other adjectives also contain the idea of locality and may be mentioned in this connection. These are Agrinus, Barbarus, Gentilis, Marinus, Maritimus, Montanus, (Muntanus), Peregrinus, Provincialis, Rusticus, Silvanus, Silvinus, Silvester, Urbanus, Urbicus, and Vicanus. The names Ger- 
manus, Sabinus, Silvanus, and Urbanus are found with some frequency and have been discussed in Chap. I. Romanus appears as a cognomen in nineteen names.

Names of this kind which can be dated during the first century are Etruscus (before the year 42), Hispelo (before the year 43), Laco (37-41), Hister, Maurinus, and Tuscus (42-70), Romulus (before the year 62), Tarquiniensis (before the year 63), Albanus, Campanus, Celtiber, and Italicus (before the year 70); Atticinus, Iadestinus, and Lugudunolus belong to the first century.

The natural conclusion regarding the names containing geographical indications is that the names constitute a reference to the particular regions from which came the men who bear them. There appear to be some exceptions to this supposition and these may be due to the fact that the name was employed without conscious reflection upon its literal meaning. The following cases throw some light on the usage of "geographical" cognomina. Africanus and Africus are the cognomina of men in service at Lambaesis. Capetolinus is borne by a centurion whose home is Capetolias. Celtiber is the cognomen of a centurion in Spain. Cilicianus is found on a stone in Syria. Moesicus is the cognomen of a veteran in Moesia Inferior. Iadestinus is borne by a soldier whose home is Iader. Raeticus is found in Raetia and also in England. Noricus is found in England as well. Panno and Parthicus are taken from inscriptions in Germany. Gallicus and Laurentinus are found in Africa. Gaetulicus appears in Africa and England. C. Iulius Lugudunolus, a soldier in Africa, was born at Augustodunum. L. Publicius Florentinus was born at Lambaesis. Aurelius Germanus adds natione Dacus to his name. Theveste is the home of M. Valerius Aquileiensis, cf. Chap. III, Double Cognomina, for the supernomen Aquensis. Cuiculum, also in Africa, is the birthplace of C. Iulius Arabus. Cirta, in the same province, is the home of Mummius Atticus. M. Aurelius Romanus was born at Antioch, Caecilius Romanus at Tipasa, and M. Nóvellius Romanus at Milan. In these cases the men may have become citizens early in life or perhaps through pride in the citizenship of their fathers they took the name Romanus. The reasons are not so apparent for the use of Sabinus, which has been noted as the cognomen of men born in Caesarea Augusta, Nicomedia, 
Ratiaria, Carthage, Amasium, Narbo, Forum Brentanum, and Spain. Germanus is read as the cognomen of a soldier at Lambaesis who was born in camp. M. Cocceius Germanus, a soldier in Arabia, had in addition a native name, 'Aoveiōos. Gaius Seius Atticus, an optio in the VIth legion at Hierapolis, was also known

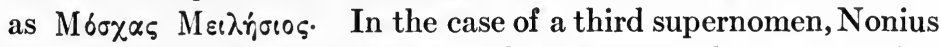
Saloninus qui et signo Dalmatis, there seems to be a connection between the two names. The cognomen Saloninus indicates the town Salonae and the supernomen Dalmatis is obviously a reference to the province Dalmatia in which Salonae is located.

The name Aurassus is connected with the name of a mountain in Numidia, $c f$. Chap. III, Double Cognomina, for an example of a supernomen Aurassius. Curia and Curta are names of places in Pannonia. Sausa may be related to Sau, the name of a river in Pannonia. Soranus is perhaps from Sora.

Romanus as a cognomen in the names of legionaries can not be dated earlier than the second century. Nineteen examples have been noted. Africa and the Danube provinces, including Dalmatia, afford seven examples each. Germany and England contribute two each and Italy has one soldier's name with this cognomen. Three of the five examples of Ponticus are found in a single inscription in Moesia which is dated earlier than the reign of Marcus Aurelius. One other instance is noted in Moesia and a soldier in Egypt in the year $\mathbf{9 0}$ has this cognomen. His home is outside of Egypt.

A list of this kind, $i$. e., cognomina formed from the names of towns and provinces, may well be used to supplement the data from inscriptions in regard to the birth-place of men in the legions.

A few names have a second cognomen which contains a reference to the home of the man who bears it. These are discussed in Chap. III, Double Cognomina. The "geographical" cog-

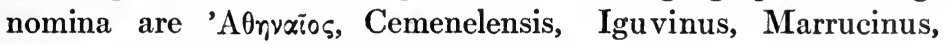
Narbonensis, and Vicetinus.

\section{Numeral Adjectives}

All the numeral adjectives except those for "eighth" and "ninth," are used among the soldiers as cognomina. Primus (Protus), Secundus, Tertius, Quartus, Quintus (Cointus), Sextus (Sexstus), Septimus, and Decimus are represented in the 
present collection by one or more instances. These are accompanied by diminutives and derivatives which may be consulted in the alphabetical list. Secundus, Primus, and Tertius have been found most frequently and some discussion of these cognomina appears in Chap. I. Septimus and Sextus are used least. The use of Primus, Secundus, Tertius, Quintus, Sextus, and Decimus as praenomina is noted in a later section. Quintus and Sextus, the latter particularly, seem to have been used longer as praenomina and for that reason their employment as cognomina falls later than the first century. Primus, Secundus, and Tertius are found on several stones cut in the first century. Numerus appears as a cognomen in the name of a soldier serving in Pannonia.

\section{Adjectives Relating to Birthdays}

Cognomina in the form of adjectives which relate to birthdays are found in the following names: The first group, with the exception of the first word in it, is made up of the names of the months. Kalendinus (Kalandinus), Ianuarius, Martialis, Aprilis, Iunius, Iulius, Augustalis, October, and December. The names of the second group refer to seasons or festivals, Natalis, Brumasius, Capratinus, Cerialis, Cerealis, Liberalis, Neptunalis, Quirinalis, Kupevádıos, Saturnalis, Saturnilus, Saturninus, and Terminalis. For a recent discussion of these names and others of similar import not appearing in this collection vid. Gottanka, Epigraphische Beiträge, Augsburg, 1912. The most common names in this class are Ianuarius, Martialis, and Saturninus, which have been discussed in Chap. I. These names are especially abundant in Africa and there are doubtless other reasons for their widespread popularity in that province than a reference to birthdays. These names are mentioned again in the section relating to the names of divinities. Consult further Chap. III, The Cognomina of African Legionaries, and for Martialis, Section One of this chapter. Iulius and Iunius are more strictly nomina, vid. Cognomina ending in -ius. The word Liberalis is also connected with some other idea than that of the god. The fourteen examples extend from the period before the reign of Claudius to that of Aurelian (270-275). It is interesting to note that a man whose name is Cerealis enjoyed the office of frumentarius at Rome for his legion and possibly this occupation would serve to account for his cognomen. 


\section{Participial Adjectives}

The following adjectives in participial form appear as cognomina in the names of men in the legions:

$\begin{array}{llll}\text { Acceptus } & \text { Dubitatus } & \text { Optatus } & \text { Restitutus } \\ \text { Amandus } & \text { Emeritus } & \text { Oriens } & \text { Restutus } \\ \text { Ampliatus } & \text { Exoratus } & \text { Pacatus } & \text { Rogatus } \\ \text { Citus } & \text { Extricatus } & \text { Potens } & \text { Sequens } \\ \text { Cogitatus } & \text { Exuperatus } & \text { Potitus } & \text { Servatus } \\ \text { Collatus } & \text { Fruendus } & \text { Praesens } & \text { Servandus } \\ \text { Concessus } & \text { Frunitus } & \text { Privatus } & \text { Spectatus } \\ \text { Constitutus } & \text { Honoratus } & \text { Probatus } & \text { Speratus } \\ \text { Crescens } & \text { Impetratus } & \text { Processus } & \text { Statutus } \\ \text { Cupitus } & \text { Insequens } & \text { Profuturus } & \text { Stratus } \\ \text { Datus } & \text { Libens } & \text { Promotus } & \text { Successus } \\ \text { Decoratus } & \text { Mandatus } & \text { Quadratus } & \text { Timens } \\ \text { Dolens } & \text { Meritus } & \text { Cutratus } & \\ \text { Donatus } & \text { Obsequens } & \text { Renuntiatus } & \end{array}$

Of this number, thirty-nine are in the form of past participles, ten in the form of present participles, three in gerundive form, and one seems to be in the form of a future participle. The names found most frequently are Crescens, Datus, Donatus, Emeritus, Honoratus, Optatus, and Rogatus. Some explanation of their popularity in Africa is given in Chap. III, The Cognomen of African Legionaries, vid. also Chap. I. The uses of these seven names number two hundred and seventyeight and all but fifty-nine have been noted in African inscriptions. More instances of Crescens have been found outside of Africa than of any other of the seven just mentioned. The remaining cognomina in the form of present participles appear outside of Africa. Other cognomina in this group which are found in this province only are Ampliatus, Collatus, Concessus (four examples), Exoratus, Extricatus (seven examples), Meritus, Potitus, Privatus, Processus (six examples), Profuturus, and Renuntiatus, cf. Caligatus, Chap. III, Double Cognomina. In ten other names one or more examples come from Africa. Omitting the present participial form, African inscriptions contribute all or part of the examples in twenty-seven out of fortythree cognomina in participial form. For the significance of this form and its prevalence in Africa, vid. Chap. III, The Cognomina of African Legionaries. 
The names in this group which can be dated in the first century are Servatus, Quadratus, Constitutus, Libens, and Oriens. Emeritus appears in one case with the spelling Aemeritus. For an early cognomen, Relatus, see the Addition to the introductory note to the Alphabetical List.

\section{Adjectives in the Comparative and Superlative Forms}

A small number of cognomina take the form of the adjective in the comparative and superlative degrees. These are Maior, Melior, Prior, Dignissimus, Felicissimus, Maximus, Postumus, Proxumus, and Verissimus. The name Aristo appears among the cognomen of Greek origin. Maximus is the only one of this group to attain a wide use as a cognomen, vid. discussion in Chap. I. Maior appears as the cognomen of a soldier whose period of service falls in the first century. The other dated instances are later than this century. Postumus is recorded as the cognomen of a centurion serving in Dalmatia in the period between the year 42 and the reign of Vespasian. All the other dated examples of this cognomen and of the others in this group are later than the first century With the exception of Maximus, no superlative form gained popularity among the men in the legions. The formation of cognomina by the addition of endings such as -ianus to the stem seems to have been preferred to the use of the superlative. Primitius would seem to be the comparative form of the adverb primitus; both are legionary cognomina.

\section{Adjectives not Elsewhere Classified}

To avoid the unnecessary multiplication of classes all adjectives not hitherto classified are arranged here in three groups. The first contains such words as have in them a reference to time: Aeternalis, Annalis, Avitus, Cordus, Iuvenis, Iuvenalis, Maturus, Perpetuus, Primigenius, Primitivos, (Primitus and Primitius), Priscus, Saecularis, Senilis, Superstes, and Vetus. Priscus has already been discussed in Chap. I. Cordus, Iuvenis, Perpetuus, Priscus, and Senilis appear in names borne by men in service during the first century.

A second group is composed of words which indicate relationship or birth: Consors, Fraternus, Geminus, cf. Didymus, Gemellus, Ingenuus (Ingenus), Maternus, Paternus, Propinquus 
(Propincus and Prupincus). Ingenuus is found in several names and a discussion of these occurs in Chap. I. Cf. Liberalis and Eugenus. Gemellus receives some attention in the section devoted to Diminutives. Names which appear as early as the first century are Geminus, Gemellus, Ingenuus, Maternus, and Paternus.

There is a certain number of adjectives, which have been found as cognomina, the meaning of which does not permit insertion under any of the headings already given. These are Catervarius, Civilis, Communis, Dativus, Fatalis (Fatales), Fructuosus, Hibernus, Leonatus, Peculiaris, Reginus, Reginalis, Salutus, Scaenicus, Similis, Solus, and Superus. Several will be found mentioned in the sections devoted to cognomina which have certain endings. For comment on the name in which Scaenicus appears vid. Chap. III, Double Cognomina. Reginus can be dated in the first century; the other names are later. This is the only cognomen of this group to be found in as many as four names.

\section{Nouns Used as Cognomina}

The following list presents the nouns which have been found as cognomina in the names of Roman legionaries.

$\begin{array}{llll}\text { Adiutor } & \text { Congius } & \text { Mercator } & \text { Senecio } \\ \text { Adventus } & \text { Kopvoũs } & \text { Messor } & \text { Sera } \\ \text { Aedilis } & \text { Derisor } & \text { Mica } & \text { Siliquarius } \\ \text { Agricola } & \text { Dosso } & \text { Mucco } & \text { Socellus } \\ \text { Aper } & \text { Elepans } & \text { Naso } & \text { Sodalis } \\ \text { Aquila } & \text { Emporus } & \text { Natulus } & \text { Stella } \\ \text { Aquilo } & \text { Faber } & \text { Nepos } & \text { Taurus } \\ \text { Arator } & \text { Favor } & \text { Numerus } & \text { Tiro } \\ \text { Artemo } & \text { Flaminalis } & \text { Pastor } & \text { Tribunus } \\ \text { Auster } & \text { Fronto } & \text { Paterculus } & \text { Turbo } \\ \text { Baculus } & \text { Fructus } & \text { Pequarius } & \text { Tutor } \\ \text { Ballista } & \text { Gallus } & \text { Pietas } & \text { Ursus } \\ \text { Bucco } & \text { Cf. Callus } & \text { Polio } & \text { Ursaris } \\ \text { Buculus } & \text { Gaulus } & \text { Porcellus } & \text { Ursulus } \\ \text { Capito } & \text { Homullus } & \text { Princeps } & \text { Verna } \\ \text { Caprarius } & \text { Omuncio } & \text { Procus } & \text { Vernuleus } \\ \text { Capreolus } & \text { Hospes } & \text { Pupus } & \text { Veteranus } \\ \text { Castellus } & \text { Laenas } & \text { Questor } & \text { Viator } \\ \text { Catulus } & \text { Lappus } & \text { Reditus } & \text { Victor } \\ \text { Censor } & \text { Leo } & \text { Regulus } & \text { Vindex } \\ \text { Cicatricula } & \text { Lucus } & \text { Rixula } & \text { Vinitor } \\ \text { Cilo } & \text { Lupus } & \text { Sacerdos } & \text { Vitulus } \\ \text { Colonus } & \text { Salinator } & \\ \text { Conductor } & \text { Lupulus } & \text { Scaena } & \end{array}$


The ninety-three cognomina in this group involve four hundred and thirty-nine names, of which Fronto and Victor constitute 47 per cent. These two names are discussed in Chap. I. Capito is next in order of frequency and barely escapes a place in Chap. I. (Vid. comment on this below.)

Nouns were early employed as cognomina and among this group of names several belong to the first half of the first century Aquila, Baculus, Castellus, Salinator, and Viator. Others of the latter half of this century are Adventus, Aper, Arator, Ballista, Bucco, Buculus, Capito (four examples are dated in this period), Cicatricula, Fronto, Leo, Nepos, Pastor, Taurus, Tiro, and Vindex. The following diminutives are employed as cognomina: Buculus, Capreolus, Castellus, Catulus, Cicatricula, Homullus, Omuncio, Lupulus, Natulus, Paterculus, Porcellus, Regulus, Rixula, Socellus, Ursulus, Vernuleus, and Vitulus. For these and other diminutives vid. next section.

Several groups of related nouns deserve mention. Some words denote military offices and are to be expected as the cognomina of soldiers. Pequarius and Polio, borne by men born in camp, Princeps, and Questor have been found in Africa. Tribunus appears in an inscription in Germany. Veteranus is the name on a stone found at Dertona. Tiro and Pupus are suitable names for newly enrolled members of a legion. Castellus and Ballista are not inappropriate names for soldiers. Many nouns indicate an office or occupation other than military, Aedilis, Censor, Viator; Agricola, Arator, Caprarius, Colonus, Conductor, Messor, Pastor, and Vinitor; Faber, Mercator, Emporus, Salinator, Sacerdos, and Flaminalis. Adiutor, Tutor, Vindex, and, pre-eminently, Victor, are suitable names for soldiers. Several names of animals appear as cognomina: Aper, Buculus, Capreolus, Catulus, Elepans, Leo, Lupus (Greek, Lycus), Porcellus, Taurus, Ursus, Ursulus, and Vitulus. Aquila and Gallus are the only names of birds adopted by the soldiers as cognomina. Aquilo and Auster are the names of winds which are employed as cognomina. Adventus, Reditus, Favor, and Pietas are abstract nouns. Names of objects are Baculus, Congius, Kopvoũs, Gaulus, Laenas, Lappus (probably connected with Lappa, which is also used as a cognomen, though not in this collection), Lucus, Mica, Scaena, Sera, and Stella. Cicatricula seems clearly to point to a personal feature of the man who bore 
it. Mucco (connected with muccus) and Derisor are doubtless uncomplimentary names. Bucco, Cilo, Dosso (from dorso), Fronto, and Naso refer to parts of the body. Hospes, Socellus, and Sodalis are desirable names for men in any occupation.

The cognomen Capito has been found in nineteen names. The spelling Capiton appears in one case. Ten instances are taken from the countries the inscriptions of which are published in CIL III. African inscriptions contribute three. Four examples have been found on Italian soil. One use of the cognomen is recorded on stones in England and Spain. The first century instances of Capito have been referred to above. Aprum is the home of a soldier in England during this period. Hadrumetum is recorded as the birthplace of C. Iulius Capito. In this inscription the reading Capito (Bull. Archeol. 1905 p. 235) is a correction for Cupitus, the former reading (VIII 18068). A. Considius Capito records his lineage to the second generation. The inscription was cut later than the reign of Trajan.

\section{Diminutives Used as Cognomina}

Cognomina in the form of diminutives appear among the names of soldiers in the following words:

$\begin{array}{llll}\text { Auricullus } & \text { Gemellus } & \text { Nampulus } & \text { Rixula } \\ \text { Antulus } & \text { Gudullus } & \text { Natulus } & \text { Satullus } \\ \text { Buculus } & \text { Homullus } & \text { Nigel(I)io } & \text { Socellus } \\ \text { Capreolus } & \text { Omuncio } & \text { Novellus } & \text { Tertiolus } \\ \text { Castellus } & \text { Lugudunolus } & \text { Paterculus } & \text { Tertullus } \\ \text { Catulus } & \text { Lupulus } & \text { Porcellus } & \text { Titullus } \\ \text { Cicatricula } & \text { Macellus } & \text { Primul(l)us } & \text { Ursulus } \\ \text { Datullus } & \text { Marcellus } & \text { Proculus } & \text { Vernuleus } \\ \text { Eppillus } & \text { Marculus } & \text { Quintilus } & \text { Vindilus } \\ \text { Fabullus } & \text { Masculus } & \text { Quintulus } & \\ \text { Faustiolus } & \text { Mustiolus } & \text { Regulus } & \end{array}$

The diminutives from noun stems have been mentioned in the preceeding section. The following are diminutives from nomina: Antulus (from Antius), Eppilus (from Eppius), Fabullus (from Fabius), Mustiolus (perhaps from Mustius or of Greek origin). Names formed on adjectives stems are Datullus, Faustiolus, Gemellus, Macellus, Mascellio, Masculus, Nigellio, Novellus, Primul(l)us, Quintilus, Quintulus, Satullus, Tertiolus, and Tertullus. Gudullus and Nampulus are the diminutive forms of two Punic names. Marculus and Titullus are diminu- 
tives formed from the praenomina Marcus and Titus. Marcellus and Proculus are the cognomina in this section most frequently found and these have been discussed in Chap. I. For Vindilus vid. Cognomina of Celtic origin, perhaps from Vindicatus. Lugudunolus is the only diminutive form in a cognomen referring to the name of a town. In the name Auricullus the reading of the stone is not beyond question.

The distribution of these diminutive forms in the several provinces corresponds closely to the general proportional division of all the cognomina in this collection. Names which appear in the first century are Buculus, Castellus, Cicatricula, Fabullus, Lugudunolus, Mustiolus, and Tertiolus. Diminutives ending in -io are Omuncio, Mascellio, and Nigellio.

Apart from Marcellus and Proculus, which though diminutive in form owe their popularity to other reasons, Gemellus is the most common cognomen among the diminutives. Fifteen examples have been collected and one case of the spelling Gemelus. Seven instances have been taken from names in Africa. Ammaedara, Cirta, Thysdrus, and the camp are the homes of five men bearing this cognomen. M. Numisius Gemelus is possibly the same man as M. Numisius Gemellus on another stone. Three papyri from Egypt have preserved soldiers' names with the cognomen Gemellus. The men named in these were in service between the years 95 and 140. Syria and Moesia are localities in which the name Gemellus has been found.

Four of the five cognomina ending in -olus are found in names in Africa, Faustiolus, Lugudunolus, Mustiolus, and Tertiolus. Cf. Cognomina ending in -osus.

\section{Praenomina Used as Cognomina}

(On praenomina in Roman names vid. Schneider, Beiträge zur Kenntniss der römischen Personennamen). Gaius (Caius), Lucius, Marcus, and Titus which are usually praenomina appear also as cognomina in several names. Gaius has been noted in the inscriptions from Lambaesis later than the reign of Hadrian, and in Moesia probably not earlier than the principate of Marcus Aurelius. Four inscriptions containing legionary names preserve the cognomen Caius; two are later than the first century and two can be dated about the year 220. Lucius is the cog- 
nomen in twelve names and all the dated instances are later than the first century. Savaria is the home of $T$. Cervonius Lucius, a centurion at Ancrya in the XVI Flavia. Tib. Claudius Lucius at Lambaesis indicates Philadelphia as his birth-place. The sixteen cases of the cognomen Marcus have already been commented on in Chap. I. These too are probably later than the first century. Titus as a cognomen is represented by five examples. The known dates of inscriptions preserving this cognomen are in the second and third centuries.

The numeral adjectives Primus, Secundus, Tertius, and Sextus were employed as praenomina at one time. The use of Sextus as a praenomen is probably more common than as a cognomen. The other three have been discussed in Chap. I. Praenomina of the early period which became cognomina under the Empire are Agrippa, Postumus, Proculus, Salvius (note the name Salvius Febranus Baculus borne by a centurion of the XXth legion at the beginning of the first century), Tullus, and Vibius. Tiberius has not been found as a cognomen.

\section{Cognomina Connected with the Names of Divinities}

The cognomina in names of men enrolled in the legions which show connection with the names of divinities are the following:

$\begin{array}{llll}\text { Apolinaris } & \text { Ascla } & \text { Iovinus } & \text { Salutaris } \\ \text { Apolinarius } & \text { Asclepiades } & \text { Liberalis } & \text { Saturnalis } \\ \text { Apollinaris } & \text { Asclepiodorus } & \text { Martialis } & \text { Saturnilus } \\ \text { Apollodorus } & \text { Bacchius } & \text { Martis } & \text { Saturninus } \\ \text { Apollonius } & \text { Castor } & \text { Mercurialis } & \text { Saturnus } \\ \text { Apollophanes } & \text { Cerealis } & \text { Minervalis } & \text { Terminalis } \\ \text { Apollos } & \text { Cerialis } & \text { Neptunalis } & \text { Vestalis } \\ \text { Apulinaris } & \text { Hermes } & \text { Nereus } & \\ \text { Apulonius } & \text { Ianuarius } & \text { Sabasianus } & \end{array}$

Ianuarius, Martialis, and Saturninus are the most frequently used of this group of names. These are discussed in Chap. I. Further comment on the significance of the widespread use of these three names in Africa will be found in Chap. III. The Cognomina of African Legionaries. Asclepiades, Cerialis, Liberalis, Martialis, and Saturninus have been found in inscriptions of the first century. Several of these name are noted in the section dealing with names referring to birthdays. The Greek 
name of the divinity is retained in names referring to Apollo, Asclepius, Bacchus, Hermes, and Nereus.

The remaining gods are Roman, except that Sabasianus refers to a Phrygian divinity Ceres, Minerva, and Vesta are the female divinities to receive mention in the names of legionaries The adjective Salutaris may contain a reference to the personification of Salus. For Saturus consult Saturninus in Chap. I.

\section{Names of Emperors Used as Cognomina}

The following names which are chiefly known to us as the names of Emperors are also found in use as the cognomina of men in the legions; Antoninus, Augustus, Aurelius, Claudius, Com(m)odus, Domitius, Nero, Nerva, Otho, and Septimius. Antoninus is the most commonly used and has been discussed in Chap. I. Aurelius, Claudius, Domitius, and Septimius are usually nomina, vid. Chapter III, Imperial Nomina. As cognomina their use is certainly later than the first century-Aurelius and Septimius can be dated in the third century. Tiberius has not been found in the names of soldiers as a cognomen. The single instance of Nerva is dated in the year 70. The only example of the name Otho belongs to the period before the reign of Claudius. Nero appears in the name L. Ulpius Nero natus Berito borne by a veteran at Lambaesis. Com(m)odus is found at the same place, the cognomen of a man born in camp. Augustus is represented in the names of two legionaries in service later than the first century.

Well-known Cognomina at Rome which are Found in the . Names of Legionaries

In the names of Roman legionaries there are found many instances of the use of cognomina which are well-known to us from their designation of prominent persons. Some of these names, as we know, came to be regarded as typifying a man of a certain character. Sulla seems to have been such a name. It is not impossible that other names like Crassus, Cato, or Varro were given to men for similar reasons. Our ignorance of the actual circumstances under which these cognomina were bestowed forbids anything more than idle speculation in regard to their applicability to the character of the men who bore them. 
The following list presents the names of this sort.

$\begin{array}{llll}\text { Agrippa } & \text { Farsuleus } & \text { Naso } & \text { Scaeva } \\ \text { Bassus } & \text { Galba } & \text { Nero } & \text { Scipio } \\ \text { Caesernus } & \text { Glabrio } & \text { Otho } & \text { Seneca } \\ \text { Cato } & \text { Horte(n)sis } & \text { Pedo } & \text { Sulla } \\ \text { Cinna } & \text { Lucillus } & \text { Pansa } & \text { (Silla) } \\ \text { Cossutus } & \text { Lucullus } & \text { Plancus } & \text { Varro } \\ \text { Cotta } & \text { Maro } & \text { Plotus } & \text { Varus } \\ \text { Crassus } & \text { Messalla } & \text { Pollio } & \text { Veranus } \\ \text { Fabullus } & \text { Metelus } & \text { Porcio } & \text { Vetulenus }\end{array}$

This list might be extended by the addition of such names as Capito, Fronto, Proculus, and others, but the cognomina for which this section was designed are those which have no apparent connection with any of the sections which precede this. Bassus is the cognomen most commonly used, vid. discussion of these instances in Chap. I. Caesernus, Cossutus, Farsuleus, and Plotus are ordinarily nomina ending in -ius. These then may be joined to the list of nomina which is given under the heading of Cognomina Ending in -ius.

The supernomen Caligatus which accompanies the cognomen Cato is discussed in Chapter III, Double Cognomina.

\section{Cognomina Ending in -A}

The cognomina which end in -a number fifty-four, involving ninety-one names, and are as follows:

$\begin{array}{llll}\text { Agricola } & \text { Curia } & \text { Mica } & \text { Sera } \\ \text { Agrippa } & \text { Curta } & \text { Mucatra } & \text { Silla } \\ \text { Andra } & \text { Diza } & \text { Nerva } & \text { Sinna } \\ \text { Aquila } & \text { Dizza } & \text { Nimmira } & \text { Sita } \\ \text { Arpocra } & \text { Drigissa } & \text { Nocina } & \text { Soteria } \\ \text { Ascla } & \text { Fana } & \text { Pansa } & \text { Stella } \\ \text { Atta } & \text { Galba } & \text { Papia } & \text { Sulla } \\ \text { Ballista } & \text { Gerula } & \text { Parra } & \text { Sura } \\ \text { Calla } & \text { Geta } & \text { Rixula } & \text { Tara } \\ \text { Cicatricula } & \text { Heracla } & \text { Salica } & \text { Tarsa } \\ \text { Cinna } & \text { Heraclida } & \text { Sausa } & \text { Vala } \\ \text { Coma } & \text { Mangala } & \text { Scaena } & \text { Vepitta } \\ \text { Costa } & \text { Messalla } & \text { Scaeva } & \text { Verna } \\ \text { Cotta } & \text { Mestula } & \text { Seneca } & \end{array}$

Of this number the following names are well-known cognomina 
among Roman families: Agricola, Agrippa, Cinna, Cotta; Galba, Messalla, Nerva, Scaeva, and Sulla. Pansa and Parra are common names in Etruria and seem to have originated there. Papia is perhaps formed from the nomen Papius. The following are nouns; Aquila, Ballista, Cicatricula, Mica, Rixula, Scaena, Sera, Stella, and Verna. Names in this group of Greek origin are Arpocra, Ascla, Coma, Heracla, Heraclida, and Soteria. Names of Thracian origin which end in -a are Diza, Dizza, Drigissa, Mucatra, Sita, and Tarsa. The following are of Celtic origin: Atta, Calla, Nocina, Salica, and Vepitta. Curia and Curta, words of Celtic origin, are place names used as cognomina. Geta is a cognomen which contains a reference to the original home of the soldier who bears it. The same is probably true of the word Sura. Sausa is puzzling and perhaps is to be connected with the river Sau. Vala is a name of Arabic origin. Andra may be a Thracian name. Nimmira is possibly a native African word. Costa, the reading of the stone, has been restored as Constans. The following are of doubtful origin: Fana, Gerula (cf. Gerulata, Holder s. v. Altcelt. Sprachsch.), Mangala (cf. Nimmira above), Mestula, and Sinna.

\section{Cognomina Ending in -anus}

The thirty cognomina which end in -anus have been separated from those ending in -ianus; vid. next section. These are:

$\begin{array}{llll}\text { Africanus } & \text { Easuctanus } & \text { Leuganus } & \text { Soranus } \\ \text { Albanus } & \text { Firmanus } & \text { Lucanus } & \text { Urbanus } \\ \text { Auluzanus } & \text { Galicanus } & \text { Montanus } & \text { Veranus } \\ \text { Bellicanus } & \text { Germanus } & \text { Muntanus } & \text { Veteranus } \\ \text { Campanus } & \text { Herculanus } & \text { Proculeanus } & \text { Vicanus } \\ \text { Catanus } & \text { Hispanus } & \text { Romanus } & \text { Violanus } \\ \text { Cattanus } & \text { Ispanus } & \text { Saturnanus } & \\ \text { Dazanus } & \text { Iulanus } & \text { Silvanus } & \end{array}$

Several adjectives with geographical or racial significance end in -anus: viz., Africanus, Albanus, Campanus, Galicanus, Germanus, Hispanus, Ispanus, Lucanus, Romanus, and Soranus. Other adjectives which were also mentioned under this heading are Montanus, Muntanus, Silvanus, Urbanus, and Vicanus. Bellicanus is formed from the adjective bellicus. (Bellicianus is also found.) Proculeanus is connected with the well-known cognomen Proculus. Iulanus has been considered an engraver's 
error for Iulianus. Saturnanus is evidently a variant form of the common name Saturninus. Firmanus corresponds in a similar way to Firminus. Veteranus is a noun used as a cognomen. (Consult the section devoted to nouns for other instances of words denoting military offices used as cognomina.) Herculanus is a name of Greek origin. Leuganus and Violanus, possibly also Catanus and Cattanus, are Celtic names. Auluzanus is Thracian in origin, and perhaps Dazanus is to be assigned to the same source. For Easuctanus vid. reference under Cognomina of Punic origin. Veranus is classed among the cognomina well-known at Rome. Germanus and Silvanus are the names of this group which have been found frequently enough to class them among the popular cognomina, vid. Chapter I.

\section{Cognomina Ending in -ianus}

Cognomina which end in -ianus are found in the present collection to the number of two hundred and thirty-one, involving six hundred and twelve names. For convenience in reference these are subdivided into three classes. The first list contains such names as are formed on adjective stems, e. g., Acutianus from acutus, Iustianus from iustus and so on.

$\begin{array}{llll}\text { Acutianus } & \text { Euticianus } & \text { Iustianus } & \text { Quintil(1)ianus } \\ \text { Amandianus } & \text { Faustianus } & \text { Maximianus } & \text { Rogatianus } \\ \text { Atticianus } & \text { Faustinianus } & \text { Nigrianus } & \text { Sabinianus } \\ \text { Avitianus } & \text { Felicianus } & \text { Nobilianus } & \text { Secundianus } \\ \text { Bellicianus } & \text { Festianus } & \text { Pacatianus } & \text { Severianus } \\ \text { Campanianus } & \text { Finitianus } & \text { Paternianus } & \text { Sexstianus } \\ \text { Candidianus } & \text { Flaccianus } & \text { Peregrinianus } & \text { Sextianus } \\ \text { Celerianus } & \text { Firmianus } & \text { Pervincianus } & \text { Successianus } \\ \text { Concessianus } & \text { Firminianus } & \text { Primianus } & \text { Superianus } \\ \text { Crescentianus } & \text { Florianus } & \text { Primicianus } & \text { Tacitianus } \\ \text { Cupitianus } & \text { Fortunatianus } & \text { Priscianus } & \text { Tertianus } \\ \text { Datianus } & \text { Fuscianus } & \text { Priscillianus } & \text { Tertullianus } \\ \text { Decuminianus } & \text { Gemellianus } & \text { Probianus } & \text { Valentianus } \\ \text { Dextrianus } & \text { Geminianus } & \text { Pudentianus } & \text { Vetustianus } \\ \text { Donatianus } & \text { Gratianus } & \text { Quintianus } & \text { Vitalianus } \\ \text { Eutichianus } & \text { Honoratianus } & \text { Pintianus } & \end{array}$

The second and most numerous group consists of cognomina formed from nomina, e. g., Aemilianus from Aemilius, Sittianus from Sittius. 


\begin{tabular}{|c|c|c|c|}
\hline Acilianus & Cattianus & Maecianus & Rutilianus \\
\hline Aelianus & Cirrenianus & Magnianus & Sallubianus \\
\hline Aemilianus & Claudianus & Maianus & Sallustianus \\
\hline Albucianus & Cornelianus & Manlianus & Salvianus \\
\hline Ambrelianus & Deccianus & Marcianus & Sedianus \\
\hline Annianus & Decianus & Marinianus & Sempronianus \\
\hline Antonianus & Dentilianus & Martianus & Sennianus \\
\hline Appianus & Domitianus & Martinianus & Sentianus \\
\hline Apronianus & Egnatianus & Marullianus & Seppianus \\
\hline Arellianus & Egrilianus & Messianus & Sertorianus \\
\hline 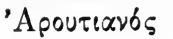 & Epianus & $\mathrm{M} \varepsilon \sigma \tau \rho เ \alpha \nu \delta \varsigma$ & Servianus \\
\hline Arrianus & Fabianus & Minucianus & Sittianus \\
\hline Arruntianus & Fabricianus & Modianus & Sossianus \\
\hline Atil(l)ianus & Fabullianus & Mucianus & Statilianus \\
\hline Attianus & Fadianus & Munatianus & Sulpicianus \\
\hline Aufidianus & Farianus & Mussianus & Tartianus \\
\hline Aurelianus & Flavianus & Nonianus & Terentianus \\
\hline Avellianus & Furennianus & Novellianus & Trebonianus \\
\hline Balerianus & Gargilianus & Novianus & Tuttianus \\
\hline Caecilianus & Herenianus & Numerianus & Ulpianus \\
\hline Caecinianus & Herennianus & Octavianus & Valerianus \\
\hline Caesennianus & Horatianus & Ostilianus & Varianus \\
\hline Calianus & Oratianus & Paccianus & Vereianus \\
\hline Calpurnianus & Iulianus & Petianus & Vettianus \\
\hline Carianus & Iunianus & Pompeianus & Vibianus \\
\hline Carpianus & Licinianus & Pontianus & Virianus \\
\hline 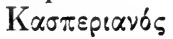 & Livianus & Pomponianus & Vultilianus \\
\hline Cassianus & Lucianus & Porcianus & \\
\hline . & Macrianus & Roscrianus & \\
\hline
\end{tabular}

The third class is made up of names formed by -ianus to noun stems, e.g., Nepotianus from nepos; to words of foreign origin, e. g. Sabasianus; to praenomina, e. g. Titianus from Titus; to a cognomen, e. g., Bassianus from Bassus, etc.

\begin{tabular}{|c|c|c|}
\hline Agrippianus & Eufretianus & Meridianus \\
\hline Ammonianus & Euphemianus & Negotianus \\
\hline Amyntianus & Frontinianus & Nepotianus \\
\hline Antiochianus & Frontonianus & Passerianus \\
\hline Atreccesianus & Gaianus & Passinianus \\
\hline Augurianus & Graesianus & Phillippianus \\
\hline Bassianus & Hermianus & Plancianus \\
\hline Bruttianus & Hilarianus & Plotianus \\
\hline Chaeremonianus & Iamianus & Proclianus \\
\hline Charitonianus & Iassianus & Proculeianus \\
\hline Cilicianus & Leontianus & Regillianus \\
\hline Cretianus & Longinianus & Regulianus \\
\hline Dasianus & Lupianus & Sabasianus \\
\hline Demetrianus & Melcidianus & Saburianus \\
\hline Epaphroditianus & Menecratianus & Safidianus \\
\hline
\end{tabular}

Sarnianus

Seccianus

Senecianus

Sigillianus

Socissianus

Telesphorianus

Throphimianus

Tiberianus

Titianus

Tychianus

Umbrianus

Ursianus

Ursinianus

Victorianus 
Cognomina ending in -ianus are found in all parts of the Roman empire. The names which are used most frequently are Iulianus, Marcianus, Rogatianus, and Valerianus. These have been discussed in Chap. I. Rogatianus has been noted in African inscriptions only.

The development of cognomina which end in -ianus in the names of legionaries is for the most part later than the first century. The great majority of the names can be dated and only a comparatively small number belong to the first century. All the names in the first list given above are probably later than the first century. The cognomen Marullianus was borne by a soldier in the IV Macedonica before the reign of Vespasian, and the home of this man was Narbo. Valerianus is the cognomen of a soldier of the XI Claudia in Dalmatia in the interval between the year 42 and the reign of Vespasian. A veteran of the III Augusta in Africa in the year 86 bore the cognomen Paccianus. Tiberiarus is preserved in a Greek inscription in Egypt as the cognomen of a centurion serving in the year 8384. Octavianus is recorded on a papyrus from the same province as the cognomen of a soldier who was in service in the year 90. Aelianus, Flavianus, and Iulianus are the cognomina of centurions of the XV Apollinaris at Carnuntum in the first century. Aelianus is borne by a man whose son of eight years is recorded as having come from Aquileia. The other two names are not preserved entire on the stones, but are the restored readings of editors.

An inscription from Iconium in Syria would furnish the earliest example of a cognomen ending in -ianus, if the restoration were certain. P. Mestrius P. f. Maec is the reading of the stone and in a Greek version which accompaies the Latin the word following the letter " $f$ " has two more letters making

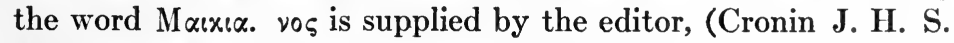
XXII, 1902, p. 356). Inasmuch as the legion is cited with only the numeral (?) and another veteran is recorded without a cognomen on this stone, it may be possible that we have here not a cognomen, but the name of the tribe to which P. Mestrius belonged.

In the early second century cognomina which end in -ianus are found with growing frequency; they reach their greatest popularity in the early third century. 
For the supernomen in the name Aurelius Secundianus qui et Itrius vid. Chap. III, Double Cognomina.

\section{Cognomina Ending in -inus}

The ending -inus is found in one hundred and twenty-eight cognomina involving seven hundred and sixty-five names. These cognomina are listed under several subheadings. Considerably more than half of the total number of names are noted under eight cognomina which have already been discussed in Chap. I: viz., Antoninus, Longinus, Marcellinus, Rufinus, Sabinus, Saturninus, Valentinus, and Victorinus.

Cognomina formed by adding the ending -inus to adjectival stems appear most frequently, e. g., Clementinus from clemens, Ingenuinus from ingenuus. Nearly half of this group are formed in this way. These are:

$\begin{array}{llll}\text { Albinus } & \text { Deciminus } & \text { Materninus } & \text { Rufinus } \\ \text { Amandinus } & \text { Faustinus } & \text { Max(s)iminus } & \text { Sanctinus } \\ \text { Auctinus } & \text { Firminus } & \text { Memorinus } & \text { Septiminus } \\ \text { Caelestinus } & \text { Flavinus } & \text { Nigrinus } & \text { Severinus } \\ \text { Celestinus } & \text { Florinus } & \text { Onestinus } & \text { Sextinus } \\ \text { Candidinus } & \text { Fuscinus } & \text { Paetinus } & \text { Solinus } \\ \text { Carinus } & \text { Gemellinus } & \text { Patruinus } & \text { Tertinus } \\ \text { Castinus } & \text { Gratinus } & \text { Paulinus } & \text { Tertullinus } \\ \text { Celerinus } & \text { Ingenuinus } & \text { Placidinus } & \text { Urbicinus } \\ \text { Celsinus } & \text { Iustinus } & \text { Potentinus } & \text { Valentinus } \\ \text { Certinus } & \text { Laetinus } & \text { Priscinus } & \text { Valetinus } \\ \text { Clementinus } & \text { Laevinus } & \text { Probinus } & \text { Verinus } \\ \text { Constantinus } & \text { Longinus } & \text { Quartinus } & \text { Vetustinus } \\ \text { Crescentinus } & \text { Macrinus } & \text { Quintinus } & \\ \text { Crispinus } & \text { Masculinus } & \text { Repentinus } & \end{array}$

The ending is added to place-names to form the following cognomina:

$\begin{array}{llll}\text { Aretinus } & \text { Caudinus } & \text { Laurentinus } & \text { Saloninus } \\ \text { Atticinus } & \text { Faventinus } & \text { Lavinus } & \text { Telesinus } \\ \text { Aventinus } & \text { Florentinus } & \text { Maurinus } & \text { Tevestinus } \\ \text { Camerinus } & \text { Helvinus } & \text { Olympilinus } & \text { Thevestinus } \\ \text { Capetolinus } & \text { Iadestinus } & \text { Praenestinus } & \\ \text { Capitolinus } & \text { Latinus } & \text { Sabinus } & \end{array}$

Noun stems with the addition of -inus serve as cognomina in several cases. 


$\begin{array}{llll}\text { Aprinus } & \text { Capratinus } & \text { Reginus } & \text { Viatorinus } \\ \text { Aquilinus } & \text { Censorinus } & \text { Sementinus } & \text { Victorinus } \\ \text { Augurinus } & \text { Equinus } & \text { Silvinus } & \\ \text { Kalandinus } & \text { Frontinus } & \text { Taurinus } & \\ \text { Kalendinus } & \text { Piscinus } & \text { Ursinus } & \end{array}$

The addition of -inus to certain well-known cognomina is observed in ten names; Agrip(p)inus, Antullinus, Bassinus, Catullinus, Marcellnus, Messallinus, Nervinus, Proclinus, and Proculinus. Tiberinus shows the same process at work with a praenomen. Antoninus, Aponinus, Maicinus, Martinus, and Valerinus are formed from nomina by the addition of this suffix. Iovinus and Saturninus are related to the names of divinities. Calinus and Charinus are of Greek origin. Agrinus, Nervinus, and Reburrinus are formed from Celtic roots. The following names are of uncertain origin; Cittinus, Colinus, Iullinus, Rosinus, and Stiminus. Geminus, Marinus, and Peregrinus are adjectives taken directly into use as cognomina.

Cognomina ending in -inus are found in the names of legionaries somewhat earlier than those ending in -ianus as far as one may judge from a comparison of the instances which can be dated in the first century. Aquilinus is found in the name of a soldier who served before the year 42. Stiminus is the cognomen of a centurion in Palestine in the year 68. Colinus is the cognomen of a soldier born at Eporedia who served in the XVth legion before the reign of Vespasian. Firminus and Flavinus are borne by men enrolled in the X Gemina while in Spain before the year 70. M. Iulius Marinus whose home is Forum Iulii was a soldier at Mainz also before the year 70. Maurinus belongs to this early period. Iadestinus is the cognomen of a soldier whose home is Iader serving at Mainz in the interval between the years 70 and 100. Other cognomina with this suffix which can be assigned to the first century are Clementinus, Longinus, Macrinus, Marinus, Maxsiminus, Rufinus, Sabinus, Saturninus (seven instances), Valentinus, and Victorinus. For comment on the name Aurelius qui et Septimius Constantinus vid. Chap. III, Double Cognomina.

\section{Cognomina Ending in -ius}

Cognomina which end in -ius in this collection number one hundred and thirty and include a total of three hundred and 
twenty-two names. For convenience in reference these cognomina have been subdivided. The first group consists of nomina of Roman gentes which are used as cognomina.

$\begin{array}{llll}\text { Accius } & \text { Dasius } & \text { Lucilius } & \text { Seius } \\ \text { Acculeius } & \text { Dassius } & \text { Macrinius } & \text { Septimius } \\ \text { Antonius } & \text { Dasumius } & \text { Macrobius } & \text { Servilius } \\ \text { Atilius } & \text { Domitius } & \text { Magius } & \text { Sextilius } \\ \text { Attius } & \text { Egnatius } & \text { Magnius } & \text { Sossius } \\ \text { Aufidius } & \text { Eppanius } & \text { Marius } & \text { Staius } \\ \text { Aurelius } & \text { Erennius } & \text { Martius } & \text { Statilius } \\ \text { Avillius } & \text { Fabius } & \text { Messius } & \text { Tannonius } \\ \text { Barbius } & \text { Fabricius } & \text { Mestrius } & \text { Terentius } \\ \text { Bebius } & \text { Fanius } & \text { Minutius } & \text { Trinius } \\ \text { Blasius } & \text { Flavius } & \text { Modius } & \text { Tullius } \\ \text { Caecilius } & \text { Fundanius } & \text { Octavius } & \text { Tuttius } \\ \text { Caelius } & \text { Gallonius } & \text { Opsilius } & \text { Valerius } \\ \text { Carius } & \text { Gellius } & \text { Pavius } & \text { Valius } \\ \text { Cassius } & \text { Gessius } & \text { Pontius } & \text { Veratius } \\ \text { Casius } & \text { Horatius } & \text { Pullaenius } & \text { Vettius } \\ \text { Castricius } & \text { Iulius } & \text { Roscius } & \text { Vibius } \\ \text { Cerfonius } & \text { Iunius } & \text { Rulius } & \text { Victorius } \\ \text { Claudius } & \text { Licinius } & \text { Saenius } & \text { Vincentius } \\ \text { Cocaius } & \text { Lucius } & \text { Salvius } & \text { Volusius }\end{array}$

The practice of using nomina as cognomina is largely confined to the later period of the Empire. The only nomina so used which can be dated in the first century are Accius, Fabius, and Trinius. Trinius is the name of a centurion in Dalmatia before the year 42 and it is possible that this is a true nomen and not a cognomen. The name on the stone is in the genitive case, Trini. Accius is the cognomen of a soldier in Italy perhaps before the year 89. Fabius appears in the name L. Fabius Fab(i)us borne by a soldier whose home is Nertobriga serving before the reign of Vespasian. This is the only case of a name among the soldiers in which the nomen and cognomen seem to be identical. (For instances of close similarity between nomen and cognomen vid. Chap. III.) Acculeius, Eppanius, Fanius, and Rulius are the cognomina of soldiers in Egypt before the year 108. (The reading of Wessely has been adopted in the names from this papyrus.) Saenius is the name of a centurion in service during the period between the reigns of Vespasian and Trajan.

The nomen most commonly employed as a cognomen is Val- 
erius. Sixteen examples have been collected from the names of legionaries.

Attention may be called to the name Dasius or Dassius. (Vid. Pauly-Wissowa, s. v., Schulze Lat. Eigennamen p. 44, note 5, p. 39, note 1, \& Index.) Four of the six cases of Dassius appear in a military list in Moesia cut in the year 195. Dasumius belongs to the same root. Cf. Dazanus, and Dasianus. In the inscription noted above the name Mestrius is recorded three times and another instance is found in the name of a veteran in the same province and legion (VII Claudia). Only one other case of Mestrius has been found and this is also preserved in the Danube region.

The second group of cognomina ending in -ius contains names of various kinds, as follows:

$\begin{array}{llll}\text { Ammausius } & \text { Caius } & \text { Gumasius } & \text { Placidinius } \\ \text { Ammonius } & \text { Caprarius } & \text { Gusorius } & \text { Primigenius } \\ \text { Anatolius } & \text { Catervarius } & \text { Guzabius } & \text { Primitius } \\ \text { Apolinarius } & \text { Ceprucius } & \text { Hellenius } & \text { Sabius } \\ \text { Apollonius } & \text { Congius } & \text { Heraclius } & \text { Sarmatius } \\ \text { Apricius } & \text { Curtavius } & \text { Ianuarius } & \text { Silamius } \\ \text { Apulonius } & \text { Demetrius } & \text { Matthaius } & \text { Siliquarius } \\ \text { Ascanius } & \text { Dionisius } & \text { Mocetius } & \text { Sterceius } \\ \text { Aspadius } & \text { Dionysius } & \text { Mucrubius } & \text { Sudius } \\ \text { Aulucentius } & \text { Doncius } & \text { Numidius } & \text { Tertius } \\ \text { Balius } & \text { Dubius } & \text { Nummenius } & \text { Thubunius } \\ \text { Bienius } & \text { Firmidius } & \text { Pequarius } & \\ \text { Brumasius } & \text { Florius } & \text { Petunnatius } & \\ \text { Buturarius } & \text { Gaius } & \text { Pius } & \end{array}$

In this group the names of Greek origin are Anatolius, Apolinarius, Apollonius, Apulonius, Demetrius, Dionisius or Dionysius, Hellenius, and Heraclius. Celtic in origin are Ammausius, Aspadius, Balius, Bienius (Bienus), Congius, Curtavius, and Mocetius. Aulucentius and Sudius are Thracian names. The following names were found in Africa and if not Punic in origin they are perhaps native names, Buturarius, Mucrubius, Gumasius, Guzabius, and Nummenius. Numidius and Thubunius also from this province indicate the homes of the men who bear them. Ammonius is an Egyptian name. Ascanius seems to be Phrygian in origin. Matthaius is a Semitic name. Doncius and Gusorius are possibly Celtic. Petunnatius and Silamius are of uncertain origin. 
Adjectives ending in -ius serve as cognomina in the words Catervarius, Dubius, Ianuarius, Pius, Primigenius, Sterceius, and Tertius. The following are from adjectival stems: Firmidius, Florius, Placidinius (probably an engraver's error for Placidinus), and Primitius. Siliquarius and Pequarius are nouns ending in -ius. Apricius, Brumasius, and Caprarius are formations from nouns. Sabius is doubtless an error for Sabinus. Caius or Gaius and Lucius are praenomina used as cognomina. Bienius or probably Bienus (Vid. Holder Altcelt. Sprachsch. Nachträge) is the name of a centurion in service before the reign of Claudius. Ascanius also belongs to this early period. The only other cognomen of this group which can be assigned to the first century is Dubius borne by a soldier whose home is Milan serving during the principate of Domitain. Gusorius is the name of a centurion in Germany in service in the period between the reigns of Vespasian and Trajan. For Tertius and Ianuarius which are most frequently found, vid. Chapter I.

\section{Cognomina Ending In -Lis}

Thirty-seven cognomina which end in -lis appear in the present collection involving two hundred and thirty-two names. The following cognomina constitute this group:

$\begin{array}{llll}\text { Aedilis } & \text { Facilis } & \text { Liberalis } & \text { Saturnalis } \\ \text { Amabilis } & \text { Fatalis } & \text { Martialis } & \text { Senilis } \\ \text { Aeternalis } & \text { Fidelis } & \text { Mercurialis } & \text { Similis } \\ \text { Annalis } & \text { Flaminalis } & \text { Minervalis } & \text { Sodalis } \\ \text { Aprilis } & \text { Genialis } & \text { Mucatralis } & \text { Terminalis } \\ \text { Augustalis } & \text { Gentilis } & \text { Natalis } & \text { Vestalis } \\ \text { Aulutralis } & \text { Gracilis } & \text { Neptunalis } & \text { Virilis } \\ \text { Cerealis } & \text { Hospitalis } & \text { Provincialis } & \text { Vitalis } \\ \text { Cerialis } & \text { Ingenuilis } & \text { Quirinalis } & \text { Vitealis } \\ \text { Civilis } & \text { Iuvenalis } & \text { Reginalis } & \end{array}$

Among this number the names Martialis and Vitalis are employed as cognomina most frequently. These have been discussed in Chap. I. Aulutralis and Mucatralis are of Thracian origin. All the other cognomina are native Latin words. Aedilis, Aprilis, Flaminalis, and Sodalis are nouns. The remaining names are adjectives. A large number of these relate to divinities and birth-days; Cerialis, Liberalis, Martialis, Minervalis, Mercurialis, Neptunalis, Saturnalis, Vestalis, Augus- 
talis, Quirinalis, and Terminalis, Natalis is also a birth-day cognomen. The following adjectives imply the possession of mental or moral qualities; Amabilis, Facilis, Genialis, and Hospitalis. Gracilis, Virilis, and Vitalis contain a reference to physical qualities. Four adjectives have something of a temporal element in them: Aeternalis, Annalis, Iuvenalis, and Senilis. Provincialis carries with it a "local" significance. Gentilis, Ingenuilis, Fatalis, Reginalis, and Similis are adjectives with this suffix not already mentioned in this section.

\section{Cognomina Ending in -o}

Cognomina which end in -o have been noted in one hundred names involving a total of one hundred and ninety-eight instances. The following list presents these names.

\begin{tabular}{llll} 
Aelurio & Domnio & Mommo & Satto \\
Agatho & Dosso & Mucco & Saturio \\
Andio & Fronto & Myro & Saxo \\
Aquilo & Glabrio & Namfamo & Scipio \\
Arimo & Glico & Namphamo & Senecio \\
Aristo & Hilario & Naso & Serapio \\
Artemo & Hispelo & Nerido & Serrapio \\
Athenio & Iunio & Nero & Silo \\
Atto & Laco & Nigellio & Solo \\
Baricio & Lellavvo & Nio & Sorio \\
Bato & Leo & Omuncio & Strabo \\
Baudio & Libo & Otho & Subsio \\
Betto & Longo & Panno & Surio \\
Bito & Lycao & Pedo & Tatulo \\
Britto & Macedo & Plato & Thrupo \\
Bucco & Macro & Polio & Tiro \\
Cabrio & Magio & Pollio & Tucco \\
Calvio & Magnio & Porcio & Turbo \\
Capito & Maro & Pussinio & Ulpro \\
Cato & Mascellio & Quartio & Ursio \\
Cilo & Matto & Restio & Valerio \\
Daizo & Matuco & Rhyto & Vario \\
Diabo & Maximo & Sacco & Varro \\
Dizo, Dizzo & Militio & Samunio & Virilio \\
Domitio & Milo & Sarapio & Vocco \\
& & & \\
\hline
\end{tabular}

The cognomina which are found most frequently are Fronto, vid. Chap. I, and Capito. Names of Greek origin ending in -o are Aelurio, Agatho, Aristo, Artemo, Athenio, Glico, Hilario, Laco, Lycao, Milo, Myro, Nio, Plato, Rhyto, Solo, and Strabo. 
Similar to these are several names which preserve the final

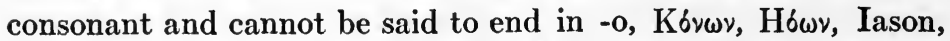

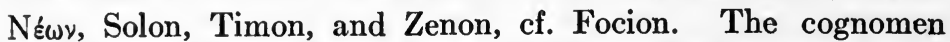
Libo is possibly Greek in origin. Zimmermann (Vid. Bibliography) concludes that the name contains the same stem as libet. Schulze, Lat. Eigennamen, Index s. v. "Unsicher bleibt die gleiche Auffassung für die cognomen Libo." The cognomen Bato according to Kretschmer E.p. 246 is an Illyrican name = "Fürst und B $\alpha \tau \omega \nu$, Fürst der Illyrier. Hierher auch Iulius Betto VI 3333." Zimmermann op. cit. p. 233, Schulze, Lat. Eigennamen p. 32 note 1 . The name Betto mentioned above may be Thracian. It is also cited by Schönfeld ( $V i d$. Bibliography) as a Germanic name. Names which are certainly Thracian are Bito, Daizo, Dizo, and Dizzo. Celtic names in -o are Andio, Cabrio, Matto, Matuco, Mommo, Nerido, Restio, Sacco, Saxo, Sorio, Subsio, Surio, Tatulo, Tucco, and Vocco. Names of Germanic origin are Atto, Baudio, Lellavvo, and Thrupo. Baricio and Namfamo or Namphamo are Punic names. One Egyptian name appears in three forms Sarapio, Serapio, and Serrapio.

Nouns ending in -o employed as cognomina are Aquilo, Bucco, Capito, Cilo, Dosso, Fronto, Leo, Mucco, Naso, Omuncio, Polio, Senecio, Tiro, and Turbo. The following are well-known cognomina in Rome: Cato, Maro (possibly of Celtic origin), Naso, Nero, Otho, Pedo, Pollio, Porcio, Scipio, and Varro. The names Britto, Hispelo, Macedo, and Panno contain a reference to the birth-place of the men who bore them. Glabrio, Macro, and Silo are also mentioned with adjectives denoting physical qualities. Pedo might be included with these. The form Macro may be due to Greek influence.

The following group has been reserved to the end of this section for especial comment because the names which compose it appear to be comic formations in -o. Eighteen of them have been noted in the names of men enrolled in the legions. These are Athenio, Calvio, Domitio, Domnio, Iunio, Longo, Magio, Magnio, Mascellio, Maximo, Militio, Nigel(l)io, Pussinio (connected with pusilio, pusillus), Quartio, Saturio, Ursio, Valerio, Vario, and Virilio. The names Naso, Pedo, and Porcio may have had a similar origin. Ten of these cognomina were found in the Danube provinces. Three can be dated in the year 195, Domitio borne by a veteran from Nicopolis, Magnio borne by 
a veteran from Remesiana (?), and Maximo. Militio and Nigelio are later than the year 170. Pussinio is later than the first century. Athenio, Calvio, Domnio, and Nigellio are found in the Danube region in undated inscriptions. (For Athenio vid. App. Mithr. 59 cited by Kempf, Romanorum Sermonis Castrensis Reliquiae, p. 356). Iunio, a native of Napoca, was at Lambaesis during the principate of Antoninus Pius. Magio and Mascellio were centurions at the same camp in the year 162. Quartio is found in Africa in the second half of the second century and in the early third. Longo is the cognomen of a centurion in Egypt serving before the year 108. This name with Virilio are the earliest cases of names in this group. Virilio is found twice in Germany; one instance is earlier than the reign of Vespasian, the second in the name of a soldier whose home is Milan is possibly in the first century. Saturio is noted on a stone at Mainz. Ursio is found in one name in Italy and again at Lyons.

Names of uncertain derivation are Arimo, Diabo, Samunio, and Ulpro. With the exception of the last which is undated all are later than the year 195 .

Proclion and Viction appear to be formations in -o with the addition of a final consonant in imitation of Greek names. Viction is considered a Celtic name by Holder, vid. section devoted to Cognomina of Celtic origin.

\section{Cognomina Ending in -osus}

(Vid. Mommsen, Cognomina Africana, Ephem. Epig. pp. 520-524). Among the cognomina of legionaries the following have been found ending in -osus, Albosus, Apricosus, Barosus, Bonosus, and Fructuosus. All except Apricosus appear at Lambaesis in Africa. Of these names we know that two are cognomina of men who were born in the African towns of Carthage and Simitthus. On account of the frequency of names with the ending -osus in this province it is very probable that the other two of these names are borne by men who were natives of Africa. Apricosus is the cognomen of a centurion in the II Parthica stationed in the Ager Albanus. All these men having names ending in -osus were in service toward the end of the second century, or during the first half of the third. 


\section{Cognomina Ending in - $\mathrm{x}$}

Thirteen names ending in $-x$ will be found in the alphabetical list of cognomina of men enrolled in the legions. These are Audax, Efficax, Eudox, Farnax, Felix, Ferox, Ieraxs, Pertinax, Simplex, Tenax, Velox, Verax, and Vindex. Three of these are words of Greek origin: viz., Eudox, Farnax, and Ieraxs. The remaining names are of Latin origin and all except Vindex are adjectives. The Greek names have been taken from inscriptions in the Danube provinces. The others are well scattered among the various provinces of the Empire. Felix has been found to be the most commonly used cognomen in the names of soldiers, vid. discussion of Felix in Chap. I. Excepting Simplex, Verax, and the Greek names the cognomina ending in - $\mathrm{x}$ appear to be appropriate ones for men in military service and have been noted with others in the first section of this chapter. Vid. Introductory Note to Alphabetical List.

\section{Cognomina of Arabic Origin}

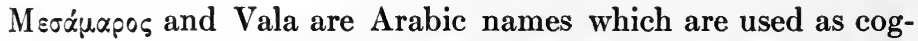
nomina by legionary soldiers. The latter name is borne by a soldier in Germany in the period between the reigns of Ves-

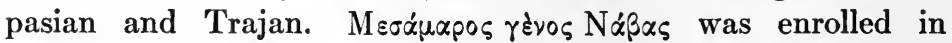
the III Cyrenaica in Arabia after the year 108. The name 'Aousiojos appears as a supernomen with the cognomen Germanus, $q . v$. Chap. I and $c f$. Chap. III, Double Cognomina.

\section{Cognomina of Celtic Origin}

An exhaustive collection of Celtic names has been made by Alfred Holder, Altceltischer Sprachschatz and Nachträge, and that work has been used in making the present classification. Eighty names are represented in the following list:

$\begin{array}{llll}\text { Aludisas } & \text { Attillus } & \text { Caeticcus } & \text { Curtavius } \\ \text { Ammausius } & \text { Atta } & \text { Calenus } & \text { Eppillus } \\ \text { Andiccus } & \text { Atto } & \text { Calla } & \text { Essus } \\ \text { Andio } & \text { Balius } & \text { ?Callus = Gallus? } & \text { Gedus } \\ \text { Annamatus } & \text { Baudio } & \text { Carantus } & \text { Gusorius } \\ \text { Artillus } & \text { Bersimes } & \text { Catullus } & \text { Lavenus } \\ \text { Arusenus } & \text { Bienus } & \text { Celtiber } & \text { Leuganus } \\ \text { Aspadius } & \text { Boniatus } & \text { Comargus } & \text { Maccaus } \\ \text { Atreccesianus } & \text { Bucco } & \text { Condunus } & \text { Magio } \\ \text { Atrectus } & \text { Cadarus } & \text { Cotus } & \text { Manduccus }\end{array}$




$\begin{array}{llll}\text { Mascellio } & \text { Nocina } & \text { Satto } & \text { Tatulo } \\ \text { Matto } & \text { Parasenus } & \text { Saxo } & \text { Tucco } \\ \text { Matuco } & \text { Parra } & \text { Seccianus } & \text { Vepitta } \\ \text { Mocetius } & \text { Pintianus } & \text { Seccus } & \text { Viction } \\ \text { Moenenus } & \text { Reburrinus } & \text { Sorio } & \text { Vindilus } \\ \text { Mommo } & \text { Reburrus } & \text { Stambon } & \text { Violanus } \\ \text { ?Mude(nus?) } & \text { Sacco } & \text { Subsio } & \text { Virilio } \\ \text { Nerido } & \text { Salica } & \text { Sugasis } & \text { Vithannus } \\ \text { Nertus } & \text { Sallubianus } & \text { Surio } & \text { Vitullus } \\ \text { Nervinus } & \text { Sammus } & \text { Tara } & \text { Vocco }\end{array}$

It may prove helpful to make use here of the comments of Holder and others on some of these names: Aludisas, reading corrupt (Holder, Nachträge); Arusenus, vid. Schulze, Lat. Eigennamen, Index s. v.; Atta cf. Festus, Epit. p. 12-13M.; Atto, partly Celtic, partly Germanic; Bienus not Bienius is the reading of Holder, Nachträge; Calenus, Celtic origin not wholly certain; Eppillus "m. cognomen w ebill (an auger, a chisel, the key of a harp)"; Matto, Kosenamen also Greek; Matuco, Kosenamen; "Nervinus von ethnicon Nervius"; Satto partly of Germanic origin; Vindilus ef. Vindillus "kurzname für Vindicatus(?)."

Cognomina which may be Celtic in origin are Agrinus, Cabrio, Cattanus (possibly Catanus), Congius (Congus in Holder, Nachträge), Curia and Curta, place names (cited in Holder with a "?" as to origin), Dioratus (Diorata and Diratus in Holder), Doncius (Donicus and Donicius in Holder), Gainas (Gainia, feminine nomen in Holder, cf. Caina. The stem Gain seems to be Germanic), Gerula (Gerulata in Holder connected with Chertobalos in Pannonia Superior, i. e., Karlburg?), Labrases (in Holder with “?”), Nerva, Pardus, and Sinna. Surus is also considered Celtic by Holder, Tomaschek places it among the Thracian names.

Nearly three-fourths of the Celtic names have been found in the provinces the inscriptions of which are published in volumes III and XIII of the CIL. The remainder, slightly over onefourth, appear in inscriptions found in England, Spain, Africa. and Italy. By far the earliest Celtic name to be found in a military inscription is Cotus, the name of a centurion in Egypt during the principate of Augustus. In Germany the following names belonging to the first century have been noted: Bienus (Bienius), the cognomen of a centurion in service possibly before 
the reign of Claudius, Andiccus, Bucco, Parra (the cognomen of a soldier born at Baeterrae), Sacco (the cognomen of a soldier whose home is Milan), and Virilio-all names of men serving before the year 70. Early names outside of this province are Celtiber in Spain probably before the year 70, Salica, the cognomen of a legionary in England, born at Lyons, shortly after the year 71, Surio which seems to be Celtic rather than Thracian is borne by a soldier, whose home is Caesaraugusta, serving in Dalmatia before the year 70. Examples of Celtic names can be dated as late as the first quarter of the third century. Names which appear as cognomina in more than one instance are Atillus, Reburrinus, Reburrus (Surus), and Virilio. All four examples of the name Reburrus are found in Spanish inscriptions. Besides the towns already mentioned, the following, Ratiaria, Virunum, Iguvium, Cambodunum, Emerita, Verona, Bononia, and Cirta, are the homes of men who have Celtic names.

\section{Cognomina of Egyptian Origin}

The names Ammonius, Ammonianus, Sarapammon, Sarapio, Serapio, Serrapio, and $\Sigma_{0 u \chi} \_\delta \tilde{\alpha}_{\varsigma}$ are Egyptian in origin. Ammonius is found in Egypt in three names, one can be dated in the year 167-8, two in the year 194. One instance is in the name of a man born in Alexandria. Ammonianus is the cognomen of a veteran serving in the year 194, who was born in camp. The stone was found at Alexandria. Sarapio and Serapio appear in six names at Lambaesis. Three instances are in the names of men born in camp, and serving during the reign of Antoninus Pius. One example can be dated in the year 198. Serrapio is found in a name at Rome borne by a man in service after the year 193. Sarapammon is noted in the names of three veterans in the year 194 at Alexandria; two were born in camp, the third at Tani.

$\Sigma$ oux $1 \delta \tilde{\alpha}_{\zeta}$ is perhaps as late as the fourth century in Egypt.

\section{Cognomina of Germanic Origin}

(Vid. Schönfeld, Wörterbuch der altgermanischen Personenund Völkernamen.) The following are considered Germanic by Schönfeld Atto, "teil germanisch" (vid. Celtic section), Baudio (also in list of Celtic names), Lellavvo "wol germanisch," Thrupo (Schönfeld sub Trupo, perhaps Germanic though 
by no means certain), and Ulfus. The name Ulfus is the only name of this group to be dated with certainty and can be assigned to the reign of Alexander Severus (222-235).

\section{Cognomina of Greek Origin}

The cognomina of Greek origin in the names of Roman legionaries number one hundred and ninety-two, involving three hundred and twenty-eight names. The following list presents these:

\begin{tabular}{|c|c|c|c|}
\hline Achilleus & Asmenus & Difilus & Heraclida \\
\hline Aelurio & Atalus & Diogenes & Heraclius \\
\hline Agatho & Atticianus & Diomedes & Herculanus \\
\hline Agathocles & Atticinus & Diodorus & Hermes \\
\hline Alexander & Atticus & Dionisius & Hermias \\
\hline Alexandrus & Athenio & Dionysius & Hermianus \\
\hline Amarantus & Bacchius & Dioscorus & Herodes \\
\hline Amyntianus & Basilides & Eleuther & 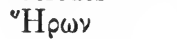 \\
\hline Anatolius & Berulus & Emporus & Hilarianus \\
\hline Andromacus & Burrus & Enthimus & Hilario \\
\hline Andronicus & Caeneus & Epaprhoditianus & Hilarus \\
\hline Anicetus & Calamus & Epaproditus & Hymnus \\
\hline Antigonus & Calicles & 'E $\pi i x \tau \eta \tau \circ 5$ & Iason \\
\hline Antiochianus & Calinus & Esper & Ieraxs \\
\hline Antiochus & Callimachus & Eúonuos & Ischyrion \\
\hline Apelles & Callisthenes & Eugenus & Isidorus \\
\hline Apolinaris & Callistratus & Euphemianus & Laco \\
\hline Apolinarius & Carpophorus & Euphrosynus & Laenas \\
\hline Apollinaris & Chaeremonianus & Eutrofus & Laficus \\
\hline Apollodorus & Chaireas & Eutichianus & Leonides \\
\hline Apollonius & Charinus & Euticianus & Libo \\
\hline Apollophanes & Charitonianus & Eutyches & Lisimacus \\
\hline Apollos & Cleonicus & Farnax & Lusimacus \\
\hline Apolodorus & Coma & Filiscus & Lycao \\
\hline Apulinaris & Comastos & Focion & Lycus \\
\hline Apulonius & 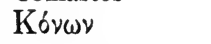 & Glaucus & Lysias \\
\hline Aratus & Corus & Glico & Maccus \\
\hline Archelaus & Crysomallus & Hadrias & Melissus \\
\hline Aristaenetus & Daphnus & Haniochus & Menander \\
\hline Aristides & Dardanus & Arpocra & Menecratianus \\
\hline Aristo & Deiotarus & Hebenus & Menilaeus \\
\hline Artemidorus & Demetrianus & Helenus & Metrodorus \\
\hline Artemo & Demetrius & Hellenius & Milo \\
\hline Asclepiades & $\Delta \eta \mu o x p \alpha ́ \tau \eta s$ & Heliodorus & Monimus \\
\hline Asclepiodorus & Demostenes & Heracla & Moschus \\
\hline Ascla & Didymus & Heracles & Mustiolus? \\
\hline
\end{tabular}




\begin{tabular}{|c|c|c|c|}
\hline Myro & Patroclus & Solo & Theopompus \\
\hline Neptolemus & Phileterus & Solon & Timon \\
\hline Nereus & $\Phi(\lambda เ v \circ \varsigma$ & Sophaenetus & Timotheus \\
\hline Nestor & Philippianus & Sosigenes & Threptus \\
\hline Naestor & Philippus & Sotas & Throphimianus \\
\hline Nicomachus & Plato & Soter & Trofimas \\
\hline Nicostratus & Protus & Soteria & Troilus \\
\hline Nio & Ptoleus & Strabo & Tychianus \\
\hline 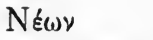 & Ptolmeus & Telesphorianus & Tyrannus \\
\hline Olympilinus & Pyrrus & Thalamus & Zenon \\
\hline 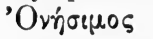 & Rhyto & Theodorus & Zenophilus \\
\hline Onesiphorus & Seleucus & Theomolpus & Zenostratus \\
\hline
\end{tabular}

Forty-two per cent., plus, of the Greek names have been found in the provinces the inscriptions of which are published in CIL III. Twenty-seven per cent., plus, of these names are taken from African inscriptions. The remainder of the instances of the Greek names are scattered in other parts of the Empire. Greek cognomina in the names of Roman citizens are not common during the first century. The names which can be assigned to this period are Asclepiades natione Cilice, Burrus (possibly of Celtic origin cf. Reburrus), borne by a soldier whose home was Forum Iulii, Diomedes (68), Laco (37-41), Laenas, Milo (domo) Luca, Strabo, the cognomen of a soldier who was born at Ptolomais. Atticinus and Melissus probably belong to the first century and Zenon is earlier than the year 108. Greek names can be dated throughout the second and third centuries and as late as the beginning of the fourth century. A military list of the year 194 at Alexandria contains nineteen Greek cognomina and ten of these belong to the names of men born in camp. A similar inscription of the year 195 found at Viminacium in Moesia preserves ten names of Greek origin. In Africa the series of Greek names continues as late as the inscriptional evidence from the province supplies the names of men in the legion stationed there.

For the ending -ianus attached to Greek names vid. section devoted to cognomina ending in -ianus in this chapter. Several Greek names suited to soldiers are noted: viz., Achilleus, Anicetus, Nicomachus and others.

The several instances of a supernomen in Greek names are collected in Chapter III, Double Cognomina. Alexander is the cognomen to be most commonly used and this name has 
received some comment in Chapter I. Didymus, Eleuther, Eutyches, Eugenus, and Protus would seem to be translations of Latin cognomina already in use.

\section{Cognomen of Illyrian Origin}

The cognomen Bato recorded as the son of Neritanus, a soldier of the II Adiutrix, is found on a stone at Aquincum in Pannonia. For other occurrences of the name Bato in inscriptions vid. Index cognominum in CIL III, the Thesaurus Linguae Latinae s. $v$., and Schulze, Lat. Eigennamen p. 32, note 1. Batus Neritanes, the reading of Gündel, De legione II Adiutrice, p. 67, is not supported by other authorities who have dealt with this inscription.

\section{Cognomen of Ligurian Origin}

The name Aunus is considered a name of Ligurian origin, vid. Thesaurus Linguae Latinae $s$. $v$. and Schulze, Lat. Eigenamen p. 130. It has been noted as the cognomen of a veteran serving in the VI Victrix perhaps before the removal of that legion to England during the principate of Hadrian. The stone was found at Remi in Belgium.

\section{Cognomina of Persian Origin}

Persian names appear as cognomina in the names of legionary soldiers in the following cases: Arsaces, $\Delta$ apeios, Mithridaticus, and Oúapdinns. Arsaces is the cognomen of a soldier serving before the year $87 . \Delta \alpha p \varepsilon i 0 \varsigma$ is borne by a centurion serving in Syria in the years 224-225. The other two are found in inscriptions of uncertain date in the East.

\section{Cognomina of Phrygian Origin}

Ascanius and Sabasianus are names from Phrygia. Ascanius is the cognomen of a centurion in service before the reign of Claudius. Sabasianus, which contains a reference to a Phrygian divinity, is borne by a soldier in Dalmatia whose period of enrollment is not definitely dated.

\section{Cognomina of Punic Origin}

(Vid. Jules Toutain, Les Cités romaines de la Tunisie, and Paul Schroeder, Die Phönizische Sprache.) Ten names of Punic 
origin have been found in the names of Roman legionaries. These are Aris, Baricio, Birzil, Gududus, Gudullus, Hiddibal, Motthunus, Namfamo, Namphamo, and Nampulus. With the exception of Aris which is recorded in a Spanish inscription all the Punic names were found in Africa. Those which can be dated are later than the year 193. Baricio is preserved in four names. Two men having this cognomen were born in the camp at Lambaesis. Gudullus, a diminutive of Gududus, Hiddibal, and Namphamo are the cognomina of men born in camp. Sufetula is the birth-place of Motthunus. Namphamo corresponds to Latin Felix. Toutain op. cit. p. 176 and Clermont Ganneau Rec. d'Arch. or. 6 (1905) p. 120.) Nampulus is a diminutive of Namphamo.

The following names have been found in Africa and, though not Punic, may be of native origin: Buturarius, Gumasius, Guzabius, Mangala, Mucrubius, Nimmira, and Porturitus. All these names appear during the third century. The names Aurassus and Thubunius are formations from place names which are probably of local origin. Numidius is a name of similar character. For Easuctanus cf. Iasucta, Schroeder op. cit. p. 91.

Further comment on the cognomina which are common among the soldiers of Africa will be found in Chap. III, The Cognomina of African Legionaries.

\section{Cognomina of Semitic Origin}

Names of Semitic origin found as cognomina in the names of soldiers are Beliabus, Eufratianus, Iamianus, Malchias, Malchus,

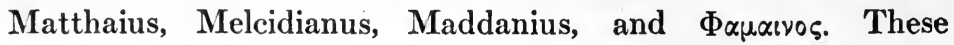
names are scattered in many provinces. The earliest is Matthaius, the name of a man whose first service was in the fleet; afterwards he was transferred to the I Adiutrix on its formation in the year 68. The other dated instances of names of this group are later than the first century.

\section{Cognomina of Thracian Origin}

Among the cognomina found in the names of Roman legionaries the following are of Thracian origin: 


$\begin{array}{llll}\text { Aulucentius } & \text { Bitus } & \text { Dizza } & \text { Mucatralis } \\ \text { Aulupor } & \text { Bytytralis } & \text { Dizze } & \text { Rescuporis } \\ \text { Aulutralis } & \text { Kó } \tau \text { S } & \text { Dizzo } & \text { Sita } \\ \text { Auluzanus } & \text { Deospor } & \text { Drigissa } & \text { Sudius } \\ \text { Auluzon } & \text { Dines } & \text { Eptacentus } & \text { Sudicentus } \\ \text { Bithus } & \text { Diza } & \text { Mucapor } & \text { Tarsa } \\ \text { Bito } & \text { Dizo } & \text { Mucatra } & \end{array}$

These twenty-seven names appear as cognomina in forty-six instances. (For Thracian names vid. Dumont, Mélanges, and Tomaschek, Die alten Thraker [complete titles in Bibliography].) Several other names present strong resemblances to Thracian names. Bethus is probably connected with Bithus. Daizo may well be related to Dizo. Surus and Surio are considered Thracian by Tomaschek, op. cit., and Celtic by Holder, cf. Cognomina of Celtic origin and Holder, altcelt. Sprachschatz. For Thithi $c f . \theta \varepsilon i \theta \circ$ in Tomaschek, op. cit. Index s. $v$. Andra is preserved on a stone in Syria together with the name Mucapor, cut in the early third century. Betto is either Thracian or Germanic (vid. Schönfeld in Bibliography, and $c f$. Bato, a cognomen of Illyrican origin).

Dazanus is related to Dasius, $q . v$., under cognomina ending in -ius, $c f$. (Dumont, op. cit. p. 551) $\Delta \alpha \delta \alpha \varsigma$ and may be Thracian in origin. Thiumpus is doubtfully Thracian.

Thracian names, as might be expected, have been found most frequently in the provinces of the Danube region. Nearly onehalf of the instances are from this part of the Empire. Italy and Germany contribute nearly one-fourth each and a few Thracian names are found in Africa, but borne in at least three cases by men who are not natives of that province: Auluzanus is the name of a man born in Thrace. Napoca is the birthplace of men named Bitus and Tarsa.

If the name Surio be Thracian, then L. Icconius Surio whose home is Caesar Augusta, serving in Dalmatia in the period between 42 and 70, is the earliest soldier to bear a cognomen of Thracian origin. The principate of Antoninus Pius is the next period to which Thracian names may be assigned. The latest date when these names are found is in the beginning of the fourth century. A single military list in Moesia of the year 195 has preserved several Thracian names. All three examples of the name Bithus appear in this inscription. The name Mucatra is recorded three times on a stone in Germany cut in the year 
223. Frequently both names are Thracian. Such names are found as Aulupor Alusa(ni filius?), Mucatralis Auluzanus, Bytytralis Biti (filius), Mucapor Mucatralis. Aurelius and Septimius are nomina joined with cognomina of Thracian origin. Septimius has been noted in seven names, Aurelius in twentysix, nearly three-fourths of the whole number of examples of Thracian cognomina.

\section{Cognomina of Uncertain Origin}

The following cognomina are certainly not of Roman or Italian origin but their derivation is obscure.

$\begin{array}{llll}\text { Acrinis } & \text { Fana } & \text { Labracenus } & \text { Saburianus } \\ \text { Arimo } & \text { Feanus } & \text { Mestula } & \text { Samunio } \\ \text { Canetus } & \text { Gerfennus } & \text { Mesuquas } & \text { Silamius } \\ \text { Cinnus } & \text { Glaus } & \text { Pertur } & \text { Sinna } \\ \text { Cittinus } & \text { Godes } & \text { Petunnatius } & \text { Stiminus } \\ \text { Colinus } & \text { Iassianus } & \text { Pitonatus } & \text { Thamarcus } \\ \text { Diabo } & \text { Iullinus } & \text { Rosinus } & \text { Ulpro }\end{array}$

Glaus is perhaps for Greek Glaux a plant. Canetus is possibly related to Canethus.

\section{Cognomina not Elsewhere Classified}

The following cognomina have not been mentioned in any of the preceding sections: Avos, Bassilas, Center, F(C)aricus, and -irmus. Avos is probably due to the loss of some letters; the original cognomen may have been Flavos. Bassilas is evidently related to Bassus. The name which is listed here as Center appears on the stone in the dative form Centro. The uncertainty of the name Faricus or Caricus has caused the insertion of this cognomen in this place. The cognomen -irmus is incomplete in the inscription and it is impossible to determine whether it should be restored as Firmus or Primus. 


\section{CHAPTER THREE.}

\section{SUPPLEMENTARY PARAGRAPHS}

1. Double Cognomina.

2. The Earliest Cognomina.

3. The Cognomina of African Legionaries.

4. Legionary Cognomina in the Provinces of which the Inscriptions are published in CIL III.

5. Uncomplimentary Cognomina.

6. Similarity of the Nomen and Cognomen in the same name.

7. Imperial Nomina.

\section{Double Cognomina}

The several instances of the appearance of a supernomen have already been noted in the chapter devoted to the classification of cognomina, and this section comprises a collection of such instances with some further comment on them. For a general discussion of names containing a supernomen one should consult the work of Lambertz, Zur Ausbreitung des Supernomen oder Signum im roemischen Reiche, Glotta, 1913, IV, p. 78-143, V, p. 99-169.

L. Cornelius Cato qui et Caligatus is the name of a centurion of the III Augusta at Lambaesis, probably about the year 200, certainly so if the name L. Cornelius Cato, designating an optio at the same camp, refers to the same person. The supernomen Caligatus reminds us at once of the name Caligula applied to the Emperor C. Caesar Germanicus. Domaszewski, A. E. M. 10 (1886) pp. 23-25, does not regard Caligatus as a part of the centurion's name but as a true participle. "Denn ich glaube, dass Caligatus hier nicht als Cognomen verstanden werden darf." Lambertz, Glotta, IV, p. 101 and Cagnat, L'Armée Romaine, 2nd ed. p. 301, n. 8, consider Caligatus as a supernomen. The name of this centurion's father also contains a supernomen: $M$. Cornelius Cato qui et Aurassius. On this name Cagnat remarks, 
'Le sobriquet du père, Aurassius, indique qu'il était originaire des environs de Lambése ou tout au moins d'un village de l' Aurès. Aurassus has already been found in the name of a legionary at Lambaesis. Cagnat believes that M. Cornelius Cato, the elder, was attached to the legion in some capacity, but in the absence of definite information his name has not been added to this list.

Another inscription in Africa preserves the name C. Tannonius Felix qui et Aquensis borne by a soldier whose period of service can not be definitely dated, but it is probably later than the reign of Hadrian. Lambertz, Glotta IV p. 101, observes "Aquensis Bezeichnung nach seiner Herkunft, also eine Art Spitzname, jedenfalls sein Rufname." The cognomen Aquileiensis has been found in the name of a legionary at Lambaesis during the reign of Alexander Severus (222-235). He was born at Theveste.

In the general region of the Danube provinces there are four instances of a supernomen in the names of legionaries whose period of service was probably later than the first century. These are, Salonius Sabinianus signo Scammatius, Nonius Saloninus qui et signo Dalmatis, Aurelius Secundianus qui et Itrius, and P. Aelius Septimius Audeus qui et Maximus. The relation between the cognomen, Saloninus, and the supernomen, Dalmatis, has already been noted in commenting on the cognomen in Chap. II, Cognomina with geographical significance. Audeus has been mentioned in the first section of Chapter II devoted to cognomina suited to men in military service. For the double nomen Aelius Septimius cf. other cases in this section below, On the name Itrius, Lambertz says. "Keltisch oder illyrisch ist das Supernomen des Aur. Secundianus qui et Itrius. The formation of names in -ius during the later period of the Empire has been noted by Lambertz in the article already cited and by Diehl, Rh. Mus. 62, and both Itrius and Scammatius are names of this kind. In view of the uncertainty concerning the derivation of Itrius is it not possible that what we have here is a comic formation from the word iterum to accompany the cognomen Secundianus, cf. Dalmatis with Saloninus above? The name L. Decrius Iulianus qui et Numisianus found at Naples is dated in the first half of the second century. The following names in

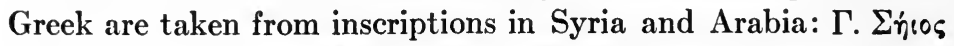

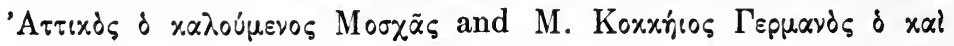


'Aoveiঠos. In the former case both names are of Greek origin, in the latter, the supernomen 'Aoveioos is a native name and not a transliteration of the Latin Avidus, Ins. Gr. ad Res Rom. Pert. III 1282, 'Aoueĩos nomen non ex latino Avidus sed ex nabataeo Aoueida dictum, and Prentice, Gr. and Lat. Ins. p. 239. In a third name 'A cognomen is Latin and the supernomen which seems appropriate to a soldier is of Greek origin.

The name T. Flavius super Cepula Scaenicus exhibits a form which is thus far without parallels. The veteran who bore this name is recorded as serving in the XXX Ulpia victrix at Lyons in the year 207. The position of the words, super Cepula, between the nomen and cognomen is not usual. Cepula is found as a supernomen in Christian names, vid. Lambertz, Glotta, IV, p. 86f, and Diehl, Rh. Mus. 62 p. 395f. From the meaning of the word Cepula, "little onion," one might suppose that we have the veteran's nickname in this word. "Super" may be an abbreviaation for the word supernomen. The word svpernomen is used as the means of indicating a second cognomen, apparently the equivalent of the words "qui et" or "signo," e. g., on a stone found atMilan, CIL V 6260, B. M. Quirace supernomen Micines, etc., cited by Lambertz, Glotta, IV, p. 85.

Another inscription found in the province Lugudunensis reads Melius Gervinius mlt Nervinus. The name Nervinus is a word of Celtic origin, but the connection with the other parts of this centurion's name is not wholly clear. If the letters mlt may be interpreted as standing for the word militavit, then it would seem that Nervinus is the name which the centurion bore during his period of service in the legion. The date of the inscription is uncertain.

The cognomen which appears in the alphabetical list as Carius aut Caristus appears in two inscriptions referring to the same person, one in Latin reading Carius, the other in Greek reading Xápıros. Carius is corrected to Carinus by Cumont, Studia Pontica, III (1910) 269, p. 241, who explains the difference between the Latin and Greek forms of the cognomen in this way, "Ulpius Carinus_- entrant au service militaire avait latinisè son nom grec de Charistos." Cumont believes this centurion was enrolled during the reign of Trajan. 
In addition to these instances where a second cognomen is added with the words qui et or signo, etc., there are some examples of what may be called a second cognomen placed after the usual cognomen without any connecting word. This additional cognomen often indicates the town from which the man who bears the name probably came. The earliest example of this is in the name Q. Annaeus Balbus Faventinus of the tribe Pollia, borne by a meiles of the fifth legion in Africa before the year 70. M. Petronius Classicus Marrucinus is the name of a centurion in the VIII Augusta in Pannonia. This legion was stationed at Poetovio, where this inscription was found, before the principate of Nero and this officer may have served in the early period. $\mathrm{Cn}$. Terentius Rufus Iguvinus is the name of a soldier of the III Augusta perhaps before the legion went to Lambaesis during the reign of Hadrian. An inscription at Cemenelum reads $\mathbf{P}$. Enistalius P. f. Cl. Paternus Cemenelensis and these words were cut after the year 87. Another stone in Pannonia preserves the name Q. Frendullus Rufus Vicetinus borne by a legionary in service after the first century, $c f$. CIL VII 155, M. Petronius L. f. Men(enia) Vic(etinus) A soldier in Cilicia later than the

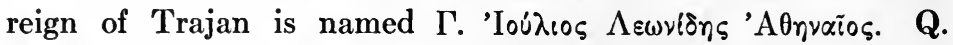
Moneius Verecundus Narbonensis is the name of a veteran found in an inscription of uncertain date in Spain. The fourth part of the name of $\mathbf{Q}$. Aurelius Processus Maddanius, an optio at Lambaesis, may contain a reference to his birth-place or to an earlier name of Semitic origin.

Another group of names is composed of those which have two cognomina one of which ends in -ianus. At Lambaesis a centurion of five legions has the name I(ulius) Bassus Sulpicianus; his period of service is later than the reign of Septimius Severus. A veteran at the same place bears the name P. Granius Auctus Caesennianus; the inscription is not dated. Q. Papius Saturninus Iulianus is the name of a centurion of the II Parthica, a legion formed by Septimius Severus. An inscription in England preserves a veteran's name, L. Ecimius Bellicianus Vitalis; whose period of service is not dated. One legionary in Syria can boast of a second nomen as well as a additional cognomen. The name in question is, following the order of words on the stone, $M$.

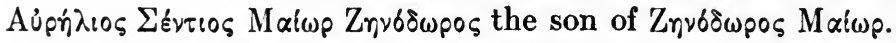

While it is digressing from the strict province of cognomina 
to discuss nomina, the last mentioned inscription contains a name with two nomina and several similar cases can be found among the names of men enrolled in the legions. In so far as these names can be dated they belong to the third century. The most noteworthy case of a name having two nomina is Aurelius qui et Septimius Constantinus borne by a soldier in Pannonia whose period of service is later than the first century. For the formation of the name vid. Lambertz, Glotta, IV, p. 132. This inscription preserves several names of this kind. The nomina Aurelius and Septimius were adopted by the children of parents who bore these names. Aurelius Superinius Marcus is the name of a legionary in Germany in the year 214. Vibius Cassius Victorinus designates a beneficiarius consularis in Noricum in the year 215. A centurion in Syria in the year 212 bears the name M. Aurelius Valerius Valerianus.

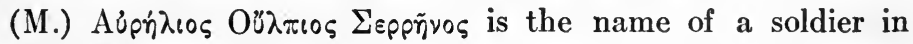
Arabia about the year 215. The name P. Aelius Septimius Mucapor is borne by a centurion at Carnuntum during the reign of Alexander Severus (222-235). M. Aurelius Cocceius Florianus was a primus pilus at Vienna about the year 225. T. Aurelius Antonius Longinus is the name of a speculator of the III Gallica in Syria in the third century. The following cases are certainly later than the reign of Trajan: P. Aelius Septimius Audeus qui et Maximus (for the cognomen Audeus vid. Chap. II, Adjectives denoting qualities suited to men in military service), his son(?) Aelius Septimius Romanus and Valerius Vibius Valerianus (Note comment in CIL III 823, Vibii nomen miles fortasse derivavit ab imp. C. Vibio Treboniano Gallo, 251-253). C. Atilius Livius Victorianus is the name of a veteran of the III Augusta at Lambaesis in the period after the reign of Hadrian. M. Flavius Caecilius Telesphorianus was enrolled in the $\mathbf{V}$ Macedonica at Lambaesis; the inscription is not definitely dated. L. Veratius Aufidius Rufus, a centurion of the XXII Primigenia, seems to indicate Beneventum as his native town but this restoration of the place-name is not wholly certain. The name of a centurion of the III Cyrenaica in Belgica, Q. Cattus Libo Nepos, is puzzling and no satisfactory explanation has been made. Libo (vid. Chapter II, Cognomina ending in -o), and Nepos are apparently cognomina. What is to be said of the name Aelius Ant. Aeternalis? Ant is explained as Antonius in A. E. M. XIX, 
p. 87, but the Index to CIL III throws no light on its interpretation. The inscription was found in Moesia and is not dated.

Another small group of names seems to present a peculiar form of praenomina, unless it also is to be understood as a part of the group which shows two nomina. The names so used are Claudius, Flavius, and Iulius. The complete names read as follows: Cl. Atteius Celer in Dacia; the inscription is later than the year 142; Cl. Maximius Sabinus (Sabinus is the reading of the stone according to the Index on CIL VIII, Cagnat, L'Armée Romaine 1st ed p. 202, reads Sabinianus.); Fl. Sabinius Attillus, Fl. Iulius Maternus, Fl. Iulius Reginus, the names of three brothers; the inscription is later than the year 89; Fl. Antonius Romanus, the name of a soldier in the year 218; Iul. Licinius Sanctinus, Iul. Marcius Saecularis, and Iul. Val. Valentinus, the name of a veteran about the year 134. The occurrence of Statius Popius Saturninus, the name of a centurion whose term of service may have been in the latter half of the century, suggests that Statius may still retain its early force as a praenomen, but this reading of Statius is not without question. M. Uttedius Sallubianus C. Petilius Amandus who was born at Iguvium and is recorded as a veteran in Dalmatia has two complete names. The cognomen Sallubianus is Celtic in its origin. The date of the inscription is not known. L. Cassius Clemens Taurus is not an example of a name with two cognomina for what appears to be a second cognomen is the engraver's error for Taurin(o), vid. CIL XIII 8732 and Ephem. Epigr. V p. 220.

\section{The Earliest Cognomina}

In the earliest period men of the rank of soldiers or underofficers did not have any cognomen. The reign of Claudius is generally taken as the turning point, before which cognomina are rare and after which it is unusual to find them omitted from a name. (Schulze, Lateinische Eigennamen, p. 497, “Denn im Allgemeinen ist die Sitte des persönlichen Cognomens schon etwas früher ( $i$. e., than the reign of Trajan), unter Claudius und Nero allgemein durchgedrungen und rasch auch obligatorisch geworden." W. Baehr, De Centurionibus Legionariis, p. 22, "Itaque sub Claudio edictum videtur, ut militum in laterculis, codicillis, aliis libellis publiciis cognomina quoque adscriberentur, id quod milites in titulis privatis statim imitatos esse consentaneum 
est." Cf. CIL XIII 1121, Kubitschek, Pauly-Wissowa 3:1601, E. Bormann, A. E. M. 18, p. 223, K. Patsch, A. E. M. 14, p. 103, Siebourg, Bonn. Jahrbb. 107 (1901), p. $187 \mathrm{f}$.

Several names have been found which contain a cognomen borne by legionaries whose period of service is earlier than the reign of Claudius. There is a group of cognomina preserved on stones found in Italy which probably were cut during the reign of Augustus. Some seem to belong to men who served in the battle of Actium and were retired later on land given to them at Ateste. Some of these names lack a cognomen altogether. One name, M. Billienus M. f. Rom., adds the word Actiacus in the place of a cognomen. While this is a cognomen in form, it has not been listed as such in the Index Cognominum of CIL V, and that precedent has been followed in the present collection. The following names of this group contain a cognomen: C. Titius Magnus and M. Tudius Niger of the V Urbana, C. Aebutius Rufus of the XIth legion and L. Labicius Celer of the VI Ferrata; the inscription containing Celer was found at Beneventum. $\mathbf{M}$. Verrius Celsus is the name of a centurion whose term of service should probably be assigned to the reign of Augustus.

By far the earliest laterculus of soldiers is that found in Coptos, Egypt (CIL III 6627). This inscription has been dated by the editor, Mommsen, in the reign of Augustus. The list given on this stone contains seventy-two names, thirty-six are the names of soldiers, an equal number are names of centurions. No soldier's name has a cognomen. Of the names of the centurions twenty-two have no cognomen, Mommsen says twenty-three, but only twenty-two are indexed as nomina in CIL III while fourteen are indexed as cognomina. (Cotus may have been considered a nomen by Mommsen.) In this number we have some of the earliest testimony on the matter of cognomina in the names of legionaries. Of the fourteen cognomina, nine are adjectives in form: Castus, Clemens, Firmus, Flaccus, Iustus, Longus (2), Maternus, Rufus, and Varus. Servatus is a participial adjective, Aquila is a noun, Galba and Varus are names well known at Rome. Cotus is a name of Celtic origin.

Two men of the XXXth legion and both belonging to the tribe Stellatina saw service in this early period, possibly before the beginning of our era. Their names are M. Crassicius Castellus and P. Clodius Pius. T. Atidius Porcio, a soldier of the XIIth 
legion at Ateste, must have served about the year 9 A. D. because

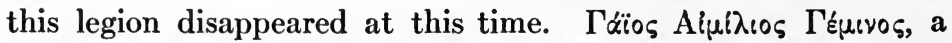
centurion of the VIIth legion in Asia Minor belongs to the year 11-12 A. D. Salvius Febranus Baculus is the name of a centurion of the XXth legion in Dalmatia at the opening of the century. C. (?) Iulius Albus, a soldier of the IId legion and his centurion, Laenas, in Aquitania have been assigned to the period before the year 21 A. D. by Allmer, CIL XIII 1122. Other names which belong to men in service during the reign of Tiberius are T. Iulius Festus borne by a soldier in the XVIth legion at Nemausus, P. Aelius Optatus and L. Antonius Quadratus, two names of men enrolled in the XXth legion in Italy, and M. Vibrius Marcellus borne by a centurion of the XVIth legion at Rome. T. Flavius Titullus of the tribe Stellatina serving in the XXth legion is mentioned in an undoubtedly early inscription at Beneventum. A group of inscriptions earlier than the reign of Claudius is found in Dalmatia preserving the names of men enrolled in the VIIth and XIth legions. Another also in this early period is found in Germany with the names of men belonging to the XVIth legion. About twenty names altogether can be assigned to the period before the reign of Claudius. From the reign of this Emperior to the end of the first century between 350 and 400 names can be definitely dated. There are others, of course, to which exact dates can not be given, although they may belong to the first century.

Some characteristics of the names of the first century have already been noted in separate sections of Chapter II. These may be recalled here briefly: The cognomina of the first century are for the most part adjectives. Nouns are not infrequent. Cognomina ending in -ianus are found in a few names. Nomina of Roman gentes are rarely used as cognomina. Cognomina of Greek origin are occasionally employed; other names of foreign origin are not common during the first century. The cognomina which are found in five or more names belonging to this century are Bassus, Celer, Firmus, Fronto, Optatus, Priscus, Proculus, Pudens, Rufus, Saturninus, Saturninus, Secundus (nineteen examples), Severus, Silvanus, Valens, Verecundus, Verus, and Vitalis.

Note: In regard to the omission of cognomina it can be said that an examination of over 350 inscriptions which contain the names of legionaries without a cognomen 


\section{The Cognomina of African Legionaries}

More than one-third of the names of men who served in the legions have been found on African soil and the large number of cognomina in these possess certain features which are noteworthy. G. Boissier (Revue des Deux Mondes, 1895, p. 56, vid. also "Roman Africa") summarizes the practice of assigning names among the Africans by saying that some adopted names such as Maurus, Gaetulus, and Numida. Others contented themselves by translating their Punic or Berber names "par un a-peuprès latin." The boldest spirits adopted an entirely new name or took a name from some famous Roman family. Mommsen (Ephemeris Epigraphica, Cognomina Africana, IV, p. 520-524) has mentioned some distinctive points in the formation of cognomina in Africa, chiefly the ending -osus. Among the soldiers cognomina with this ending are rare; those found are Albosus, Barosus, Bonosus, and Fructuosus. (Apricosus is found in a name in Italy.) Vid. Renier, Melanges d'Epigraphie, pp. 273284. There are also several cognomina which are Punic in origin in the names of African soldiers. These have been discussed in Chapter II, Cognomina of Punic Origin. (The Roman inscriptions from Africa have preserved many Punic names, some in the names of peregrini and slaves, others as cognomina for Roman citizens outside of the legions. These are similar to the names in Semitic inscriptions. They appear in Africa from the beginning of the Roman dominion to the latest Christian times.)

The most striking characteristic about the cognomina from Africa which are dealt with here is the unexpected frequency

has shown that about three-fourths of these can be assigned to the period before the close of the reign of Claudius. On several stones cut during the first half of the first century one with a cognomen will be found by the side of another name which lacks it. The absence of a cognomen is not certain proof, however, that the inscription should be dated earlier than the reign of Claudius, but it creates a probability in favor of an early date. Cf. W. Baehr, op. cit. p. 20f. Two names lacking a cognomen are worthy of mention because of the late date; M. Antonius M. filius is the name of a veteran at Aquileia of the I Adiutrix, a legion formed in the year 68. His father has the cognomen Vettianus; he is not enrolled in the legions. M. Titurius Gai filius natione Italus is the name of a soldier of the II Traiana at Alexandria in Egypt. The II Traiana, as the name indicates, was formed by the Emperor Trajan and consequently M. Titurius can not have served before the year 98. 
of names in the form of past participles. The use of participles as cognomina is by no means confined to this region, but it is among the names of soldiers at Lambaesis that this form of cognomen appears commonly enough to be considered popular. Several cognomina in participial form have been found often enough to be included with the "popular" cognomina of Chapter I.

The majority of the instances under all these names came from Africa. The cognomina are Datus (22)* 20, Donatus (68) 62, Emeritus (23) 16, Honoratus (30) 27, Optatus (34) 19, and Rogatus (44) 42. (Rogatianus has been noted in African inscriptions only.) Other cognomina in this form which have been found in Africa only are Ampliatus, Collatus, Concessus (four examples), Exoratus, Extricatus (seven examples), Meritus, Potitus, Privatus, Processus (six examples), and Renuntiatus. Restutus, Speratus, and Successus are also more frequent in Africa than elsewhere. The present participle Crescens (50) 27 is the only present participial form to be found in Africa. (cf. Caligatus, Chapter III, Double Cognomina, vid. also Chapter II, Participial Adjectives.)

The peculiarities of Roman names in Africa have already been observed by Jules Toutain (Les Cités romaines de la Tunisie. Essai sur l'Histoire de la Colonisation romaine dans l'Afrique du Nord. Bibliothèque des Écoles françaises d'Athenes et de Rome, fascicule 72, livre II, chapitre premier, "La Nomenclature et l'Onomastique," pp. 184-186), R. Cagnat (Journal des Savants, Mai 1896, pp. 259-272), Rudolf Herzog (Namensübersetzungen und Verwandtes, Philologus LXI, 1897, pp. 33-70), and G. Boissier (Revue des deux Mondes, 1895, p. 56). On Donatus, Toutain writes, "L'idée exprimée par le mot latin "Donatus" paraît bien avoir été identique a celle que rendaient les mots puniques Iatan et Mattan: Iatansidi signifait Sed deditMattanelim=donum deorum etc." Toutain compares the French name "Dieudonne" to the Latin "Donatus." Herzog mentions with Donatus the following names, Dativus, Datullus, Datianus, and Donatianus, which are to be found in the present collection, and Adeodatus. He adds, "Donatus ist vor der afrikanischen

\footnotetext{
*'The number given in parenthesis refers to the total number found, the second number refers to those from Africa.
} 
Namengabung nicht ( $c f$. CIL I, 1, 866) und auszerhalb derselben selten nachzuweisen. Wir können also von diesem Cognomen behaupten, dass es in Africa geschaffen worden sei, übrigens zunächst nicht von den Vollnamen aus, sondern von den in CIL VIII häufigsten Kurznamen Muttun, Methun, Methen, etc. (Toutain, p. 169, 173) die eben nichts anderes bedeuten als Donatus. Man sollte meinen, dass die Doppelnamen mit qui et oder signo die Cognomina einer Familie leicht Uebersetzung konstatieren lassen, aber trotz eifrigen Suchens nach dieser Hinsicht hat sich mir sehr wenig ergeben, so CIL VIII 169-Valerius Donatus filius eorum et Valerius Muthunus frater eius." On Rogatus, Toutain remarks, "Les cognomina Rogatus et Rogatianus, qui étaient aussi très populaires en cette région (Tunisie), dérivent sans aucun doute d'une idée religieuse et morale, l'idée de prière." With Rogatus, Herzog mentions Optatus, Impetratus, etc., and explains the significance of the names as "das (von Gott) gewünschte, erbetene, erlangte Kind, könnte vielleicht kombiniert werden mit Sama '(baal), B(aal) hat (die Bitte) erhört, Jazanel Gott hat erhört, etc." Herzog connects Honoratus with Kabdat, or Kebuddat, $c f$. Kabedmelqart and Chubud. On the cognomen Extricatus vid. Clermont-Ganneau, Recueil d'Archéologie orientale, I, 1898, p. 165f. It seems probable, then, that this particular form of word was considered an equivalent of names in the Semitic language and the significance of the names contributed to their popularity.

Other cognomina popular not only in the ranks of the III Augusta legion, but elsewhere in Africa, are Faustus, Felix, Fortunatus, and Victor. These names appear to be especially suited to men in the military calling, because names of good omen may bring the bearer good luck. Men in other occupations in this province seem to have been ready to avail themselves of whatever good fortune an auspicious name might bring. The widespread use of these names prevents any supposition that they were particularly sought after by the legionaries. In regard to Felix attention was called in Chapter $I$ to the fact that it is considered the Latin equivalent of the Punic name Namphamo. (Cf. Cagnat op. cit. supra, "Il en est de même du mot phénicien Namphamo, qui signife, d'apres saint Augustin, boni pedis homo, id est cuius adventus adferat aliquid felicita- 
tis, de Gadnaam qui offre à peu près le même sens et exprime aussi une idée de bonne chance. Le latin avait divers mots pour rendre la même pensée: les Fortunatus, les Faustus, les Felix sont des Gadnaam, des Namphamo déguisés." Herzog compares Benedicta, Eutyches, Faustus, Felix, Fortunatus, and their related forms with the Punic Namphamo and Naamgad or Gadnaam in their various forms. Baric-and its cognate forms he considers names of good fortune also.) It is altogether probable that other names are translations of Punic names in common use and this fact would explain the popularity of the Latin form of the name. Herzog connects the cognomen Adiutor with the name Azrubaal or Hasdrubal; "help of Baal" or "Baal helps." The following equivalents are pointed out by the same authority. Hospes, Hospita, and Hospitalis are related to Ger, Fremdling, Schutzbefohlener einer Gottheit. Hilarus and its derivatives together with Laetus he finds are to be connected with Simhat. He suggests Hagg(a)i as the equivalent of Festus and in a footnote adds that Pudens may be a translation of a Berber name, Juzula or Juzala.

Martialis is another cognomen popular in Africa. It is a desirable name for soldiers and this fact quite as much as its religious import may have led to its frequent use. Outside of military circles the name is in common use, so that the religious significance may have been the predominating factor in determining its use. In commenting on Martialis Herzog says, "Das sehr häufige Cognomen Martialis können wir nicht gut unterbringen, da ein entsprechenden punischer Gott nicht zu Gebot steht. Dagegen wird das häufige und wie es scheint, in Africa entstandene Venerius, -a, -e, -osa, Aphrodisius, -a, auf Astarte zurückzuführen sein." There are two other names in which the religious idea was one of the causes of their popularity. These are Ianuarius and Saturninus. The frequency of the former as a cognomen in the names of soldiers is noted by Gottanka (Epigraphische Beiträge, Geburtstagcognomina). For the prevalence of the name Saturninus Toutain advances the following explanation: "Cette préférence des Africaines de l'époque impériale s'explique par la faveur dont jouissait auprès d'eux le culte du dieu Saturne: Or le Saturne d'Afrique était, non pas le Cronos de le mythologie grecque ou le Saturnus des 
legendes italiques, mais l'antique Baal carthaginois. (Toutain op. cit. p. 183, and Toutain, De Saturni dei in Africa romana cultu, pp. 59-62). Saturninus is then, according to Toutain, an equivalent of a compound with the Punic name Baal and in giving this cognomen to their children, "ils (i.e., the parents) les mettaient en quelque manière sous la protection de cette divinité." Herzog reviews this explanation and comments as follows: "Saturninus ist ein altrömisches Cognomen, nicht erst von den Puniern geschaffen. Doch ist es in den anderen Theilen des Reichs und bei echten Römern viel seltener. Ob wir alle Composita mit Baal als zu Saturninus geworden annehmen sollen, ist doch fraglich, da die punischen Kurznamen zeigen, dass das Individualle meist nicht der Gottesname, sondern der

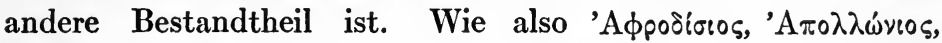

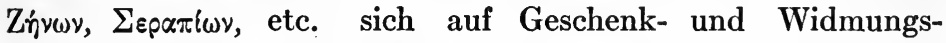
namen beschränken werden, so wohl auch Saturninus auf Namen wie Baaljatan, Jatanbaal, Maharbaal, Abibaal, etc." Some other names frequent in Africa are Maximus, Primus, and Secundus, but these are almost colorless and as far as the army goes the numerical superiority of Africa in the number of instances of their use is not marked.

Toutain in the chapter already referred to calls attention to the emphasis placed upon the cognomen among the Africans and observes that they are distinguished from the Romans in that respect. He believes that the cognomina which are preferred by the Punic people are really an expression of their own soul and genius.

It is interesting to observe that in another section of the Roman world from which the names of soldiers have come down to us in large numbers there are "popular" names different from those in Africa. In the Danube provinces and Eastern Mediterranean the names Firmus, Severus, and Valens are found frequently. Perhaps these cognomina were not liked by the peoples of Northern Africa and consequently were little used.

The importance of the cognomen in African names is a fact which should be borne in mind in this connection where this part of the name is the object of attention. Since we can feel sure that cognomina were not given without taking into consideration the significance of the word one need not be accused of drawing on one's fancy in seeking to interpret the meaning 
of cognomina in the names of African soldiers serving in Roman legions.

Legionary Cognomina in the Provinces of which the Inscriptions are Published in CIL III

The awkwardness of this heading is excused by its convenience, since the inscriptions from these regions have been massed together and contrasted with the African group. The cognomina from the provinces of CIL III constitute a little less than one-third of the whole number, while those from Africa amount to more than one-third of the total.

The names which enjoy a special popularity are either adjectives or cognomina well known among the Romans in Italy. In the former class Valens, Severus, and Firmus are excellent examples.* Other common names are Celer, Clemens, Longus, Longinus, Priscus, Pudens, and Verus. For the numerical distribution of all these names vid. table at the end of Chapter I.

In the second class one should note Bassus, Capito, and Fronto. $\dagger$ Slightly different are the names Marcellinus, Marcellus, and Marcianus. Like the last mentioned name are Iulianus and Valerianus. Rufus is a common name in these countries. Sabinus and Germanus which have little geographical significance ( $c f$. Chap. I, s. v.) are frequent in these parts of the Empire. Proculus has a popularity not easy to account for, but its use among the soldiers may well have been due to its employment in the names of men of high rank. Alexander is the only Greek name which seems to have been popular. The majority of the instances are found in the Eastern provinces and in the Danube region.

\section{Uncomplimentary Cognomina}

As might be expected, those cognomina which for one reason or another would be undesirable are not often found. If a man

* Prof. D. R. Stuart has kindly informed me that Valens or OÚ' $\lambda^{\prime} \eta \varsigma$ is a popular name in Arabia. This popularity is due to the fact that Valens is a natural transcription of the Arabic $W a l$ or $W a l^{\prime}$ ' $a$, vid. P.A.E.S. No. 358. Severus is also one of the most common names in Arabia and Syria. Vid. Chalot, Index to Waddington-Le Bas.

† $\mathrm{B} \alpha \dot{\sigma \sigma o s}$ (spelled also $\mathrm{B} \dot{\alpha} \sigma \circ \varsigma$ ) is especially frequent in Arabia-the natural transliteration of $\mathrm{B} \alpha \varsigma^{\prime}$ or $\mathrm{B} \alpha \varsigma$ vid. Stuart. P.A.E.S. No. 281, 282. 
bore a nickname of that kind it is likely that he had at the same time a dignified cognomen and it is the latter which appears in the military list and on the gravestone. It is reasonable to suppose that uncomplimentary names were current among men in military life, but these names have now almost entirely perished.

There are four cognomina which should be mentioned under this heading and which may very well have been given to the persons concerned out of a dislike which grew up in some way. These cognomina were adopted by their bearers and have been preserved up to the present day. They are Barbarus, Mucco, Mutilus, and Sterceius. About the significance of the last name there can be no uncertainty. Mutilus causes the editor of the inscription (CIL XIII 8591) some anxiety, but the reading and the meaning of the cognomen seem to be certain. Barbarus is found in the name of a legionary at Carnuntum whose term of service may have been before the year 63; if not, it was certainly during the first century. Barbarus is the cognomen in three names of men at Lambaesis. Two of the men were enrolled in the third century and the third served later than the reign of Hadrian. The early use and the late instances point to the conclusion that Barbarus as a cognomen may refer to some distinguishing quality of the men who bore it. Mucco is probably derived from Muccus (vid. Forcellini-DeVit, Onomasticon). Such a word would scarcely have been applied as a cognomen unless it had been appropriate to the bearer.

It is tempting to add other names to this list but it may not be wise to venture too far in the interpretation of cognomina when we know so little about the circumstances under which they were given.

Similarity of the Nomen and Cognomen in the Same Name

It will be observed that there are many names which have a nomen and cognomen formed on the same stem. In several names the cognomen has been formed by the addition of the ending -ianus. Nearly all the dated examples of names of this kind can be assigned to the third century. The combination which is found most frequently is the nomen Iulius with the cognomen Iulianus; thirteen cases of the name Iulius Iulianus have been collected. The earliest instance of this name occurs in the case of a centurion in Egypt before the year 108. Valerius 
Valerianus is recorded as the name of five legionaries, and the earliest of all the names of this kind is Valerius Valerianus, borne by a soldier of the XI Claudia in Dalmatia in the period between the year 42 and the reign of Vespasian. Claudius Claudianus is preserved in five names; four of these can be assigned to the third century. Aelius Aelianus and Aurelius Aurelianus appear in two names each; one of the former is dated in the year 228, and one of the latter about the year 253. Other instances of this kind are Flavius Flavianus, the son of a Flavinus (undated) L. Marinius Marinianus (the name of a man serving during the reign of Alexander Severus), Nepotinius Nepotianus (227), Geminius Geminianus (undated), Octavius Octavianus (undated), Pontius Pontianus (155), Rutilius Rutilianus (undated), Severius Severianus (238-244), Sittius Sittianus (200), Successus Successianus (third century?), Terentius Terentianus (about 212), and Vereius Vereianus (about 202).

In some names the cognomen has the ending -inus. These are Catullius Catullinus (undated), Ingenius Ingenuinus (239), Marcellinius Marcellinus (after 170), and Rufinius Rufinus (undated). Another variety is shown in the Augustius Augustalis borne by a man whose period of service is later than the year 89 .

In a few cases the cognomen is not altered, but the nomen may perhaps have been formed to be appropriate to the cognomen. In the name L. Fabius Fab(i)us we seem to have the nomen used directly as the cognomen. This is the only example which has been found in the present collection of names. The birth-place of the legionary bearing this name is Nertobriga and his period of service was before the reign of Vespasian. Felicius Felix (undated), C. Masculinius Masculus (undated), Placidius Placidus (222-35), Primanius Primulus (after 89), Severius Severus (about 212) are the names in this group. In the name Silvanius Silvester the nomen and cognomen have a similar meaning in addition to their likeness in form. The relation between the nomen and cognomen in the name Voconius Vitulus has been pointed out by Otto Keller, Lateinische Volksetymologie (Leipzig 1891) p. 115. The nomen Voconius is also spelled Vacconius from vacco, $c f$. vitulus. The name Secundius Primus shows its peculiarity through contrast between the nomen and cognomen. The soldier who bears this name was born at Tubunae and served in the III Augusta at Lambaesis. 


\section{IMPERIAL NOMINA}

The words of Mommsen (Hermes XIX p. 3, quoted in Introduction, q. v.) have prompted these paragraphs on the appearance in the names of legionaries of the nomina used in the names of Emperors.

Aelius. The nomen Aelius is rarely found in names which can be dated in the first century. Two brothers, veterans in the XVIth legion in Germany (the stone was found at Rome), who bear the nomen Aelius were in service before the reign of Claudius probably. The home of these men is Brixia, and they have no cognomen. P. Aelius Optatus, is the name of a soldier in the XXth legion whose term of enrollment has been assigned to this early period before Claudius, but not with certainty. Aelius Asclepiades is the name of a soldier in the IXth legion who served during the first century. The stone was found at Puteoli. In the second century an inscription at Troesmis in Moesia containing a list of veterans which can be dated about the year 134 does not preserve the name Aelius. (CIL III 6178). A similar inscription at Viminacium also in Moesia cut in the year 135 records the nomen Aelius fourteen times in thirty-four lines. (CIL III 8110.) A laterculus of soldiers at Almus in Moesia which is dated in the year 155 has eight instances of the name Aelius. (CIL III 7449.) Vid. Cagnat, L’Armée Romaine, 2d. ed., p. 293. An inscription at Lambaesis belonging to the reign of Hadrian contains no use of Aelius.

Aurelius. The nomen Aurelius is found three times without a cognomen in the early period: A? Aurelius, the name of a veteran from Bononia serving in the 1st legion (CIL XIII 8276); C. Aurelius of the tribe Quirina, the name of a veteran of the XIth legion in Achaia (CIL III 503); and M. Aurelius, the name of a soldier of the XIV Gemina at Aquileia (CIL V 8272). $L$. Aurelius Celer is the name of a soldier of the XV Apollinaris at Carnuntum perhaps before the year 63, certainly during the first century. The name L. Aurelius Rufus designates a primus pilus of the XVIth legion whose term of service seems to be earlier than the reign of Vespasian. Aurelius Rufus is the name of a soldier in Dalmatia who apparently was enrolled in the XI Claudia and consequently his term of service falls between the years 42 and 70 when the legion was assigned to this province. 
Aurelius Verus and Aurelius Vitalis are names of men in the same province and also belong to the early period. M. Aurelius Metelus from Alba Pompeia is the name of a soldier of the IV Macedonica (disbanded by Vespasian) at Mainz. Three other instances of the use of the nomen Aurelius can be dated before the reign of Hadrian. The military laterculi referred to under Aelius are important also for the use of Aurelius. In Moesia it is found once on the stone cut in the year 135 and seventeen times on that cut in the year 155. In Lambaesis Aurelius does not appear in any soldier's name before the year 162. From the middle of the second century it is found frequently.

Flavius. The nomen Flavius is found first in a military list assigned to the reign of Augustus recovered in Coptos, Egypt, (CIL III 6627); the name in question is P. Flavius from Paphos: the cognomen is lacking from all names of soldiers on this stone (vid. The Earliest Cognomina, in this chapter.). T. Flavius also without a cognomen is the name of a soldier at Theveste probably in the latter half of the first century. The cognomen Viator is found on this inscription. T. Flavius Titullus of the tribe Stellatina designates a member of the XXth legion who served before the region of Claudius; the stone was found at Beneventum (CIL IX 1608). T. Flavius Secundus is the name of a custos armorum, born in camp, serving in the XV Apollinaris at Carnuntum perhaps before the year 63. The name Flavius becomes common in the names of soldiers much earlier than Aelius and Aurelius. On a papyrus from the Fayoum which can be dated in the reign of Domitian (81-90) it occurs seven times. (Pap Gen Lat I). The nomen is used with great frequency throughout the second and third centuries.

Septimius. The use of the nomen Septimius before the reign of Septimius Severus is rare among the men enrolled in the legions. L. Septimius, the name of a soldier of the $V$ Macedonica, is the only instance without a cognomen and also the only one which can be assigned to the period before the reign of Claudius. (Westd. Zeitschr., 21, n. 212.) The only other instance which has been noted earlier than the year 193 is in the name Septimius Celer borne by a verteran, also of the V Macedonica, in Moesia about the year 134. L. Septimius Cassianus is assigned to the reign of Septimius Severus, vid. Roemische Limes, II (1901) p. 145 note. A long list of veterans found at Viminacium of the 
year 195 contains no case of the nomen Septimius. This nomen is not a common one in the camp at Lambaesis.

Ulpius. Only two examples of the nomen Ulpius in the names of legionaries have been found which could be dated in the first century and one of these is not without question. The inscription (CIL III 2833) containing the questionable name reads $P$. Ulpius D. f. Silvester (changing to the nominative case) and so the editors of this volume have indexed the nomen as Ulpius. Patsch (Arch. epigr. Untersuchungen II, 1897, p. 3, n. 4) corrects the nomen to Pulpidius and this correction has been adopted by Van der Weerd, Trois Legiones romaines du Bas-Danube, p. 225. The reading of CIL is accepted here. The man whose name is under discussion was a centurion of the XI Claudia in Dalmatia and his period of service falls between the year 42 and the principate of Vespasian.

The other first century use of Ulpius appears more certain. M. Ulpius Dasius the son of Marcus of the tribe Quirina from Sirmium is the name of an optio of the XV Apollinaris at Carnuntum perhaps before its departure for the East in the year 63, certainly during the first century. A papyrus in Egypt (Wessely, Schriftafeln 8) contains the names of soldiers in the III Cyrenaica before the year 108 and Ulpius is recorded three times. The majority of the dated cases of Ulpius belong to the third century; comparatively few examples of its use are definitely dated in the second century. This nomen is not often found at Lambaesis and the majority of the instances there are in the names of centurions.

\section{BIBLIOGRAPHY.}

Baehr, Walterus. De Centurionibus Legionariis. Berlin. 1900.

Beucher, Felix. De legione Romanorum I Italica. Leipsic. 1903.

Cagnat, René. L'Armée romaine d'Afrique et l'Occupation militaire sous les Empereurs. Paris. 1892 and 1913.

Dumont, Albert. Mélanges d'Archéologie et d'Épigraphie. Paris. 1892.

Ellendt, Fridericus. De Cognomine et Agnomine Romano. 1853.

Fisch, Richard. Lateinische Substantiva personalia auf -o (-io), -onis (-ionis). Berlin. 1888.

Substantiva personalia auf -o, -onis. ALL V, (1888) 56-88.

Forcellini-De Vit. Totius Latinitatis Onomasticon.

Gottanka, Hans. Epigraphische Beiträge. Augsburg. 1912.

Gündel, Fridericus. De Legione II Adutrice. Leipsic. 1895.

Hofrmann, Ernst. De titulis Africae Latinis, Quaestiones Phoneticae. 1907. Holder, AlFred. Alt-celtischer Sprachschatz and Nachträge. Leipsic. 1896- 
Jưnemann, Augustus. De legione Romanorum I Adiutrice. Leipziger Studien zur classischen Philologie, sechzehnter Band. 1894.

LAMbertz, Zur Ausbreitung des Supernomen oder Signum im roemischen Reiche. Glotta, 1913, IV, pp. 78-143 and V, pp. 99-169.

Mexer, Padr M. Das Heerwesen der Ptolomäer und Römer in Aegypten. Leipsic. 1900.

Ritterling, Emil. De legione Romanorum X Gemina. Leipsic. 1885.

Schulung, Otro. De legionibus Romanorum I Minervia et XXX Ulpia. Leipziger Studien zur classischen Philologie, fünfzehnter Band. 1893.

Schneider, A. Beiträge zur Kenntniss der roemischen Personnenamen Zürich. 1874.

Schönfeld, Maurwitz. Wörterbuch der altgermanischen Personen- und Völkernamen. Heidelberg. 1911.

Schroeder, Paul. Die Phoenizische Sprache. Halle. 1869.

Schultze, Ennestus. De legione Romanorum XIII Gemina. Keil. 1887.

Schulze, Wilhelm. Zur Geschichte lateinischer Eigennamen. Abhandlungen der königlichen Gesellschaft der Wissenschaften zu Göttingen, Philologisch-historische Klasse, Neue Folge V, q. Berlin. 1904.

Tomascheк, Wilhelm. Die alten Thraker, eine ethnologische Untersuchung. II Die Sprachreste. II Hälfte, Personen- und Ortsnamen.

Sitzungsberichte der kaiserlichen Akademie der Wissenschaften in Wien. Band CXXXI, Vienna. 1894.

Toutain, Jules. Les Cités romaines de la Tunisie. Essai sur l'Histoire de la Colonisation romaine dans l'Afrique du Nord. Bibliothèque des Écoles francaises d'Athènes et de Rome, Fascicule 72. Paris. 1894.

Trommsdorff, Paulus. Quaestiones duae ad historiam legionum Romanarum spectantes. Leipsic. 1896.

van der Weerd, Hubert. Étude historique sur trois Legions romaines du Bas-Danube. (Ve Macedonica XIe Claudia Ie Italica.) Paris. 1907.

Zimmermann, August. Die lateinischen Personennamen auf -o, -onis. ALL 13, (1903-4), pp. 225-252, 415-426, 475-501.

\section{ABBREVIATIONS.}

A. D. = Anno Domini.

A. E. =L'Année Epigraphique.

actar leg = actarius legati.

Adiut $=$ Adiutrix.

Adi $\mathrm{p} \mathbf{f}=$ Adiutrix pia fidelis.

Aem. = Aemilia tribus.

AEM = Archaeologische-epigraphische Mitteilungen.

aet $=$ aetas.

Alexand (Alex) = Alexandriana.

ALL $=$ Archiv für lateinische Lexikographie und Grammatik.

Ani. = Aniensis tribus.

Antonin = Antoniniana.

Anzeig f Schweiz Alter = Anzeiger für Schweizer Alterthümer.

$\mathrm{AP}=$ Archiv. für Papyrusforschung.

Apol $=$ Apollinaris.

aquil $=$ aquilifer. 
ARBL = Académie royale de Belgique, classe de Lettres.

arm cust $=$ armorum custos.

Ath Mitth = Mittheilungen des kaiserlichen deutschen archaeologischen Instituts, Athenische Abteilung.

Aug = Augusta.

Aur $=$ Aurelius.

b $\mathbf{s}$ = beneficiarius semestris.

bell Iud = bellum Iudiacum.

bf $\cos =$ beneficiarius consularis.

bf lat $=$ beneficiarius laticlavius.

bf leg = beneficiarius legati.

bf trib = beneficiarius tribuni.

BGU = Aegyptische Urkunden aus den koeniglichen Museen zu Berlin. Griechische Urkunden.

buc = bucinator.

Bull Archeol $=$ Bulletin archéologique du Comité des Travaux historiques et scientifiques.

7 = centurion.

$\mathrm{c}=$ circa .

Cam. = Camilia tribus.

can $=$ candidatus.

Cas $=$ Castris (domo).

c c $=$ constans Commoda.

CIL $=$ Corpus Inscriptionum Latinarum.

$\mathrm{Cl}=$ Claudia.

Claud = Claudius.

Coll. = Collina tribus.

cor $=$ cornicen .

corn $=$ cornicularius.

CRAI = Comptes Rendus de l'Académie des Inscriptions et Belles-Lettres.

Cyr = Cyrenaica.

$\mathrm{d}$ aq $=$ discens aquiliferum.

$\mathrm{d}$ ar $=$ discens architectum.

$\mathrm{d} s=$ discens signiferum.

d, dom $=$ domus.

$\operatorname{dec}=$ decurio.

dup $=$ duplarius, dupliciarius.

Eng = England.

eq $=$ eques.

evoc $=$ evocatus.

f. $=$ filius.

f $\mathrm{c}=$ fidelis constans.

Fab. = Fabia tribus.

Fal. = Falerna tribus.

Ferr = Ferrata.

firm = firma.

Fl = Flavia.

fort $=$ fortis. 
Fr $=$ Fretensis.

frum $=$ frumentarius.

Fulm $=$ Fulminata.

$\mathbf{G} \mathbf{m} \mathbf{v}=$ Gemina martia victrix.

G p $\mathbf{f}=$ Gemina pia fidelis.

Gal. = Galeria tribus.

Gall = Gallica.

Gall Narb = Gallia Narbonensis.

Gem = Gemina.

Gem fel (G f) = Gemina felix.

Ger = Germanica.

Germ Inf = Germania Inferior.

Germ Sup = Germania Superior.

Gordian = Gordiana.

Greek pap = Greek Papyri, Grenfell and Hunt.

hast $=$ hastatus.

hast $\mathrm{pr}=$ hastatus princeps.

Hisp = Hispana.

Iesson $=$ Iessoniensis.

IG = Inscriptiones Graecae.

IG a RR = Inscriptiones Graecae ad Res Romanas pertinentes.

imag $=$ imaginifer.

imm $=$ immunis.

Ital $=$ Italica.

Jahres Wien $=$ Jahreshefte des Oesterreichischen archaeologischen Instituts.

Beibl $=$ Beiblatt.

JDAI $=$ Jahrbuch des kaiserlichen deutschen archaeologischen Instituts.

kanab $=$ kanabensium

$\mathbf{K}=$ Karthago.

leg = legio.

lib $=$ librarius.

lib leg (leg) = librarius legati (legionis).

Mac = Macedonica.

Maec. = Maecia tribus.

MAH = Mélanges d'Archéologie et d'Histoire de l'École française de Rome.

Mém de l'Acad des Inscr = Mémoires de l'Institut national de France. Academie des Inscriptions et Belles Lettres.

mil $=$ miles.

Min = Minervia.

Moes Inf = Moesia Inferior.

Moes Sup = Moesia Superior.

Ner $=$ Nerva.

off $=$ officium.

Ox Pap $=$ Oxyrhynchus Papyri.

p $\mathrm{c}=$ pia constans.

p $\mathrm{f}=$ pia fidelis.

$\mathbf{p} \mathbf{p}=$ primus pilus.

$\mathrm{p} \mathbf{v}=$ pia vindex. 
PAES $=$ Publications of the Princeton University Archaeological Expedition to Syria.

Pais Suppl= Pais, Hector Corporis Inscriptionum Latinarum Supplementa Italica, consilio et auctoritate Academiae regiae Lynceorum edita. Fasc. I Additamenta ad Vol. V Galliae Cisalpinae. Rome. Atti dei Lincei 1888, Serie 4, Tome V.

Pal. = Palatina tribus.

Pann Inf = Pannonia Inferior.

Pann Sup = Pannonia Superior.

Pap. = Papiria tribus.

Pap Brit $=$ Greek Papyri in the British Museum.

Pap Gen Lat 1 = Archives militaires du Ier Siècle. Texte inédit du Papyrus latin de Genève No. 1. J. Nicule et $\mathrm{Ch}$. Morel, Genève 1900 fol.

Parth $=$ Parthica.

ped sing $=$ pedes singularis.

pol = polia.

Pol. = Pollia tribus.

Pom. = Pomptina tribus.

Praef kastror $=$ praefectus castrorum.

Prim = Primigenia.

$\operatorname{Pr} \mathbf{p} \mathbf{f}=$ Primigenia pia fidelis.

prin vex $=$ princeps vexillationis.

prob $=$ probatus.

Prov $=$ Provincia .

prov Lugudun = provincia Lugudunensis.

Pup. = Pupinia tribus.

quaest $=$ quaestionarius.

Quir. = Quirina tribus.

Rap $=$ Rapax.

RAE = Revue des Études Anciennes.

$\mathbf{s}=$ saeculum.

Sab. = Sabatina tribus.

Scap. = Scaptina tribus.

Scyt $=$ Scythica .

Serg. = Sergia tribus.

Sever $=$ Severiana.

sept $=$ septima.

Ste, Stel. = Stellatina tribus.

sig = signifer.

singular $=$ singularis .

strat $=$ strator.

str $\cos =$ strator consularis.

tess $=$ tesserarius

Tr $=$ Traiana.

$\operatorname{tra}(\mathrm{ns})=$ translatus.

Tro, Trom. $=$ Tromentina trius.

tub $=$ tubicen.

Ulp = Ulpia.

Ulp vict $=$ Ulpia victrix. 
Urb $=$ Urbana.

val $=$ valetudinarius.

Vel. = Velina tribus.

vet $=$ veteranus.

Vict $=$ Victrix .

Vol $=$ Voltinia tribus.

$\mathrm{V} \mathbf{v}=$ Valeria victrix.

Westd Zeitschrift $=$ Korrespondenzblatt der westdeutschen Zeitschrift für Geschichte und Kunst.

Wessely Lat $\mathbf{P a l}=$ Schrifttafeln zur ältercn lateinischen Palaeographie, Dr. C. Wessely, Leipzig 1898. 


\section{THE ALPHABETICAL LIST}

The following list of soldiers and under-officers of the legions is arranged alphabetically according to cognomina. The name including tribe and domus (when given) is printed in bold face type. All letters restored are enclosed in parentheses. Whenever the cognomen is complete on the stone it is not repeated here, but it is indicated by the first letter. This letter always a capital letter is not followed by a period. So in reading a name in which the cognomen is not spelled in full, the cognomen is to be supplied after the first capital letter not followed by a period which is the same as the first letter of the cognomen under which it occurs.

In addition to the name the following items are added in this order: (1), rank and legion, these are regularly indicated by the same abbreviations; the exact letters of the stone are disregarded in the attempt to secure uniformity. $E$. g. Min is regularly the abbreviation for Minervia, when the stone has only "M," (2), Date, wherever possible. "Date?" means that no definite date can be assigned to the inscription. (3), Place where the stone is found. Except for certain well-known places the Latin form of the name has been retained. (4), Place where the inscription or papyrus is published. Volumes of the CIL are cited by Roman numerals. For other publications vid. Table of Abbreviations.

The first cognomen in this list is Acceptus. The first name is that of Baebius Acceptus. The nomen appears on the stone in the form Bebius. The man was a soldier (miles) in the II Italica pia fidelis. The inscription is assigned to the third century (3s). The stone was found at Virunum in the province of Noricum. Lastly, the inscription is published in CIL III, no. 4837. Another example may be taken under the cognomen Adiutor. The third name is that of M. Iulius Adiutor, the son 
of Marcus, whose home is Apta of the tribe Voltinia. This man was a soldier in the XXII Primigenia at Mainz, where the stone was found. The inscription is not definitely dated and is published in the L'Annee Epigraphique for 1910, no. 62.

Different spellings of the same cognomen are kept separate in the list, e. g., Alexander and Alexsander, Clemens and Clemes, Bassus and Basus, and so on. This separation seemed necessary to insure accuracy and to increase the usefulness of the list as a reference list for cognomina.

Through an oversight the following names were omitted both from the Alphabetical List and from the sections devoted to the Classification of Cognomina: T. Statius P. f. Serg. Marrax p p XIII Gem Date? Aquileia Pais Suppl n1163 and Cn. Acilius Relatus mil leg VIII missicius 1s Aquileia Pais Suppl n1160. The cognomen Marrax is perhaps to be explained as a formation from the noun marra, similar to pugnax from pugna, minax from mina, etc. For the etymology of marra vid Walde, Lateinesches etymologisches Wörterbuch; it is also to be found in Holder, altcelt Sprachsch., s. v. The cognomen Relatus may be classified as a participial adjective or as a noun. In view of the probable early date of the inscription we may interpret the name as an adjective used as a cognomen. For other participials so used, vid Chapter II, Participial Adjectives. For cognomina ending in -x, vid. this heading in Chapter II.

\section{ACCEPTUS}

B(a) ebius A mil II Ital p f 3 s Virunum Noricum . . . . . . . . . . . III 4837 Iulius A 7 III Aug coh VII 162 A.D. Castra Lambaesitana . . . . . . VIII 18065

\section{ACCIUS}

M. F1(avius) A mil leg XXII ante 89? Aquae Statiellae......... V 7508 ACCULEIUS

Aufrius Ac(c)ul(eius) 7 III Cyr ante 108 Egypt.... Wessely Lat Pal 8 ACER

Cl(audius) A 7 leg? coh I Date? Carnuntum Pann Sup.....III 14358:16 ACHILLEUS

M. Aur(elius) A (vet) ex arm cust 1 (I) Adiut \&-3s? Mursa Pann Inf III 10270 ACILIANUS

M. Ulpius A bf $\cos$ II Ital 2 -3s Celeia Noricum............ III 5180 Acil(i)anus 7 (leg?) Date? Magnae Eng............ VII 781a ACRINIS

Acrini(s) vet XI Cl p f 42-Vespas Tragurium Dalmatia....III 9709 


\section{ACUTIANUS}

- A bf cos leg XIIII Gem Gordian 239 A.D. Novae Dalmatia...III 1911 ACUTUS

Aur(elius) A mil I Adiut post 114 Crumerum Pann Inf.......... III 3660

L.(Br)uttius A Iusti(f.) $7 \mathrm{leg} \mathrm{V}$ ante $70 \mathrm{Col}$ Agrippinensium.A.E.. 1906:57

Gavius A dup III Aug p v Antonin 218 A.D. Castra Lambaesitana.. VIII 2564 ADIUTOR

C. Appius C. f. Lem. A princeps XXII Prim primipilaris? Date?

Hispellum........................... 5273

Aur(elius) A vet I Adiut Sever c 225 Brigetio Pann Sup......... III 4312

M. Iulius M. f. Vol. A Apta mil XXII Prim Date? Mainz. . . A.E. 1910:62

C. Iunianus A 7 III Aug $p \vee$ 3s Castra Lambaesitana .......... A.E. 1909:3 Iun(ius) A spec I et II Adi p f Sever 228 A.D. Aquincum Pann Inf. III 3524 Menenius Adiu(t)or vet XXII Pr p f post 89 Mainz .........XIII 6732 Q. Vatinius A 7 II Adiut 2-3s? Aquincum Pann Inf...........III 3571 ADVENTUS

(L. Anti)sti(us) (Adv)entus vet ex leg XIIII ante 62 Lincoln Eng. . VII 187 M. Pud -A mil XXX Ulp vict $\mathrm{p}$ f 3s? Avaricium Biturgium. XIII 1196 AEDILIS

Vitellius A 7 III Aug coh V 162 A.D. Castra Lambaesitana..... VIII 18065 AELIANUS

Ael(ius) A mensor VII Cl Sever 228 A.D. Viminacium Moes Sup... III 8112 Ael(ius) A 7 (leg?) coh VIIII Date? Chesters Eng............. VII 601 C. Cassius A 7 XV Apol 1s Carnuntum Pann Sup........... III 14358:15 Iulius A lib III Ital Date? Castra Regina Raetia ............. III 5953 G. Papirius A medicus ordinarius III Aug Date? Lambaesis . . . . VIII 18314 M. Seius A (mil? III Aug) c200 Castra Lambaesitana Bull Archeol 1905 p 240 M. Terentius A 7 VIII Aug Sever Alexand ce25 Nola.........X 1254 - A 7 II Aug Date? Stanwix Eng........VII 914 add E.E. III p136 AELURIO

C. Iulius A 7 III Aug Antonin aet Caracallae Burgi Numidia ..... . VIII 2494 AEMERITUS

Iulius A mensor (III Aug) 3s? Castra Lambaesitana......... A.E. 1904:72 AEMILIANUS

P. Aelius A spec II Tr fort Date? Alexandria Egypt. . . . . . . . III 14135 (An)ton(ius) A 7 (XXII) Pr p f Date? Saalburg ............... 1903:311 G. Iul(ius) A vet VII Cl Date? Almus Moes Inf.............III 7421 L. Iulius A ? (III Aug) 209-211 A.D. Castra Lambaesitana...... VIII 2556 ulius Ae(m)il(ianus) (mil? III Aug) Date? Castra Lambaesitana.............................E. $1899: 91$ AEQUOS

C. Papirius A 7 III Aug 72 A.D. Rome.............. VI 932 AEQUUS

C. Papirius A 7 III Cyr ante 108 Caenopolis Egypt........... III 6628 AETERNALIS

Ael(ius) Ant A sig XI Cl post Claud Tropaeum Moes Inf . III $14214: 6$ 
Iul(ius) A tess XI Cl 155 A.D. Almus Moes Inf..............III 7449 AFRICANUS

Aemilius A dup III Aug p v Antonin 218 A.D. Castra Lambaesitana VIII 2564 Iulius A 7 III Aug coh X 162 A.D. Castra Lambaesitana........ VIII 18065 C. Iul(ius) A optio (III Aug) 198-211 A.D. Castra Lambaesitana.. VIII 2554

C. Iulius A cor III Aug p v 203 A.D. Castra Lambaesitana... . . . . VIII 2557 AFRICUS

Q. Ventidius A vet (III Aug) Date? Lambaesis............. VIII 2885 AGATHO

Cla(u)dius Aga0o mil III Cyr ante 108 Egypt....... Wessely Lat Pal 8 AGATHOCLES

Aur(elius) A mil XI Cl 155 A.D. Almus Moes Inf............III 7449 AGRICOLA

Albanius A eq? XXII $\operatorname{Pr} p \quad 231$ A.D. Mainz ............. XIII 6669

Fl(avius) A mil VI Vict post Hadrian London ............... VII 25

Gellius A 7 XI Cl p f Vespas-Traian Vindonissa............. XIII 5210 -A optio II Aug c200? Petrianae? Eng.............. VII 912b AGRINUS

Iullus Agri(n)us vet ex sig (III Aug) \&11-2 A.D. Lambaesis ..... . VIII 2618 A GRIPINUS

M. Aurelius A bf $\cos 212-17$ A.D. Nettersheim............E. 1911:156 AGRIPPA

M. Alpini(us) A 7 (leg?) Date? Carnuntum Pann Sup.........III 4454 Aur(ellus) A (vet) ex arm cust (V Mac?) Date? Potaissa Dacia... III 7688 L. Cl(audius) A Nico(media) vet? (III Aug) aet Hadriani Castra Lambaesitana........................... VIII 18084

Iulius A Tripoli vet? (III Aug) aet Hadriani Castra Lambaesitana.................................. VIII 18084

C. Iulius C. f. (Se)r. (Agr)ippa mil VII pf 42-70 A.D. Corinium Dalmatia................................... 2885

Pompeius Agri(ppa) corn VII Gem c800 Tarraco.............II 4182 AGRIPPIANUS

Iulius A arm cust III Aug c225 Castra Lambaesitana......A.E. 1902:11

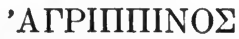

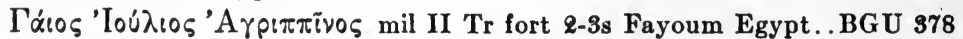
'A $\gamma \rho i \pi i \nu(0 \varsigma)$ mil II Tr fort 161 A. D. Fayoum Egypt. BGU 195 ALBANUS

L. Cassius Cla. A Aeq(uiculis) mil XV Apol 1s Carnuntum Pann

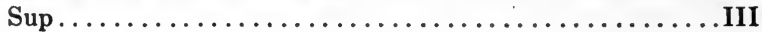

C. Iul(ius) A R(emesiana?) vet VII Cl 195 A.D. Viminacium

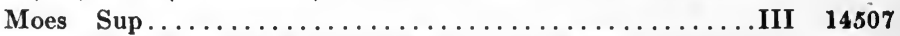

M. Lutatius M. f. Ser. A dom Cor(finio) mil IIII Mac ante Vespas Mainz.............................. XIII 6869 ALBINUS

Fla(vius) A mil XIIII Gem post 100 Ager ad Colapim Pann Sup...III 14046 
Cla. A mil leg? Date? Bonn.................. XIII 8083

\section{ALBOSUS}

Vibius A (mil? III Aug) c218? Castra Lambaesitana Bull Archeol 1904 p206 ALBUCIANUS

L. Albucius Claud. A Miseno 7 I Adi pf post 114 Brigetio Pann Sup III 10979 ALBUS

L. Aemilius A arm cust III Aug Date? Lambaesis........... VIII 2795

M. Antonius M. f. Pol. Alb(u)s Cas (mil III Cyr aut XXII

Deiot) 90 A.D. Fayoum Egypt.................... Gen Lat 1

(C? I) ul(ius) A mil e leg II 1s Ager Santonum Aquitania........ XIII 118e

\section{ALEXANDER}

C. A(e)lius A mil III Aug Date? Lambaesis ............... VIII 3028

P(.Antoni(us) Alexand(er) vet (III Aug) Date? Lambaesis..... VIII 2789

AtAius Alex(ander) vet ex optione (V Mac) c134 Troesmis........III 6178

A trelius A mil leg XXII Date? Mainz................. XIII 6956

Aurel(ius) A 7 VII Cl Date? Viminacium Moes Sup.........III 14509:1

Aurel(ius) A (mil? II Parth?) Date? Rome................ VI 2410

Auru(elius) A(lexa)nder (lib)rarius II Parth Date? Ager Albanus XIV 2278

M. ) ur(elius) A p p (I Adiut) post 114 Brigetio Pann Sup........ III 4915

M. Aur(elius) A vet II Adiut Date? Intercisa Pann Inf..... A.E. 1910:144

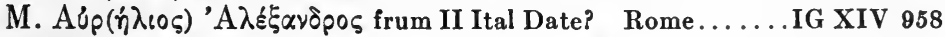

Caesennus Alexand(er) arm cust (III Aug) 200 A.D. Castra

Lambaesitana............................... 1908:10

T. Caesennius S sig (III Aug) Date? Lambaesis...........VIII 18294

Cl(audius) Alexande(r) bf cos (leg?) Date? Apulum Dacia......III 1190

Cl(audius) Alex(an)der 7 VII Cl Sever 228 A.D. Viminacium

Moes $\operatorname{Sup} . \ldots \ldots \ldots \ldots \ldots \ldots \ldots \ldots \ldots \ldots \ldots \ldots$ III 8118

Dom(itius) A 7 XV Apol post Traian Trapezus Pontus Cappa-

docicus.................................... 674

C. Domitius A 7 III Aug Date? Lambaesis.............. VIII 28637

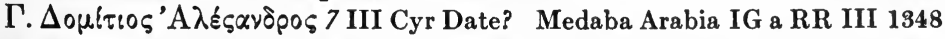

F1(avius) A mil XI Cl 155 A.D. Almus Moes Inf .............III 7450

T. Fl(avius) A optio (III Aug) 198-211 A.D. Castra Lambaesitana. VIII 2549

Gaius A corn III Gall aet M. Aurel Perinthus Thrace..........III 7394

Iulius Alexa(nder) vet (V Mac) c134 Troesmis............III 6178

Iul(ius) A mil XI Cl 155 A.D. Almus Moes Inf ...............III 7449

Iul(ius) A spec I et II Adi p f Sever 228 A.D. Aquincum Pann Inf ..III 3524

Iul(ius) A actar XIII Gem post Traian Apulum Dacia.......... III 7753

I(u)1(ius) A vet ex bf $\cos$ (V Mac?) M. Aurel-274 Potaissa Dacia... III 7692

Iul(ius) Alex(ander) 7 (leg?) Date? Aquincum Pann Inf...... III 10459

G. Iulius A mil III Aug Date? Lambaesis............... VIII 3127

C. Iul(ius) A mil IIII Fl Date? Alexandria Troas Asia..........III 387

M. Iul(ius) A vet ex optione III Aug Date? Lambaesis........ VIII 2885

Longi(us) Alex(ander) vet VII Cl 135 A.D. Viminacium Moes Sup. III 8110

Sep(timius) A (vet) ex dup (V Mac?) Date? Potaissa Dacia..... III 7688

Sep(timius) Alexand(er) can (leg?) Date? Apulum Dacia....... III 1190

Servili(us) A arm cust III Aug c225 Castra Lambaesitana....A.E. 1902:11 
Ulpius A bf $\cos$ XI Cl 155 A.D. Almus Moes Inf............. III 7449 O ${ }^{\prime} \lambda(\pi / 0 \varsigma)$ 'A $\lambda \hat{\varepsilon} \xi \alpha \nu \delta \rho \circ \varsigma$ vet ex optione III Gall Date? Aeritae Syria

IG a RR III 1183

Val(erius) Alexa(nder) vet VII Cl 135 A.D. Viminacium Moes Sup.III 8110

Val(erius) Alex(ander) vet VII Cl 135 A.D. Viminacium Moes Sup. III 8110

Val(erius) Alexand(er) (bis) (7 XXII Pr p f) 204 A.D. Mainz.... XIII 6801

Val(erius) A 7 XXII Pr p f 205 A.D. Mainz.............. XIII 6710

M. Valerius Alexan(der) (vet II Tr fort?) 140 A.D. Fayoum Egypt. BGU 610 U(I)pi(u)s Alexa(nder) mil III Cyr ante 108 Egypt.... Wessely Lat Pal 8 (Alex)ander Cas polio (III Aug) aet Antonini Pii Castra

Lambaesitana........................... VIII 18085

- lius T. f. Pol. A Castr. vet II Tr fort 194 A.D. Alexandria

Egypt................................. III 6580

- (Ale)xa(nder) Sc(upis) vet VII Cl 195 A.D. Viminacium

Moes Sup................................III 14507

C1. Ti. f. Col A - onia vet ex arm cust III Aug Date?

Lambaesis................................ VIII 2840

$A$ vet (V Mac) Date? Troesmis...................III 6180

Alexand(er) 7 (leg?) Date? Proclitia Eng............. VII 627

ALEXANDRUS

Aurel(ius) A sig II Tr fort Ger natione Macedon post 214 Alex-

andria Egypt.............................III 6598

ALEXSANDER

(? Aure)lius A b(f) XI Cl post Claud Salonae Dalmatia.........III 8727 ALUDISAS

A vet I Min $\boldsymbol{\ell}$-ss Lyons...................... XIII 1887

AMABILIS

Q. Casinius (Am)abilis optio 7 frum II Ital post 170 Rome

Bonn Jahrbb 117 p267

FI(avius) A pollio III Ital Date? Castra Regina Raetia......... III 5949

Hilarinius A bf $\cos 232$ A.D. Col Agrippinensium........... XIII 8206

\section{AMANDIANUS}

(Ulpi)us (?A)m(a)ndianus mil XIIII Gem aet Veri Maximini

Carnuntum Pann Sup......................... 11135

AMANDINUS

Aelius A (mil? II Parth?) Date? Rome.................. VI $\$ 410$

AMANDUS

Aelius A 7 III Aug coh X 162 A.D. Castra Lambaesitana....... VIII 18065

Aemil(ius) A (mil? II Parth?) Date? Rome............... VI 2410

Aurelius A(man)dus T. f. 7 III Aug Date? Lambaesis........VIII 2817

M. Aur(elius) A corn trib III Ital Date? prope Reginum Raetia. III 5974

Q. Flavius A mil I Min $p$ f Date? Vettweis Germ Inf.......... XIII 7854

Iul(ius) A mil III Ital lib cos Date? Augusta Vindelicum Raetia.. III 5814

Iulius A frum XXX Ulp vict Date? Rome............... VI 3334

L. Pompeius A Am(maedara) imm III Aug 2s? Castra Lam- 
L. Sabinus A vet I Min 3s? Lyons................. XIII 1885 U(1)pius A vet XIIII Gem aet Veri Maximini Carnuntum Pann Sup III 11135 M. Uttedius Sallubianus C. Petilius A domo Iguvio vet XIIII

Gem Date? Salonae Dalmatia...................III 2066 Val(erius) Amand(us) d ar I Min 210 A.D. Iversheim Germ Inf . . XIII 7945 AMARANTUS

Aufidius $\Lambda$ bf trib (III Aug) Date? Lambaesis..............VIII 2815 AMBRELIANUS

Ti. Cl(audius) A 7 V Mac c200 Rome................. VI 1408 AMENUS

L. Sallustius A vet (III Aug) Date? Lambaesis............VIII 3231 AMMAUSIUS

Cessorinius A ursarius XXX Ulp vict Date? Vetera Germ Inf..XIII 8639 AMMONIANUS

M. Gabinius M. f. A Castr vet II Tr fort 194 A.D. Alexandria Egypt.................................... 6580 AMMONIUS

Aemilius A 7 II Tr fort 194 A.D. Alexandria Egypt........... III 6580

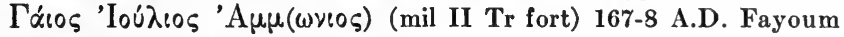
Egypt...................................... 240 A Alex(andrea) sig II Tr fort 194 A.D. Alexandria Egypt. . III 6580 AMPLIATUS nonius a (mil? III Aug) c200 Castra Lambaesitana

Bull Archeol 1905 p239 (A)mpliatus Kar mil? (III Aug) aet Antonini Pii Castra

Lambaesitana............................. VII 18085

AMYNTIANUS

P. Aelius A 77 frum II Tr. 170 A.D. Salonae Dalmatia......... III 1980 ANATOLIUS

Val(erius) A mil II Herculiae post Diocletianum Rome.......A.E. 1909:94 ANDICGUS

C. Iulius C. f. Vol. A mil leg XVI ante 69 Mainz.......... XIII 6940 ANDIO

Aur(elius) A R(atiaria) vet VII Cl 195 A.D. Viminacium Moes Sup................................ $1450 \gamma$

ANDRA

Septimius A imm buc (II Parth Sever p f f) c225 Kalaat-el-

Muldik Syria........................... 1908:272

ANDROMACUS

Iul(ius) A arm cust (III Aug) 200 A.D. Castra Lambaesitana ..A.E. 1902:10 ANDRONICUS

L. Aur(elius) A vet ex sig VII Cl Date? Viminacium Moes Sup..III 12658 ANICETUS

Mo(destius) Anicet(us mil?) I Min Date? Bonn.......... XIII 8053 


\section{ANNALIS}

C. Iul(ius) A arm cust XXX Ulp vict pf 3s Vetera Germ Inf XIII 8626 ANNAMATUS

Aurelius?) A mil (II Ital) 3 s Lauriacum Noricum........... III 11822 ANNIANUS

P. Aelius A.mil frum X Fr Date? Athens............... III 6108 Aur(elius) A 7 (XIIII Gmv?) post 100 Mursa Pann Inf........ III 3284 ANTIGONUS

Aurelius A 7 II Tr fort 194 A.D. Alexandria Egypt...........III 6580

C. Iulius A 7 V Mac p c M. Aurel-274 Potaissa Dacia...........III 881 ANTIOCHIANUS

Aelius A tess XI Cl post Claud Cibyra Phrygia...............III 13665

C. Iulius A Cas sig III Aug 166 A.D. Castra Lambaesitana . . . . . . VIII 18067

M. Oppius A 7 III'Aug p v 194 A.D. Aquae Flavianae......... VIII 17726

M. Oppius A 7 III Aug Date? Lambaesis.............. VIII 2958

— 1 A Tha(rso) (mil? III Aug) Date? Castra Lambaesitana A.E. 1899:90 ANTIOCHUS

P. Ael(ius) A vet VII Cl Date? Viminacium Moes Sup.......... III 8115

M. Aur(elius) Antio(chus) Cap- sig vet VII Cl 195 A.D.

Viminacium Moes Sup...................III 14507

M. Aurelius A mil XXX Ulp vict Date? Col Agrippinensium... XIII 8292

$\longrightarrow$ A Prusia vet? (III Aug) aet Hadriani Castra Lambae-

sitana................................ IIII 18084

\section{ANTONIANUS}

L. Claudius A ? (III Aug) Date? Castra Lambaesitana........ VIII 2562 Flavius Antonian(us) ? (III Aug) 253-268 A.D. Castra Lam-

baesitana............................. VIII 18061

$\mathbf{P}$ (ompeius) Antoni(an)us domo Meliten(s)is? 7 VI Vict post

Hadrian Coccium Eng........................ VII 218

\section{ANTONINUS}

Ann(ius) A spec legg III Antonin (=X Gem XIV Gem I Ad) c212

Carnuntum Pann Sup.......................... 4II 4458

Aur(elius) A sig II Adiut Date? Aquincum Pann Inf........... III 3534

M. Aurel(ius) A mil XIII Gem post Traian Ampelum Dacia...... III 1317

M. Aurelius A 7 III Aug Date? Lambaesis............... VIII 2818

Buccius A vet (III Aug) Date? Lambaesis................ VIII 2811

Cla(u)dius A mil III Cyr ante 108 Egypt...........Wessely Lat Pal 8

Ti. Claudius Anto(ni)nus do(mo H)ierap(oli) mil III Cyr Date?

Amman Arabia.............................. 1905:214

Domitius A mil III Aug Date? Lambaesis................ VIII 3096

F1(avius) A vet $(\mathrm{V}$ Mac) $c 134$ Troesmis................. III 6178

T. Fl(avius) A p p I Adiut ex n(avarcho) princ cl(assis) 1s? Puteoli X 3348

C. Fullon(ius) Antonin(us) optio (III Aug) 198-211 A.D. Castra

Lambaesitana............................ VIII 2554

C. Iul(ius) Anton(inus) vet VII Cl 195 A.D. Viminacium Moes Sup III 14507

(C. Iu)lius A Kas vet? (III Aug) aet Hadriani Castra Lambae-

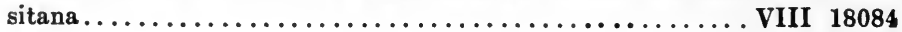


C. Iulius A Iunior spec III Aug Date? Seriana .......... VIII 4381

(G. Iulius) A 7 XII Fulm Date? Troesmis............... III 6191

L. Lucius A Dian(a) vet III Aug p vc198 Castra Lambaesitana. . VIII 18068

Terentius A arm cust III Aug c225 Castra Lambaesitana.... A.E. 1902:11

Ulpius (A)ntonin(us) princeps (III Aug) c253 Castra Lambae-

sitana................................. 18072

Valer(ius) A spec I Ital Sever c225 Ad Haemum Moes Inf ...... . III 13719

A Castr vet II Tr fort 194 A.D. Alexandria Egypt........ III 6580

ANTONIUS

Val(erius) A mil XI Cl 155 A.D. Almus Moes Inf........... III 7449

ANTULLINUS

Ael(ius) A mil XI Cl 155 A.D. Almus Moes Inf.............III 7449

M. Ulpius A 7 XVI Fl post Traian? Ancyra.............III 6767

\section{ANTULUS}

(Cor)nelius C. f. Pol A Castr(is) ? (III Aug) Date? Castra

Lambaesitana........................... VIII 2565

APELLES

Ael(ius) A mil XI Cl 155 A.D. Almus Moes Inf.............III 7449

APER

Q. Annius A spec VII Gem fel Date? Tarraco.............. II 4143

T. Fl(avius) A Sir(mio) vet VII Cl 195 A.D. Viminacium Moes Sup III 14507

T. Flavius A 7 ex leg III Aug p v ante 240? Seriana. VIII 4378 add 18554

L. Maelonius A vet bf $\cos$ VI Vict pf ante 70? Emerita Lusitania.. II 491

(V)al(erius) A mil (II Adiut) Date? Ticinum............. 6428

\section{APOLINARIS}

C. Gemellius A sig III Aug Date? Lambaesis. . . . . . . . . . . VIII 2886

C. Iulius A 7 leg VI post Hadrian Corbridge England....E.E. IX 1141

\section{APOLINARIUS}

P. Aul(ius) A mil III Aug ex III Gall ss init Lambaesis.... . . . . VIII 3049

\section{APOLLINARIS}

P. Ael(ius) Co(1. Apol) linaris mil II (Adiut) 2-3s? Aquin-

cum Pann Inf........................... III 10498

L. Antonius Apollin(aris) vet I Adi pf 107-117 A.D. Apulum Dacia III 1004

Cla(u)dius Apulinar(is) mil III Cyr ante 108 Egypt.... Wessely Lat Pal 8

C. Claudius A vet ex (imag? II Tr fort?) 140 A.D. Fayoum Egypt. BGU 610

Cosidi(us) A (mil? II Parth?) Date? Rome............... 2410

T. Flavius T. f. Pol. A Castr vet II Tr fort 194 A.D. Alexandria

Egypt.............................. 6580

C. Iulius A vet III Aug Date? Lambaesis............... VIII 3188

Q. Iulius A (vet II Tr fort?) 140 A.D. Fayoum Egypt. . . . . . . BGU 610

Valerius Apollin(aris) cor III Aug p v 203 A.D. Castra Lambaesitana............................... 2557

C. Valerius C. f. Col. A Hierapol(i) vet II Tr fort 194 A.D. Alexandria Egypt........................... 6580 


\section{APOLLODORUS}

Ael(ius) A mil XI Cl 155 A.D. Almus Moes Inf ..............III 7449

Ael(ius) Apoll(odorus?) vet VII Cl 135 A.D. Viminacium Moes

Sup................................... III 8110

APOLLONIUS

Aurelius A dup III Aug pv Antonin 218 A.D. Castra Lambaesitana VIII 2564 M. (A)ur(elius) Apo(11)on(ius) vet XV Apol 1s? Tauchira

Cyrenaica .................................... 6

Iu(lius) Apollon(ius) 7? XIII Gem post Traian Veczel Dacia III 8065:28 APOLLOPHANES

Aur(elius) A 7 (III Aug) Date? Lambaesis................ VIII 8818

APOLLOS

M. Aurelius Pol. A Castris vet II Tr fort 194 A.D. Alexandria

Egypt................................... 6580

APOLODORUS

Iulius A mil II Parth Date? Rome..................... VI 3406

APONINUS

C. Nigldius A 7 X Gem p \& 89-Traian Brohl .............XIII 7718

APPIANUS

Aurelius A mil XI El 155 A.D. Almus Moes Inf..............III 7449

us L. f. Pol. A Castr. vet Il Tr fort 194 A.D. Alexandria

Egypt..................................III 6580

APRICIUS

Iul(Ius) A mil II Ital $p f$ bf praef $3 \mathrm{~s}$ Fafiana Noricum ..........III 5671 APRICOSUS

Villius Apricos(u8) 7 II Parth Sever c215? Ager Albanus..E.E. IX 658 APRILIS

T. Aurelius A 7 VI Vict ante Hadrian? Lyons .............XIII 1840

Celsius A Cas optio eq (III Aug) Date? Castra Lambaesitana... VIII 2568

Iulius A dup III Aug pv Antonin 218 A.D. Castra Lambaesitana.. VIII 2564

K? A 7 XXII Prim Date? Brohl..................... XIII 7703

A 7 (leg?) coh VI? Date? Vindobala Eng............. VII 550

A bf cos Date? Col Agrippinensium................ XIII 8804

APRINUS

A 7 VII Gem fel Date? Lambaesis................ VIII $\$$ \&445 APRONIANUS

Publicius A hast XXII Prim Date? Tarraco...............II 4146 APULONIUS

A 7 VII Gem fel Date? Carthage.................VIII 12590

AQUILA

L. Domitius L. f. Ani. A domo Myliada vet leg VII ante 42 A.D.

Ljubuski Dalmatia.............................III 8487

Iul(ius) A vet (V Mac) c134 Troesmis..................III 6178

Q. Iulius C f. Quir Aqu(i)la 7 I Adiut 7 XXX Ulp vict 7 X Fr

Date? Sicca................................. 15872 
M. Licinius M. f. Coll. A Bera vet III Aug Date? Lambaesis.. VIII 3175 Lucret(ius) A 7? XIII Gem post Traian Apulum Dacia....... III 1629:22 M(e)tt(ius) Aqui(la) imag? (I Ital) 2s exe-3s Almus Moes Inf III 14409:1 Petronius A 7 I Min 210 A.D. Iversheim Germ Inf . . . . . . . . . . XIII 7945 Val(erius) Aquil(a) vet bf VII Cl 135 A.D. Viminacium Moes Sup III 8110 A 7 (leg XXII aut III Cyr) aet Augusti Coptos Egypt. . . . . III 6627 AQUILEIENSIS

M. Valer(ius) A Thev(este) bf $\cos$ III Aug c225 Lambaesis.... . . VIII 2586 AQUILINUS

Ael(ius) Aquili(nus) vet VII Cl 135 A.D. Viminacium Moes Sup. . III 8110

(C.) Long(ius) A vet XIII Gem post Traian Apulum Dacia........ III 1155

C. Domitius L. f. Ani. (A)qui(1)inus mil leg VII 42 ante A.D.

Ljubuski Dalmatia.......................II 848 r AQUILO

C. Iulius A vet (III Aug) Date? Lambaesis.............. VIII $\$$ I129 AQUILUS

Ael(ius) Aqui(lus) mil VII Gem piae Date? Tarraco..........II 4148

Ti. Claudius A vet (leg?) Date? Caesarea Mauretania Caesariensis ....................................... 21023

\section{ARABUS}

C. Iulius A Cuic(ulo) vet III Aug pv c198 Castra Lambaesitana VIII 18068 ARATOR

L. Cornel(ius) A 7 XIIII G m v 70-100 A.D. Nida Germ Sup.. XIII 7331

C. Iulius A (vet? III Aug?) Date? Lambaesis...............VIII 3181

C. Vibius A mil frum VII Cl pf Date? Scupi Moes Sup........ III 8200 ARATUS

Anto(nius) A 7 (leg?) coh VI Date? Castlecary Eng.........VII 1100 ARCHELAUS

Aurelius A bf trib leg ? \&s Oxyrhynchus........... Ox Pap I 32

C. Iulius Arc(he)laus mil III Aug Date? Lambaesis......... VIII 3131 ARELLIANUS

Cl(audius) A vet? (III Aug) aet Hadriani Castra Lambaesitana . VIII 18084 A Zeug(ma) vet? (III Aug) aet Hadriani Castra Lambae-

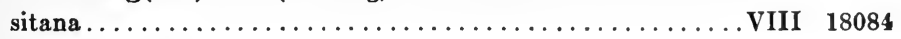
ARETINUS

Iul(ius) A sig IIII Scyt Date? Enesch Syria.............. 1908:25 ARIMO

L? Aur(elius) A imm XIII Gem Antonin ce15 Veczel Dacia III 12565 cf A.E. 1912:305

\section{ARIS}

L. Aurelius A vet VII Gem $p$ f 3s? Lucus Augusti Tarraconensis II \&58\& ARISTAENETUS

Aurel(ius) A vet I Min Date? Col Agrippinensium........XIII 8278 


\section{ARISTIDES}

(A)urelius A(ris)tides mil bf cos I Min Date? Col Agrippinen-

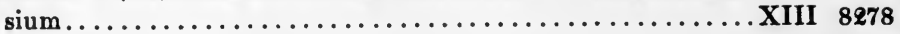

ARISTO

(Ac)utius Arist(o) 7 III Aug Date? Lambaesis............ VIII 2781 APOTTIANOE

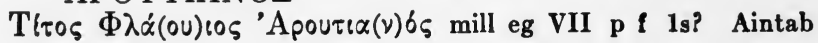
Syria.............................ARBL 1907 ps63 ARPOCRA

P. Aelius A sig III Aug Date? Lambaesis............. VIII 2792 ARRIANUS

L. Caelius A medicus II Ital Date? Brixia..............V 4367

C. Iulius A vet ex imag (II Tr fort?) 140 A.D. Fayoum Egypt..BGU 610 ARRUNTIANUS

(A)elius Arruntian(us) Had(rumeto) mil? (III Aug) aet

Antonini Pii Castra Lambaesitana ................ VIII 18085

ARSACES

C. Valerius C. f. Aem. A leg V Alaudae ante 87 Ligures Baebiani IX 1460 ARTEMIDORUS

Aelius A 7 (I) Ital Date? Montanensium Moes Inf...........III 12371 Aur(elius) A bf leg II Adi p f Sever 228 A.D. Aquincum Pann

Inf .................................... 3412

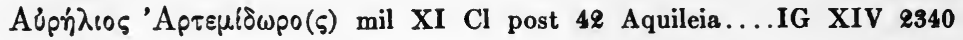
ARTEMO

Aurel(ius) A medicus XI Cl 155 A.D. Almus Moes Inf.........III 7449

Aur(elius) A mil XI Cl 155 A.D. Almus Moes Inf........... III 7449 ARTILLUS

G. Geminius A vet ex corn VIII Aug Date? Lyons..........XIII 1860 ARUSENUS

Aureli(us) Arusen(us) Turesi vet ex leg I Min 3s? Bonn.... XIII 8066 ASCANIUS

Cicereius Ascan(ius) p p leg XI ante Claud Burnum Dalmatia..III 14996 ASCLA

M. Ulpius A optio III Aug 198-211 A.D. Castra Lambaesitana.. VIII 2554 ASCLEPIADES

Aelius A nati(one) Cil(ice) mil leg IX 1s Puteoli..........X 1769 Domit(ius) A domo Arethusa Suriae 7 XXII Prim An-

tonin c215 Mainz.......................... 1906:63

L. Furnasi(dius) A arm cust III Aug Date? Lambaesis..... . VIII 2912 'A $\sigma x \lambda \eta \pi \iota \alpha ́ \delta \eta \zeta$ medicus II Tr fort 147 A.D. Thebes Egypt

\section{ASCLEPIODORUS}

IG a RR I 1212

Cordius A 7 III Aug coh X 162 A.D. Castra Lambaesitana.... VIII 18065 ASMENUS

Sept(imius) A mil XIII Gem Antonin c215 Carnuntum Pann Sup III 4440a 


\section{ASPADIUS}

M. Ulp(ius) A (vet) ex sig leg XXX 210 A.D. Vetera Germ Inf.. XIII 8654 ASPER

C. Calpurnius A 7 leg XXII ante Hadrian Thebes Egypt......III 56 Iulius A arm cust (III Aug) 200 A.D. Castra Lambaesitana.. A.E. 1902:10

G. Minicius G. f. Stelatina A Augu(s)ta Taurinoru(m) mil

IIII Mac ante Vespas Mainz................. XIII 6870

(? Sulpicius) P. f. Sca. A (p p VI) Ferr aet Neronis Milet Bithy-

nia................................. 1908:130

ATALUS

P. A vet ex bf (V Mac) c134 Troesmis................ III 6178 ATERNUS

Valerius A vet (V Mac) Date? Troesmis.............III 6179 ATHENIO

M. Aur(elius) A vet ex bf IIII Fl Date? Apamea Phrygia....III 13663 ATILIUS

T. Ael(ius) A Sal(onis) vet VII Cl 195 A.D. Viminacium Moes

Sup.............................III 14507

Iul(ius) At(i)lius mil XIIII Gem post 100 Ager ad Colapim Pann

Sup............................ 14048

ATILLIANUS

T. Vitellius A T. f. Viminaci 7 III Aug IIII Fl VII Cl XII Fulm

XV Apol II Aug VII Cl II Adiut VI Vict Date? Lambaesis.. VIII 3001 ATRECCESIANUS

A mil XIIII Gem Date? Salonae Dalmatia...........III 12896 ATRECTUS

Attius A 7 XXII Pr p f post 89 Mainz............... XIII 6994 ATTA

Ael(ius) A actar II Adi p f Antonin c215 Aquincum Pann Inf.. A.E. 1910:127

T. Aur(elius) A mil III Fl str cos Date? Naissus Moes Sup..III 8249 ATTIANUS

(Anto)nius A comm cos VIII Antonin 213-217 A.D. Mainz.... XIII 6803 ATTICIANUS

Flavius A mil I Adiut post 114 Ad Lacum Pelsonem Pann Sup... III 4129

G. Vitellius A 7 VI Vict pf post Hadrian Whitley Castle Eng .. VII 308 ATTICINUS

Sex. Valerius Att(i)cinus vex eq III Aug 1s Theveste....... VIII 16549 ATTICUS

T. Aur(elius) A vet ex sig III Fl Date? Singidunum Moes Sup................................ 1910:178

Dumi(us) A vet ex actar (III Aug) 270-275 A.D. Lambaesis.. VIII 2626

C. Fictorius C. f. A 7 III Gall Date? Rome..............VI 3592

C. Iulius C. f. Col. A Tar. optio III Aug Date? Lambaesis... . VIII 2886

Mummius A Cir(ta) bf trib (III Aug) Date? Castra Lambaesi$\tan a \ldots \ldots \ldots \ldots \ldots \ldots \ldots \ldots \ldots \ldots \ldots \ldots \ldots \ldots \ldots$ 


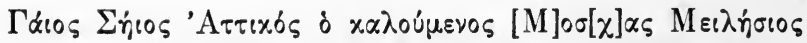
optio leg VI Date? Hierapolis.............IG a RR IV 825 Val(erius) A bf cos VII Gem p Date? Tarraco..............II 4167 ATTILIANUS

us Attil(ianus)? (mil? III Aug) Date? Castra Lambaesitana ............................. Bull Archeol 1904 p208

\section{ATTILLUS}

L. Adiutorius A (vet?) leg XXII 3s? Wiesbaden......... XIII 7570b

F1. Sabinius A vet XXII Pr p f post 89 Castellum Mattiacorum. XIII 7291 ATTIUS

M. Aur(elius) A Sc(upis) vet VII Cl 195 A.D. Viminacium Moes Sup.................................... 14507

ATTO

M. Faricius A frum I Adiut Date? Rome............... VI 3332 AUCTINUS

Q. Geminius A Kar can (III Aug) Date? Castra Lambaesitana VIII 2569 AUDAX

Fl(avius) A nat Germanic 7 I Adiut $2-3$ s Ancyra.......... III 265 AUDEUS

P. Ael(ius) Sept(imius) A qui et Maximus vet ex 7 (XIII Gem) post Traian Sarmizegetusa.................... III 1471 AUFIDIANUS

G. Iullus A vet III Aug Date? Lambaesis..............VIII 3132

A. Octavius A arm cust III Aug Date? Lambaesis......... VIII 2955 AUFIDIUS

Ael(ius) A (vet? V Mac?) Date? Potaissa Dacia............ III 7688 AUGURIANUS

M. Cornel(ius) Augurian(us) exactus III Aug p v c202 Castra Lambaesitana ............................. 1898:109

\section{AUGURINUS}

Avitius A mil XIIII G m v Date? Salonae Dalmatia..........III 6549

Q. Caesonius A vet? (III Aug) aet Hadriani Castra Lambaesi-

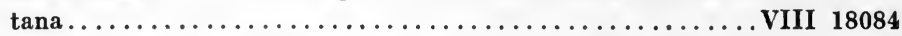

Iul(ius) A comm legg III Antonin ( $=$ X Gem XIV Gem I Ad) c21\& Carnuntum Pann Sup.......................III 4452 A mil X Gem Date? Vienna....................III 4556 AUGUSTALIS

Attius Augusta(lis) (mil? III Aug) Date? Castra Lambaesitana $\ldots \ldots \ldots \ldots \ldots \ldots \ldots \ldots \ldots \ldots \ldots$ Bull Archeol 1904 p 207 Augustius A vet ex leg XXII Pr p f Date? Lyons..........XIII 1838 Fla(vius) A mil? I Ital Date? Aquileia................. 914 Iulius A dup III Aug pv Antonin 218 A.D. Castra Lambaesitana. . VIII 2564 L. Octavius A Kart vet III Aug pv c198 Castra Lambaesitana.. VIII 18068 


\section{AUGUSTINUS}

P. Ael(ius) August(inus) corn? VII Cl 135 A.D. Viminacium

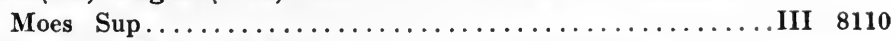

M. Antonius M. f. Gal. A Pace mil VII Gem fel Date? Bracara

Aug Tarraconensis.............................II 2425

AUGUSTUS

Quintinius A optio XXII Pr p f Date? Lyons...........XIII 1882

-a A (7? I Min) aet Getae Bonn............... XIII 8050 AULUGENTIUS

Val(erius) A 7 XI $\mathrm{Cl} 3 \mathrm{~s}$ exe-4s init Aquileia............. 940 AULUPOR

Aur(elius) A vet II Adiut 3s? Aquincum Pann Inf........... III 10504 (Aulup)or Aulusa(ni fil?) mil XXII Pr p fives civitate Anche-

(alo) 3s? Castellum Mattiacorum................XIII 7898 AULUTRALIS

Aurel(ius) Aulutral(i)s mil VII $\mathrm{Cl}$ \&s exe-3s init Viminacium Moes Sup..............III 8118 et Jahres Wien 1903 Beibl p16 AULUZANUS

Aur(elius) A mil II Parth Date? Rome................VI 3397

Mucatralis A mil III Aug natione Thrace natus in civitate Augusta Traianesie Date? Lambaesis................VIII 18318 AULUZON

M. Aur(elius) A R(emesiana?) vet VII Cl 195 A.D. Viminacium Moes $\quad$ Sup................................ 14507 AUNUS

Aurel(ius) Aunus? vet VI Vict ante Hadrian Remi Belgica..VIII 3258 AURASSUS

Iuliu(s) A vet ex actar (III Aug) $270-275$ A.D. Lambaesis.... VIII 2626 AURELIANUS

M. Aurelius A opt pp (III Aug) c253 Castra Lambaesitana.... VIII 18072

M. Aur(elius) Aurelia(nus) ex frum bf cos Date? Josephsthal Dalmatia.............................III 3080 add 10057

L. Caecilius L. f. Pap. A Had(rumeto) mil III Aug Date?

Lambaesis............................. VIII 3062

C. Iulius A exactus III Aug p v c202 Castra Lambaesitana...A.E. 1898:109

M(arcus) A vet ex str cos II Adiut Date? Intercisa Pann Inf A.E. 1910:144

I. Solicius A $7 \mathrm{~V}$ Mac et I Min $p$ aet Domitiani aut postea

Forum Iulii.............................. 264

AURELIUS

Iulius A 7 (III Aug) $285-305$ A.D. Lambaesis............ VIII 2660

\section{AURIGULLUS}

(C. Domitius) C. (f) (Au)ricullus arm cust VII Cl Date? Viminacium Moes Sup.........................III 8119

AUSTER

Atidius A 7 III Aug coh III 162 A.D. Castra Lambaesitana.... VIII 18065 


\section{AVELLIANUS}

Octavius A 7 II Tr fort 194 A.D. Alexandria Egypt...........III 6580 AVENTINUS

Iul(ius) $A$ vet I Min $2-3$ s Lyons...............XIII 1862 AVIDUS

Cl(audius) Avid(us) 7 (leg?) coh I Date? Magna Eng......E.E. IV 686 AVILLIUS

C. Vallicius A Volt. Nemauso vet VII Gem fel Date? Tarraco II 4173 AVITIANUS

M. Aur(elius) A mil I Adiut Date? Intercisa? Pann Inf ......E. 1909:147 AVITUS

Aelius A mil? X Gem Date? Vienna.................III 4568

M. Aurelius A Avitiani f. c R Carnuntiensis mil II Tr fort

Date? Alexandria Egypt......................... 6593

T. Aur(elius) A vet II Adiut Date? Mursa Pann Inf........III 3283 Caecilius A Emer(ita) Aug(usta) optio XX V v Date? Chester

Eng................................ IX 1058

Cassi(us) A (7 ? I Min) aet Getae Bonn...............XIII 8050

P. Ferrasius C1. A Savar(ia) 7 VIII Aug p f c c ex aquil I Adiut

191 A.D. Stockstadt......................XIII 6646

T. F(lavius)? A bf cos Date? Stockstadt..............XIII 6648a

Iulius A corn VII Gem ce00 Tarraco...................II 4122

C. Iulius A (eq? III Aug) \&2\&-35 A.D. Castra Lambaesitana

M. Iulius A Ultinia Reis Apollinar 7 XV Apol V Mac XVI FI

M A H $1897 \quad$ p447

firm c100 Perinthus...........................III 7397

Q. Memmius A Cast vet III Aug pv c198 Castra Lambaesitana VIII 18068

Paternius A corn VIII Antonin 213-217 A.D. Mainz......... XIII 6803

C. Sittius A arm cust III Aug c225 Castra Lambaesitana.....A.E. 1902:11

M. Ulpius A 7 III Aug (7) IIII Fl 3s Ager Haeduorum septentrionalis ............................... XIII 2828

Umidius A mil bf VII Gem fel Date? Nemausus...........XII 3168 AVOS

(Au)relius T. f. Gal. Avos? Cal(agurri) mil X Gem 70-Traian

Ulpia Noviomagus.....................XIII 8732 .

BACGHIUS

Ulp(ius) B 7 XIII Gem 197-209 A.D. Apulum Dacia...........III 14479

BACULUS

Sal(vius) Frebranus T. f. Quir. B hast pr leg XX 1s init Burnum

Dalmatia............................ II 2836

BALBUS

Flavius B corn? bf? trib III Aug c200 Castra Lambaesitana . . . . . VIII 18078 Q. Marcius B missicius leg XXI 70-Hadrian Mainz .......... XIII 6951a

\section{BALERIANUS}

Iuli(us) Baler(ianus) vet (V Mac) c134 Troesmis...........III 6178 


\section{BALIUS}

(A)elius B 7? XIII Gem post Traian Veczel Dacia..........III 1629:3 BALLISTA

P. Asinius L. f. B vet XV Apol 1s? Verona. ............ 3357 BARBARUS

L. Atilius B Mil(evo) bf $\cos$ III Aug c225 Lambaesis.......... . VIII 2586

Q. Iulius B ? (III Aug) Date? Castra Lambaesitana........... VIII 2562

L. Octavius B mil III Aug p v 3s? Lambaesis............... VIII 3209

C. Sacidius B 7 XV Apol 1s Carnuntum Pann Sup............III 4418 BARBIUS

M. Aur(elius) B Sal(onis) vet VII Cl 195 A.D. Viminacium Moes Sup................................. 14507

BARICIO

Cornelius B dup III Aug p v Antonin 218 A.D. Castra Lambae-

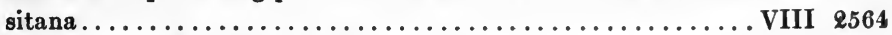

Iulius Baric(io) dup III Aug p v Antonin 218 A.D. Castra Lambae-

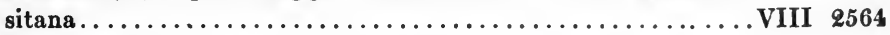

C. Iulius Baric(io) Cast vet III Aug p v c198 Castra Lambaesi$\tan a \ldots \ldots \ldots \ldots \ldots \ldots \ldots \ldots \ldots \ldots \ldots \ldots \ldots$. . . . 18068

C. Pinaeus Baric(io) Cast vet III Aug p v c198 Castra Lambaesitana............................... 18068 BAROSUS

C. Marius B Sim(ithu) mil? (III Aug) Date? Castra Lambaesitana.................................... 2568 BASILIDES

F(lavius) B Tes $=$ (Thessalonica?) p p III Cyr Date? Bostra Arabia............................. 14149:4 BASSIANUS

Octavius B vet (III Aug) Date? Lambaesis.............. VIII 18313 BASSILAS

L. Servilius B mil I Min Date? Cartenna Mauretania Caesariensis.................................... 9662 BASSINUS

Iulius B mensor (III Aug) 3s? Castra Lambaesitana ........ A.E. 1904:72 BASSUS

Aelius B 7? XIII Gem post Traian Veczel Dacia............II 1629:4 P. Aelius P. f. Serg. Bass(us) 7 XX V v Date? Watercrook Eng VII 292 (Ae)milius B Apam(ea) vet? (III Aug) aet Hadriani Castra Lambaesitana..............................VIII 18084

L. Aemilius B Had(rumeto) eq (III Aug) \&s? Castra Lambaesitana........................... 1808 III

M. Antonius B Apam(ea) vet? (III Aug) aet Hadriani Castra

Lambaesitana........................ VIII 18084

C. Apidius P. f. Qui. B Amiterni p p leg XI ante Claud Latium XIV 3906

C. (Ap)onius B ? (III Aug) Date? Castra Lambaesitana VIII 2562 et 18051

L. Arnius L. f. Pup. B mil XV Apol 7 XIIII Gem 7 II Aug 7 
VI Vict Date? Tergeste...................... 528 Aurelius B tub III Aug p v 202 A.D. Castra Lambaesitana...A.E. 1907:184 L. Caesius L. f. Cam. B domo Pisauri vet VII $\mathrm{Cl} p$ f $1 \mathrm{~s}$

Salonae Dalmatia...........................III 2014 Capitonius M. f. Cam. B sig XV Apol Date? Augusta Bagien-

norum......................... Pais Suppl n977

Cervius B bf trib (III Aug) Date? Lambaesis............. VIII 2839 Claudius Bass(us) 7 III Aug coh V 162 A.D. Castra Lambaesi-

tana.................................. 18065

(Claudius) Bass(us) sig leg I post 114 Brigetio Pann Sup......III 10994

T. Cominius B Damasco mil III Cyr 80 A.D. Alexandria Egypt III 6603 Cornel(ius) B vet (V Mac) c134 Troesmis...............III 6178 C. Epidius C. f. Pol. B vet X Fr 94 A.D. Alexandria Egypt A.E. 1910:75 Iulius B dup III Aug p v Antonin 218 A.D. Castra Lambaesitana VIII 2564 Iul(ius) B mil III P(arth) 3s Viminacium Moes Sup....III 1651 et p1021 Iulius B 7 XXII Prim 3s? Lambaesis................ VIII 2888-9 Iulius B 7 III Aug Date? Lambaesis.................. VIII 2890 I(ulius) B vet $\mathrm{V}$ Mac Date? Drobeta Dacia.............III 14216:5 C. Iulius B vet ex imag (II Tr fort?) 140 A.D. Fayoum Egypt BGU 610 C. Iulius C. f. B Maec. Pelago vet VIII Aug Date? Stobi Macedonia................................. 7325

C. Iulius B Cas mil? (III Aug) Date? Castra Lambaesitana.. VIII 2567

L. Lucretius B (7) III Aug Date? Seriana..............VIII 4382

Q. Marcius Q. f. Cor. B domo Benevento mil leg VII ante $\mathbf{4 2}$

Gardun Dalmatia.........................III 14932

$\mathrm{Na}$ (evius?) B 7 (leg?) coh I Date? Chesters Eng...........VII 597

C. Oppius C. f. Vel. B 7 IIII Fl fel et II Tr fort Date? Auximum IX 5840

C. Paconius B vet (III Aug) Date? Verecunda............ VIII 4244

L. Refidius L. f. Ter B domo Venafro 7 leg XVI ante 43?

Mainz.................................. 1909:73

L. Satrius B mil III Cyr Date? Rome...............VI 3626

L. Serenius B 7 II Adiut 2-3s? Aquincum Pann Inf........ III 6456

G. Terentius B 7 VI Vict ante Hadrian Brohl............ XIII 7695-6 Ulp(ius) B mil XI Cl 155 A.D. Almus Moes Inf............ III 7449 Valerius B (7?) XIIII G m v c68? Aquae Germ Sup.........XIII 6304 Valeri(us) (Ba)ssus optio I Min p f Date? Rigomagus Germ Inf..................................... 7795

C. Valerius C. f. Pol. B Cas (mil III Cyr aut XXII Deiot) 90 A.D. Fayoum Egypt...................... Gap Len Lat 1

C. Val(erius) B mil I Adiut c150 Caesarea Mauretania Caesariensis............................... VIII 21049

M. Verginius B 7 IIII Scyt Date? Rome.............. VI 403 Veru-_ Bassu(s) vet $(\mathrm{V}$ Mac) c134 Troesmis............III 6178 Pol. B Samosata optio II Tr fort 194 A.D. Alexandria

Egypt................................. $\quad 6580$

\section{BASUS}

M—— B mil III (Aug) Date? Lambaesis............. VIII 3205 
BATO

B Neritani (fil) mil II Adiut 3s? Aquincum Pann Inf III 3558 BAUDIO

Florius B ducenar protector ex ordinario II Ital divit Date? Spoletium................................. XI $\mathbf{4 7 8 7}$ BEBIUS

C. Oppius B bf cos II Ital p f Sever 226 A.D. Teutoburgium Pann

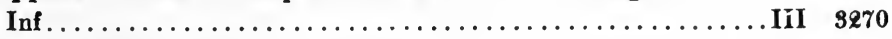
BELIABUS

Rabil(ius) B tub IIII Scyt Date? Enesch Syria............ 1908:25 BELLICANUS

L. Sentius B optio (et 7) (I) Ital Date? Rome...........VI 9628 BELLICIANUS

L. Antistius B vet I Adiut post 114 Brigetio Pann Sup........ III 4311

L. Antistius B mil exactus off praesidis I Adiut post 114 Brigetio

Pann $\operatorname{Sup} \ldots \ldots \ldots \ldots \ldots \ldots \ldots \ldots \ldots \ldots \ldots \ldots \ldots \ldots \ldots \ldots \ldots$ III 4311

C. Licinius B bf (leg) leg II Ital p f 211 A.D. Celeia Noricum. . .III 5187 BELLICUS

L. Antistius B mil II Adiut bf cos post 114 Brigetio Pann Sup.. III 4311 Calvonius Belli(c)us mil leg XXII Date? Lyons...........XIII 1872 L. Coelius B mil? leg VII? Date? Tarraco.............II 4175

A. Geminius B Sicc(a) mil? (III Aug) Date? Castra Lambaesi-

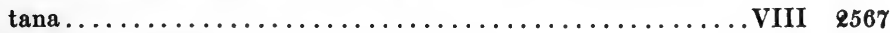
Iul(ius) $B$ vet XXII Pr p f Date? Mainz..............XIII 6667 M. Laetor(ius) B optio (III Aug) 198-211 A.D. Castra Lambaesitana................................. 2554

C. Nonius (B)ellicus Cas mil? (III Aug) Date? Castra Lambaesitana................................... $\$ 567$

C. Rutil(ius) B vet (III Ág) Date? Lambaesis............ VIII 3228

M. Ulpius $B$ vet $\mathrm{XXX}$ Ulp vict Date? Riva........... 5010 BELLUS

L. Septimius B sig XXII Prim optio navali 198 A.D. Mainz.. XIII 6718 BERSIMES

Aurelius B vet (leg?) Date? Brixia................. 4966 BERULUS

M. Aurelius B frum XIII Gem Date? Rome............VI 9356 BETHUS

T. Aurelius B 7 III Aug Date? Lambaesis............ VIII 2820-1 BETTO

Fl(avius) B 7 XX V v Date? Rough Castle Eng........... III 1092 Iulius B frum I Min Date? Rome................. 3333 BIBULUS

Cn. Decimius Cn. f. Lem. B evocatus leg XIII 1s init? Hispellum XI 5275 BIENIUS

Bieni(us aut-us) 7 leg II ante Claud? Argentorate..XIII 5977 
BIRZIL

Manilius B dup III Aug p v Antonin 218 A.D. Castra Lambaesitana..................................... $\mathbf{8 5 6 4}$ BITHUS

M. Aur(elius) B Paul(talia) vet VII Cl 195 A.D. Viminacium Moes Sup................................ 14507

T. Aur(elius) B Rat(iaria) vet VII Cl 195 A.D. Viminacium Moes $\operatorname{Sup} . . \ldots \ldots \ldots \ldots \ldots \ldots \ldots \ldots \ldots \ldots \ldots$ III 14507 (B)it(h)us Sc(upis) vet VII Cl 195 A.D. Viminacium Moes Sup..............................III 14507 BITO

Aur(elius) B natione Trax cives Filopopulitanus mil I Ital Date? Rome............................... VI 2601 BITUS

Aelius B Napoca mil? (III Aug) aet Antonini Pil Castra Lambaesitana............................... VIII 18085 Aur(elius) B corn II Adiut 2-3s Aquincum Pann Inf ....... III 15159-60 Aurel(ius) B mil II Parth Date? Rome................ 3378 (A) urel(ius) B v(et leg I Min?) 3s? Lyons............. XIII 1843 L. Valerius B natione Bessus mil III Cyr Date? Bostra Arabia..III 104 BLASIUS

Alfius B 7 III Aug Date? Lambaesis.................VIII 2801 BONIATUS

Aur(elius) B mil II Ital Sever c225 Virunum Noricum......III 4791 add BONOSUS

Egnatius B arm cust (III Aug) 200 A.D. Castra Lambaesitana A.E. 1908:10 BONUS

M. Aur(elius) B Sc(upis) vet VII Cl 195 A.D. Viminacium

Moes Sup.................................III 14507

C. Aninius Lem. B mil leg VIIII 1s? Aquileia.......... Pais Suppl n180 BRITTO

Fl(avius) B 7 XIIII Gem Date? Rome.................. 3594

P. us B Kar vet? (III Aug) \&s? Castra Lambaesitana.... VIII 18087 BRUMASIUS

Aemil(Ius) B mil III Aug Date? Affreville ..............E. 1904:20 BRUTTIANUS

C. Iullus B 7 VI Ferr Date? Puteoli.................... 1737 BUCCO

Q. Helvius B 7 XIIII Gem ante 62 Mainz ...............XIII 6907 BUGULUS

Claudius B 7 I Adiut 70-100 A.D. Mainz...............XIII 6837

BURRUS

L. Flavius $\mathrm{B}$ mil $\mathrm{XI}$ Cl pf Vespas-Traian Vindonissa Anzeig \& Schweiz Alter VI p160-1 
Q. Pompeius Q. (f) Aniensis Foro Iuli B mil ex leg XV ante

Vespas Col Agrippinensium.....................XIII 8884 BUTURARIUS

Noni(us) Butur(arius) arm cust III Aug c225 Castra Lambaesitana................................ 1902:11

BYTYTRALIS

- Bytyt(r)al(is) Biti(fil) vet leg XXI(I) Date? Ager

Mogontiacensis..............................XIII 7813 .

CABRIO

(A) ur(elius) C aquil leg? Date? Bonn.............XIII 8084 GADARUS

C. Lovesius Papir C Emerita mil XX V v Date? Chester Eng.

E. E. IX 1063

GaEgilianus

Arabonius Caecilian(us) dup III Aug p v Antonin 218 A.D.

Castra Lambaesitana.......................... VIII 2564

Q. Faonius C (eq? III Aug) $28 \varepsilon-35$ A.D. Castra Lambaesitana

MAH $1897 \quad \mathbf{p 4 4 7}$

Firmidius G(a)ecilianus bf cos VII Gem p f Date? Tarraco...II 4153

Gabin(ius) C sig (III Aug) Date? Castra Lambaesitana...... VIII 18073

C. Iulius-G vet III Aug Date? Mastar...............VIII 6358

C. Octavius C mil exactus III Aug Date? Lambaesis........ VIII 2956

Sex. Pomponius C vet ex str (III Aug) Date? Lambaesis ...... VIII 2597 CAEGILIUS

C. Iulius C mil III Aug Date? Lambaesis............... VIII 3133 GAECINIANUS

C. Iulius C 7 (II Aug?) Date? Isca Eng ............... VII 114 GAELESTINUS

Octavius G aelestin(us) dup III Aug p v Antonin 218 A.D. Cas-

tra Lambaesitana ........................... VIII $\mathbf{e 3 6 4}$

GAELIUS

F1(avius) Cael(ius) vet (V Mac) Date? Troesmis..........III 6180 GAENEUS

L. Pompeius $\mathrm{C}$ princeps leg XIIII G m v post 100 Carnuntum

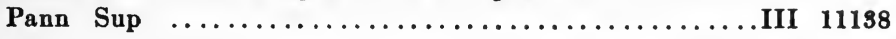

GaESENNIANUS

P. Granius Auctus C vet (III Aug) Date? Lambaesis....... VIII 3180

GAESERNUS

Septimius C dup I Adiut post 114 Brigetio Pann Sup.........III 4984 GaETICGUS

lus $\mathrm{C}$ vet I Adi p f 70-100 A.D. Remi Belgica

XIII 3860

CAIUS

P. Aelius G mil XIII Gem post Traian Apulum Dacia.........III 1034

Aurelius C 7? XIII Gem post Traian Apulum Dacia....III 1689:14 
M. Aur(elius) Caiu(s) mil VII Cl str cos 220 A.D. Naissus Moes Sup ............................... III 12678

M. Ulp(ius) C III Ital Antonin 211-222 A.D. Apulum Dacia.....III 1178 CALAMUS

Pomponius C Sic(ca) mil? (III Aug) Date? Castra Lambaesitana .......................... VIII 2567 et 18084

\section{KALANDINUS}

A. Cesonius K 7 protector (II Adiut)? 3s init Aquincum Pann Inf $\ldots \ldots \ldots \ldots \ldots \ldots \ldots \ldots \ldots \ldots \ldots \ldots \ldots$ III 10508 - K mil leg X Date? Fl Raab Noricum.............III 5486 KALENDINUS

Q. Caecilius K optio (II Tr fort) Date? Alexandria Egypt.....III 6577

(M) Ul(pius) $\mathrm{K}$ bf $\cos$ (I) Ital 225 A.D. Narona Dalmatia....... III 1781 K Celati f mil II Adiut Date? Vallis Fl Mur Noricum..III 5417 CALENUS

G. Iulius Gal. Cal(e)nus Lug(uduno) vet ex leg VI Vict $p$ post Hadrian Lincoln Eng............VII 182 add E. E. IX p 556 CALIANUS

L. Aemilius C optio cor (III Aug) 198-211 A.D. Castra Lambaesitana VIII 2554

CALICLES

(C)alicles Nic(omedia) vet? (III Aug) aet Hadriani

Castra Lambaesitana .........................VIII 18084 CALINUS

L. Valerius C frum VI(I) Gem Date? Aquileia ............V 941 GALLA

Ulp(ius) C mil XIIII G m v Date? Salonae Dalmatia III 6549 et p 1510 GALLIMACHUS

Annius C p p (leg?) Date? Aquincum Pann Inf............III 10503 GALLISTHENES

Aur(elius) C vet V Mac Date? Ancyra ................III 6762 GALLISTRATUS

Aur(elius) Callistr(atus) $7 ?$ XIII Gem post Traian Veczel

Dacia ..............................III 1689:10

GALPURNIANUS

Lucius Calpurnian(us) (mil? III Aug) c218? Castra Lambaesitana ..................... Aull Archeol 1904 p\&06

C. (S)a(1)vius $\mathbf{C}$ mil XII Fulm domo Priverno ex Italia 1-8s?

Amorium Phrygia ...........................III 353

K 7 (leg?) Date? Borcovicium Eng ............... VII 679 GALLUS

Sept(imius) C cand XXX Ulp vict 283 A.D. Col Ulpia Traiana

Germ Inf ........................... XIII 8607

CALVIO

Sulpicius C 7 I Min Date? Novae Dalmatia.............III 1918 


\section{GalvUS}

P. Carsidius P. f. Gal. C Lugd(uno) aquil IIII Fl firm Date?

Scardona Dalmatia.......................III 14995

? Helvius C Cas har(uspex) (III Aug) Date? Castra Lambae-

sitana

VIII 2567

KAMEPINO $\Sigma$

$\Delta$ aßépıos Kauspivos 7 V Mac 116-7 A.D. Budrum Cilicia....III 12117 GAMERINUS

L. Noverius C optio XXII Pr p f 178 A.D. Mumbach........XIII 7210 CAMPANIANUS

C-C frum I Adiut es? Carnuntum Pann Sup...........III 4462

CAMPANUS

C. Cotonius? C. f. Pol. C vet XV Apol 1s Scarbantia Pann Sup

JDAI 1912 Beibl p 540

L. Naevius C Kast IIII Fl Date? Aquincum Pann Inf ........III 3468

M. Sullius M. f. Vol. Via(na) C mil IIII Mac ante Vespas

Mainz ............................... XIII 6879

C. Valerius C. f. Vol. C Vienna mil XI Cl p f Vespas-Traian

Vindonissa

XIII 5214

CANDIDIANUS

Aurel(ius) C spec legg III Antonin ( = X Gem XIV Gem I Ad)

c212 Carnuntum Pann Sup .....................III 4452

C. Iul(ius) $\mathrm{C}$ bf leg leg I Adiut $\mathrm{p} f$ post 114 Brigetio Pann Sup ... III 4321

Secundinius $C$ bf $\cos$ Date? Ovilava Noricum............III 5631

GANDIDINUS

L. Ael(ius) C tess XIII Gem post Traian Recka Dacia.........III 1592a

GANDIDUS

Ael(ius) $\mathrm{C}$ spec I et II Adi p f Sever 228 A.D. Aquincum Pann Inf. III 3524 Aurelius C mil II Aug Date? Vallis Fl Mur Noricum.........III 5476 M. Aurelius C 7 III Aug 50-100 A.D. Theveste............ E. 1909:37

M. Aur(elius) $\mathrm{C}$ vet ex imag I Adiut post 114 Brigetio Pann Sup. III 4313 L. Cassius C mil VII Cl Date? Naissus Noes Sup...........III 14567 Concaoni(us) Candid(us) 7 (leg?) Date? Amboglanna Eng

VII 857 add E. E. IX p601

T. Flavius C bf $\cos$ Date? Siscia Pann Sup ..............III 3948

M. Furius M. f Papiria C Theveste 7 III Aug Antonin c215

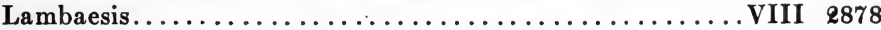

Iullus Candi(dus) vet (V Mac) c134 Troesmis............III 6178

Iul(ius) C 7 III Aug Date? Lambaesis................ VIII 2593

Iul(ius) (Ca)ndidus bf praef castr (III Ital) Date? Castra

Regina Raetia ........................... 5953

Iuli(us) C 7 (leg?) coh I Date? Borcovicium Eng...........VII 667

C. Iul(ius) G p p XIII Gem Date? Ancyra...............III 267

L(icinius?) $\mathbf{C}$ mil (leg?) Date? Aquincum Pann Inf......... III 10459

Maevius C arm cust (III Aug) 200 A.D. Castra Lambaesitana A. E. 1902:10

Probinius C 7 III Aug coh V 162 A.D. Castra Lambaesitana.... VIII 18065 
Sirifius G exactus (III Aug) Date? Lambaesis............. VIII 8977 Tit(1)us C sig (I Adiut) post 114 Brigetio Pann Sup...........III 4326 Q. Valerius C mil I Adiut post 114 Brigetio Pann Sup..........III 4326 Veranius C 7 III Aug coh I 162 A.D. Castra Lambaesitana....... VIII 18065 -lonius Q. f. An. Can(didus? mil? III) I Mac ante Vespas Mainz................................ 6878

— G 7 II Tr fort 148 A.D. Arsinoe Egypt........... E. E. VII p 459 inius (Can)didus (mil) I Min p f bf $\cos 195$ A.D. Nettersheim ............................... E. 1911:158 GANETUS

Iulius C K(arthagine) mil? (III Aug) Date? Castra Lambaesitana .................................... $\mathbf{e 5 6 7}$ CAPETOLINUS

M. Domitius $\mathrm{G}$ domo Capetoliade $7 \mathrm{XI} \mathrm{Cl}$ p $\mathrm{f}$ post Hadrian Tomi Moes Inf............................... III 771 GAPITO

M. Aemili(us) G vet I Adiut 68 A.D. Sardinia ............. X 7891 Aur(elius) G mil VII Gem fel Date? Oppida circa Burgos Tarraconensis................................ $\mathbf{8 9 0 1}$ C. (C)afatius C. f. Ani. C vet leg VIIII 1s Forum Iulii. ......... XII 260 Ce_ C 7 XIII Gem post Traian Apulum Dacia..........III 14216:20 A. Considius M. f. Q. n. C mil XXX Ulp vict Date? Vicetia...... 3105 P. Cornelius C (vet II Tr fort?) 140 A.D. Fayoum Egypt........ BGU 610 Fontelus $\mathrm{C}$ vet (V Mac) c134 Troesmis.................. III 6178 Iu(lius) G(a)pito mil XI Cl 155 A.D. Almus Moes Inf..........III 7449 C. Iulius Capito Had(rumeto) vet III Aug p v c198 Castra Lambaesitana ............................ VIII 18068

M. Iunius G Lindo mil X Gem Date? Albulae Mauretania

Caesariensis ...................................

G. Iuventius G. (f.) Cla. C Apro mil II Adi p f c71 Chester Eng E. E. IX 1048 M. L_C eq (III Aug) Date? Lambaesis................VIII 3180 Mem(mius) $G$ vet (V Mac) c134 Troesmis...............III 6178 G. Roscius G. f. Ani. C Troad(e) vet V Mac post M. Aurel Oescus

Moes Inf............................ E. 1918:188

Salius Capiton mil III Cyr ante 108 Egypt .......... Wessely Lat Pal 8 Ti(berius) $\mathrm{C}$ vet (V Mac) c134 Troesmis................III 6178

C. Vatinius Sex. f. G domo Arreti(o) vet VII Cl p f 42-70 Salonae Dalmatia.............................. 8 III 8764 Vellei(us) $G$ vet (V Mac) c134 Troesmis.................. 6178 C 7 III Cyr Date? Rome.....................VI 3628 GAPITOLINUS

—ius M. f. Pol. C Cas bf praef II Tr fort 194 A.D. Alexandria Egypt ...................................III 6580 CAPRARIUS

Iul(ius) $\mathbf{C a}$ (pra)rius optio (II Aug?) Date? Isca Eng.........E. E. III 64 P. Pompeius G Cir(ta) vet ex pol (III Aug) \&11-\& A.D. Lambaesis VIII 2618 


\section{GAPRATINUS}

Cn. Fulv(ius C)apratinus ex p(rov) Baetic (It)alicensi probatus in leg VI Ferr tra(ns) frum in leg VII Gem $p$ f factus (bf) $\cos$ Date? Tarraco......................... 4154 CAPREOLUS

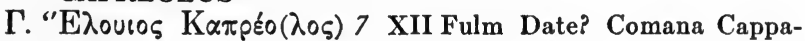
docia.............................IG a RR III 180

Q. Etuvius Sex. f. Vol. G domo Vienna mil eq et 7 IIII Scyt

Date? Aquileia.......................... E. 1902:41 GARANTUS

Securius C mil XXII Pr $p \mathrm{f}$ bis 3s? Ager Mogontiacensis....... XIII 7248 GARIANUS

C. Iul(ius) C p p I Ital ex eq Romano Date? Lezan Moes Inf

CARINUS

III 750 add et p998

Verrius C mil imm II Adiut 2 -3s? Poetovio Pann Sup......... III 10880 GARIUS aut CARISTUS

Ulp(ius) C 7 leg XXX Date? Zilleh Pontus.............. E. 1903:200 GARPIANUS

Sep(timius) Carpia(nus) (? leg?) Date? Apulum Dacia........III 1190 GARPOPHORUS

M. Iulius M. f. Col. C Pa vet II Tr fort 194 A.D. Alexandria ..... . III 6580 GARUS et KARUS

T. Acileius T. f. Volt. C Luco vet ex leg VIII Aug Date? Mainz XIII 6882 Antonius K 7 VIIII Hisp 1s Rome................... VI 3639

L. Gradon(i)us K mil I Min p $\mathrm{f}$ Date? Kircheim........... XIII 7950

L. Porcius L. f. Voltin. K mil optio sig II Aug Date? Ucetia

Gall Narb............................. XII 2989

Sept(imius) C mil II Adi p f Sever 231 A.D. Aquincum Pann Inf...III 3457 CASIUS

C. Atius C 7 XIIII Gem 184 A.D. Carnuntum Pann Sup........ III 14071

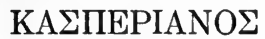

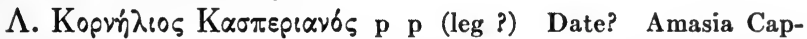
padocia ...................................... RR III 108 CASSIANUS

Cass(ius) C spec legg III Antonin ( $=$ X Gem XIV Gem I ad) c212

Carnuntum Pann Sup......................... 4452

L. Sept(imius) C sig IIIIII Hisp 193-211? A.D. Aquileia. Pais Suppl n165

Valeri(us) Cassia(nus) 7 (leg?) Date? Magnae Eng..........VII 789

Victorius $\mathbf{C}$ vet leg VII Date? Mainz.................. XIII 6881 CASSIUS

Ael(ius) C (aquil? V Mac?) Date? Potaissa Dacia............III 7688 Annius C 7 XV Apol 1s Carnuntum Pann Sup.............III 11218 M. Aur(elius) C aquil I (Min) Date? Bonn............. XIII 8039

M. Aurel(ius) C bf cos Date? Ad Dravum Pann Sup..........III 10890

C. Iccius C 7 XIIII Gem post 100 Carnuntum Pann Sup......A.E. 1905:238 


\section{GASTELLUS}

M. Crassicius M. f. Ste. C vir pro(bus) ? leg XXX post 31B.C.

Beneventum ................................ IX 1610

GASTINUS

M. Aur(elius) G mil I Adiut Date? Mursella Pann Sup........III 10956 CASTOR

Aurel(ius) G mensor V Mac p 3s Siebenburgen. . Jahres Wien V Beibl p97 n' CASTRENSIS

M. Antonius C (eq? III Aug) 222-35 A.D. Castra Lambaesitana

\section{CASTRICIUS}

MAH $1897 \quad$ p447

Iullus C mensor (III Aug) 3s? Castra Lambaesitana......A.E. 1904:78 CASTUS

C. Aemilius C (eq? III Aug) \&2\&-35 A.D. Castra Lambaesitana MAH $1897 \quad$ p447

T. Aur(elius) C Rat(iaria) tub vet VII Cl 195 A.D. Viminacium

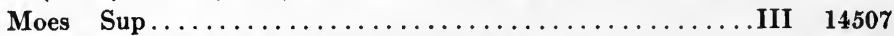
Avianius C dup III Aug p v Antonin 218 A.D. Castra Lambaesitana ................................. $\mathbf{8 5 6 4}$

C. Caecilius C (mil? III Aug) c\&00 Castra Lambaesitana Bull Archeol 1905 p240

Tib. Claudius C Girt(a) vet III Aug p v c198 Castra Lambaesitana............................... 18068

T. F1(avius) $G$ bf cos Date? Mainz................ XIII 7000 Iulius C dup III Aug p v Antonin 218 A.D. Castra Lambaesitana. VIII 2564 Iulius G sig (III Aug) Date? Castra Lambaesitana........VIII 18073 M. Iulius Pol. G cor III Aug Date? Lambaesis...........VIII 18303 M. Licin(i) u(s) C bf cos Date? Ager ad Colapim Pann Sup ....III 3938 Mattius C arm cust (III Aug) 200 A.D. Castra Lambaesitana.. A.E. 1902:10 Naevius C 7 III Aug coh VII 162 A.D. Castra Lambaesitana ... VIII 18065 Paconius C bf cos III Aug Date? Vazaivi............... VIII 17628 Petronius G imm III Aug p v Antonin 218 A.D. Castra Lambaesi-

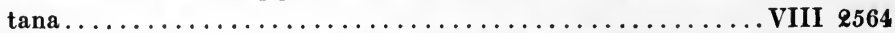

(Petr)onius Cast(us vet) ex leg I Min ex optione Date? Valentia Gall Narb............................. XII 1749

L. Sentius G ? VI Vict post Hadrian Vindobalia Eng......... VII 544 Sep(timius) C (? leg?) Date? Apulum Dacia............III 1190 Timinius $\mathrm{C}$ dup III Aug $\mathrm{p} v$ Antonin 218 A.D. Castra Lambaesitana................................ VIII 2564

L. Trebellius C Ca(s) mil? (III Aug) Date? Castra Lambaesitana.................................... $\quad \mathbf{2 5 6 9}$

(Va)lerius C tub III Aug p v 20\% A.D. Castra Lambaesitana...A. E. 1907:184

G. Valerius C. f. Papiria C The(veste) mil III Aug Date? Lambaesis................................VIII 3251

L. Vib(ius) C imm. leg XXX Date? Col Ulpia Traiana Germ Inf .................................... 8610 C 7 (leg XXII aut III Cyr) aet Augusti Coptos Egypt..III 6627 


\section{GATANUS}

Iul(ius) $\mathrm{C}$ vet (III Aug) Date? Verecunda...............VIII 4241 CATERVARIUS

C. Serg(ius) Catervari(us) optio (III Aug) 198-211 A.D. Castra Lambaesitana............................. VIII $\mathbf{2 5 5 4}$

CATO

L. Cornelius C optio III Aug 198-211 A.D. Castra Lambaesitana. VIII 2554

L. Cornelius G qui et Caligatus 7 III Aug Date? Lambaesis.. VIII 2848 GATTANUS

Iul(ius) C im III Ital Date? Castra Regina Raetia...........III 11969 Gatullus

C. Terentius C. f. Cl. C Vir(uno) vet VII Cl p f ex sig 224 A.D.

Viminacium Moes Sup.......................II 8124

CATULUS

M. Aemilius C bf trib lat III Aug p v 198 A.D. Castra Lambaesitana................................ VIII 2551

Q. Iulius C Lamb bf cos III Aug c225 Lambaesis........... VIII 2586

(? V)al(erius) Catul(us) (7 XXII Pr p f) 204 A. D. Mainz.. XIII 6801

Valerius C dup III Aug p v Antonin 218 A.D. Castra Lambaesi-

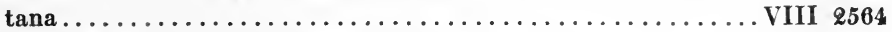

C Viruno mil XXII Prim Date? Mainz............XIII 6984

\section{CATUS}

Rutilius C marsus III Aug p v Antonin 218 A.D. Castra Lambaesitana.................................. 2564

GAUDINUS

Aurelius Gaudin(u)s arm cust III Aug c225 Castra Lambaesitana.............................. 1902:11

\section{CELER}

L. Aelius L. (f) Gal. C Clun(ia) mil VII Gem fel Date? Augusta Emerita..................................II $\quad 5265$ Anni(us) Cel(e)r optio (I Ital) 2s exe-3s Almus Moes Inf....III 144091: M. Antonius $\mathrm{C}$ eq VII $\mathrm{Cl}$ p f 42-70 A.D. Dalmatia incerta.... III 3162a M. Antonius M. f. Pol. C vet X Fr 94 A.D. Alexandria Egypt.............................. 1910:75

M. Antoni(us- P)apiria G (T)icino vet XIIII G $m$ v post

100 Carnuntum Pann Sup.....................II 11209

C1. Atteius $\mathrm{G}$ vet XIII Gem post 142 Apulum Dacia.........III 1093 Atti(us) C 7 (leg?) Date? Chester Eng................. IX 1045 L. Aufidius - C vet (VII) Cl p f Date? Scupi Moes Sup.....III 8194

L. Aurelius Cl. C Ar(a) mil XV Apol 1s Carnuntum Pann Sup...III 4456

G. Calventius G. f. Claud. C Apro mil II Adi p f c71 Chester

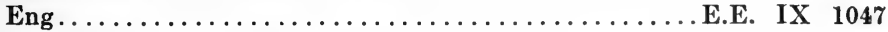

C. Cassius C. f. Aniesis C Cre(mona) vet VIII Aug 1s? Poetovio Pann Sup..............................III 10878

Q. Cerfonius Q. f. Scap. C Flo(rentia) mil X Gem Date? Carnuntum Pann Sup........................... 44I 4463a 
(A?) (Cla)udiu(s Cel)er domo Verona $7 \mathrm{XI} \mathrm{Cl}$ p f 42-Vespas Burnum Dalmatia...........................III 2834

Q. Cumelius Q. Fab. C Bric(xia) vet II Adiut Date? Asturica

Tarraconensis .............................. $\mathbf{2 6 3 9}$

C. Domitius (C)e(ler) (mil III Cyr aut XXII Deiot) 90 A.D.

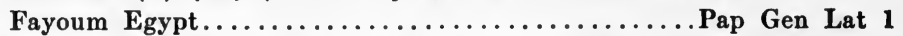

A. Eburius C mil XV Apol 1s Carnuntum Pann Sup......III 14358:17

T. Flavius C (mil III Cyr aut XXII Deiot) 87 A.D. Fayoum

Egypt.................................... Gen Lat 1

Iulius $C$ arm cust III Aug c225 Castra Lambaesitana..........E. 1902:11

C. Iulius C. f. Col. C vet V Mac Date? Oescus Moes Inf....III 7428

T. Iulius T. f. Cla.G(el)er (7) II Aug Date? Asseria Dalmatia..III 15024

L. Labicius L. f. Ste. C ? VI Ferr post 31 B.C. Beneventum. IX 1613

L. Licinius C (vet II Tr fort?) 140 A.D. Fayoum Egypt..... BGU 610

$\mathrm{M}(\dot{\alpha} \rho x<10 \varsigma) \mathrm{K} \varepsilon \dot{\lambda} \lambda \varepsilon \rho 7 \mathrm{XI} \mathrm{Cl}$ post $4 \&$ Istifan Bithynia.......IG a RR III 1426

M. Memmius C (spec VII Gem fel) Date? Tarraco...........II 4143

Mum(mius) $\mathrm{C}$ mil XI Cl 155 A.D. Almus Moes Inf..........III 7449

C. Plotidius G. f. Vo(It) ? C ex Ispan(ia) mil (I) III Mac ante

Vespas Narbo............................. XII 4366

Pompeus C (mil? III Aug) c218? Castra Lambaesitana

Bull Archeol 1904 p206

? Ravillius L. f. Arn. C Cartha vet II Tr fort 194 A.D. Alex-

andria Egypt.............................. 6580

(S)alvidius C Cas ? (III Aug) Date? Castra Lambaesitana.... VIII 2565

Scribonius C mil V Mac post M. Aurel Oescus Moes Inf ....A.E. 1912:188

M. Sempronius M. f. Col. C domo Pessenunto aquil X Fr

Date? Rome................................. VI $\mathbf{3 6 2 7}$

Septimius $\mathrm{G}$ vet $(\mathrm{V}$ Mac) c134 Troesmis..............III 6178

C. Sossius C. (mil III Cyr aut XXII Deiot) 90 A D. Fayoum

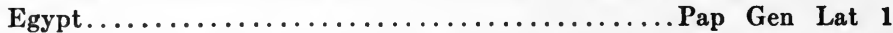

L. Valerius T. f. Fab. C 7 X Fr aet Neronis Heliopolis Syria..III 14387g Vari(us) C 7 (II Aug?) coh II Date? Segedunum Eng......VII 491 Vibius C (eq? III Aug) 228-35 A.D. Castra Lambaesitana. . MAH 1897 p447 C. Vibius C Nicom(edia) vet? (III Aug) aet Hadriani Castra

Lambaesitana.............................. VIII 18084

C 7 II Tr fort 194 A.D. Alexandria Egypt ...........III 6509

\section{GELERIANUS}

L. Gellius L. f. Flavia C Nemes XXII Pr p f 204 A.D. Seligen-

stadt.................................... XIII 6659

\section{CELERINUS}

M. Aur(elius) C vet II Adi p f Sever bf trib 2 \&9 A.D. Cirpi Pann

Inf ................................... III 10580

Domit(ius) Celeri(nus) optio (I Ital) \&s exe-3s Almus Moes Inf. III 14409:1

Iulius G 7 XV Apol 1s Carnuntum Pann Sup.............III 4473

Iul(ius) $G$ spec I et II Adi $p$ f Sever 228 A.D. Aquincum Pann Inf. III 3524

Nertius G p p XIIII G m v 205 A.D. Carnuntum Pann Sup III 14356:3a

P(ostu)mius? C 7 VIII Aug 2-3s? Argentorate............XIII 5979 
Ulpius C salariarus I Adi p f Antonin c215 Brigetio Pann Sup ... . III 10988 M. Val(erius) C Papiria Astigi cives Agrippine vet X Gem p f

89-Traian Col Agrippinensium................ XIII 8283 CELERIS

C. Iul(ius) C 7 IIII Scyt et XVI Fl firm et XIII Gem post Traian Apulum Dacia......................III 1044 CELESTINUS

(M)agnius Celestin(us) sig (III Aug) Date? Castra Lambaesitana.................................. 18073

\section{CELSINUS}

Ael(ius) C mil II Adiut 2-3s? Bassiana Pann Inf...........III 15133 F1(avius) $G$ spec I et II Adi $p$ f Sever 228 A.D. Aquincum Pann Inf .................................... 3524

L. $\operatorname{Sep}$ (timius) $\mathrm{C}$ vet $\mathrm{X}$ Gem Date? Vienna.............III 4574 CELSUS

Aur(elius) C (vet? V Mac?) Date? Potaissa Dacia........III 7688 Caelius C (eq? III Aug) 222-35 A.D. Castra Lambaesitana . . MAH 1897 p447 Ti Cl(audius) G p p V Mac aet Antonini Troesmis...........III 6168 Cominius C 7 X Gem 70- Traian Ulpia Noviomagus........XIII 8733 Florius G exactus III Aug p v c202 Castra Lambaesitana . . . . . A.E. 1898:109 Sex. Maesius Sex. f. Rom C 7 IIII Mac ante Vespas......... XIV 2989 Sep(timius) C can (leg ?) Date? Apulum Dacia............III 1190 C. Statius C. f. Serg. C 7 VII Gem in Hisp aet Traiani Risinium

Dalmatia............................. 6359

Q. Tul(lius) $\mathbf{C}$ imm III Aug Date? Lambaesis............ VIII 2987 (Val)erius L. f. G(al) Celsu(s) spec II Aug 1s? London......VII 24 L Val(erius) C mil VII Cl Date? Viminacium Moes Sup Jahres Wien 1909 Beibl p156

M. Verrius M. f. Fal. C 7 III Cyr aet Augusti Atella ........... X 3734 C 7 leg III aet Augusti Alexandria Egypt.........III 6591 CELTIBER

Fabius $\mathrm{C} 7 \mathrm{X}$ Gem ante 70? Iria Tarraconensis............ 2545 GENSOR

M. Anicius M. (f.) Cla. C Dinia mil XV Apol 1s Carnuntum Pann Sup............................ 13481

M. Aur(elius) Cen(sor aut -sorinus) vet VII Cl 195 A.D. Viminacium Moes Sup......................II 14507 Minicius C 7 III Aug coh IX 162 A.D. Castra Lambaesitana ... . VIII 18065 C 7 X Gem Date? Arand de Duero................. 1908:147 CENSORINUS

C. Publ(icius) C vet ex optione XIIII Gem 201 A.D. Carnuntum Pann Sup.......................... 15191

L. Val(erius) L. f. C1. G vet I Adiut ex bf cos 2s? Savaria Pann Sup. III 4191 CENTER?

A. Terentius A. (f.) C1. C Apamea ex Syria 7 XVI Fl post Traian? Ancyra....................... 6766 


\section{CEPRUGIUS}

Fl(avius) C vet ex aquil III Aug Date? Lambaesis......... VIII 2868 CEREALIS

Aure(lius) $\mathbf{C}$ frum II Adiut Date? Rome..............VI 32871

C. Terentius $\mathbf{C}$ vet ex arm cust (III Aug) Date? Lambaesis... . VIII 2982 CERFONIUS

Aurelius $\mathrm{C}$ mil XI Cl 155 A.D. Almus Moes Inf...........III 7449 CERIALIS

L. Giamillius L. f. Cla. C Veruni mil IIII Mac ante Vespas

Mainz................................XIII 6864

C. Petronius C mil III Aug Date? Lambaesis............ VIII 3218 CERTINUS

T. Carsi(us) Teret. $G$ vet XX V v Date? Arelate...........XII 679 CERTUS

T. Aurelius C1. C Cemeneli frum XX V v Date? Rome..... VI 32878 Tib. CI(audius) C bf $\cos$ VII Cl Date? Runjevo Moes Sup...... III 8184 C. Iulius C 7 XIII Gem primus hastatus posterior 139-143 A.D.

Rome............................. 31158

Tonneius $\mathrm{C}$ arm cust (III Aug) 200 A.D. Castra Lambaesitana.. A.E. 1902:10

L. Veratius C 7 leg? Date? Antium............... 6674 M. f. Volt. G Vien(na) vet XIII Gem ante 50 Tenendo

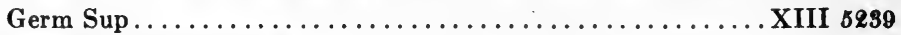
CHAEREMONIANUS

L. Aurelius L. f. Pol. C Cas vet II Tr fort 194 A.D. Alexandria Egypt..............................III 6580

T. Aurelius T. f. Pol. C Cas vet II Tr fort 194 A.D. Alexandria Egypt.............................III 6580 CHAIREAS

Aurel(ius) $\mathrm{C}(\mathrm{h})$ aireas mil XI Cl 155 A.D. Almus Moes Inf.....III 7449 CHARINUS

Ael(ius) $\mathbf{G}$ mil frum IIII Fl firm Date? Tibur........... XIV 3570 GHARITONIANUS

L. Aelius Charitonian(us) Cas ? (III Aug) Date? Castra Lambaesitana.............................III 2567 CICATRICULA

T. Flavius Cicatricul(a) 7 (leg?) 1s exe Chester Eng. . . . . . . E.E. IX 1046 CILICIANUS

C 7 IIII Scyt Date? Enesch Syria

A.E. 1908:25 CILO

L. Leuconius L. f. Fab. C vet leg XXI ante Hadrian Sabini.... V 4902 Sulpicius G mil VII Gem Antonin p f c215 Vivatia Tarraconensis. .II 3337 CINNA

C. Mestri(us) G mil leg? Date? prope Agram Raetia ........III 12031:5

L. Cornelius L. (f) (P)oll C Mut(ina) vet ex leg XX c43?

Ulpia Noviomagus.....................XIII 8787 


\section{GINNUS}

Staberius C dup III Aug p v Antonin 218 A.D. Castra Lambaesi-

tana.

VIII 2564

GIRRENIANUS

Porcius Girrenian(us) arm cust (III Aug) 200 A.D. Castra Lambaesitana................................ 1908:10 GITTINUS

Aurelius C dup III Aug p v Antonin 218 A.D. Castra Lambaesi-

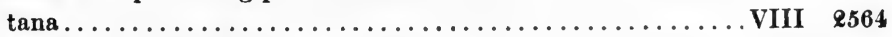

M. Aurelius C vet III Aug p v c198 Castra Lambaesitana.... VIII 18068 GITUS

P. A- Ci(t)us optio leg XIIII post 100 Siscia Pann Sup....III 3943 V(a)1(erius) Ci(t)us 7 (V)III Aug Date? Boeckingen........XIII 6475 CIVILIS

Ael(ius) C mil VII Cl Date? Viminacium Moes Sup........III 8104 Fl(avius) Civi(li)s? 7 (leg ?) coh ? Date? Chesters Eng....VII 604 G. (Li)cin(ius) $\mathbf{G}$ bf cos Date? Virunum Noricum..........III 4776 GLARUS

Aemilius G exactus III Aug p v c202 Castra Lambaesitana .....A.E. 1898:109 Annaeus C 7 III Aug Date? Lambaesis................ VIII 2805 Q. Annius G 7 X Gem Date? Lambaesis.................VIII 18283 Q. Glodius C Cirt(a) vet III Aug p v c198 Castra Lambaesitana. . VIII 18068 C. Iul(ius) C vet ex bf lat (III Aug) Date? Lambaesis........VIII 2892 C. Pass(ienius) C optio (III Aug) 198-211 A.D. Castra Lambaesitana.................................... 2554

Volussius C dup III Aug p v Antonin 218 A.D. Castra Lambaesi-

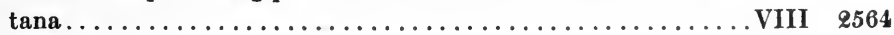
GLASSICUS

L. Iu(1)ius Classi(c)us (7) leg XVI ante 43? Brohl........XIII 7780

M. Petronius M. f. Arn. C. Marrucinus 7 VIII Aug ante Nero Poetovio Pann Sup...........................III 4060

\section{CLAUDIANUS}

Aelius Glaudian(us) optio leg (XX) Date? Chester Eng.........VII 166 M. Aurel(ius) $\mathrm{C}$ vet ex $1 \mathrm{t}$ (III Aug) 270-275 A.D. Lambaesis... VIII 2626 Cla(udius) C 7 V Mac 197-209 A.D. Apulum Dacia....... III 7741 =14479 Cl(audius) C spec legg III Antonin (=X Gem XIV Gem I Ad) c212 Carnuntum Pann Sup......................III 4452 Cla(udius) C 7 II Adi p f Sever 230 A.D. Aquincum Pann Inf..III 3515 Cl(audius) C optio I Adiut post 114 Brigetio Pann Sup........ III 10983

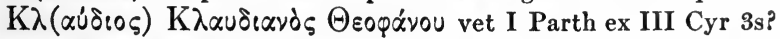

Zorava Syria.......................... 125 add $p 970$

Cornelius Glaudian(us) Lamb bf cos III Aug c225 Lambaesis... . VIII 2586 Flavius C arm cust III Aug c225 Castra Lambaesitana....A.E. 1902:11 M. Helvius $\mathrm{G}$ vet (III Aug) Date? Lambaesis............VIII 3121 Heren(nius) $C$ arm cust III Aug c225 Castra Lambaesitana..A.E. 1902:11 Iulius $\mathrm{C}$ mil XI Cl 155 A.D. Almus Moes Inf............III 7449 
M. — C medicus III Aug Date? Lambaesis............. VIII 2951 CLAUDiUS

Cornelius C bf $\cos$ (III Aug) Date? Vazaivi............. VIII 17623 CLEMENS

Sex. Ammap. s G bf cos Date? Apulum Dacia..............III 1040

M. Antonius C 7 III Aug coh IV 162 A.D. Castra Lambaesitana.. VIII 18065

C. Arrius C. f. Cor. C 7 p p III Aug aet Traiani Matilica........ XI 5646

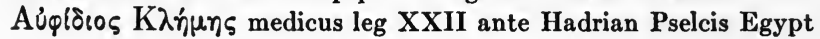

IG a RR I 1361

M. Aur(elius) C 7 VI Ferr prob in leg II \&s exe Aquincum Pann

Inf ................................... 10507

Aulus Baebius C. f. Scap. Gleme(n)s Faes(ula) mil leg XXII

Date? Mainz................................ XIII 6957

Caecili(us) Cleme(ns) 7 (leg ?) coh VIII Date? Hunnum Eng. . VII 569

Caecili(us) Cleme(ns) 7 (leg?) coh VIII Date? Vindolana Eng.. VII 718

C. Calpurnius C imm III Aug Date? Lambaesis.............VIII 2831

L. Cassius L. f. Stell. G Taurus mil X Gem 70-Traian Ulpia

Noviomagus..............................XIII 8734

Cocce(i) us G mil III Cyr ante 108 Egypt.............Wessely Lat Pal 8

M. Coelius C. f. Cam. C 7 IIII Fl fel Mys Sup Date? Pedemon-

tana incerta.............................. $7 \mathbf{7 1 6 0}$

(L. ? F)idius-Trom (Cle?)mens (Ae)q(u)o mil I Adiut

70-100 A.D. Mainz .......................... XIII 6830

P. Fl(avius) P. f. Quirina C 7 III Aug p v 3s? Lambaesis...... VIII 2869

T. Fl(avius) C mil III Ital Date? Augusta Vindelicum Raetia.. III 5812

M. Granius C Cast vet III Aug p v c198 Castra Lambaesitana.. VIII 18068

Honoratius C mil XXII Pr p f 204 A.D. Mainz............ XIII 6686

Iulius C 7 II Adi $\mathrm{p} f \mathrm{c} 71$ Chester Eng................E. IX 1048

Iul(ius) $C$ aquil III Ital Date? Augusta Vindelicum Raetia....III 5816

C. Iul(ius) Clem(ens) vet VII Cl 195 A.D. Viminacium Moes

Sup.....................................III 14507

M. $\mathrm{Ma}(\mathbf{r}) \mathbf{c}$ (ius) $\mathrm{Cl}(\mathrm{e}) \mathrm{men}(\mathrm{s})$ (mil III Cyr aut XXII Deiot) 90

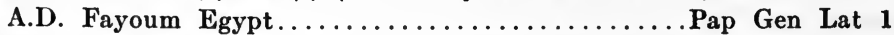

Pupius C 7 III Aug coh VIII 162 A.D. Castra Lambaesitana.... VIII 10658

P. Talpidius C 7 VIII Aug aet Flaviorum impp Mediomatrici

Belgica.................................. XIII 4625

Val(erius) Clem(ens) vet VII Cl 135 A.D. Viminacium Moes Sup..III 8110

Valerius C 7 I Ital ante M. Aurel Ad Haemum Moes Inf........IIII 1443

Valer(ius) $C$ vet (V Mac) Date? Troesmis.................III 6179

C. Val(erius) C 7 leg XIIII post 100 Carnuntum Pann Sup......II 14356:53

C. Va(leri)us C 7 XV Apol post Traian Lystra Cappadocia......III 6787

C. Vereius (Cl)emens mil VIII Aug. bf cos Date? Heidelberg. .XIII 6397

Vibius Clem(ens) 7 II Adi $p$ f c71 Chester Eng............E.E. IX 1047

Vispanius C mil leg VII Date? Ad Haemum Moes Inf........III 12416 (C1)emens Gabal(is) vet? (III Aug) aet Hadriani Castra

Lambaesitana ................................. VIII 18084

(Cl)emens Nap(oca) mil? (III Aug) aet Antonini Pii

Castra Lambaesitana............................. VIII 18807 
C 7 (leg XXII aut III Cyr) aet Augusti Coptos Egypt.... III 6625

C 7 II $\operatorname{Tr}$ fort 194 A.D. Alexandria Egypt.......... III 6580

\section{GLEMENTINUS}

C. Sulpicius Clementin(us) Sic(ca) mil? (III Aug) Date?

Castra Lambaesitana......................... VIII 2567

Val(erius) C spec I et II Adi p f Sever 228 A.D. Aquincum Pann

Inf ..................................III 3524

L. Valerius Clemen(tinus) vet $X$ Fr 94 A.D. Alexandria

Egypt.............................. 1910:75

CLEMES

Cla(u)dius C mil III Cyr ante 108 Egypt...........Wessely Lat Pal 8 Fla(vi) us $\mathbf{C}$ mil III $\mathrm{Cyr}$ ante 108 Egypt............Wessely Lat Pal 8

P. Valerius $G$ vet $V$ Mac 139-161 A.D. Troesmis...........III 6162 GLEONICUS

Cla(udius) G 7 (leg ?) coh III Date? Borcovicium Eng....VII 670 COCAIUS

P. Aelius $\mathrm{G}$ vet VII Cl Sever 223 A.D. Naissus Moes Sup.......III 14565 COINTUS

Aur(elius) G mil II Tr Date? Alexandria Egypt...........III 12054 COGITATUS

Fl(avius) $G$ sig II Adiut 3s? Aquincum Pann Inf........... III 3548

L. Maiorius G bf $\cos 211$ A.D. Mainz.............XIII 6665

Sept(imius) G arm cust II Adi p f Sever 231 A.D. Aquincum

Pann Inf............................III 3457

COLINUS

L. Cornelius L. f. C Pol. Eporedia mil leg XV ante Vespas near

Mainz....................................... 1907:188

\section{COLlatUS}

M. Aufidius C mil III Aug Date? Lambaesis............ VIII 3045

COLONUS

Cornelius C dup III Aug p v Antonin 218 A.D. Castra Lambaesi-

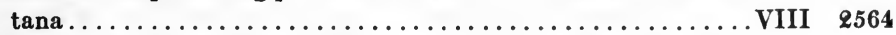

P. Pompeius P. f. Volt. G Viana vet IIII Fl firm Date?

Scarbantia Pann Sup.......................... 4245

COMA

M. Alfius $\mathrm{C}$ vet ex sig (II Tr fort?) 140 A.D. Fayoum Egypt..BGU 610 Marci(us) G 7 (leg ?) coh VIIII Date? Hexham Eng......EE. VII 996 COMARGUS

G. - C bf $\cos \mathrm{X}$ Gem Date? Dalmatia incerta...........III 3158a COMASTUS

Aur(elius) Comas(t)us d(omo) Ver(ona) mil leg Parth Date?

Rome............................. 3996

COMODUS

(A1)lidius G P. Ca(s) ? (III Aug) Date? Castra Lambaesitana... VIII 2565 


\section{COMMUNIS}

A(ni)us aut Ae(1i) us C mil II Adiut 2-3s? Poetovio Pann Sup... III 10880 CONGESSIANUS

Bibuleius Concessian(us) dup III Aug p v Antonin 218 A.D.

Castra Lambaesitana........................... VIII 2564 CONGESSUS

Gaecilius C corn (III Aug) 162 A.D. Lambaesis........... VIII 2739

C. Caecilius G mil III Aug Date? Lambaesis............. VIII 3067

L. Glodius C b s III Aug c225 Lambaesis ................ VIII 2586

Q. Octavius C mil? (III Aug) Date? Castra Lambaesitana....VIII 2568 CONDUGTOR

M. Helvius G Cast bf cos III Aug c225 Lambaesis........... VIII 2586 CONDUNUS

G. Urbici(us) C mil XIII Gem post Traian Apulum Dacia......III 1204 CONGIUS

Iunius $\mathrm{C}$ dup III Aug $\mathrm{p}$ v Antonin 218 A.D. Castra Lambaesi-

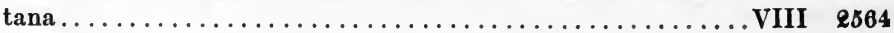
KON $\Omega N$

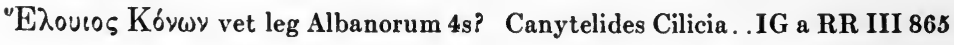
CONSORS

L. Vitellius G ex pilo VI Vict ante Hadrian? Iuliacum Germ Inf . . XIII 7869 CONSTANS

Attonius G vet XXII Pr p f Date? Lyons................ XIII 1837

Ti. Gl(audius) G mil II Adiut 2-3s Aquincum Pann Inf........III 10510

T. Fl(avius) G 7 (leg XXX) Date? Col Agrippinensium......XIII 8291

G. Iul(ius) $\mathbf{G}$ bf cos Date? Mursella Pann Sup............III 10955

C. Nummius C. f. Fal. G p p II Tr 7 III Cyr et VII Cl 132-5 A.D.

Atella.................................. $\mathbf{3 7 3 3}$

Secund(ius) $\mathrm{C}$ mil VIII Aug bf trib sexm Date? Lyons........ XIII 1850

Val(erius) $\operatorname{Co}(\mathbf{n})$ sta(n)s vet XIII Gem post Traian Apulum

Dacia....................................III 1194

\section{CONSTANTINUS}

Aur(elius) qui et $\operatorname{Sep}($ timius) $\mathrm{G}$ mil I Adiut Date? Lussonium

Pann Inf ................................III 10899

L. Sept(imius) G optio II Adi p f Antonin 218 A.D. Aquincum

Pann Inf.................................III $\mathbf{8 4 4 5}$

CONSTAS

P. Aelius G qustor arm II Adiut Date? Campona Pann Inf....III 3399 CONSTITUTUS

(Aurelius) C (mil) II Adi p f In bello (Germ)anico Intercisa Pann Inf ............................... 1910:138

L. Barb(ius L. f.) Cla. Con(stitu)tus Ivao (vet) XV Apol 1s

Carnuntum Pann Sup........................III $4 \mathbf{4 6 1}$

L. Domitius C mil bf $\cos$ X Gem 217 A.D. Siscia Pann Sup....III 15180 


\section{CORDUS}

T. Avidius C eq XXII Prim 1s? Mainz...............XIII 6954

P. Flavoleius P. f. Pol. Mutina C mil XIIII Gem ante 62? Ager

Mogontiacensis............................. 785

Valerius C 7 II Tr fort 162 A.D. Alexandria Egypt..........III 14147:4 CORNELIANUS

Aurel(ius) Cornelia(nus) arm cust (I Ital) is exe-3s Almus

Moes Inf..............................III 14409:1

M. Censorius M. fil. Voltinia (Co)rnelianus ex provincia

Narbon. domo Nemauso 7 X Fr Date? Uxellodunum Eng.. VII 371

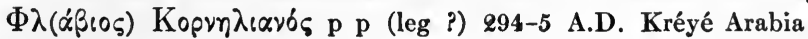

IG a RR III 1317

V- C bf leg (III Aug) Date? Verecunda.............VIII 4246 KOPNOTs

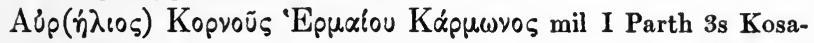
gatch Lycia ............................IG a RR III 479 CORUS

Annius G 7 III Aug coh II 162 A.D. Castra Lambaesitana.... VIII 18065 COSSUTUS

M. Iulius C 7 VI Vict $p$ f ante Hadrian? Brohl .... XIII $7697=7715-6$ COSTA

Q. (T)al(o)n(ius Q. f.) An(i). C Arimini vet I Ital 1s Oescus

Moes Inf ................................ III 12352

COTTA

M. Valerius G mil XX V v ? Date? Kugelstein Noricum....III 11746 C 7 X Gem aet Traiani Carnuntum Pann Sup....III 14358:13a KOTTOS

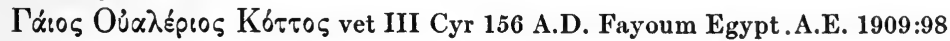
COTUS

C 7 (leg XXII aut III Cyr) aet Augusti Coptos Egypt....III 6627 GRASSUS

C. Iulius C comm VII Gem c200 Tarraco................II 4122 GRESCENS

(Ae)milius C tub III Aug p v 202 A.D. Castra Lambaesitana...A.E. 1907:184 L. Aemilius L. f. Cla. G Ara mil XIIII G m v c62? Aquae Germ Sup..................................... 6304

M. Aemil(ius) C Cuic(ulo) mil? (III Aug) Date? Castra

Lambaesitana............................... VIII 2567

Aestivius C vet leg VIII Date? Agedincum prov Lugudun...... XIII 2944

C. All(ius) G R(emesiana?) arm cust vet VII Cl 195 A.D.

Viminacium Moes Sup.......................III 14507

Sex. Anicius C optio III Aug Date? Lambaesis............ VIII 2994

C. Antistius C ? (III Aug) 209-211 A.D. Castra Lambaesi-

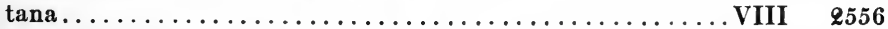

Q. Apronius Crescen(s) cor III Aug p v 203 A.D. Castra 
Lambaesitana................................... VIII $\mathbf{2 5 5 7}$ (Ap)uleius C sig (III Aug) Date? Castra Lambaesitana....VIII 18073 C. Atrius G. f. Crustumina C Carsulis mil XIII Gem post

Traian Apulum Dacia........................III 1188 Aufidius $\mathrm{C}$ dup III Aug $\mathrm{p}$ v Antonin 218 A.D. Castra Lambaesitana................................. VIII 2564 Aurelius Cresce(ns) 7 III Aug Sever c225 Lambaesis........VIII 2753 Aur(elius) C (vet? V Mac?) Date? Potaissa Dacia.......III 7688 M. Aur(elius) C ? VI Ferr libertinus M. Aurelii ef C. I. G.

3888 Rome..................................VI 3571

L. Bebius Aug. G Vin(delicum) mil VI Vict $p$ f post Hadrian

York Eng............................. IX 1375

Brittic G p p leg ? Date? Carnuntum Pann Sup..........III 14356:5a Q. Bruttius Q. f. Sergia C domo Tucci mil IIII Mac ante Vespas

Mainz.................................... 6856

Clodius C 7 III Aug coh II 162 A.D. Castra Lambaesitana... VIII 18065

L. Clodius G mil III Aug Date? Lambaesis..............VIII 2844 Coponius C arm cust (III Aug) 200 A.D. Castra Lambaesitana .. A.E. 1902:10 C. Coponius G vet Aug leg XIV sig Date? Tuscana..........XI 2956

T. Fla(vius) Gres(cens) vet (III Aug) Date? Lambaesis....VIII 3105

G. Geminius C Gir(ta) mil? (III Aug) Date? Castra Lambaesitana.................................. VIII 2567

Q. Geminius G (mil? III Aug) c200 Castra Lambaesitana Bull Archeol 1905 p 240

Iulius $\mathrm{C} 7 \times \mathrm{X}$ Gem 2-3s? Aquincum Pann Inf...........III 3550 Iul(ius) G $7 \mathrm{XV}$ Apol post Traian Ancyra.................III 268 Iul(ius) $\mathrm{C}$ ex leg VII Cl ordinatus 7 in leg IIII Scyt Date? Rome.. VI 3603 Iulius G (mil III Aug) Date? Lambaesis............... VIII 3201 G. Iulius Cresc(ens) vet III Aug 166 A.D. Castra Lambaesitana.. VIII 18067 G. Iulius $\mathrm{G}$ mil XI $\mathrm{Cl}$ post Hadrian Thyatira Asia............III 404

(C) Iul(ius) G vet VII Cl 195 A.D. Viminacium Moes Sup......III 14507 G. Iulius C 7 I Ital Date? Oescus Moes Inf...............III 7428 M. Iulius G vet XXII Pr p f post 89 Ager Mogontiacensis....XIII 7217 M. Lic(inius) G Rat(iaria) vet VII Cl 195 A.D. Viminacium Moes $\quad$ Sup...............................III 14507

A. Marcius G Cir(ta) vet? (III Aug) 2s? Castra Lambaesitana.................................. 18087

M. Memmius G Cas mil? (III Aug) Date? Castra Lambaesitana.................................... $\mathbf{2 5 6 7}$

Menius C (eq? III Aug) 222-35 A.D. Castra Lambaesitana.. MAH 1897 p447 Q. Oppius C Hippo vet III Aug p v c198 Castra Lambaesitana.. VIII 18068 Pontius $G$ vet (leg?) Date? Vetera................XIII 8636 P. Rustius Fabia C Brix(ia) mil XX V v Date? Chester Eng. . E.E. VII 899 Satrius G p p III Aug 162 A.D. Castra Lambaesitana......... VIII 18065 C. Satrius C 7 III Aug Date? Lambaesis.............. VIII 18317 M. Sempron(ius) G K(arthagine) mil? (III Aug) Date? Castra Lambaesitana.........................VIII $\mathbf{2 5 6 7}$ Sittius G dup III Aug p v Antonin 218 A.D. Castra Lambaesi- 
$\operatorname{tana} . \ldots \ldots \ldots \ldots \ldots \ldots \ldots \ldots \ldots . \ldots \ldots$ VIII 2564

C. Valerius C Cas tub (III Aug) Date? Castra Lambaesitana.. VIII 2569

L. Valerius L. (f) Ani. C Vercellis mil II Adi p f \&-3s? Aquincum Pann Inf............................... 3567

Venconius $\mathrm{C}$ bf leg leg 1 Min $\mathrm{p} f$ 252 A.D. Bonn............ XIII 8015

L. Volumnius G optio III Aug Date? Lambaesis.......... VIII 3004 - Pollia C Fano Fortunae vet ex leg XXI 43-69? A.D. Col

Ulpia Traiana Germ Inf..................... XIII 8651

—ius C Tev(este) (mil? III Aug) Date? Castra Lambaesitana................................E. 1899:98 GRESCENTIANUS

Iul(ius) $\mathrm{C}$ arm cust (III Aug) 200 A.D. Castra Lambaesitana. . A.E. 1902:10

C. Iulius C exactus III Aug p v c20z Castra Lambaesitana. . A.E. 1898:109

G. Iulius $G$ vet III Aug Date? Zarai.................

Modius Cres(centia)n(us)? bf III Aug Date? Lambaesis

GRESCENTINUS

VIII 2945 ef 18157

Aur(elius) C mil II Adiut 2-3s? Ager Aquincensis Pann Inf..III 10378 M. Aurel(ius) C imm XIII Gem Antonin 211-22 A.D. Apulum

Dacia.................................. 1038

Claud(ius) C mil XIIII Gem post 100 Carnuntum Pann Sup....III 4467

Iulius Crescentin(us) dup III Aug p v Antonin 218 A.D. Castra Lambaesitana................................. 8564

Sittius Crescenti(nus) cor III Aug p v 203 A.D. Castra Lambaesitana...................................... 2557

Sittius $\mathrm{C}$ cor III Aug p v Antonin 218 A.D. Castra Lambaesitana. VIII 2564 CRESCES

Q. Cerficius G eq III Aug Date? Lambaesis............. VIII 3080 Dubidi(us) G vet ex librario (III Aug) 270-275 A.D. Lambaesis................................... III 2626

Elius C vet ex librario (III Aug) 270-275 A.D. Lambaesis.... VIII 2626

$(M$ ? Ma)nlius (? f.) $\mathbf{C} \longrightarrow \mathbf{a}$ vet (VI) Vict post Hadrian York Eng.................................. III 79

L. Tannonius C Qui. Cir(ta) vet (III Aug) \&11-2 A.D. Lambaesis..................................... VIII 2618

L. Volumius $\mathbf{C}$ optio principis III Aug 253 A.D. Gemellae Numidia.................................. VIII $\& 48 \varepsilon$ CRETIANUS

(A)ntonius $\mathbf{G}$ bf $\cos$ Date? Winchester Eng............. VII 5 CRETICUS

T. Aelius C Cast vet III Aug p v c198 Castra Lambaesitana.. VIII 18068 GRISPINUS

Q. Granius C tub III Aug p v 202 A.D. Castra Lambaesitana.. A.E. 1907:184 Cri(s)pinus 7 III Aug 1s Theveste............. VIII 16549 GRISPUS

G. Aelius C Castr mil? (III Aug) Date? Castra Lambaesitana.................................... VIII 
Antoni(us) Grisp(us) vet (V Mac) Date? Troesmis.........III 6179 M. Anto(n)i(u)s Gri(sp)us (mil III Cyr aut XXII Deiot) 90

A.D. Fayoum Egypt.................... Pap Gen Lat 1 Atil(ius) $\mathrm{C}$ mil XI Cl 155 A.D. Almus Moes Inf...........III 7449 Aur(elius) C (vet? V Mac?) Date? Potaissa Dacia.........III 7688 Glau(dius) $\mathrm{G}$ vet $(\mathrm{V}$ Mac) c134 Troesmis...............III 6178 Claudius G Sido(nia) vet? (III Aug) aet Hadriani Castra

Lambaesitana.............................. VIII 18084

Iul(ius) Cri(spus) mil IIII Fl Date? Aquincum Pann Inf ......III 10508

L. Loro-us L. f (Pol?) Gris(pus?) Vale(ntia mil?) IIII (Mac)

ante Vespas Mainz........................... XIII 7235

L. Lucceius G Cas mil? (III Aug) Date? Castra Lambaesi-

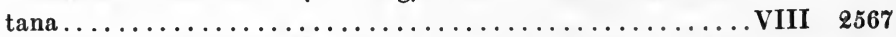
Ottacilius C Had(rumeto) peq (III Aug) Date? Castra

Lambaesitana............................ VIII 2568

L. Petronius L. f. Pol. G vet X Fr 94 A.D. Alexandria Egypt. A.E. 1910:75 Sallustius C (eq? III Aug) 222-35 A.D. Castra Lambaesitana.............................. $1897 \mathbf{p 4 4 7}$ Sep(timius) Cris(i)(pus) (vet? V Mac?) Date? Potaissa Dacia..................................III 7688

(Va)lerius — Cla. C Sav(aria) mil I Adiut 70-100 A.D. MainzA.E. 1911:235 Val(erius) Crisp(us) vet VII Cl 135 A.D. Viminacium Moes Sup.. III 8110 Valerius $G$ vet (III Aug) Date? Lambaesis................ VIII 3252 C. Valerius G vet ex leg II Adi (p f) c71 Chester Eng........E.E. IX 1051

C. Val(erius) G. f. Berta Menenia C mil VIII Aug Date?

Wiesbaden.................................. 75 III

L. Val(erius) G vet VII Cl 195 A.D. Viminacium Moes Sup.....III 14507 M. Vetidius G mil III Aug Date? Tigzirt.............. VIII 20713 C eq III Cyr aut XXII Deiot) 90 A.D. Fayoum Egypt

Pap Gen Lat 1 G 7 XI Cl p f Vespas-Traian Vindonissa.............XIII 5197 (C)rispus vet ex bf leg.leg (V Mac) Date? Troesmis....III 6180 CRYSOMALLUS

Aur(elius) C quintanesis leg ortus c Apamia Date? Ager Albanus. XIV 2282 GUPITIANUS

Cetron(ius) C spec legg III Antonin (=X Gem XIV Gem I Ad) c212 Carnuntum Pann Sup........................III 445\& GUPITUS

(Aurelius) Cupi(t)us vet ex aquil I Adiut 3s? Savaria Pann Sup..................................III 4821

T. Aur(elius) C Rom(ula) vet VII Cl 195 A.D. Viminacium Moes Sup............................... III $\mathbf{1 4 5 0 7}$

Carminius C optio I Min Date? Solva Noricum ............ III 5333 Ti. Cla(udius) C mil leg XXI ante Hadrian Virunum Noricum.. III 4840

- Clodius P. f (?Cu)pitus mil leg XXII Date? Narbo...... XII 4360

M. Gavius M. f. Ani. F(oro) Iuli G mil X Gem aet Traiani Carnuntum Pann Sup........................ 14358:18a 
L. Sep(timius) C vet I Adi p f Sever c225 Brigetio Pann Sup . III 14355:23 Vindil(ius) G sig XIIII Gem Antonin c215 Carnuntum Pann Sup. III 11152 GURIA

T. Aur(elius) C vet VII Cl 195 A.D. Viminacium Moes Sup.... III 14507 $\mathrm{K}$ ҮPINA $\Lambda \mathrm{IO} \Sigma$

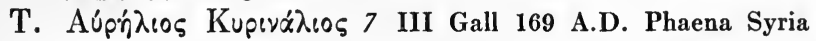

IG a R III 1114 = 1179

\section{CURTA}

M. Aur(elius) C Rat(iaria) vet VII Cl 195 A.D. Viminacium

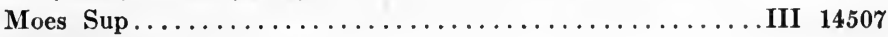
CURTAVIUS

Octavius $\mathrm{C}$ bf $\cos$ Date? Rigomagus Germ Inf...........XIII 7818 CUTRATUS

Iulius $\mathbf{C}$ mil III Cyr ante 108 Egypt............ Wessely Lat Pal 8 . DAIZO

M. Aur(elius) D Sc(upis) vet VII Cl 195 A.D. Viminacium Moes Sup $\ldots \ldots \ldots \ldots \ldots \ldots \ldots \ldots \ldots \ldots \ldots \ldots \ldots \ldots \ldots \ldots \ldots \ldots \ldots \ldots$ III 14507

\section{DAPHNUS}

Valerius D b s III Aug c225 Lambaesis. VIII $258 \grave{6}$

\section{DARDANUS}

An(to)nius D curator II Aug 1s? London VII 24

$\triangle \mathrm{APEIO \Sigma}$

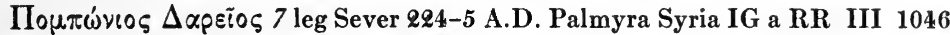
DASIANUS

M. Ulp(ius) D vet II Adiut Date? Aquincum Pann Inf ........ III 3540

\section{DASIUS}

M. Aurelius D mil IIII Fl Date? Antium .............. 6670

Ti. Cl(audius) D vet (II) Adiut 2-3s? Aquincum Pann Inf..... III 10511

M. Ulpius Marci f. Quirina D Sirmi optio XV Apol 1s Carnuntum Pann Sup ......................... III 4491

\section{DASSIUS}

P. Aelius D Cas mil? (III Aug) aet Antonini Pii Castra Lambaesitana ............................. 18085

P. Ael(ius) D Rat(iaria) vet VII Cl 195 A.D. Viminacium Moes Sup ................................. 14507

Aurelius D mil II Parth Antonin p f c215 Rome............... VI 3373

M. Aur(elius) D Sc(upis) vet VII Cl 195 A.D. Viminacium Moes

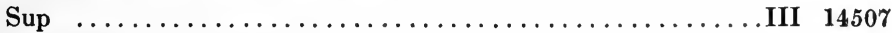

(M.) Aur(elius) D Sc(upis) vet VII Cl 195 A.D. Viminacium

Moes Sup.............................III 14507

(D)assius R(atiaria) tub VII Cl 195 A.D. Viminacium

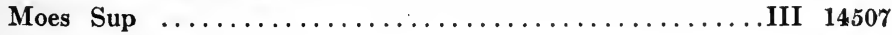

\section{DASUMIUS}

Aurelius D mil II Parth Sever p f aetern c225 Rome............ VI 3403 


\section{DATIANUS}

M. Vettius M. f. D mil III Aug Date? Lambaesis........... VIII 3272

\section{DATIVUS}

Sempronius D dup III Aug p v Antonin 218 A.D. Castra Lam-

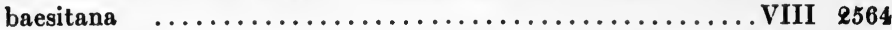

\section{DATULLUS}

Alf(ius) D arm cust III Aug c225 Castra Lambaesitana..... A.E. 1902:11

\section{DATUS}

L.? Aelius D Thab(arca) mil? (III Aug) Date? Castra Lambaesitana ........................ 2568 et 18055

C. Aemilius D Cas mil? (III Aug) Date? Castra Lambaesitana .................................... 256

T. Arranius D sig III Aug 198 A.D. Castra Lambaesitana...... VIII 2527 Domitius D arm cust III Aug c225 Castra Lambaesitana..A.E. 1902:11 L. Evatius D Ca(s) ? (III Aug) Date? Castra Lambaesitana.... VIII 2565 L. Fabius Da(da)tus vet (III Aug) Date? Lambaesis......... VIII 18298 M. Granius D vet II Adiut domo Africa Sufetla post 150 Pann Inf incerta ............................. III $\mathbf{3 6 8 0}$

C. Helvidius D Tha(mugadi) mil? (III Aug) Date? Castra

Lambaesitana .............................. VIII 2567

Iulius D tub III Aug p v 202 A.D. Castra Lambaesitana.... A.E. 1907:184 Iulius D tub III Aug p v Antonin 218 A.D. Castra Lambaesitana. VIII 2564 Iulius D dup III Aug p v Antonin 218 A.D. Castra Lambaesitana VIII 2564 M. Iul(ius) D mil II Adiut 2 -3s? Carnuntum Pann Sup........ III 447\& Nonius D vet librator evoc III Aug ante 147 Lambaesis.......... VIII 2728 M. Nuerius Da(tus) Cirt(a) vet III Aug p v c198 Castra Lambaesitana .................................. VIII 18068

Numerius D vet III Aug $p$ v 3s? Phua................ VIII 6310 Pompeus D tub III Aug p v 202 A.D. Castra Lambaesitana.. A.E. 1907:184 Pompeus D tub III Aug p v Antonin 218 A.D. Castra Lambaesi-

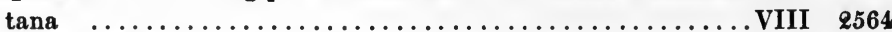

C. Salust(ius) D mil III Aug p v 3s? Lambaesis............VIII 3232 Sextilius D cor III Aug p v 203 A.D. Castra Lambaesitana...... VIII 2557 Sextilius D cor III Aug p v Antonin 218 A.D. Castra Lambaesi-

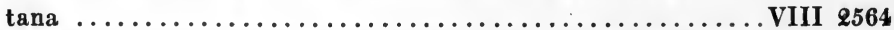

Sextilius D dup III Aug p v Antonin 218 A.D. Castra Lambaesi-

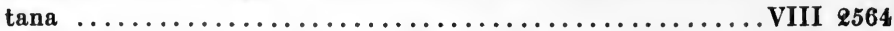

L. Tadius D vet (III Aug) Date? Lambaesis.............. VIII 3248 DAZANUS

Aur(elius) D ? II Adiut Date? Stuhlweissenburg Pann Inf....III 3349 DECGIANUS

M. Calpurnius D natione Italus mil II Adiut 2-3s Aquincum Pann Inf

\section{DECEMBER}

Iulius D dup III Aug p v Antonin 218 A.D. Castra Lambaesitana VIII 2564 


\section{DEGIANUS}

C. Marius Decian(us) Sicc(a) bf cos (III Aug) Date? Castra

Lambaesitana VIII 2567

DECIMINUS

Aemilius D medicus ordinarius I Adiut post 114 Adiaum Pann Sup $\ldots \ldots \ldots \ldots \ldots \ldots \ldots \ldots \ldots \ldots \ldots \ldots \ldots \ldots \ldots \ldots \ldots \ldots$ III $\mathbf{4 8 7 9}$

Titus Vettius D vet leg VIII imm cos 3 s? Lyons...........XIII 1903 DECIMUS

Aur(elius) D mil XI Cl 155 A.D. Almus Moes Inf.............III 7449

T. Aurel(ius) D 7 VII Gem fel 182 A.D. Tarraco . . . . . . . . . . . . II 4083

L. Caelius L. f. Quir. D mil III Aug 1s Theveste............ VIII 16545

C. (I aut P) u(11)inius D tess XXII Pr p f post 89 Castellum Mattiacorum .............................. 7893 Cla(udia) D (Sava)ria 7 V Mac ante M. Aurel Troesmis.. III 6187 DECORATUS

F1(avius) D? ? III Ital Date? Augusta Vindelicum Raetia....... III 5883 DECUMINIANUS

C. Iulius Decumini(anus) vet? II Aug Date? Isca Eng....... VII 120 DEIOTARUS

Ael(ius) D 7? XIII Gem post Traian Apulum Dacia........... III 1629:5

Iu(lius) D 7 ? XIII Gem post Traian Apulum Dacia.......... III 8065:29 DEMETRIANUS

Aemilius Demetrian(us) dup III Aug p v Antonin 218 A.D.

Castra Lambaesitana............................. 2564

C. Aemilius D Ten(is) d s (III Aug) Date? Castra Lambaesi-

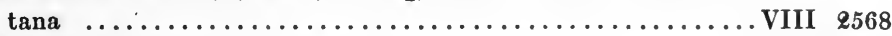

C. Aemilius D aquil (III Aug) Date? Lambaesis........... VIII 2796

Q. Apollonius D mil III Aug Date? Lambaesis............ VIII 3037

Cosconius D dup III Aug p v Antonin 218 A.D. Castra Lambaesi-

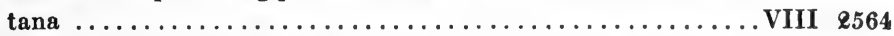

L. Fonteius Demetrian(us) Masc(ula) bf cos III Aug c225 Lambaesis .................................. 2586 Iul(ius) De(m)etrianus V(III) Aug $p$ f Commoda 187 A.D.

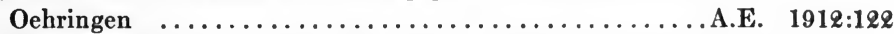

C. Iulius D Cas mil? (III Aug) Date? Castra Lambaesitana.. VIII 2569 I- D mil III Aug Date? Lambaesis............... VIII 3134

\section{DEMETRIUS}

Ael(ius) D 7 XXII Prim Date? Bischofsheim Germ Sup...... XIII 6429a Aur(elius) Demetr(ius) 7? XIII Gem post Traian Apulum Dacia III 8065:15 Tib. Cl(audius) D quod mil frum XV Apol Date? Rome..A.E. 1905:68 L. Hapion L. f. Pol. D vet II Tr fort 194 A.D. Alexandria Egypt III 6580

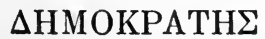

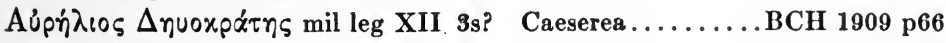
DEMOSTENES

Aurelius D vet leg XXX Date? Lyons..............XIII 1841 


\section{DENTILIANUS}

T. Honoratius Dentil(i)anus optio XXII Pr p 207 A.D. Obern-

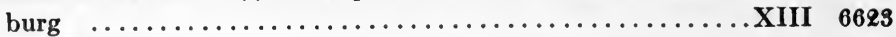

DEOSPOR

Sept(imius) D cand XXX Ulp vict 223 A.D. Col Ulpia Traiana

Germ Inf............................ XIII 8607

DERISOR

Aurelius D dup III Aug p v Antonin 218 A.D. Castra Lambaesi-

tana ................................... VIII 5264

DEXTER

Aemilius D cor III Aug p v 203 A.D. Castra Lambaesitana...... VIII 2557

C. Agrius Dext(er) vet ex bf trib (III Aug) Date? Lambaesis..... VIII 2800

Atteius D 7 II Adiut Date? Aquincum Pann Inf ............. III 3530

T. F1(avius) D Eur- vet VII Cl 195 A.D. Viminacium Moes

Sup $\ldots \ldots \ldots \ldots \ldots \ldots \ldots \ldots \ldots \ldots \ldots \ldots \ldots \ldots \ldots \ldots \ldots \ldots \ldots$ III 14507

Iulius D bf trib III Aug p v Antonin 218 A.D. Castra Lambaesi-

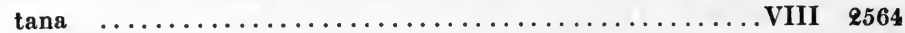

C. Iulius D Theves(te) spec III Aug c225 Lambaesis........... VIII 2586

C. Iulius D Girt(a) ?(III Aug) Date? Castra Lambaesitana... VIII 2566

M. I(u)n(ius) D bf cos 227 A.D. Siscia Pann Sup............III 10843

Sallustius D arm cust III Aug c225 Castra Lambaesitana....A.E. 1902:11

L. Vireius D seplasiarius in leg I Adiut 70-100 A.D. Mainz ...... XIII 6778 DEXTRIANUS

Umbilius D arm cust III Aug c225 Castra Lambaesitana..A.E. 1902:11 DIABO

Furnius D 7 II Tr fort 217-8 A.D. Ile d'Elephantine........ A.E. 1905:54 DIDYMUS

P. Aelius D Cas mil? (III Aug) aet Antonini Pii Castra Lambaesitana ................................... VIII 18085

DIFILUS

M. Aur(elius) D vet II Aug Date? Arelate..............XII 677 DIGNISSIMUS

Valen(tinius) Digniss(imus) (mil?) I Min Date? Bonn..... XIII 8053 DIGNUS

Iul(ius) D spec legg III Antonin ( = X Gem XIV Gem I Ad) c212

Carnuntum Pann Sup........................ 44II

G. Iul(ius) Dign(us) bf $\cos$ X Gem 250 A.D. Latobici Pann Sup.. III 10789 D Nap(oca) mil? (III Aug) aet Antonini Pii Castra Lambaesitana ............................... VIII 18085

DINES

M. Aur(elius) D Trim(ontio) vet VII Cl 195 A.D. Viminacium Moes Sup............................III 14507

DIODORUS

C. Iulius Di(o)dorus Cas mil? (III Aug) aet Antonini Pii Castra

Lambaesitana ...........................VIII 18085 
(Dio)dorus Cas mil? (III Aug) aet Antonini Pii Castra

Lambaesitana ........................... VIII 18085

DIOGENES

M. Aur(elius) (Diog)ene(s) bf cos XIIII Gem (Sever) c225 Siscia

Pann Sup.............................. 15181:1

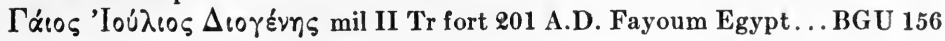
DIOMEDES

D Artemonis f. Phrygio vet I Adiut 68 A.D. Stabiae....... X 770

DIONISIUS

Aur(elius) Dionis(ius) 7 ? XIII Gem post Traian Apulum Dacia

III $1629: 12=8065: 16$

DIONYSIUS

Ael(ius) D vet (XIII Gem) 160 A.D. Verespataki Dacia........III p959 P. A(elius) D vet ex sig IIII Fl firm Date? Singidunum Moes Inf. III 12663 Aurel(ius) Diony(sius) imag (I Ital) 2s exe-3s Almus Moes Inf . .III 14409:1

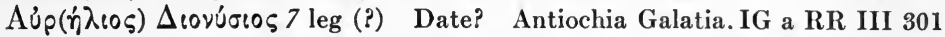
- L. f. Pol. D Cas vet II Tr fort 194 A.D. Alexandria Egypt III 6580 f. Pol. D Cas vet II Tr fort 194 A.D. Alexandria Egypt... . III 6580 DIORATUS

Q. Iulius Q. f. Quir. D Autr(ico) mil III Aug 1s Theveste..... VIII 1876 DIOSCORUS

-8 C. f. Pol. D Cas vet II Tr fort 194 A.D. Alexandria Egypt III 6580

(Di)oscorus Cas sig? (III Aug) aet Antonini Pii Castra

Lambaesitana .......................... 18085

DISERTUS

C. Ligustinius C. f. Clu. D 7 XX V v 7 IIII Scyth Date? Piti-

num Mergens?............................ 5960

DIZA

M. Aur(elius) D mil II Parth Sever c215? Ager Albanus...E.E. IX 658 DIZO

T. Ael(ius) D Trim(ontio) vet VII Cl 195 A.D. Viminacium

Moes $\quad$ Sup.............................. 14507

Aurel(ius) D mil XI Cl 3s exe-4s init Aquileia ................ 893

Valerius D ? IIII Fl cives Filopopolita(nus) Date? Venafrum..... X 4874 DIZZA

Aur(elius) D arm cust II Parth 3s? Worms Germ Sup........ XIII 6231 DIZZE

Aurel(ius) D vet (I Ital?) Date? Ad Haemum Moes Inf....... III 12408 DIZZO

M. Aur(elius) D aquil VII Cl Date? Viminacium Moes Sup Jahres Wien 1909 Beibl p157 n21

DOLENS

M. Aur(elius) D R(atiaria) vet VII Cl 195 A.D. Viminacium Moes Sup.............................III 14507

C. Iulius D vet ex bf $\cos \mathrm{X}$ Gem Date? Salonae Dalmatia...... III 8745 
-1(ius) D Rat(iaria) vet VII Cl 195 A.D. Viminacium Moes

Sup ................................. 14507

DOMITIANUS

Ael(ius) D imm lib IIII Fl Date? Viminacium Moes Sup....... III 8120

C. Arrius D 7 XX V v aet Antonini Pii prope Newstead Eng.......VII 1081

G. Arrius D 7 XX V v aet Antonini Pii Newstead Eng.......E.E. IX 1234-85 Aurelius D bf I Adiut Date? Aquileia................. 894 T. Flavius D domo Nicomedia spec III Parth Sever hast X Fr

222-235 A.D. Rome........................ Dessau 484

T. Flavius D? vet (III) Aug? 1s Simitthus............. VIII 14604

T. Flavius D bf (III Aug) Date? Lambaesis.............. VIII 8870

Iulius D vet III Aug Date? Lambaesis...........VIII 18304 ef 3135

Marius Domitian(us) arm cust (III Aug) 200 A.D. Castra Lam-

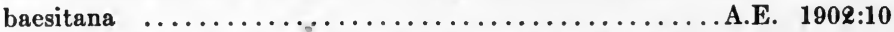

G. Variolen(us) G. f. Domi(t)i(anus) Bononia mil leg VI 1s

Calagurris Tarraconensis.........................II $\mathbf{8 9 8 3}$

DOMITIO

(Do)mitio Nico(poli) vet VII Cl 195 A.D. Viminacium

Moes Sup..............................III 14507

DOMITIUS

Aelius D domo Erupuli cives Surus vet II Adiut 2-3s prope

Brigetionem Pann Sup........................III 11076

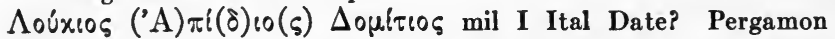

Ath Mitth 24 p169

C. Iul(ius) D vet (III Aug) Date? Lambaesis.............VIII 3136

C. Iul(ius) D mil III Aug Date? Lambaesis..............VIII 3186

DOMNIO

Aur(elius) D (vet) ex imm (V Mac?) Date? Potaissa Dacia.....III 7688

DONATIANUS

Iulius Donatian(us) sig (III Aug) Date? Castra Lambaesitana VIII 18073 DONATUS

Aelius D arm cust (III Aug) 200 A.D. Castra Lambaesitana. . A.E. 1902:10 Aelius D (eq? III Aug) 222-35 A.D. Castra Lambaesitana.. MAH 1897 p447 P. A(el)ius Do(na)tus Nap(oca) tub (IIİ Aug) aet Antonini Pii

Castra Lambaesitana ..........................VIII 1808 s

Aemilius D dup III Aug p v Antonin 118 A.D. Castra Lambaesitana .......................................

C. Aemilius Do(natus) mil? (III Aug) Date? Castra Lambaesitana ................................ $251 I I$

M. Antonius D Thy(sdro) mil? (III Aug) aet Antonini Pii Castra

Lambaesitana ............................. VIII 18085

T. Aonius D Bagai vet III Aug p v c198 Castra Lambaesitana ... VIII 18068

M. Apuleius D (eq? III Aug) 228-35 A.D. Castra Lambaesitana.................................. $1897 \quad \mathbf{p 4 4 7}$

Caecilius D dup III Aug p v Antonin 218 A.D. Castra Lambaesitana .VIII e564 
Caecilius D ? (III Aug) Date? Castra Lambaesitana.......... VIII 2565 C. Caecilius (Do)nat(us) Cas ? (III Aug) Date? Castra Lambaesitana ................................ 2566 Q. Caeçil(ius) Donat(us) mil? (III Aug) Date? Castra Lam-

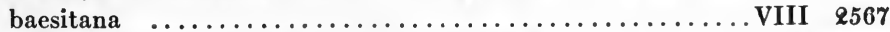

M. Cassius D mil III Aug Date? Lambaesis............. VIII 3076 Cecil(ius) D vet ex librario (III Aug) 270-275 A.D. Lambaesis.. VIII 2626 Cecilius D Bessus natione mil (leg?) Date? Chester Eng.....E.E. VII 890 C. Cerellius D (mil? III Aug) c200 Castra Lambaesitana

Bull Archeol 1905 p 240 Cerellius Don(atus) lib (III Aug) Date? Castra Lambae-

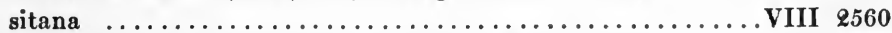

C1(audius) D eq III Ital Date? Castra Regina Raetia..........III 5947

C. Domitius D ? (III Aug) 209-211 A.D. Castra Lambaesitana. VIII 2556

P. Egnatius D can III Aug Date? Lambaesis............. VIII 2866

Q. Fabius Donat(us) tub III Aug p v 202 A.D. Castra Lambaesitana........................... 1907:184

Flavius D arm cust (III Aug) 200 A.D. Castra Lambaesitana . A.E. 1902:10 Flavius Donat(us) arm cust III Aug c225 Castra Lambaesitana. A.E. 1902:11 L. Gargil(ius) Don(atus) mil? (III Aug) Date? Castra Lambaesitana.................................... 2567

Iulius D optio (III Aug) 198-211 A.D. Castra Lambaesitana... VIII 2554 Iulius D dup III Aug p v Antonin 218 A.D. Castra Lambaesi-

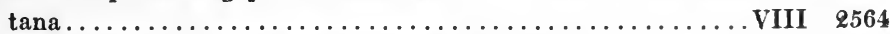

Iulius D arm cust III Aug c225 Castra Lambaesitana.......... 1902:11 Iulius D eq ex optione III Aug Date? Lambaesis............. VIII 2894 Iul(ius) $\mathbf{D}$ arm cust (III Aug) Date? Lambaesis...........VIII 2893 Iulius D vet (III Aug) Date? Lambaesis.............. VIII 3155 Iulius D mil (III Aug) Date? Lambaesis............... VIII 3139 Iulius D Cas mil? (III Aug) Date? Castra Lambaesitana.... VIII 2568 C. Iulius D optio (III Aug) 198-211 A.D. Castra Lambaesitana.. VIII 2554 C. Iulius D cor III Aug p v 203 A.D. Castra Lambaesitana... . . VIII 2557

C. Iulius D Castr quaest III Aug c225 Lambaesis........... VIII 2586

C. Iulius V-ius D vet II Adiut $\&$-3s Aquincum Pann Inf.... III 3554 C. Iulius D mil III Aug Date? Lambaesis........VIII 3137 (et 3138?) M. Iulius D cor III Aug p v 203 A.D. Castra Lambaesitana. . . . . VIII 2557 ? Iulius Do(n)atus dup III Aug Date? Lambaesis............ VIII 2895 Licinius D Cas mil? (III Aug) Date? Castra Lambaesitana.. VIII 2568 Q. Longeius D Cas mil? (III Aug) Date? Castra Lambaesitana. VIII 2568 L. Loreius D (T)he (veste) vet? (III Aug) \&s? Castra Lambaesi$\tan \ldots \ldots \ldots \ldots \ldots \ldots \ldots \ldots \ldots \ldots \ldots \ldots \ldots$. . . . . . . 18087

C. Manil(ius) D opt has pr (III Aug) c253 Castra Lambaesitana. . VIII 18072 Memmius D 7 III Aug X pilus (posterior) post 253 Lambaesis.. VIII 18239 L. Minucius (D)onatus (7) III Aug Date? Lambaesis......VIII 2944 C. Numisius D mil III Aug Date? Lambaesis............. VIII 3208 M. Octavius D (eq? III Aug) 222-35 A.D. Castra Lambaesitana 
L. Omidius D Tham(ugadi) sig III Aug p v c198 Castra Lambaesitana .............................. VIII 18068

Percennius Donat(us) arm cust (III Aug) 200 A.D. Castra

Lambaesitana .............................. 1908:10

Perellius Do(natus?) ? (III Aug) 253-268 A.D. Castra Lambaesitana..............................III 18061

Perelius Donatu(s) vet ex 1 are (?) (III Aug) 270-275 A.D. Lambaesis................................ VIII 2626

Petidius D mil III Aug Date? Lambaesis...............VIII 3217

Pomponius D bf cos Date? Binchester Eng...........E. IX 1133

P. Pomponius D mil (III Aug) Date? Lambaesis........... VIII 3222

P. Popilius D Cas arm cust (III Aug) Date? Castra Lambaesi-

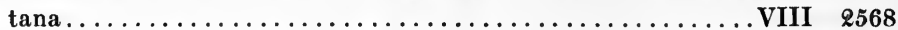

Sempronius D bf trib (III Aug) Date? Lambaesis..........VIII 2972

Servilius Donatu(s) arm cust III Aug c225 Castra Lambaesi-

tana................................ 1902:11

L. Sextius D vex III Aug Date? Lambaesis................. VIII 2974

Tannonius $D$ arm cust III Aug Date? Lambaesis........... VIII $\$ 979$

Valerius D vet (III Aug) Date? Lambaesis.............VIII 3253

P. Valerius D bf leg Aug pr pr (III Aug) 208-211 A.D. Lam-

baesis................................. VIII 2733

C. Vinicius D Cast vet III Aug p v c198 Castra Lambaesitana . . VIII 18068

M. _ D Cas d s (III Aug) Date? Castra Lambaesitana.... VIII 18086 D ? (III Aug) 253-268 A.D. Castra Lambaesitana.... VIII 18061 (D)onatus Ci(rta?) (mil? III Aug) Date? Castra

Lambaesitana .............................. 1899:90

D Gal mil I Ital Date? Moes Inf incerta.............III 6232

(D)onatus optio III Ital Date? Castra Regina Raetia..... III 5958

DONCIUS

Aurelius D mil X Gem Date? Ager ad Colapim Pann Sup.....III 14044

DOSSO

T. Aurelius D mil XXX Ulp vict Date? Vinxtbach........XIII 7732

DRIGISSA

T. Aurelius D Rat(iaria) vet VII Cl 195 A.D. Viminacium

Moes $\operatorname{Sup} \ldots \ldots \ldots \ldots \ldots \ldots \ldots \ldots \ldots \ldots \ldots \ldots \ldots \ldots$ III 14507

DUBITATUS

Fadius D Hadr(umeto) spec III Aug c225 Lambaesis.........VIII 2586

L. Fl(avius) D strat (I Min) Date? Hersel Germ Inf....... XIII 8150

Iuni(us) D 7 VIII Aug 1s Segedunum Eng.............. VII 495

(Sep)t(imius) D mil II Adi p f 2-3s Voeroesvar Pann Inf...... III 10569

\section{DUBIUS}

L. Magius L. (f) Ouf. D Mediolani mil I F(laviae) $M$ (in) p f

$\mathrm{D}$ (omit) arm cust aet Domitianae Bonn........... XIII 8071

EASUCTANUS

M. Porcius Easuctan(us) 7 XX V v Sever c225 Lambaesis.... . . VIII 2638 


\section{EFFICAX}

T. Cl(audius) E mil leg II $p$ f bf cos domo Luceria Apia 2-3s? Aquincum Pann Inf......................... III 3544 EGNATIANUS

C. Fufius Egnatianu(s) ? (III Aug) Date? Castra Lambaesitana................................. VIII 2565 EGNATIUS

Paconius E mil III Cyr ante 108 Egypt............ Wessely Lat Pal 8 EGRILIANUS

Cornelius E 7 III Cyr aet Severi Bostra Arabia.............III 103 ELEPANS

C. Mattius E optio (III Aug) 198-211 A.D. Castra Lambaesitana. VIII 2554 ELEUTHER

Antoni(us) Eleu(ther) vet (V Mac) c134 Troesmis..........III 6178 EMERITUS

P. Aelius E vet (III Aug) Date? Lambaesis............... VIII 3013

P. Aelius E Ca(s) ? (III Aug) Date? Castra Lambaesitana.. VIII 2565

L. Atilius E ? (III Aug) Date? Castra Lambaesitana......VIII 2562

M. Aur(elius) E dom Sergia Karnunto 7 I Adiut post 114 Brigetio

Pann Sup................................. III 11019

Fl(avius) E spec I et II Adi p f Sever 228 A.D. Aquincum Pann

Inf .................................... 3524

Iulius E dup III Aug p v Antonin 218 A.D. Castra Lambaesitana.. VIII 2564

Iulius $\mathrm{E}$ dup III Aug $\mathrm{p}$ v Antonin 218 A.D. Castra Lambaesitana . VIII 2564

Iulius E mil VIII Aug Sever Alexand 223 A.D. Mainz........ XIII 6738

Iul(ius) E spec I et II Adi $p$ f Sever 228 A.D. Aquincum Pann Inf.. III 3524

Iulius E sig (III Aug) Date? Castra Lambaesitana.......... VIII 18073

C. Iulius E cor III Aug Date? Lambaesis............... VIII 2898

C. Iul(ius) E eq III Aug Date? Lambaesis............... VIII 3140

C. Iulius E tub III Aug Date? Lambaesis.............. VIII 2897

C. Iunius Eme(ritus) mil? (III Aug) Date? Castra Lam-

baesitana................................. VIII 2567

Lartidi(us) Emerit(us) arm cust (III Aug) 200 A.D. Castra Lam-

baesitana ............................. 1902:10

Licinius E 7 III Aug coh VI 162 A.D. Castra Lambaesitana.... VIII 18065

M. Lutatius E Cas tess (III Aug) Date? Castra Lambaesitana. . VIII 2568

Paconius E vet III Aug Date? Verecunda..............VIII 4245

Servilius E Vico Gallorum mil XIIII Gem 195 A.D. Carnuntum

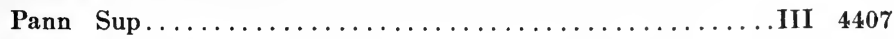

Ulpius E 7 III Aug coh IX 162 A.D. Castra Lambaesitana... VIII 18065

M. Ulp(ius) E bf cos II Adiut 210 A.D. Aquincum Pann Inf...III 10429

Q. Valerius E vet ex bf leg III Aug Date? Lambaesis......... VIII 2990

Vibius E mil X Gem 3s? Latobici Pann Sup..............III 10792

EMPORUS

- (?E)mporus Cas mil? (III Aug) aet Antonini Pii Castra

Lambaesitana............................... VIII 18085 


\section{ENTHIMUS}

Aur(elius) Enthim(us) 7 ? XIII Gem post Traian Apulum Dacia .III 1689:13 EPAPHRODITIANUS

Ti. Claudius $\mathrm{E}$ vet VII $\mathrm{Cl} \mathrm{p} f$ Date? Aquileia............ V 808 EPAPRODITUS

M. Aurelius E bf trib (III Aug) Date? Lambaesis..........VIII 2822 EPIANUS

Ael(ius) E spec legg III Antonin ( $=$ X Gem XIV Gem I Ad) c212

Carnuntum Pann Sup........................III 4458 EПIKTHTOE

Aup $(\dot{\eta} \lambda เ \circ \varsigma)$ 'E $\mathrm{i}\{x \tau \eta \tau \circ \varsigma$ mil mensor (XI Cl) post 42 Aquileia.. IG XIV 2340 EPPANIUS

Pompeius Ep(p)an(ius) 7 III Cyr ante 108 Egypt....Wessely Lat Pal 8 EP(P)ILLUS

Q. Ennius T. f. Quir E 7 III Aug ante 244 Bisica......... VIII 18297 EPTACENTUS

M. Aurel(ius) E strator leg leg II Adi p f Sever c\&25 Aquincum

Pann Inf..................................III 10411 EQUINUS

(P? Ae)1(ius) Fab. Eq(uin)us Ancyra (mil) II Adiut 2-3s?

Aquincum Pann Inf...........................III 10498 ERENNIUS

Rusticinius E vet XXX Vict Date? Lyons.............XIII 1884 ESPER

Mem(mius) E tub XIIII Gem post 100 Carnuntum Pann Sup..III 11121 ESSUS

Varron(ius) E ? XX V v Date? Whitley Castle Eng. VII 305 et E.E. IX p683 ETRUSCUS

C. Appuleius E spec vet leg XI ante 42 Novae Dalmatia......III 1914 ET $\triangle H M O \Sigma$

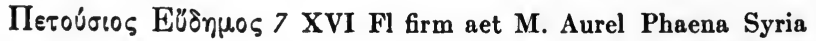

IG a RR III 1121-2

\section{EUDOX}

Au(relius) E 7 ? XIII Gem post Traian Apulum Dacia....III 8065:19 EUFRATIANUS

L. Domitius E ? (III Aug) Date? Castra Lambaesitana.... VIII 2570 EUGENUS

(I) u(lius) E (mil?) I Min Date? Bonn............... XIII 8053

\section{EUPHEMIANUS}

Tib. T(et)tius Euph(em)ianus p p VII Cl c150 Viminacium

Moes Sup..............................E. 1903:883

\section{EUPHROSYNUS}

T. Gallius Euphros(y)n(us) mil II Ital Date? Aquileia......V 8277 


\section{EUTICHIANUS}

Aurel(ius) Eutichian(u)s sig (III Aug) Date? Castra Lam-

baesitana.............................. 18073

EUTICIANUS

Aurelius E vet ex sig (III Aug) $270-275$ A.D. Lambaesis.... VIII 2626 EUTROFUS

- (Eut)rofus Nap(oca) mil? (III Aug) aet Antonini Pii

Castra Lambaesitana............................ 18085

\section{EUTYCHES}

Aur(elius) E salariarius I Adiut post 114 Brigetio Pann Sup....III 11011

Cossutius E (mil) II Parth Sever 210 A.D. Rome............ VI 32877

EXORATUS

G. Bruttius E vet III Aug 1s Theveste.............. VIII 16544

Ulp(ius) E mil leg XXII Date? Vesunna............... 1911:239

\section{EXTRICATUS}

C. Atinius E Sic(ca) vet III Aug 166 A.D. Castra Lambaesitana. . VIII 18067

T. Fl(avius) E mil (III Aug?) Date? Zarai.............VIII 4520

A. Geminius E mag k ? (III Aug) Date? Castra Lambaesitana. VIII 2568

Iulius $E$ immunis III Aug $p$ v 3s? Lambaesis............. VIII 2899

C. Iulius Extricat(us) Thev(este) vet III Aug p v c198 Castra

Lambaesitana ............................. VIII 18068

C. Manilius E mil III Aug Date? Lambaesis.............. VIII 3188

Q. Maximius E Madau(ra) vet? (III Aug) \&s? Castra Lam-

baesitana................................. 18087

EXUPERATUS

Tib. Cl(audius) E bf $\cos$ II Adiut 210 A.D. Aquincum Pann Inf . . III 10429 EXUPEREUS

- E mil II Ital 3s? Vallis Fl Mur Noricum..........III 5412 FABER

Q. Fabius (F)abe(r) (mil III Cyr aut XXII Deiot) 90 A.D.

Fayoum Egypt...................................... Gat 1

FABIANUS

G. Iulius $\mathrm{F}$ bf cos mil II Tr fort aet Hadriani? Sidon Syria....III 151

Vatinius Fabian(us) arm cust (III Aug) $\$ 00$ A.D. Castra Lambaesitana................................. 1902:10

FABIUS

L. Fabius L. f. Gal. Fab(i)us Nerto(briga) mil III Mac ante

Vespas Bingium........................XIII 7506

FABRIGIANUS

Iulius F arm cust III Aug c\&25 Castra Lambaesitana......A.E. 1902:11

FABRICIUS

Q. Glicius F (mil? III Aug) c 200 Castra Lambaesitana

Bull Archeol 1905 p 240

FABULLIANUS

C. Attius Fabullian(us) (mil? III Aug) c200 Castra Lambaesi- 
$\operatorname{tana}$ Bull Archeol 1905 p 240

FABULLUS

M. Valerius F (vet II Tr fort?) 140 A.D. Fayoum Egypt...... BGU 610 - Fabu(llus) leg $\mathrm{X}$ - 1s init Alexandria Egypt.........III 6597 FACILIS

M. Favon(ius) M. f. Pol. F 7 leg XX aet Vespasiani? Colchester Eng............................. $\quad \boldsymbol{\theta 0}_{0}$ FADIANUS

Valerius F 7 XXII Deiot ante 108 Alexandria Egypt.........III 6602 FANA

Capito(nius?) F mil III Cyr ante 108 Egypt.......... Wessely Lat Pal 8 FANIUS

Subur F 7 III Cyr ante 108. Egypt............... Wessely Lat Pal 8 FARIANUS

Bal(ius) $F$ vet (V Mac) Date? Troesmis...............III 6179 F? (vel G?)ARICUS

Postumi(us F?)aricus ex frum bf $\cos$ (III Aug) Date? Vazaivi.. VIII 17627 FARNAX

Aur(elius) F (vet? V Mac?) Date? Potaissa Dacia......III 7688 FARSULEUS

C. Aufidius F vet III Aug p v 198 A.D. Castra Lambaesitana.. VIII 18068 FATALES

L. Valerius F frum VIII Aug Date? Ephesus.............III 6084 FATALIS

M. Aurelius F Thev(este) vet III Aug p v c198 Castra Lambaesitana................................... VIII 18068

(? Ga)rgilius Q. f. Ar. F Sic(ca) ? (III Aug) Date? Castra

Lambaesitana............................ VIII 2565

P. Sittius F Cir(ta) str (III Aug) Date? Castra Lambaesitana.. VIII 2569 FAUSTIANUS

L. Baebius F sig III Aug p v 198 A.D. Castra Lambaesitana..VIII 2528 Esuvius F dup III Aug p v Antonin 218 A.D. Castra Lambaesitana. VIII 2564 Titi(us) F bf cos Date? Aquincum Pann Inf.............III 10456

FAUSTINIANUS

Aur(elius) F sig IIII Fl Date? Singidunum Moes Sup......III 8155 FAUSTINUS

C. Aelius F Kar vet? (III Aug) 2s? Castra Lambaesitana..VIII 18087 M. Cattius F Girt(a) vet III Aug p v c198 Castra Lambaesitana. VIII 18068 Dioc-anus F vet ex librario (III Aug) 270-275 A.D. Lambaesis. . VIII 2626 Q. Enn(ius?) (Fa) ustinus Kar adqs (III Aug) Date? Castra

Lambaesitana.............................. VIII 2568 Gargi(lius) Faust(inus) ? (III Aug) 253-268 A.D. Castra

Lambaesitana..............................VIII 18061 Iulius F corn XIIII Gem Sever c225 Carnuntum Pann Sup......III 11172 G. Iulius F Cas lib (III Aug) Date? Castra Lambaesitana..VIII 2568 
M. Iul(ius) F mil (III Aug) Date? Lambaesis............VIII 3141 Nonius F cor III Aug p v 203 A.D. Castra Lambaesitana...... VIII 2557 L. Papirius Faust(inu)s $\mathrm{K}$ (arthagine) vet III Aug 166 A.D.

Castra Lambaesitana.........................VIII 18067

(PI)ot(ius) Faust(i)nus ( 7 ? I Min) aet Getae Bonn........XIII 8050

Sallustius F tess III Aug p v Antonin 218 A.D. Castra Lam-

baesitana................................ VIII 8564

M. Trebellius F K(arthagine) vet III Aug 166 A.D. Castra

Lambaesitana................................VIII 18067

- F 7 II $\operatorname{Tr}$ fort 194 A.D. Alexandria Egypt..........III 6580

FAUSTIOLUS

C. Nevius F Tipa(sa) mil ? (III Aug) Date? Castra Lam-

baesitana................................. VIII 2568

FAUSTUS

C. Aelius F bf trib lat III Aug p v 198 A.D. Castra Lambaesitana.................................... $\ell 551$

M. Ann(i)olenus F vet ex corn trib III Aug Date? Thagora.... VIII 4642

Annius $F$ dup III Aug p v Antonin 218 A.D. Castra Lambaesi-

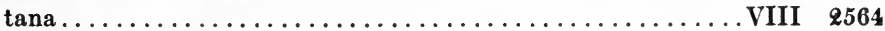

Antonius F dup III Aug p v Antonin 218 A.D. Castra Lam-

baesitana................................. VIII 2564

M. Antonius F Kar eq (III Aug) \&s? Castra Lambaesitana.... VIII 18087

C. Areius F (eq? III Aug) 222-35 A.D. Castra Lambaesitana

C. Attius $\mathrm{Fa}$ (ust) us (T)ipas(a) bf trib III Aug p v c198 Castra

MAH $1897 \quad$ p447

Lambaesitana............................... VIII 18068

M. Aufidius F 7 III (Aug) Date? Lambaesis.............. VIII 18287

Q. Caecilius F vet? (III Aug) 2s? Castra Lambaesitana.... VIII 18087

Caelius F tub III Aug p v 202 A.D. Castra Lambaesitana...A.E. 1907:184

Cornelius Fau(s)tu(s) $7 \mathrm{XI} \mathrm{Cl}$ post Hadrian Durostorum Moes

Inf ................................... III $\mathbf{7 4 7 5}$

C. Corneli(us F)austus ? (III Aug) Date? Castra Lambaesi-

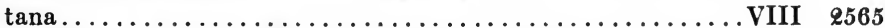

M. Cornelius F 7 III Aug Date? Calceus Herculis Numidia.. VIII 2503

C. Faonius F (eq? III Aug) 222-35 A.D. Castra Lambaesitana

MAH $1897 \mathrm{p} 447$

Iulius F sig (III Aug) Date? Castra Lambaesitana........VIII 18073

C. Iulius F mil? III Aug c200 Castra Lambaesitana Bull Archeol 1905 p240

C. Iulius F Cas d s (III Aug) Date? Castra Lambaesitana.. VIII 2569

C. Iulius F Cas mil? (III Aug) Date? Castra Lambaesitana.. VIII 2568

L. Iulius F Cilio vet III Aug p v c198 Castra Lambaesitana..VIII 18068

Q. Laelius F Am(maedara) vet III Aug 166 A.D. Castra Lambaesitana................................ VIII 18067

Q. Laelius F corn lat (III Aug) Date? Lambaesis........... VIII 8930

Q. Luccius Q. f. Pollia F Polentia mil XIIII G m v 70-100

A.D. Mainz............................. XIII 6898

Q. Naevius F Cap(sa) mil (III Aug) Date? Castra Lambaesi-

tana....................................VIII 
Petellius F 7 III Aug coh VI 162 A.D. Castra Lambaesitana.. VIII 18065 P. Porcius F p p IIIIII Hisp 193-211? A.D. Aquileia..Pais Suppl n165 M. Silius M. f. Quir. F Am(maedara) mil III Aug aet Severi?

Lambaesis............................... 2975

T. Speccius F mil III Aug Date? Lambaesis.............. VIII $\$ 244$

Val(erius) F mil III Aug Date? Lambaesis...............VIII 3254 F Thev(este) mil? III Aug c200 A.D. Castra Lambaesi-

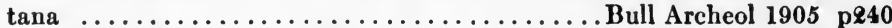
F vet ex br? (V Mac) Date? Troesmis............III 6179 FAVENTINUS

Q. Annaeus Q. f. Pol. Balbus F meiles leg V ante 70 Ad Aquas. VIII 14697

G. Iulius Faventin(us) corn leg leg I Adiut post 114 Aquincum

Pann Inf..............................III 14841:5

L. Val(erius) F bf $\cos X$ Gem Antonin 217 A. D. Latobici

Pann Sup...........................III 8907

FAVOR

Braet(t)ius F vet V Mac ante M. Aurel? Istrus Moes Inf....III 7524 (?F)avor vet XXII Pr $p$ f post 89 Mainz..........XIII 6985

FEANUS

Cla(u)dius F mil Cyr ante 108 Egypt.............Wessely Lat Pal 8 FELICIANUS

Aur(elius) F princeps VII Cl Date? Viminacium Moes Sup..III 13806 Geminius Fel(icia)nus (eq? III Aug) 2q2-35 A.D. Castra

Lambaesitana........................... 1897 p447

Iulius F arm cust III Aug ce25 Castra Lambaesitana....A.E. 1902:11 Sertorius F arm cust (III Aug) 200 A.D. Castra Lambaesitana. A.E. 1908:10 L. Sittius Felician(us) Mil(evo) mil? (III Aug) Date? Castra

Lambaesitana.......................... 2 III 2567

\section{FELICISSIMUS}

Hosidius F lib III Aug Date? Lambaesis...............VIII 2884

Iulius F (mil? II Parth?) Date? Rome................. 2410

FELIX

Aelius F ? (III Aug) Date? Castra Lambaesitana.......... VIII 2570

C. Aelius F (eq? III Aug) $22 \&-35$ A.D. Castra Lambaesitana

MAH 1897 p447

L. Aemilius F sig III Aug Date? Lambaesis.............. VIII 2960

L. Aemilius F Kart mil? (III Aug) Date? Castra Lambaesi-

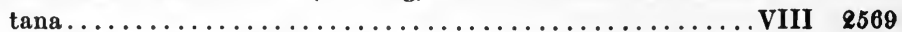

M. Aemilius (mil? III Aug) c200 Castra Lambaesitana

Q. Aemilius Man(liana) vet? (III Aug) \&s? Castra Lambaesitana............................... VIII 18087

Q. Aemilius F mil III Aug Date? Lambaesis..............VIII 3022

L. Agrius F Utica bf $\cos$ (III Aug) c225 Lambaesis......... VIII 2586

Q. Albius Q. f. Hor. F corn pr pr XX V v aet Traiani Falerii.... XI 3108 (An)n(ius) Fel(ix) (mil) III Aug Date? Lambaesis.......VIII 18284 
C. (A)nnius F Sim(itthu) mil? (III Aug) Date? Castra

Lambaesitana............................. VIII $\quad \mathbf{2 5 6 7}$

Antistius F dup III Aug p v Antonin 218 A.D. Castra Lam-

baesitana.................................... VIII $\mathbf{8 5 6 4}$

Anton(ius) F 7 III Aug Date? (2s?) Lambaesis..........VIII 3174

Antonius F 7 (leg?) Date? inter Cilurnum et Proclitiam Eng.. VII 1353

An(tonius?) F vet (leg ?) Date? Chester Eng.........E.E. IX 1073

L. Antonius L. f. Arnensis F Karthagine 7 III Aug 7 X Gem 7 I

Ital is Troesmis.............................. 6185

L. Antonius F vet (III Aug) Date? Lambaesis...........VIII 3015

L. Antonius F vet (III Aug) Date? Lambaesis........... VIII 3031-8

M. Antonius F mil III Aug Date? Lambaesis............ VIII 3033

L. Arruntius F mil (III Aug) Date? Lambaesis.......... VIII 18286

As-enius F dup? III Aug p v Antonin 218 A.D. Castra Lambaesitana................................. 2564

M. Atinius F Tham(ugadi) vet III Aug p v c198 Castra

Lambaesitana.............................. VIII 18068

Aufidius F vet (III Aug) 1s? Thamugadi Numidia. Bull Archeol 1911 p124

Aufidius F dup III Aug p v Antonin 218 A.D. Castra Lambaesi-

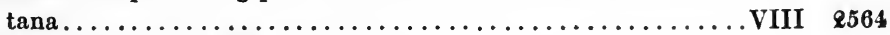

Aufldius F dup III Aug p v Antonin 218 A.D. Castra Lambaesi-

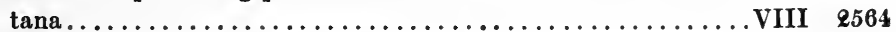

Aufidius F p p (III Aug) Date? Lambaesis............. VIII 2759

Aufidius F dup III Aug Date? Lambaesis...............VIII 2816

P. Aufidius F sig III Aug Date? Lambaesis............. VIII 2815

Q. Aufidius F Kar eq (III Aug) \&s? Castra Lambaesitana.... VIII 18087 Aurelius F dup III Aug p v Antonin 218 A.D. Castra Lambaesi-

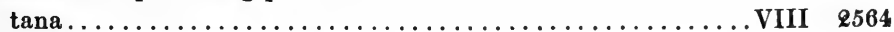

Aurelius F ? (III Aug) 253-268 A.D. Castra Lambaesitana.... VIII 18061 Aur(elius) F ? (III Aug) 253-868 A.D. Castra Lambaesitana.. VIII 18061 Aurel(ius) F vet ex actar (III Aug) 870-875 A.D. Lambaesis.... VIII 2626 M. Aurelius Fel(ix) Tha(mugadi) vet (III Aug) \&11-2 A.D. Lambaesis.................................... VIII 2618

P. Aurelius F Uri? vet? (III Aug) \&s? Castra Lambaesitana.. VIII 18087

P. Aurel(ius) F domo Thamug(adi) spec III Aug Date? Lambaesis................................ VIII 2603

L. Baebius F vet ex sig III Aug p v 198 A.D. Castra Lambaesitana.................................... 2528

P. Blaesius 7 II Tr fort aet Hadriani post bell Iud Saldae......VIII 8934

Caecilius F dup III Aug p v Antonin 218 A.D. Castra Lambaesi-

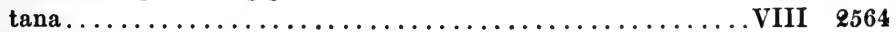

Caecilius F dup III Aug p v Antonin 218 A.D. Castra Lambaesi-

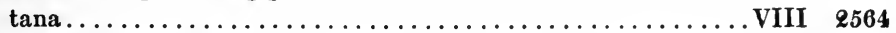

C. Caecilius F Bisica spec III Aug c\&25 Lambaesis.......... VIII 2586

C. Caecilius F d s (III Aug) Date? Castra Lambaesitana.... VIII 18086

C. Caecilius F vet (III Aug) Date? Lambaesis............VIII 3063 
C. Caecil(ius) F Gir(ta) mil? (III Aug) Date? Castra Lambaesitana................................ VIII 2567

L. Caec(ilius) F optio (III Aug) 198-211 A.D. Castra Lambaesi-

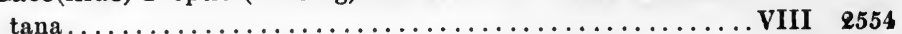

Sex. Caecilius F bf trib lat III Aug p v 198 A.D. Castra Lambaesitana................................. VIII 2551

C(aius) F bf trib (III Aug) Date? Lambaesis............ VIII 18291

L. Calpurnius F mil III Aug Date? Lambaesis........... VIII 3071

M. Calvisius F bf (III Aug) Date? Lambaesis....... VIII $2836=2835$ ?

M. Calvisius F vet (III Aug) Date? Lambaesis............VIII 2836

C. Cestius F ? (III Aug) Date? Castra Lambaesitana...... VIII 2562

Ti. Cl(audius) Fab. Rom. F 7 I Min Antonin c215 Lyons.... XIII 1893

C. Clodius F Cas mil? (III Aug) Date? Castra Lambaesitana .. VIII 2567

C. Cornelius F corn praef .II Adiut 2-3s? Aquincum Pann Inf...III 3565

D. Cornelius D. f Arn. F domo Karthag mil frum III Aug

Date? Rome.............................. VI 232

L. Cornelius F bf (III Aug) Date? Lambaesis............VIII 2849

M. Cornelius F ? (III Aug) Date? Castra Lambaesitana.... VIII 2565

Cornificius F vet (III Aug) Date? Lambaesis.............VIII 3094

C. Domitius F mil (III Aug) Date? Lambaesis............ VIII 3097

M. Domitius F 7 III Aug Date? Lambaesis..............VIII 2864

L. Duronius F bf trib lat III Aug p v 198 A.D. Castra Lambaesi-

tana..................................... 2551

Edinius $F$ vet (III Aug) Date? Lambaesis.............VIII 3011

P. Egnatius F Karth bf cos III Aug c225 Lambaesis........ VIII 2586

Egrilius F vet (III Aug) 211-2 A.D. Lambaesis............ VIII 2618

L. Emeritus Fel(ix) vet (III Aug) Date? Verecunda........ VIII 4239

L. Equitius F optio (III Aug) 198-211 A.D. Castra Lambaesitana.................................... $\$ 554$

C. Faianius F (mil? III Aug) c800 Castra Lambaesitana

Bull Archeol 1905 p 240

Felicius F mil IIII Scyt Date? Beroea Syria.............III 6705 Figilius F arm cust (III Aug) 200 A.D. Castra Lambaesitana. . A.E. 1902:10 Firmius F Cast bf cos III Aug c225 Lambaesis............ VIII 2586 (F1)avius F tub III Aug p v 200 A.D. Castra Lambaesitana... . A.E. 1907:184 T. Fla(vius) T. f. Pa(pi)ria F Thelep(te) mil III Aug Date?

Lambaesis................................ VIII 3106

T. Flavius F mil III Aug Date? Lambaesis............. VIII 3107-8

L. Fufius F mil III Aug Date? Lambaesis..............VIII 3114 Furfanius F b s III Aug c225 Lambaesis.............. VIII 2586 Gabinius F mil II Aug Date? Chester Eng..........E.E. IX 1072 C. Gargilius F optio (III Aug) 198-211 A.D. Castra Lambaesitana.................................... $\mathbf{8 5 5 4}$

C. Gargilius F Ca(s) ? (III Aug) Date? Castra Lambaesitana. . VIII 2565

L. Gargilius F optio III Aug Date? Lambaesis........... VIII 2879

P. Gavidius F mil leg ? Date? Leichtenstein Raetia.......III 12031:3

S. Gavius F mil III Aug Date? Lambaesis.............. VIII 3116 
L. Gellius F Kar vet? (III Aug) aet Hadriani Castra Lambaesitana.................................VIII 18084

Geminius F dup III Aug p v Antonin 218 A.D. Castra Lambaesitana............................... $\mathbf{2 5 6 4}$

(G)eminius F sig (III Aug) Date? Castra Lambaesitana....VIII 18073 Granius $F$ vet ex d e? (III Aug) 270-275 A.D. Lambaesis.... VIII 2626 Helvius F dup III Aug p v Antonin 218 A.D. Castra Lambaesi-

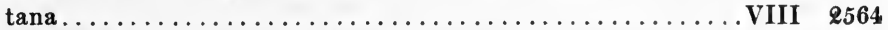

Herennius F dup III Aug p v Antonin 218 A.D. Castra Lambaesi-

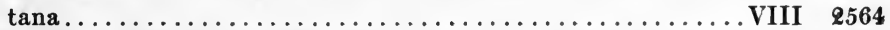

Heren(nius) Fel(ix) mil III Aug Sever p v 224 A.D. Saltus Aurasius................................ VIII 2467

C. Herrenius F Kar can (III Aug) Date? Castra Lambaesitana. . VIII 2568

C. Hortensius F Sim(ithu) mil? (III Aug) Date? Castra Lambaesitana.............................. 2567

- Hostilius -f. Arn. F (K)arthag vet ex bf leg (III Aug?)

Date? Lamsortense......................... VIII 18595

C. Hostilius F mil III Aug Date? Lambaesis............ VIII 3126 Icturius $F$ d aq III Aug Date? Lambaesis............. VIII 18302 (I)ulius F (mil? III Aug) c200 Castra Lambaesitana

Bull Archeol 1905 p\&39

Iu(lius) F arm cust (I Ital) \&s exe-3s Almus Moes Inf......III 14409:1 Iulius F lib III Aug $\mathrm{p} v$ Antonin 218 A.D. Castra Lambaesitana.. VIII 2564 Iulius F dup III Aug p v Antonin 218 A.D. Castra Lambaesitana . VIII 2564 Iulius F (mil? III Aug) c218? Castra Lambaesitana Bull Archeol 1904 p206 Iulius $F$ bf leg leg I Min $\mathrm{p} f$ 252 A.D. Bonn............ XIII 8015 Iulius F mil I Adiut Date? Carthage................ VIII 12877 Iul(ius) F lib III Aug Date? Lambaesis.......... VIII 2900 cf 2564 Iulius F vet (III Aug) Date? Lambaesis.............. VIII 3144 Iulius F Cas mil? (III Aug) Date? Castra Lambaesitana.... VIII 2568 C. Iulius F Cast vet III Aug p v c198 Castra Lambaesitana.. VIII 18068 C. Iulius F optio (III Aug) 198-211 A.D. Castra Lambaesitana.. VIII 2554

C. Iulius F cor III Aug p v 203 A.D. Castra Lambaesitana..... VIII 2557

C. Iulius F dup III Aug p v Antonin 218 A.D. Castra Lambaesitana................................... 2564

G. Iulius F Tham(ugadi) b s III Aug c225 Lambaesis......... VIII 2586

C. Iulius F Seq (eq? III Aug) 222-35 A.D. Castra Lambaesi-

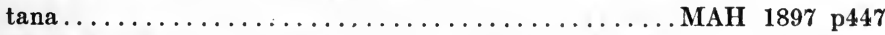

C. Iulius F Cas d s (III Aug) Date? Castra Lambaesitana.... VIII 2568

C. Iul(ius) F bf (III Aug) Date? Lambaesis............. VIII 2901

C. Iulius F vet (III Aug) Date? Lambaesis.............. VIII 3142

C. Iulius Fel(ix) mil (III Aug) Date? Lambaesis..........VIII 3145

C Iul(ius) F mil III Aug Date? Lambaesis.............. VIII 3146

C. Iulius F vet? (III Aug) Date? Castra Lambaesitana.... VIII 18086

C. Iulius F ? (III Aug) Date? Castra Lambaesitana......VIII 2570

G. Iulius F vet (III Aug?) Date? Casae .............. VIII 4328

L. Iulius F Cas d aq (III Aug) Date? Castra Lambaesitana............................... 2568 et 18055 
L. Iulius F eq III Aug Date? Lambaesis..............VIII 8143

M. Iulius F (mil III Cyr aut XXII Deiot) 90 A.D. Fayoum

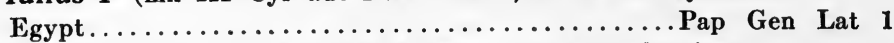

Q. Iulius F Pr (eq? III Aug) 222-35 A.D. Castra Lambaesitana

MAH 1897 p447

Q. Iulius An. F mil III Fl firm Date? Tergeste........... V 542

S. Iulius F Thev(este) haruspex III Aug c225 Lambaesis....VIII 2586

C. Iunius F Kar vet? (III Aug) 2s? Castra Lambaesitana.. VIII 18087

D. Iunius F Utica bf cos III Aug c225 Lambaesis..........VIII 2586

L. Longeius F imag (III Aug) Date? Lambaesis........... VIII 2935

L. Lucceius F Thev(este) vet III Aug p v c198 Castra Lambaesi-

tana................................... VIII 18068

(Mae)vius F (eq? III Aug) 222-35 A.D. Castra Lambaesitana

MAH 1897 p447

L. Magnius F mil X Fr bf trib Date? Aelia Capitolina Pales-

tine.................................III 14155:3

C. Malius F cor III Aug p v 203 A.D. Castra Lambaesitana..... . VIII 2557 Manilius F (eq? III Aug) 222-35 A.D. Castra Lambaesitana

MAH 1897 p447

Q. Manilius F can? d s (III Aug) Date? Castra Lambaesitana. VIII 18086 Sex. Marcius F Assur(ibus) bf cos III Aug c225 Lambaesis.... VIII 2586 Ma(r)ius F dup III Aug p v Antonin 218 A.D. Castra Lambaesitana.................................... 2564

M. Marius F Cirt(a) vet III Aug p v c198 Castra Lambaesitana. VIII 18068 M. Marius F vet (III Aug) Date? Lambaesis............VIII 3192 Mat(tius) F arm cust III Aug c225 Castra Lambaesitana..A.E. 1902:11 L. Mellonius F Cirt(a) vet III Aug p v c198 Castra Lambaesi-

tana.................................. VIII 18068

Minu(cius) F arm cust III Aug c285 Castra Lambaesitana.. A.E. 1902:11 M. Modius F mensor III Aug Date? Lambaesis ........ VIII $2935=2946$ L. Munatius F exactus III Aug p v c202 Castra Lambaesitana. A.E. 1898:109 Murius F dup III Aug p v Antonin 218 A.D. Castra Lambaesitana................................... $\mathbf{2 5 6 4}$

(M)ussius F sig (III Aug) Date? Castra Lambaesitana....VIII 18073 Myrismus F dispensator VII Cl Sever 228 A.D. Viminacium

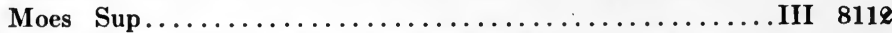

Naevidius F dup III Aug $p$ v Antonin 218 A.D. Castra Lam-

baesitana...................................... 2564

Q. Nonius F Castr mil? (III Aug) Date? Castra Lambaesitana. VIII 2567

L. Numerius L. f. F 7 VII G 7 XX Vict 7 III Cyr 7 XXII Pr 7

III Ital post M. Aurel Tarraco.................... 4162

Q. Numitor(ius) F 7 I Adi p f 2-3s Aquincum Pann Inf......III 3557 Octavius F dup III Aug p v Antonin 218 A.D. Castra Lambaesi-

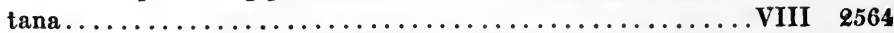

Octavius F mensor (III Aug) 3s? Castra Lambaesitana....A.E. 1904:72

C. Octavius F optio (III Aug) 198-211 A.D. Castra Lambaesitana.................................... 2554

L. Octavius F dup III Aug p v Antonin 218 A.D. Castra Lam- 
baesitana................................ VIII 2564

Q. Octavius F Cas mil? (III Aug) Date? Castra Lambaesi-

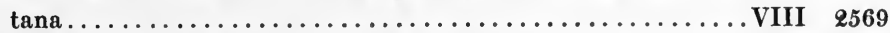

Oppius F optio II Aug Date? Stanwix Eng..............VII 914

L. Orbius F comm trib leg III Aug c\&25 Lambaesis......... VIII 2586

P. Perellius F optio (III Aug) 198-211 A.D. Castra Lambaesi-

tana.................................. 8554

Pinarius F dup III Aug p v Antonin 218 A.D. Castra Lam-

baesitana................................. 2564

Ploticius F 7 III Aug coh VI 162 A.D. Castra Lambaesitana..VIII 18065

Plotius F (eq? III Aug) 222-35 A.D. Castra Lambaesitana. MAH 1897 p447

Pompeius F Cas mil? (III Aug) Date? Castra Lambaesitana.. VIII 2567

C. Pomponius Feli(x) N- vet III Aug p v c198 Castra Lam-

baesitana................................. VIII 18068

L. Pomp(onius) F mil (III Aug) Date? Lambaesis.......... VIII 2961

Pontius F mil Caesari (ani?) III Aug p v 3s? Lambaesis...... VIII 3224

C. Popilius F cor III Aug p v 203 A.D. Castra Lambaesi-

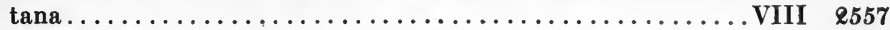

L. Popilius F bf leg (III Aug) Date? Lambaesis........... VIII 2963

L. Propertius F Via? vet? (III Aug) \&s? Castra Lambaesitana................................. 18087

L. Publicius F ? (III Aug) Date? Castra Lambaesitana.... VIII 2565

P. Sallustius F mil II Tr fort 3s? Alexandria Egypt........ III 14138:4

Q. Sallustius F Cirt(a) vet III Aug p v c198 Castra Lambaesitana................................. VIII 18068

C. Sempronius F optio (III Aug) 198-211 A.D. Castra Lambaesitana.................................. 2554

Q. Semp(ronius) F optio (III Aug) 198-211 A.D. Castra Lambaesitana..........................VIII $2554=18078$ Siliu(s) F vet VII Cl 135 A.D. Viminacium Moes Sup........III 8110 Supenin(ius) F bf cos 242 A.D. Rigomagus Germ Inf..... XIII 7794

C. Tannonius L. f. Quir. F qui et Aquensis mil III (Aug) Date? Phua...................................... 6311

Titinius F bf XX V v Date? Chester Eng............E.E. VII 902

Q. Tuccius F ? (III Aug) Date? Castra Lambaesitana.... VIII 2562

L. Tullius F d aq III Aug Date? Lambaesis............. VIII 2988

Umbrius F arm cust (III Aug) 200 A.D. Castra Lambaesitana. A.E. 190\&:10 Val(erius) F mil XI Cl 155 A.D. Almus Moes Sup..........III 7449 Valerius F arm cust (III Aug) 800 A.D. Castra Lambaesitana.. A.E. 1902:10 Valerius F arm cust (III Aug) 200 A.D. Castra Lambaesitana .. A.E. 1902:10 (V)alerius F pr(inceps?) tub III Aug p v 200 A.D. Castra Lambaesitana........................... 1907:184

Valerius F DX Prim p p III Aug p v Antonin 218 A.D. Castra Lambaesitana............................. VIII 2564

Valerius F dup III Aug p v Antonin 218 A.D. Castra Lambaesi-

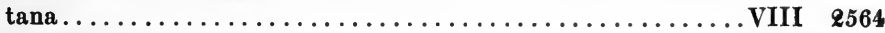

Valerius F dup III Aug p v Antonin 218 A.D. Castra Lambaesitana...................................... 
Valerius F ? (III Aug) 253-268 A.D. Castra Lambaesitana.... VIII 18061 Valerius $F$ mil III Aug $p$ v $3 s$ ? Lambaesis..............VIII 3255 Valerius $\mathbf{F}$ vet (III Aug) Date? Lambaesis.............VIII 3257 Valerius F mil III Aug Date? Lambaesis.............VIII 3258

C. Valerius F (mil III Cyr aut XXII Deiot) 90 A.D. Fayoum

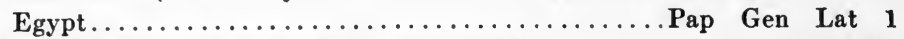

C. Valerius F eq III Aug Date? Lambaesis............... VIII 3256

M. Valerius F optio (III Aug) 198-211 A.D. Castra Lambaesi-

tana................................ 2554

M. Va(lerius) Fe(lix) mil II Aug 224 A.D. Isca. . . . VII 103 add E.E. III p117

P. Valerius P. f. Ael. F Then(is) aquil III Aug Date? Lam-

baesis............................... 29991

Q. Valerius F Cas vet III Aug 166 A.D. Castra Lambaesitana.. VIII 18067 Varius F vet ex actar leg (III Aug) 270-275 A.D. Lambaesis.. VIII 2626 L. Vibius $\mathbf{F}$ vet ex sig III Aug 3s? Lambaesis........... VIII 3000 M. Vibius F vet III Aug Date? Lambaesis............... VIII 3276 Q. Vibius F cor III Aug p v 203 A.D. Castra Lambaesitana.... . VIII 2557 ? (V)ibius $F$ mil III Aug $p$ v 3 s? Lambaesis............VIII 3275 Vitalinius $\mathbf{F}$ vet I Min $2-3$ s Lyons. ................ XIII 1906 C. Volusius C. f. F vet (III Aug) Date? Lambaesis......... VIII 3281 M. I__-ini(us) F Kar vet? (III Aug) \&s? Castra Lambaesitana $\ldots \ldots \ldots \ldots \ldots \ldots \ldots \ldots \ldots \ldots \ldots \ldots \ldots \ldots \ldots \ldots$ III 18087

Sex. - -ius F Kar vet? (III Aug) 2s? Castra Lambaesitana VIII 18087 (F)elix (mil? III Aug) c200 Castra Lambaesitana

Bull Archeol 1905 p \&41 F dup III Aug p v Antonin 218 A.D. Castra Lambaesi-

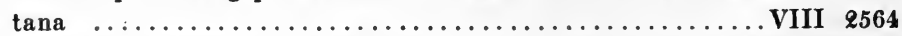
-nius F Cast str (III Aug) Date? Castra Lambaesitana A.E. 1899:92 - F Kar mil? (III Aug) Date? Castra Lambaesitana..... VIII 2567 F vet (V Mac) Date? Troesmis................. III 6179 F 7 (leg?) Date? Magnae Eng.............E.E. VII 1060

\section{FEROX}

Sex. Aetrius S(ex. f) Ouf. F 7 II Tr fort aet Antonini Pii Tuficum XI 5693-4 Metius F 7 II Adi $\mathrm{p}$ f $\mathrm{c71}$ Chester Eng..............E. IX 1056

\section{FESTIANUS}

Elpinius F frum I Adiut Date? Ephesus.................III 433

Licin(ius) F spec legg III Antonin ( $=$ X Gem XIV Gem I Ad) c212

Carnuntum Pann Sup ...................... 4452

\section{FESTIVUS}

Q. Flavius C. f. F (7?) VII Gem fel Date? Barcino Tarraconensis... II 4517

\section{FESTUS}

Ael(ius) Festu(s) vet VII Cl 135 A.D. Viminacium Moes Sup.... III 8110 C. Annius F ? (III Aug) Date? Castra Lambaesitana........ VIII 2568 M. Attius M. f. Quir F M(a)d(auris) mil III Aug Date? Lambaesis .................................. 3043

M. Attius Fes(tus) sig III Aug Date? Lambaesis...........VIII 2814 
M. Aurelius T. f. Gal. F Calag(urri) (mil X Gem) 70-Traian

Ulpia Noviomagus.................................. 8732

Caecilius F ? (III Aug) Date? Castra Lambaesitana......... VIII 2562

M. Cassius F mil leg X Date? Summus Poeninus ............E. 1894:150

Tib. Cl(audius) F ? VII Gem fel 1s exe-2s init Italica Baetica

E.E. VIII p388

M. Cornelius F mil III Aug architectus Date? Lambaesis..... VIII 2850

C. Gargilius F Sim(ithu) mil? (III Aug) Date? Castra Lambaesitana ................................... 2567

C. Iulius F Simit(tu) vet III Aug p v c198 Castra Lambaesitana ................................... 18086

T. Iulius $\mathbf{F}$ miles missicius militavit in leg XVI aet Tiberii Nemausus .................................. 3179

L. Licinius F 7 XXI Rap 70-Hadrian Brohl............XIII 7708

L. Lucanius Fla. F Sisc(ia) mil XIIII Gem post 100 Brigetio Pann Sup..........................III 11089

I. Mi-icius F Kar vet? (III Aug) 2 s? Castra Lambaesitana. . VIII 18087 Q. Sertorius L. f. Pob. F. 7 XI Cl p f Claud-Caracalla Verona ...... V 3374 Val(erius) F spec I et II Adi $p$ f Sever 228 A.D. Aquincum Pann Inf ................................. 3584

L. Valer(ius) F (spec VII Gem fel) Date? Tarraco............ 4 II 443 Vasidius F vet ex librario (III Aug) $270-275$ A.D. Lambaesis... . VIII 2626 L. Vetulenius Quirina Bul(la) F eq III Aug Date? Lambaesis. . VIII 3274 FIDELIS

L. Annius L. f. Qu(ir) F mil III Aug vind 2-3s? Sicca Veneria. . VIII 1642 Celerinius Fide(lis) civis Batavus mil (X) XX-Date? Lyons. XIII 1847 Valerius F 7 (III Aug) 1s? Theveste................. 1897:29 FIDUS

Iuli(us) Fi(dus?) vet (V Mac) c134 Troesmis............ III 6178

Petronius F 7 II Adi p f c71 Chester Eng...........E.E. IX 1055

Solemnius F mil imag I Min $2-3$ s Lyons................ XIII 1895

M. Valerius Ani. F F(oro) Iul(ii) mil X Gem ante Traian Aquincum

Pann Inf.......................... 10517

FILISCUS

C. Val(erius) F Nic(opoli) vet VII Cl 195 A.D. Viminacium Moes

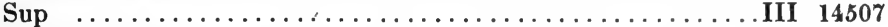

FINITIANUS

Tar(tonius) F Daiberi vet (XIIII Gem) post 100 Savaria Pann

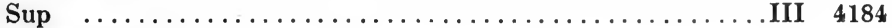
FIRMANUS

M. Alpinius F 7 I Min Date? Hersel Germ Inf ............ XIII 8150

L. Sempronius F spec VII Gem c200 Tarraco..............II 4122

L. Vettius M. f. Publilia Firma(n)u(s) Verona vet VI Vict $p$ ante Hadrian? Asberg .................... 8 III 8590 FIRMIANUS

C. Pompeius F Cas mil? (III Aug) Date? Castra Lambaesitana 


\section{FIRMIDIUS}

Aur(elius) Firmidiu(s) (vet? V Mac?) Date? Potaissa Dacia..III 7688 FIRMINIANUS

P. Ael(ius) F vet II Adiut Date? Ager Aquincensis Pann Inf.... III 3976 FIRMINUS

- Ael(ius) F bf cos XIIII Gem Date? Narona Dalmatia........III 8481 T. Aurel(ius) F 7 XXII Pr p f 178 A.D. Stockstadt........ XIII 6629 6644-5

C. Iulius F victimarius XXX Ulp vict Date? Col Agrippinensium XIII 8 89

P. Iul(ius) F bf cos 209-11 A.D. Varmezo Dacia............III 7646

T. Iullius F bf cos Date? Latobici Pann Sup................III 10787

P. Turran(ius) F vet ex corn II Adi Antonin 216 A.D. Aquincum

Pann Inf ................................. 8526

G. Urbanius $\mathbf{F}$ mil leg $\mathrm{X}$ ante 70 ? Tucci Baetica............ II 1691

C. Val(erius) Fir(m)inus vet VII Gem $p$ fs? Tritium Tarraconensis $\ldots \ldots \ldots \ldots \ldots \ldots \ldots \ldots \ldots \ldots \ldots \ldots \ldots \ldots \ldots \ldots$ II 2888

FIRMUS

Ael(ius) Firm(us) vet VII Cl 135 A.D. Viminacium Moes Sup...III 8110 Aestivius F(irm)us? vet leg XXII Date? Castellum Mattia-

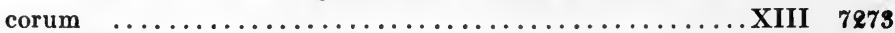

C. Appuleius C. f. Ani. F 7 IIII Scyth Date? Carsioli ........ IX 4058 Apulonius Fir(mus) 7 (I) Adiut Date? Kis-Igmand Pann Sup. III 11078 Aur(elius) F (vet) ex dup (V Mac?) Date? Potaissa Dacia.......III 7688 Aurel(ius) F (mil? III Aug) cel8? Castra Lambaesitana

Bull Archeol 1904 p\&06

M. Aur(elius) F Cas corn vet VII Cl 195 A.D. Viminacium Moes

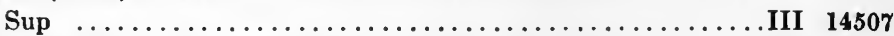

C. Calidius F 7 XV Apol ante 63 Carnuntum Pann Sup........III 15193

T. Cassius T. f. F 7 VIIII Hisp 1s? Aquileia..............V 906

Ti. Cl(audius) F prin (7) III Aug Date? Lambaesis.......... VIII 2841

M. Coccei(us) F 7 II Aug aet Antonini Pii Auchindavy Eng. . VII 1111-1114

L. Comagius F mil II Parth 3s? Milan............... 5884

Cornelius F 7 I Ital aet M. Aurel Gergina Moes Inf .......... III 7514

C. Cornelius C. f. Pol. F Castr vet II Tr fort 194 A.D. Alexandria

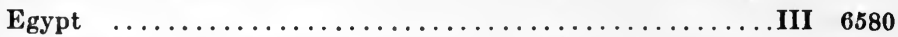

L. Cornelius L. f. F Teretina Arelate mil XV Apol 1s Carnun-

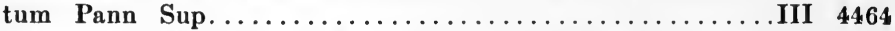

G. Crispinus G. f. Claudia F Aspendo vet I Ital Date? Cclei Dacia .............................. 14491

Crittius F 7 leg XXII ante Hadrian Alexandria Egypt.........III 6608

P. Durmius F mil III Aug 1s Theveste................. VIII 16548

P. D(urmius) $F$ (irmus) vet (III Aug) 1s Theveste.........VIII 16548

L. Faltonius F 7 XXI Rap 70-Hadr Mainz.............XIII 6950

F1(avius) F mil I Adiut post 114 Brigetio Pann Sup.......... III 11036

F1(avius) F vet II Adiut Date? Lussonium Pann Inf...........III 3321

T. Flavius T. f. Tromen. F. Salona p p III Aug 147 A.D. Castra

Lambaesitana .............................. 1898:11

M. Gavius F Vellin(a) Firmo Picen(o) p p II Ital 191 A.D.

Lauriacum Noricum..................III 15208 cf A.E. 1918:294 
C. Iulius F P. G(as) vet (III Aug) 211-2 A.D. Lambaesis... . . . . VIII 2618 C. Iulius F Cas vet? (III Aug) Date? Castra Lambaesitana.. VIII 18086 T. Iuli(us) Firm(us) ? leg XII- Date? Poetovio Pann Sup.. III 4058 M. Livius F vet (III Aug) Date? Lambaesis............. VIII 3179 Mettius F 7 XI Cl p f Vespas-Traian Vindonissa...........XIII 5216 L. Mettius F emeritus XXX Ulp vict Date? Lyons...........XIII 1873 Patius F 7 III Aug coh II 162 A.D. Castra Lambaesitana...... . VIII 18065 C. Petil(ius) F vet ex bf praef II Adi p f 2-3s Aquincum Pann Inf. III 3559 (P)ub(licius) Fir(mus) Veron(a) (mil) I Adiut 70-100 A.D.

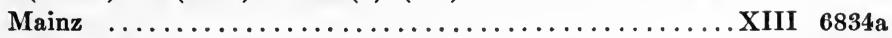

L. Purtisius F (7) hast (III Aug) Date? Lambaesis........... VIII 2640

L. Sertorius L f. Pob. F sig aquil XI Cl p f Claud-Caracalla Verona. . V 3375

C. Trebius C. (f.) F vet leg XI ante 42 Iader Dalmatia......... III 2918

Urbicius $F$ mil? X Gem Date? Vienna ................ III 4568

Valerius $\mathbf{F}$ vet $(\mathrm{V}$ Mac) $\mathbf{c 1 3 4}$ Troesmis................ III 6178

Val(erius) F mil XI Cl 155 A.D. Almus Moes Inf............ III 7449

C. Val(erius) F 7 I Ital 173 A.D. Troesmis..............III 6176

C. Valerius F mil III Aug Date? Lambaesis.............. VIII 3259

C. Vibius F mil bf V Mac 68 A.D. Emmaus Nicopoli Palestine. .III 14155:12 - F 7 (leg XXII aut III Cyr) aet Augusti Coptos Egypt..... III 6627

FLACGIANUS

T. Fl(avius) F optio (III Aug) 198-211 A.D. Castra Lambaesitana VIII 2554

FLACCUS

L. Aemilius F frum XX V v Date? Rome................ VI 3357

Marcus Aurelius Flac(cus) mil I Ital Date? Rome.... VI $2803=32578$

L. Caesius L. f. Anie. F Caesara Aug 7 IIII FI firm Date? Vim-

inacium Moes $\operatorname{Sup} \ldots \ldots \ldots \ldots \ldots \ldots \ldots \ldots \ldots \ldots \ldots$ III 14511

L. Cornelius F mil III Aug p v 3s? Lambaesis............. . VIII 3090

Iul(ius) F mil XI Cl 155 A.D. Almus Moes Inf . . . . . . . . . . III 7449

C. Sentius C. f. Sulp. F Antiq vet XIIII G m v Date? Apulum

Dacia ............................. III 1196

-ius F Sab(ratha) mil? (III Aug) Date? Castra Lam-

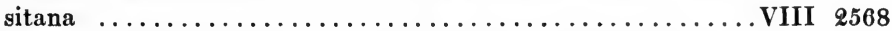

- F 7 (leg XXII aut III Cyr) aet Augusti Coptos Egypt...... III 6627 FLACUS

L. Aelius F sig II Aug Date? Aquae Flaviae Tarraconensis...... II 2480 FLAMINALIS

Cornelius Flam(ina)lis (eq? III Aug) 222-35 A.D. Castra Lambaesitana......................... 1897 p447

Geminius F dup III Aug p v Antonin 218 A.D. Castra Lambaesitana ................................... 2564

(I) ul(ius) $\mathbf{F}$ bf III Aug Date? Calama............... VIII 5411

T. Papius Fl(a)min(alis)? Nicom(edia) vet? (III Aug) aet

Hadriani Castra Lambaesitana.................. VIII 18084

FLAUS

P. Valerius F mil VII Gem fel Date? Augusta Emerita.......... II 5266 


\section{FLAVIANUS}

C. Annius F vet ex leg XXX Date? Lyons.............. XIII 1831 Antonius F vet ex lib leg III Aug 270-275 A.D. Lambaesis...... VIII 2626 Aurelius F 7 II $\operatorname{Tr}$ fort 194 A.D. Alexandria Egypt..........III 6580 Aur(elius) F (vet) ex imm (V Mac?) Date? Potaissa Dacia....... III 7688 Aur(elius) F ? (III Aug) 253-268 A.D. Castra Lambaesitana..... VIII 18061 Cassius Flav(ianus) 7 XV Apol 1s Carnuntum Pann Sup......... III 4456 Cor(nelius) Flavia(nus) vet VII Cl 135 A.D. Viminacium Moes Sup III 8110 Fl(avius) F Tro. Flavini f. mil X Gem Date? Wiener Neustadt

Pann Sup............................... 15196

C. Iulius $F$ corn leg leg XXII Pr $p f$ post 89 Mainz....... XIII 6962 Stenius $F$ vet ex lib leg (III Aug) $270-275$ A.D. Lambaesis....VIII 2626 FLAVINUS

Ael(ius) $\mathrm{F}$ mil XI Cl 155 A.D. Almus Moes Inf........... III 7449 L. Anteius F bf cos civi Asturic VII Gem p f Date? Tarraco....II 4144 Aurelius F optio XI Cl 3s exe-4s init Aquileia............. 895 T. Cassius F 7 X Gem ante 70? Tarraco................ 4151

C. Comat(ius) F imm caerei XIIII Gem Antonin 213 aut 228

A.D. Carnuntum Pann Sup.................III 14358:2

C. Dellius M. f. Pom. F vet VII Gem fel Date? Lara Tarraconensis................................... $\quad \mathbf{8 8 5 \boldsymbol { Z }}$

Iulius F comm VII Gem fel Date? Tarraco..............II 4156 L. Sempronius F mil leg VIIII aet Claudii? Lincoln Eng....VII 184 M. Ulpius M. f. F opt sig XIII Gem post Traian Apulum Dacia... III 1202 Val(erius) F 7 (leg ?) Date? Cambriae oppida Eng. VII 153 add E.E. VII 862 $\Phi \Lambda A O Y I O \Sigma$

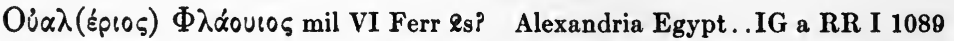
FLAVOS

Q. Iulius F (7) I Min $p$ f Date? Col Agrippinensium......XIII 8172 FLAVUS

M. Aur(elius) F mil dup (II Adiut?) 2-3s? Aquincum Pann Inf ................................... 10505

Cornelius - F 7 XIIII Gem post 100 Aquincum Pann Inf....III 8547

Geminius F 7 XI Cl p f 4q-Vespas Burnum Dalmatia........III 14998

C. Iulius Flav(us) bf cos Date? Siscia Pann Sup..........III 3949 Valerius F p p (VII Gem fel) Date? Carthage............VIII 12590 Valeri(us) F 7 (II Aug?) coh II Date? Isca Eng..........VII 110 C. Valerius (Fla)vus mil VII (Gem) Date? Tritium Tarraconensis...................................II $\quad 8889$

M. Valerius F bf VII Gem ex arm cust Date? Tarraco........II 4168 FLORENTINUS

Aurel(ius) Florentin(us) vet ex actar evocatus (III Aug) 270275 A.D. Lambaesis........................ VIII 2828

M. Aurel(ius) F bf cos Date? Aquincum Pann Inf..........III 3535 Cerel(lius) Floren(tinus) mil? III Aug) c218? Castra Lambaesitana ......................... Bull Archeol 1904 p206

C. Cornelius F 7 III Aug Date? Lambaesis............. VIII 2851-\& 
Fann(ius) F mil XIIII Gem post 100 Poetovio Pann Sup......III 14065

G. Iulius F spec VII Gem c 200 Tarraco................ II 4122

L. Publicius Florentin(us) Lamb spec III Aug c225 Lambaesis. . VIII 2586 (F1)orent(inus) (7 XXII Pr p f) 204 A.D. Mainz....... XIII 6801 FLORIANUS

Ael(ius) F vet? (II Adiut) 2-3s? Ager Aquincensis Pann Inf...III 10360 Ant(onius) F optio I Ital Date? Carsium Moes Inf ......... III 14214:19 Aur(elius) F vet ex bf $\cos 240$ A.D. Aquincum Pann Inf.......III 3474 M. Aur(elius) Cocceius F p p X Gem Sever c225 Vienna . . . . . III 14359:26 Iul(ius) F 7 IIII Fl Date? Singidunum Moes Sup..........III 8156 Flor(i)anus mil X (X V v) Date? Chester Eng....E.E. IX 1067 FLORINUS

L. Cass(ius) F vet ex arm cust XIIII Gem aet Maximini Carnuntum $\operatorname{Pann} \operatorname{Sup} \ldots \ldots \ldots \ldots \ldots \ldots \ldots \ldots \ldots \ldots \ldots \ldots \ldots \ldots \ldots$ III 11189

Cornelius Florin(us) frum $X$ Gem Date? Ephesus..........III 433 - F vet XI Cl 42-Vespas Novae Dalmatia............II 1915 F 7 (leg ?) Date? Proclitia Eng................VII 630 FLORIUS

F 7 (leg ?) Date? Borcovicium Eng...........VII 678 FLORUS

Aelius F ? (III Aug) 253-268 A.D. Castra Lambaesitana....VIII 18061 Aemilius F bf III Aug Gallienae 253-268 A.D. Lambaesis.... VIII 2797 Ant(onius) F bf cos (I Ital?) Date? Carsium Moes Inf....III 14214:19 Aurel(ius) F spec legg III Antonin ( $=$ X Gem XIV Gem I Ad) c212 Carnuntum Pann Sup..................III 4452

Sex. Careius Sex. f. Vol. F Foro Aug mil XXII Prim Date? Mainz .................................. XIII 6958

Q. Cornelius F Thev(este) tess (III Aug) Date? Castra Lambaesitana............................... 2568

Q. Cornelius F tess III Aug Date? Lambaesis............ VIII 2853

T. Flavius F domo Philippopoli ex prov Tracia vet ex bf proc

I Min $\mathrm{p} f \mathrm{2}-3 \mathrm{~s}$ Lyons......................... XIII 1856

T. Flavius F cor III Aug p v 209-211 A.D. Castra Lambaesitana. . VIII 2557 Fufius F ? (III Aug) Date? Castra Lambaesitana........... VIII 2562 Q. Iulius F optio (III Aug) 198-211 A.D. Castra Lambaesitana. VIII 2554 Messorius $\mathbf{F}$ vet $\mathrm{I}$ Min $\mathrm{p} f$ s $\mathrm{Lyons} . \ldots \ldots \ldots \ldots \ldots \ldots$ XIII 1849 Niusstius F 7 XXII Pr p f 3s? Cartenna Mauretania Caesariensis..................................... 9656 lius F ? III Aug Date? El-Gehara................. VIII 18025 F 7 (II Aug?) coh I Date? Segedunum Eng......... VII 488 FOCION

M. Aurelius Pol. F Alexan(drea) vet II Tr fort 194 A.D. Alexandria Egypt...................... FORTIS

Ael(ius) F 7 III Ital 181 A.D. Inter Danuvium et limitem Raetia. III 14370:8 Aurelius F (eq? III Aug) 222-35 A.D. Castra Lambaesitana. MAH 1897 p447 C. Caelius F Cas p dup (III Aug) Date? Castra Lambaesitana. . VIII 2568 
Iulius F mil III Aug Date? Lambaesis................ VIII 3148

C. Iul(ius) F mil I Adi p f post 114 Ager ad Colapim Pann Sup...III 14047

T. Statius F mil III Aug Date? Lambaesis.............. VIII 3246

Valerius For(tis?) vet ex imm (III Aug) 211-2 A.D. Lambaesis.. VIII 2618

FORTUNATIANUS

P. Baebius Fortunatian(u)s Kar bf (III Aug) Date? Castra

Lambaesitana............................... VIII 2568

L. M(a)gnius F (Q)uirina Caralis mil III Aug Date? Lambaesis................................. VIII 3185

FORTUNATUS

Q. Aedinius F mil III Aug Date? Lambaesis.............. VIII 301غ

C. Aelius Fortunatu(s) Cirt(a) vet III Aug p v c198 Castra

Lambaesitana.............................. VIII 18068

P. Ael(ius) Fort(unatus aut -is?) sig VII Cl 185 A.D.

Viminacium Moes Sup.......................III 8110

Alveius Fortunat(us) sig III Aug Date? Castra Lambaesitana. VIII 18073

C. Antonius C. fil. F domo Lamigo vet (III Aug?) Date?

Seriana................................ VIII $\mathbf{4 3 7 6}$

M. Antonius Fortunatus vet (III Aug) Date? Lambaesis....VIII 3034

Arellius F dup III Aug p v Antonin 218 A.D. Castra Lambaesi-

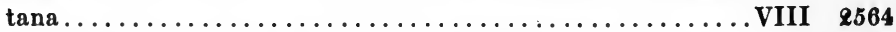

Q. Aurelius F mil (III Aug) Date? Lambaesis............. VIII 18289

Caelius Fortunat(us) arm cust (III Aug) 200 A.D. Castra Lam-

baesitana.............................. 1908:10

C. Caelius Fort(unatus) vet III Aug 166 A.D. Castra Lambaesitana............................. VIII 18067

Calabius F tub III Aug p v Antonin 218 A.D. Castra Lambaesi-

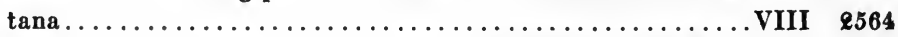

Calp(urnius) F vet ex actario (III Aug) 870-875 A.D. Lambaesis.................................... VIII 2626

Canidius F bf III Aug Date? Lambaesis................. VIII 2887

L. Carinius F vet (III Aug) Date? Lambaesis............. VIII 2883

L. Cassius For(tunatus) tub III Aug p v 202 A.D. Castra

Lambaesitana............................ 1907:184

L. Clodius F arm cust III Aug Date? Lambaesis......... VIII 2844

Cornificius F mensor III Aug Date? Lambaesis......VIII 2856-7 et 18150

Q. Crepereius F eq (III Aug) Date? Lambaesis............VIII 3095

8 (Eg)nat(ius) F optio (III Aug) 198-811 A.D. Castra Lambaesitana................................ VIII $\mathbf{8 5 5 4}$

T. Flavius F Hadr(umeto) bf $\cos$ III Aug c225 Lambaesis..VIII 2586

? (F)onteius Fortunat(us)? (III Aug) Date? Castra Lambaesitana................................... $e 56 \boldsymbol{E}$

Gellius F dup III Aug p v Antonin 218 A.D. Castra Lambaesitana.................................. 2564

T. Gemmius F Cas mil? (III Aug) Date? Castra Lambaesi-

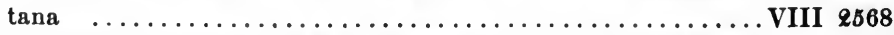

C. Homullius Fortunat(us) K(arthagine) mil? (III Aug) Date? 
Castra Lambaesitana.......................... VIII 2567 Iulius F vet ex librario (III Aug) $270-275$ A.D. Lambaesis . . . . . . VIII 2620 Iulius F mensor (III Aug) 3s? Castra Lambaesitana............ 1904:72 Iulius F vet (III Aug) Date? Lambaesis............... VIII 3149 Iul(ius) F bf cos Date? Summus Poeninus................. 1894:151 C. Iulius F Kar vet? (III Aug) \&s? Castra Lambaesitana..... VIII 18087 C. Iulius F mil III Aug p v 3s? Lambaesis.............. VIII 3150 C. Iulius F arm cust (III Aug) Date? Lambaesis............. VIII 2908 Q. Iulius Q. f. Pol. F Cas mil III Aug Date? Lambaesis........ VIII 3151 T. Iulius F 7 II Adi $p$ f $\&$-3s? Aquincum Pann Inf. .......... III 3578 Iunius F (eq? III Aug) 222-35 A.D. Castra Lambaesitana. MAH 1897 p447 M. Laberius Fortun(a)tus mil II Tr Date? Alexandria Egypt... III 6605 Lurius F vet ex librario (III Aug) $270-275$ A.D.Lambaesis........ VIII 2626 L. (M)agnius (Fo)rtunatus vet III Aug Date? Djerma........ VIII 4374 L. Mallius F vet (III Aug) Date? Lambaesis.............. VIII 3187 Manilius F bf praef (III Aug) Date? Lambaesis............. VIII 2937 L. Marius F mil IIII Fl firm Date? Salonae Dalmatia.......... III 2021 Minucius Fortun(atus) arm cust III Aug c225 Castra Lambae-

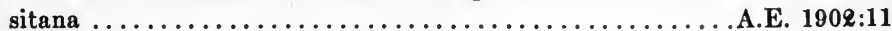

M. Modius (Fortunatus) Cas vet? (III Aug) Date? Castra

Lambaesitana...........................VIII 18086

L. Mundicius F mil III Aug Date? Lambaesis.............. VIII 3201

C. Mustius C. f. Aurelia F Lam(ba)es vet ex sig (III Aug) Date?

Lambaesitana ............................. VIII $\$ 2949$

C. Mustius For(t)unatus vet (III Aug) Date? Lambaesis..... VIII 3204

L. Papius F 7 XXI Rap 70-Hadr Brohl . . . . . . . . . . . . . . XIII 7714

M. Petronius F 7 XXII Prim 7 II Aug c215 Cillium Byzacena.... . VIII 217

Sertor(ius) F 7 III Cyr Antonin c215 Lyons. . . . . . . . . . . . . . XIII 1893

T. Silicius F Cas sig III Aug 166 A.D. Castra Lambaesitana ... . VIII 18067

(T)uccius Fortun(atus) tub III Aug p v 202 A.D. Castra Lam-

baesitana ............................ 1907:184

Valentinius F mil I Min? Date? Lucus Augusti Gall Narb..... XII 1576

L. Valerius F mil (III Aug) Date? Lambaesis............. VIII 3262

M. Valerius F eq legionarius (III Aug) Date? Lambaesis....... VIII 3260

L. Vereius F 7 VI Vict post Hadrian Amboglanna Eng. . . . . . . . . VII 839

L. Vidius $\operatorname{For}(t u) n($ atus) mil V Alaudae ante 87 Tergeste........V 547

Q. - ius F Had(rumeto) vet? (III Aug) 2 s? Castra Lam-

baesitana ................................. VIII 18087

-ius Fortunat(us) tub III Aug p v 202 A.D. Castra Lam-

baesitana .............................. 1907:184

- F mil III Aug Date? Lambaesis................ VIII 3230

(— Fort)unatus Kar vet? (III Aug) aet Hadriani Castra

Lambaesitana ............................. VIII 18084

FRATERNUS

Flavius F mil VII Gem fel Date? Carthage............ VIII 12590

FRONTINIANUS

M. Aur(elius) F mil II Adiut 213 aut $2 \ell \ell$ A.D. Matrica Pann Inf III 3383-4 


\section{FRONTINUS}

M. Firminius Frontin(us) frum VIII Aug Date? Velitrae......X 6575

S. Matucenius F vet ex opt XXII Pr p f post 89 Inter Ucetiam

et Namausum........................... 3035

(Fr)ontin(us) Sc(upis) vet VII Cl 195 A.D. Viminacium

Moes $\operatorname{Sup} \ldots \ldots \ldots \ldots \ldots \ldots \ldots \ldots \ldots \ldots \ldots \ldots \ldots \ldots \ldots \ldots$ III 14507

FRONTO

P. Ael(ius) F vet ex bf $\cos$ Date? Apulum Dacia.............III 1091

Aemilius F 7 VIII Aug Date? Rome.................. VI $\mathbf{3 6 4 0}$

C. Antonius F vet ex bf $\cos$ XIII Gem Date? Tomi Moes Inf ... III 7545 Aquilius Fro(nto?) 7 XI Cl p f 4\&-Vespas Burnum Dalmatia.. III 15005:1 A ur(elius) F tub IIII Fl Date? Aquincum Pann Inf . . . . . . . . . III 10518 M. Aur(elius) F mil II Adiut 213 aut 222 A.D. Matrica Pann Inf III 3383-4 _ Calvius T. f. ol. F ? leg I 1s? Bonn ................ XIII 8045

L. Cornelius F vet ex imag I Ital Date? Sisto v Moes Inf III 756 add p993 p1338

L. Gerellanus Sex. f. Fab. F p p X Fr prae castr XII Fulm aet

Neronis? Heliopolis Syria....................III 14387 g.h.

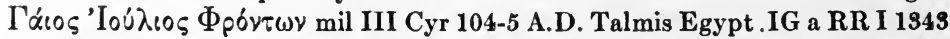

C. Iulius F optio (III Aug) 198-211 A.D. Castra Lambaesitana. . VIII 2554

C. Iulius F dup III Aug p v Antonin 218 A.D. Castra Lambaesitana VIII 2564

M. Iulius F Cas mil? (III Aug) Date? Castra Lambaesitana.. VIII 2569

M. Liburnius F 7 II Aug aet Hadriani Condercum Eng. . . . . . . VII 506

L. Murrius Fro. F vet ex leg II Adiut c150. Hr-Bou-Allouch A.E. 1899:39

Cn. Numerius Cn. f. Vol. F vet eq VIII Aug Date? Altinum .... . . V 2162

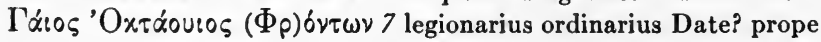

Hieropolim Castabalam Cilicia...............IG a RR III 913

C. Tarquitius F Cas mil? (III Aug) Date? Castra Lambaesitana ................................... 2569

T. Terentius T. f. Menenia F imag XV Apol 1s Carnuntum

Pann Sup............................. 14358:22

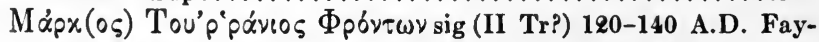

oum Egypt.................................. 600

Ulp(ius) F 7? XIII Gem post Traian Deva Dacia ............III 1629:24

Val(erius) Fron(to) 7 I Adiut 70-100 A.D Mainz............ XIII 6739

Val(erius) $\mathbf{F}$ vet $(\mathrm{V}$ Mac) c134 Troesmis.................. III 6178

Valeri(us) Fron(to) vet (V Mac) c134 Troesmis.............III 6178

Val(erius) F mil XI Cl 155 A.D. Almus Moes Inf .............. III 7449

L. Val(erius) F mil in leg XXX Date? Rome..............VI 3636

Q. Valerius Q. f. Cla. Fro(n) to Celea mil II Adi p f c71 Chester

Eng ............................E. IX 1058

Sex. Valer(i)us F aquil XV (Apol) 1s Carnuntum Pann Sup.......III 11238

L. Veirius L. f. Qui. F vet XII Fulm Date? Patrae Achaia........ III 7261

C. Vibius C. f. Fab. F domo Brixia vet V Mac 1s Oescus Moes Inf III 12348

s F Sid(onia) vet? (III Aug) aet Hadriani Castra Lambae-

sitana............................... VIII 18084

- (F)ronto vet (V Mac) Date? Troesmis.............III 6179 


\section{FRONTONIANUS}

C. Iul(ius) F vet ex bf $\cos$ V Mac M. Aurel-274 A.D. Apulum Dacia. . III 987 FRUCTUOSUS

Q. Iulius F Kart bf $\cos$ III Aug ceq5 Lambaesis............. VIII 2586 FRUCTUS

C. Cerellius F Cast corn III Aug p v c198 Castra Lambaesitana. . VIII 18068 (A) Didius F bf lat (III Aug) Date? Lambaesis............ VIII 2861- $\ell$ Flavius F frum (XXX Ulp?) Date? Rome ................ 3962 Cn. Pompeius F bf cos Date? Tarraco....................II 4164 C- F Tham(ugadi) vet? (III Aug) \&s? Castra Lambaesitana ................................. VIII 18087

FRUENDUS

T. Flavius F frum VIII Aug Date? Rome ................ VI 3351

M. Superinius F emeritus I Min Date? Arelate............ XII 687 FRUGI

M. Castricius F exactus III Aug p v c£0£ Castra Lambaesitana A.E. 1898:109 FRUNITUS

Aur(elius) (F)runitus vet II Parth Sever c225 Rome .......... VI 3398 FUNDANIUS

Iul(ius) F arm cust (III Aug) 200 A.D. Castra Lambaesitana..A.E. 1908:10 FURENNIANUS

Aetrilius F 7 III Aug coh VII 162 A.D. Castra Lambaesitana ... . . VIII 18065 FUSCIANUS

Aemilius F imm III Aug p v Antonin 218 A.D. Castra Lambaesitana .................................... 2564

Domitius F 7 III Aug coh IX 16\& A.D. Castra Lambaesitana . . . . VIII 18065

Marius F 7 II Tr fort 194 A.D. Alexandria Egypt............III 6580

T. Sat(riu)s Fus(c)ianus p p III Cyr Date? Bostra Arabia....... III 97 FUSGINUS

P. Ael(ius) F mil bf cos I Adiut 194 A.D. Plevlje Dalmatia ........ . III 13847 Cass(ius) F spec I et II Adi p f Sever 228 A.D. Aquincum Pann Inf. . III 3524 Iulius F vet I Adiut post 114 Brigetio Pann Sup............. III 11008 M. Iulius F optio (III Aug) 198-211 A.D. Castra Lambaesitana.. VIII 2554 FUSCUS

(A)emilius F dup III Aug p v Antonin 218 A.D. Castra Lambaesitana ................................. VIII $\$ 564$

M. Aemilius M. f. Cla. F Sava(ria) mil I Adiut 70-100 A.D. Mainz XIII 6825 Caesellius F 7 XXII Deiot ante Hadrian Alexandria Egypt...... III 6598

P. Caivilius? F tub (III Aug) \&s? Castra Lambaesitana ........ VIII 18087

P. Calvidius F vet (III Aug) Date? Lambaesis............. VIII 3078

C. Cerficius F (mil III Cyr aut XXII Deiot) 90 A.D. Fayoum

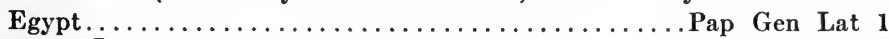

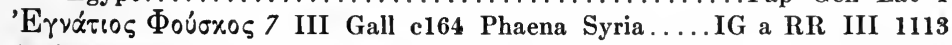
(Eg)rilius F Kar? (III Aug) Date? Castra Lambaesitana....... VIII 2565 L. Fadienus L. f. Pomp. F dom Dert(ona) vet spec (XIIII Gem?)

Date? Iader Dalmatia.........................III 8915 
Felic(ius) F (mil?) leg XXX Date? Bonn .............. XIII 8053 Q. Horatlus F vet (III Aug) Date? Lambaesis............. VIII 3204 Iulius F mil I Adiut post 114 Arrabona Pann Sup............III 4375 C. Iun(ius?) Fuscu(s) vet (III Aug) 1s? Thamugadi Numidia

Bull Archeol 1911 p184

L. Laelius F 7 CCC VII Cl p f Date? Rome ............... 1899:143 Maevius F dup III Aug p v Antonin 218 A.D. Castra Lambaesitana VIII 2564 Manilius F vet (III Aug) Date? Lambaesis.............. VIII 3189 M. Plotius M. f. Pol. F vet X Fr 94 A.D. Alexandria Egypt A.E. 1910:75 T. Riburrinius Gal. F Lugo mil VII Gem Date? Lambaesis.... VIII 3226 L. Terentiu(s C)1. F (A)pro mil II Adi p f c71 Chester Eng. . E.E. IX 1050 C. Umbrius F mil III Cyr ante 108 Ptolemais Hermiu Egypt... . . . III 12071 Velius F 7 XI Cl p f Vespas-Traian Vindonissa.............. XIII 5807 (Fu)scus The(veste) mil? (III Aug) aet Antonini Pii

Castra Lambaesitana............................ VIII 18085

GAETULICUS

Lucius Maximius G 7 XX V v Date? Greatchesters Eng. E.E. IX 1198

L. Maximius G 7 (XX V v) Date? Newstead Eng........E.E. IX 1233 GAIANUS

Aur(elius) G (vet? V Mac?) Date? Potaissa Dacia........ III 7688 Aur(elius) $G$ vet I Adiut Date? Intercisa Pann Inf..........III 10317 Clodius G Epipa vet? (III Aug) aet Hadriani Castra Lambaesi$\tan a \ldots \ldots \ldots \ldots \ldots \ldots \ldots \ldots \ldots \ldots \ldots \ldots$. . . . . . . . 18084

Iulius $\mathbf{G}$ dup III Aug $\mathrm{p}$ v Antonin 218 A.D. Castra Lambaesi-

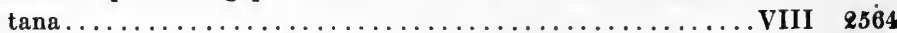

Varius Quintius G 7 XX V v ex trecenario Date? Rome....VI 33033 GAINAS

Aurelius Gain(as) 7 III Aug Sever c225 Lambaesis.........VIII 2753 GAIUS

Aur(elius) G evoc (III Aug) Date? Lambaesis............. VIII 2636

Aur(elius) G mil leg VII str cos Date? Naissus Moes Sup....III 1674 GALBA

G. Iulius G. f. Gorn G hast XXII Prim 164 A.D. Mustis...... VIII 15576

(? Li) $\operatorname{cin}(\mathbf{i}) \mathbf{u}(\mathbf{s}) \mathbf{G}$ mil bf $\cos$ I Adiut post 114 ad Privilicam fontem Dalmatia.............................III 15066

— G 7 (leg XXII aut III Cyr) aet Augusti Coptos Egypt....III 6627 GALICANUS

(Ae)I(ius)? Galica(nus) vet ex bf cos Date? Apulum Dacia..III 7736 GALLICANUS

Sollius G mil I Adiut optio (arm) cust 1s Mainz.......... XIII 6739 GALLICUS

L. Claudius G eq III Aug Date? Lambaesis..............VIII 308\&-3

L. Rufius G mil (III Aug) Date? Lambaesis............. VIII 3287 GAILLNIUS

L. Aemilius G Thel(epte) mil? (III Aug) Date? Castra Lambaesitana............................... VIII $256 \boldsymbol{g}$ 


\section{GALLUS}

C. Aninius C. f. Pom. G domo Arretio 7 III Scyth Date?

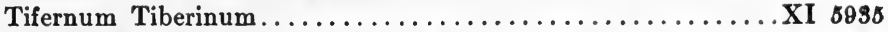

G. Iulius G Emeritesis vet VII Gem fel Date? Elvas Lusi-

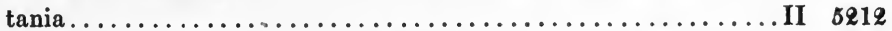

C. Iulius G Cir(ta) mil? (III Aug) Date? Castra Lambaesitana.......................................... 2568

Iuventius $G$ dup III Aug $p$ v Antonin 218 A.D. Castra Lambaesitana................................ VIII 2564

\section{GARGILIANUS}

M. Iulius $\mathbf{G}$ vet (III Aug) Date? Lambaesis.............VIII 3152 GARRULUS

Ti(b)erius Babuleius G Tib(e)ri (f) Ofent Medioleanio mil leg II 1s Argentorate.................... XIII 5976 GAULUS

(Ti)b. (C)laud(i)us Gau(1)us sig I Min 161 A.D. Iversheim Germ Inf.............................. XIII 7947 GEDUS

- Clodius G mil III Aug Date? Lambaesis.............. VIII 3084 GELLIUS

Dassiu(s) Gelli(us) (7 ? I Min) aet Getae Bonn..........XIII 8050 GEMELLIANUS

T. Tor(ius) G quondam (d)oc(tor?) fabrum II Adiut \&-3s? Aquincum Pann Inf....................... 10516 GEMELLINUS

Iul(ius) G 7 II Tr fort Date? Iconium................ 1912:871

C. Iulius C. f. Pol. G Castris vet II Tr fort 194 A.D. Alexandria Egypt........................... 6580

M. Ulp(ius) Gemellin(us) $\mathrm{Z}$ (armizegetusa ? ) sig vet VII Cl 195 A.D. Viminacium Moes $\operatorname{Sup} \ldots \ldots \ldots \ldots \ldots \ldots \ldots \ldots$ III 14507

\section{GEMELLUS}

M. Antonius Gemell(us) vet ex corn (II Tr fort?) 140 A.D.

Fayoum Egypt............................ 610 Kupevád Prentice Gr \& Lat Insc 380-1

C. Iulius G Cas mil? (III Aug) Date? Castra Lambaesitana.. VIII 2568 Iul(ius) Geme(llus) vet (V Mac) Date? Troesmis..........III 6180

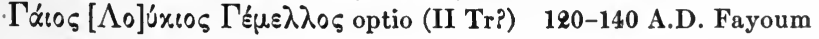

Egypt ............................. 600

P. Magnius G Thusd(ro) vet III Aug p v c198 Castra Lambaesi-

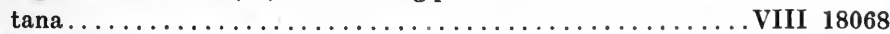

I. Marcius G quaest III Aug c225 Lambaesis............. VIII 2586

- (Mari)us G vet (III Aug) Date? Verecunda............VIII 4243 M. Numisius G Cast vet III Aug p v c198 Castra Lambaesitana . . VIII 18068 M. Pontius $G$ vet ex bf proc I Min p f 3s? Lyons..........XIII 1880 


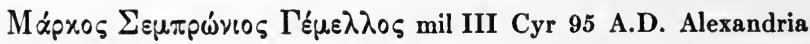
Egypt ................................ Bap Brit II 142 L. Servilius G A(mmaedara)? (III Aug) Date? Castra Lambaesitana................................. 2565

M. Terentius G Cirt(a) vet III Aug p v c198 Castra Lambaesitana.................................. VIII 18068 Geme(llus) vet (V Mac) Date? Troesmis...........III 6179

\section{GEMELUS}

M. Numisius G vet (III Aug?) Date? Zarai............ VIII 4529

\section{GEMINIANUS}

T. Aur(elius) G vet XIII Gem Antonin 211-222 A.D. Ad Mediam

Dacia...................................III 1569

C. Cutelius G Cas mil? (III Aug) Date? Castra Lambaesi-

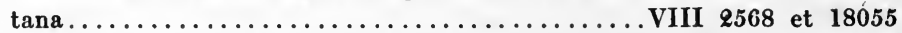

Geminius G ? (III Aug) Date? Castra Lambaesitana......VIII 2570 GEMINUS

Aem(ilius) Gem(inus?) vet (V Mac) c134 Troesmis........III 6178

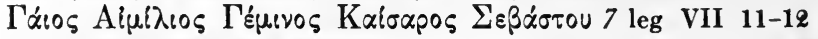

A.D. Gjoelde Asia Minor ......................E. 1911:143 Anton(ius) Gem(inus?) vet (V Mac) c134 Troesmis.........III 6178 Aurelius G 7 III Aug coh I 162 A.D. Castra Lambaesitana.... VIII 18065 C. Cassius L. f. G Ouf. Medio(lano) mil XV Prim 39-41 A.D.

Mainz...............................E. 1913:189

L. Flavius M. f. Quir Kalama mil III Aug ante Gordian Lam-

baesis................................. VIII 2639

Granius $G$ arm cust (III Aug) 200 A.D. Castra Lambaesitana . A.E. 1902:10 M. Maesius G Bononia p p I Ital 182 A.D. Moes Inf incerta...III 6223 S. Titius G 7 leg VII c4\& Corinium Dalmatia

III 9973 et Jahres Wien 1909 Beibl p31-2

Sex Vettius G vet ex sig (III Aug) Date? Lambaesis. VIII $2999=4248=18514$ D_ G vet (V Mac) c134 Troesmis..............III 6178 GENIALIS

Agrius Geniali(s) optio (III Aug) 198-Q11 A.D. Castra Lambaesitana............................... VIII 2554

C. Atilius Gen(ialis?) mil XIII Gem? I Adiut \&s init Novae Dalmatia................................III 1907

L. Bodlius L. f. Pol. G Pollent mil XI Cl pf 42-Vespas Burnum

Dalmatia................................ 1903:303

C. Sallustius G corn (III Aug) Date? Castra Lambaesitana..VIII 18086 Ulp(ius) $G$ mil leg X Date? Gugging ......Jahres Wien 1909 Beibl p210 Val(erius) $\mathbf{G}$ mil leg secund(a)e divitensium Italic(a)e sig Date?

Rome................................. VI $\mathbf{3 6 3 7}$ - $\mathbf{m}$ - G vet ex sig II Aug Date? Isca Eng.............. VII 119

\section{GENTILIS}

Aurelius G 7 III Aug coh II 162 A.D. Castra Lambaesitana.. VIII 18065 Aurelius G 7 III Aug Date? Lambaesis................VIII 2817 


\section{GERFENNUS}

Fla(vi)us G mil III Cyr ante 108 Egypt.............Wessely Lat Pal 8

\section{GERMANUS}

Al $\lambda \cos \Gamma \varepsilon p \mu \alpha \nu \delta ́ \varsigma$ p p (leg ?) Date? Gerasa Arabia..IG a RR III 1378 M. Antonius $G$ vet X Fr 94 A.D. Alexandria Egypt.........E. 1910:75 L. Attius G mil III Aug Date? Lambaesis...............VIII 3044 Aurel(ius) G mil XI Cl 155 A.D. Almus Moes Inf...........III 7449 Aur(elius) German(us) nat Dacus mil lectus ex (leg) XIII 3s Mainz.................................XIII 6824

M. Aurelius Pol. G vet II Tr fort 194 A.D. Alexandria Egypt....III 6580

M. Aur(elius) G Sc(upis) vet VII Cl 195 A.D. Viminacium Moes Sup.................................... 14507

M. Aur(elius) G d Emon(e) p p? XXII Pr p f -ianae 3s init Mainz.................................... XIII 6708

P. Calventius Q. f. G medicus (III Aug) Date? Lambaesis.... VIII 2834 Cassi(us) German(us) vet (V Mac) c134 Troesmis...........III 6178

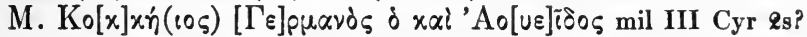

Soada Arabia.........................IG a RR III 1282

Domitius Germa(nus) mil III Cyr ante 108 Egypt.. Wessely Lat Pal 8 C. Domitius G vet III Aug p v 3s? Thubursicum........... VIII 4880 Titus Flavius $\mathbf{G}$ vet XXII Pr p $\mathbf{f}$ natione Batavus Date? Wiesbaden................................... 7577

(F1)avius Germ(anus) mil? (III Aug) c200 Castra Lambaesitana ............................... Archeol 1905 p239 Gelli(us) German(us) vet ex eq (V Mac) c134 Troesmis........III 6178 'Ioú $\lambda \cos \Gamma$ epuavò 7 III Gall 192 A.D. Aera Syria.....IG a RR III 1188 Iullus G ? (III Aug) 253-268 A.D. Castra Lambaesitana.... VIII 18061 Iulius G 7 VII Gem fel Date? Augusta Emerita............II 5266 Iul(ius) $G$ vet $(\mathrm{V}$ Mac) Date? Troesmis................III 6179 C. Iul(ius) G optio (III Aug) 198-211 A.D. Castra Lambaesitana .. VIII 2554 C. Iul(ius) G 7 III Cyr 170 A.D. Bostra Arabia.............III 96 M. Octavius G ? (III Aug) Date? Castra Lambaesitana...... VIII 2562 L. Sextilius G(e)rm(a)nus (mil III Cyr aut XXII Deiot) 90 A.D. Fayoum Egypt.................................... Gen Lat 1

C. Valerius G Tyr(o) (mil III Cyr aut XXII Deiot) 81 A.D.

Fayoum Egypt...................................... Gen Lat 1 P. Valerius G mil I Ital Date? Almus Moes Inf............. III 7441

T. Valerius T. f. Collina G Pessenunto imag VII Cl pf Date? Tomi Moes Inf............................III 12498 (Ger)manus Cas mil? (III Aug) aet Antonini Pii Castra

Lambaesitana.............................. VIII 18085 - (Ge)r(man)us sig I Min Date? Col Agrippinensium.... XIII 8281 GERULA

Aur(elius) G tess VII Cl Sever Alexand c£25 Carlovo Moesia.... A.E. 1912:53 GESSIUS

Tertinius $\mathbf{G}$ vet VIII Aug 3s? Lyons.................. 1897 


\section{GETA}

G bf (V Mac) Date? Troesmis

III 6179

\section{GETULICUS}

Q. Octavius G (? III Aug) Date? Lambaesis............VIII 2645 GLABRIO

M. Aurel(ius) G vet ex bf $\cos$ XIIII Gem post 100 Siscia Pann Sup . . III 3970 GLAUCUS

T. Ant(onius) G Murs(a) bf vet VII Cl 195 A.D. Viminacium Moes Sup...............................III 14507 GLAUS

C. Iulius G mil II Parth Antonin of $\mathrm{f}$ aetern c215 Rome........ VI 2579 GLICO

G 7 (leg?) Date? Westerwood Eng.. VII 1108 add E.E. IX p625 GODES

Aur(elius) G 7 ? XIII Gem post Traian Apulum Dacia......III 1689:15 GRACILIS

Aur(elius) G 7 X Gem 198-209 A.D. Arrabona Pann Sup..... A.E. 1908:46 (Gr)acilis Castr vet? (III Aug) aet Hadriani Castra

Lambaesitana...............................VIII 18084 GRAESIANUS

C. Terentius G Max(ula) vet? (III Aug) 2s? Castra Lambaesitana....................................VIII 18087

\section{GRATIANUS}

P. Cornel(ius) G (spec VII Gem fel) Date? Tarraco.........II 4143

L. Licinius G sig III Aug Date? Lambaesis............. VIII 2932 GRATINUS

L. Crescentinius $G$ bf leg? 218 A.D. Mainz........... XIII 6696

L. Pompeius G mil VIII Aug bf $\cos 179$ A.D. Iagsthausen.... XIII 6557 GRATUS

Ael(ius) G spec legg III Antonin ( $=$ X Gem XIV Gem I Ad) c212 Carnuntum Pann Sup......................II 4452

P. Bruttius P. f. Vel. G domo Aquileia p p XIIII - Date? Fundi................................. 6282

L. Carantius G bf cos Date? Neviodunum Pann Sup.......III 3912

Cartinius $G$ frum X Gem Date? Rome................. 3331 Iulius G arm cust III Aug c225 Castra Lambaesitana......A.E. 1902:16 L. Vectimarius L. f. Voltinia Reis G mil leg? Date? Salakta

GUDUDUS

Bull Archeol 1911 p ccxxi

Cossutius G mensor (III Aug) 3s? Castra Lambaesitana....A.E. 1904:72 GUDULLUS

C. Iulius G Cast vet III Aug p v c198 Castra Lambaesitana.... VIII 18068

Valerius G cor III Aug p v 203 A.D. Castra Lambaesitana...... VIII 2557 GUMASIUS

Cor(nelius) G arm cust III Aug c225 Castra Lambaesitana..A.E. 1902:11 


\section{GUSORIUS}

- Gusor(ius) 7 XI Cl p f Vespas-Traian Vindonissa......XIII 5215 GUZABIUS

Iulius G mensor (III Aug) 3s? Castra Lambaesitana.........E. 1904:72 HADRIAS

C. Iulius H The(veste) sig (III Aug) Date? Castra Lambaesi-tana.................................... $\$ 566$

\section{HANIOGHUS}

C. Maenius $\mathrm{H}$ domo Corinthi $7 \mathrm{XI} \mathrm{Cl} \mathrm{p}$ f et I Ital et II $\mathrm{Tr}$ fort 187 A.D. Thebes Egypt...................... III $4 \&$ HEBENUS

M. Antonius H Kar imm (III Aug) \&s? Castra Lambaesitana.. VIII 18087 Iulius H pol III Aug p v Antonin 218 A.D. Castra Lambaesitana.. VIII 2564 HELENUS

Aurel(ius) $\mathrm{H}$ mil XI Cl 155 A.D. Almus Moes Inf..........III 7449 HELIODORUS

M. Aur(elius) Heliodor(us) vet VII Cl Date? Viminacium Moes Sup................................. 14510

Flavius Helio(dorus) 7 ? XIII Gem post Traian Apulum Dacia...III 1689:80

L. P. Valerius H ? II Adiut $2-3 \mathrm{~s}$ ? Aquincum Pann Inf........ III 3568 HELLENIUS

Helleni(us) 7 (leg ?) Date? prope Procolitiam Eng.. E.E. III 199 HELVINUS

M. Titius $\mathbf{H}$ vet VI Vict ante Hadrian Lyons ............. XIII 1899 HERACLA

Fla(vius) (H)eracl(a) mil XI Cl 155 A.D. Almus Moes Inf......III 7449 HERACLES

M. Aur(elius) H Her(aclis f) natione Trax dup I Min Sever c825 Bonn............................... XIII 8067 HERACLIDA

Ael(ius) $\mathrm{H}$ bf $\cos$ Date? Stockstadt.................. XIII 6632 HERACLIUS

M. Aur(elius) H hast VII Cl Date? Intercisa Pann Inf....A.E. 1906:113 HERCULANUS

T. Ael(ius) Hercu(lanus) vet VII Cl 195 A.D. Viminacium Moes $\operatorname{Sup} \ldots \ldots \ldots \ldots \ldots \ldots \ldots \ldots \ldots \ldots \ldots \ldots \ldots \ldots \ldots \ldots \ldots$ III 14507 Aurelius $H$ aeques II Aug (?) Date? Isca Eng.............. VII 118

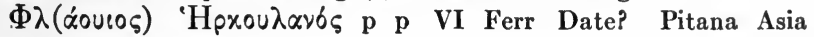
IG a RR IV 266

T. Flavius T. f. Ulpia H Retiaria 7 III Aug $\mathrm{p}$ v Antonin c\&15

Lambaesis.................................. VIII 8871 Iul(ius) $\mathrm{H}$ bf cos I Ital Date? Ljubuski Dalmatia...........III 14631 C. Iulius $\mathrm{H}$ vet VII $\mathrm{Cl}$ p f Date? Naissus Moes Sup...........III 14577 Pompon(ius H)erculanus (vet) ex eq XI Cl 155 A.D. Almus 
C. Pyrr- Herculan(us) vet VII Cl 195 A.D. Viminacium Moes Sup..............................III 14507 HERENIANUS

Iul(ius) Herenian(u)s arm cust III Aug c225 Castra Lambaesitana.................................. 1908:11

HERENNIANUS

Horatius H (mil) II Tr fort 148 A.D. Arsinoe Egypt .........E.E. VII p459 - H 7 (leg ?) Date? Condercum Eng............VII 529 HERMES

Pontius H 7 (leg ?) Date? Carthage................ VIII 12580 HERMIANUS

C. Lucceius H Kast vet? (III Aug) aet Hadriani Castra Lambaesitana................................ VIII 18084 HERMIAS

P. Aelius P. f. Pol. H Castris vet II Tr fort 194 A.D. Alexandria

Egypt................................ $\mathbf{6 5 8 0}$

P. Aeli(us) H aquil III Aug Date? Lambaesis............. VIII 2782

P. Aelius $\mathbf{H}$ mil III Aug Date? Lambaesis................VIII 3014 Aur(elius) $\mathbf{H}$ bf leg (III Aug) Date? Lambaesis............ VIII 2883 HERODES

M. Aurelius M. f. Pol. H Castris vet II Tr fort 194 A.D. Alexandria Egypt............................ $\mathbf{6 5 8 0}$ $\mathrm{HP} \Omega \mathrm{N}$

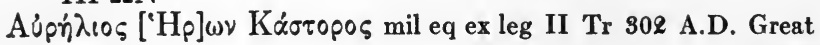
Oasis .......................................... Pap II 74

HIBERNUS

Magissius H arm cust XXII Pr p f post 89 Altenstadt Germ Sup. . XIII 6078 HIDDIBAL

M. Aemilius H Cast vet III Aug p v c198 Castra Lambaesitana.. VIII 18068 HILARIANUS

C. Aquilius H Cas d s (III Aug) Date? Castra Lambaesitana .... VIII 18086 M. Volcacius H Tusd(ro) mil? (III Aug) Date? Castra Lam-

baesitana ................................. VIII 2569

\section{HILARIO}

Iul(i) us $\mathrm{H}$ vet $\mathrm{XXX}$ Ulp vict Date? Burginatium Germ Inf ...... XIII 8666 Priscin(ius) H mil XX(X) Ulp vict ante 120? Brigetio Pann Sup..III 10974 — H 7 III Aug Date? Lambaesis...................VIII 2943 HILARUS

Aqu(i)llius H dup III Aug p v Antonin 218 A.D. Castra Lambaesitana................................. VIII 2564

G. Aufidius H spec VII Gem c200 Tarraco...............II 4122

L. Aufidius H optio (III Aug) 198-211 A.D. Castra Lambaesi-

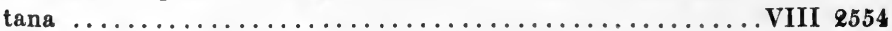

C. Iulius H Kar c? (III Aug) \&s? Castra Lambaesitana........ VIII 18087 


\section{HISPANUS}

Caesilius H 7 III Aug Date? Lambaesis................ VIII 2830 Iul(ius) Hispan(us) (7 XXII Pr p f) 204 A.D. Mainz ......... XIII 6801 L. Manti(us) L. f. Gal. H 7 VII Gem fel 7 III Aug Date? Lambaesis .................................. VIII 2938 HISPELO

L. Novellius T. f. Polia H mil leg XVI ante 43? Mainz........ XIII 6843 HISTER

T? Octavius T? (f) Vel. $\mathrm{H}$ vet $\mathrm{XI} \mathrm{Cl} \mathrm{p} \mathrm{f} 42$-Vespas Tragurium Dalmatia ................................ 9 . 9709

Sex. Palpelli(us) H mil IIII Fl Date? Pola................ 48 HOMULLUS

M. Coelius M. f. Fl. H Sol(va) mil frum VI Vict Date? Verona . . . . . . . V 3362 sius $\mathbf{H}$ mil leg? Date? Verona...................V 3870 HONESTUS

T. Flavius H Cas can (III Aug) Date? Castra Lambaesitana.... VIII 2569 HONORATIANUS

M. Calpurnius H 7 III Aug Date? Lambaesis............ VIII 2832 (Hono)ratianus 7 III Aug c150 Gigthi............ VIII 11089

\section{HONORATUS}

Aemil(ius) $\mathbf{H}$ arm cust III Aug c225 Castra Lambaesitana....A.E. 1902:11 Anicius H dup III Aug p v Antonin 218 A.D. Castra Lambaesitana .................................... VIII 2564

Annius $H$ dup III Aug p v Antonin 218 A.D. Castra Lambaesitana VIII 2564 M. Annius H corn trib lat III Aug p v 198 A.D. Castra Lambae-

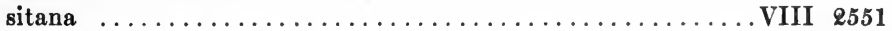

M. Caesius H Tham(ugadi) bf cos III Aug c225 Lambaesis.....VIII 2586 L. Calpurnius H Cir(ta) imm (III Aug) Date? Castra Lambaesitana ................................. VIII 18086

Clodius H optio III Aug Date? Lambaesis.............. VIII 2845

L. Clod(ius) H optio (III Aug) 198-211 A.D. Castra Lambaesitana VIII 2554

C. Cornelius H Tham(ugadi) vet III Aug p v c198 Castra Lambaesitana ................................ VIII 18068

C. Florius C. f. H mil III Aug Date? Verecunda............ VIII 4240

L. Geminius H ? (III Aug) Date? Castra Lambaesitana........ VIII 2570 Iulius Honoratu(s) optio (III Aug) 198-211 A.D. Castra Lambaesitana ................................ 2554

Iulius H dup III Aug 218 A.D. Castra Lambaesitana.......... VIII 2564 Iul(ius) H 7 II Aug Date? Segedunum Eng.............E.E. IX 1157 C. Iulius H Cirt(a) vet III Aug p v c198 Castra Lambaesitana... . VIII 18068 C. Iul(ius) H optio (III Aug) 198-211 A.D. Castra Lambaesitana. VIII 2554 C. Iul(ius) H vet ex sig (III Aug) 211-12 A.D. Lambaesis....... VIII 2618

L. Licinius H ? (III Aug) Date? Castra Lambaesitana........ VIII 2565

C. Mundius H vet ex opt III Aug Date? Lambaesis........... VIII 2948

L. Minucius Honorat(us) sig X Gem Date? Vienna.......... III 13497 
Novianius H buc XXII Pr p f Date? Mainz............E. 1913:\&40 C. Octavius Q. f. Cornel. H 7 II Aug 7 VII Cl p $\mathrm{XVI}$ Fl firm 7 X

Gem $p$ f Date? Ad Aquas..................... VIII 14698

C. Offelius H str (III Aug) Date? Lambaesis............. VIII 2957

Pacculus $H$ arm cust III Aug c285 Castra Lambaesitana....A.E. 1902:11 Pomponius H dup III Aug $\mathrm{p} v \mathrm{v}$ Antonin 218 A.D. Castra Lambaesitana ...................................... 2564

Pomponius $\mathbf{H}$ tess III Aug Date? Lambaesis.

VIII 2960

Valerius $H$ arm cust (III Aug) 200 A.D. Castra Lambaesitana A.E. 1908:10 —ius H sig (III Aug) Date? Castra Lambaesitana.......... VIII 18073 P. f. Honora(tus) vet? III Aug Date? Mactar Byzacena VIII 628 H Kart (mil? III Aug) Date? Castra Lambaesitana A.E. 1899:80 HORATIANUS

Publilius H 7 III Aug coh IV 162 A.D. Castra Lambaesitana... . VIII 18065

_-ius H ? III (Aug) Date? Lambaesis................. VIII 3283 HORATIUS

C. Plotius (Hora)tius Utica vet? (III Aug) Date? Castra Lambaesitana .............................. VIII 18086 HORTESIS

Iuliu(s) H mil IX Cl 155 A.D. Almus Moes Inf ............III 7449 HOSPES

C. Iulius H ? III Aug Date? El-Gara................... VIII 8794

Rutilius H dup III Aug p v Antonin 818 A.D. Castra Lambaesitana $\ldots \ldots \ldots \ldots \ldots \ldots \ldots \ldots \ldots \ldots \ldots \ldots \ldots \ldots$ VIII 2584

Silius $H$ hastatus X Gem ante 70? Tarraco............... II 4114 H 7 leg IX post Claud Lincoln Eng............E.E. IX 1111 HOSPITALIS

M. Aurelius H vet (III Aug) Date? Lambaesis............. VIII 3051-\&

T. Fl(avius) H 7 I Min 188 A.D. Ager Tungrorum Belgica....... XIII 3605

C. Iunius $\mathbf{H}$ vet (III Aug) Date? Lambaesis.............. VIII 18309

Q. Sallustius H mil? (III Aug) Date? Castra Lambaesitana..VIII 2568

- is Hospital(is) (mil? III Aug) Date? Castra Lambaesitana ............................. Aull Archeol 1904 pe08 HYMNUS

Ti. Claudius $\mathrm{H}$ medicus leg XXI ante Hadrian Vindonissa..... XIII 5208, IADESTINUS

L. Appuleius L. f. Sergia I Iader mil I Adiut 70-100 A.D. Mainz. XIII 6827 IAMIANUS

Aurel(ius) I (mil? II Parth?) Date? Rome............... 2410 IANUARIUS

Aelius I 7 III Aug coh VII 162 A.D. Castra Lambaesitana....... VIII 18065 P. Ael(ius) Ian(uarius) vet VII Cl 195 A.D. Viminacium Moes Sup ................................... 14507

L. Agrius I Kart vet III Aug p v c198 Castra Lambaesitana.... . VIII 18068 Alfius I 7 III Aug Date? Lambaesis.................. VIII \&808 Q. Alfius I spec VII Gem ce00 Tarraco.................. 4182 
Apuleliue I eq II Adi p f Date? Aquincum Pann Inf ...........III 3480 Q. Arruntius I vet (III Aug) Date? Verecunda............ VIII 4838 G. Aufidius I Kar dup (III Aug) Date? Castra Lambaesitana.. VIII 2565 Aur(elius) I eq I Adi $p$ f Sever c285 Scarbantia Pann Sup....... III 15188:3 Aurelius I mil III Aug Date? Lambaesis............... VIII 3053 Aur(elius) I mil leg Ital Date? Salonae Dalmatia............II 8719 Aure(lius) I tess leg XIII Date? Dertona................ 7367 C. Aurelius I(a)nuarius mil III Aug Date? Lambaesis........VIII 3054 M. Aurelius I vet ex leg XXX Ulp vict Date? Lyons..........XIII 1848 (M?) Au(relius) I vet I Adi $p$ f post 114 Brigetio Pann Sup......III 11084 Q. Baebius I peq (III Aug) Date? Lambaesis..............VIII \&8\&7 Bibius Ianuariu(s) vet ex librario (III Aug) 270-275 A.D. Lambaesis .................................... VIII $86 \boldsymbol{\ell} 6$

C. Blosius I ? (III Aug) Date? Castra Lambaesitana.......... VIII 2565 Brut(tius) I arm cust III Aug c285 Castra Lambaesitana.....A.E. 1908:11 C. Caecllius Ian(uarius) Hippo vet III Aug p v c198 Castra Lambaesitana ............................ VIII 18068

M. Caec(1lius) Ianuar(Ius) optio (III Aug) 198-211 A.D. Castra Lambaesitana ................................ 2554

L. Caesius Ian(uarius) mil? (III Aug) Date? Castra Lambaesitana...................................... 8567

Calicius Ianuar(ius) arm cust (III Aug) 800 A.D. Castra Lambaesitana ............................ 1908:10

C. Calventius I 7 III Aug Alexand c\&\&5 Lambaesis........... VIII 874\&

C. Calventius Ianuar(ius) Cas corn III Aug c225 Lambaesis... VIII 2586 Clau(dius) I mil XI Cl 155 A.D. Almus Moes Inf ............ III 7449 Claudius Ianuar(ius) dup III Aug p v Antonin 218 A.D. Castra Lambaesitana ............................... 2564

Tib Cl(audius) I spec XIIII Gem Date? Salonae Dalmatia......III 2015 Q. Egnatius I Mas(cula) mil? (III Aug) Date? Castra Lambaesitana .. ........................... 25 III 2568

Q. Ennius Ianuar(ius) bf $\cos$ V Mac p c M. Aurel 274 Potaissa Dacia .................................. 878

Faltonius I 7 III Aug coh X 162 A.D. Castra Lambaesitana..... VIII 18065

L. Faonius I Sufi mil? (III Aug) Date? Castra Lambaesitana. VIII 2569 Fl(avius) I adiutor off corn (III Aug) Is Theveste...........VIII 1875 C. Fulvi(us) Ianuar(ius) optio (III Aug) 198-811 A.D. Castra Lambaesitana ............................. $\mathbf{8 5 5 4}$

Geminius I bf trib lat III Aug p v 198 A.D. Castra Lambaesitana VIII 2551 $\mathbf{G e ( m i n i u s ) ~ I a ( n ) u a r i u s ~ a r m ~ c u s t ~ I I I ~ A u g ~ c e 2 5 ~ C a s t r a ~ L a m b a e - ~}$ sitana .............................. 1908:11

Homullius I imm III Aug Date? Lambaesis............. VIII 8883 Iulius I arm cust III Aug p v Antonin 218 A.D. Castra Lambaesitana .................................. VIII 2564

Iulius I dup III Aug p v Antonin 218 A.D. Castra Lambaesitana.. VIII 2564 Iulius I (mil ? III Aug) c218? Castra Lambaesitana Bull Archeol 1904 p200 Iul(ius) Ianua(rlus) ? (III Aug) 253-268 A.D. Castra Lambaesi- 
C. Iulius Ian(uarius) mil? (III Aug) Date? Castra Lambaesitana ....................................... 2587

C. Iulius Ianu(arius) mil? (III Aug) Date? Castra Lambaesitana .................................... 2567

C. Iulius I C(as) mil? (III Aug) Date? Castra Lambaesitana.. VIII 2569

D. Iulius Ianu(arius) mil? (III Aug) Date? Castra Lambaesitana ....................................... 2569

M. Iulius I vet III Aug Date? Lambaesis...............VIII 3153

L. Licinius I Tibursi Numid vet ex imm (III Aug) \&11-\& A.D. Lambaesis ................................. 2618

L. Licinius Ianuar(ius) Am(maedara)? (III Aug) Date?

Castra Lambaesitana......................... VIII 2566

M. Licinius Ia(nu)arius corn II Adiut 8-3s Aquincum Pann Inf III 14349:6

P. Magnius P. f. I mil III Aug Date? Lambaesis...........VIII 3186

C. Mallius I cor III Aug $p$ v 209-211 A.D. Castra Lambaesitana.. VIII 2557

C. Marius Ia(nuarius) lib (III Aug) Date? Castra Lambaesi-

tana ..................................... 2560

Munatius I mil (III Aug) Date? Lambaesis.............. VIII 3200

L. Novius I ? (III Aug) 209-211 A.D. Castra Lambaesitana...... VIII 2556

L. Paternius T. (f) Ianuar(ius) vet IIII (Fl firm) Date? Viminacium Moes Sup..........................III 8123

8 Pescennius Ianua(rius) (mil? III Aug) Date? Castra Lambaesitana.........................Bull Archeol 1904 p207

P. Pomponius I mil III Aug Date? Lambaesis............ VIII 3223

Sallustius I dup III Aug p v Antonin 218 A.D. Castra Lambaesitana ....................................... 2564

Sallustius I mensor (III Aug) 3s Castra Lambaesitana....... A.E. 1904:72

Sallustius I imag III Aug Date? Lambaesis..............VIII 2971

M. Sextilius Ia(h)n(uarius) mil (III Aug) Date? Lambaesis.. VIII 3239

L. Sextius I Had(rumeto) vet III Aug 166 A.D. Castra Lambaesitana.............................. VIII $\mathbf{1 8 0 6 7}$

C. Silicius I Cast vet III Aug p v c198 Castra Lambaesitana... . VIII 18068 M'. Silius I 7 I Adiut 70-100 A.D. Mainz.............. XIII 6842 Sittius (Ian)uariu(s) (mil) III Aug Date? Lambaesis........VIII 3241-8 Tonneius I dup III Aug p v Antonin 218 A.D. Castra Lambaesitana ................................... 2564

M. Ulp(ius) Ianuar(ius) R(emesiana?) vet VII Cl 195 A.D.

Viminacium Moes Sup......................II 14507

M. Ulp(ius) I Rat(iaria) bf cos vet VII Cl 195 A.D. Viminacium

Moes Sup.............................. 14507

M. Ulpius I (eq? III Aug) $282-35$ A.D. Castra Lambaesitana

M. Ulp(ius) M. f. Ulpi(a) I Traia(na) (mil? leg?) Date? Chester Eng...............................E. IX 1093 Val(erius) I vet (V Mac) c134 Troesmis................III 6178

C. Valerius I Cas mil? (III Aug) Date? Castra Lambaesitana. VIII 2568

L. Val(erius) I optio (III Aug) 198-211 A.D. Castra Lambaesisitana 
G. Vib(ius) Pom. I(a)nu(a)rius bf $\cos$ I Adiut $2 s$ Novae Dalmatia ..................................... 1910

L. Volussius I (eq? III Aug) 222-35 A.D. Castra Lambaesitana

(I)anuarius ? (III Aug) 253-268 A.D. Castra Lambaesitana ................................. VIII 18061 estius Ian(uarius) lib (III Aug) Date? Castra Lambaesitana .................................. (Ian)uariu(s) mil? (III Aug) aet Antonini Pii Castra

Lambaesitana .............................VIII 18085

IASON

M. Aur(elius) I 7 I Ital Date? Bela Slatina Moes Inf........ III 12388

\section{IASSIANUS}

(Aurelius) I str leg leg II Adiut Date? Intercisa Pann Inf....... III 10317 IERAXS

Aurelius I vet II Adi $\mathrm{p}$ f Antonin c\&15 Aquincum Pann Inf......III 15161 IMPETRATUS

F1(avius) I vet (III Aug) Date? Lambaesis............... VIII 8109

C. Iulius I Kart vet III Aug p v c198 Castra Lambaesitana..... . VIII 18068

C. Iul(ius) Im(p)etratus bf $\cos$ X Gem 257 A.D. Latobici Pann Sup III 3906 Sep(timius) I vet ex leg III Ital ex t(u)b Date? Castra Regina

Raetia ...................................... 5957

Servilius I (? III Aug?) Date? Lambaesis................VIII 2641 INGENUILIS

Ael(ius) I vet II Adiut 2 -3s Intercisa Pann Inf..............III 10320 INGENUINUS

M. Ingenius I bf $\cos 239$ A.D. Col Agrippinensium......... XIII 8207 INGENUS

M. Acutius I 7 (III Aug) 211-12 A.D. Lambaesis........... VIII 2618

Ael(ius) I bf leg (XI Cl) post Traian Ad Haemum Moes Inf...... III 12401

C. Arrius I bf trib lat III Aug p v 198 A.D. Castra Lambaesitana. . VIII 2551 Aurel(ius) I mil XIII Gem Antonin 211-12 A.D. Sarmizegetusa... III 1479 Aur(elius) I nat prov Dacia mil XIII Gem 3s Rome........... VI 2425

C. Cassius In(g)enus mil leg VIIII 1s Forum Iulii ........... XII 249

Domitius I vet ex librario (III Aug) 270-275 A.D. Lambaesis.... VIII 2626 F1(avius) I sig (XV Apol) 1s Carnuntum Pann Sup........... III 11218 Iul(ius) I spec I et II Adi $p$ f Sever 228 A.D. Aquincum Pann Inf. . III 3524 Titus Iulius I vet (XXII Pr $p f$ ) post 89 Ager Mogontiacensis... XIII 7218 Numen(ius?) I spec legg III Antonin ( $=$ X Gem XIV Gem I Ad)

c212 Carnuntum Pann Sup....................III 445\&

L. Pompeius I bf cos Date? Neviodunum Pann Sup..........III 3919

C. Publicius I Hippo vet? (III Aug) aet Hadriani Castra Lambaesitana ............................... VIII 18084

Q. Sabi(nius) I sig III Aug post 253? Lambaesis........... VIII 2970

Sextilius I dup III Aug $p$ v Antonin 218 A.D. Castra Lambae- 
sitana VIII 2564 (I)ngenus Kar mil? (III Aug) aet Antonini Pii Castra

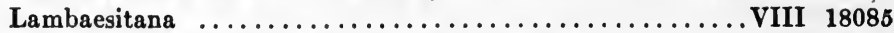

- (In)genus vet (V Mac) Date? Troesmis...........III 6179

INGENUUS

(A)el(ius) I R(emesiana?) vet VII Cl 195 A.D. Viminacium Moes

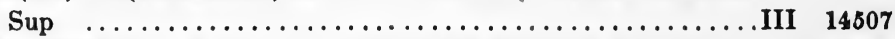

C. Aemilius I mil XI Cl bf cos post Claud Magnum Dalmatia . . . . III 9790 (Corn)elius Ingen(uus vet?) I Adiut post 114 Carnuntum Pann

Sup $\ldots \ldots \ldots \ldots \ldots \ldots \ldots \ldots \ldots \ldots \ldots \ldots \ldots \ldots \ldots \ldots \ldots \ldots$ III 14092

C. Crepereius I Cas d s (III Aug) Date? Castra Lambaesitana. . VIII 2569

F1(avius) I vet (III Aug) Date? Lambaesis.............. VIII 3110

T. Flavius I prov Brittaniae Infer mil VI Vict $p$ tara ............................... VIII 5180

Iul(ius) Ingen(uus) optio (VII Cl) Date? Ancyra...........III 863

C. Iul(ius) F1. Ingen(uus) mil VI Vict post Hadrian Bremenium

Eng ................................. VII 1057

(I)ul(ius) Ing(enuus) $7 \mathrm{leg} X$ ante 70 Tucci Baetica..........II 1691

Q. Iulius I mil VII Gem fel Date? Carthage...... Rev Archeol 1898 II p340

Lucili(us) I 7 (leg?) Date? Chester Eng.............E.E. IX 1094

C. Maecius I eq X Gem Date? Narbo.................XII 4364

C. Memmius I Kar mil? (III Aug) Date? Castra Lambaesi-

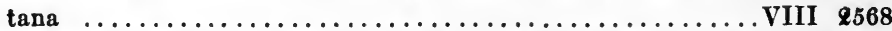

Pet(ronius) Inge(nuus) tess (I Ital) is exe-3s Almus Moes Inf III 14409:1

Sabinius I sig III Aug post 253? Lambaesis.............. VIII 18224

L. Sempronius I p p III Aug 15\& A.D. Castra Lambaesitana . . . VIII 2543

Sept(imius) I eq XIIII Gem post 100 Carnuntum Pann Sup.... III 4480

Val(erius) I mil XIIII Gem post 100 Savaria Pann Sup......... III 14066

- Ingenu(us) bf $\cos 198-222$ A.D. Nettersheim Bonn Jahrbb 1910 p312

- I ? (V)II Cl 3s Viminacium Moes Sup...............E. 1905:163

I 7 (III Ital) Date? Augusta Vindelicum Raetia........ III 5818

INNOCENS

Rennius I (mil III Cyr aut XXII Deiot) 81 A.D. Fayoum

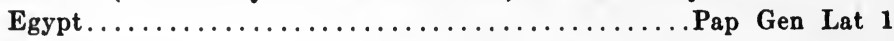

INSEQUENS

Aurelius I mil leg XXII Date? Virunum Noricum.......... III 4848

T. Ulpius I bf cos Date? Virunum Noricum..............III 4860

\section{IOVINUS}

M. Antoni(us) I mil III Aug Date? Verecunda............ VIII 4286

Aurelius I vet XIII Gem 1s? Emona Pann Sup .............III 3844

M. Aur(elius) I frum II Adiut Aquincum Pann Inf........... III $\$ 466$

C. Caecilius I bf leg (III Aug) Date? Lambaesis............ VIII 2828

C. Caecilius I tess III Aug Date? Lambaesis............. VIII 2888

Caelius I dup III Aug p v Antonin 218 A.D. Castra Lambaesitana. VIII 2564

Q. Cornelius I Tev(este) mil? (III Aug) Date? Castra Lam-

baesitana $\ldots \ldots \ldots \ldots \ldots \ldots \ldots \ldots \ldots \ldots \ldots \ldots \ldots \ldots \ldots \ldots$ VIII 2569 
C. Iulius I The(lepte) mil? (III Aug) Date? Castra Lambaesitana ............................ VIII $\$ 569$ IRMUS

L. Messius I 7 I Ital aet Antonini Pii Almus Moes Inf . . . . . . . . III 7420 ISCHYRION

L. f. Pol. I Cas vet II Tr fort 194 A.D. Alexandria Egypt. . III 6580 ISIDORUS

Aelius I 7 III Aug coh V 162 A.D. Castra Lambaesitana....... VIII 18065 M. Aurelius Pol. I Alexandr(ea) vet II Tr fort 194 A.D. Alex-

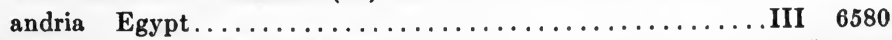

Baebius I 7 leg? Date? Mainz....................

Iulius C. f. Pol. I Castris vet II Tr fort 194 A.D. Alexandria Egypt III 6580

$\longrightarrow$ P. f. Pol. I Thebis vet II Tr fort 194 A.D. Alexandria Egypt III 6580 ISPANUS

C. L_I mil VII Gem fel Palentinus Date? Aquileia.......... V 920 ITALICUS

P. Calventiu(s) I sig III Aug Date? Lambaesis............. VIII 2834

Gratti(us) Ital(icus) vet (V Mac) c184 Troesmis.............III 6178

Ti. Iulius Ti. f. Fal. I 7 VII Mac 7 XV Prim 7 XIII Gem ante

Vespas Ager Falernus..................... 4723

ITALUS

T. Flavius I medicus III Aug Date? Lambaesis ............ VIII 2878 IUCUNDUS

Ammius I arm cust (III Aug) 200 A.D. Castra Lambaesitana .. A.E. 1902:10 T. F1(avius) I frum XXX Ulp Date? Rome...............VI 3362

C. Iulius I Cirt(a) vet III Aug p v c198 Castra Lambaesitana . . . . VIII 18068

M. Praeconi(us) I Sir(mio) tub XV Apol 1s Carnuntum Pann

Sup ............................III 14358:21a

Sattonius I p p III Aug 253 A.D. Lambaesis............. VIII 2634

C. Tetius I vet XV (Apol) Date? Hr-ben-Gasom-ben-Nasser Africa .................................. 1918:207 us I mil leg I? 189? 21\&? Dottendorf Germ Inf ....... XIII 7999 IULANUS

Valerius I 7 VII Cl Date? Apamea Phrygia.............III 7056 IULIANUS

C. Aelius I Sarmiz(egetu sa) bf cos III Aug c\&\&5 Lambaesis. . . . VIII 2586

C. Aemilius I Kar d s (III Aug) Date? Castra Lambaesitana.. VIII 2568 Allius I arm cust III Aug c£25 Castra Lambaesitana........... 1908:11 C. Annius I Castr bf cos III Aug c225 Lambaesis.... . . . . . . . . VIII 2586 M. Anton(ius) I bf cos Date? Neviodunum Pann Sup........ III 10799 (A)sinius Iulian(us) Th(amugadi?) mil? (III Aug) Date?

Castra Lambaesitana.......................... $\$ 567$ Aufidius Iuli(anus) vet (V Mac) c134 Troesmis............III 6178 Aur(elius) I mensor VII Cl Sever 228 A.D. Viminacium Moes Sup III 8112 Aur(elius) I (vet? V Mac?) Date? Potaissa Dacia............III 7688 C Bebius I arm cust III Aug Date? Kesur el Ghennaia........VIII 4907 
Q. Carmeus I 7 vII Gem aet Sept Severi Daruvar Pann Sup..... III 3998

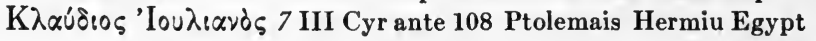

IG a RR I 1153

Cl(audius) I mil XIII Gem 160 A.D. Verespataki Dacia......... III p959 Ti. Cl(audius) I Tyro vet? (III Aug) aet Hadriani Castra Lam-

baesitana .............................. VIII 18084

L. Decrius L. f. Ser. I qui et Numisianus princeps XI Cl p f

100-150 A.D. Naples....................... 1913:215

Domitius Iulian(us) mil III Aug Date? Lambaesis......... VIII 3098

(L?) Domiti(us) I p p XXII Prim (Alexand) 229 A.D. Mainz.... XIII 6758

(F1)avius I tub III Aug p v 202 A.D. Castra Lambaesitana... A.E. 1907:184

T. Flavius I vet VIII Aug Date? Beroea Syria..............III 191

C. Gentius I Cast vet III Aug p v c198 Castra Lambaesitana... VIII 18068

Iulius Iuli(anus) 7 III Cyr ante 108 Ptolemais Hermiu Egypt.... III 18071

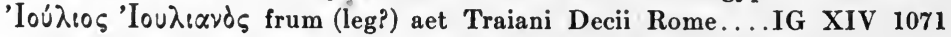

(I) ulius I Nic(omedia) vet? (III Aug) aet Hadriani Castra

Lambaesitana ............................. VIII 18084

Iulius I 7 III Aug coh VII 162 A.D. Castra Lambaesitana........ VIII 18065

Iul(ius Iuli)anus sig VII Gem (p f) c167 Castrum S. Christoph

Tarraconensis ....................II 2556 = A.E. 1910:6

Iulius I (mil ? III Aug) c218? Castra Lambaesitana Bull Archeol 1904 p206 Iul(ius) Iulia(nus) ? (III Aug) 253-268 A.D. Castra Lambaesi-

tana .................................. 18061

Iulius I sig (III Aug) Date? Castra Lambaesitana.......... VIII 18073

Iul(ius) I mil II Aug Date? Isca Eng...................VII 121

Iul(ius) I (vet) leg II ex arm cust Date? Aquincum Pann Inf....III 13373

Iulius Iul(i)anus 7 leg D Date? Durostorum Moes Inf..III 14213:2

C. Iul(ius) I 7 XIII Gem post Traian Apulum Dacia........... III 7858

C. Iul(ius) I vet XIIII Gem post 100 Savaria Pann Sup.........III 4187

Macrinius Iuli(a)nus eq? XXII Pr p f 231 A.D. Mainz ....... XIII 6669

C. Maximius I optio praet V Mac M. Aurel-274 Apulum Dacia.... III 7765

Por(cius) Iulian(us) tess (leg?) Date? Apulum Dacia ......... III 1189

Rutilius I vet ex imm (III Aug) $211-12$ A.D. Lambaesis........ VIII 2618

C. Secundinius I eq XXII Pr $\mathrm{p} f$ post 89 Ancyra ............ III 6763

P. Sedulius (I)ulianus mil VIII Aug Antonin bf cos c215 Cannstatt XIII 6440

Sept(imius) I mil pequarius II Adi p 238 A.D. Aquincum Pann Inf III 10428

Sept(imius) I eq XI(III? Gem) post 100 Carnuntum Pann Sup...III 4480

Q. Tarronius I 7 XXII Pr $\mathrm{p}$ f post 89 Mainz ................ 1906:61

P. Tiburti(us) Iulian(us) mil (III Aug) Date? Lambaesis..... VIII 3249

(Valer)ius Iulian(us) mil VII Cl bf cos Date? Naissus Moes Sup III 8258

L. Valerius I Tham(ugadi) bf cos III Aug c225 Lambaesis. .... VIII 2586

C. Vib(ius) I mil I Adiut $2 s$ ? Burnum Dalmatia.............III 2823

-nlius? f. Papir. I Had(rumeto) vet II Tr fort 194 A.D.

Alexandria Egypt........................... III $\quad 6580$

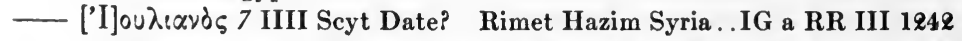

I Tharso (mil? III Aug) Date? Castra Lambaesitana.A.E. 1890:90

- Iu(1)i(an)us 7 XV Apol ante 63 Carnuntum Pann Inf.... III 4465 


\section{IULIUS}

P. Ael(ius) I Sirm(1o) vet VII Cl 195 A.D. Viminacium Moes

Sup............................... 14507

Aur(elius) I vet (I Adiut) post 114 Brigetio Pann Sup........III 11021

Aur(elius) I (vet) ex bf trib (V Mac?) Date? Potaissa Dacia...III 7688

T. Aur(elius) I Sc(upis) bf praef VII Cl 195 A.D. Viminacium

Moes Sup............................. 14507

Avicius I mil leg XIV Date? Lambiridi............... VIII 18568

\section{IULLINUS}

Iul(ius) Iu(1?)linus 7 III Ital 181 A.D. Inter Danuvium et

limitem Raetia.......................II 14370:2

\section{IUNIANUS}

Calvisius I 7 III Aug coh IV 162 A.D. Castra Lambaesitana.... VIII 18065

M. Rustius P. (f. I) unianus bf $\cos$ II Ital p f Sever 230 A.D.

Boiodurum Noricum....................... III 5690

\section{IUNIO}

P. Aelius I Nap(oca) mil? (III Aug) aet Antonini Pii Castra

Lambaesitana.......................... VIII 18085

\section{IUNIUS}

Pomp(ulenius) I 7 II Adiut 8-3s? Aquincum Pann Inf......III 3561

\section{IUSTIANUS}

Claudius I 7 ordiniarius II Adiut Date? Aquileia........... V 8275

Sept(imius) I arm cust XIIII Gem Antonin c215 Scarbantia

Pann Sup............................III 10948-3

Aul. Tullius I p p III Aug Sever c225 Lambaesis............VIII 2737

\section{IUSTINUS}

Ael(ius) I quaest XI Cl post Traian Ad Haemum Moes Inf....III 12401

Ael(ius) I lib leg leg I Adiut bellum Dacicum Intercisa? Pann

Inf ............................... 1909:144

P. Ael(ius) I mil II Adiut $8-3$ s? Csabae Pann Inf ............ III 3634

Aur(elius) I mil II Ital 182 A.D. Bedaium Noricum..........II 5567

Aur(elius) I mil II Ital $\&-3 \mathrm{~s}$ Celeia Noricum..............III 5218

Aurelius I eq XI Cl $3 \mathrm{~s}$ exe-4s init Aquileia................ 896

T. Cl(audius) I Sc(upis) vet VII Cl 195 A.D. Viminacium

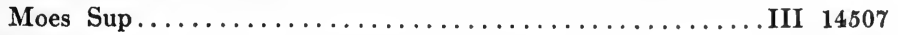

T. Fl(avius) I mil XIII Gem 200 A.D. Apulum Dacia......... III 1042 .

L. Gailonius L. f. I mil II Adiut Date? Aquileia . . . . . . . . . V 915

C. Iul(ius) I bf cos Date? Stockstadt................. XIII 6648

M. Ulpius M. f. I mil II Adiut frum domo Savaria Date? Rome. VI 3336

M. Ulpius I mil ter? leg II Date? Aquincum Pann Inf........ III 3573

T. Val(erius) I (mil aut 7) VIII Aug Date? Duenhausen Germ

Sup..................................... 6318

- I 7 (II Aug?) coh X Date? Segedunum Eng........... VII 489

\section{IUSTUS}

Aelius I mil? X Gem Date? Vienna................III 4568 
L. Apul(eius) I R(emeslana?) sig vet VII Cl 195 A.D. Viminacium Moes Sup..........................III 14507 Aur(elius) Iustu(s) lib? (leg ?) Date? Apulum Dacia......III 1189 T. Aelius I hydraularius salariarius II Adiut 2-3s? Aquincum

Pann Inf ................................ 10501 Ael(ius) Iu(stus?) Sa(lonis) vet VII Cl 195 A.D. Viminacium

Moes Sup..............................III 14507

M. Aurel(ius) I domo Ho(r)rei Margensis Moesiae Superioris

ex CCC p p I Ital Sever 224 A.D. Moes Inf incerta.........III 7591

M. Aurel(ius) I bf cos II Ital p f 217 A.D. Celeia Noricum...... III 5189

C. A-I bf $\cos 181$ A.D. Stockstadt............... XIII 6633

Q. Caesius (I) ustus bf cos Date? Bonn............... XIII 8012 Ti. Cl(audius) I 7 III Aug Date? Lambaesis.............VIII 2848 Comidius I vet (III Aug) Date? Lambaesis............. VIII 3086 Fla(vius) I arm cust III Aug c225 Castra Lambaesitana.... A.E. 1902:11 F1(avius) Iust(us) (mil?) I Min Date? Bonn.............XIII 8053 Iulius I 7 III Aug Date? Lambaesis.................VIII 2903 (L.) Lepidius I vet XXX Ulp vict post Traian Ferrara .........V 2391 M(am)ertinius I optio XXII (Antonin Pr p f) 212 A.D. Trenn-

furt ................................... 6618

C. Managnius I 7 III Ital Date? Augusta Vindelicum Raetia....III 5817 Metilius I 7 XV Apol 1s Carnuntum Pann Sup..............III 1345e Romelei(us) I 7 (leg ?) Date? Borcovicium Eng.......E.E. IX 1189 Septimius I (mil) III Aug Date? Lambaesis.............VIII 18319 C. Val(erius) Iu(s)tus actar leg XX Date? Chester Eng.....E.E. IX 1065 L. Va(lerius) I mil leg VI post Hadrian? Hexham Eng.........VII 477 Varsidius I 7 (leg ?) Date? Ebchester Eng.............. VII 464 Vettius I arm cust III Aug c225 Castra Lambaesitana.......... 1902:11 Q. Vettius I 7 III Aug Date? Calceus Herculis............ VIII 18008 - I 7 (leg XXII aut III Cyr) aet Augusti Coptos Egypt....III 6627 \& I ? II Aug Date? Isca Eng....................VII 99 -us I ? XXX Ulp vict Date? Harenatium Germ Inf.... XIII 8703 I 7 (leg ?) Date? Condercum Eng.................VII 531 (I) us(tu)s $\operatorname{Sir}(\mathrm{mio})$ vet VII Cl 195 A.D. Viminacium

Moes Sup................................III 14507

IUVENALIS

C. Arruntius I mil? (III Aug) Date? Castra Lambaesitana..VIII 2568 Flavius I 7 III Aug coh VIII 162 A.D. Castra Lambaesitana.... VIII 18065 T. Flavius I vet XXII Pr p f post 89 Arelate............. XII 68\& Q. Numisius I lib III Aug Date? Lambaesis.............VIII 2954 IUVENIS

T. Caesen(nius) I mil II Adiut c150 Cartenna Mauretania Caesariensis............................... VIII $\mathbf{9 6 5 3}$ Cogitatinius I bf leg leg I Min 3s Lyons.................XIII 1797 Iul(ius) I bf cos II Ital Antonin 219 A.D. Bedaium Noricum.... III 5580 Iuli(us I) uvenis optio III Ital Date? Raetia incerta.......... III 5976 Marin(ius) Iu(v)enis (mil?) I Min Date? Bonn..........XIII 8053 
L. Memmius I bf $\cos 166$ A.D. Stockstadt............. XIII 6649

D. Seius D. f. Quir. I Burdigalia mil III Aug 1s Gurai Numidia.VIII 2103 I 7 VII Gem Date? Catania..................... 1897:138

\section{LABRACENUS}

Iulius L dup III Aug p v Antonin 218 A.D. Castra Lambaesitana. . VIII 2564 LABRASES

Aurel(ius) L 7 XV Apol 185 A.D. Vagharschapt Galatia......... III 6058 LACO

—nus L (7 ?) leg VII 37-41 A.D. Corinium Dalmatia........III 2888 LAENAS

L 7 leg II 1s Ager Santonom Aquitania..........XIII 1182 LAETINUS

Laetin(us) 7 (leg ?) coh II Date? Amboglanna Eng. . E.E. VII 1076 LAETUS

(Q. Carmaeus) Lae(t)us Aq(uis) Ver(cellis) corn trib XI Cl Date? Durostorum Moes Inf....................III $7 \mathbf{7 4 7 6}$

(Flavius) L mil III Aug Date? Zarai.................VIII 4521

Q. Longinius Pometina L. Luco mil (leg?) Date? Chester Eng................................. VII 897

C. Minutius $\mathrm{L}$ vet VII $\mathrm{Cl}$ p f 76 A.D. Philippopolis Thracia....III 6180 Mucius L ? (III Aug) Date? Castra Lambaesitana..........VIII 2570 Tannonius L dup III Aug $\mathrm{p}$ v Antonin 218 A.D. Castra Lambaesitana................................ 2584

Q. Vettius L K(arthagine) vet III Aug 166 A.D. Castra Lambaesitana............................... VIII 18067 LAEVINUS

M. Val(erius) La(e)vinus bf cos Date? Emporiae Tarraconensis.. II 4624 LAEVUS

Cicereius L p p leg XI ante 42? Burnum Dalmatia...........III 14996 LAFICUS

Marcus Aur(elius) L Rediti filius domo Nicapolis vet XIIII Gem post 100 Carnuntum Pann Sup.................III 4458 LAPPUS

-L 7 II Tr fort 151 A.D. Egypt...............E. VII p459

\section{LATINUS}

Blandius C. (f.) Vol. L 7 I Ital 7 II Aug 7 VIIII Hisp 7 leg XX 67-c180 A.D. Genava......................... XII 2601

Pupin(ius) Lati(nus) vet VII Cl 135 A.D. Viminacium Moes Sup.................................III 8110

M. Valerius M. fil. L c(ivis) Eq(uester) mil leg XX post 43 Bath Eng.............................

\section{LAURENTINUS}

Caelius L optio (III Aug) 198-211 A.D. Castra Lambaesitana.. VIII 2554 Titinius Laurent(inus) imm III Aug $\mathrm{p} v$ Antonin 218 A.D.

Castra Lambaesitana.......................... VIII $\mathbf{2 5 6 4}$ 


\section{LAVENUS}

T. Camul(ius) L. f. L emeritus III Gall aet Antonini Pii Gratianopolis XII 2230

LAVINUS

T. Aur(elius) L mil XXX Ulp vict Date? Rigomagus Germ Inf . . XIII 7789 LELLAVVO

M. Ulp(ius) L mil XXX Ulp vict Date? Rigomagus Germ Inf . XIII 7789 LEO

L. Aelius L mil XIII Gem post 100 Carnuntum Pann Sup...... III 11148 L 7 leg ? 1s Thabraca.................... VIII 17334

LEONATUS

Aurelius Leon(atus?) dup III Aug p v Antonin 218 A.D. Castra

Lambaesitana............................ VIII 2564

$-\mathrm{L}$ vet $(\mathrm{V}$ Mac) $\mathrm{c} 134$ Troesmis.................. 6178 LEONIDES

L. Aelius L mil III Aug Date? Lambaesis................ VIII 3015

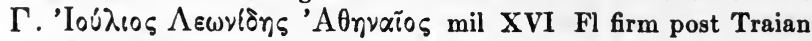
Mopseutia Cilicia....................... IG a RR III 917

- (Le)onides mil? (III Aug) aet Antonin Pii Castra Lam-

baesitana............................. VIII 18085

LEONTIANUS

Leontia(nus) vet (V Mac) c134 Troesmis...........III 6178 LEPIDINUS

Aelius L 7 III Aug coh III 162 A.D. Castra Lambaesitana..... . VIII $1806 \delta$ LEPIDUS

C. Iulius Gal. L Iesson pp 7 XIII Gem p 7 I Ad 7 X G p $f$ (7)

XX V v (7 VII G) p $f$ Date? Aeso Tarraconensis........... II 4463

L. Licinius L. f. Clau. Lepid(us) dom Verona vet leg II?

Date? Savaria Pann Sup...................III 4188

(C.) Sextilius L vet XXX Ulp vict Date? Col Ulpia Traiana

Germ Inf.......................... XIII 8609

\section{LEUGANUS}

L. Iul(ius) T. (f) Galer. L Clunia vet XIIII $\mathbf{G} \mathbf{m}$ v aedis custos c $R$ leg XIII 3s? Apulum Dacia................ III 1158

\section{LIBENS}

Q. Valerius Q. f. Fab. L Brixa mil XI Cl p Vespas-Traian

Tenendo Germ $\operatorname{Sup} \ldots \ldots \ldots \ldots \ldots \ldots \ldots \ldots \ldots \ldots$ XIII 6241

\section{LIBERALIS}

Q. Aebutius L 7 XI Cl p f c4\& Corinium Dalmatia............III 9978

Q. Aebutius L 7 leg XI ante Claud Corinium Dalmatia....A.E. 1905:164

Aelius L 7 II Tr fort 194 A.D. Alexandria Egypt............. III 6580

(C)aesonius L vet (VIII? Aug) Date? Borbetomagus Germ

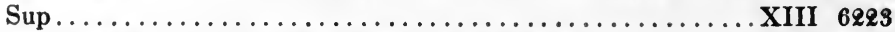

C. Cornelius L vet (III Aug) Date? Lambaesis............ VIII 3091

Elius $L$ vet ex 1 f (III Aug) $270-275$ A.D. Lambaesis... . VIII 2626 cf 18090 
Fa(b)ius (Li)bera(lis) 7 ? VI Vict post Hadrian Westerwood

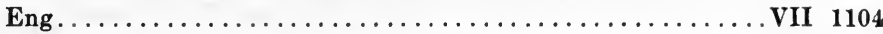

C. Iulius $L$ vet (III Aug?) Date? Zarai............... VIII 4523

D. Iulius L optio (III Aug) Date? Lambaesis.............. VIII 2683-4

Sex. Iulius L Kar vet? (III Aug) 2s? Castra Lambaesitana . . VIII 18087 Valer(ius) L (mil? III Aug) Castra Lambaesitana. . Bull Archeol 1904 p206 M. Valerius L domu Cl Aequo mil XI Cl p f 4q-Vespas Burnum

Dalmatia................................III 15004

- L 7 (leg ?) Date? Chesters Eng................... 605

Liberal(is) ? XXX Ulp vict Date? Lyons..........XIII 1866 LIBO

Olc(atius) L 7 (leg ?) coh I Date? Borcovicium Eng

VII 668 add E.E. IX p588

Val(erius) $\mathbf{L}$ vet $(\mathrm{V}$ Mac) c134 Troesmis..............III 6178 LICINIANUS

Annam(ius) $L$ spec legg III Antonin (= X Gem XIV Gem

I Ad) ce1e Carnuntum Pann Sup.................. III 445\&

Q. Dexius $L$ optio III Aug Date? Lambaesis............ VIII 2858-60

C. Munat(ius) L optio (III Aug) 198-211 A.D. Castra Lam-

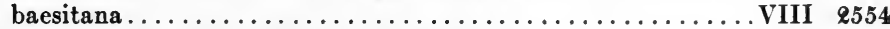

Seius $L$ mil (III Aug) Date? Lambaesis.............. VIII 3235

M. Valerius - Gal. Licini(anus) ex m Cas(tulonensi mi)l?

V (II G)e(m) Date? Asturica...................II 2641

\section{LICINIUS}

M. Aurel(ius) L optio III Aug 253 A.D. Gemellae Numidia... . . VIII 248 \&

M. Aurel(ius) L optio hast post (III Aug) c253 Castra Lambaesi-

tana..................................... 18072

Iul(ius) Licin(ius) vet (V Mac) c134 Troesmis...........III 6178

Sept(imius) L spec legg III Antonin ( = X Gem XIV Gem I Ad)

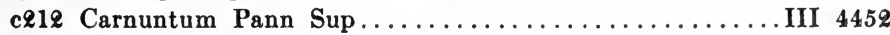

Sept(imius) L imm lib II Parth Date? Rome.............. VI 9395

M. Ulp(ius) L Sir(mio) vet VII Cl 195 A.D. Viminacium Moes

Sup............................ 14507

\section{LIGUS}

Cassius L. f. (F)ab. L vet ex leg VI Vict Date? Calavino

Trient................................ 1904:187

\section{LISIMACUS}

Aurel(ius) L vet ex librario (III Aug) $270-275$ A.D. Lambaesis. . VIII 2626

\section{LIVIANUS}

? Iulius C. f. domo Arethusa $L$ vet ex aquil III Aug Sever

trans ex leg III Gall c225 Lambaesis................ VIII 2904

LOCEUS

Licin(ius) Loce(us?) mil III Cyr ante 108 Egypt.... Wessely Lat Pal 8

\section{LONGINIANUS}

Aurel(ius) L 7 III Aug 3s Lambaesis................VIII 8676 
Iullus L 7 (III Aug) Date? Lambaesis...... VIII 2905-6 et 2962 et 2983 C. Iul(ius) Longinian(us) opt (III Aug) 198-211 A.D. Castra

Lambaesitana................................ 2554 Val(erius) $L$ natus in $M$ (oe)si(a) Infer Castell Abritanor 7

XI Cl 8 s exe $4 \mathrm{~s}$ init Aquileia................... 948

L (mil?) II Adi p $f$ \&-3s Ager Aquincensis Pann Inf ........ III 10365

LONGINUS

P. Aelius L 7 I Min Date? Rome .................. VI 31169 Albani(us) Longin(us) 7 (leg?) Date? Carnuntum Pann Sup...III 4400 Antonius L 7 III Cyr ante 108 Egypt...........Wessely Lat Pal 8 M. Antonius L Cas can (III Aug) Date? Castra Lambaesitana. . VIII 2568 Aur(elius) Ant(onius) L spec III Gall 3s Heliopolis Syria

III $14385 \mathrm{~b}$ ad $138(\mathrm{p} 970)$

(Au)r(elius)' $\mathbf{L}$ mil IX Cl 155 A.D. Almus Moes Inf.......... III 7449 Aurelius L mil II Tr fort Ger Sever c225 Alexandria Egypt..... III 6594a Aurel(ius) L mil VII Cl \&s exe-3s init Viminacium Moes Sup.... III 8118 Bius Longin(us) mil III Cyr ante 108 Egypt.......Wessely Lat Pal 8 Cassius Longin(us) vet $(V$ Mac) $c 134$ Troesmis ............III 6178 Cassi(us) $L$ vet (V Mac) c134 Troesmis..............III 6178 C. Cassius C. f. Cla. L Sav(aria) mil I Adiut 70-100 A.D. Mainz XIII 6829 L. Cassius Longinu(8) bf leg leg III Cyr Date? Bostra Arabia

C. Cornelius C. f. Fab. Longi(n)us Heracla eq leg XVI c69? Bull Archeol 1904 p36

Novaesium Germ Inf...................... 8552

Fera- L vet $(V$ Mac) $c 134$ Troesmis..............III 6178 Fl(avius) Lon(g)inus mil XI Cl 155 A.D. Almus Moes Inf...... III 7449 T. Fl(avius) L dec Kanab leg XIII Gem aet Traiani Apulum Dacia III 1100 T. Fl(avius) L R(emesiana?) vet VII Cl 195 A.D. Viminacium

Moes $\quad$ Sup.............................. 14507

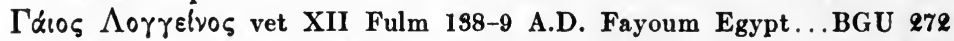
Iul(ius) $L$ vet $(V$ Mac) $c 134$ Troesmis.................III 6178 Iul(ius) Longin(us) vet VII Cl 135 A.D. Viminacium Moes Sup . . III 8110 Iul(ius) $\mathrm{L}$ imm venator XI Cl 155 A.D. Almus Moes Inf........ III 7449 Iul(ius) $L$ bf cos ex V Mac Date? Ljesce Dalmatia..........E. 1910:214 C. Iulius C. f. L domo Voltinia Philippis Macedonia vet VIII

Aug aet Vespasiani Reate...................IX 4684 C. Iul(ius Lon)ginus (vet) VII (Cl) Date? Scupi Moes Sup....III 8197 M. Lic(Inius) L R(atiaria) vet VII Cl 195 A.D. Viminacium

Moes $\quad$ Sup.............................III 14507

A. Nonius L 7 III Aug Date? Lambaesis............... VIII 2952 Sep(timius L)ongin(us) corn II Adi p f Sever ce25 Transaquincum

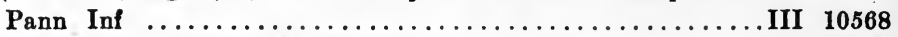

Sosius $L$ vet $(V$ Mac) $c 134$ Troesmis.................III 6178.

Val(erius) Longin(us) vet (V Mac) c134 Troesmis..........III 6178

C. Val(erius) L Rat(iaria) vet VII Cl 195 A.D. Viminacium Moes $\operatorname{Sup} . \ldots \ldots \ldots \ldots \ldots \ldots \ldots \ldots \ldots \ldots \ldots \ldots \ldots \ldots \ldots$ III 14507

C. Valerius C. f. Fab. L Her(aclea) mil I Ital Date? Almus 
Moes Inf . III 7441 M. Val(erius) M. f. L medicus VII Cl Date? Drobeta Dacia... III 14216:8 (L)onginus ? III Aug Date? Lambaesis............VIII 3181 LONGO

Antonius L 7 III Cyr ante 108 Egypt ............ Wessely Lat Pal 8 LONGUS

Ael(ius) Longu(s) vet VII Cl 135 A.D. Viminacium Moes Sup... III 8110 P. Ael(ius) L vet VII Cl 195 A.D. Viminacium Moes Sup........III 14507 M. Antonius $L$ Pull vet $X$ Fr 94 A.D. Alexandria Egypt..A.E. 1910:75 M. Antonius $L$ vet bf $\cos$ XII Fulm Date? Cappadocia........ III 6800 Cocceius Long(us?) mil XI Cl 155 A.D. Almus Moes Inf........ III 7449 M. Furfanius M. f. Col. L Paraeton(io) vet II Tr fort 194 A.D.

Alexandria Egypt........................III 6580

Iulius L 7 III Aug 52-57 A.D. Simitthus............... VIII 14603

Iull(us) Long(us?) vet (V Mac) c134 Troesmis............III 6178

Iul(Ius) Long(us?) vet (V Mac) c134 Troesmis.............III 6178

C. Iulius L Miso (mil III Cyr aut XXII Deiot) 90 A.D. Fayoum

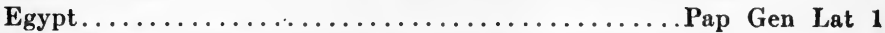

C. Iulius Long(u)s Sipo (mil III Cyr aut XXII Deiot) 90 A.D.

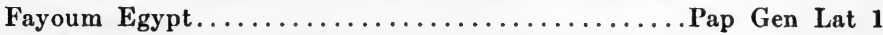

C. Iul(ius) Lon(g) us vet I Adiut post 114 Brigetio Pann Sup.... III 435\&

M. I(uli)us L (mil III Cyr aut XXII Deiot) 90 A.D. Fayoum

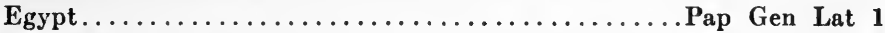

T. Sergius L 7 XV Apol post Traian? Carystus Euboea........ III 12886

Val(erius) Long(us?) vet (V Mac) c134 Troesmis............III 6178

Val(erius) L mil XI Cl 155 A.D. Almus Moes Inf............. III 7449

L. Valerius Long(us) (mil? III Aug) Date? Castra Lambaesitana .............................. 1899:81

-anlus L Apam(ea) vet? (III Aug) aet Hadriani Castra Lam-

baesitana ............................. 18084

- L 7 (leg XXII aut III Cyr) aet Augusti Coptos Egypt.... III 6627

L 7 (leg XXII aut III Cyr) aet Augusti Coptos Egypt...... III 6627

LUCANUS

P. Aelius L 7 VII Gem Date? Rome................. VI 3211

Q. Aelius L mil (III Aug) Date? Lambaesis.............. VIII 2784

Annius L ? (III Aug) 253-268 A.D. Castra Lambaesitana. . . . . . VIII 18061

Mamilius L 7 VII Gem fel Date? Bracara Aug Tarraconensis.... II \&4\&5

Sicinius $L$ vet XIII Gem post Traian Dacia incerta..........III 1606

C. Tadius L 7 VII Gem fel Date? Tarraco............... 4165 -omullius L (mil? III Aug) c800 Castra Lambaesitana

Bull Archeol 1905 pes9

Lus L Kar mil? (III Aug) aet Antonini Pii Castra Lambae-

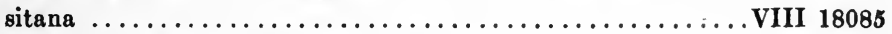

— L 7 III Aug Date? Lambaesis................ VIII 9100 LUCIANUS

L. Antistius L Nicom(edia) vet? (III Aug) aet Hadriani Cast-

ra Lambaesitana..........................VIII 18084 
C. Aponius L bf trib III Cyr Date? Bostra Arabia..........III 101 Aurelius L frum II Ital Date? Rome................. VI 3340 Aur(elius) L mil IIII Fl Date? Guberuci Moes Sup...........III 8166 Bassilius $L$ arm cust III Aug c285 Castra Lambaesitana.... A.E. 1902:11 Fla(vius) I mil II Aug Date? Auchindavy Eng............VII 1118 Iulius L DXPrim p p III Aug p v Antonin 218 A.D. Castra Lambresitana $\ldots \ldots \ldots \ldots \ldots \ldots \ldots \ldots \ldots \ldots \ldots \ldots \ldots \ldots \ldots \ldots$ VIII 2564

C. Iulius L cor III Aug p v 203 A.D. Castra Lambaesitana . . . . . . VIII 2557 C. Iulius L Ca(8?) mil? (III Aug) Date? Castra Lambaesitana VIII 2569 Terent(ius) L sig II Ital Date? Pola .................. 46 -ius L Cla(udio)pol(1) vet? (III Aug) aet Hadriani Castra

Lambaesitana .......................... VIII 18084

$\longrightarrow$ L Lamasb(a) mil? (III Aug) aet Antonini Pii Castra

Lambaesitana .......................... VIII 18085 onius L 7 II Tr fort 194 A.D. Alexandria Egypt..........III 6580 LUCIDUS

Aelius L dup III Aug p v Antonin 218 A.D. Castra Lambaesitana. VIII 2564 L ? II Adiut Date? Aquincum Pann Inf..............III 3541 L mil? II Adiut 2-3s? Aquincum Pann Inf..........III 10458

\section{LUCILIUS}

Aur(elius) L agr? (leg?) Date? Apulum Dacia............III 1189 Aur(elius) L (vet) ex optione (V Mac?) Date? Potaissa Dacia..III 7688 T. F1(avius) L mil XIII Gem post 100 Carnuntum Pann Sup..... III 11217

\section{LUGILLUS}

M. Aur(elius) M. f. Pap. Lucil(1)us Poetovio 7 I Ad II Tr VIII

Aug XIII Gem VII Cl VII Gem Date? Tarraco............II 4147

\section{LUCIUS}

P. Aelius 7 VII Gem Date? Rome.................. VI 31175

Afranius L mensor (III Aug) 3s? Castra Lambaesitana. . . . A.E. 1904:72 Aufidius L 7 (III Aug) probatus in leg III Gall c210 Castra Lam-

baesitana ............................. 1898:19

Aur(elius) L (vet) ex arm cust (V Mac?) Date? Potaissa Dacia III 7688

Q. Aquilius L 7 II Aug Date? Ancyra..................III 261

T. Cerv(onius) Luci(us) natus Savariae 7 XVI Fl post Traian

Ancyra ............................... 264

Tib. Claudius L Ael. Philadel. Emese ? (III Aug) Date? Cas-

tra Lambaesitana............................. 2568

F1(avius) L mil XIIII Gem post 100 Carnuntum Pann Sup. . . . . III 11217

Perel(ius) L (mil? III Aug) c218? Castra Lambaesitana

Bull Archeol 1904 p206

L. Retonius L p p I Adiut post 114 Brigetio Pann Sup..........III 11031

Sept(imius) L spec legg III Antonin ( $=$ X Gem XIV Gem I Ad)

c212 Carnuntum Pann Sup....................II 4452

Vibinius $L$ bf $\cos$ Date? Lancaster Eng................ VII 286

LUCULLUS

M. Cl(audius) Ti. f. L 7 leg XIII 7 leg XIII Date? Solva Noricum III 5336 


\section{LUGUS}

P. Ael(ius) Cla. L Thessa(lonica) vet II Adiut 8-3s? Aquincum

Pann Inf ........................... 10500

LUGUDUNOLUS

C. Iulius C. filius Quirina L Augustiduno mil (III Aug) 1s?

Theveste $\ldots \ldots \ldots \ldots \ldots \ldots \ldots \ldots \ldots \ldots \ldots \ldots \ldots . \ldots \ldots$. 1897:29

\section{LUPIANUS}

— L dup X Gem Date? Ager Celianus Noricum......... III 5293 LUPULUS

Cassianus $L$ mil I Min p f 2 s Lyons

XIII 1846

$L$ vet (V Mac) c134 Troesmis

III 6178

L 7 leg? Date? Col Agrippinensium................ 1903:278 LUPUS

P. Aelius L bf cos Date? Salonae Dalmatia...............III 200 f

Aur(elius) $L$ spec I et II Adi $\mathrm{f}$ Sever 228 A.D. Aquincum Pann

Inf $\ldots \ldots \ldots \ldots \ldots \ldots \ldots \ldots \ldots \ldots \ldots \ldots \ldots \ldots \ldots \ldots \ldots \ldots \ldots$ III 8524

Hos(tilius) L 7 (leg?) Date? Vindobala Eng............. VII 558

T. Publienius $\mathrm{L}$ comm VII Gem c200 Tarraco..............II 4182

L. Valerius L (eq? III Aug) $22 \&-35$ A.D. Castra Lambaesitana

\section{LUSIMACUS}

MAH 1897 p447

P. Aelius C1. L Tessalonica mil II Adiut 3s? Aquincum Pann Inf III 9588 LYCAO

Cn. Curius L 7 I Adiut post 114 Brigetio Pann Sup........... III 4885-6 LYCUS

P. Ael(ius) L vet II Adiut $2-38$ ? Aquincum Pann Inf.........III 10500 LYSIAS

C. Iul(ius) L 7 XIII Gem Sever c225 Apulum Dacia........... III 14468 MACCAUS

M. Magius M. (f) Pop. M Verona mil XI Cl p f Vespas-Traian

Vindonissa

XIII 5211

MACCUS

C. Harnius M mil III Aug Date? Lambaesis.............. VIII 18301

MACEDO

Caelius $M$ vet (III Aug) Date? Lambaesis............... VIII 3070

Fl(avius) Mace(do?) vet VII Cl 135 A.D. Viminacium Moes Sup III 8110

C. Val(erius) M 7 VII Cl 168 A.D. prope Cuppas Moes Sup...... III 8097

Q. Val(erius) Mac(edo) vet V (Mac) M. Aurel-274 Apulum Dacia III 7798

MACELLUS

T. Metius L. f. Rom. M vet ex leg XXI ante 69? Novaesium

Germ Inf ............................. 8558

MACER

Iul(ius) $M$ vet VI Vict $p$ f ante Hadrian? Novaesium Germ Inf . . XIII 8549

C. Iulius $M 7(\operatorname{leg} \mathrm{XV}) \mathbf{1}$ ? Sarmizegetusa.............III 1478

T. Iulius L. f. Gal. M dom Nertobriga mil IIII Mac ante Vespas

Mainz .................................. 6865 
L. Pedanius C. f. M vet leg XI ante 42 Florentia........... XI 1598

M. Sentius L. f. Ouf. M vet IIII Scyt Date? Sibrium.........V 5595 MACRIANUS

Iul(ius) $M$ vet ex bf cos Date? Augusta Vindelicum Raetia..... III 8816 MACRINIUS

P. Maevius M vet (III Aug) Date? Lambaesis............. VIII 8184 MACRINUS

P. Ael(ius) Macrin(us) optio (III Aug) 198-211 A.D. Castra

Lambaesitana ............................... 2554

Aemil(ius) M arm cust (III Aug) 200 A.D. Castra Lambaesitana A.E. 190\&:10

C. Domitius M mil XXII Pr p f Date? Cartenna Mauretania

Caesariensis ................................

Iul(ius) $M$ vet (V Mac) c134 Troesmis................III 6178

Iul(ius) M imm VIII Aug Date? Grosskrotzenburg Germ Sup .. XIII 7416

M. Iulius Marci f. Aniensis Foro Iuli M mil IIII Mac ante Ves-

pas Mainz............................... 6866

Q. Licinius M 7 IIII Fl firm Date? Veczel Dacia............III 1353

(M)immius M Laud(icea) vet? (III Aug) aet Hadriani Castra

Lambaesitana ............................ VIII 18084

Olcinius M 7 XXII Pr p f post 89 Sinope Paphlagonia.........III 1440\&b

T. Pompeius T. f. M vet III Aug 1s? Thala Byzacena........VIII 504

L. Rutilius L. f. Sergia M mil (XI Cl p f) Vespas-Traian Vindonissa ........................ Anzeig f. Schwiez Alter VI p160-1

M. Sossius M Nicom(edia) vet? (III Aug) aet Hadriani Castra Lambaesitana ............................. VIII 18084 - M Cirt(a) bf leg (III Aug) aet Hadriani Castra Lambaesitana ................................. VIII 18084 M mil leg II -Date? Rusicade................VIII 7982 MACRO

- stius M 7 II Tr fort 194 A.D. Alexandria Egpyt..........III 6580 MACROBIUS

T. Aelius M bf cos VIII Aug Date? Antipolis Gall Narb....... XII 5723 MAECIANUS

P. Mestrius P. f. Maecia(nus) vet leg VII ante Claud? Iconium

MAGIO

A.E. 1903:74

Ae(mi)lius M 7 III Aug coh IV 162 A.D. Castra Lambaesitana.. VIII 18065 MAGIUS

C. Atilius $M$ vet VIII Aug Date? Meda.............. 5713

Tertius Magi(us?) 7 III Aug coh V 162 A.D. Castra Lambaesitana .................................. 18065 MAGNIANUS

T. Clodius M Pap? pec (III Aug) Date? Castra Lambaesitana VIII 18086 MAGNIO

M. Ulp(ius) M R(emesiana?) vet VII Cl 195 A.D. Viminacium Moes Sup..............................III 14507 


\section{MAGNIUS}

Logius $M$ vet ex dup? (III Aug) 270-275 A.D. Lambaesis...... VIII 2626 8 M Hadr(umeto) arm cust (III Aug) Date? Castra

Lambaesitana ........................... 2585

\section{MAGNUS}

L. Antonius L. f. Lem. M Bon(onia) mil X Gem aet Traiani

Carnuntum Pann Sup ....................... 14358:13a

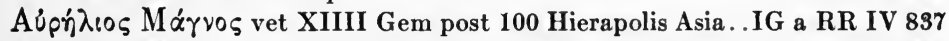
Aur(elius) $M$ mil XIIII Gem post 100 Carnuntum Pann Sup..... III 4459

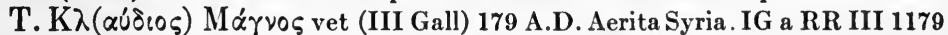
Cornelius $M$ vet? (III Aug) aet Hadriani Castra Lambaesitana VIII 18084 T. F1(avius) T. (f) Quir. M 7 XII Fulm 7 III Gall 7 VII? Date?

Aquincum Pann Inf..................... 14II 1449:3

Iul(ius) M 7 VIII Aug 1s Segedunum Eng............. VII 495

C. Iulius M 7 III Cyr 90 A.D. Coptos Egypt.............III 13580

T. Manius T. f. Pollia M Senope 7 XXII Pr p f 28 ? Steinbach. XIII 6502

P. Pompeius P. f. (A)em. M S(t)ob(is) vet I Ital Date? Ad

Haemum Moes Inf ......................... III 12400

Sep(timius) $M$ bf $\cos$ (leg?) Date? Apulum Dacia...........III 1189

M. Septimius M. f. Fab M 7 III Gall IIII Scyt XX V v I Min

X Fr ante 218 Aradus Syria................... 186

T(iberius) Magn(us) vet (V Mac) c134 Troesmis............III 6178

C. Titius C. f. $\operatorname{Ro}(\mathbf{m}) \mathbf{M} \operatorname{sig} \operatorname{leg} V$ Urb c31 B.C. Ateste ......... V 2514

Volusius M 7 X Fr Date? Rome................... 3614 MAIANUS

C. Iul(ius) M 7 VIII Aug Date? Ems............. XIII 7733 MAICINUS

P. Aelius $M$ vet II Parth 3s? Ager Hastensis............. 7591 MAIOR

Ael(Ius) M optio XXII Pr p f 178 A.D. Stockstadt..........XIII 6630

Ael(ius) $M$ arm cust III Aug Date? Lambaesis............. VIII 2783

P. Aelius $M$ vet III Aug Date? Lambaesis............... VIII 3016

P. Afranius M mil XV Apol 1s Carnuntum Pann Sup.......... III 13480 Atilius M 7 (leg ?) coh II Date? Chester Eng.........E.E. VII 878 Aur(elius) Maio(r) Cart ex sagittaris salarius II Parth Sever c215? Ager Albanus....................E. IX 659

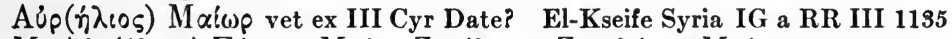

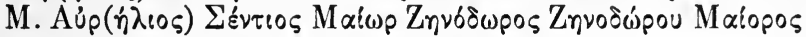
vibs vet ex III Cyr Date? Saccaea Syria.......IG a RR III 1193

M. Pomentinus M 7 III Aug Date? Bir Umm Ali.......VIII 17591 MALCHIAS

M. Aur(elius) Malc(h)ia(s) (mil) II Adiut str off cos $2-3$ s Intercisa Pann Inf ......................... 10315 MALCHUS

Aurel(ius) Malc(h)us vet ex 1 s? (III Aug) 270-275 A.D. Lambaesis..........................VIII 2626 ef 18098 
C. Iulius M Cas mil? (III Aug) Date? Castra Lambaesitana.. VIII 2569

M. Ulpius $M 7$ XXII Pr $p$ is? Miltenberg............ XIII 6606 MANDATUS

Sex. Salaniu(s) P. f. Mandat(us) mil leg XV Date? Verona....V 3973 MANDUCCUS

Ti. Claud(ius) $M$ mil III Aug 1s Theveste............. VIII 16547 MANGALA

C. Petronius M Cuic(ulo) vet III Aug p v c198 Castra Lambaesitana................................. VIII 18068 MANLIANUS

L. Iulius Manlian(us) lib (III Aug) Date? Castra Lambaesi$\operatorname{tana} \ldots \ldots \ldots \ldots \ldots \ldots \ldots \ldots \ldots \ldots \ldots \ldots \ldots$ VIII $\mathbf{2 5 6 0}$

C. Nonius M 7 III Ital Date? Lambaesis............... VIII 2953 MANSUETUS

T. Fl(avius) M 7 III Aug Date? ante Gordian Calceus Herculis Numidia.............................. VIII $\mathbf{2 4 9 7}$

Iulius Mans(uetus) 7 (leg ?) Date? Cambriae oppida Eng......VII 143

C. Iulius G. f. Gale. Lug(uduno) Ma(n)suetus mil III Aug

1s? Ammaedara ............................ 1912:803

C. Iul(ius) $M$ mil I Min $\mathrm{p} f$ Date? Col Agrippinensium........ XIII 8213

Maximius M 7 XII Fulm Date? Neviodunum Pann Sup....III 3926

M. Petronius M. f. Vol. M Viana mil IIII Mac ante Vespas Mainz................................ 6871

Q. Ref(idius?) M p p XIIII Gem post 100 Carnuntum Pann Sup....................................III 14074

Val(erius) M p p (III Aug) Date? Lambaesis..............VIII 18321 Va(lerius?) M dup (XIIII Gem?) ante 178 Carnuntum Pann Sup................................III 11180

Sex. Valerius Sex. f. Vol. Ma(n)suetus Viena mil IIII Mac ante Vespas Mainz .......................... XIII 6873

MARCELLINUS

Ael(ius) Marce(llinus?) vet VII Cl 135 A.D. Viminacium Moes Sup ............................. III 8110

L. Aemil(i)us Ma(r)c(ell)inus p p (III Aug) Date? Lambaesis. VIII 2598

T. Aridius M 7 II Tr fort 155 A.D. Alexandria Egypt........III 14147:3

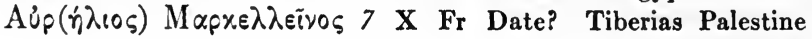

IG a RR III 1204

Baebius M 7 II Tr fort 194 A.D. Alexandria Egypt.........III 6580 G. Baeb(ius) $M$ bf $\cos$ X Gem 225 A.D. Latobici Pann Sup..... III 3903 T. C(a)miliu(s? Mar)cellinus (mil) VI(II Aug) Date? Stockstadt........................................ 6654 Claren(ius?) M corn legg III Antonin ( $=$ X Gem XIV Gem I

Ad) c212 Carnuntum Pann Sup...................III 4452 Cl(audius) M bf $\cos 190$ A.D. Rigomagus Germ Inf ......... XIII 7790 M. Clodius M mil I Min 2s? Bonn................... XIII 8021

Q. Clodius M 7 I Min p $f$ \&s? Bonn.................. XIII 8010 Fla(vius) Ma(r)cellinus tess (V Mac) M. Aurel-274 Potaissa 
Dacia III 7686

F1(avius) $M$ mil III Ital Date? Castra Regina Raetia......... III 5950 Iul(ius) M (7) II Aug Date? Amboglanna Eng........E.E. VII 1071 C. Iulius C. f. Ser. M Tavio mil III Cyr ante 108 Alexandria

Egypt.............................. 14I 148:8

C. Iulius M (eq? III Aug) \&2q-35 A.D. Castra Lambaesitana

(M)arcellinius Marce(1li)nus sig (III Ital) Date? Castra

Regina Raetia..............................III 5958

Marius M mil II Parth Date? Rome.................VI $\mathbf{3 2 7 7}$

L. Papius $M$ vet I Ital Date? Pirano ................... 481

L. Septimius L. f. n. Pannonius d Ulp. Papir Petavione M

7 I Adiut XIIII Gem XXX Ulp vict Sever Alexand c285 Lyons. XIII 1890

M. Val(erius) M Sc(upis) vet VII Cl 195 A.D. Viminacium

Moes Sup..................................III 14507

L. Vib(ius) (M)arcellinu(s) vet XIIII $\mathrm{G} m$ v post 100 Carnuntum

Pann Sup.................................. $\mathbf{4 4 4 9}$

MARCELLUS

(A)el(ius) Marcell(us) mil II Parth Date? Rome...........VI 3967

P. Aelius M Iv(?) mil? (III Aug) aet Antonini Pii Castra

Lambaesitana............................... VIII 18085

Aur(elius) M mil I Adiut Date? Perinthus Thracia............III 7396

M. A(urelius) M mil ? VIII Aug 1s? Cyrrhus Syria...........III 193

M. Claudius M vet (III Aug) Date? Verecunda............ VIII 18513

Cl(audius) M(a)rcel(lus) mil leg XIIII post 100 Carnuntum

Pann Sup................................. 11118

Coetius M 7 X Gem ante Traian Brohl.................. XIII 7698

Cornel(ius) Marcel(lus?) (7) XXII Pr p f Date? Mainz....XIII 6668

(Flavius?) M Larisa vet? III Aug aet Hadriani Castra Lam-

baesitana............................... VIII 18084

M. Fuficius M. f. Vel. M Aquil(eia) 7 I Adi p f post 114 Brigetio

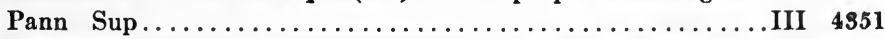

Maecius M 7 XI Cl 75 A.D. Bovianum Undecimanorum......IX 2564

P. Marcius Marcel(lus?) arm cust (III Aug) 200 A.D. Castra

Lambaesitana.............................E. 1908:10

C. Octavius M mil III Aug Date? Lambaesis.............. VIII 3211

M. Paccius C. f. Gal. M p p IIII Scyt Date? Ager Compsinus..IX 1005

Salvius M 7 XV Apol 1s Carnuntum Pann Sup..........II 14958:14

M. Seius Mar(cell)us For(o) Iul(i) mil X Gem Date?

Athens..........................III $7888=14405 \mathrm{~d}$

Teltonius $M$ bf trib? III Aug c200 Castra Lambaesitana....VIII 18078

M. Ulp(ius) M bf cos IIII Fl firm Date? Sopianae Pann Inf.... III 15149

M. Valerius M. (f.) Aniesis Marcel(1)us Vercelis mil II Aduti

\&-3s Aquincum Pann Inf ......................III 14349:9

Vasellius M 7 I Ital Date? Almus Moes Inf..............III 7441

M. Vibrius M 7 leg XVI Date? aet Tiberii vel Gai Rome......VI 31706 M 7 III Aug 1s Ammaedara Numidia.......... MAH 1912 p128 M 7 II Tr 298 A.D. Tingitana Egypt Acta Martyr p30\& ed Ruinart 


\section{MARGIANUS}

C. Acilius M Caralitanus 7 princeps XIIII Gem Date? Velitrae............................. 6574

Ael(lus) M(a)rcia(nus) vet VII Cl 185 A.D. Viminacium Moes Sup .................................III 8110

M. Ant(onius) Marcian(us) Sc(upis) bf trib vet VII Cl 195

A.D. Viminacium Moes Sup................... III 14507

(Au)rel(ius) Mar(ci)anus mil I Ital Sever c£25 Salonae Dalmatia...............................III 12898

Aur(elius) Marcia(n)us sta leg VII Cl 270 A.D. Viminacium Moes Sup..............................III 8117

Aurel(ius) $M$ (vet) III Aug Date? Lambaesis...............VIII 3055

M. Aur(elius) Marcianu(s) (bf) cos leg ? Se(ver Alexand p) v 234 A.D. Naissus Moes Sup..................III 14564

P. Aur(elius) M mil leg VII Date? Horreum Margi Moes Sup................................III 12666

(P. Aurelius?) $M$ vet leg VII Date? Horreum Margi Moes Sup................................III 12666

C. Cassius Marcian(us) Oea mil? (III Aug) Date? Castra Lambaesitana...........................VIII $\mathbf{2 5 6 7}$

F1(avius) M 7 XIIII Gem 7 XV Apol c100 Ancyra............III 248

(T) Flavius M. (f) Col. M domo Philad(elphia) optio hast

VI Ferr Date? Bostra Arabia ................... 1909:132 Iul(ius) Marcia(nus)? (III Aug) 253-268 A.D. Castra Lambaesitana................................ VIII 18061

Iul(ius) M 7 ? XIII Gem post Traian Apulum Dacia........III 8065:30

Iulius $\mathbf{M}$ mil frum XXX Ulp Date? Formiae............... 6095

C. Iul(ius) Marcian(us) Nic(opoli) vet VII Cl 195 A.D. Viminacium Moes $\operatorname{Sup} . \ldots \ldots \ldots \ldots \ldots \ldots \ldots \ldots \ldots \ldots$ III 14507

P. Lucceius $M$ Nicom(edia) vet? (III Aug) aet Hadriani Castra Lambaesitana........................ VIII 18084

Petr(onius) M (vet) ex lib (V Mac?) Date? Potaissa Dacia...III 7688 Q. Sallustius M Tham(ugadi) mil? (III Aug) Date? Castra Lambaesitana............................VIII 2568

Staberius Marcian(us) dup III Aug p v Antonin 218 A.D. Castra Lambaesitana............................ VIII 2564

Staberius $M$ imm III Aug p v Antonin 218 A.D. Castra Lambaesitana............................... VIII 2564

M. Strobilius Marcian(us) exactus III Aug $p$ v c\&0\& Castra Lambaesitana......................... 1898:108 Valer(ius) $M$ vet ex librario (III Aug) 270-275 A.D. Lambaesis. . VIII 2626 Val(erius) M sig III Aug Date? Lambaesis.............. VIII 2992 G. Valerius $M$ spec VII Gem c200 Tarraco..................II 4128 (M) Val(erius) Marcian(us) Rat(iaria) vet VII Cl 195 A.D.

Viminacium Moes Sup.....................III 14507

P. Val(erius) M mil dup X Gem Antonin c215 Poetovio Pann Sup................................... III 4030

(T. Valerius) T. f. Pol(1)ia Marci(anus) Cas vet V Mac ex bf cos 
170 A.D. Troesmis . III 7505

Veturius Marcian(us) vet XIII Gem post Traian Dacia incerta. .III 8044 Vivius $M$ mil II Aug Dater London.................. VII 23 - M Nic(omedia) vet? (III Aug) aet Hadriani Castra

Lambaesitana............................ VIII 18084

M optio II Adi p f Date? Aquileia.............. V 811

MARCULUS

Marc(u)lus? mil? leg X Date? Vienna...........III 11309

\section{MARGUS}

P. Ael(ius) M 7 X Gem Date? Rome................ VI 31182a

Aur(elius) M 7 IIII Fl Gallienae $253-268$ A.D. Singidunum

Moes $\operatorname{Sup} \ldots \ldots \ldots \ldots \ldots \ldots \ldots \ldots \ldots \ldots \ldots \ldots \ldots \ldots \ldots \ldots \ldots \ldots \ldots$ III 8148

A(urelius) $M$ bf cos XIIII Gem post 100 Neviodunum Pann Sup.. III 3918

Aurel(ius) M (mil? II Parth?) Date? Rome..............VI $\$ 410$

Aur(elius) M mil (leg?) Date? Magnae Eng............... VII 793

M. Aurelius M.f. Pol. M vet II Tr fort 194 A.D. Alexandria Egypt III 6580 F1(avius) M spec legg III Antonin ( = X Gem XIV Gem I Ad) c212

Carnuntum Pann Sup...................... 4II 4452

Iul(ius) M mil XI Cl 155 A.D. Almus Moes Inf............. III 7449

C. Iul(ius) M R(emesiana?) vet VII Cl 195 A.D. Viminacium

Moes $\operatorname{Sup} \ldots \ldots \ldots \ldots \ldots \ldots \ldots \ldots \ldots \ldots \ldots \ldots \ldots \ldots$ III 14507

T. Mans(uetius?) Marcu(s) mil XXX Ulp vict Date? Rigomagus

Germ Inf...........................XIII 7789

Pompei(us) M (mil? II Parth?) Date? Rome.............. 2410

Aur. Superinius M bf $\cos 214$ A.D. Dottendorf Germ Inf . . . . . XIII 7998

Valerius $\mathrm{M}$ mil XI Cl 3s Durostorum Moes Inf.............III 7477

Oن́ $\alpha \lambda(\varepsilon ́ p l o \varsigma)$ M $\alpha p x \circ \varsigma$ vet ex eq leg VI Date? Lake of Tiberias

Syria .......................... IG a RR III 1110

- I- M Kastris vet II Tr fort 194 A.D. Alexandria Egypt.... III 6580

- M ? (I)II(I F)l Date? Eporedia............... 6783

MARIANUS

Clod(ius) M frum VII Gem Date? Bedaium Noricum.........III 5579 $\Gamma$ 'Exoúıos Mapıavds (7) III Gall 182-92 A.D. Phaena Syria

IG a RR III 1116

us M Sirm(io) optio? (III Aug) aet Hadriani Castra Lam-

baesitana ............................ VIII 18084

MARINIANUS

Fl(avius) Marin(i)a(nus) mil VIII Aug Is? Duenhausen Germ

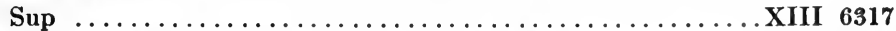

L. Marinius M 7 VII Gem Alexand ante 235 Wiesbaden....... XIII 7564

- Mari(ni)anus vet XIII Gem Date? Aquileia......... 850

MARINUS

P. Aelius M 7 I Min Date? Hersel Germ Inf ............ XIII 8150

Q. Aemilius $M$ singular II Aug Date? Rome.............VI 3339

Aurel(ius) M vet ex actar (III Aug) 270-275 A.D. Lambaesis.... . . VIII 2626

L. Aur(elius). M vet XIII Gem Antonin c215 Apulum Dacia.....III 14476 
M. Aur(elius) $M$ vet XIII Gem post Traian Apulum Dacia. III 989

Cornel(ius) $M$ arm cust (III Aug) 800 A.D. Castra Lambaesitana

A.E. $1902: 10$

G. Iul(ius) M Ara armatura XIIII G m v 70-100 A.D. Mainz ... XIII 6895

L. Valerius L. f. Vol. Mar(i)nus Tol(osa) mil X Gem 70-Traian

Ulpia Noviomagus.......................... 8796

M. Val(erius) $M$ vet I Adi $p$ ex sig 2 s Brigetio Pann Sup....... III 4298

- M 7 II Tr fort 194 A.D. Alexandria Egypt............III 6580

M strator leg (leg I Ad)iut post 114 Brigetio Pann Sup....III 4317

MARITIMUS

Aelius $M$ bf cos Date? oppida circa Burgos Tarraconensis......II 2915

C. Iulius C. f. Cl. M Ara 7 VI Vict 7 XX V v 7 II Aug 7 III Aug

Date? Lambaesis ............................. 2907

M. (L?)ucr(etius) Mar(i)tumu(s) Lugu(d)un(o) mil III Aug

1s Ammaedara ........................... 1900:123

MARIUS

Aurel(ius) $M$ opt sig XIII Gem post Traian Apulum Dacia......III 1124

Cl(audius) M 7 XIII Gem 160 A.D. Verespataki Dacia.........III p959

MARO

T. V(a)rronius $M$ frum et 7 frum III Cyr aet M. Aurel Salonae

Dalmatia ............................III 8063

MARSUS

C. Lic(inius) $M$ vet III Aug Date? Lambaesis ............. VIII 3176

Mars(us) 7 (leg?) coh VIII Date? Borcovicium Eng...... VII 678

MARTIALIS

Aelius Martial(i)s mil XI Cl 155 A.D. Almus Moes Inf........ III 7449

P. Ael(ius) $M$ vet ex arm cust II Adiut Date? Aquincum Pann Inf III 3529

Aemilius M Apamea vet? (III Aug) aet Hadriani Castra Lam-

baesitana ............................. III 18084

(A)emilius M dup III Aug p v Antonin 218 A.D. Castra Lambaesitana $\ldots \ldots \ldots \ldots \ldots \ldots \ldots \ldots \ldots \ldots \ldots \ldots \ldots \ldots \ldots \ldots$. $256 \ldots \ldots$

Annius Martial(is) arm cust (III Aug) 200 A.D. Castra Lambaesitana ............................... 1908:10

M. Annius M. f. Quir. M mil et 7 (III) Aug et 7 XXX Ulp vict

162 A.D. Thamugadi Numidia................... VIII 2354

Ant(onius) M 7 XXII P r p f 3s? Cartenna Mauretania Caesariensis ................................VIII 21508

Q. Apuleius M Kar vet? (III Aug) aet Hadriani Castra Lam-

baesitana ................................ 18084

Aufidius M 7 I Min aet Domitiani Bonn...............XIII 8071

Aur(elius) $M$ mil I Ital Date? Salonae Dalmatia............. III 2008

L? Aurelius M Am(maedara) vet? (III Aug) 2s? Castra Lam-

baesitana ........................... VIII 18087

M. Aur(elius) M vet ex sig II Adiut Date? Aquincum Pann Inf...III 3538

Baebius $M$ dup III Aug p v Antonin 218 A.D. Castra Lambaesi- 
L. Cassius L.f. Trom. M Aq(uis) Sta(tiellis) mil XI Cl p f 4qVespas Burnum Dalmatia.....................II 2833

Cerellius Martial(is) dup III Aug p v Antonin 218 A.D. Castra Lambaesitana ........................... 2564

C. Domitius M August str (III Aug) Date? Castra Lambaesitana ................................... 2568

C. Egnatius M Tham(ugadi) vet III Aug p v c198 Castra Lambaesitana .............................. 18068

F1(avius) $M$ spec legg III Antonin ( $=$ X Gem XIV Gem I Ad) c212 Carnuntum Pann Sup........................ 4452

Flavius M dup III Aug $p$ v Antonin 218 A.D. Castra Lambaesi-

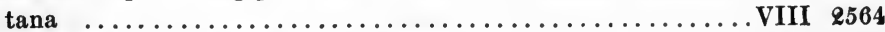

T. Flavius $M$ (mil III Aug) 1s Theveste................ VIII 1876

C. Gellius M Gilio vet III Aug p v c198 Castra Lambaesitana. . . . . VIII 18068 Iulius M 7 (IIII Mac) ante Vespas Mainz.............. XIII 6858 Iulius Marti(alis) ? (III Aug) 253-268 A.D. Castra Lambaesi-

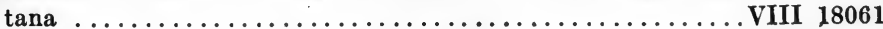

Iulius $M$ vet (III Aug) Date? Lambaesis............... VIII 3155

C. Iulius M cor III Aug p v 203 A.D. Castra Lambaesitana...... VIII 2557

C. Iulius M ? (III Aug) 209-211 A.D. Castra Lambaesitana ... . . VIII 2556

C. Iulius M Cas vet? (III Aug) Date? Castra Lambaesitana.. VIII 18086

C. Iul(ius) $M$ vet (III Aug?) Date? Zarai................ VIII 4524

C. Iulius M arm cust III Aug Date? Lambaesis..... VIII 2908-9 (et 2910)

C. Iulius $M$ vet II Adi p f c150 Rokba................. 1896:77

C. Lollius M ? (III Aug) Date? Castra Lambaesitana......... VIII 2562

P. Longinius $M$ tub III Aug Date? Lambaesis.............. VIII 2936

C. (Ma)rrucinus $M$ vet (III Aug?) Date? Zarai............. VIII 4528

C. Memmius M 7 leg XI Vespas-Traian Mainz.............XIII 6706

L. Nonius M Vag(a) bf (III Aug) Date? Castra Lambaesitana. . VIII 2568 Octavius Martial(is) arm cust III Aug c225 Castra Lambaesitana

A.E. $1902: 11$

C. Postumius M eq III Aug Commodae aet Commodae Lambaesis VIII 3163

C. Rutilius M Cas mil? (III Aug) Date? Castra Lambaesitana VIII 2568 Sa(lvideniu)s Marti(al)is mil (III Aug) Date? Lambaesis.... VIII 18316 L. Tonneius $M$ cerarius III Aug p v c20\& Castra Lambaesitana A.E. 1898:109

(L.) Tonneius $M$ lib cerarius III Aug Date? Lambaesis...... . VIII 2985-6

L. Tonneius $M$ vet III Aug Date? Lambaesis.............. VIII 2985

M. Ulp(ius). M 7 I Min aet Hadriani Rome............... VI 31158

Valerius $M$ mil III Aug Date?' Bagai Numidia.............. VIII 2278 M. Valer(ius) M. f. Claud. M (eq? leg?) Date? Chester Eng E.E. IX 1089 M. Vibius M 7 X Gem aet Vespas-Domitiani Mediomatrici Belgica XIII 4624 Volcacius $M$ bf $\cos$ Date? Ivenna Noricum...............III 5078 M. Ulp(ius) Martial(is) Sc(upis) interpres vet VII Cl 195 A.D.

Viminacium Moes Sup......................III 14507 cius (Mar)tialis Kar mil? (III Aug) aet Antonini Pii Castra Lambaesitana ............................ 18085

—lius M Kar ? (III Aug) Date? Castra Lambaesitana....... VIII 2565 
- ius M Pa. Tel(epte) str (III Aug) Date? Castra Lambaesitana .................................... VIII 2565 _ Mart(Ialis) vet III Aug Date? Lambaesis............VIII 3193 MARTIANUS

Aelius $M$ bf $\cos$ I Ital Date? Salonae Dalmatia.............III 2023

G. Pollius G. filius domo Col. Ael. Mursa M vet ex arm cust II

Adiut $\mathbf{\ell - 3 s}$ Aquincum Pann Sup...................III 3560 MARTINIANUS

Serenn(ius) Mart(i)n(i)a(nus) 7 (V Mac)? M. Aurel-274 Potais-

sa Dacia................................III 7698

MARTINUS

Ael(ius) M 7 XXII (Pr p f) Date? Mainz................ 1908:257

Aur(elius) M mil IIII Fl \&-3s? Cyrrhus Syria...............III 195

T. Cla(udius) $M$ aquil II Adiut 2-3s? Aquincum Pann Inf..... III 6457

Flavi(us) M 7? XIII Gem post Traian Apulum Dacia.......III 1689:21

A. Hennius Mar(tinus?) 7 XII Fulm Date? Ancyra.......... III 266

C. Iul(ius) M bf cos III Aug provinciae Daciae 3s? Vazaivi.....VIII 17628

Ti. Marcius $M$ frum I Min Date? Rome................VI 3334

Pub(licius?) M spec I et II Adi p f Sever 228 A.D. Aquincum Pann

Inf $\ldots \ldots \ldots \ldots \ldots \ldots \ldots \ldots \ldots \ldots \ldots \ldots$ III 3524

Sept(imius) $M$ mil II Adi $\mathrm{p}$ \&-3s Vorosvar Pann Inf..........III 10569

Ulp(ius) $M$ singular consular VII Cl Sever Alexand c225 Naissus

Moes Sup.............................III 8844

M. Ulp(ius) Martin(us) Mur(sa) str vet VII Cl 195 A.D. Vimin-

acium Moes Sup.......................... 14507

M. Ulp(ius) M str cos VII Cl Sever 225 A.D. Naissus Moes Sup..III 1676

Val(erius) $M$ mil XIIII Gemnatione Pannonius 3s Rome........VI 2758

M 7 II Adiut 8-3s? Aquincum Pann Inf ............ III 10499

\section{MARTIS}

Q. Aenius M dup (III Aug) Date? Lambaesis............. VIII 2799 MARTIUS

M. Iul(ius) M 7 XXX Ulp vict XXII Pr p f 189 A.D. Vetera Germ

Inf $\ldots \ldots \ldots \ldots \ldots \ldots \ldots \ldots \ldots \ldots \ldots \ldots \ldots \ldots \ldots \ldots \ldots \ldots \ldots \ldots$ XIII 8640

L. Senecianius M 7 VI Vict post Hadrian Manchester Eng....... VII 211 MARULLIANUS

Cn. Coelius Cn. f. Pap. M do Narbo mil IIII Mac ante Vespas

Mainz .................................... XIII 6863

MASGELLIO

Vinnius Mascel(1io) 7 III Aug coh III 162 A.D. Castra Lambaesi-

tana ................................... $1806 s$

MASGULINUS

Ulp(ius) $M$ vet ex sig V Mac 204 A.D. Napoca Dacia..........III 7657 MASGULUS

Aemilius $M$ dup III Aug $p$ v Antonin 218 A.D. Castra Lam-

baesitana................................ VIII $\mathbf{2 5 6 4}$

Gargillius M cor III Aug p v 203 A.D. Castra Lambaesitana...... VIII 2557 
Ti. Iul(ius) $M$ prin II Adi p f 2 -3s Aquincum Pann Inf........ III 3501

C. Masculinius M 7 I Adiut Date? Virunum Noricum........III 4787

Vagionius Mas(cu)lus vet Aug (V)I Vict Date? Rome........VI 3635 MASGILUS

(A)ur(elius) Masgil(us) bf VIII Aug Date? Treveri Belgica... XIII 3645 MATERNINUS

C. Silvinius M (vet?) leg XXII 3s? Wiesbaden...........XIII 7570b MATERNUS

C. Antonius M domo Clunia 7 III Aug Date? Lambaesis.... . VIII 2807 Attici(us) $M$ mil I Min p? Date? Endwich Germ Inf. ........ XIII 8003a Aur(elius) $M$ vet II Ital natio Noric 3s Salonae Dalmatia........III 8730

F1. Iulius $M$ vet XXII $\operatorname{Pr} p$ f ex dup post 89 Castellum Mattiaco-

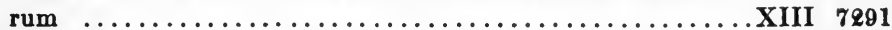

C. Iul(ius) $M$ vet ex leg I Min Date? Col Agrippinensium..... XIII 826 r

M. Iulius M. f. Qui. M Aug(usto) N(emeto) mil III Aug Is The-

veste ................................. 16549

M. (I)ul(ius) M bf cos Date? Weingarten Germ Inf.........XII 7956-7

Lucretius $M$ imag VII Gem 167 A.D. Castrum S. Christoph Tar-

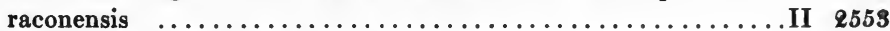

C. $\mathrm{Ma}(\mathbf{r})$ ius $\mathrm{M} 7 \mathrm{VII} \mathrm{Cl} \mathrm{p}$ aet Claudii Narona Dalmatia........III 18794

C. Sempronius M Lugu(duno) vet? (III Aug) aet Hadriani

Castra Lambaesitana.......................VIII 18084

L. Sempr(onius) M (spec VII Gem fel) Date? Tarraco........II 4143

C. Stabilius Pom. M Iuliobriga mil VII Gem fel Date? Lam-

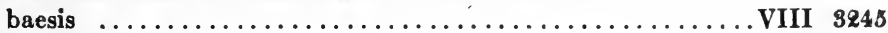

L. Valer(ius) $M$ (spec VII Gem fel) Date? Tarraco............II 4143

L. Vitellius $\mathrm{M} 7 \mathrm{X}$ Gem Date? Aquileia................ 950 M 7 (leg XXII aut III Cyr) aet Augusti Coptos Egypt.... III 6627 Matern(us) mil I min Date? Aquileia..........Pais Suppl n187 MATTHAIUS M Polai f. Suros vet I Adiut 68 A.D. Stabiae.......... X 771 MATTO

M. Val(erius) M. f. Lem. M Bononiae mil XXI Rap 70-Hadrian

Mainz XIII 6950

MATUCO

Messo(r)i(u)s $M$ vet II Ital \&-3s Ovilava Noricum. III 5624

MATURUS

Aur(elius) $M$ vet? (II Adiut) \&-3s? Ager Aquincensis Pann Inf III 10360 Caecilius M 7 frum VII Gem Date? Tarraco.............. 4150 C. Sulpicius M 7 XXII Pr p f post 89 Brohl............ XIII 7704 MAURINUS

M. Vallius M. f. Qui. M Seg. mil XI Cl p f 4q-Vespas Burnum

Dalmatia III 6419

MAURUS

Kalemerus M lib III Aug Date? Lambaesis............. VIII 2989 


\section{MAXIMIANUS}

Ael(ius) Maximia(nus) (vet) ex tess (V Mac?) Date? Potaissa

Dacia ................................III 7688

(Aurelius) $M$ sig (XIIII G $\mathrm{m}$ v?) post 100 Mursa Pann Inf ......III 3284 Aur(elius) $\mathbf{M}$ mil I Adiut Date? Aquileia................. 892 Iul(ius) M 7 (V Mac?) M. Aurel-274 Potaissa Dacia..........III 7672 C. Tocernius $\mathbf{M}$ mil II Ital Date? Naples............... 375 C. Val(erius) $M$ arm cust IIII Fl Date? Aquincum Pann Inf.... III 10518 - (M)axi(mian?) us arm cust VII $\mathrm{Cl}$ \&s Viminacium Moes

Sup.......................Jahres Wien VI Beibl n 19

\section{MAXIMINUS}

Aur(elius) $M$ (vet? V Mac?) Date? Potaissa Dacia.........III 7688 Aur(elius) $M$ tess (VII Cl) Date? Ancyra...............II 263 M. Aur(elius) $M$ vet XIII Gem post Traian Ampelum Dacia.... III 1320 Iul(ius) Maximin(us) dup (XIIII Gem?) ante 178 Carnuntum

Pann Sup........................... 11180

C. Iul(ius) M arm cust I Adiut Sever c2e5 Brigetio Pann Sup.... III 10984

C. Iu(lius) M ? VI Vict post Hadrian Segedunum Eng........... VII 494

Galus Iulius M emeritus leg VIII bf proc Date? Treveri Belgica XIII 3983

M. Lici(nius) $M$ mil II Ital \&-3s Poetovio Pann Sup....... III 15184:6 MAXIMO

M. Aur(elius) M vet VII Cl 195 A.D. Viminacium Moes Sup....III 14507 MAXIMUS

Accius $M$ mil II Ital frum $2-3$ s? Virunum Noricum......... III 4830 Ael(ius) Maxi(mus) vet VII Cl 135 A.D. Viminacium Moes Sup.. III 8110 Ael(ius) M mil V Mac M. Aurel-274 Potaissa Dacia...........III 899

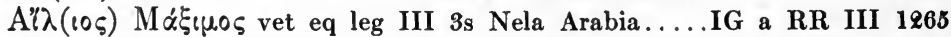
Aelius M 7 XXII Prim Date? Mainz.................. 1904:106 L. Aelius M Tus(dro) mil? (III Aug) Date? Castra Lambaesitana................................. 2568

P. A(e)1(ius) M Rat(iaria) vet VII Cl 195 A.D. Viminacium Moes $\operatorname{Sup} . \ldots \ldots \ldots \ldots \ldots \ldots \ldots \ldots \ldots \ldots \ldots \ldots \ldots$ III 14507

P. Aelius Ma(x)imus Cas mil? (III Aug) aet Antonini Pii

Castra Lambaesitana. . . . . . . . . . . . . . . . . . . . . . . . . VIII 18085

Anneus $M$ mil I Min Date? Fectio Germ Inf ............... XIII 8813

C. Ann(ius) Maximu(8) optio (III Aug) 198-211 A.D. Castra

Lambaesitana........................... 2554

C. Annius Max(imus) mil? (III Aug) Date? Castra Lam-

baesitana............................ 2567

Antonius $\mathbf{M}$ mil III Cyr ante 108 Egypt........... Wessely Lat Pal 8 Antonius $M$ cor III Aug p v 203 A.D. Castra Lambaesitana...... VIII 2557 L. Antonius Maximu(s) cor III Aug p v 203 A.D. Castra

Lambaesitana.............................. 2557

Arruntius M mensor (III Aug) 3s? Castra Lambaesitana..A.E. 1904:72 Attienius M 7 XI Cl p f Vespas-Traian Tenendo Germ Sup..... XIII 5241 Attius Max(imus) (mil) $X$ Gem Date? Vienna............III 4571 M. Aufidius M 7 VI Vict post Hadrian Bath Eng............ VII 40-41 
Aur(elius) M mil V Mac p Gordian 238-44 A.D. Siebenburgen

Jahres Wien V Beibl p 100:6

Aurel(ius) M vet II (Adiut) \&-3s? Aquincum Pann Inf .......... III 10474

Aur(elius) M 7 II Adiut aet Dioclet Josephsthal Dalmatia.... III 10060

Aur(elius) $M$ vet II Adiut Date? Pann Inf incerta..........III 3678

Aur(elius) Maxi(mus) vet IIII Fl Date? Singidunum Moes

Sup............................. 1665

Aur(elius) M (vet) ex arm cust (V Mac?) Date? Potaissa

Dacia.................................III 7688

Aur(elius) Maximu(s) (vet) ex arc(hitecto V Mac?) Date? Po-

taissa Dacia.............................. III 7688

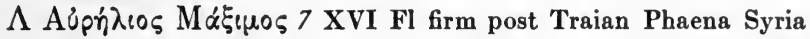

IG a RR III 1117-8

M. Aurelius M eq I Ital Antonin 215 A.D. Ad Haemum Moes Inf ..................................III 12394

(M. A)urel(ius) Max(imu)s mil I (Min? bf) cos (ex) prov

Thra (cia) 3 s? Lyons......................... 1843

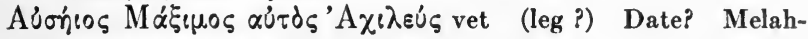

es-Sarrar Arabia...................... a RR III 1318

L. Blos(ius) Max(imus) vet (III Aug) Date? Lambaesis.... VIII 3061

C. Caecilius M mil III Aug Date? Lambaesis.............. VIII 3064

C. Calpurnius M Cas d s (III Aug) Date? Castra Lambaesitana........................................ 2569

M. Carmeius M bf cos I Adi p f 245 A.D. Dalmatia incerta...... III 3161

L. Cassius - (f) Cla. M 7 VI Ferr ante Domitiani mortem Celeia

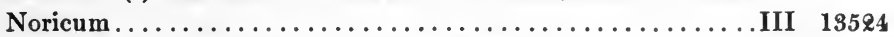

Cervius M mil XI Cl 155 A.D. Almus Moes Inf............III 7449

Claudius M 7 leg XXII ante Hadrian Thebes Egypt..........III 57

Cl(audius) $M$ vet (V Mac) c134 Troesmis...............III 6178

Cl(audius) Maxim(us) vet (V Mac) c134 Troesmis..........III 6178

Tib. Cl(audius) M 7 III Aug Date? Lambaesis............VIII 2843

T. Cl(audius) M (vet) VIII Aug Date? Rogatica Dalmatia....III 8369

M. Clodius M Ar? polio (III Aug) Date? Castra Lambaesi-

add 12749 tana.................................. 18086

(Cominius) $\mathbf{Q}$ (uirin)a? Sirmi(o) $\mathbf{M}$ vet ex sig II Adiut Date?

Lussonium Pann Inf...................... 3320

Cominius $M$ mil III Aug Date? Lambaesis.............VIII 3087

Decimius $M$ imm III Aug $p$ v Antonin 218 A.D. Castra Lam-

baesitana..................................... 2564

F1(avius) M 7 XI Cl 155 A.D. Almus Moes Inf .............III 7449

Flavi(us) $M$ vet ex actar (III Aug) 270-275 A.D. Lambaesis.... VIII 2626

F1(avius) $M$ arm cust III Aug Date? Lambaesis............. VIII 2873

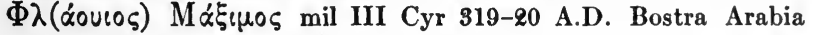

IG a RR III 1329

T. Fla(vius) Max(imus) vet VII Cl 195 A.D. Viminacium Moes

Sup............................. 14507

T. Fl(avius) $M$ mil XIIII Gem post 100 Fl Raab Noricum......III 5497 
T. Flavius M Cap(sa) mil? (III Aug) Date? Castra Lam-

baesitana................................... VIII $\mathbf{Q 5 6 9}$

Furius M mil XX V v Date? Chester Eng............E.E. VII 895

L. Geminius $M$ vet $I$ Adi $p$ post 100 Aquileia.............. 4123

Horte(nsius) M 7 (leg ?) Date? Chesters Eng.............VII 608

L. Iucundinius $M$ bf $\cos$ Date? Rigomagus Germ Inf.......XIII 7817 Iulius $\mathrm{M}$ mil III Cyr ante 108 Egypt............... Wessely Lat Pal 8 Iul(ius) $M$ vet (V Mac) c134 Troesmis.................III 6178 Iulius M Cast (mil? III Aug) c800 Castra Lambaesitana

Bull Archeol 1905 p239

Iulius $M$ dup III Aug p v Antonin 218 A.D. Castra Lambaesitana. VIII 2564 Iulius $M$ arm cust III Aug c\&25 Castra Lambaesitana..... A.E. 1908:11 Iul(ius) $M$ mil II Adiut \&-3s? Aquincum Pann Inf.......... III 10518 Iu(lius) M(a)ximus eq III Aug Date? Lambaesis...........VIII 8156 Iulius $M$ vet (III Aug?) Date? Zarai.................VIII 4525

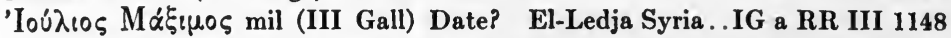
C. Iulius $M$ (vet II Tr fort?) 140 A.D. Fayoum Egypt...... BGU 610 C. Iulius M (mil? III Aug) c 200 Castra Lambaesitana

Bull Archeol 1905 p 240

C. Iul(ius) Maxim(us) bf $\cos$ V Mac M. Aurel-874 Also-Kosaly

Dacia...................................III 886

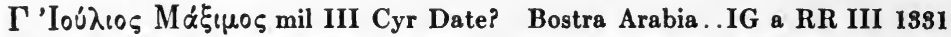

M. Iulius M. f. Sab. M Mantua 7III Cyr coh V \&s Bostra Arabia.. III 108 M. Iulius M ? (III Aug) Date? Castra Lambaesitana......VIII 2562 (M ? I) ulius M. f. (Qui)r Maxim(us) (A)ugusto (Ne)meto mil structor XI Cl p f Vespas-Traian Vindonissa........ XIII 8209 Licinius $M$ dup III Aug $p \mathrm{v}$ Antonin 218 A.D. Castra Lambaesitana.................................. 2564

L. Licinius M Nap(oca) mil? (III Aug) aet Antonini Pii Castra Lambaesitana............................ VIII 18085

C. Lucre(t)ius M Had(rumeto) vet? (III Aug) \&s? Castra Lambaesitana............................. VIII 18087 Marius M dup II Parth Sever c\&25 Rome................VI 8407 C. Mar(ius) Maxi(mus) 7 VII Gem p f Date? Limici Tarraconensis................................... II 2528

L. Memmius M ? (III Aug) Date? Castra Lambaesitana.... VIII 2562 Munati(us) Max(imus) 7 (leg ?) Date? Magnae Eng......VII 785 Nason(ius) Max(imus) vet VII Cl 195 A.D. Viminacium Moes

Sup......................................III 14507

L. Naevius M bf $\cos \mathrm{XI}$ Cl p f post Claud Domavianum Dalmatia .III 14219:4 Ocratius M 7 (leg?) coh I Date? Chester Eng............VII 178 Octavius M mil III Gall Date? Sidon Syria..............III 152

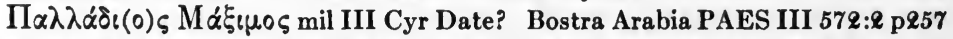
Pinarius $M$ arm cust (III Aug) 200 A.D. Castra Lambaesitana. A.E. 1902:10 C. Plotius M Cas mil? (III Aug) Date? Castra Lambaesitana.. VIII 8567 M. Pompeius M Tolom(aida) vet? (III Aug) aet Hadriani

Castra Lambaesitana ........................... VIII 18084

Pomp(onius?) $M$ vet (V Mac) c134 Troesmis.............II 6178 
(Pom)ponius Ma(xi)mus bf cos (III Aug) Date? El-Gehara.... VIII 18025 C. Pomponius $M$ vet ex cor (III Aug) Date? Lambaesis.... VIII 2968 L. Pomp(onius) Max(imus) vet ex cor (III Aug) Date? Lambaesis................................... VIII 2961 L. Pomp(onius?) $M$ mil (III Aug) Date? Lambaesis........ VIII 3220 Refrius M 7 III Aug 188-19\& A.D. Lambaesis.............. VIII 2749 A. Resius $\mathrm{M} 7 \mathrm{XI} \mathrm{Cl}$ p $\mathrm{f}$ c4\& Corinium Dalmatia............III 9973 Q. Scaevius $M$ frum VII Gem Date? Rome...............VI 3949 Sibidien(i)us Max(imus) mil (XV Apol) 1s Carnuntum Pann Sup................................II 14358:21a

L. Silius $M$ vet I Adi $p$ f c114 Apulum Dacia..............II 1008

M. Statius M Nicom(edia) sig (III Aug) aet Hadriani Castra Lambaesitana............................ VIII 18084

8 Stertinius M Nicom(edia) vet? (III Aug) aet Hadriani Castra Lambaesitana............................ VIII 18084

T. Terentius M optio (III Aug) \&s exe-3s init Castra Lambaesitana.......................

Q. Trebellius Q. f. (F)ab. M Roma 7 V Mac ante Caracall?

Tomi Moes Inf............................. 7689

Tutius M spec III Aug Date? Lambaesis................ VIII 2989

M. Tutius M vet III Aug Date? Lambaesis.............. VIII 2989 Val(erius) Maximu(s) vet (V Mac) cl34 Troesmis............III 6178 Val(erius) $M$ vet (V Mac) c134 Troesmis...............III 6178 Valerius Max(imus) vet (V Mac) c134 Troesmis............III 6178 Val(erius) Maxi(mus) vet VII Cl 135 A.D. Viminacium Moes

Sup................................ III 8110

Val(erius) M mil XI Cl 155 A.D. Almus Moes Inf...........III 7449

Valerius M 7 II Tr Fort 174 A.D. Alexandria Egypt..........III 12048

Valerius M mil II Parth Sever c2\&5 Rome................VI 3399

Val(erius) M 7 IIII FI Date? Concordia................. 1870

Val(erius) $M$ vet leg (V) 3s? Potaissa Dacia............. Klio 1911 p501 (Valeriu)s $M$ vet (III Aug) Date? Lambaesis.............VIII 3263 Valerius M Cas mil? (III Aug) Date? Castra Lambaesitana.. VIII 2568 Val(erius) M 7 (leg ?) coh V Date? Magnae Eng...........VII 778 Val(erius) Maxi(mus) 7 (leg ?) Date? Greatchesters Eng....VII 737 Val(erius) Maxi(mus) 7 (leg ?) Date? Borcovicum Eng....VII 685 C. Val(erius) Maxim(us) Sc(upis) vet str VII Cl 195 A.D.

Viminacium Moes Sup.......................III 14507

C. Val(erius) M Rat(iaria) arm cust vet VII Cl 195 A.D. Viminacium Moes Sup..........................III 14507

C. Val(erius) M Sc(upis) vet VII Cl 195 A.D. Viminacium Moes Sup.................................. 14507

C. Val(erius) M Sc(upis) vet VII Cl 195 A.D. Viminacium Moes Sup................................III 14507

C. Val(erius) C. f. M vet (III Aug) Date? Lambaesis.........VIII 3265

C. Val(erius) $\mathrm{M}$ vet VII $\mathrm{Cl}$ ex corn Date? Viminacium Moes Sup .......................Jahres Wien 1910 Beibl pq0\& 
(G. Valerius) M 7 II Parth 7 VI Ferr 7 XIII Gem 3s Pann Inf incerta................................. 10810

L. Valerius Maxi(mus) vet (V Mac) Date? Troesmis..........III 6179 (M) Val(erius) M Pau(talia) vet VII Cl 195 A.D. Viminacium Moes Sup................................. 14507

L. Varius L. f. Fab. M 7 VII Cl Date? Apamea Phrygia........III 7055

L. Vecna(tius) -(f) Pol Maxim(us) For(o) Cor(nelii) mil XI

(Cl) $\mathrm{p} f$ Vespas-Traian Vindonissa................ XIII 5215

M. Volusius M 7 XVI Fl firm 163-5 A.D. Viae Syriacae......III 200-1

Q. Volussius Maxim(us) Lamb vet III Aug p v c198 Castra

Lambaesitana............................ VIII 18068 (Ma)ximus Pareth(onio) vet? (III Aug) aet Hadriani

Castra Lambaesitana......................... VIII 18084 eus M Th(eveste) sig III Aug aet Antonini Pii Castra Lambaesitana............................... VIII 18085 -vius T. f. Col. M Caesarea vet II Tr fort 194 A.D. Alexandria

Egypt............................... $\quad 6580$ m(ius) $M$ sig I Adiut post 114 Brigetio Pann Sup......... III 4306 (M)aximus Sav(aria) mil? (III Aug) aet Antonini Pii

Castra Lambaesitana.......................... VIII 18085 (M)aximus Tha(rso) (mil? III Aug) Date? Castra

Lambaesitana............................. 1898:90

ius $M$ aquil III Aug Date? Lambaesis............... VIII 18311 Maxim(us) Cast (mil? III Aug) c200 Castra Lambaesi-

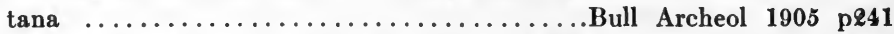
Maxi(mus) mil VIII Aug 1s? Albona Dalmatia........III 3051 Maxi(mus) 7 (leg ?) Date? prope Magnas Eng....E.E. IX 1803

MAXSIMINUS

Deccius Maxsi(minus?) 7 XV Apol 1s Carnuntum Pann Sup.III 14358:17 MAXSIMUS

C. Attius C. f. Pupi. M Baet(erris) mil IIII Mac 43-70 A.D.

Mainz..................................... 1913:128

L. Attius M mil (I Ital) Date? Moes Inf incerta............III 6832

P. Fannius M 7 XIIII G m v 1s exe? Ad Flexum Pann Sup...III 13444 Valen(ius) M 7 (II Aug?) coh VIII Date? Isca Eng..........VII 113

MAXSUMUS

- Iulius - Maxsum(us) mil (VII Gem p f) 3s? Villavicosa Lusitania................................ 151 MAXUMUS

Q. Lurius Q. f. Pup. M vet leg XV ante 63? Savaria Pann Sup..III 4 289

L. Tullius L. f. M mil leg V Date? Concordia...........E. 1907:807 MELCIDIANUS

C. Iul(ius) M vet ex bf cos V Mac Date? Drobeta Dacia....III 14216:6 MELIOR

Sex. Rutilius M mil III Aug Date? Batna.............. VIII 4894 
MELISSUS

P. Messius P. f. Q. M Aug(usto)du(no) mil III Aug 1s Theveste. VIII 16550 MELLITUS

M. Aurelius M lib leg leg II Adiut Date? Aquincum Pann Inf.... III 3538 MEMOR

Salvius $M$ vet ex optione I Min $2-3$ s Lyons..............XIII 1887

-us C. f. Camil. Memo(r Al)ba Pompeia (p p III Aug)

Date? Castra Lambaesitana......................II 2533 MEMORINUS

P. Iulius Memorinu(s) 7 I Min Date? Hersel Germ Inf . . . . . . XIII 8150 MENANDER

Aur(elius) M (7?) XIII Gem post Traian Apulum Dacia......III 1629:17 MENECRATIANUS

Aelius M 7 III Aug coh VIII 162 A.D. Castra Lambaesitana.... VIII 18065 MENILAEUS

C. Iu(1i)us M. (f) M mil I Adiut 2-3s? Aquincum Pann Inf ....III 10512 MERCATOR

Q. Aurel(ius) Mercat(or) mil III Aug Date? Lambaesis......VIII 3056

G. Iul(ius) Me(r)cator mil XXII Pr p f post 89 Aquincum Pann

Inf ................................. III 14347:5

Iustinius $M$ civis Treveri vet XXX Ulp vict Date? Cavillonum

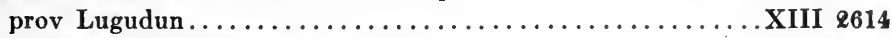

$(\longrightarrow$ sius Me)rcator vet leg ? Date? Verona............ 3970 MERCURIALIS

(?Me)rcurialis mil? (III Aug) Date? Castra Lam-

baesitana............................ 2567

MERIDIANUS

M. Caecilius M Cast vet III Aug p v c198 Castra Lambaesitana. . VIII 18068 MERITUS

C. Volussiu(s) M (eq? III Aug) 222-35 A.D. Castra Lam-

baesitana.................................. 1897 p447

ME $\Sigma A M A P O \Sigma$

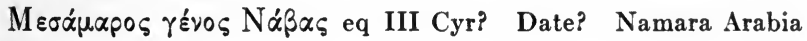

IG a RR III 1257

\section{MESSALLA}

(?Mess)alla Cl Tol(omaida) vet? (III Aug) aet Had-

riani Castra Lambaesitana.................... VIII 18084

MESSALLINUS

M. Aunicius M. f. Pub. M vet XV Apol 1s? Aquileia.......... 891

L. Licinius Messal(li)n(u)s 7 XIII Gem post Traian Veczel

Dacia............................. 1354

MESSIANUS

(I) ulius M tub III Aug p v 202 A.D. Castra Lambaesitana ... A.E. 1907:184 MESSIUS

Ael(ius) $M$ imm I Adiut Date? Aquincum Pann Inf........ III 3531 
Aur(elius) M eq II Adiut 3s? Aquincum Pann Inf...........III 10506 MESSOR

C. Carminius M vet (III Aug) Date? Lambaesis............VIII 3074

C. Iul(ius) M Cas mil? (III Aug) Date? Castra Lambaesitana.. VIII 2567

C. Lucilius $M$ mil XXII Pr f 196 A.D. Mainz............ XIII 6678

M. Munatius M Cast vet III Aug p v c198 Castra Lambaesi-

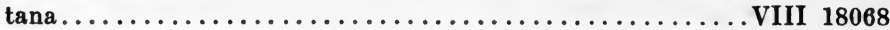

M. Ulpius M Sir(mio) vet VII Cl 195 A.D. Viminacium Moes Sup....................................III 14507

Vis(ellius) Messo(r) sig (leg ?) Date? Stanwix Eng.........VII 915 ME $\Sigma T P I A N O \Sigma$

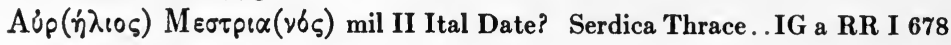
MESTRIUS

P. Ael(ius) P. f. Maecia M Pela(gonia) optio II Adiut Date? Aquincum Pann Inf......................... III $\mathbf{3 5 3 0}$

M. Aur(elius) M Sc(upis) vet VII Cl 195 A.D. Viminacium Moes Sup............................... 14507

M. Aur(elius) M Sc(upis) vet VII Cl 195 A.D. Viminacium Moes Sup............................... 14507

M. Aurelius M vet VII Cl Date? Scupi Moes Sup............III 8195 - M(e)st(r)iu(s) Cas vet VII Cl 195 A.D. Viminacium Moes Sup................................ 14507 MESTULA

M. Aur(elius) M Sc(upis) vet VII Cl 195 A.D. Viminacium Moes Sup...............................III 14507 MESUQUAS

Aurel(ius) M (eq? II Adiut) 3s? Aquincum Pann Inf........III 10506 METELUS

M. Aurelius M. f. Camilia M Alba mil IIII Mac ante Vespas Mainz.................................... $\mathbf{6 8 5 5}$ METRODORUS

M. Aur(elius) Metrod(orus) Nic(opoli) sig vet VII Cl 195 A.D.

Viminacium............................. 14507

MICA

Aurelius M 7 XI Cl post Hadrian Ad Haemum Moes Inf........III 12440 MILITARIS

Iul(ius) M dup? (leg ?) Date? Apulum Dacia............III 1189 MILITIO

M. Aur(elius) M m h m ex eq III Ital Date? Castra Regina Raetia................................... III 5955

MILO

G. Annius C. f. Ani. M Luca vet V Mac 1s Oescus Moes Inf ..III 14415 MINERVALIS

Pontius M ? (III Aug) Date? Castra Lambaesitana........VIII 2562 


\section{MINUCIANUS}

P. Aelius P. f. Sardis (Min)ucianus mil (III Aug) Date? Lambaesis.............................. 3017

Q. Aelius M bf praef leg leg (III Aug) Date? Lambaesis......VIII 2784 Aurel(ius) M (mil ? II Parth?) Date? Rome..............VI 2410 MINUTIUS

Val(erius) Min(utius) corn? (I Ital) \&s exe-3s Almus Moes Inf . . . III 44109:1

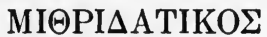

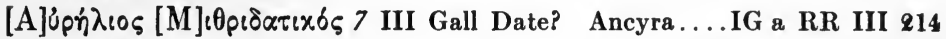
MOCETIUS

C. Atilius $M$ vet VIII Aug Date? Meda................ 5713

\section{MODERATUS}

Antonius M 7 III Aug coh III 162 A.D. Castra Lambaesitana.. VIII 18065

C. Livius $M$ bf cos Date? Siscia Pann Sup........ III $3950=10839$

C. Mucius M eq III Aug Date? Lambaesis....... VIII 3199 cf 18172 Roesi(us) Modera(tus) 7 (II Aug?) coh VI Date? Isca Eng...... VII 112

C. Vedennius C. f. Qui. M Antio milit in leg XVI Gall aet

Vespasiani Rome........................ 2725

MODESTUS

C. Anto(nius) Modes(tus) 7 VI Vict $p$ f post Hadrian Doncaster

Eng............................... 199

L. Antonius L. Pol. M Industria vet XIII Gem 69-84 A.D.

Poetovio Pann Sup.....................III 10877

M. Att(ius) Modest(us) $\mathrm{Sc}($ upis) vet VII Cl 195 A.D. Vimin-

acium Moes Sup....................... 14507

Eptidius M 7 V Mac ante M. Aurel Ad Haemum Moes Inf.....III 14433

C. Iavolenus M 7 XIII Gem post Traian Sarmizegetusa........III 1434

Marcius M 7 XI Cl p f Vespas-Traian Vindonissa..........XIII 5211

C. Murrius C. f. Arniensis Foro Iuli $M$ mil II Adi $p$ c71

Bath Eng........................... 48

Sex. Pilonius Sex. f. Ste. M Benevento 7 IIII Fl firm mil VII

$\mathrm{Cl} p \mathrm{f}$ et VIII Aug XI Cl p f I Min p $\mathrm{f}$ Date? Sarmizegetusa. III 1480

Vale(rius) Modest(us) bf trib (III Aug) Date? Lambaesis.... VIII 2993

L. Valerius M 7 I Adiut 70-100 A.D. Mainz.............. XIII 6843

Sex. Valer(ius) $M$ mil leg I - Date? Rome .............. VI 33031

L. Vinicius L. f. Gal. domo M Lugud(uno) mil IIII Mac ante

Vespas Mainz.......................... 6876

MODIANUS

C. Iulius Modi(a)nus vet II Adiut c150 Simitthus...........VIII 14605

\section{MODIUS}

Sallus(tius) Modiu(s) vet ex librario (III Aug) 270-275 A.D.

Lambaesis............................ $\mathbf{2 6 2 6}$

Q. Sallustius $M$ vet III Aug Date? Lambaesis............VIII 3233

MOENENUS

M. Aurel(ius) M (bf) cos VIII Aug? Date? Also Kosaly Dacia..III 822 


\section{MOESICUS}

Aponi(us) Moe(sicus) vet (V Mac) c134 Troesmis.........III 6178

MOMMO

Aur(elius) M 7 ? XIII Gem post Traian Sarmizegetusa........III 8065:23

\section{MONIMUS}

P. A(elius M)onim(us 7) I Ital Date? Ad Haemum Moes Inf..III 13780 Aurelius M str leg leg I Adiut Date? Intercisa Pann Inf........III 10316 C. Iul(ius) M optio (III Aug) 198-211 A.D. Castra Lambaesitana. . VIII 2554

\section{MONTANUS}

M. Ae(lius) $M$ mil III (Aug) Date? Lambaesis.............. VIII 3018 Aur(elius) M mil V Mac M. Aurel-274 Potaissa Dacia...........III 879 M. Aur(elius) Monta(nus) vet VII Cl 195 A.D. Viminacium

Moes Sup..............................III 14507

Buccius M 7 III Aug coh VIII 162 A.D. Castra Lambaesitana.. VIII 18065

Q. Eniboudius M 7 III Ital aet M. Aurelii Cemenelum......V 7865-6

Galerius $\mathrm{M}$ armatura XI Cl post Claud Olbia Chersonese...... A.E. 1909:167

Pri(mius?) M 7 XXII Prim Date? Osterburken...........XIII 6583

M. Talla(rius) Monta(nus) sig e num leg XIIII Gem post 100

Carnuntum Pann Sup.........................II 11235

Tit. Va(lerius) Glau. Mont(a)n(us) Savar(ia) mil I Adiut 70100 Mainz................................ XIII 6832

MOSCHUS

C. Iulius M ? XII Fulm Date? Tarraco................II 3158

\section{MOTTHUNUS}

Petronius Motthun(us) Su(fetula) mil? (III Aug) Date?

Castra Lambaesitana..........................VIII $\mathbf{2 5 6 7}$

MUCAPOR

P. Ael(ius) Sept(imius) M 7 XIIII Gem Sever c\&\&5 Carnuntum

Pann Sup...............................III 14357

$\mathrm{Se}(\mathrm{p}) \mathrm{ti}(\mathrm{mi})$ us (M) ucapor dup II Parth Sever p f $\mathrm{f}$ c225? Kalaat-

el-Muldik Syria.........................E. 1908:278

MUCATRA

\& Aelius Mucat(ra?) mil? (III Aug) aet Antonini Pii Castra

Lambaesitana.............................. VIII 18085

Aurelius M mil I Ital Date? Salonae Dalmatia............. III 2009

Aurel(ius) $M$ mil leg - A(u)g Date? Samnium............ 190\&:89

Sept(imius) M imag XXX Ulp vict p $f$ 223 A.D. Col Ulpia

Traiana Germ Inf..........................XIII 8607

Sept(imius) M cand XXX Ulp vict p 223 A.D. Ulpia Traiana Germ

Inf..................................... XIII 8607

Sept(imius) M cand XXX Ulp victpf 223 A.D. Col Ulpia Traiana

Germ Inf................................

MUGATRALIS

Aulus M bf leg leg XXII - Alexandr 227 A.D. Mainz....... XIII 6716 
M. Aur(elius) Mucatral(is) R(emesiana?) vet VII Cl 195 A.D. Viminacium Moes Sup....................III 14507 Mucapor Mu(ca)tralis mil XXII Pr p f 3s? Castell Mattiacorum................................... XIII $7 \& g \varepsilon$ M vet leg XXII Date? Mainz..................XIII 6740 MUCCO

Aur(elius) M R(emesiana?) vet VII $\mathrm{Cl} 195$ A.D. Viminacium Moes Sup..............................III 14507 MUGIANUS

P. Ael(lus) $M$ spec II Adiut Date? Rome...............VI 9568 Aurelius M imm buc (II Parth Sever p f f) c225 Kalaat-el-Muldik Syria............................. 1908:27\& Aur(ellus) M (vet) ex arm cust (V Mac?) Date? Potaissa Dacia.................................III 7688

M. Aurel(ius) M vet ex bf leg leg I Ital Date? Ad Haemum Moes Inf..................................III 12408 Fl(avius) $M 7$ frum II Ital $\mathrm{f} 200$ A.D. Luna..............XI 1328 L. Sept(imius) M m h m ex leg XXX Ulp vict $\mathrm{p} f$ domo Philippopoli Date? Lyons......................... XIII 1891

M. Ulpius M mil XIII Gem 211-17 A.D. Apulum Dacia.........III 1070 M ? II Tr fort Ger post 214 Alexandria Egypt........III 14132

M) ucia(nus) p p XIIII Gem Date? Concordia...Pais Suppl. n1080:48 MUGRUBIUS

Abbonius M mensor (III Aug) 3s? Castra Lambaesitana...A.E. 1904:72 MUDENUS

M. Minu(cius) Mude(nus?) mil VI Vict post Hadrian York Eng. VII 238 MUNATIANUS

L. Pomponius Munatian(us) Cas mil? (III Aug) Date? Castra Lambaesitana............................... VIII 2569 MUNTANUS

L. Fabius M (eq? III Aug) 222-35 A.D. Castra Lambaesitana

MUSSIANUS

MAH $1897 \quad \mathrm{p} 447$

$M$ vet (V Mac) Date? Troesmis III 6179 MUSTIOLUS

P. Sittius P. f. Papiria Teveste ex Africa $M$ vet II Adiut 3s? Aquincum Pann Inf ..................... III 10515 MUTILUS

M. Caesius L. f. $M$ vet XXX Ulp vict Date? Asberg.......XIII 8591 MYRO

Aemi(lius) Myr(o) vet VII Cl 135 A.D. Viminacium Moes Sup..III 8110 M. Aurelius M A(mmaedara) ? (III Aug) Date? Castra Lambaesitana............................ VIII 2565

(L. Eg)natius M optio (III Aug) 198-211 A.D. Castra Lambaesitana.................................. VIII 2554 
M optio III Aug is exe Ksar-Ghelane.

A.E. $1900: 127$ NAESTOR

C. Iul(ius) $\mathbf{N}$ vet (III Aug) Date? Lambaesis.............. VIII 2800 NAMFAMO

- (Na)mfamo vet III Aug Date? Simitthus...........VIII 14606 NAMPHAMO

C. Marius (N)amphamo vet (II P)arth 3s? Diana Numidia... VIII 4607

_lacius N Cast (mil? III Aug) ce00 Castra Lambaesitana

NAMPULUS

Bull Archeol 1905 p\&39

Fablus $N$ arm cust (III Aug) 800 A.D. Castra Lambaesitana A.E. 1908:10 NASO

O-storius $\mathbf{N}$ mil (III Aug) Date? Lambaesis............... VIII 3213

N 7 (leg?) Date? Chesters Eng.................. VII 610 NATALIS

Antonius $\mathbf{N} 7$ XXII Pr p f post 89 Steinbach..............XIII 6509

T. Fl(avius) $\mathbf{N}$ vet (leg?) Date? Isca Eng................ IX 1019 Iu(lius) $\mathbf{N}$ (atal)is vet VII Cl 195 A.D. Viminacium Moes Sup....III 14507 (Po)mpeius N Sicc(a) mil? (III Aug) Date? Castra Lambaesitana $\ldots \ldots \ldots \ldots \ldots \ldots \ldots \ldots \ldots \ldots \ldots \ldots \ldots \ldots \ldots \ldots$ VII 2567

M. Ulp(ius) $\mathbf{N}$ vet ex bf $\cos$ Date? Aquincum Pann Inf ........ III 10528 NATULUS

Q. Fulviun N Kart bf cos III Aug ce25 Lambaesis. VIII 2586

Numisius N p p (III Aug) Gallienae 253-68 A.D. Castra Lambaesitana .............................. 1904:71 NEGOTIANUS

C. Motilius Negotian(us) (mil? III Aug) c200 Castra Lambae-

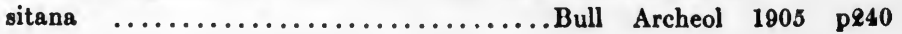
$\mathrm{NE} \Omega \mathrm{N}$

Néwv X $\alpha \mu\{$ ou mil III Cyr Date? Umm idj-Djimal Arabia. PAES III 349 p178 NEPOS

L. Attius L. f. Gal. N Nertobriga mil IIII Mac ante Vespas Mainz XIII 6853 M. Aur(elius) N 7 XX V v Date? Chester Eng...........E.E. VII 889 Q. Cattus Libo N 7 III Cyr Date? Tungri Belgica...........XIII 3592 Gelasin(ius) N (mil? III Aug) c218? Castra Lambaesitana

Bull Archeol 1904 pe06

Iulius $\mathbf{N}$ (mil III Aug $\mathrm{p}$ v) 3 s? Lambaesis................ VIII 3150

C. Iul(1us) N Sal(onis) corn praef vet VII Cl 195 A.D. Viminacium Moes Sup.........................III 14507

C. Iul(lus) N domo Ammedara ped sing (III Aug) c225? Lambaesis .................................

Petron(iu)s N(epos?) corn? (I Ital) es exe-3s Almus Moes Inf. . III 14409:1 Sep(timius) $\mathbf{N}$ can (leg?) Date? Apulum Dacia............III 1190 Trebonius $\mathbf{N} 7$ (leg?) Date? Petrianae Eng................ VII 905 L. Valerius $\mathbf{N}$ mil VII Gem post 172? Italica Baetica.........II 1126 N 7 III Aug 1s Gurai Numidia................. VIII 2103 


\section{NEPOTIANUS}

Nepotinius $\mathrm{N}$ bf $\cos 227$ A.D. Nettersheim

A.E. $1911: 150$ NEPTOLEMUS

T. Aur(elius) N Her(aclea) vet VII Cl 195 A.D. Viminacium Moes Sup...............................III 14507 NEPTUNALIS

Hortensius N dup III Aug p v Antonin 218 A.D. Castra Lambae-

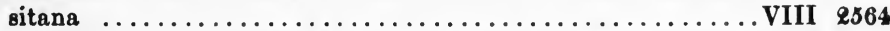

Ulpius N (eq? III Aug) 282-35 A.D. Castra Lambaesitana MAH.1897 p447 NEREUS

Antonius N 7 III Aug coh VIII 162 A.D. Castra Lambaesitana.. VIII 18065 NERIDO

Res(e)r- N 7 X Fr Date? Bilak Dacia...............III 768s NERO

L. Ulpius N natus Berito vet (III Aug) Date? La mbaesis.....VIII 9278 NERTUS

Urogenus $\mathbf{N}$ vet XXII $P \&$ Date? Lyons............... XIII 1907 NERVA

N Laidi f. Desidiati vet II Adi p \& 70 A.D. Herculaneum.. X 1408 NERVINUS

Melius Gervinius mIt N 7 (I Min?) p \& Date? Iuliomagus prov Lugudun ................................. 3088 NESTOR

Aelius N (mil? II Parth?) Date? Rome................. 2410

C. Iul(ius) $\mathbf{N}$ vet contributus ex leg III Gall in leg III Aug $\mathbf{3 s}$ init Lambaesis ............................... VIII $\mathbf{3 1 5 7}$ NICOMACHUS

A(ur)elius $\mathbf{N}$ bf $\cos$ VII Cl 213 A.D. Ulpia Ratiaria Moes Sup....III 6291 NICOSTRATUS

M. Aurel(ius) N Thars(o) bf cos III Aug ce25 Lambaesis....... VIII 2586 NIGELIO

N mil II Ital 3s? Vallis Fl Mur Noricum............ III 5448 NIGELLIO

L. Blassius N spec VII Cl Date? Viminacium Moes Sup III 1650 add p1021 NIGER

(A)nicius N Plus(iade) vet? (III Aug) aet Hadriani Castra Lambaesitana .............................. VIII 18084

M. Arrius N (mil III Cyr aut XXII Deiot) 90 A.D. Faoyum

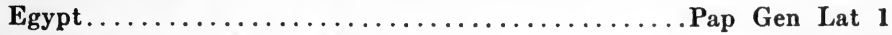

Caesonius $\mathrm{N}$ vet (V Mac) c134 Troesmis................III 6178

Tib. Claud(ius) Tib. f. Sergia Nicopoli N vet I Ital Date? Ad Haemum Moes Inf......................... 6144

Domitius N 7 III Aug coh IX 162 A.D. Castra Lambaesitana.....VIII 18065

T. Flavius Nige(r) (mil III Cyr aut XXII Deiot) 90 A.D. Fayoum Egypt.................................... Gen Lat 1 
Iulius $\mathbf{N}$ mil III Cyr ante 108 Egypt..............Wessely Lat Pal 8

C. Iulius G. f. Vol. Carc(asone) $\mathbf{N}$ mil leg II Date? Ager Mogon-

tiacensis ..................................... 7234

Mu(mmius) $\mathbf{N}$ mil XI Cl 155 A.D. Almus Moes Inf..........III 7449

L. Petronius $N$ vet $X$ Fr 94 A.D. Alexandria Egypt..........E. 1910:75

Pub(licius?) N centurio IV leg Date? Ad Varum Super Alpes

Maritimae ............................. 7989

C. $\mathbf{P u}$ (bli)cius N (mil) V Mac ante M. Aurel Troesmis......... III 7503

P. Puticius P. f. Mae. N mil leg VI Date? Tarentum........IX 6157

L. Sentius L. f. Ouf. $\mathbf{N}$ sig IIII Scyth Date? Sibrium.........V 5595

L. Sertorius L. f. Ouf. Nig(er aut-rinus) vet leg? Date? Mon-

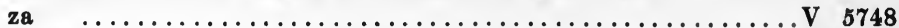

M. Tudius M. f. Rom. N leg V Urb c31 B. C. Ateste........... 2515

Tull(ius) N 7 III Cyr ante 108 Alexandria Egypt...........III 6602

L. Valerius N Thamug(adi) bf cos III Aug c225 Lambaesis..... VIII 2568

Q. Valerius Q. f. Ani. $\mathrm{N}$ domo Foro Iulii vet $\mathrm{XI} \mathrm{Cl}$ p 4 4q-Vespas

Burnum Dalmatia...........................III $\quad 8839$

C. Vettius C. f. Col. N domo Antiochla Syria vet XII Fulm

Date? Rome ............................. $\mathbf{3 6 4 4}$

NIGRIANUS

Aeltus $\mathbf{N}$ mil? $\mathrm{X}$ Gem Date? Vienna.................III 4568

NIGRINUS

P. Aelius Nig(ri)nus Nap(oca) mil? (III Aug) aet Antonini Pii

Castra Lambaesitana ......................... VIII 18085

M. Aemilius M. f. Cl. N Ara mil frum XXX Ulp vict Date?

Rome ................................ $\mathbf{3 3 8 0}$

Iul(ius) $\mathbf{N}$ mil XI Cl 155 A.D. Almus Moes Inf............III 7449

L. Pontius Gal. N ....ac frum VII Gem Date? Rome....... VI 3949

M. Porcius N mil XXI Rap ante Hadrian Villanueva Tarraconen-

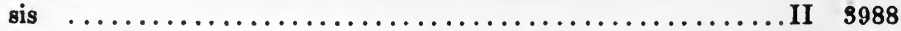

- N ? XIIII Gem post 100 Carnuntum Pann Sup.........III 11 es5 NIMMIRA

Aurelius N dup III Aug p v Antonin 218 A.D. Castra Lambaesitana VIII 2564 NIO

M. Aurelius $\mathbf{N}$ quondam mil II Tr fort Ger Sever ceq5 Alexandria

Egypt ................................III 14138:\&

NOBILIANUS

C. Iul(ius) $\mathbf{N} 7$ XVI Fl firm post Traian? Verona..........V 3250 NOBILIS

Iul(ius) Nob(ilis?) vet (V Mac) c134 Troesmis............III 6178 NOGINA

Burius N 7 XIII Gem Date? Novaria ................ 6518 NONIANUS

L. Paccius L. f. Pal. N Fundis 7 VI Vict p f Date? Alpis Poenina V 6881 NORICUS

F(lavius) $\mathbf{N} 7$ (leg?) coh X Date? Magnae Eng............. VII 779 
NOVELLIANUS

Petron(ius) Novellian(us) vet ex librario (III Aug) 270-275 A.D.

Lambaesis .............................. 2626

NOVELLUS

C. Aetereus N optio (III Aug) 198-211 A.D. Castra Lambaesitana VIII 2554 Murius N DX Prim p p III Aug p v Antonin 218 A.D. Castra

Lambaesitana.......................... VIII 2564

NOVIANUS

Octavius $\mathbf{N}$ optio (III Aug) Date? Castra Lambaesitana. . . . . . VIII 18086 NUMERIANUS

Q. Cornelius $\mathbf{N}$ bf (III Aug) Date? Lambaesis............. VIII 2854 NUMERUS

T. Aur(elius) $\mathbf{N}$ mil medicus XXII Pr p f post 89 Aquincum Pann

Inf $\ldots \ldots \ldots \ldots \ldots \ldots \ldots \ldots \ldots \ldots \ldots \ldots \ldots \ldots \ldots \ldots \ldots \ldots \ldots \ldots \ldots \ldots$ III 14347:5

NUMIDIUS

C. Iulius $\mathbf{N}$ lib princ (III Aug) c253 Castra Lambaesitana. . . . . . VIII 18078

NUMMENIUS

Aelius $\mathbf{N}$ exactus III Aug $\mathrm{p} v$ ce0 Castra Lambaesitan ......E. 1898:108 OBSEQUENS

- Obseq(ens) 7 (leg?) Date? Magnae Eng............VII 793

OCTAVIANUS

C. Aelius $O$ vet (III Aug?) Date? Zarai................ VIII 4519

P. Aelius 0 mensor III Aug Date? Lambaesis.............. VIII 3028

L. Iulius Oc(ta)via(nus) (mil III Cyr aut XXII Deiot) 90

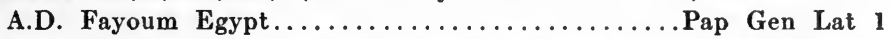

Oct(avius) Octav(ianus) (mil leg?) bf Date? Carthage........VIII 12580

L. Purius O The(veste) cas (III Aug) Date? Castra Lambaesi-

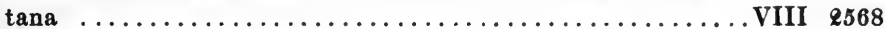

\section{OCTAVIUS}

G. Aurelius $\mathrm{O}$ spec VII Gem c200 Tarraco............... II 4122

Luciu(s) O (7? I Min) aet Getae Bonn............... XIII 8050

Petuceus O(c)ta(vi)us mil III Cyr ante 108 Egypt..... . Wessely Lat Pal 8 OCTOBER

L. Muslus Q. f. Pol. O Nicom(edia) 7 III Aug Date? Rome... VI 2780 OLYMPILINUS

Sulpicius O 7 III Aug coh III 162 A.D. Castra Lambaesitana. . . . VIII 18065 OMUNGIO

T. Marcius O vet IIII Fl fel Date? Brixia . . . . . . . . . A.E. 1908:220

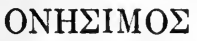

Aúp(ท่́

Caria......................................... 8873

ONESIPHORUS

T. F1(avius) O medicus III Aug Date? Lambaesis.........VIII 2874 


\section{ONESTINUS}

P. Publiaius O C $\longrightarrow$ c corn tr III Aug p v c198 Castra Lambaesi-

tana ................................... VIII 18068

\section{OPSILIUS}

O 7 (leg?) coh I Date? Amboglanna Eng

E.E. VII 1074

\section{OPTATUS}

Ael(ius) $O$ spec I et II Adi p f Sever 298 A.D. Aquincum Pann Inf III 3524 P. Aelius $\mathbf{O}$ mil leg XX aet Tiberii? Ager Novariensis........V 6638 P. Annius $O$ imm III Aug Date? Serianae.............. VIII 4375 Aurelius $O$ exactus III Aug p v c20\& Castra Lambaesitana .... A.E. 1898:109 Aurel(ius) O (mil? III Aug) c218? Castra Lambaesitana

Bull Archeol 1904 p206

L. Caecilius L. f. Pap. 07 VII Gem fel et 7 XV Apol aet M. Aurel

Barcino Tarraconensis.............................II 4514

T. Clodius T. f. Ste. O Aug(usta) Taur(inorum) mil IIII Mac ante Vespas Mainz........................... XIII 6862

Com(minius) O mil XIIII Gem post 100 Savaria Pann Sup......III 4184 M. Cornelius M. f. Voltinia O Aquis Sextis mil XXII Prim Date? Mainz ............................. XIII 6959

L. Domitius O Cla. mil III Aug Date? Lambaesis...........VIII 3099

Q. Domitius Q. f. Cla. O Viruno (mil? XIIII Gem?) 1s Chester

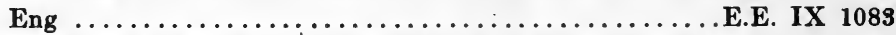

Flavius $\mathrm{O}$ dup III Aug $\mathrm{p}$ v Antonin 218 A.D. Castra Lambaesi-

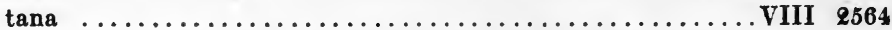

Q. Gavius Q. f. Arn. O dom Brixel mil leg XI ante 42 Burnum Dalmatia III $14321: 13$

M. Gellius Optat(u)s Ba(gai?) vet III Aug p v c198 Castra Lambaesitana ................................ VIII 18068

Iulius $O$ vet $X$ Gem Date? Aquileia.................. 919

C. Iulius C. f. Gal. Lug(uduno) $O$ mil leg XVI ante? 43 Mainz. . XIII 6941

C. Iulius O Hipp(o) vet III Aug p v c198 Castra Lambaesitana. . VIII 18068

C. Iulius O ? (III Aug) Date? Castra Lambaesitana.......... VIII 2568

C. Iulius O ? (III Aug) Date? Castra Lambaesitana.......... VIII 2562

M. Laberius O(pt)atus Tipas(a) vet III Aug p v c198 Castra

Lambaesitana ............................ VIII 18068

M. Licinius M. f. Volt. Luco O vet I Ital Date? Scupi Moes Sup III 8198 C. Magnius O Cas d s (III Aug) Date? Castra Lambaesitana ... . VIII 18086 Numisius 0 ? (III Aug) Date? Castra Lambaesitana.......... VIII 2562 Q. Numitorius O Cas mil? (III Aug) Date? Castra Lambaesitana ................................. VIII 2568

L. Piperacius L. f. Stell. O domo Taurinus mil XV Prim ante

Vespas Bonn............................. XIII 8080

Tad(ius) $O$ arm cust III Aug ceq5 Castra Lambaesitana........E. 1908:11 M. Ulpius $O 7$ III Aug p v 3s? Lambaesis.............. VIII 3002

M. Ulp(ius) $O$ vet II Adiut \&-3s Aquincum Pann Inf ........... III 15165

C. Valerius C. f. Sar. O Milev(o) mil III Aug Date? Lambaesis VIII 3266

C. Valerius O cor III Aug p v 203 A.D. Castra Lambaesitana.....VIII 2557 
P. Valerius 0 vet (III Aug) Date? Lambaesis.............. VIII 3267

T. Vibius T. f. Pol. O Eporedia mil XXII Prim 1s? Mainz . . . XIII 6981

Vol(usius?) $O$ arm cust III Aug c225 Castra Lambaesitana .... A.E. 1902:11

O mil II Ital $\&-3 \mathrm{~s}$ Noreia Noricum................ III 11648 ORATIANUS

Iul(ius) $O$ bf trib I Adiut 243 A.D. Syria incerta.............II 196 ORIENS

C. Allius C. f. Pom. O domo Dert(ona) 7 XIII Gem ante 50 Vindonissa ................................ 5206 OSTILIANUS

M. Iulius O Cas mil? (III Aug) Date? Castra Lambaesitana.. VIII 2568 OTHO

L. Veratius L. f. Cla. O mil leg XI ante 42 Albona Dalmatia..... III 3052 PACATIANUS

(A)nnius Pacatian(us) sig (III Aug) Date? Castra Lambaesitana ................................... 18073

M. Attius P Cirta bf cos III Aug ce25 Lambaesis............. VIII 2586

Litorius $\mathbf{P}$ bf $\cos$ Date? Borcovicium Eng................ VII 645 PACATUS

Q. Fabius $\mathrm{P}$ Volt. Viennae mil XI Cl p f 4q-Vespas Salonae Dalmatia ............................... 8 III 8740

L. Laetorius $\mathbf{P}$ sig III Aug Date? Lambaesis............... VIII 2931

Vale(rius) $P$ vet (XV Apol) Date? Lystra Cappadocia.........III 6787

- P Mucaris (fil?) mil II Adiut 3s? Aquincum Pann Inf... III 3558 PACCIANUS

P. Ennius T. f. Eppilli n. Quir P commodis acceptis ex leg III Aug 86 A.D. Hr Brighita................... VIII 12241 PAETINUS

- P 7 (II Aug?) coh V Date? Isca Eng. VII 111 PAETUS

Ael(ius) $\mathbf{P}$ mil leg IIII Date? Prizren Moes Sup............. III 8239 M. Ulp(ius) P Rat(iaria) vet VII Cl 195 A.D. Viminacium Moes

Sup ............................. 14507

PANNO

M. Ulp(ius) P mil XXX Ulp vict Date? Rigomagus Germ Inf . . XIII 7789 PANSA

L. Tettennius T.f. $\mathrm{S}(\mathrm{t}) \mathrm{e}(11)$. $\mathrm{P}$ vet $\mathrm{XI} \mathrm{Cl} \mathrm{p} \mathrm{f} 4$-Vespas Salonae

Dalmatia ........................... 8758

PAPIA

Aur(elius) $\mathbf{P}$ vet II Adiut 2 -3s Aquincum Pann Inf .......... III 13387 PARASENUS

Aurelius $\mathbf{P}$ vet XIIII Gem post 100 Vienna............. III 4550

PARDUS

Maternius $\mathbf{P}$ armatura leg XXII Date? Mainz............ XIII 6999 


\section{PARRA}

C. Caecilius C. f. Pup. P dom Bae(terris) mil IIII Mac ante

Vespas Mainz........................ 6 III 6857

PARTHICUS

Saturn(ius) Parthic(us) (mil?) I Min Date? Bonn.........XIII 8058

PASSERIANUS

L. Val(erius) P sig XIIII Gem post 100 Carnuntum Pann Sup....III 4407a

\section{PASSINIANUS}

— P 7 VII Gem Date? Lambaesis..................VIII 3226

\section{PASTOR}

M. Aurelius P natione Thrax mil II Parth Sever c225 Fabrateria. . X 5652

Domitius P vet leg sept Gem Date? Emerita Lusitania..........II 489

C. Octavius P. f. P Publ. ${ }^{\circ}$ Vero(n)a sig leg VIIII aet Vespasiani

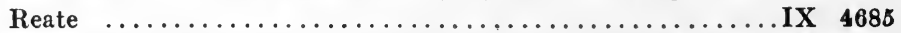

C. Paccius $P$ vet XXII Pr p f D(omitianae) aet Domitiani Brohl . XIII 7725

PATERCLUS

Sammonius $P$ arm cust XXII Pr $\mathrm{p} f$ post 89 Mainz .........XIII 6970

ПATEPKO $\Lambda O \Sigma$

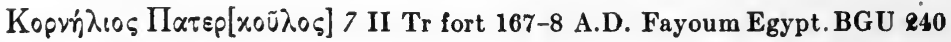

\section{PATERNIANUS}

Exomnius $P 7$ leg? Date? Lyons................XIII 1854

PATERNUS

(An)tist(ius_- f. Gal. $\mathrm{Pa}(\mathbf{t}) \mathbf{e}(\mathbf{r}) \mathbf{n}(\mathbf{u s})$ mil IIII Mac ante Vespas

Narbo .................................... 4365

Aur(elius) $\mathbf{P}$ mil II Adiut Date? Ticinum............... 6422

Domit(ius) P (mil? II Parth?) Date? Rome...............VI 2410

P. Enistalius P. f. Cl. P Cemenelensis optio ad ordin 7 XXII Pr

p f post 89 Cemenelum................... 7878

Fannius $\mathbf{P}$ mil $\mathbf{X X X}$ Ulp vict Date? Arelate .............XII 683

Faonius $P$ (7?) $X$ Gem Date? Rome................. VI 2898

L. Fl(avius) $\mathbf{P}$ bf $\cos 187$ A.D. Stockstadt. . . . . . . . . . XIII 6634

Iulius $\mathbf{P}$ sig I Adiut post 114 Arrabona Pann Sup............ III 475

Iul(ius) $\mathbf{P}$ mil XXII $\operatorname{Pr} \mathrm{p} f$ post 89 Bonn ............... XIII 8082

M. Iul(ius) M. f. Vol. P Aquis Sextiis mil VI Vict (7) VIII Aug

7 XIIII G $\mathrm{m} v$ et XI Cl $\mathrm{p}$ f ante 42 Salonae Dalmatia .........III 2035

M. Iustinius P vet I Min Date? Mediolanum Santonum Aquitania XIII 1047 Licinius Pater(nus) 7 VII Gem 163 A.D. Castrum S Christoph

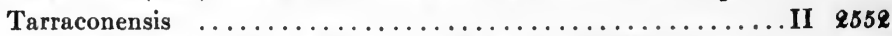

(Opp)onius Pater(nus?) (Agri)pp vet ex arm cust I (Min) Date?

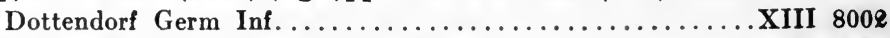

Placidinus $\mathbf{P}$ frum I Min Date? Rome................. 3835

L. Valer(ius) P mil X Gem optio Date? Arand de Duero...A.E. 1908:147

L. Verat(ius) P mil VIII Aug Date? Durlach Germ Sup....... XIII 6334

C. Vetinius $\mathbf{P}$ vet leg XXII 3 s? Wiesbaden...........XIII 7570b P 7 II Tr fort 194 A.D. Alexandria Egypt............III 6580 


\section{PATROCLUS}

M. Pettronius $\mathbf{P}$ bf $\cos$ Date? Nettersheim.............. 1911:153 PATRUINUS

Aur(elius) P mil III Ital Date? Castra Regina Raetia......... III 6571 PAULINUS

Ael(ius) Paulin(us) vet VII Cl 135 A.D. Viminacium Moes Sup.. III 8110 Cominius P 7 II Adi p f $2-3$ s Aquincum Pann Inf ............ III 3567

Domitius P exactus III Aug p v c202 Castra Lambaesitana...A.E. 1898:109

Flavius $\mathbf{P}$ tess (III Aug) Date? Castra Lambaesitana......... VIII 2562

C. Iulius P cor III Aug p v 203 A.D. Castra Lambaesitana . . . . . . VIII 2557

T. Iulius P (mil? III Aug). c200 Castra Lambaesitana Bull Archeol 1905 p 240

C. Lic(inius) Paulin(us) Sc(upis) cerarius vet VII Cl 195 A.D.

Viminacium Moes Sup......................III 14507

Moget(ius) P corn legg III Antonin ( $=$ X Gem XIV Gem I Ad)

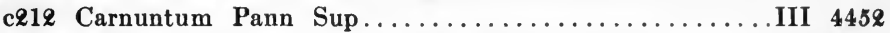

Mogetius $P$ mil? X Gem Date? Vienna...............III 4568

L. Rutilius P 7 III Aug Date? Lambaesis............... VIII 2968

S. Ulpius P 7 III Aug es exe Ksar-Ghelane............... 1900:127

\section{PAULLUS}

P. Audasius P. f. Pol. P vet X 94 A.D. Alexandria Egypt....A.E. 1910:75

Cornel(ius) P p p II Adiut Date? Aquincum Pann Inf......... III 3478

C. Rittius C. f. Vol. P Vienna mil XXII Prim Date? Mainz. . . XIII 6969

C. Vettius P 7 I Adiut $70-100$ A.D. Mainz.............XIII 6845 PAULUS

Ael(ius) $\mathbf{P}$ mil XI Cl 155 A.D. Almus Moes Inf............. III 7449

Q. Aemilius $\mathbf{P}$ vet (III Aug) Date? Lambaesis............. VIII 3023

L. Considius P Rusic(ade) corn III Aug c225 Lambaesis... . . . . VIII 2586

M. Cupitius M.f. Pol. P Amasia mil XI Cl p f 4q-Vespas Corin-

ium Dalmatia.......................... III 13263

L. Domitius P Cas can (III Aug) Date? Castra Lambaesitana. . VIII 18088

L. Minucius P. Nicom(edia) vet? (III Aug) aet Hadriani Cast-

ra Lambaesitana......................... VIII 18084

Petilius P 7 III Aug coh IV 162 A.D. Castra Lambaesitana. . . . . VIII 18065

L. Trebius $\mathbf{P}$ vet VIII Aug Date? Curictae Dalmatia......... III 3127 P mil III Ital Antonin c215 Perinthus Thrace . . . . . . . . . III 14207:6 PAVIUS

Fullonius $P$ arm cust (III Aug) 200 A.D. Castra Lambaesitana A.E. 1902:10 PECULIARIS

Iulius P 7 XX V v Date? Petrianae? Eng............. VII 912h PEDO

Aurel(ius) P mil XI Cl 155 A.D. Almus Moes Inf........... III 7449

C. Marius P Sido(nia) vet? (III Aug) aet Hadriani Castra Lam-

baesitana ............................... VIII 18084

$\mathbf{M} \longrightarrow$ P 7 VII Gem Date? Aquileia................ 828

PEQUARIUS

C. Iulius P Cas mil? (III Aug) Date? Castra Lambaesitana... VIII 2567 


\section{PEREGRINIANUS}

Maturius P 7 (III Aug) Date? Lambaesis............. VIII 2942 PEREGRINUS

P. Aelius Peregrin(us) Ha(drumeto) arm cust (III Aug) aet

Antonini Pii Castra Lambaesitana................. VIII 18085

T. Arranius T. f. Ar. P mil III Aug Date? Thala Byzacena.... VIII 11680

T. Flavius T. f. Ofentina P Mediolani mil VIII Aug \&-3s?

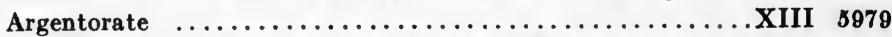

Geminiu(8) $P$ arm cust III Aug ce25 Castra Lambaesitana... A.E. 1902:11

Geminius P dup III Aug p v Antonin 218 A.D. Castra Lambae-

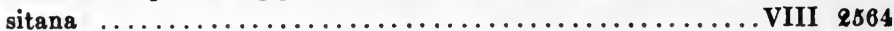

C. Iul(ius) Peregr(in)us bf $\cos 182$ A.D. Stockstadt......... XIII 6635

C. Iulius P (eq? III Aug) e22-85 A.D. Castra Lambaesitana MAH 1897 p447

C. Modestin(ius) P civis Agripplnensis vet I Min \&s Lyons.... XIII 1844

L_- P decurio leg XIII 1s? Luca................. 1526

-ovius L. f. (St)e. P (bf?) legati optio 7 XXII Pr p f post 89

Taurini $\ldots \ldots \ldots \ldots \ldots \ldots \ldots \ldots \ldots \ldots \ldots \ldots \ldots \ldots \ldots$ 7004

- Peregri(nus) 7 (leg?) Date? Cambriae oppida Eng

VII 147 add E.E. VII 855

P 7 (leg?) Date? Condercum Eng ...............VII 593

PERPETUUS

P. Aelius Proculi f. Cl. Ara P 7 III Aug Date? Lambaesis.... VIII 2785

Iul(ius) P 7 (leg?) Date? Cambriae oppida Eng.. VII 1339a add E.E. IX

Maternius Perpetu(u)s mil strator (cos) (X)XII Pr p f Date?

1020-24

Mainz ..............................XIII 6670

T. Paternius $\mathbf{P}$ corn leg leg XXX Ulp vict Date? Vetera Germ

Inf $\ldots \ldots \ldots \ldots \ldots \ldots \ldots \ldots \ldots \ldots \ldots \ldots \ldots \ldots \ldots \ldots \ldots \ldots \ldots \ldots \ldots$ XIII 8634

-lus P (Vien)na? mil (VIII Au)g Date? Duenhausen Germ

Sup ................................. 6319

- P 7 III Aug Is Theveste.................. VIII 16546

PERTINAX

Aur(elius) $P$ frum I et II Adi p $f$ Sever 228 A.D. Aquincum Pann

Inf $\ldots \ldots \ldots \ldots \ldots \ldots \ldots \ldots \ldots \ldots \ldots \ldots \ldots \ldots \ldots \ldots \ldots \ldots \ldots$ III 8524

Cl(audius) P str cos (II Adiut) 2 -3s Ager Aquincensis Pann Inf. . III 10378

Pereg(rinius) $\mathbf{P}$ mil? I Min Date? Bonn.............XIII 8053

PERTUR

Aurunc P librar centur leg IV Date? Tungri Belgica.........XIII 3595

PERVINCIANUS

Aur(elius) P eq III Ital 240 A.D. Castra Regina Raetia........ III 5948

PERVINCUS

(P)lacidius $\mathbf{P}$ vet leg XXII Date? Lyons.............XIII 1877

C. Senilius P vet ex sig III Ital Date? Augusta Vindelicum Raetia III 5818

C. Tallonius $\mathbf{P}$ vet VIII Aug Date? Lyons............. XIII 1896

PETIANUS

(Anto)ni(us) P corn VIII Antonin $213-217$ A.D. Mainz........ XIII 6803 


\section{PETUNNATIUS}

G. Iul(ius) P bf $\cos 167$ A.D. Stockstadt.............. XIII 6636 $\Phi$ AMAINOS

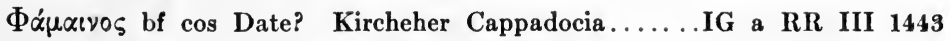
PHILETERUS

L. Aurelius $\mathbf{P}$ spec VII Gem cl00 Tarraco................ 4128 $\Phi \mathrm{I} \Lambda \mathrm{INO \Sigma}$

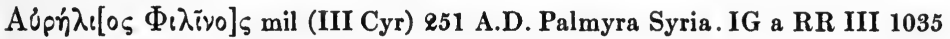
PHILIPPIANUS

Fl(avius) P 7 II $\operatorname{Tr}$ fort 194 A.D. Alexandria Egypt.......... III 6580 PHILIPPUS

Aurelius P 7 (leg?) Date? Aquincum Pann Inf.............III 10503 Gelli(us) Philip(pus) 7 (leg?) Date? Proclitia Eng

VII 631 add E.E. IX 1187 . at Phil(ippus) vet ex bf (V Mac) c134 Troesmis.........III 6178 $-1 \mathrm{P}$ vet $(\mathrm{V}$ Mac) c134 Troesmis................... 6178 (Phili)ppus vet (V Mac) Date? Troesmis..........III 6180 PIETAS

M. Antonius P Art? discens polio (III Aug) Date? Castra

Lambaesitana ......................... VIII 18086

C. Cornelius $\mathbf{P}$ arm cust III Aug Date? Lambaesis.......... VIII 2855 PINTIANUS

V(alerius?) (P)intianu(s)? (mil) leg VI post Hadrian Borcovicium Eng.......................... 6 II 644 PISCINUS

Q. Lucilius P 7 I Ital Date? Tropaeum Moes Inf...........III 12468 PITONIATUS

Troianius P eq I Adiut post 114 Brigetio Pann Sup...........III 11039 PIUS

T. Aurelius P frum VI Vict Date? Rome.............. VI 3344 P. Clodius P. f. Ste. P leg XX(X) post 31 B.C. Ager Beneventanus IX 2114 Septimius $\mathbf{P}$ mil XIII Gem post Traian Apulum Dacia........III 1052 Titienius $P$ arm cust (III Aug) 200 A.D. Castra Lambaesitana A.E. 1902:10 Titinius $P$ arm cust III Aug Date? Lambaesis........... VIII 2984

PLACENTUS

- P Nap(oca) vi(ctimarius?) (III Aug) aet Antonini Pii Castra

Lambaesitana ......................... VIII 18085

PLACIDINIUS

M Callienius P bf leg leg I Min Date? Rome............ 3935

PLACIDINUS

M. Antist(ius) Placidin(us) (vet) ex sig leg XXX 210 A.D. Vetera

Germ Inf................................. 8654

C. Iul(ius) P vet XXII Pr p f Date? Lyons..............XIII 1863

M. Ulp(ius) P bf $\cos 189$ A.D. Ad Dravum Pann Sup......... III 15188 


\section{PLACIDUS}

Iul(ius) $\mathbf{P}(7$ ? I Min) aet Getae Bonn .............. XIII 8050

M. Munatius M. f. Coll. P Icconio vet I Adi $p$ post 114 Brigetio

Pann Sup........................... 11030

Placidius $P$ vet VII Gem (Alexs) p f ante 235 Asturica Tarraconen-

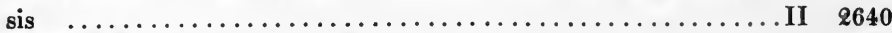

C. Valerius $\mathbf{P}$ mil leg XIV Date? Forum Iulii............ XII 265 PLANCIANUS

L. Valerius $P$ mil III Aug Date? Lambaesis............. VIII 2995 PLANCUS

Valerius $\mathbf{P}$ arm cust III Aug Date? Lambaesis............. VIII 2995

- $\mathbf{P}$ curator veteranorum III Mac ante Vespas Taurini...... V $\mathbf{7 0 0 5}$ PLATO

Scribonius $P$ arm cust III Aug c\&25 Castra Lambaesitana A.E. 1902:11 PLOTIANUS

Aur(elius) P mil I Adiut post 114 Brigetio Pann Sup .......... III 11021 PLOTUS

T. Tettius Plotu(s) vet II(II) Fl firm Date? Almus Moes Inf ... III 7425 POLIO

L. Vedius P Cas vet III Aug 166 A.D. Castra Lambaesitana . . . . VIII 18067 POLLIO

L. Cominius P mil XIII Gem bf leg cos Date? Ager Comensis... V 5451

G. Statius $\mathbf{P}$ vet XIII Gem post Traian Apulum Dacia........ III 1101

Valer(ius) $P$ vet (V Mac) Date? Troesmis..............III 6179

P 7 V Mac 68 A.D. EmmausNicopoli Palestine......... III 14155:12

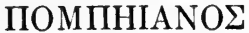

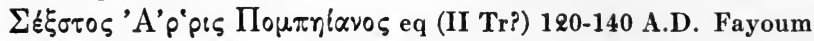

Egypt................................ 600

Aur(elius) P mil II Parth Date? Rome...............VI 3894-32690

M. Aurel(ius) Cl. P mil VIII Antonin Aug bf $\cos 213$ A.D. Mainz XIII 7338

Equinus $P$ optio (II Tr) Date? Alexandria Egypt...........III 6605

\section{POMPONIANUS}

T. Fl(avius) P 7 II Tr fort 7 XII Fulm 7 XIV Gem 7 I(III) Fl 7

XVI Fl Date? Salonae Dalmatia..................III 2029

\section{PONTIANUS}

Aurelius $\mathbf{P}$ mil I Ital Date? Salonae Dalmatia..............III 2010

Fl(avius) Pont(ianus?) vet (V Mac) Date? Troesmis.........III 6179

Fl(avius) Po(n)tianus mil XI Cl 155 A.D. Almus Moes Inf..... III 7449

Ponti(us) $P$ mil XI Cl 155 A.D. Almus Moes Inf.............III 7449

$\mathbf{M}-\mathbf{P}$ vet $(\mathrm{V}$ Mac) $\mathbf{c 1 3 4}$ Troesmis................III 6178 PONTICUS

Iul(ius) P natus Amastris mil V Mac ante M. Aurel Troesmis...III 7502

C. Iulius $P$ vet VII Cl p f Date? Scupi Moes Sup..........E. 1910:174

Q. Iulius Q. f. Col. P Ga? (mil III Cyr aut XXII Deiot) 90

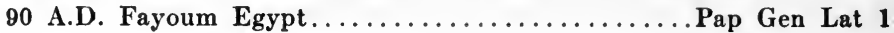


Sentius $P$ vet $V$ Mac ante $M$. Aurel Troesmis.............II 7502

Sentius $P$ mil V Mac ante M. Aurel Troesmis..............III 750 \& PONTIUS

Ti. Claudius P 7 XV Apol 1s Siscia Pann Sup............. III 10853 Pomp(onius?) $P$ vet ex 11 t? (III Aug) 270-275 A.D. Lambaesis........................................ 2626 PORCELLUS

L. Appius P Oea vet III Aug p v c198 Castra Lambaesitana. . . VIII 18068 PORCIANUS

Acutius Porcian(us) 7 III Aug Date? Lambaesis......... VIII 2781 PORCIO

T. Atidius T. f. Rom $P$ miles leg XIIX ante 9 A.D.? Ateste... V 2499 PORTURITUS

Iul(ius) P ? (III Aug) $253-268$ A.D. Castra Lambaesitana.... VIII 18061 POSTUMUS

Aurelius $P$ tub XI Cl 155 A D. Almus Moes Inf.......... III 7449 Val(erius) Pos(tu)mus $7 \mathrm{XI} \mathrm{Cl} \mathrm{p} \mathrm{f} \mathrm{4q-Vespas} \mathrm{Burnum} \mathrm{Dal-}$ matia................................III 6419

Vir(ius) Post(umus) 7 II Tr fort Ger post 214 Alexandria Egypt............................ 6609 - (Po)stumus Tharso (mil? III Aug) Date? Castra

Lambaesitana .......................... 1899:90 (P)ostumu(s) vet? XIII (Gem) Date? Clastidium....V 7350 Postum(us) 7 (leg ?) Date? Chester Eng........E.E. IX 1090 POTENS

Albanius P vet XXII Pr p f Date? Lyons.............. XIII 1830 Ant(onius) P ? III Ital Date? Castra Regina Raetia........III 6531 L. Cassianus $\mathbf{P}$ mil VII Cl p f Date? Viminacium Moes Sup Jahres Wien 1909 Beibl p151 Lucius $P$ bf cos non ante Antoninum Pium Mainz...... KWZ 1906 p74 C. (S)ervil(ius P)otens mil? X Gem Date? Carnuntum Pann Sup................................. 11182

Ulp(ius) $P$ bf cos Date? Carnuntum Pann Sup.........III 15192:\& POTENTINUS

Q. Terentius $P$ mil $X$ Gem p f 227 A.D. Scarbantia Pann Sup ......................... 1912 Beibl p541 POTITUS

Thoranius P 7 III Aug coh VIII 162 A.D. Castra Lambaesitana. . VIII 18065 Q. Vinntus $\mathbf{P}$ vet (III Aug) Date? Lambaesis...........VIII 327 \%

\section{PRAENESTINUS}

P. Florius P. f. Vol. $\mathbf{P}$ mil leg in Norico Ael Obilab b trib $2-3 \mathrm{~s}$ ?

Terventum............................ 2593

PRAESENS

T. Elupius Galer. P Gunia princeps XX V v 154 A.D. Chester

Eng.............................. 168

Val(erius) Pra(esens) tess II Adiut 2-3s? Aquincum Pann Inf. . III 10483 


\section{PRIMANUS}

(A)lbani(us P)rimanus sig (X)XII Pr (p f) Date? Mainz....XIII 6661 T. Albanius $P$ sig XXII Pr p f optio navali 185 A.D. Mainz.... XIII 6714

P. Helvius P mil XIII Gem lib cos post Traian Ampelum Dacia... III 1318 Quintinius $\mathrm{P}$ civis Treveri vet XXX Ulp vict Alexand c225

Lyons.................................... 1883

PRIMIANUS

Fuficius P Cas str (III Aug) Date? Castra Lambaesitana.... VIII 2568 T. Seranius P 7 V Mac Date? Rome................. VI 3631 PRIMICIANUS

Seius $P$ ? (III Aug) Date? Castra Lambaesitana ..........VIII 2562 PRIMIGENIUS

Coelius $P$ mil IIII Fl Date? Rusicade............... VIII 7981 PRIMITIUS

Iulius $\mathbf{P}$ mil III Aug Date? Lambaesis..............VIII 3158 PRIMITIVOS

Libellius P 7 evocatus III Aug coh X 162 A.D. Castra Lambaesitana.............................. 18065 PRIMITUS

Sp(urius?) $P$ mil I Adiut post 114 Brigetio Pann Sup......... III 11003 PRIMULLUS

Vigilius P mil II Adiut $\&-3$ s? Aquincum Pann Inf.......... III 10524 PRIMULUS

Primanius P 7 XXII Pr p f post 89 Ager Mogontiacensis....XIII 7256 PRIMUS

P. Ael(ius) P (R)at(iaria) str cos VII Cl 195 A.D. Viminacium Moes $\operatorname{Sup} \ldots \ldots \ldots \ldots \ldots \ldots \ldots \ldots \ldots \ldots \ldots \ldots \ldots \ldots \ldots \ldots$ III 14507 Arra(nius) P arm cust III Aug c225 Castra Lambaesitana ...A.E. 1902:11 C. Arruntius C. f. Polli. Assta P vet XV Apol 1s Carnuntum

Pann Sup................................ 4455 Atilius P 7 XIIII Gem ex evoc X Gem p f post 100 Carnuntum

Pann Sup............................ 11189

L. Aurelius $P$ aquil (III Aug) Date? Castra Lambaesitana.. VIII 18086

M. Aurel(ius) $\mathbf{P}$ vet $\mathbf{I}$ Min $\&$ Lyons................XIII 1844

M. Aur(elius) Primu(s) vet VII Cl 195 A.D. Viminacium Moes

Sup .............................. III 14507

Bruttius P mil II Tr Date? Alexandria Egypt.............III 12056

C. Bruttius $P$ vet (III Aug?) Date? Seriana.............VIII 4377

M. Caecilius $\mathbf{P}$ optio III Aug Date? Diana.............VIII 18652

M. Caecilius $P$ optio III Aug Date? Lambaesis............VIII 1829\&

C. Censorius $P$ tess (III Aug) Date? Lambaesis............. VIII 2838

Cornelius $P$ vet XIII Gem post Traian Apulum Dacia........III 1041

Q. Duronius P Vaga bf cos III Aug c225 Lambaesis........ VIII 2586

Q. Duronius P Kar bf leg (III Aug) Date? Castra Lambaesi-

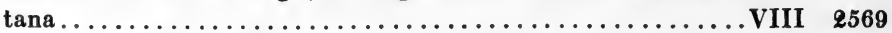

Ecetius Pri(mus) 7 XV Apol 1s Carnuntum Pann Sup........II 4484 
Etereius P arm cust (III Aug) 200 A.D. Castra Lambaesitana.. A.E. 1908:10

C. Fabricius C. f. Ouf. P Como mil XI Cl p f 42-Vespas Burnum

Dalmatia..............................III 14998

Faonius P dup III Aug p v Antonin 218 A.D. Castra Lambaesi-

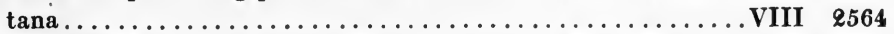

C. Firminius $\mathbf{P}$ vet II Adiut Date? Vallis Fl Mur Noricum.... III 5430

Fl(avius) $P$ mil XI Cl 155 A.D. Almus Moes Inf ............. III 7449

T. Gavidius T. f. Qui. P Utica mil XXII Deiot ante 108 Alex-

andria Egypt............................ 6602

Geminius $P$ arm cust (leg ?) Date? Mainz.............XIII 6680

P. Granius P. f. P mil (III Aug) Date? Lambaesis..........VIII 3120

P. Gratinius $P$ vet XXX Ulp vict Date? Novaesium Germ Inf . . XIII 8567

M. Hortensius $P$ cor III Aug $p$ v 203 A.D. Castra Lam-

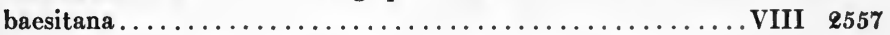

Iul(ius) P 7 XIII Gem post Traian Apulum Dacia............III 1045

Iul(ius) $\mathbf{P}$ vet I Min $\mathrm{p} f$ Date? Col Agrippinensium........XIII $822 \varepsilon$

Iulius $\mathbf{P}$ ? (III Aug) Date? Castra Lambaesitana........VIII 2568

Iul(ius) $\mathbf{P}$ sig (X Gem) Date? Albulae Mauretania Caesariensis. VIII 21669

C. Iulius $P$ mil XXII Pr p f 3 s? Cartenna Mauretania Caesariensis..................................... 21508

L. Iulius Prim(us) sig III Aug Date? Lambaesis.......... VIII 2912

Q. Iul(ius) P nat Afer domo Theveste imag II Tr Ger fort Antonin tr ex III Aug $p \mathrm{v}$ post 214 Alexandria Egypt........III 12057

C. Licinius P Cas mil? (III Aug) Date? Castra Lambaesi-

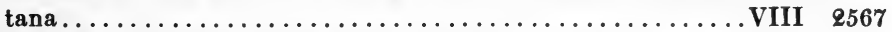

Lucilius $P$ dup III Aug $p$ v Antonin 218 A.D. Castra Lambaesitana.............................. 2564

Lurius P buc III Aug p v Antonin 218 A.D. Castra Lambaesitana. VIII 2564 C. Mundius $P$ vet (III Aug) Date? Lambaesis.............. VIII 3203 Nepotius P Kar d s (III Aug) Date? Castra Lambaesitana. . . VIII 2568 C. Novellius $P$ vet $X I$ CI $p$ f Vespas-Traian Vindonissa....A.E. 1900:115 $\mathbf{P}$ (er)enni(us) $\mathbf{P}$ arm cust (I Ital) is exe-3s Almus Moes Inf..III 14409:1 Pescennius $P$ arm cust (III Aug) 200 A.D. Castra Lambaesi-

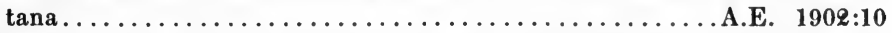

Pinarius $P$ vex (III Aug) Date? Castra Lambaesitana...... VIII 2562 Rufini(us) P 7 (leg ?) coh III Date? Isca Eng.......E.E. IX 1017 Secundius P Tubu(nis) (mil? III Aug) c200 Castra Lambaesitana............................ Archeol 1905 pe39

C. Staberius P Cast vet III Aug p v c198 Castra Lambaesitana. . VIII 18068

P. Valerius $\mathbf{P}$ mil III Cyr ante 108 Alexandria Egypt......... III 6602

L. Veturius Sp. f. Vot. Plac(entia) $\mathbf{P}$ vet ex leg XIIII Gem ante 62? Wiesbaden....................... 7575

-ilius $P$ tub III Aug p v 202 A.D. Castra Lambaesitana..A.E. 1907:184 -lius P Kar arm cust (III Aug) Date? Castra Lambaesitana. . VIII 2565 -tai- Fab. P vet leg XXII Date? Riva.............. 4988 PRINCEPS

Aurelius $P$ dup III Aug $p$ v Antonin 218 A.D. Castra Lambaesi- 


\section{PRIOR}

(S)ex Pullaenius P Sicc(a) mil? (III Aug) Date? Castra

Lambaesitana............................... VIII $\mathbf{2 5 6 7}$

PRISCIANUS

Aurelius P mil II Adiut Date? Intercisa Pann Inf.......... III 10316

Iul(ius) $P$ spec I et II Adi $p$ f Sever 228 A.D. Aquincum Pann

Inf ...................................... 3524

Valerius $P$ mil II Ital $p$

Valerius $P$ spec III Aug Date? Lambaesis............... VIII 2998

PRISCILLIANUS

C. f. Col. P Caesar(ea) sig II Tr fort 194 A.D. Alexandria

Egypt.................................. III $\mathbf{6 5 8 0}$

\section{PRISGINUS}

M. Aurel(ius) P spec II Adiut 209-11 A.D. trans Aquincum Pann

Inf.................................. $\mathbf{3 6 1 5}$

\section{PRISCUS}

P. Ael(ius) $P$ mil VII Cl Date? Viminacium Moes Sup......III 8116 Agrilius P natione Italicus mil III Aug Date? Lambaesis... VIII 3026 Aninius P 7 III Aug coh I 162 A.D. Castra Lambaesitana... VIII 18065 (A)nnaeus $P$ tub III Aug p v 202 A.D. Castra Lambaesitana..A.E. 1907:184 (A)ntonius P Ant(iocha) vet? (III Aug) aet Hadriani Castra

Lambaesitana............................. VIII 18084

Aterius P (mil? II Parth?) Date? Rome............... 2410

L. Atilius $P$ mil XIIII $G \mathrm{~m} v$ post 100 Savaria Pann Sup..... III 10930

M. Aur(elius) P Sc(upis) vet VII Cl 195 A.D. Viminacium

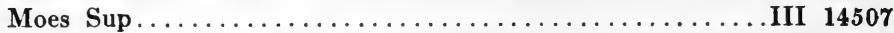

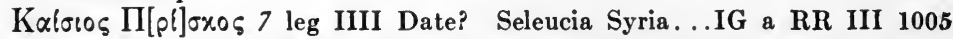

M. Caesius Q. f. Ani. P vet VIII Aug Date? Aquileia ......... 908

Cassi(us) P 7 (leg ?) coh VI Date? Amboglanna Eng.........VII 849

L. Centyllius L. (f) Arnie. P Crem(ona) (mil XV Apol ?) 1s

Carnuntum Pann Sup...................... 11I 1458:15a

Cl(audius) Prisc(us) p p (III) Aug Date? Lambaesis...... VIII 18295

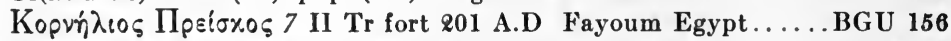

$\mathbf{C}($ or)nelius (Pr)iscus mil leg $\mathrm{XXX}$ - Date? Paris........XIII 3038

L. Dasumius P vet XIII Gem post Traian Sarmizegetusa.......III 1476

L. Domitius P 7 I Adiut 70-100 A.D. Mainz........... XIII 6838

T. Flavius Priscu(s) (mil III Cyr aut XXII Deiot) 90 A.D.

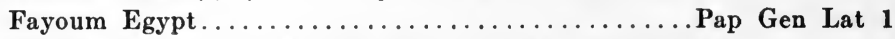

T. Flavius P (mil? IIl Aug) c\&00 Castra Lambaesitana

Bull Archeol 1905 p 240

M. Germanius P (vet II Tr fort?) 140 A.D. Fayoum Egypt.... BGU 610 (?H)erennius M. f. (Cl)aud. P p p II Tr fort Date? Ruteoli....X 1593 Iulius P 7 XI Cl p f 4q-Vespas Burnum Dalmatia............III 14999 Iulius P ? (III Aug) Date? Castra Lambaesitana...........VIII 2562 G. Iulius G. f. Vol. P Tol(osa) mil IIII Mac ante Vespas Mainz ...................................

L. Iulius $\mathbf{P}$ mil mensor agrari(us) I Adiut Date? Rome......... VI 3600 
Lucretius $P$ vet II Adiut $2-3$ s? Aquincum Pann Inf......... III 10420

Q. Manlius P 7 X Gem ante Traian Brohl.............. XIII 7699

C. Matteius C. f. Lemon. P Bono(nia) mil XXII Prim Date?

Mainz................................ 6 III 6964

Senti(us) P 7 (II Aug? Date?) coh V Segedunum Eng......VII 490

Senti(us)? Prisc(us) 7 (leg ?) Date? Magnae Eng.......VII 787

Sep(timius?) P eq I Adiut post 114 Adiaum Pann Sup.........III 10962

Turriani(us) P 7 (leg ?) Date? Vindobala Eng..........VII 553

M. Ulp(ius) P bf leg leg I Adiut post 114 Brigetio Pann Sup...... III 4328

Valerius $P 7$ leg XXII c65 Thebes Egypt............... III 6606

Valerius P 7 leg XXI is Ammaedara................... 1912:206

Valeri(us) Pris(cus) vet (V Mac) c134 Troesmis..............III 6178

C. Valerius P 7 leg XXII 65 A.D. Thebes Egypt............III 30

Vibius $\mathbf{P}$ vet $(\mathrm{V}$ Mac) c134 Troesmis..................III 6178

$-\mathbf{P}$ ? XV Apol 1s Aquileia.................... 988

- P 7 XXX Ulp vict $\mathrm{p}$ f 211 A.D. Col Agrippinensium ...... XIII 8201 PRIVATUS

Pomponius $\mathbf{P}$ arm cust (III Aug) 200 A.D Castra Lambaesitana

A.E. 1902:10

M. Servilius P ? (III Aug) Date? Castra Lambaesitana........ VIII 2562

_ P vet? (III Aug) Date? Castra Lambaesitana........ VIII 18086 PROBATUS

Sep(timius) $\mathbf{P}$ vet II Adiut Date? Sopianae Pann Inf......... III 3914 PROBIANUS

(A)urel(ius) Probian(us) sig (III Aug) Date? Castra Lambaesitana ............................... VIII 18073

C. Iul(ius) $\mathbf{P}$ can II Adiut Date? Campona Pann Inf ......... III 3398 PROBINUS

Iul(ius) $\mathbf{P}$ spec I et II Adi p f Sever 228 A.D. Aquincum PannInf. III 3524

PROBUS

Anton(ius) P corn III legg Antonin ( a X Gem XIV Gem I Ad)

c212 Carnuntum Pann Sup........................ 4II 4452

L. Arrius $\mathbf{P}$ bf $\cos$ Date? Apulum Dacia................. III 1080

Aur(elius) P sig VII Cl p f Philipp 244-49? A.D. Dacia incerta..III 8047

Q. Helvius $\mathbf{P}$ vet VII Cl Date? Viminacium Moes Sup.........III 8121

C. Iulius $P$ mil $X$ Gem Sever 234 A.D? Vallis Fl Mur Noricum.. III 5460

M? Iul(ius) $\mathbf{P}$ vet II Adiut Date? Campona Pann Inf......... III 3398

Maecius P 7 III Aug coh VII 162 A.D. Castra Lambaesitana .... . VIII 180C5

Mamius P 7 III Aug coh VI 162 A.D. Castra Lambaesitana. . . . . VIII 18065

(Terentius) $\mathbf{P}$ spec II Aug 1s? London................. 24

Viri(u)s P mil leg XXII Alexandria p 2 22? 226? 229? A.D.

Nantuates Alpes Poeninae....................... 144

- P 7 leg Date? Celei Dacia................III 14490

- P 7 (leg?) coh IV Date? Amboglanna Eng............ VII 848

PROCESSUS

Aufidius $\mathbf{P}$ vet ex librario (III Aug) $\$ 70-\$ 75$ A.D. Lambaesis.... VIII 2626 
Q. Aurel(ius) Processu(s) optio (III Aug) 198-811 A.D. Castra

Lambaesitana ............................... VIII 8554

Q. Aurelius P Maddanius optio III Aug Date? Lambaesis.... VIII 2824

C. Iul(ius) P mil III Aug Date? Lambaesis.............. VIII 2893

M. Iulius P ? (III Aug) Date? Castra Lambaesitana.......... VIII 2568

Q. Valerius P (eq? III Aug) 222-35 A.D. Castra Lambaesitana

\section{PROGLIANUS}

Fl(avius) Procli(a)nus p p (leg ?) Date? Umm idj-Djimal

Arabia................................ III 236 p135

(I)ul(ius) $P$ arm cust leg? Date? Vienna...........III 14359:26a

P. Nasellius P 7 VIII Aug 148 A.D. Boeckingen XIII 6469, 6479, 6477 PROCLINUS

P mil I Adiut post 114 Brigetio Pann Sup.............III 11086

\section{PROCLION}

P. Aurelius Pol. P Alexandr(ea) vet II Tr fort 194 A.D. Alex-

andria Egypt............................. $\quad 6580$

PROGLUS

P. Ael(ius) $P$ vet XIII Gem post Traian Apulum Dacia........III 7796

Appius $P$ vet XIII Gem 142 A.D. Verespataki Dacia........III p940-3

Caecill(us) P 7 (leg?) Date? Proclitia Eng................ VII 625

Flavius P mil IIII Fl c128? Noviomagus Germ Sup........... XIII 6104

M. $\Lambda$ เxivios $\left[\Pi_{\rho}\right] \delta x \lambda \circ \varsigma 7$ III Gall Date? Cyrrhus Syria.IG a RR III 1004

M. Lucretius $P$ vet leg Adiut $\varepsilon$ aut 3 s Pontus.............III 343 add

Valerius P ? XI Cl p f 42-Vespas Burnum Dalmatia.......... III 15004:1

L. Val(erius) L. f. P mil et $7 \mathrm{~V}$ Mac 7 I Ital 7 XI Cl 7 XX V v 7

VIIII Hisp aet Domitiani Ad Haemum Moes Inf...........III 12411

Пр $6 x \lambda_{0 \varsigma} 7$ (II Tr?) 120-140 A.D. Fayoum Egypt......... BGU 600 PROCULEANUS

M. Ael(ius) Proculean(us) mil (III Aug) Date? Lambaesis....VIII 3019 PROGULEIANUS

Cecillus $\mathbf{P}$ mil can III Aug Date? Lambaesis.............. VIII 2801

C. Iulius P vet? (III Aug) aet Hadriani Castra Lambaesitana.. VIII 18084

PROCULINUS

Ael(ius) P sig IIII Fl Date? Viminacium Moes Sup...........III 1649

Aur(elius) P mil (II Adiut) Date? Lugio Pann Inf...........III 3301

G. Iu(lius) $P$ quaestionarius I Adiut 2-3s? Aquincum Pann Inf. . III 10458

Ulp(ius) P spec XIII Gem Gordian 238-44 A.D. Apulum Dacia....III 990

PROCULUS

C. Aemilius C. f. Pol. P (mil III Cyr aut XXII Deiot) 90 A.D.

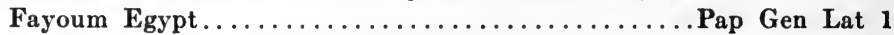

P. Alfius P vet III Aug Date? Lambaesis................VIII 8027

(A)ntonius Procul(us) optio III Aug p v 202 A.D. Castra Lam-

baesitana ............................. 1907:184

Antoni(us) Procul(us) vet (V Mac) Date? Troesmis.........III 6179

M. Antonius P vet (III Aug) Date? Lambaesis........... VIII 3035-6 
Ansius $P$ p p leg? Date? Carnuntum Pann Sup........III 14356:5b M. Aquilius M. f. Anies. P Arimin(o) comm (III Aug) Date?

Lambaesis ........................VIII 2812 add 18143 Aur(elius) P nation Surus domo Hemesa vet II Adiut Date?

Lugio Pann Inf.......................... 3301

Q. Baebius $P$ vet XIII Gem post Traian prope Tomi Moes Inf. . . III 12497 Caecili(us) Procul(us) 7 (leg?) coh V Date? Chesters Eng...... . VII 598 Calpur(nius) $P$ vet ex librario (III Aug) 270-275 A.D. Lambaesis VIII 2626 P. Cleusius P f. Pob. P p p VII Cl p f ex corn Date? Verona

C. Cornelius C. Pollia P Regio mil XIII Gem bf trib 70-84 A.D.

Pais Suppl. n1253

Poetovio Pann Sup....................... 14.355:2

Dossennius P 7 II Adi $\mathrm{p} f \mathrm{c} 71$ Lincoln Eng............. VII 185

Hortens(ius) Procul(us) 7 XX V v Date? Hunnum Eng........VII 566

Granius P 7 X Fr Date? Byblus Syria................ III 6697

T. Iavennius C. f. (P)ol. P Faventia (7) XXII Prim Date?

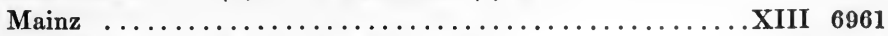

Inulani(us) $P 7$ (I Min?) c100 Bonn.................. 1905:63 Iulius P Sidonia vet? (III Aug) aet Hadriani Castra Lambaesitana ................................. IIII 18084

Iul(ius) $\mathbf{P}$ vet ex imm (V Mac) c134 Troesmis..............III 6178

Iul(ius) Proc(ulus) vet (V Mac) c134 Troesmis.............III 6178

Iul(ius) P(r)ocur(lus?) 7 XII Fulm 3-4s Trapezus Pontus Cap-

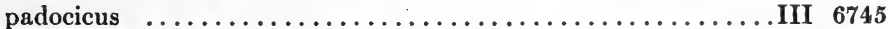

Iulius P 7 V Mac et III Gall et XXII Prim Date? Lambaesis... VIII 2627 Iuli(us) P 7 (leg?) Date? inter Condercum et Vindobalam Eng E.E. IX 1169 C. Iul(ius) Fab. Procu(1)us 7 XXX Ulp Date? Frkelenz Germ

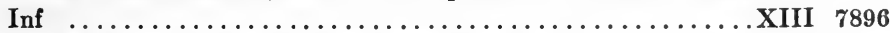

M. Iulius P Lamb bf $\cos$ III Aug c225 Lambaesis............ VIII 2586 M. Iul(ius) P vet corn trib I Adiut post 114 Brigetio Pann Sup... . III 11027 M. Iulius Col. P Adan(a) vet III Aug Date? Lambaesis....... VIII 3159 Q. Iulius $\mathbf{P}$ (D)am(asco) (mil III Cyr aut XXII Deiot) 81 A.D. Fayoum Egypt................................. Gen 1

L. Lepidius L. f. An. P mil V Mac 7 V Mac 7 VI Vict 7 XV Apol p p XIII Gem 70-c100 Ariminum .................. XI 390-1

Lucretius $P$ arm cust (VII Gem) post 100? Asturica Tarraconensis................................... 2668

M. Minucius P Thel(epte) mil? (III Aug) Date? Castra Lambaesitana ............................... III 2569

Decum(us) Mussidius $P$ 7 V Mac ante M. Aurel Ad Haemum

Moes Inf.............................III 14211:10

Oppius P 7 leg? coh VIIII Date? Lancaster Eng........... VII 449

(P)ontius P 7 II Adi p f c71 Lincoln Eng............... VII 186

Quinctius P 7 III Cyr ante 108 Alexandria Egypt............ III 14138:3

P. Septimius P dup II Parth Sever 3s? Ager Albanus.......... XIV 2290 Sexti(us) Proc(ulus) 7 (leg?) coh V Date? prope Magnas Eng E.E. IX 1202 Sulpicius P mil IIII Scyt Date? Samosata Syria...........III 6048 M. Sulpi(cius) P imag III Aug Date? Lambaesis............ VIII 2814 
P. Tarrutenius Stel. P Taurinis evocatus II Adiut 2-3s Aquincum Pann Inf............................. III 3565 Val(erius) $P$ vet (V Mac) c134 Troesmis................III 6178 (Valerius) P. Savaria optio II Adiut 2-3s Aquincum Pann Inf... III 10525

C. Valerius G. f. Gla. P domo Baeterris vet IIII Mac ante Vespas Luceria.............................IX 799

C. Valerius G. f. Gal. P Calagurri eq XI $\mathrm{Cl} f$ aet Traiani Carnuntum Pann Sup.........................III 11839

L. Val(erius) Procu(lus) vet VII Cl 135 A.D. Viminacium Moes

Sup III 8110 M. Valerius P exactus III Aug p v c\&0\& Castra Lambaesitana A.E. 1898:109 Vaterculi(us) P 7 VIII Aug Date? Oehringen.............XIII 6548 - (Pr)oculus Kart vet? (III Aug) aet Hadriani Castra

Lambaesitana ............................ VIII 18084

-u(r)ius P (vet?) XXII Prim Date? Bostra Arabia..PAES III 531 p231 us Procul(us) vet (V Mac) Date? Troesmis..........III 6179

PROCUS

T. Cl(audius) P bf cos II Adi p f Antonin 213 A.D. Intercisa Pann

Inf III 10306

PROFUTURUS

Fisculius Profut(rus) arm cust III Aug ce25 Castra Lambaesitana A.E. 1902:11

PROMPTUS

Claudius Prom(p)tus 7 III Aug coh V 162 A.D. Castra Lambae-

sitana VIII 18065

PROMOTUS

Im- P (mil? II Parth?) Date? Rome..............VI 2410 PROPINCUS

Aur(elius) P mil II Adi $p$ f $2-3 s$ Aquincum Pann Inf ..........III 13382 PROPINQUUS

M. Ammonius Propin(quus) (vet II Tr fort?) 140 A.D. Fayoum Egypt ........................................ 610

$-\mathbf{P}(\mathbf{r})$ o(pin)quus 7 III Aug 3 aut 4s Soada Syria.........III 6036 PROTUS

Fl(avius) P mensor VII Cl Sever 228 A.D. Viminacium Moes Sup III 8112 PROVINGIALIS

P. Ael(ius) $P$ vet II Adiut $2-3$ s Aquincum Pann Inf.......... III 3587

P. Ael(ius) $P$ vet ex sig II Adiut $8-3$ s Aquincum Pann Inf . . . . . . . III 14354:1

M. (A)ur(elius) Provincial(is) R(emesiana?) vet VII Cl 195 A.D.

Viminacium Moes Sup........................II 1.4507

Marc(us) Didius $P$ bf cos Date? Lanchester Eng............VII 441

Iulius P 7 III Aug coh III 162 A D. Castra Lambaesitana ....... VIII 18065

Novius $P$ mil II Adiut $3 s$ ? Aquincum Pann Inf............. III 3556

L. Orbius P Ticib(a) mil? (III Aug) Date? Castra Lambaesitana 


\section{PROXUMUS}

Q. Statius P 7 XXII Prim Date? Mainz............... XIII 6959

\section{PRUDENS}

T. Atarenus P 7 princeps III Aug Date? Lambaesis..........VIII 18231 PRUPINGUS

- (P)rupincus Kas vet VII Cl 195 A.D. Viminacium Moes

Sup $\ldots \ldots \ldots \ldots \ldots \ldots \ldots \ldots \ldots \ldots \ldots \ldots \ldots \ldots \ldots$ III 14507

\section{PTOLEUS}

M. Aurel(ius) P mil II Tr Date? Alexandria Egypt..........III 6595 PTOLMEUS

P. Aelius P ? (III Aug) Date? Castra Lambaesitana.......... VIII 2562

\section{PUDENS}

Adauc(tius) Pud(ens?) 7 (leg?) Date? Inter Ciliunum et Procli-

tiam Eng............................... III 101

Aemilius P mil VII Gem fel Date? Emerita Lusitania........... II 488

P. Aemilius P quaestionarius (III Aug) Date? Lambaesis...... VIII 18281

L. A(n)nius P Kar vet? (III Aug) 2s? Castra Lambaesitana.. VIII 18087 Aponius Pud(ens) 7 (XV Apol) 1s Carnuntum Pann Sup..III 14358:21a M. Blossius Q. f. Ani. P 7 V Mac aet Vespas Rome.......... VI 3580

L. Cassius P mil (II A)diut Date? Aquincum Pann Inf....... III 3543

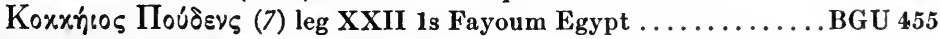

C. Domitius G. f. Maec. P Pelag(onia) III Aug Date? Lambaesis ........................................... 2865

L. Flavius P 7 I Adiut 70-100 A.D. Mainz............. XIII 6839

M. Herrenius P vet II Adi p f domo Claudia Apamie Date? Intercisa Pann Inf......................... 1906:108

Hilarinius P dup III Aug p v Antonin 218 A.D. Castra Lambaesitana ................................... III 2564

G. Iulius Clau. P (I) u(l) E(m)ona vet $X$ Gem p f 89-Traian Ulpia Noviomagus......................... 8735

Sex. Licinius P 7 leg XXII 84 A.D. Thebes Egypt............III 36

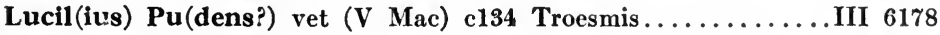

Q. Lucilius Q. f. Vo(1)t. P Bergomi mil XI Cl $p$ f Vespas-Traian

Vindonissa ................................ XIII 5210

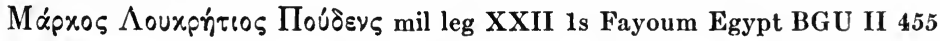

M. Messa(1a) P Rat(iaria) str cos vet VII Cl 195 A.D. Viminacium

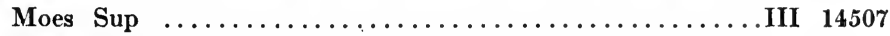

M. Messius M. f. Col. P dom Ancyra singular X Fr Date?

Rome .................................. VI 3614

M. Mucius M. f. Pub. Albi(ngauno) Pud(ens) mil leg XXII

Date? Mainz .................................. 6966

Naevi(us) $P$ vet (V Mac) c134 Troesmis.................II 6178

Numi(dius aut-sius) $\mathbf{P}$ arm cust III Aug c225 Castra Lambae-

sitana .............................. 1908:11

Percennius P 7 (III Aug) Date? Lambaesis.............. VIII 18315

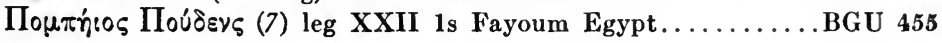


T. Sempronius P frum XX V v Date? Rome.......VI 3357 et 3359 Servilius P 7 II $\operatorname{Tr}$ fort 194 A.. Alexandria Egypt............III 6580 T. Sextil(ius) Puden(s) mil? (III Aug) Date? Castra Lambaesitana ....................................... $\mathbf{2 5 6 7}$ (Val)erius P spec II Aug 1s? London................... VII 44 C. Val(erius) Pud(ens) vet V Mac aet Hadriani Troesmis........III 6166 C. Val(eri)us Pud(e)n(s) mil V Mac post M. Aurel Oescus Moes Inf

A.E. 1912:188

T. Valerius T. f. Cla. P Sav(aria) mil II Adi $p$ f c71 Lincoln Eng.....VII 185 Volumnius P 7 XIIII Gem post 100 Vienna...............III 4578 - esis Pudens? C. fil. Ser(gia) Augusta eq II Adi p f c71 Chester Eng............................. IX 1054 ius P Cast (mil? III Aug) c 800 Castra Lambaesitana

Bull Archeol 1905 p\&39 P tess? mil II Aug Date? Ilkley Eng.............E.E. III 76 -8 $P$ vet (V Mac) Date? Troesmis..................III 6179 (P) udens Em(ona) mil? (III Aug) aet Antonini Pii Cas-

tra Lambaesitana................................ VIII $1808 s$ PUDENTIANUS

C. Iulius Pudenti(anus) lib (III Aug) Date? Castra Lambae-

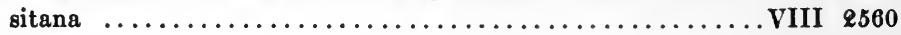
PUDES

C. Valerius C. f. Cla. (P) udes Sava(ria) mil II Adiut 1s Mainz...XIII 6580

C. Vibius C. f. Pompt. P dom Arretio 7 VII $\mathrm{Cl}$ p f 4\&-70 Tragurium Dalmatia..............................III 2678

\section{PULlaENIUS}

Q. Sextius P bf cos II Ital 192 A.D. Celeia Noricum ........... III 5178

Sossib(ius) P sig (III Aug) Date? Castra Lambaesitana....... VIII 18073 PUPUS

L. Virillus $\mathbf{P}$ bf $\cos$ Date? Siscia Pann Sup..............III 3955 PUSSINIO

Cl(audius) P? mil I Adiut post 114 Brigetio Pann Sup.........III 11011 F1(avius) $P$ optio leg II Pannonice Date? Mainz............ XIII 6849 Iul(ius) $P$ imm II Adiut 2 -3s Aquincum Pann Inf...........III 3489 IIYPOS

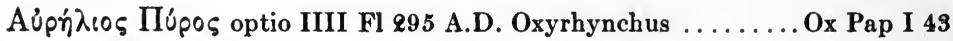
PYRRUS

(Au)r(elius) P mensor VII Cl Sever 2 \&8 A.D. Viminacium Moes Sup III 8112 QUADRATUS

L. Aemilius $Q$ exactus III Aug p v c£0\& Castra Lambaesitana . . A.E. 1898:109 L. Antonius L. f. Fab. $Q$ ? $\operatorname{leg} \mathrm{XX}$ aet Tiberii Brixia......... 4365 Appinius Pol. Faventia Q 7 vett IIII Mac ante Vespas Scardonia

Dalmatia................................ III $\mathbf{2 8 1 7}$ Aur(elius) Q mil XI Cl 155 A.D. Almus Moes Inf............III 7449 C. Cassius Q Pol. Cas vet (III Aug) 211-12 A.D. Lambaesis.... VIII 2618 
Q. Creperius Quadrat(us) Thev(este) mil? (III Aug) Date?

Castra Lambaesitana.......................... VIII 2567

Flavius M. f. Gal. $\mathbf{Q}$ aquil leg II Date? Olisipo Lusitania........II 266 Iul(ius) $Q$ vet VII $\mathrm{Cl}$ 3s Viminacium Moes Sup.............III 1651 Umi(dius) $Q$ mil XI Cl 155 A.D. Almus Moes Inf ............III 7449 M. Valerius M. f. Pol. $Q$ vet X Fr 94 A.D. Alexandria Egypt... A.E. 1910:75 (Qu)adratus (mil III Cyr aut XXII Deiot) 1s exe Fayoum

Egypt.................................. II $\mathrm{p} 63$

QUARTINUS

Vep(onius) Quart(Inus) mil (II) Ital p f ss Virunum Noricum.... III 4857 QUARTIO

Aelius $Q$ dup III Aug p v Antonin 218 A.D. Castra Lambaesitana. VIII 2564

C. ? Titurnius Q eq III Gall 150-200 A.D. Mateur Tunis. . CRAI 1913 p 28 QUARTUS

Aufidius $\mathbf{Q}$ bf trib (III Aug) Date? Lambaesis............ VIII 2815

M. Aurelius M. f. Q eq II Parth Sever dup c225 Sentinum.....XI 5746

C. Iulius C. (f) Cl. Q Cel(eia) mil XX V v Date? Chester Eng. E.E. IX 1060

Matius Q p p III Aug Date? Lambaesis................ VIII 8768

C. Mattius Q Ficino princeps III Aug Date? Lambaesis....VIII 2941

T. Valerius T. Cla. Q Vir(uno) mil XV Apol 1s Carnuntum

Pann Sup.............................. 4484

C. Vibius C. f. Cor. Q mil V Mac ante Caracall? Philippi

Macedonia...............................II 647

Q mil XIII Gem post Traian Sarmizegetusa...........III 7921

Quart(us) mil aut hastatus in leg I Min 3s? Lyons...... XIII 1881 QUESTOR

M. Sallustius Q optio (III Aug) 198-211 A.D. Castra Lambae-

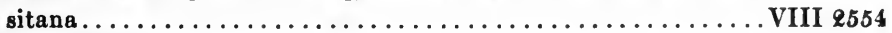
QUIETUS

Q. Atius Q. f. Gal. Q domo Nertobriga mil IIII Mac ante Vespas Mainz............................... XIII 6854

Aur(elius) Q mil (V Mac?) M. Aurel-874 Potaissa Dacia......III 7675 (C)aecilius (Qu)ietus Tha(mugadi) mil? (III Aug) Date?

Castra Lambaesitana........................... VIII 2567

M. Cuspius $Q$ frum XXX Ulp vict Date? Rome............VI 3961

Fulv(ius) $Q$ arm cust (III Aug) Date? Lambaesis........... VIII 2913

Iulius Q optio (III Aug) 198-\&11 A.D. Castra Lambaesitana.... VIII 2554

M. Sabinianus $Q$ mil medicus I Min p f 161 A.D. Iversheim

Germ Inf ............................... XIII 7949

Silius Q mil III Aug aet Severi? Lambaesis............. VIII 2975-6 QUINTIANUS

P. Ael(ius) Q Magni fil $7 \mathrm{~V}$ Mac 161-9 A.D. Troesmis........III 6169

Aur(elius) $\mathbf{Q}$ mensor $\mathrm{V}$ Mac Date? Dertona.............. 7368

Q. Caecilius Q ? (III Aug) Date? Castra Lambaesitana....VIII 2562

Tib. Gl(audius) $\mathbf{Q}$ bf cos Date? Binchester Eng............VII 4\&4

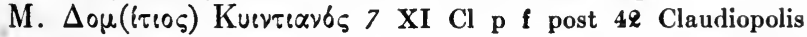

Bithynia.............................. IG a RR III 74 
Iulius Q arm cust (III Aug) 200 A.D. Castra Lambaesitana..A.E. 1902:10 Iulius Q buc III Aug p v Antonin 218 A.D. Castra Lambaesitana.. VIII 2564

C. Iulius Q 7 (III Aug) Date? Lambaesis............. VII 2914-17

C. Iulius Q Cas ds buc (III Aug) Date? Castra Lambaesitana. . VIII 18086

C. Iulius Q Cas-s (III Aug) Date? Castra Lambaesitana.....VIII 2568

C. Iul(ius) Q Max(ula) mil? (III Aug) Date? Castra Lam-

baesitana.................................. 2567

M. Ulpius Q 7 III Aug Date? Lambaesis..............VIII 2647

C. Val(erius) $Q$ S(irmio) vet VII Cl 195 A.D. Viminacium

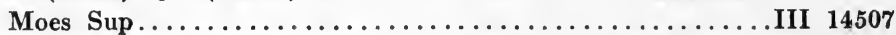

D. Valerius Quintian(us) exactus III Aug p v c20z Castra

Lambaesitana ............................ 1898:109

Q. Va(lerius) Q Rat(iaria) bf cos vet VII Cl 195 A.D. Viminacium Moes $\operatorname{Sup} \ldots \ldots \ldots \ldots \ldots \ldots \ldots \ldots \ldots \ldots \ldots$ III 14507

QUINTILIANUS

—ius Qui(nti)l(i)an(u)s bf cos II Ital \&-3s Atrans Noricum. .III 11676 QUINTILLIANUS

Aur(elius) Q (vet? V Mac?) Date? Potaissa Dacia..........III 7688 QUINTILUS

Sex. Iulius Sex. (f) Serg. Q Anti(ochia) mil XV Apol 1s Car-

nuntum Pann Sup.................... 14358:20

QUINTINUS

(L.?) Val(erius) Quin(t)inus vet VII Cl Date? Viminacium

Moes Sup .................Jahres Wien 1909 Beibl p156

—cutius Q vet XIII Gem 191 A.D. Apulum Dacia.........III 1172 QUINTULLUS

- (Qui)ntullus Nico(media) vet? (III Aug) aet Hadriani

Castra Lambaesitana...................... VIII 18084

QUINTULUS

M. Iulius Q Girt(a) vet III Aug p v c198 Castra Lambaesitana . . VIII 18068 QUINTUS

Aurel(ius) Quint(us) bf cos Date? Siscia Pann Sup........III 3957

L. Aurelius Q 7 VII Gem 160 A.D. Rome................ 768

T. Barbius A. f. Q mil XV Apol Date? Lauriacum Noricum.... III 5680

Tib. Claudius $Q$ dup II Adi p f 211-2 A.D. Aquincum Pann

Inf ...................................III 14341:3

Fl(avius) Quint(us) vet VII Cl 135 A.D. Viminacium Moes Sup.. III 8110

Iul(ius) Quin(t)us VII (Cl) Date? Viminacium Moes Sup....III 8122

C. Iulius $Q$ arm cust III Aug Date? Lambaesis.......... VIII 2918-9

(M) Pompeius Qu(i)ntus vet ex bf trib XXX Ulp vict Date?

Lyons.................................... 1879

M. Ulpius Ner. Q Glevi frum VI Vict Date? Rome........... VI 3346

Val(erius) $Q$ discens eq? $\mathrm{XI} \mathrm{Cl} 3$ s exe-4s init Aquileia........... 944

Q. Vetius $Q$ optio XXX Ulp vict p f 233 A.D. Vetera Germ Inf . XIII 8629

(Q)uintus mil XI Cl 155 A.D. Almus Moes Inf .........III 7449 


\section{QUIRINALIS}

P. Clodius Q mil XV Apol 1s Tergeste................. 540

Iul(ius) Q 7 II Adiut c150 Cartenna Mauretania Caesariensis.............................. 9653 et 9660

RAETICUS

C. Iul(ius) $\mathbf{R} 7$ VI Vict post Hadrian Vindolana Eng......... VII 708 REBURRINUS

G. Terentius Reburri(nus) vet VII Gem Date? Lara Tarracon-

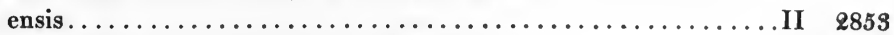
R 7 (leg ?) Date? Slack Eng................ VII 201 REBURRUS

T. Flavius R (spec VII Gem fel) Date? Tarraco............. II 4143

C. Iulius R d Segisama Brasaca mil VII Gem fel Date? Tarraco. . II 4157

C. Val(erius) $R$ vet (VII Gem p f) Date? Tarraco........... II 4169

L. Val(erius) $R$ frum VII Gem p f 2 s Tarraco............... II 6088 REDITUS

M. Aurel(ius) $\mathbf{R}$ bf leg leg II Adi p f Sever c225 Salmar Pann Inf III 3624 REGILLIANUS

(Aurelius) $\operatorname{Re}(\mathbf{g}) \mathbf{i}(\mathbf{1 1})$ ianus lib leg leg I Adiut Date? Intercisa

Pann Inf............................III 10310

REGINALIS

P. Omidius R ? (III Aug) Date? Castra Lambaesitana......VIII 2565 REGINUS

Annius $R$ mil III Aug Date? Lambaesis.............. VIII 3029

Fla(vius) $R$ mil XI Cl 155 A.D. Almus Moes Inf ............. III 7449

F1. Iulius $R$ mil XXII Pr p f post 89 Castellum Mattiacorum... XIII 7291

L. Vettius L. f. Vol. R aquil leg XXI 43-69? Col Ulpia Traiana

Germ Inf.............................. 8650

REGULIANUS

L. Cassius $\mathbf{R}$ vet ex bf $\cos$ II Adiut Date? Aquincum Pann Inf..III 3543 REGULUS

Cocceius R 7 (leg?) Date? Amboglanna Eng...........E.E. VII 1075

T. Minucius R Cas mil? (III Aug) Date? Castra Lambaesisitana ............................. 2568

Sex. Palpell(ius) Sex. f. Regu(lus) vet ex bf cos VII Cl Date?

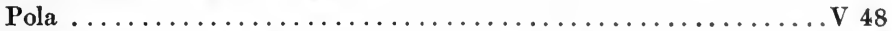

ius R mil VI(II) Aug Antonin c215 Tilena Germ Sup.......XIII 5623

R7 (leg?) coh? Date? Borcovicium Eng............VII 675 RENUNTIATUS

Munatius $\operatorname{Re}(n u)$ ntiatus optio pr III Aug Date? Batna...... VIII 4294 REPENTINUS

C. Manlius Ouf. $\mathbf{R}$ vet VIII Aug Date? Milan............ 5827

L. Munatius R optio (III Aug) Date? Lambaesis ............ VIII 2947

Pomponius Repentin(us) dup III Aug p v Antonin 218 A.D.

Castra Lambaesitana......................... 2564

Q. Salonius R Tha(mugadi) quaest III Aug c225 Lambaesis.... VIII 2586 
RESCUPORIS

Aur(elius) Rescupor(is) Ier- vet VII Cl 195 A.D. Vimin-

acium Moes Sup........................III 14507

RESPECTUS

C. Aemil(ius) R bf $\cos$ II Ital p f 209 A.D. prope Virunum Noricum III 14361 Aur(elius) $R$ vet II Adi $p$ f 230 A.D. Grani Pann Inf .......... III 10594 Aur(elius) (R)espectus vet II Adi p f \&-3s Vorosvar Pann Inf..III 10569 C. Catonius R bf $\cos 230$ A.D. Asberg............... XIII 8588 Cervius R mil III Aug Date? Lambaesis............... VIII 2839 Crescentin(i)us R 7 VIII Aug Date? Limes prope Ems...... XIII 7613 L. Dindius R 7 XIII Gem Date? Celeia Noricum............III 5223 L. Titulenius L. f. $R$ vet bf $X$ Gem Date? Tragurium Dalmatia III $\mathbf{2 6 7 7}$ Respe(c)tus Pol. Tev(este) sig (I) Adi p f Date? Cyrrhus Syria...$\ldots \ldots \ldots \ldots \ldots \ldots \ldots \ldots \ldots \ldots \ldots \ldots \ldots \ldots \ldots$ III 6706

RESTIO

(?O)pillus R mil XXII Antonin p p f 219 A.D. Salodurum Germ

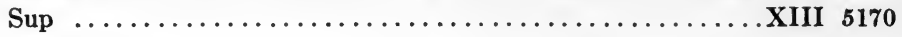

\section{RESTITUTUS}

C. A(1)pinius $R$ frum XXII Prim Date? Velitrae.....X $6575=$ VI 32873 Apo(nius) $R$ vet XXII Pr p f post 89 Dibio Germ Sup........ XIII 5486 G. Caecilius R spec VII Gem c\&00 Tarraco...............II 4128 Ti. Cl(audius) R Tolo(maida) vet? (III Aug) aet Hadriani

Castra Lambaesitana..........................VIII 18084

Constant(ius) R comm cos VIII Antonin 213-817 A.D. Mainz... XIII 6803

C. Iullus $R$ mil II $\operatorname{Tr}$ fort Date? Cnidus...............III 6098

C. Novetius $R$ vet I Adiut ex bf cos post 114? Latobici Pann Sup III 3902 M. Ulpius R exercitator eq (XIII Gem) post Traian Apulum Dacia III 14477 T.? $\quad R$ mil XXII Pr p f post 89 Worms Germ Sup.......... XIII 6287 R 7 VII Gem fel Date? Oppida circa Burgos Tarraconensis II 2901

\section{RESTUTUS}

Aelius R 7 I Adiut 7 III Aug Date? Lambaesis............. VIII 2788 An(t)onius $R$ (mil? III Aug) c200 Castra Lambaesitana

Bull Archeol 1905 p\&s9

Caecilius R mil III Aug Date? Lambaesis...............VIII 3065 T. Flavius $R$ bf trib (III Aug) Date? Lambaesis............ VIII 2876 Iuvenius $R$ vet (III Aug) Date? Lambaesis.............. VIII 18310 Q. Saedius $\operatorname{Res}(t) u(t)$ us? sig? (III Aug) 209-211 A.D. Castra

Lambaesitana ............................... 2556

Secundius R 7 X Gem Date? Daruvar Pann Sup...........III 3999 Sept(imius) $R$ comm legg III Antonin ( = X Gem XIV Gem I Ad)

c218 Carnuntum Pann Sup.......................II 4452

Tarquitius f. Camilia Restu(tu)s Pisauro 7 I Min

p f Date? Col Agrippinensium..................... 1910:61

RETICUS

Cl(audius) $R$ vet III Ital Date? Castra Regina Raetia.........III 11968 


\section{RHYTO}

R Ant(iocha) vet? (III Aug) aet Hadriani Castra Lambaesitana ............................. 18084 RIXULA

C. Iulius $\mathbf{R}$ vet $\mathbf{X}$ Gem Date? Sicca. VIII 15874 ROBUSTUS

L. Lucretius Serg. R Scallabi mil (III Aug) Date? Lambaesis.. VIII 3182 ROGATIANUS

Aurelius R mensor (III Aug) 3s? Castra Lambaesitana...A.E. 1904:72 Emilius $R$ bf III Aug Date? Lambaesis................ VIII 2798 Emonius $R$ dup III Aug $p$ v Antonin 218 A.D. Castra Lambaesi-

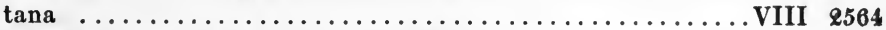

Gabinius R dup III Aug p v Antonin 218 A.D. Castra Lambaesi-

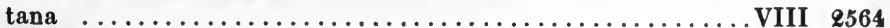

Gargilius R mil III (Aug) Date? Lambaesis............... VIII 3115

Q. Geminius R P(ollia) Cas vet ex cand (III Aug) 211-2 A.D. Lambaesis ..................................... 2618

L. Ianuar(ius) R Tusd(ro) vet cand (III Aug) \&11-\& A.D. Lambaesis ........................................... 2618

Iulius Rogatian(u)s sig (III Aug) Date? Castra Lambaesitana VIII 18073 Q. Iulius R sig (III Aug) Date? Lambaesis.............. VIII 2920 T. Iulius R ? (III Aug) Date? Castra Lambaesitana........... VIII 2562 Lolius Rogatian(us) sig (III Aug) Date? Castra Lambaesitana. .VIII 18073 Lurius Rogatian(us) dup III Aug p v Antonin 218 A.D. Castra Lambaesitana .............................. 2564

Maenius $R$ (eq? III Aug) e2\&-35 A.D. Castra Lambaesitana

Octavius R (dup) III Aug p v Antonin 218 A.D. Castra LambaeMAH 1897 p447

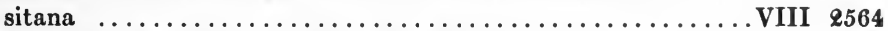

C. Pontius Roga(ti)anus ? (III Aug) 209-211 A.D. Castra Lambaesitana ................................ 2556

C. Raecius Rogatianu(s) ? (III Aug) Date? Castra Lambaesitana ..................................... 2565

C. Rupil(ius) $R$ optio (III Aug) 198-211 A.D. Castra Lambaesitana ................................. 2554

Tonneius $R$ dup III Aug p v Antonin 218 A.D. Castra Lambaesi-

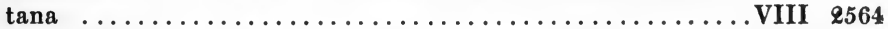

L. Valerius R ? (III Aug) Date? Castra Lambaesitana. ........ VIII 2570 -us R Lambes(e) (mil? III Aug) Date? Castra Lambaesitana A.E. $1899: 92$ ROGATUS

M. Aelius R Cas vet III Aug 166 A.D. Castra Lambaesitana..... VIII 18067 Q. Aenius $\mathbf{R}$ mil (III Aug) Date? Lambaesis.............. VIII 2799 Anicius $R$ dup III Aug p v Antonin 218 A.D. Castra Lambaesi-

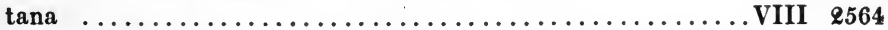

Anneius $R$ dup III Aug p v Antonin 218 A.D. Castra Lambaesitana 
C. Aponius R mil (III Aug) Date? Lambaesis............. VIII 3038 Areius $R$ dup III Aug $p$ v Antonin 218 A.D. Castra Lambaesitana VIII 2564 C. Arrius R (mil? III Aug) c200 Castra Lambaesitana

Bull Archeol 1905 p239

Q. Attius R Cast vet III Aug p v c198 Castra Lambaesitana. .... VIII 18068 Aufidius $R$ mil III Aug Date? Lambaesis...............VIII 3046 Caecilius R arm cust (III Aug) 200 A.D. Castra Lambaesitana A.E. 1902:10 C. Caecilius R ? (III Aug) Date? Castra Lambaesitana........ VIII 2562 Claudius $R$ arm cust (III Aug) 200 A.D. Castra Lambaesitana A.E. 1908:10 Cornelius R dup III Aug p v Antonin 218 A.D. Castra Lambaesitana ...................................... 2564

C. Cornel(ius) Roga(tus) mil? (III Aug) Date? Castra Lambaesitana ................................... 2567

Flavius Rogat(us) tub III Aug p v 202 A.D. Castra Lambaesitana ................................. 1907:184

M. Flavius R Amm(aedara) vet III Aug p v c198 Castra Lambaesitana .................................. VIII 18068

T. Flavius R vet (III Aug?) Date? Seriana.............VIII 4379-80

M. Fundanius R ? (III Aug) Date? Castra Lambaesitana..... VIII 2562 (G)ellius R tub III Aug p v 202 A.D. Castra Lambaesitana A.E.1907:184 L. Geminius R Cas mil? (III Aug) Date? Castra Lambaesitana ................................... VIII 2569

C. Helvius R ? (III Aug) Date? Castra Lambaesitana......... VIII 2562 Herenius Rogatu(s) optio (III Aug) 198-211 A.D. Castra Lambaesitana .................................... 2554

C. Iulius R Pa. Hadr(umeto) vet (III Aug) aet Hadriani Castra Lambaesitana ............................ VIII 18084

C. Iul(ius) R mil III Aug vet II Adiut 211 A.D. Aquincum Pann Inf $\ldots \ldots \ldots \ldots \ldots \ldots \ldots \ldots \ldots \ldots \ldots \ldots \ldots \ldots \ldots \ldots \ldots$ III 10419

C. Iul(ius) $\mathrm{R}$ bf $\cos \mathrm{XI}$ Cl post Claud Gradina Dalmatia......... III 9862

C. Iulius $R$ dup III Aug $p$ v 3s? Lambaesis............... VIII 2921

C. Iulius R vet (leg?) Date? Carthage................. VIII 12591

Q. Iulius Rog(atus?) lib (III Aug) Date? Castra Lambaesitana VIII 2560

L. Memius R vet III Aug Date? Kesur el Ghennaia.......... VIII 4308 Memmius $R$ dup III Aug p v Antonin 218 A.D. Castra Lambaesitana................................. VIII 2564

Q. Mundicius Roga(tus) (vet? III Aug?) Date? Lambaesis.. VIII 3202 Nonius $R$ dup III Aug $p$ v Antonin 218 A.D. Castra Lambaesitana. VIII 2564 Q. Oppius C. f. Q. R vet I Adi p f 2-3s Civitas Celtianensium... VIII 19694 Pettius $R$ bf trib III Aug p v Antonin 218 A.D. Castra Lambaesitana ................................ VIII 2564

Marcus Sentius R mil III Aug Date? Lambaesis...........VIII 3236 G. L. Servilius R 7 III Aug Date? Lambaesis............. VIII 2616 C. Servilius R optio (III Aug) Date? Castra Lambaesitana.... VIII 2531 Marcus Sin(n)ius R mil III Aug Date? Lambaesis.......... VIII 3240 Sittius $R$ dup III Aug p v Antonin 218 A.D. Castra Lambaesitana VIII 2564 P. Sittius R Cas dup (III Aug) Date? Castra Lambaesitana.... VIII 2568 
P. Vetulenius Rogat(us) cor III Aug p v 203 A.D. Castra

Lambaesitana ............................... VIII 2557

Vibius $R$ dup III Aug $p$ v Antonin 218 A.D. Castra Lambaesitana VIII 2564

Q. Volusius $\mathbf{R}$ mil III Aug Date? Lambaesis..............VIII $328 \varepsilon$ -ius R Kar mil? (III Aug) aet Antonini Pii Castra Lambaesitana $\ldots \ldots \ldots \ldots \ldots \ldots \ldots \ldots \ldots \ldots \ldots \ldots \ldots \ldots \ldots$ VIII 18085

\section{ROMANUS}

P. Aelius P. f. R ex Mysia 7 III Aug VII Cl XX V v I Ital ante

Caracall Lambaesis............................VIII 2786

P. Ael(ius) $R$ vet ex actar X Gem Date? Scarbantia Pann Sup.. III 4232

F1. Antonius (R)omanus (bf) $\cos \mathrm{XI}(\mathrm{II}) \mathrm{Gem}$ Antonin 218 A.D.

Troesmis ................................ 6161

Audac(ius) R 7 leg VI. XX. (II) Aug Date? Magnae Eng........ . VII 749

Aurelius R dup III Aug p v Antonin 218 A.D. Castra Lambaesi-

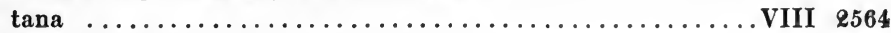

Aurel(ius) R (mil? III Aug) c218? Castra Lambaesitana

Bull Archeol 1904 p 206

Aurel(ius) R (mil? II Parth?) Date? Rome............... 2410 M. Aurel(ius) $R$ dom Antioc(hia) vet X Gem Date? Savaria

Pann Sup .............................. 10920

(C)aecilius R Tipasa (mil? III Aug) c200 Castra Lambaesitana

Bull Arch 1905 p 239

Sextus Caesonius R bf cos XIIII Gem Date? Narona Dalmatia III 8435 T. Fl(avius) R 7 XXII Pr p f 232 A.D. Walldürn........... XIII 6592 Iulius $R$ arm cust (III Aug) 200 A.D. Castra Lambaesitana..A.E. 1902:10 Iul(ius) $\mathbf{R}$ spec legg III Antonin ( = X Gem XIV Gem I Ad) c212

Carnuntum Pann Sup.........................III 4452

M. Munat(ius) R optio (III Aug) 198-211 A.D. Castra Lambaesitana ...................................... 2554

M. Novellius M. f. Ouf. Rom(anus) Mediolani mil XXII Prim

Date? Mainz ............................ 6967

Ael. Sept(imius) $R$ adiut offic cornicul XIII Gem post Traian

Sarmizegetusa $\ldots \ldots \ldots \ldots \ldots \ldots \ldots \ldots \ldots \ldots \ldots \ldots \ldots \ldots \ldots \ldots \ldots \ldots$ III 1471

Ulp(ius) Roman(us) vet II Adi p f Date? Aquincum Pann Inf...III 3459 Q. R mil III Cyr aet Antonini Pii inter Calamam Sigus Cir-

tam ................................... 5678

R 7 (leg?) Date? Petrianae Eng.................... VII 904

ROMULUS

Aquil(ius) $R$ spec legg III Antonin ( $=$ X Gem XIV Gem I Ad) c212

Carnuntum Pann Sup.......................... 4II 4452

C. Attius R Augusta mil X Gem ex arm cust Date? Vienna....III 4578

Aur(elius) $R$ mil II Parth Sever $p$ f aetern c225 Rome..........VI 3403

Cl(audius) $R$ dup (XIIII Gem?) ante 178 Carnuntum Pann Sup..III 11180

Val(erius) $R$ bf cos (leg?) Date? Apulum Dacia..............III 1189

C. Valerius R mil leg XIIII ante 62? Aquae............ E. 1907:109 ROSGIUS

Iul(ius) $R$ vet ( $\mathrm{V}$ Mac) c134 Troesmis.................III 6178 


\section{ROSCRIANUS}

G. Iul(ius) P. f. $\mathrm{R}$ arm cust VII Cl 270 A.D. Viminacium Moes Sup III 8117 ROSINUS

Gellius R tub III Aug p v 202 A.D. Castra Lambaesitana. .A.E. 1907:184 RUFINUS

C. Aelius R Cas arm cust (III Aug) Date? Castra Lambaesitana VIII 2569

P. Ael(ius) $R$ corn praef kastror XIII Gem post Traian Apulum

Dacia ..................................III 1099

P. Ael(ius) $R$ frum VII Cl Date? Rome............... VI 3347

L. Aemilius R Cas mil? (III Aug) Date? Castra Lambaesi-

tana ..................................... $\mathbf{2 5 6 7}$

M. Aemilius R bf trib lat III Aug p v 198 A.D. Castra Lambaesi-

tana .................................... 2551

Aetrius R optio III Aug 162 A.D. Castra Lambaesitana........ VIII 18065

Antonius R? 7 VI Vict post Hadrian York Eng........... VII 24\&:4

Q. Aranius R mil III Aug Date? Lambaesis..............VIII 3039

T. Aurelius R vet I Min Date? Col Agrippinensium......... XIII 8277

G. Avidius $R$ vet (III Aug) Date? Lambaesis............. VIII 3048

G. Caecilius $\mathbf{R}$ vet II Adiut Date? Lambaesis..............VIII 3066

Caelius R Cas vet ex armatura (III Aug) \&11- 2 A.D. Lambaesis. VIII 2618

Caesius R (eq? III Aug) 282-35 A.D. Castra Lambaesitana MAH 1897 p447

Q. Cumelius R mil II Adiut Date? Asturica Tarraconensis...... II 2639

L. Duccius L. (f) Volt. R Vien(na) sig leg VIIII aet Agricolae

York Eng. ............................... VII $\mathbf{2 4 3}$

P. Helvius R mil (III Aug) Date? Lambaesis............. VIII 3128

Iulius $\mathrm{R}$ dup III Aug $\mathrm{p}$ v Antonin 218 A.D. Castra Lambaesitana. . VIII 2564

Iulius R ? (III Aug) Date? Castra Lambaesitana........... VIII 2570

Q. Iulius R bf trib lat III Aug p v 198 A.D. Castra Lambaesitana. VIII 2551

Sex. Iulius R mil III Aug Date? Sra Wartan.............VIII 16333

Tib. Iulius Tib. f. Cl. R Vir(uno) eq XXII Pr p f post 89 Mainz. XIII 6963

G. Licinius R 7 VII Cl Date? Rama prope Lederatam Moes Sup III 8099

T. Plotius Tromentina $R$ Aequo vet II Adi $p$ f Date? Ravenna.... XI 83

Rufi(nius) $R 7$ III Aug Date? Lambaesis............... VIII 8967

C. Sempronius R Kar vet? (III Aug) \&s? Castra Lambaesi-

tana ................................... VIII 18087

L. Silius R sig III Aug aet Severi? Lambaesis............ VIII 2975-6

Valerius $R$ tess (III Aug) Date? Lambaesis.........VIII $2880=2996$

L. Valerius Gal. R Iu- mil VII Gem fel Date? Lambaesis. VIII 3268

T. Valerius R 7 III Aug 17q-4 A.D. Lambaesis............ VIII 2730-1

Vibius Rufi(n)us sig XIII Gem post Traian Apulum Dacia......III 1192

(R)ufinus T(h)e(lepte) mil? (III Aug) aet Antonini Pii

Castra Lambaesitana .........................VIII 18085

\section{RUFUS}

C. Aebutius C. f. $R$ aquil leg XI c31 B.C. Ateste.......... V 2495

Ael(ius) Rufu(s) vet VII Cl 135 A.D. Viminacium Moes Sup.... III 8110

Ael(ius) $R$ mensor II Adiut Date? Aquincum Pann Inf........III 3433

Aelius R ? (III Aug) Date? Castra Lambaesitana........... VIII 2568 
Aelius R (mil? II Parth?) Date? Rome................ 8410 L. Aelius R Cas mil? (III Aug) Date? Castra Lambaesitana.. VIII e567 Aemilius $R$ dup III Aug p v Antonin 218 A.D. Castra Lambaesi-

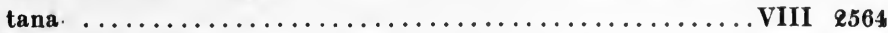

Q. Aemil(ius) $\mathbf{R}$ bf $\cos$ Date? Salonae Dalmatia............III 12895

Annius R 7 XV Apol 105-17 A.D. Mons Claudianus Egypt......... III 25

Annius R 7 XIIII Gem post 100 Vienna .............. III 15196:4

C. Antonius C. f. Cl. R Apro mil I Adiut 70-100 A.D. Mainz . . . XIII 6826

Q. Attius Q. f. Tro. R Aequ(o) mil I Adiut 70-100 A.D. Mainz. . XIII 6828

L. Aufellius $\mathrm{R}$ p p VII $\mathrm{Cl}$ p f Date? Cales............... 4.641

Aufidius R Lamb comm III Aug c225 Lambaesis............ VIII 2586

Aur(elius) Rufu(s) mil XI Cl? 4\&-70? A.D. Raetinium Dal-

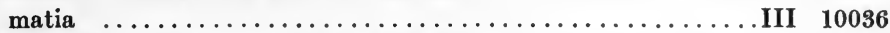

L. Aurelius L. f. Rufu(s) p p leg XVI ante Vespas? Acerrae....X 3757

M. Aurel(ius) $\mathbf{R}$ tess VII Cl \&s exe-3s init Viminacium Moes Sup. . III 8118

Q. Aurelius R Cast vet III Aug p v c198 Castra Lambaesitana ... VIII 18068 Avidi(us) R 7 (leg?) Date? inter Condercum et Vindobalam Eng

E.E. IX 1169

Avid(ius) R 7 (leg?) Date? Proclitia Eng............... VII 629

Blesius $R$ arm cust (III Aug) 200 A.D. Castra Lambaesitana A.E. 1902:10

M. Caecilius M. f. Iul. R Concord(ia) 7 III Cyr ex corn 191 A.D.

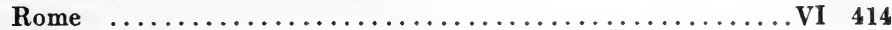

C. Caelius $R$ dom Hadr(umeto) bf praef III Aug Date? Lam-

baesis ............................... 18293

Carisius R (7) VII Gem Date? Lucus Augusti Tarraconensis.... II 2583

Cartellius $\mathbf{R}$ vet (leg?) Date? Caesarea Mauretania Caesariensis VIII 21022

L. Cassius $\mathbf{R}$ mil III Aug Date? Lambaesis............. VIII 3077

M. Cassius R vet III Aug p v c198 Castra Lambaesitana....... . VIII 18068

Q. Cassius Ru(f)us (mil III Cyr aut XXII Deiot) 90 A.D.

Fayoum Egypt............................................. 1

Ceionius R 7 III Aug coh II 162 A.D. Castra Lambaesitana.... VIII 18065

Cereli(us) $\mathbf{R}$ mil III Cyr ante 108 Egypt...........Wessely Lat Pal 8

Corn(elius) Ruf(us) vet VII Cl 135 A.D. Viminacium Moes Sup. III 8110

Cusin(ius) R 7 (XIIII Gem?) 188 A.D. Carnuntum Pann Sup A.E. 1905:237

L. Domitius $R$ mil III Aug Date? Lambaesis............. VIII 3100

T. Fl(avius) $R$ dom Amas(ia) vet $\mathrm{XI} \mathrm{Cl} p$ post 42 Raetsch Dacia III 971

T. Flavius T. f. Pup. R 7 XIIII Gem XI Cl II Aug VII Gem ante

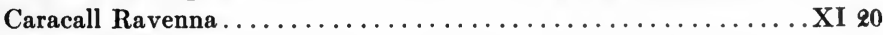

Q. Frendullus $\mathbf{R}$ Vicetinus arm cust (leg?) Date? Aquincum

Pann Inf............................ 3549

Gargilius $R$ spec VII Gem fel Date? Tarraco.............. II 4145

Iulius $R 7$ leg X Date? Summus Poeninus................ 1894:150

(I)ulius R mil (V)III (Aug?) Date? Caleti prov Lugudun...... XIII 3224

Iuli(us) $\mathbf{R} 7$ (leg?) Date? Condercum Eng.............. VII 530

Iulius $\mathbf{R}$ bf $\cos$ Date? Apulum Dacia................. III 7755

C. Iulius R Cas mil? (III Aug) Date? Castra Lambaesitana... VIII 2568

T. Iulius R 7 III Aug Date? Calceus Herculis Numidia....... VIII 2498

Iun(ius) $\mathbf{R u ( f u s ) ~} 7$ (leg?) coh X Date? Chesters Eng.......... VII 603 
Iuni(us R)ufus (domo H)erac(lea) vet leg - Date? Salonae Dalmatia................................III 18903 Licinius $R$ mil VII Gem fel Date? Tarraco...............II 4157 M. Longinu(s Ruf)us (mil III Cyr aut XXII Deiot) 90 A.D.

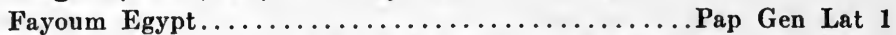

M. Magullius R vet III Aug 2s exe-3s init Castra Lambaesitana Mém de l'Acad des Inscr 38:1 p269

C. Manilius R Prusia vet? (III Aug) aet Hadriani Castra Lambaesitana ............................... VIII 18084

Mar(cius) Ruf(us) 7 (leg?) coh VIIII Date? Amboglanna Eng....VII 853 (L?) M(arci?) us L. (f) Pap. R S-era mil? leg II Date? Bur-

guillos Baetica............................ 985

M. Marcius (R)ufus sig IIII Mac ante Vespas Narbo.......... XII 4365

M. Moranus R (7?) leg VIIII ante Claud Histria............ 8197 Nonius R 7 III Cyr ante 108 Egypt...............Wessely Lat Pal 8 M. Pacilius R 7 IIII Fl firm Date? Ager Aquincensis Pann Inf.. III 10337 M. Papirius R C- (mil III Cyr aut XXII Deiot) 87 A.D.

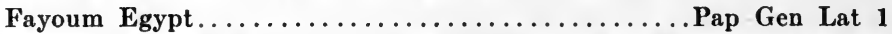

Q. Petronius M. f. Sca. R vet VII Cl p f Date? Scupi Moes Sup III 8199 (Pom)peius R ? (III Aug) Date? Castra Lambaesitana........ VIII 2562 Pompe(ius) R 7 (leg?) Date? Chesters Eng............... VII 611

Sex. Proculeius L. F. Lem. R vet leg XV ante 63? Scarbantia

Pann Sup............................... 4 III

Publicius R bf (III Aug) Date? Lambaesis.............. VIII 2966

L. Publicius R Cas ? (III Aug) Date? Castra Lambaesitana.... VIII 2566

Q. Raecius Q. f. G1. R p p XII Fulm aet Traiani Iader Dalmatia. . III 2917

C. Refidius R optio IIII Fl firm Date? Viminacium Moes Sup...III 1652 - (S)atr(ius) —Cam. R Ravenna mil XI Cl p f 42-Vespas

Burnum Dalmatia...........................E. 1903:378

Semp(ronius) $R$ vet $(V$ Mac) c134 Troesmis..............II 6178

T. Servil(ius) (R) ufus 7 leg XXII c65 Alexandria Egypt........ III 6606

Cn. Terentius Cn. (f) Clu. R Iguvinus mil III Aug Date? Tha-

la Byzacena ............................E, 1898:97

Tettius R arm cust III Aug c225 Castra Lambaesitana........E. 1902:11

M. Ulpius Ruf(us) eq I Adi p f post 114 Brigetio Pann Sup . . . . . III 14955:22

Val(erius) $R$ vet ex eq (V Mac) c134 Troesmis..............III 6178

Val(erius) $R$ mil XI Cl 155 A.D. Almus Moes Inf............III 7449

Valerius R corn XI Cl 155 A.D. Almus Moes Inf............ III 7449

Valerius R 7 III Aug post Hadrian ante erasum legionis Lambaesis VIII 18223

Val(erius) $R$ ? VI Vict post Hadrian Manchester Eng........... VII 217

(V)alerius (R)ufus eq III Aug Date? Lambaesis............ VIII 18322

Val(erius) $R$ mil frum VII Gem Date? Tarraco...........II 4170

C. Valerius R Anth(edone) vet? (III Aug) aet Hadriani Castra

Lambaesitana ............................. VIII 18084

C. Val(erius) R Rat(iaria) vet VII Cl 195 A.D. Viminacium Moes

Sup .................................... III 14507

C. (Valer)ius $R$ vet I Ital Date? Oescus Moes Inf...........III 12354

L. Val(erius) $R$ vet ex bf $\cos$ XIII Gem post Traian Sarmizegetusa III 1485 
L. Valerius L. f. Col. R domo Antiochia 7 III Aug 7 XXII Prim Date? Lambaesis............................

C. Vegelo C. f. Ani. R Cremona mil XI Cl p f Vespas-Traian

Vindonissa .................................... 5216

L. Ver(ati) us (A)ufidius R Stel. Be(nevento?) 7 prin XXII Prim

Date? Ager Beneventanus..................... 2092

Vesvi(us) R 7 (leg?) Date? inter Magnas et Amboglannam Eng E.E. IX 1208

Vettius R 7 (leg XXII aut III Cyr) aet Augusti Coptos Egypt....III 6627

Q. Vettius R 7 leg XXII Date? Col Agrippinensium.........XIII 8175

T. Vettius R 7 XIII Gem 84-Traian Vienna..............III 4563 Gla. R Ara Agrip(pinensium) mil XV Apol 1s Carnuntum

Pann Sup ................................ 4 III 49

f. Pap. R(u)fus vet ex leg XIIII G m v 70-100 A.D. Mainz XIII 6915

['P]ou९os 7 (II Tr?) 180-140 A.D. Fayoum Egypt ........ BGU 600

Ru(fus) mil? (III Aug) aet Antonini Pii Castra Lambae-

sitana ................................. VIII 18085

nius M. f. Col. R Nicomed(ia) vet II Tr fort 194 A.D. Alex-

dria Egypt...............................III 6580

-us R Cast (mil? III Aug) eq00 Castra Lambaesitana

Bull Archeol 1905 p 239

$R$ vet (V Mac) Date? Troesmis.....................II 6179

us $R$ vet (V) Mac Date? Tomi Moes Inf ...............III 14454

RULIUS

Fan(n)ius R mil III Cyr ante 108 Egypt.............Wessely Lat Pal 8 RUSTICUS

Aem(ilius) Rus(ticus) mil III Aug Date? Zarai............ VIII 4504

Aurelius $R$ mensor (III Aug) 3s? Castra Lambaesitana..A.E. 1904:72

T. Ebutius R U(tica)? (III Aug) Date? Castra Lambaesitana.. VIII 2565

T. Flavius R Thy(sdro) vet III Aug 166 A.D. Castra Lambaesitana.................................... 18067

T. Flav(iu)s R (mil? III Aug) cloo Castra Lambaesitana

Bull Archeol 1905 p240

Iulius Ru(s)ticus) mil III Cyr ante 108 Egypt........ Wessely Lat Pal 8

Iul(ius) Rus(ticus) evoc (I Ital) \&s exe-3s Almus Moes Inf....III 14409:1

Iunius Rust(icus) optio (III Aug) 198-211 A.D. Castra Lambae-

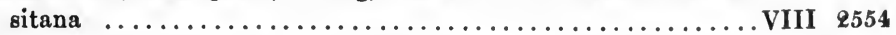

T. Licinius R 7 III Aug Date? Arelate.................. XII 684

C. Magnius R Masc(ula) mil? (III Aug) Date? Castra Lam-

baesitana .................................... 2569

Memmius R mil VI Vict Antonin c215 Cavillonum prov Lugudun XIII 2616

C. Octavius R Cas mil? (III Aug) Date? Castra Lambaesitana VIII 2567

M. Servilius R lib III Aug $p$ v 3s? Lambaesis............. VIII 2973

- (Clau)dia Rusti(c)us Teurn(i)a mil IIII Mac ante Vespas

Mainz ................................ 1909:133

RUTILIANUS

Rutilius Rutilian(us) mil? (III Aug) Date? Castra Lambaesitana .................................. III 2567 


\section{SABASIANUS}

Aurel(ius) $\mathbf{S}$ mil I Ital Date? Salonae Dalmatia............III $\mathbf{\imath} 00 \boldsymbol{\theta}$ SABINIANUS

L. Antonius $\mathbf{S}$ corn leg leg I Adi p f Sever c225 Arrabona Pann Sup

III 11079 ef 11018

Aurel(ius) S mil (III Ital) Date? Augusta Vindelicum Raetia.. III 5818 Caesern(ius) $\mathbf{S}$ sig I Adiut post 114 Brigetio Pann Sup..........III 4324 C. Coscon(ius) Sabin(ianus?) p p (XIII Gem) post Traian Apul-

um Dacia........................... 7 III

M. Iunius S Kart mil? (III Aug) Date? Castra Lambaesitana. VIII 2569 Macr(inius?) S spec I et II Adi p f Sever 228 A.D. Aquincum Pann

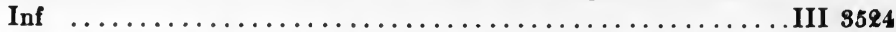

Salonius S signo Scammatius vet ex corn I Adiut $2-3$ s Salonae

Dalmatia .......................... 8758

C. Steius C. f. Polla S Cas mil III Aug Date? Lambaesis..... . VIII 3247 SABINUS

Aeli(us) $\mathbf{S}$ mil XI Cl 155 A.D. Almus Moes Inf..............III 7449

Aeli(us) S pecuarius I Adiut post 114 Brigetio Pann Sup.........III 11017

M. Antonius M. f. Collin. S Caesarea Augus 7 X Fr 7 III Aug

Date? Lambaesis ........................... 2808

Antistius Zabin(us?) dup III Aug p v Antonin 218 A.D. Castra

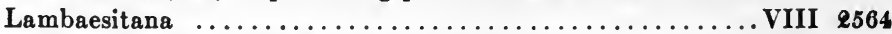

C. Apul(eius) S bf $\cos 227$ A.D. Siscia Pann Sup............ III 10843

Aur(elius) S arm cust III Ital Date? Castra Regina Raetia......III 6571

Aur(elius) Sabin(us) (vet? V Mac?) Date? Potaissa Dacia...III 7688

T. Axius S vet? (III Aug) aet Hadriani Castra Lambaesitana ... . . VIII 18084

Caecil(ius) S 7 XI Cl 4\&-Vespas Burnum Dalmatia............ III 14997

$\mathrm{K}[\lambda \alpha u ́ \delta$ เo૬ $] \Sigma[\alpha] \beta \varepsilon i v o \varsigma$ Bepplou mil (leg?) Date? Zoravia Syria

IG a RR III 1158

Tib. C(laud)lus S p p (III Aug) Date? Rusicade............ VIII 7980

(Co)rnelius S Nico(media) tess (III Aug) aet Hadriani Castra

Lambaesitana .............................VIII 18084

M. Curisius S mil XXI Rap ante Hadrian Tridentum......... V 5038

Q. Fabius S Kar mil? (III Aug) Date? Castra Lambaesitana.. VIII 2568

T. Fl(avius) Sab(inus) bf cos (I) Ital Date? Novae Dalmatia...III 1906

Q. Gemnius Q. f. Ar(n. Sa)binus 7 VII Gem VI (Fer) r (X)IV Mar

(III) Cyr Date? Turca....................... VIII 825

C. Horte(n)sius S mil III Aug Date? Lambaesis............. VIII 3125

Iul(ius) $\mathbf{S}$ vet $(\mathrm{V}$ Mac) $\mathbf{c 1 3 4}$ Troesmis................III 6178

Iulius $S$ vet (III Aug) Date? Lambaesis................ VIII 3160

C. Iul(ius) S Rat(iaria) vet VII Cl 195 A.D. Viminacium Moes

Sup ............................... 14507

C. Iul(ius) $\mathbf{S}$ mil XIII Gem post Traian Sarmizegetusa.........III 7979

P. Maecius P. f. S dom Serg(ia) vet XV Apol 1s Savaria Pann

Sup ................................III 10921

Magius $\mathbf{S}$ mil VIII Aug Date? Rome................ VI 3640

Cl. Maximius S p p III Aug Date? Lambaesis............. VIII 2763 
Orfius Sab(inus) evoc V Mac ante Aurel Tropaeum Moes Inf. . III 14214:3 L. Petronius L. f. Pup. S Foro Brent(ano?) corn pr pr X Fr

et IIII Fl p p III Cyr aet Antonini Pii Urvinum Metaurense... . XI 6055

Rufi(us) S 7 (leg?) Date? Borcovicium Eng............... VII 688

L. Rutius L. f. Serg. Italica S ex Hispania mil X Gem 1s? Aqui-

leia ................................ 932

L. Servaeus S 7 VI Vict Date? Yali Baiyat Lycaonia......... III 14398

Ulp(ius) $S$ comm legg III Antonin ( $=$ X Gem XIV Gem I Ad)

c218 Carnuntum Pann Sup....................... 4452

Ulpius S mil I Adiut post 114 Brigetio Pann Sup............III 11008

Valerius L. f. Pap. S Nar(bone) mil XXII Prim 1s? Mainz... XIII 6976

Val(erius) S optio V Mac 209-11 A.D. Potaissa Dacia.......... III 12645

Val(erius) mil I Adiut post 114 Adiaum Pann Sup............III 4278

Val(erius) $\mathbf{S}$ bf cos (leg?) Date? Apulum Dacia.............III 1189

C. Vibius $\mathbf{S}$ vet $\mathrm{V}$ Mac Date? Ager Celeianus Noricum. ........ III 5130

C. Virius $S$ vet arm cust XIIII $G \mathrm{~m} v$ Date? Comum........V 5270

Volusinius $S$ princeps XXII P r p f 207 A.D. Obernburg........ XIII 6623 Col. S Amasio mil V Mac 68 A.D. Emmaus Nicopolis

Palestine ................................ 14155:11

- $S$ vet (V Mac) c134 Troesmis.................III 6178

lius $\mathbf{S}$ princeps $\mathrm{X}$ Fr Date? Jerusalem.............III 6638

litussius S vet leg XXII Date? Agedincum prov Lugudun .. XIII 2948

SABIUS

Aurelius S nat Surus mil leg II Date? Alexandria Egypt.....III 6596 SABURIANUS

M. Pontius M. f. Col. S Gar(asa) mil XXII Deiot ante Hadrian

Alexandria Egypt.......................II 6598

SACCO

L. Varius L. f. Ouf. S Med(iolani) mil XV Prim ante Vespas

Mainz ...............................E. 1911:234

SACERDOS

Aelius S corn III Gall aet M. Aurel Perinthus Thrace..........III 7394 SAECULARIS

Iul. Marcius S 7 III Aug Date? Lambaesis.............. VIII 2896 SAENIUS

$-\mathrm{S} 7 \mathrm{XI} \mathrm{Cl}$ p f Vespas-Traian Tenendo Germ Sup.........XIII $5 \& 40$

\section{SAFIDIANUS}

T. F1(avius) S Caes(area) vet? (III Aug) aet Hadriani Castra

Lambaesitana ......................... 18III 18084

SALICA

L. Licinius L. f. Gal. S Lug(uduno) mil? II Adi p f c71 Lincoln Eng...................VII 186 add E.E. IX p557 SALINATOR

T. Elvius T. f. S 7 leg VII ante 42? Iader Dalmatia.........III 2914 SALLUBIANUS

Vid Amandus III 2066 


\section{SALLUSTIANUS}

Q. Titinius $\mathbf{S}$ mil III Aug Date? Lambaesis.............. VIII 3250 ndicius Sallust(ianus?) tub III Aug p v 202 A.D. Castra

Lambaesitana A.E. $1907: 184$

SALONINUS

Non(ius) S qui et signo Dalmatis bf cos IIII Fl Date? Viminacium Moes Sup.........................III 6300 SALUTARIS

Vitalinius $\mathbf{S}$ eq XXII P r p f post 89 Mainz.............XIII 6983 SALUTUS

C. Annius C. f. Ani. S Vercellis mil XXII Prim 1s? Mainz.... XIII 6953 SALVIANUS

Aur(elius) $\mathbf{S}$ tub XI Cl Hadrian-Maximin Chersonesus Taurica Moes Inf $\ldots \ldots \ldots \ldots \ldots \ldots \ldots \ldots \ldots \ldots \ldots \ldots \ldots \ldots \ldots \ldots \ldots$ III 782

M. Aurel(ius) $\mathbf{S a}(\mathbf{l v i})$ anus vet II Ital $\mathrm{p}$ f Sever $\mathrm{e}(\mathrm{x}$ s) tratore cos c225 Vallis Fl Mur Noricum....................III 8449 SALVIUS

Papinius S arm cust (III Aug) 200 A.D. Castra Lambaesitana A.E. 1902:10 Papinius S sig III Aug Date? Lambaesis............... VIII 2959 SAMMUS

Sept(imius) $\mathbf{S}$ cand XXX Ulp vict 223 A.D. Col Ulpia Traiana Germ Inf........................... 8607 SAMUNIO

Caecilius S dup III Aug p v Antonin 218 A.D. Castra Lambaesitana. VIII 2564 SANCTINUS

T. Fl(avius) $\mathbf{S}$ mil imm cos XXII Pr Alexandr p f 230 A.D.

Heddernheim Germ Sup...................... XIII 7935

Iul. Licinius $\mathbf{S}$ frum VIII Aug Date? Rome............VI 3358

SANCTUS

Aurel(ius) $\mathbf{S}$ mil XI Cl 155 A.D. Almus Moes Inf.............III 7449 M. Aure(lius) S vet leg XX(II) Date? Mediomatrici Belgica... XIII 4389 C. Candidinius S sig XXX Ulp vict Ulpia Noviomagus. . . . . . . XIII 8719 (S)anctus Nic(omedia) vet? (III Aug) aet Hadriani

Castra Lambaesitana ........................ VIII 18084

- S 7 II Aug Date? Stanwix Eng........VII 914 add E.E. III p136 SARAPAMMON

M. Aurelius Pol. S C(as) vet II Tr fort 194 A.D. Alexandria Egypt III 6580 T. Aurelius T. f. Pol. S Castr vet II Tr fort 194 A.D. Alexandria

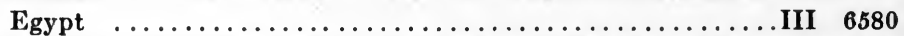

-ius M. f. Pol. S Tani vet II Tr fort 194 A.D. Alexandria Egypt III 6580 SARAPIO

Aelius Sarap(i)o Cas arm cust III Aug aet Antonini Pii Castra

Lambaesitana .......................... VIII 18085

M. Aur(eli)us Sarapio(n) ? (III Aug) Date? Castra Lambaesi- 
(S)arapio Cas mil? (III Aug) aet Antonini Pii Castra Lambaesitana ............................ VIII 18085 SARMATIUS

Val(erius) S civis Filopopuletanus mil I Ital Date? Rome VI 2785 a \& b SARNIANUS

Q. Aemilius Sarnian(us) (mil? III Aug) c 800 Castra Lambae-

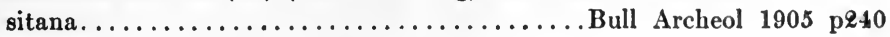
SATTO

Tib. Tiberi f. Cla. S Camboduno vet X Gem Date? Aquincum Pann Inf................................ 15162 SATULLUS

Aur(elius) Satull(us) mil I Adiut post 114 Crumerum Pann Inf .. III 3660 SATURIO

Titius S arm cust (leg?) Date? Mainz XIII 6684

\section{SATURNALIS}

T. Quartinius S sig XXX Ulp vict 239 A.D. Vetera Germ Inf . . . XIII 8625 SATURNILUS

Antonius Satu(r)nil(us) mil III Cyr ante 108 Egypt.. Wessely Lat Pal 8

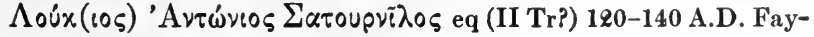
oum Egypt.................................. 600

U(1)pi(u)s Satu(r)nilus mil III Cyr ante 108 Egypt... Wessely Lat Pal 8 SATURNANUS

Val(erius) $\mathbf{S}$ mil II Ital Date? Ocriculum............. XI 4085 SATURNINUS

Q. Aebutius S optio pr pos (III Aug) c253 Castra Lambaesitana.. VIII 1807 \& Aelius S dup III Aug p v Antonin 218 A.D. Castra Lambaesitana.. VIII 2564 Aelius Saturnin(us) dup III Aug p v Antonin 218 A.D. Castra Lambaesitana .............................. VIII 2564

M. Aelius S(at) urninus Vag(a) arm cust (III Aug) 2s? Castra Lambaesitana ............................ VIII 18087 Aemilius Saturnin(us) cor III Aug p v 203 A.D. Castra Lambaesitana ..................................... 2557

T. Aemilius S Gir(ta) mil? (III Aug) Date? Castra Lambae-

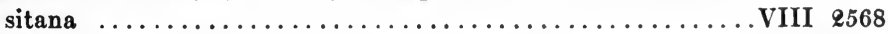

Ailius S 7 X Gem Date? Carnuntum Pann Sup............III 4463a

C. Amar(f)ius Q. f. S vet ex leg II Parth Date? Ligures Baebi-

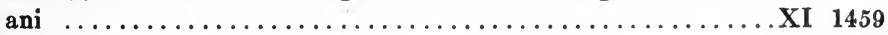

P. Ancharius S optio (III Aug) Date? Lambaesis............VIII 2804 Anneius S 7 ? XIII Gem post Traian Veczel Dacia........... III 1629:8 M. Anneus S Tha(mugadi) tub (III Aug) Date? Castra Lambaesitana ....................................... 2568 Annius S 7 XI Cl aet M. Aurel Tropaeum Moes Inf...........III 7483 Annius S vet (III Aug) Date? Lambaesis...............VIII 3030 C. Annius Saturni(nus) (mil? III Aug) c200 Castra Lambaesitana............................ Archeol 1905 p240

C. Annius Sat(urninus) mil? (III Aug) Date? Castra Lambae- 
sitana $\ldots \ldots \ldots \ldots \ldots \ldots \ldots \ldots \ldots \ldots \ldots \ldots \ldots \ldots \ldots$ VIII 2567

C. Annius S ? (III Aug) Date? Castra Lambaesitana......... VIII 2562

M. Annonius S Had(rumeto) vet? (III Aug) \&s? Castra Lambaesitana ........................... VIII 18087

C. Antistius Saturn(inus) Tha(mugadi) mil? (III Aug)

Castra Lambaesitana............................. 2567

Antonius S (vet) ex bf cos Date? Tarraco............... 4149

L. Antonius S Bag(ai) mil? (III Aug) Date? Castra Lambae-

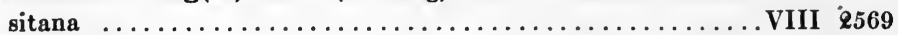

M. Antonius S Thy(sdro) vet III Aug 166 A.D. Castra Lambaesitana ................................. 18067

M. Antonius Sat(urninus) mil? (III Aug) Date? Castra

Lambaesitana ............................... III $\$ 567$

Aponius Saturnin(us) dup III Aug p v Antonin 218 A.D. Castra

Lambaesitana ............................. VIII 2564

Apo(nius) Sat (urninus) optio (III Aug) Date? Lambaesis VIII 2810 cf 2554

C. Aponius S optio (III Aug) 198-211 A.D. Castra Lambaesitana VIII 2554

C. Appul(eius) $S$ (atur)ninus vet XXII Pr p f post 89 Mainz.... XIII 6732 Areius Saturn(inus) arm cust (III Aug) 200 A.D. Castra Lambaetana................................. 1908:10

L. Arruntius S bf praef III Aug Date? Lambaesis...........VIII 2813 M. Atilius S Hel(io)p(oli) vet? (III Aug) aet Hadriani Castra Lambaesitana ............................. VIII 18084

Aurelius Satur(ninus) arm cust III Aug c225 Castra Lambaesitana ............................... 1908:11 Aur(elius) $\mathbf{S}$ mil II Ital tess $3 \mathrm{~s}$ Rome................. VI 2672 Aurelius S mil III Aug Date? Lambaesis...............VIII 3057 (M) Aur(elius) S Sc(upis) vet VII Cl 195 A.D. Viminacium Moes

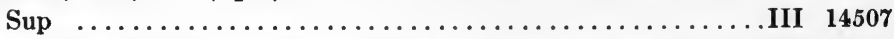

Q. Aurelius S ? (III Aug) Date? Castra Lambaesitana........ VIII 2568

(C) Badius S Th(eveste) (mil? III Aug) c 200 Castra Lambaesitana ............................ Archeol 1905 p\&39

Barbius S polio mil II Tr Germ fort post 214 Alexandria Egypt....III 12055 Bugius S ? (III Aug) Date? Castra Lambaesitana........... VIII 2562 Caecilius S dup III Aug p v Antonin 218 A.D. Castra Lambaesi-

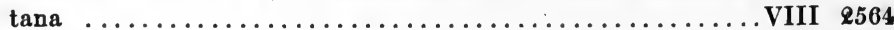

Caecilius S (bf cos) Date? Apulum Dacia...............III 7755

C. Caecil(Ius) Sat(urninus) mil? (III Aug) Date? Castra Lambaesitana ..................................

Q. Caecilius S Cas vet? (III Aug) Date? Castra Lambaesitana VIII 18086

C. Caelius S mil III Aug Date? Lambaesis...............VIII 2791

C. Caelius S vet ex bf (III Aug) Date? Lambaesis........... VIII 2829

Caelius (S)aturninus bf cos I Adi p f 194 A.D. Novae Dalmatia.. III 1909 $(\mathrm{Cl})$ audius $\mathrm{S}$ vet I Primini 1s? Col Agrippinensum.......... XIII 8280 C. Clodius S p p II Adi p f Date? Aquincum Pann Inf........ III 3464 Cornelius S dup III Aug p v Antonin 218 A.D. Castra Lambaesisitana 
Cornelius S K(ar) arm cust (III Aug) Date? Castra Lambaesi-

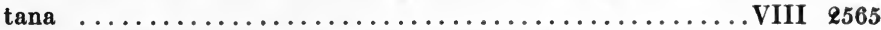

C. Cornelius Sat(urninus) Cirt(a) vet III Aug p v c198 Castra Lambaesitana .............................. 18068

C. Cor(nel)ius S Had(rumeto) vet? (III Aug) es? Castra

Lambaesitana .......................... 18087

L. Cornelius S vet (leg?) Date? Municipium Numiulitanum . . . VIII 15392 M. Cornelius Ti. f. S 7 II Aug Date? Rome.............VI 3585 P. Crescentinius F1.S Siscie mil XI Cl aet Antonini Pii Portus

Magnus ............................ 9761

C. Curiatius S 7 II Aug Date? Bath Eng............... VII 42

C. S vet? (III Aug) Date? Castra Lambaesitana............ VIII 18086 (Do)mitius Saturnin(us) The(veste) mil? (III Aug) aet

Antonini Pii Castra Lambaesitana.................. VIII 18085

L. Domitius S mil III Aug Date? Lambaesis. . . . . . . . . . . . VIII 18296

L. Domitius S mil III Aug Date? Lambaesis............. VIII 18296

C. Egnatius Saturnin(us) Kar vet III Aug p v c198 Castra

Lambaesitana .......................... VIII 18068

Elius S dup III Aug p v Antonin 218 A.D. Castra Lambaesitana. . VIII 2564

Fabius Saturnin(us) arm cust (III Aug) 200 A.D. Castra Lam-

baesitana ........................... 1902:10

L. Fabius L. f. S vet VII Cl p f 42-70 A.D. Salonae Dalmatia... . III 2022

C. Flavius S Cas mil? (III Aug) Date? Castra Lambaesitana.. VIII 2568

T. Flavius Satur(ninus) (mil III Cyr aut XXII Deiot) 87 A.D.

Fayoum Egypt....................................... 1

T. Fla(viu)s S Cast vet III Aug p v c198 Castra Lambaesitana ... VIII 18068

T. Flavius S Had(rumeto) mil? (III Aug) Date? Castra

Lambaesitana ............................. VIII 2568

T. Flavius Saturn(inus) Tha(mugadi) mil? (III Aug) Date?

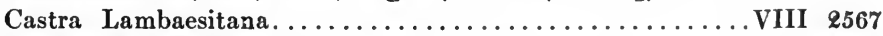

T. Fl(avius) $\mathbf{S}$ eq (III Aug) Date? Lambaesis.............VIII 3111

T. Florius $\mathbf{S}$ vet ex sig XXII Pr p f Alexand c225 Mainz. ....... XIII 6769

L. Fulvius S ? (III Aug) Date? Castra Lambaesitana......... VIII 2562

M. Furius M. f. $\mathbf{S}$ vet leg XIII 1s? Altinum.............. $\& 158$

Gargilius S dup III Aug p v Antonin 218 A.D. Castra Lambaesi-

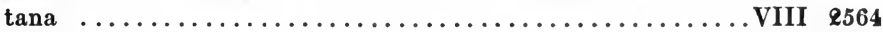

C. Geminius S vet (III Aug) Date? Lambaesis............. VIII 3119

Q. Geminius S Cirta vet III Aug p v c198 Castra Lambaesitana VIII 18068

Homullius S mil III Aug 1s Theveste............... VIII 1875

(Ho)rtensius S dup III Aug p v Antonin 218 A.D. Castra Lambae-

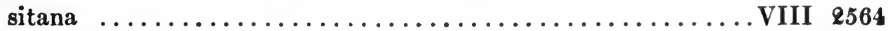

Ianuarius $\mathbf{S}$ (mil III Aug) Date? Lambaesis.............. VIII 3246

Iulius S 7 III Cyr 80 A.D. Alexandria Egypt.........III 6603 \& 6599

Iulius $S$ arm cust (III Aug) 200 A.D. Castra Lambaesitana. A.E. 1902:10

Iulius $\mathbf{S}$ cor III Aug p v 203 A.D. Castra Lambaesitana. ....... VIII 2557

Iulius Saturnin(us) (dup) III Aug p v Antonin 218 A.D. Castra

Lambaesitana .................................. 2564

Iulius S dup III Aug p v Antonin 218 A.D. Castra Lambaesitana.. VIII 2564 
Iulius S dup III Aug p v Antonin 218 A.D. Castra Lambaesitana. . VIII 2564 Iulius $S$ (mil? III Aug) c218? Castra Lambaesitana Bull Archeol $1904 \quad$ p206 Iulius $S$ arm cust III Aug c225 Castra Lambaesitana........... 1902:11 Iulius Saturnin(us) arm cust III Aug c225 Castra Lambaesitana

A.E. 1908:11

Iulius $S$ vet ex actar (III Aug) $270-275$ A.D. Lambaesis. . . . . . . VIII 2626 Iulius $\mathbf{S}$ spec III Aug Date? Lambaesis.................. VIII 8890 Iul(ius) $\mathbf{S}$ optio (III Ital) Date? Castra Regina Raetia..........III 11969 Iulius $\mathbf{S}$ mil III Aug Date? Lambaesis.................VIII $\mathbf{3 1 6 1}$ Iulius $\mathbf{S}$ vet (III Aug) Date? Lambaesis............... VIII 3162 Iulius S Cas mil? (III Aug) Date? Castra Lambaesitana..... VIII 2568 A. Iulius $\mathbf{S}$ sig X Gem p f Date? Reii Gall Narb............XII 367 C. Iulius S. domo Oesci vet ex optione V Mac aet M. Aurel Troesmis $\ldots \ldots \ldots \ldots \ldots \ldots \ldots \ldots \ldots \ldots \ldots \ldots \ldots \ldots \ldots \ldots \ldots \ldots$ III 6190

C. Iulius S mil III Aug Commodae aet Commodae Lambaesis... . VIII 3163

C. Iulius S Cast vet III Aug p v c198 Castra Lambaesitana. . . . . . VIII 18068

C. Iulius S The(veste) vet? (III Aug) \&s? Castra Lambaesitana.................................... 18087

C. Iulius S eq III Aug Antonin ce15 Lambaesis............. VIII 3164

C. Iulius S (eq? III Aug) \&2z-35 A.D. Castra Lambaesitana MAH 1897 p447

C. Iulius Satu(rnin) us (eq? III Aug) \&\&\&-35 A.D. Castra Lam-

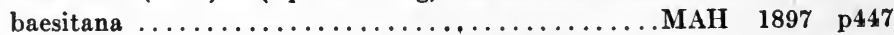

C. Iulius S lib princ (III Aug) c253 Castra Lambaesitana. . . . . . VIII 18072

C. Iuli(us) Sat(urninus) 7 III Aug Date? Lambaesis........ . VIII 2928

C. Iul(ius) S Cir(ta) arm cust (III Aug) Date? Castra Lambaesitana $\ldots \ldots \ldots \ldots \ldots \ldots \ldots \ldots \ldots \ldots \ldots \ldots \ldots \ldots \ldots \ldots \ldots$ III 2567

C. Iulius S Tev(e)s(te) mil? (III Aug) Date? Castra Lambaesitana $\ldots \ldots \ldots \ldots \ldots \ldots \ldots \ldots \ldots \ldots \ldots \ldots \ldots \ldots \ldots \ldots \ldots \ldots$. 2569

C. Iulius S Cas can (III Aug) Date? Castra Lambaesitana VIII 2568 et 18005

C. Iulius S Cas vet? (III Aug) Date? Castra Lambaesitana... VIII 18086

C. Iul(ius) S mil III Aug Date? Hr Bur mta Uled Zeian....... VIII 17967

C. Iulius S Tel(epte) mil? (III Aug) Date? Castra Lambaesi-

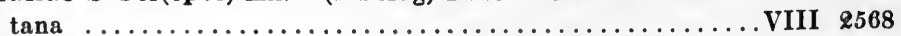

C. Iulius S mil bf $\cos \mathrm{X}$ Gem Date? Salonae Dalmatia........ III 6376

Q. Iulius S cor III Aug p v 203 A.D. Castra Lambaesitana..... VIII 2557 Iunius Saturnin(us) exactus III Aug p v ce0 2 Castra Lambaesi-

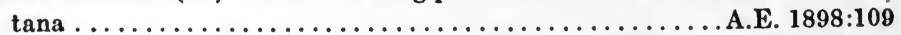

L. Lentidius $S$ vet leg I Ital p f Date? Raetinium? Dalmatia ... III 13272 M. Liburnius M. f. Pol. S Ancy(ra) sig leg XXII c65 Alexandria

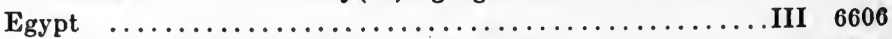

Livius S 7 (leg) XX Date? Durocornovium Eng. ...........VII 1339 Lucilius Saturnin(us) arm cust III Aug c225 Castra Lambaesi$\tan a \ldots \ldots \ldots \ldots \ldots \ldots \ldots \ldots \ldots \ldots \ldots \ldots \ldots . \ldots \ldots . \ldots \ldots$. 1902:11

Lurius S 7 III Aug coh X 162 A.D. Castra Lambaesitana....... VIII 18065 Sex. Mager Q. f. Arn. S 7 I Min Date? Histonium.......... IX 2851 (M)anilius Saturn(inus) tub III Aug p v 202 A.D. Castra Lambaesitana 
M. Marcius S Sic(ca) bf leg III Aug 166 A.D. Castra Lambaesi-

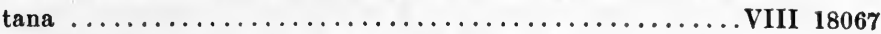

Marius Saturnin(us) dup III Aug p v Antonin 218 A.D. Castra

Lambaesitana ................................ 2564

Marius S dup III Aug p v Antonin 218 A.D. Castra Lambaesitana VIII 2564 C. Masticius S (eq? III Aug) 22\&-35 A.D. Castra Lambaesitana

MAH $1897 \quad \mathrm{p} 447$

Memmius S Cas mil? (III Aug) Date? Castra Lambaesitana. VIII 2568 Mesius Saturn(inus) vet ex librario (III Aug) 270-275 A.D.

Lambaesis ...................................... 2626

Nonius Satu(rninus?) vet (V Mac) Date? Troesmis..........III 6179 Numerius Saturn(inus) (dup) III Aug p v Antonin 218 A.D.

Castra Lambaesitana ....................... 2564

Octavius S mensor (III Aug) 3s? Castra Lambaesitana.......... 1904:78

Octavius Saturn(inus) dup III Aug p v Antonin 218 A.D. Castra

Lambaesitana ........................... 2564

C. Ofellius S ? (III Aug) 209-211 A.D. Castra Lambaesitana... . VIII 2556

Q. Orches-S Cuic(ulo) mil? adb? (III Aug) Date? Cas-

tra Lambaesitana............................... 2568

P. Papir(ius) Saturn(inus) ? III (Aug) 1s? Simitthus. . . . . . . VIII 14607

Q. Papius Q. f. S Iulianus 7 II Parth 3s Rome... . . . . . . . A.E. 1912:177

M. Paulin(i)us $\mathbf{S}$ vet XXX Vict Date? Lyons............XIII 1876

L. Pescennius L. f. Fal. S vet XI Cl p f 4 \&-Vespas Tragurium

Dalmatia ............................III 9710

Q. Petillius Q. f. S mil XXII Prim ante 89? Alpes Graiae........V 6896

Petro(nius) Satur(ninus) vet ex librario (III Aug) 270-275 A.D.

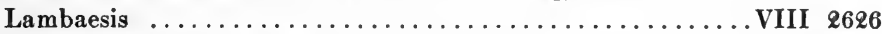

T. Pinarius S sig (III Aug) Date? Lambaesis............. VIII 2822

Statius? Popius S 7 (III Aug) 1s? Theveste.............. 1897:29

Rufinius S mil (I) Min p Date? Col Agrippinensium......... XIII 8239

Rust(icelius) Sat(urninus) mil III Aug Sever p v 224 A.D. Saltus

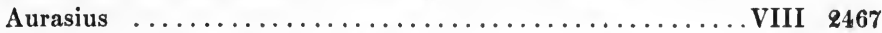

$\mathbf{R}-\mathbf{S}$ vet III Aug Date? Lambaesis............... VIII 3229

L. Saenius S Cas mil? (III Aug) Date? Castra Lambaesitana.. VIII 2569 Sallustius S arm cust (II Aug) 200 A.D. Castra Lambaesitana A.E. 1902:10

T. Senius S Cas vet ex cand (III Aug) 211-2 A.D. Lambaesis . . . VIII 2618

C. Sittius Saturnin(us) (mil? III Aug) c200 Castra Lambaesi-

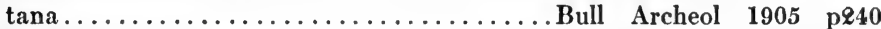

Statius S dup III Aug p v Antonin 218 A.D. Castra Lambaesitana VIII 2564

Suellius S dup III Aug p v Antonin 218 A.D. Castra Lambaesitana VIII 2564

Tadius S cor III Aug p v 203 A.D. Castra Lambaesitana...... VIII 2557

P. Tannonius S ? (III Aug) Date? Castra Lambaesitana...... VIII 2570

Tereni(us) $\mathbf{S}$ arm cust III Aug c225 Castra Lambaesitana ..... A.E. 1902:11

Terentius S 7 III Aug coh VI 162 A.D. Castra Lambaesitana ... . VIII 18065

L. Terentius S optio III Aug Date? Lambaesis............. VIII 2886

M. Terentius S hast (III Aug) Date? Castra Lambaesitana.... VIII 2562

Sex. Terentius S 7 III Aug 162 A.D. Lambaesis............. VIII 2738

C. Tiburtius S Cas mil? (III Aug) Date? Castra Lambaesitana VIII 2568 
M. Tisenius Satur(ninus) mil? (III Aug) aet Antonini Pii Castra Lambaesitana............................. VIII 18085

C. Tonneus S (eq? III Aug) 2q2-35 A.D. Castra Lambaesitana

M. Ulpius Satur(ni)nus Kart vet III Aug p v c198 Castra LamMAH $897 \quad$ p447 baesitana .............................. VIII 18068

M. Ulpius Sat(urninus) sig III Aug Date? Lambaesis........ VIII 3003 C. Umbonius $\mathbf{S}$ vet (III Aug) Date? Lambaesis............ VIII 3279 Valer(ius) Saturnin(us) arm cust (III Aug) 200 A.D. Castra Lambaesitana ........................... 1908:10 Valerius S dup III Aug $\mathrm{p} v$ Antonin 218 A.D. Castra Lambaesitana ....................................... 2564

C. Valerius S ? (III Aug) Date? Castra Lambaesitana......... VIII 2562

L. Val(erius) Sat(urninus) vet de III Aug Date? Lambaesis... VIII 3269

M. Valerius M. f. Pol. S Ancy(ra) sig leg XXII c65 Alexandria Egypt $\ldots \ldots \ldots \ldots \ldots \ldots \ldots \ldots \ldots \ldots \ldots \ldots \ldots \ldots \ldots \ldots \ldots \ldots \ldots \ldots$ III 6600

M. Valerius M. f. Ani. S Foro Iuli mil VIIII Hisp 1s Rome..... VI 3639

L. Vettius $S$ vet (III Aug) Date? Lambaesis.............. VIII 3273

M. Vettius S vet XXII Pr p f civis Traianensis Date? Col Ulpia Traiana Germ Inf........................... 8658

C. Vibius S Thys(dro) vet? (III Aug) es? Castra Lambaesitana .................................. 18087

Volcacius S Am(maedara) mil? (III Aug) Date? Castra Lambaesitana ............................ VIII \&568 et 18055 - (Satur)ninus Ha(drumeto) eq (III Aug) aet Antonini

Pii Castra Lambaesitana....................... VIII 18085 (S)aturnin(us) Sar(mizegetusa) vet VII Cl 195 A.D.

Viminacium Moes Sup.......................III 14507

- S (bf) leg III Aug expleta statione promotus ad (7?) II

Ital Date? Vazaivi.......................... VIII 17626

-ius S v(ex) (III Aug) Date? Castra Lambaesitana.........VIII 2569

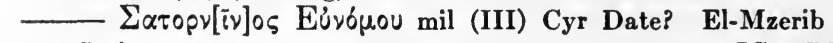
Syria............................... a RR III 1167 -nlius Saturnin(us) Bagai (mil? III Aug) Date? Castra

Lambaesitana ................................. 1899:98

- $\mathbf{S}$ vet $(\mathrm{V}$ Mac) Date? Troesmis.................. 617 . 6179

(Sa)turninus vet (V Mac) Date? Troesmis...........III 6179

(Sa)turnin(us) vet ex eq (V Mac) Date? Troesmis.....III 6180 - S mil III Aug Date? Lambaesis.................VIII 18305 (Sa)turninus Cas mil? (III Aug) Date? Castra Lam-

baesitana ................................... VIII 2568

—orius (Satu)rninus mil? XIIII Gem Date? Aquileia.....V 8284 - (Sat)urni(nus) mil? XX (V v) Date? London.......... VII 26 SATURNUS

C. Mariu(s) Saturnu(s) Cetio bf cos Date? Ager ad Colapim Pann Sup................................. 39 


\section{SATURUS}

Antistius $S$ arm cust (III Aug) 200 A.D. Castra Lambaesitana A.E. 1908:10

L. Antonius S haruspex (III Aug) Date? Lambaesis......... VIII 2809

C. Aponius Saturu(s) vet III Aug 166 A.D. Castra Lambaesitana VIII 18067

Helvius $S$ vet (III Aug) Date? Lambaesis................ VIII 3123

Q. Laelius $\mathbf{S}$ vet (III Aug) Date? Lambaesis.............. VIII 3173

C. Manilius S imm III Aug Date? Lambaesis............. VIII 2940

Ulpi(us Sat)urus mil III Aug Date? Lambaesis......VIII 2955 et 18159 SAUSA

C. Iul(ius) S Sc(upis) vet VII Cl 195 A.D. Viminacium Moes Sup III 14507 SAXO

Q. Aemilius S Cirt(a) vet III Aug p v c198 Castra Lambaesitana VIII 18068 SCAENA

C. Iulius L. f. Ser. S decurio eq 7 hastatus primus leg IIII Date?

Tucci Baetica.............................II 1681

SCAENICUS

T. F1(avius) super Cepula $S$ vet ex leg XXX Ulp vict 207 A.D.

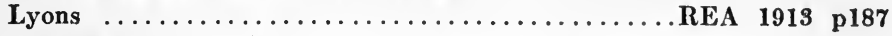

SCAEVA

P. Lastus A. f. S domo Florentia eq vet VII $(\mathrm{Cl})$ p f Date? Nar-

ona Dalmatia............................. 1814

Petr(onius?) $\mathbf{S} 7$ leg II 1s Argentorate................ XIII 5976

S 7 leg II ante Claud? Argentorate.............. XIII 5978 SCIPIO

Cari(sius) Scip(i)o 7 (leg?) Date? prope Amboglannam Eng E.E. IX 1216 SECGIANUS

L. Favonius S 7 VIII Aug Date? Bullau Germ Sup..........XIII 6516 SECGUS

S 7 (leg?) coh VIII Date? prope Magnas Eng. .......E.E. IX 1205 SEGUNDIANUS

Aur(elius) $S$ dup II Ital $\&$-3s Virunum Noricum............III 4835

Aur(elius) S qui et Itrius bf $\cos \mathbf{X}$ Gem Date? Latobici Pann

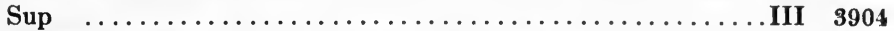

Aurel(ius) $\mathbf{S}$ imag XIII Gem Date? Dertona.............. 7366

Gra(t)ius 2eanus mil III $\mathrm{Cy}$ ante 108 Egypt......... Wessely Lat $\mathrm{Pa}^{\prime} 8$

Iulius Secundian(us) dup III Aug p v Antonin 218 A.D. Castra

Lambaesitana ............................... 2564

Iul(ius) $S$ spec I et II Adi p f Sever 228 A.D. Aquincum Pann Inf.. III 3524

Sextius Secundian(us) K(arthagine) mil? (III Aug) Date?

Castra Lambaesitana........................... III $\mathbf{2 5 6 7}$

SECUNDINUS

Ael(ius) $S$ vet ex bf cos Date? Intercisa Pann Inf............. 1910:150

M. Anc(harius) $S$ vet XIIII Gem 199 A.D. Carnuntum Pann Sup III 14076

M. Aurelius S mil str cos II Ital 2-3s Virunum Noricum........ III 4836

M. Aurelius $\mathbf{S}$ vet (III Aug) Date? Lambaesis.............. VIII 3058

M. Aur(elius) S vet leg — pf Date? Vallis Fl Mur Noricum III 5409 
F1(avlus) S mil XIII Gem post 100 Carnuntum Pann Sup.......III 4467 M. G- S bf cos Date? Habitancium Eng............ VII 996 Seccius $S$ vet II Ital $p$ f 3s Fafiana Noricum...............III 5671 Secconlus $S$ vet leg VIII Date? Agedincum prov Lugudun..... XIII 2947 Tartonius Secundi(nus) mil? XIIII Gem post 100 Savaria Pann

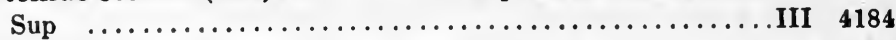

Val(erius) S mil II Adiut n Pann Date? Puteoli............ 1775 S d Sol(venses) 7 II Aug Date? Stanwix Eng VII 914 add E.E. III p136 (Sec) undinu(8) vet (V Mac) Date? Troesmis.........III 6180 SEGUNDUS

Ael(ius) Secun(dus) vet VII Cl 195 A.D. Viminacium Moes Sup...III 8110 (Ae)milius S Thev(este) vet? (III Aug) aet Hadriani Castra

Lambaesitana ............................. VIII 18084

Aemilius S 7 II Adi p $f$ Date? Duraton Tarraconensis........II 2763

C. Alfius L. f. S vet XV Apol 1s Savaria Pann Sup............III 4171

D. Apertius $\mathbf{S}$ vet II Tr fort $2 \mathrm{~s}$ ? Caelia................. IX 275

L. Appius $\mathbf{S}$ mil XXII Prim Date? Rome...............VI 8567

M. Apronius M. (f?) Fulvius S Luco Aug mil XI Cl p f Vespas-

Traian Vindonissa........................... XIII 5207

Aurel(ius) S 7 XIII G $\mathrm{m} v$ post 100 Mursa Pann Inf..........III 3284

$A(u) r(e l i u$ S)ecun(dus) (p p aut 7) in leg I (It)al Date? Vienna . III 14359:27 T. Aureli(us) Secu(ndus) vet II Adiut \&-3s? Aquincum Pann Inf .................................... 13360

Q. Bisius S Q. f. domo Brixiae mil X Gem 70-Traian Ulpia Noviomagus ............................... 8733

Caecilius Secund(us) cor III Aug p v 803 A.D. Castra Lambaesitana ................................ VIII $\$ 557$

Caecilius L. f. Hor. S Uthina mil III Aug Date? Lambaesis . VIII 3067 Caesius _ Cla Secu(ndu)s I (u)vav(o) mil (XI Cl?) ante

Vespas Burnum Dalmatia.......................III 14994

Caledonius Secund(us) 7 (leg?) coh VI Date? Amboglanna Eng

L. Calvisius L. f. Velina S Falerione p p XIII Gem 183-5 A.D.

Apulum Dacia..............................III 1098

Cassius S (vet leg?) Date? Chester Eng..............E. IX 1079

C. Cassius S mil III Aug Date? Lambaesis.............. VIII 3078

T. Cassius S 7 XV Apol post siege of Jerusalem Solva Noricum... III 5334

T Cassius $S$ frum VI Vict Date? Rome................ VI 3345

L. Cattonius L. f. S Claud. Viru(no) mil IIII Mac ante Vespas

Mainz ........................................ 6860

Cat- Secun(dus) vet (V Mac) c134 Troesmis...........III 6178

Cepasius S mil XIIII Gem post 100 Ager ad Colapim Pann Sup.... III 14045

Claudius S arm cust (III Aug) 200 A.D. Castra Lambaesitana A.E. 1902:10

Claudius Secund(us) vet ex actar (V Mac) Date? Troesmis....III 6179

P. Cl(audia?) Valerius S Valeri f. vet VII (Claudi)a Macedon-

i(ca) post 42 Edessa......................... 1903:383 
T1. Claud(lus) S Thusd(ro) arm cust (III Aug) Date? Castra

Lambaesitana ....................................... 2567

C. Clodius C. f. Vel. S mil XV Apol 1s Emona Pann Sup........III 10769

C. Clodius S mil III Aug Date? Lambaesis............... VIII 2943

L. Clodius S opt cor III Aug 203 A.D. Castra Lambaesitana...... VIII 2557

P. Clodius (S)ecun(dus) (mil III Cyr aut XXII Deiot) 90 A.D.

Fayoum Egypt........................................ Gen Lat 1

L. Cluvius $\mathbf{S}$ mil XV Apol 1s Carnuntum Pann Sup

Roemische Limes VI p165

Cornelius $S$ mil? $X$ Gem Date? Vienna................III 4568

L. Cornelius T. f. Ouf. S vet XIIII Gem Date? Milan.........V 5825

M. Cornelius S mil XXI Rap ante Hadrian Sabini...........V 4892

Cupronius S 7 III Aug coh I 162 A.D. Castra Lambaesitana..... VIII 18065

C. Curiatius T. f. Serg. S domo Augusta Troade vet VII Cl p f

42-70 A.D. Salonae Dalmatia....................III 2019

C. Cusp(ius) $\mathbf{S}$ exercitator II Adiut Date? Aquincum Pann Inf.. III 3470

C. Dannius C. f. Vol. S Vianna mil XIIII G m v 70-100 A.D.

Mainz ....................................

C. Didius S mil II Aug Date? Aoste Gall Narb.............XII 2355

C. Domitius S vet (III Aug) Date? Lambaesis............. VIII 18897

M. Egnatius S ? (III Aug) Date? Castra Lambaesitana........VIII 2562

C. Faltonius C. f. Pom. S Dertona mil XXII Prim Date? Mainz XIII 6960

Flavius S ? (III Aug) 253-268 A.D. Castra Lambaesitana........ VIII 18061

T. Fl(avius) T. (f) Pol. S Cast arm cust XV Apol 1s Carnuntum

Pann Sup...............................II 11218

T. Flavius S Cas d s (III Aug) Date? Castra Lambaesitana.... VIII 18086

L. Fulvius S mil II Adiut 2-3s Aquincum Pann Inf .......... III 14349:4

M. Gellius M. f. Cla. S Ara mil (XIIII) G m v 70-100 A.D. Mainz XIII 6894

M. Hellius S tub X Gem p f 89-Traian Brohl............. XIII 7694

Iulius S 7 XI Cl p f 42-Vespas Burnum Dalmatia............E. 1903:303

Iuli(us) $S 7$ II Adi $p$ f $c 71$ Bath Eng................... VII 48

Iulius S Adrimeto vet (III Aug) $211-2$ A.D. Lambaesis........ VIII 2618

Iulius S mil III Aug Sever p v \&24 A.D. Saltus Aurasius......... VIII 2467

Iul(ius) $\mathbf{S}$ arm cust III Aug c285 Castra Lambaesitana...... A.E. 1902:11

Iulius S 7 III Aug Date? Lambaesis................. VIII 2764

C. Iulius C. (f) Cla. S Sav(aria) (mil) XV Apol 1s Carnuntum-

Pann Sup................................ $\quad 4$ III

C. Iulius (Se)cundus mil (III Aug) Date? Verecunda........ VIII 4242

C. Iulius Sec(undus) mil? (III Aug) Date? Castra Lambae-

sitana ...................................... 2567

T. Iulius T. f. Sab. S Firmo mil XIIII G m v 70-100 A.D. Mainz XIII 6896

C. I-ius S Kar vet? (III Aug) 2s? Castra Lambaesitana.... VIII 18087

C. Laelius S Cirt(a) vet III Aug p v c198 Castra Lambaesitana... VIII 18068

Licinius Secund(us) bf trib? III Aug c $\$ 00$ Castra Lambaesitana .................................. 18078

M. Licinus S vet ex opt XIIII Gem Date? Hasta........... V 7561 T. Licinius T. f. Gal. S Thyz(dro) mil III Aug Date? Lambaesis VIII 3177 Malius $S$ bf cos Date? Odessus Moes Inf..............III 14458:1 
G. Mannius C. f. Pol. S Pollen(tia) mil bf leg princeps XX V v

Date? Viroconium Eng........................ VII 156

M. Massianius S mil XXX Ulp vict Date? Vinxtbach.......XIII 7732

Memmius $S$ vet (III Aug) Date? Lambaesis............. VIII 3194-5

Messius S 7 XV Apol 1s Carnuntum Pann Sup............III 14358:20

C. Metilius Secun(dus) arm cust III Aug Date? Lambaesis.... VIII 2943

C. M- $\longrightarrow$ S Kar vet? (III Aug) \&s? Castra Lambaesitana.. VIII 18087

M. Nasidius S vet bf (cos) X Gem p f Date? prope Verbanum

Dalmatia ............................... $\mathbf{9 8 4 7}$

L. Nonius L. f. Volt. S sig XII Aug Fulm 1s? Arelat.e....... XII 685

Q. Passius S vet III Aug Date? Lambaesis..............VIII 3215

Q. Petilius Q. f. Ofen. S domo Medio(lani) mil XV Prim ante

Vespas Bonn............................... XIII 8079

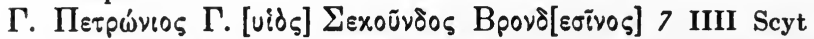

c185 ante 231 A.D. Canatha Arabia.............. IG a RR III 1830

L. Pompeius S 7 XXI Rap 1s Mediomatrici Belgica.......... XIII 4623

Pomponius S dup III Aug p v Antonin 218 A.D. Castra Lambaesitana ....................................... 2564

C. Quartius S mil XIII Gem Date? Rome............... VI 2619

Q. Secius S Kar mil? (III Aug) Date? Castra Lambaesitana... VIII 2568 Sextil(ius) S arm cust (III Aug) 800 A.D. Castra Lambaesitana A.E. 1908:10

L. Statius $S$ mil leg VI Date? Camunni............... 4958

Q. Sutorius S bf trib lat III Aug p v 198 A.D. Castra Lambaesitana VIII 2551

(T)annonius S Cast (mil? III Aug) c200 Castra Lambaesitana

Bull Archeol 1905 p 239

C. Terentius S Opiter(gio) tess III Aug Date? Lambaesis..... VIII 2983 Truc- Secun(dus) vet (V Mac) c134 Troesmis.........III 6178 Ulp(ius) $S$ mil X Gem Date? Vienna.................III 14359:88

M. Ulpius S 7 III Ital Date? Lavingen Raetia............III 5876

Valerius $S$ mil (III Aug) Date? Lambaesis.............. VIII 3271

(V)alerius Secu(ndus) mil VIII Aug Date? Rome..........VI 3640

C. Val(erius) C. f. Gal. Secu(n)dus C_— ? leg XIIII 1s Mainz XIII 6911

C. Valerius $S$ mil XXII Pr p post 89 Mainz.............XIII 6977

C. Val(erius) C. fil. Cla(u)di(a) S Aemon(a) vet II Adiut \&-3s?

Aquincum Pann Inf...........................III 105.19

C. Valerius S mil III Aug Date? Lambaesis.............VIII 3270

L. Valerius L. f. S domo Albentibili mil VII Gem p f Date?

Tarraco ..............................II $4 \mathbf{1 7 1}$

L. Vale(rius) L. f. Fab. Sec(undus?) Brixi(a) mil leg? Date?

Wiesbaden ................................. 7578

M. Val(erius) S princeps VII Gem c155 Emerita Lusitania....A.E. 1905:25

M. Valerius M. f. Pol. S Cas sig III Aug Date? Lambaesis.... VIII 2994

G. Velsius Secu(ndus) 7 XIIII G m v 70-100 A.D. Mainz..... XIII 6934

Veturius S cor III Aug p v 203 A.D. Castra Lambaesitana....... VIII 2557

C. Vibius C. f. Ste. S mil XV Apol 1s Carnuntum Pann Sup.....III 4488

Q. Vibius S Annie(n)sis Cremona mil XX V v Date? Chester

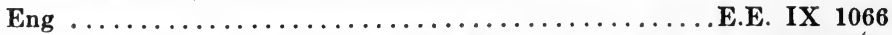

M. Vitalinius S bf cos Date? Col Ulpia Traiana Germ Inf......XIII 8621 
S 7 II Tr fort 194 A.D. Alexandria Egypt.

III 6580

-S 7 (II Aug?) coh X Date? Segedunum Eng

VII 489

(Secu)ndus? dup III Aug p v Antonin 218 A.D. Castra

Lambaesitana ................................ 2564

_. (?Sec)undus mil (III Aug) Date? Lambaesis . . . . . . . . VIII 18318

(Secu)ndus vet (V Mac) Date? Troesmis............III 6179

SECURUS

Anton(ius S)ecurus dup II Adi p f Gordian 241 A.D. Aquincum

Pann Inf........................... 15157

Sallustius Secur(us) arm cust III Aug c225 Castra Lambaesitana

A.E. 1908:11

C. Voconius $\mathbf{S}$ mil III Aug Date? Lambaesis............. VIII 3280 SEDATUS

Aurelius S sig III Aug post 253? Lambaesis............. VIII 18224

Aur(elius) S (vet) ex imm lib (V Mac?) Date? Potaissa Dacia... III 7688

M. Aurel(ius) S Furn(i) (mil? III Aug) c200 Castra Lambaesi-

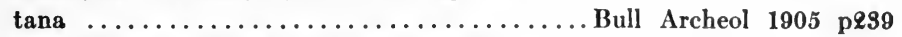

C. Homullius Sed(atus) Tha(mugadi) ? (III Aug) Date?

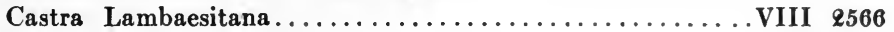

Iulius S 7 XIIII G m v 70-100 A.D. Mainz.

XIII 6929

M. Iulius M. f. Pap. S Narb(one) mil VII Gem Date? Catania

SEDIANUS

A.E. $1897: 132$

Iul(ius) $S$ arm cust III Aug c225 Castra Lambaesitana.......... 1902:11 SEDULUS

(Valerius?) $\mathbf{S} b(\boldsymbol{f}$ ?) mil (I) Min Date? Vienna...........XII 1874 SEIUS

Lurius $S$ vet II Adi p f c211? Djebel-Skrira

A.E. $1907: 202$ SELEUCUS

Q. Fl(avius) $\mathbf{S}$ vet (III Aug) Date? Lambaesis............ VIII 3112 SEMENTINUS

L. Maenaius $\mathbf{S}$ spec VII Gem c800 Tarraco..............II 4122 SEMPRONIANUS

C. Iulius Sempronian(us) (vet II Tr fort?) 140 A.D. Fayoum

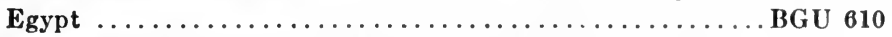

C. Pompeius (Se)m(p)ronian(us) lib (III Aug) Date? Castra

Lambaesitana ......................... VIII 18086

L. Septimius Q. f. S p p (X)IIII Gem vict Date? Castulo Tar-

raconensis

SENECA

C. Mettius S 7 leg XV ante Vespas Brohl.............. XIII 7700

C. Numitor(ius) S vet? VII Cl Date? Ratiaria Moes Sup.... . III 12649

M. Servilius M. f. Fab. S domo Brixia mil XIIII Gem ante 62

Mainz ................................... 6907

L. Valerius L. f. Claudia S Sav(aria)? II? (Adiut) c71 Chester

Eng .........................E.E. IX 1017 
Vic(cius?) $\mathbf{S}$ eq XXII Pr Antonin p f $\$ 21$ A.D. Schierstein Germ

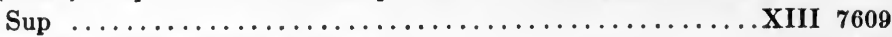

$\longrightarrow$ S 7 X Gem Date? Vienna..................... 4577

SENECIANUS

Aurel(ius) $\mathbf{S}$ bf cos Date? Viminacium Moes Sup

Jahres Wien 1910 Beibl p808

Pol(lius) Senecian(us) dup (XIIII Gem?) ante 178 Carnuntum

Pann Sup............................... 11180

SENECIO

Aur(elius) $\mathbf{S}$ dup (leg?) Date? Apulum Dacia.............III 1189

Q. (L)ivi(n)ius $S$ vet XIIII Gem post 100 Carnuntum Pann Sup

A.E. $1907: 176$

C. Magius G. f. Pub. S 7 VIII Aug Date? Rome........... VI 8815

Tertinius $S$ mil bf $\cos$ XXII $\operatorname{Pr}$ p f 194 A.D. Mainz ......... XIII 6740b

Ulp(ius) S dup (XIIII Gem?) ante 178 Carnuntum Pann Sup.... III 11180

SENILIS

Iuliu(s) $\mathbf{S}(\mathrm{e})$ ni(1)i(s)? vet? III Aug Date? Lambaesis...... VIII 18304 Ruf(us) $\mathbf{S}$ bf cos Date? Celeia Noricum.................III 5188

C. Secionius $\mathbf{S}$ bf $\cos$ Date? Stockstadt............... XIII 6638

Sex. Sulpicius Sex. f. Quir. S mil III Aug 50-100 A.D. Theveste A.E. 1909:37

Vercundin(ius) $\mathbf{S}$ vet XXX Ulp vict Date? Lyons...........XIII 1888

SENNIANUS

-S 7 leg XXII Date? Col Agrippinensium...........XIII 8890 SENTIANUS

Sta(tius) Sentian(us) (7?) XIII Gem post Traian Vajda Hunyad

Dacia .................................. 8065:33

SEPPIANUS

C. Calpurnius S p p XXII Pr p f Date? Mainz........... XIII 6730 SEPTIMINUS

Caecilius S 7 (XXII Pr p $f$ ) Date? Mainz ............... 1909:134

G. Ignius S Bag(ai) mil? (III Aug) Date? Castra Lambaesi-

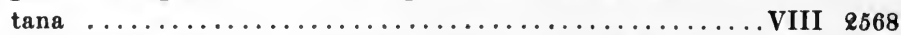

C. Iulius S Fla. Cilio mil? (III Aug) Date? Castra Lambaesi-

tana .................................... 2568

C. Iulius $\mathbf{S}$ cor III Aug p v 803 A.D. Castra Lambaesitana...... VIII 2557

C. Iulius S ? (III Aug) Date? Castra Lambaesitana........... VIII 2568

C. Pubi(icius) Septimin(us) optio (III Aug) 198-211 A.D. Cas-

tra Lambaesitana............................ VIII $\mathbf{8 5 5 4}$

SEPTIMIUS

C. Valer(ius) $\mathbf{S}$ vet V Mac p c 3s Potaissa Dacia............. III 7694

SEPTIMUS

Ael(iu8) S optio I (Adiut) post 114 Brigetio Pann Sup..........III 4310

SEQUENS

Iustien(us) S R(emesiana?) vet VII Cl 195 A.D. Viminacium

Moes $\operatorname{Sup} \ldots \ldots \ldots \ldots \ldots \ldots \ldots \ldots \ldots \ldots \ldots \ldots \ldots \ldots \ldots \ldots \ldots$ III $\mathbf{1 4 5 0 . 7}$ 


\section{SERA}

C. Frut(ius) S C. fll. Patavi(o) vet XV Apol ante 63 Carnuntum

Pann Sup.

III 11220

SERANUS

P. Aelius S Cas sig (III Aug) aet Antonini Pii Castra Lambaesi-

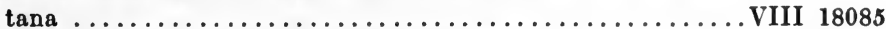

Iulius $S$ ? (III Aug) Date? Castra Lambaesitana............ VIII 2562

C. Nervilli(u8) S Cirt(a) vet III Aug p v c198 Castra Lambaesi-

tana .................................... 18068

L. Valerius Sex. f. Vol. S Luco 7 IIII Fl firm Date? Margum

Moes $\operatorname{Sup} . \ldots \ldots \ldots \ldots \ldots \ldots \ldots \ldots \ldots \ldots \ldots \ldots \ldots \ldots \ldots \ldots$ III 8143

S 7 X Gem 1s? Aquileia................. 832 SERAPIO

P. Aelius S Castr mil? (III Aug) aet Antonini Pii Castra Lambaesitana .............................. VIII 18085

P. Aelius Ser(a)pio sig III Aug Date? Lambaesis. ........... VIII 2789

L. Cornelius $S$ bf trib lat III Aug p v 198 A.D. Castra Lambaesi-

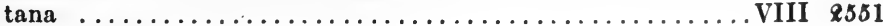

SERENUS

P. Aelius S T(heveste?) mil? (III Aug) aet Antonini Pii Castra

Lambaesitana .............................. VIII 18085

C. Censorius C. f. S FI Solva 7 XIIII Gem Date? Dacia incerta . .III 1615

['Ioú] $\lambda \cos \Sigma \varepsilon \rho \tilde{\nu} \nu \varsigma 7$ (II Tr?) 120-140 A.D. Fayoum Egypt........BGU 600

Iul(ius) S mil I Adiut post 114 Brigetio Pann Sup............ III 11028

C. Iulius $\mathrm{S}$ (vet II Tr fort?) 140 A.D. Fayoum Egypt . . . . . . . . . BGU 610

C. Iulius C. f. Col. S vet II Tr fort 194 A.D. Alexandria Egypt. . III 6580

L. Lusius $S$ mil X Gem Date? Arminum................... XI 480

C. Pompeius C. f. Pol. S Kastris vet II Tr fort 194 A.D. Alex-

andria Egypt.........................III 6580

L. Vi-leius S (mil III Cyr aut XXII Deiot) 90 A.D. Fay-

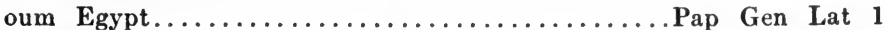

(P)ol S Castr tess II Tr fort 194 A.D. Alexandria Egypt. . III 6580

S (mil III Cyr aut XXII Deiot) 90 A.D. Fayoum

Egypt....................................... Gen Lat

SERRAPIO

Aurelius - uni S (7) II Parth Sever coh VIIII 3s Ager Alban-

us ............................ IX 660

$\Sigma \mathrm{EPPHNO \Sigma}$

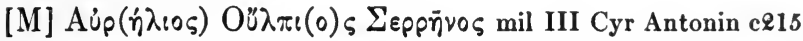

Athilia Arabia......................... IG a RR III 1839

SERTORIANUS

M. Aurelius S Sic(ca) mil? (III Aug) Date? Castra Lambae-

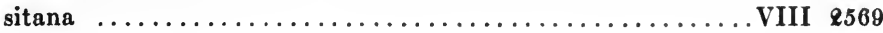

SERVANDUS

Perelius $\mathrm{S}$ vet ex librario (III Aug) $270-875$ A.D. Lambaesis.... . VIII 2626

Respectius S mil pecuar leg XXII Date? Mainz............XIII 707 
SERVATUS

Aurelius $S 7$ (XXII Pr p $f$ ) Date? Mainz ................ 1909:134

$-\mathrm{S} 7$ (leg XXII aut III Cyr) aet Augusti Coptos Egypt.....III 6687 SERVIANUS

M. Ulpius S arm cust XIIII Gem Sever c225 Carnuntum Pann Sup III 11126 SERVILIUS

M. Quintius S Bulla vet III Aup p v c198 Castra Lambaesitana . . VIII 18068 SEVERIANUS

Aurel(ius) S bf offici praesid Pann Inf leg II Adiut \&-9s? Aquileia.. V 8875 Sex. Pompeius S vet (III Aug) Date? Lambaesis........... VIII 2902 Severius S (bf) cos III Ital Gordian 238-844 A.D. Burgantium Raetia ....................................III 5768

Tertinius S 7 II Aug Date? Lyons................... XIII 1898 SEVERINUS

M. Aur(ellus) Severin(us) Sc(upis) vet VII Cl 195 A.D. Viminacium Moes Sup.........................III 14507

M. A(urelius) Severin(us) bf $\cos$ (II) Adiut 3s? trans Aquincum Pann Inf................................... $\mathbf{s 6 1 7}$

(Cas)sius S ? X Gem p f Date? Cetium Noricum............III 14369:1 Firmidius $S$ mil VIII Aug $\mathrm{p} f \mathrm{c}$ c 201 A.D. Genava........... XII 2587

T. Flavius S sig XXX Ulp vict Date? Merten Germ Inf........ XIII 8156

C. Iulius $S$ vet I Adiut post 114 prope Savariam Pann Sup......III 4148

Q. Pisentius S 7 XI Cl post $4 \&$ Ljubuski Dalmatia............III 8485 SEVERUS

T. Accius $S$ bf cos Date? ad Dravum Pann Sup............III 15187

C. Acutius Cl. S Ara frum VII Gem fel Date? Rome......... VI 3348

Ael(lus) $\mathbf{S}$ eq III Aug Date? Lambaesis................ VIII 2593

Ael(ius) $S$ sig? III(I) Fl c\&15? Aquileia............... 808

T. Aelius P. S Had(rumeto) mil III Aug Date? Lambaesis .... VIII 3020

L. Aemilius S 7 XIII Gem Date? Tropaeum Moes Inf .....III 14814:8

C. Albius C. f. Cam. S mil I Ital Date? Augusta Bagiennorum.... V 7667 Amandinius $S$ frum I Min Date? Rome................. VI 3333 Aristius Se(verus) vet (III Aug) Date? Lambaesis........... VIII 18285 Atil(ius) $S$ vet $X$ Gem Date? Vienna.................III 6485a Aurelius S vet ex bf cos VII Gem fel Date? Tarraco..........II 4148 Babudi(us) $\mathrm{S} 7 \mathrm{leg}$ VIIII aet Claudii? Lincoln Eng.. VII 184 add E.E. IX p556

Baeb(lus) $S$ vet (V Mac) c134 Troesmis.................II 6178

T. Calidius P. Cam. S 7 XV Apol ante 63 Carnuntum Pann Sup..III 11213

Q. Castricius Q.f. Pap. S Ticini mil IIII Mac ante Vespas Mainz XIII 6856

P. Cerennius P. f. Quir. S Durrac vet III Aug Date? Lambaesis VIII 3079

T? Cerfonius? $S$ mil XXII Antonin bf cos c215 Cannstatt... XIII 6441

T. Cl(audius) $\mathbf{S}$ frum III Ital Date? Alpis Poeninae.........V 6869

M. Cocceius M. f. Pol. S p p VIIII Hisp praef X Gem Date?

Pedemontana incerta.......................... 7159

Codennius A. f. Scapt. S mil III Cyr Date? Fratta Maggiore... X 5368 
T. Cominius T. f. Volt. S Vienna 7 II Adiut aet Domitiani Sirmium Pann Inf........................... 10824

Lucius Corona S mil VII Gem Date? Astures Transmontani..... II 5733 Cornelius S 7 (leg?) Date? Chester Eng.............E. VII 897 Q. Decrius S Nicom(edia) vet? (III Aug) aetHadriani Castra Lambaesitana ............................. VIII 18084

C. Domitius S mil XXII Pr p f 3s? Cartenna Mauretania Caesar-

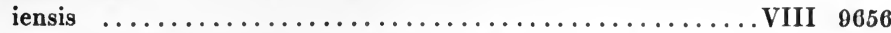

M. Domitius M. f. Fabia S Brixsia mil leg XI ante 42 Burnum Dalmatia .............................. 14I 1499:

Flavius S vet $\mathrm{X}(\mathrm{XX})$ Ulp vict Date? Vetera Germ Inf ....... XIII 8638 L. Fla(vius) Hor. Sev(e)ru(s) mil leg XXII ante Hadrian Alexandria Egypt.............................. III 6600

L. Fullonius C. f. Ste. S p p X Gem Date? Beneventum .........IX 1611 Fundanius S 7 III Aug 1s Theveste................. VIII 16545 Geminius S evoc I Ital \&s exe-3s Almus Moes Inf............ III 14409:1 Iulius Seve(rus) vet ex eq (V Mac) c134 Troesmis........... III 6178 Iuli(us) Sever(us) vet (V Mac) cl34 Troesmis.............III 6178 Iulius S(e)ver(us)? vet (V Mac) c134 Troesmis...........III 6178 Iul(ius) $\mathrm{S}$ spec legg III Antonin ( $=$ X Gem XIV Gem I Ad) c212 Carnuntum Pann Sup........................... 44I 452 Iul(ius) $\mathbf{S}$ spec legg III Antonin ( $=$ X Gem XIV Gem I Ad) c212 Carnuntum Pann Sup........................... 4452 Iulius S 7 V Mac Date? Tarsus Cilicia................... III 228 Iul(ius) S sig IIII Scyt Date? Enesch Syria.............E. 1908:25

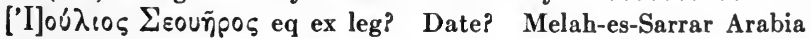

IG a RR III 1811

C. Iulius S (eq? III Aug) 222-35 A.D. Castra Lambaesitana MAH 1897 p447

C. Iulius S eq III Aug Date? Lambaesis................VIII 3165

C. Iulius S Cas bf pr (III Aug) Date? Castra Lambaesitana .... VIII 2568

C. Iul(ius) $\mathbf{S}$ eq XX V v Date? Chester Eng............E. IX 1061

G. Iulius $\mathbf{S}$ vet VI Vict ante Nero? Emerita Lusitania............II 490

C. Iul(ius) S R(emesiana?) vet VII $\mathrm{Cl} 195$ A.D. Viminacium Moes Sup................................ 14507

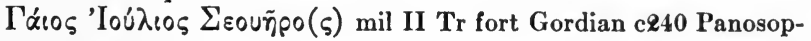
lis Egypt.......................... a RR I 1147

Q. Iulius S Dinia vet II Aug Date? Isca Eng.............VII 182

T. Laelius T. f. S 7 III Cyr Date? Salonae Dalmatia........... III 2038 L. Licinius S(eve)rus? eq IIII Mac ante Vespas Alpis Poeninae.. V 6879 M'. Maecius Vol. S Ant(ip)ol mil leg XV ante Vespas Col Ulpia

Traiana Germ Inf........................... XIII 8647

P. Mai(or?) Seve(rus) vet ex arm cust? (V Mac) c134 Troesmis...III 6178

Q. Manlius Q.f. Cam.S Alba Pompeia vet traslatus ex leg XXII

Prim Date? Rome............................... VI 2649

C. Mellonius $\mathbf{S}$ frum XXII Prim Date? Rome............. VI 3351

C. Mellonius S 7 XXII Prim Date? Mainz.............. XIII 6682

Numitorius $S$ vet $(\mathrm{V}$ Mac) Date? Troesmis...............III 6179

M. Octavius S 7 VIII Aug $\ell_{s}$ exe-3s init Welzheim.......... XIII 6526 
Sex. Pactumeius $S$ mil III Aug Date? Lambaesis...........VIII 3214 Q. Pompeius Q. f. Pub. S Ver(ona) mil XIIII G m v 70-100 A.D.

Mainz .................................. 6905

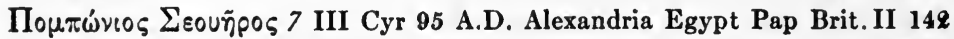
C. Rutilius $\mathbf{S}$ tub III Aug Date? Lambaesis............... VIII 2969 Sex. Sammius Volt. S (7) I Germanicae 50 A.D. Gratianopolis . . . XII 2234 Sanctinius $\mathbf{S}$ sig XXX Ulp vict Date? Ancyra............III 6764 Sem(pron)ius f. Trom. Se(ver)us Aq Sta(tiellis) sig? XI

Cl p f 4q-70 A.D. Burnum Dalmatia...............III 9904 C. Sempron(ius) $\mathbf{S}$ corn leg XIIII post 100 Siscia Pann Sup ......III 10855 Sever(ius) S spec legg III Antonin ( $=$ X Gem XIV Gem I Ad.)

c212 Carnuntum Pann Sup........................ 4452

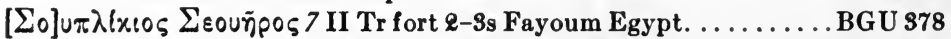
Tertinius $S$ mil VIII Aug bf cos Date? Vinxtbach...........XIII 7731 A. Titius C. f. Pom. S Arretio 7 VI Vict $p$ ante Hadrian? Col

Agrippinensium ......................... 8174 Val(erius) $S$ vet $(V$ Mac) cl34 Troesmis................III 6178

C. Val(erius) S 7 ? I Ital Date? ad Haemum Moes Inf . . . . . . III 14207:40

L. Valerius $S$ vet VII Gem fel Date? Tarraco..............II 4178

L. Valerius S mil VII Gem Date? Lucus Augusti Tarraconensis..II 2583 Sex. Valerius Sex. f. Vol. S(e)verus Luc(o) Aug mil XXII Prim

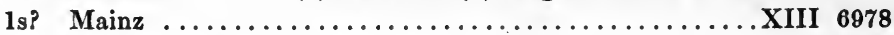

M. Vari(us) $\mathbf{S}$ bf cos Date? Dorchester Eng............... VII 83

M. Veratius S vet XXX Ulp vict ante 120? Salonae Dalmatia....III 2064

C. Vibius C. f. Trom. S Aequo mil I Adiut 70-100 A.D. Mainz . . XIII 6833 nutius S (mil III Cyr au XXII Deiot) 90 A.D. Fayoum

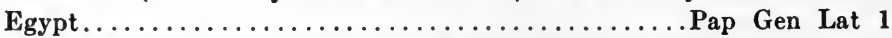
ius S Arado vet? (III Aug) aet Hadriani Castra Lambaesitana ................................ VIII 18084

S Gazza vet? (III Aug) aet Hadriani Castra Lambaesi$\tan a \ldots \ldots \ldots \ldots \ldots \ldots \ldots \ldots \ldots \ldots \ldots \ldots \ldots \ldots \ldots$. . . . . 18084 (S)everus Gen- vet? (III Aug) aet Hadriani Castra Lambaesitana .......................... VIII 18084

-nianus S Tolom(aida) vet? (III Aug) aet Hadriani Castra Lambaesitana ........................... VIII 18084 - S Am- vet (V Mac) c134 Troesmis.............III 6178 (Se)verus Narag(gara) mil? (III Aug) aet Antonini Pii

Castra Lambaesitana......................... VIII 18085 - S 7 II Tr fort 194 A.D. Alexandria Egypt............ III 6580 SEXSTIANUS

M. Granius S sig III Aug Date? Lambaesis.............. VIII 2881 SEXSTUS

C. Ersidius $\mathbf{S}$ mil I Ital Date? Almus Moes Inf ............ III 7498 SEXTIANUS

M. Aurellius M. f. Pal. S Ostia 7 frum III Aug hastatus 3s Lambaesis 
P. Marcius P. f. S Epheso p p I Adi p f Antonin 207 A.D. Arra-

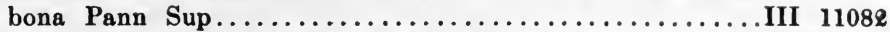

Septimius S mil VIII Aug Date? Lyons...............XIII 1874 SEXTILIUS

Iul(ius) $\mathbf{S}$ bf $\cos$ XIIII Gem Date? Avendo Dalmatia.........III 10050 SEXTINUS

L. Caiatius L. f. Gal. S Lug(uduno) mil XX V v Date? Chester Eng ............................ IX 1059 SEXTUS

L. Apic(ius) S Sc(upis) tess vet VII Cl 195 A.D. Viminacium Moes Sup............................ 14507

Emeritius S mil bf $\cos$ XXII Pr p f Sever 223 A.D. Cannstatt ... . XIII 644\& M. Aur(elius) (S)extus Sc(upls) vet VII Cl 195 A.D. Viminacium Moes Sup........................... 14507 SIGILLIANUS

Iullus S cor III Aug p v 209-\$11 A.D. Castra Lambaesitana. . . . VIII 2557 SILAMIUS

M. Ulpius S (P)oetovi mil leg? Date? Portus Magnus....... VIII 9765 SILIQUARIUS

C. Iulius S Cirt(a) vet III Aug p v c198 Castra Lambaesitana . . . VIII 18068 SILLA.

G. f. S mil XV Apol 1s Carnuntum Pann Sup...........III 4460 SILO

Q. Antonius S 7 I Adint, II Adiut, III Aug, IIII Fl firm, XI Cl p f, XXII p f (Domitianae) aet Domitiani Roethenberg Germ Sup XIII 6357

L. Autronius L. f. Sergia Norba $S$ vet ex leg II 1s? Argentorate ................................... 5975

L. Quintius S (mil? III Aug) Date? Castra Lambaesitana A.E. 1899:91 Saufeius L. f. Pol. S 7 IIII Mac et X Gem ante Vespas Segusio

Alpes Cottiae........................... $725 s$

SILVANUS

L. Aelius S(il)vanus bf cos Date? Apulum Dacia...........III 118 s

P. Aelius (S)ilvanus 7 III Aug Date? Lambaesis........... VIII 2790 Aemilius S 7 III Aug Date? Lambaesis................. VIII 3028 Ant(onius) Silvan(us) vet ex corn (V Mac) c134 Troesmis......III 6178 Antonius S arm cust III Aug ce25 Castra Lambaesitana....A.E. 1902:11 M. Anto(nius) S optio (III Aug) 198-211 A.D. Castra Lambaesi-

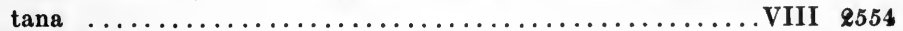
Aur(elius) $S$ vet (V Mac) Date? Troesmis..............III 6179 Aurel(ius) S (mil) XIII Gem Date? Aquileia................ 951 Q. Cerellius S Cast vet III Aug p v c198 Castra Lambaesitana... VIII 18068 Cest(ius) S eq dup (XIIII Gem?) ante 178 Carnuntum Pann Sup.. III 11180 Q. Cornel(ius) S 7 V Mac p c 3s Apulum Dacia..............III 7764 Creper(ius) Silvanu(s) arm cust III Aug c225 Castra Lambae- 
Crispius S dup III Aug p v Antonin 218 A.D. Castra Lambaesi-

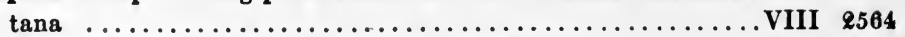

C. Ficilius $\mathbf{S}$ vet (III Aug) Date? Lambaesis............. VIII $\$ 104$ Fl(avius) S 7 XIIII Gem post 100 Brigetio Pann Sup.......... III 4299 T. FI(avius) S mil XIII Gem 200 A.D. Apulum Dacia..........III 1042 C. Gavius L. f. Stel. S p p VIII Aug 65 A.D. Taurini. . . . . . . . . . V 7003 Iul(ius) $\mathbf{S} 7$ (VIII Aug?) Date? Oehringen............. XIII 6548 Iul(ius) $\mathbf{S}$ eq (III Aug) Date? Lambaesis...............VIII 3166 Iul(ius) $\mathbf{S}$ eq (III Aug) Date? Verecunda................VIII 4237 C. Iul(ius) S optio (III Aug) 198-211 A.D. Castra Lambaesitana. . VIII 2554 Sex. Iu(lius) Ani Silva(nus) ? VII Cl p f 4q-70 A.D. Aequum

Dalmatia ..............................III 2793

L. Latinius S Kart vet III Aug p v c198 Castra Lambaesitana . . . VIII 18068

P. Maccaeus S vet ex sig (III Aug) Date? Lambaesis......... VIII 2596

L. Nonius S ? (III Aug) 200-211 A.D. Castra Lambaesitana. .... VIII 2556

L. Pomponius $\mathbf{S}$ mil leg $\mathrm{XI}$ ante 48 Aquileia. .............. 987

C. Sittius S (tub mil? III Aug) ce00? Castra Lambaesitana

Bull Archeol 1905 p 240

G. Spurius S 7 X Gem aet Commodi Carnuntum Pann Sup...... III 11134 Staberius S dup III Aug p v Antonin 218 A.D. Castra Lambae-

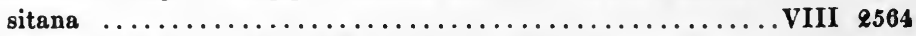

Titius S 7 XI Cl p f 4q-Vespas Burnum Dalmatia...........III 6417 Ulpius $S$ emeritus II Aug Date? London Eng...........E.E. VII 816 C. Valerius S curator scolae (III Aug) Date? Castra Lambaesitana ................................ VIII 2562

L. Valerius $\mathbf{S}$ mil VI Vict ante Vespas Conv Bracaraug Tarraconensis ............................. 5551 An? S Karth mil III Cyr 2s? Bostra Arabia......... 1904:69 SILVESTER

C. Cassius $S$ vet IIII Fl ex sig Date? Poetovio Pann Sup.......III 4056 P. Ulpius D. f. S 7 XI Cl p f 4\&-Vespas Burnum Dalmatia........ III 2833 Silvanius S mil I (Min?) Sever natus Col Agrippinense c225 Capua X 3896 SILVINUS

Severinius S mil II Ital Sever ce2s Virunum Noricum....... III 4791 add M. Ulp(ius) $S$ str praef praet ex leg II Parth $p$ f aetern Date?

Rome ................................. VI 3408

C. Valerius C. f. Fab. S Val(entia) mil leg? Date? Carnuntum

Pann Sup..........................III 4486

SIMILIS

C. Iucund(ius) S mil XXX (Ulp vict) bf $\cos 182$ A.D. Dottendorf

Germ Inf.............................XIII 7987

- S 7(leg?) Date? Chesters Eng................ VII 614 SIMPLEX

Annius S mil VII Gem fel Date? Castulo Tarraconensis........II 9275 Felicius $S$ ? VI Vict post Hadrian York Eng. .............. VII 247 L. Valerius $S$ mil XXX Ulp vict Date? Vetera Germ Inf......XXII 8631 M. Verecundinius S 7 XXX Ulp 164 A.D. Col Agrippinensium.. XIII 8203 
SINNA

T. Aur(elius) S Rat(larla) vet VII Cl 195 A.D. Viminacium Moes Sup $\ldots \ldots \ldots \ldots \ldots \ldots \ldots \ldots \ldots \ldots \ldots \ldots \ldots \ldots \ldots \ldots \ldots \ldots \ldots \ldots \ldots$ III 14507 SIRIACUS

C. Iulius $\mathrm{S}$ vet III Aug Date? Casae Numidia VIII 18532 SITA

T. Arsinius $\mathrm{S}$ vet II Adiut Date? Aquincum Pann Inf........III 3435 SITTIANUS

Sittius S arm cust (III Aug) 200 A.D. Castra Lambaesitana.. A.E. 1902:10 SOCELLUS

- Socellus? 7 (leg?) Date? Borcovicium Eng........E.E. IX 1190 SOCISSIANUS

- $\mathrm{S}$ mil arm cust et dup II Adiut 3s? Aquincum Pann Inf... III 3556 SODALIS

C. Cominius S eq III Aug Date? Lambaesis. . . . . . . . . . . VIII 3088-8 SOLINUS

M. Aur(elius) Sol(inus?) vet VII Cl 195 A.D. Viminacium Moes Sup $\ldots \ldots \ldots \ldots \ldots \ldots \ldots \ldots \ldots \ldots \ldots \ldots \ldots \ldots \ldots \ldots \ldots \ldots \ldots \ldots \ldots$ III 14507 SOLO

T. Statilius? S p p I Adi p f post 114 Brigetio Pann Sup........III 11034 SOLON

Statius $\mathbf{S} 7$ (leg?) coh VI Date? Hunnum Eng..............VII 568 M. Ulpius C. f. Col. S Philadel(fia) C vet II Tr fort 194 A.D.

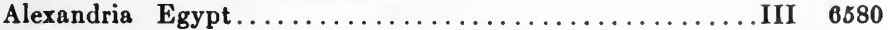
SOLUS

Q. Postumius Q. f. Papir. (S)olus? Emerita mil leg XX 7

p p Date? Chester Eng.................E.E. IX 1064 SOPHAENETUS

M. Aurelius $\mathbf{S}$ frum XIII Gem Sever c285 Rome........... VI 230 SORANUS

L. Gallius $\mathbf{S}$ mil IIII Fl fel Date? Altinum............. 2159 SORIO

- S 7 (leg ?) Date? Magnae Eng

.VII 788 SOSIGENES

- (Au)r(elius) S Thes(salonica) vet VII Cl 195 A.D. Viminacium Moes $\operatorname{Sup} \ldots \ldots \ldots \ldots \ldots \ldots \ldots \ldots \ldots \ldots \ldots$ III 14507 SOSSIANUS

M. Appius Soss(lanu)s Nic(omedia) vet? (III Aug) aet Hadriani Castra Lambaesitana........................ VIII 18084

L. Trebonius Fab. S Colonia Heliupoli 7 frum III Fl Gordian c\&40 Rome ......................... 4 I SOSSIUS

M. Aur(elius) $\mathbf{S}$ vet IIII Fl Date? Aquileia............. V 899 
SOTAS

P. Aelius S Cas mil? (III Aug) aet Antonini Pii Castra Lambaesitana................................ VIII 18085 SOTER

T. Aelius Soter- mil? (III Aug) aet Antonini Pii Castra Lambaesitana................................ VIII 18085 SOTERIA

M. Aemilius M. f. Pob. S domo Oscensis eq vet VIIII Hispanies

1s Cales............................... VIII $\$ 890$ $\Sigma \mathrm{OrXI} \Delta \mathrm{A} \Sigma$

$\Phi \lambda(\alpha \circ \circ \cup \circ \varsigma) \Sigma o u \chi 1 \delta \tilde{\alpha} \varsigma$ mil V Mac 4s? Fayoum Egypt........BGU 890 SPECTATUS

M. Firmidius $\mathrm{S}$ frum II Ital $\mathrm{p} f$ optio 800 A.D. Luna.......XI 1382 SPERATUS

Aelius S mil III Aug Date? Lambaesis................VIII 2783 Baebius S arm cust (III Aug) 800 A.D. Castra Lambaesitana. A.E. 1908:10 M. Baeblus $S$ corn praef III Aug p v 3 s Vazaivi............ VIII 1762s

C. Iulius $S$ vet (III Aug) 38 ? Casae................... VIII 4331

C. Longinius $S$ vet XXII Pr p $f$ 201 A.D. Steinheim Germ Sup..XIII 6458

M. Val(erius) $S$ vet ex b $f$ cos VII $C l$ \&s init Viminacium Moes Sup...................................III 12658

M. Valerius S optio (III Aug) 188-211 A.D. Castra Lambaesitana................................... $\mathbf{e 5 5 4}$

L. Veratius S bf praef XIII Gem post Traian Apulum Dacia....III 1056 -ius S tub III Aug p v 20 \& A.D. Castra Lambaesitana.. A.E. 1907:184 STAIUS

Sallusti(us) $\mathbf{S}$ (mil III Cyr aut XXII Deiot) 90 A.D. Fayoum

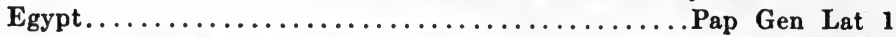

- S mil XXI Rap ante Hadrian Trumplini..............V 4887 STAMBON-

M. Curt(ius) S Rat(laria) vet b s VII Cl 195 A.D. Viminacium Moes Sup..................................III 14507 STATILIANUS

Sep(timius) Statilian(us) (? leg ?) Date? Apulum Dacia..III 1180 STATILIUS

Aur(elius) S (vet) ex dup (V Mac?) Date? Potaissa Dacia..III 7688 STATUTUS

Lucr(etius) Statu(tus) vet (V Mac) c134 Troesmis.........III 6178 STELLA

(S)empronius $\mathbf{S}(7) \times$ Gem Date? Aquileia.............. 950 STERCEIUS

C. Iulius S cor III Aug p v 203 A.D. Castra Lambaesitana..... VIII 2557 STIMINUS

S 7 V Mac 68 A.D. Emmaus Nicopolis Palestine.:....III 14155:11 


\section{STRABO}

Acutius S 7 III Aug Date? Lambaesis................. VIII 2781

G. Farsuleius S Ptolomalde $\mathbf{n}$ mil III Cyr aet Titi Alexandria

Egypt................................. $\quad 6589$

STRATUS

Iulius S 7 IIII Fl Date? Drobeta Dacia................III 14484 SUAVIS

C. Donius S G. Viruno mil XIIII Gem 70-100 A.D. Mainz..XIII 6892

Lousi(us) S 7 (leg ?) coh VI Date? Chesters Eng......VI $600=680$

P. Solius P. f. Vol. S Viana mil XXII Prim 1s? Mainz.... XIII 6972 SUBSIO

Iul(ius) $\mathbf{S} 7$ (leg ?) Date? Petrianae Eng.............. VII 899a SUCCESSIANUS

Successus S mensor (III Aug) 3s? Castra Lambaesitana..A.E. 1904:78 SUCGESSUS

(A)ntistius S tub III Aug p v 20\& A.D. Castra Lambaesitana. . A.E. 1907:184

C. Caecilius S mil III Aug Date? Lambaesis............VIII 3068

T. Cl(audius) Suc(c)essus Perg(amo) vet VII Cl 195 A.D.

Viminacium Moes Sup........................III 14507

Geminius S dup III Aug p v Antonin 218 A.D. Castra Lambaesi-

tana.................................... 2564

Graceius S Kar mil? (III Aug) Date? Castra Lambaesitana..VIII 2568

Titius Suc(c)ess(us) vet $\mathrm{X}$ Gem Date? Vienna............III 14360

SUDICENTUS

Aurelius S? mil XI Cl ss exe-4s init Aquileia.............. 900 SUDIUS

Val(erius) $S$ mil I Ital provinciae Tracie Date? Tibur..... XIV 3631 SUEBUS

Lupionius S mil dup leg XXII Date? Perinthus Thrace....III 14807:7 SUGASIS

S mil XXI Rap ante Hadrian Trumplini.............V 4987

SULLA

Cornelius S 7 (XIIII Gem?) coh VII Date? Carnuntum

Pann Sup................................. 11810

L. Cornelius S mil III Aug Date? Lambaesis............VIII 3093

Iulius S arm cust III Aug c225 Castra Lambaesitana....A.E. 1902:11

(L) Marcius L. f. S p p II Aug Date? Venafrum ............ 4871 SULPICIANUS

I. Bassus S 7 II Tr for 7 XXII Pg p 7 XIII Gem 7 III Aug

p v 7 III Parth Sever 3s Lambaesis................. VIII 2891

M. Cass(ius) Sulpician(us) Rat(iaria) vet VII Cl 195 A.D.

Viminacium Moes Sup........................III 14507

SUPERIANUS

M. Coc(ceius) S 7 X Gem Date? Poetovio Pann Sup..........III 10888 


\section{SUPERUS}

Aur(elius) $S 7$ VI (Vict) post Hadrian York Eng............ VII 246 T. Fl(avius) $\mathbf{S} 7$ leg XXX Date? Col Agrippinensium........XIII 8291 , SUPERSTES

M. Verius S 7 V Mac aet Commodi aut Sept Severi Germisara Dacia....................................III 12574

M. Verius S 7 V Mac p(iae) es exe Micia Dacia...........E. 1918:304 SURA

C. Aufidius L. f. Quir. S domo Heliop(li) vet XV Apol ante 63? Carnuntum Pann Sup.......................III 11210 SURIO

L. Icconius L. f. Ani. S Caesaraug mil XI Cl p \& 4Q-Vespas Burnum Dalmatia...........................III 6417 SURUS

Aelius $S(u)$ rus peq III Aug Date? Lambaesis............ VIII 8791 M. Antonius M. f. Ser. S vet III Fl firm Date? Salonae Dalmatia.................................... 2004

Aur(elius) S ? (III Aug) 253-268 A.D. Castra Lambaesitana... VIII 18061 M. Aur(elius) S R(emesiana?) vet VII Cl 195 A.D. Viminacium Moes Sup..............................III 14507

T. Flavius $S$ actar III Aug p v cq0\& Castra Lambaesitana..A.E. 1898:108

T. Flavius $S$ optio actar leg (III Aug) 198-211 A.D. Castra Lambaesitana............................. VIII 2554

G. Iu(lius?) $S$ bf praef I Adiut post 114 Scarbantia Pann Sup .. III 15188:4 Ulp(ius) $S$ (? leg ?) Date? Apulum Dacia..............III 1189 SYRIACUS

C. Iulius $\mathbf{S}$ vet III Aug Date? Lambaesis............... VIII 3167

M. Laetorius S mil III Aug \&s? Lambaesis.............. VIII 8174 TACITIANUS

G. Statius T bf $\cos$ XIIII Gem 209 A.D. Narona Dalmatia......III 1780 TACITUS

Iul(ius) T 7 V Mac 197-809 A.D. Apulum Dacia............III 14479 TANNONIUS

Q. Marcius T mil III Aug Date? Mina............... VIII 21598 TARA

M. Aur(elius) T vet VII Cl 195 A.D. Viminacium Moes Sup.....III 14507 TARQUINIENSIS

L. Oclatius T vet leg XV ante 63 Emona Pann Sup...........III 3845 TARSA

T. Flavius T Nap(oca) mil? (III Aug) aet Antonini Pii Castra Lambaesitana ............................ VIII 18085

TARTIANUS

F1(avius) T 7 III Aug Date? Lambaesis................ VIII 3114

TATULO

Iul(ius) $\mathbf{T}$ mil II Adiut (bf) trib 3s Aquincum Pann Inf.........III 3553 
TAURINUS

- T optio XIIII Gem post 100 Carnuntum Pann Sup........III 4439 Taupeivos A ¿ $\beta \alpha \nu \theta \alpha$ vou vet leg? Date? Sahouet-el-Khudr

Arabia IG a RR III 1301

TAURISCUS

P. Aelius T Sufet(ula) quaest III Aug c225 Lambaesis........ VIII 2586 TAURUS

P. Aelius T str (III Aug) Date? Lambaesis............. VIII 2792 (Au)r(elius) T R(atiaria) vet VII Cl 195 A.D. Viminacium Moes

Sup.................................... 14507

Lusius T (mil? II Parth?) Date? Rome.................. 2410

C. Sallustius T spec (VI)II Aug Date? Mainz............. XIII 6721

Statilius T 7 II Tr fort 140 A.D. Syene Egypt.............II 6025

Ulp(ius) $T$ mil I Adiut post 114 Ager ad Colapim Pann Sup......III 14049

G. Valerius G. f. Pap. Narb. T mil III Mac ante Vespas Mainz . XIII 6874

T 7 leg? Date? prope Agram Raetia...............III 18031:5 TELESINUS

Ti. Claudius Ti. f. Quir. T 7 XI Cl p f et XXII Deiot Claud-Traian

Rome ................................... $\mathbf{s 5 8 3}$

TELESPHORIANUS

M. Flavi(us) Caecilius T frum V Mac Date? Lambaesis.......VIII 2867 TENAX

A. Instuleius T p p XII Fulm 65 A.D. Thebes Egypt...........III 30 TERENTIANUS

M. Aur(elius) Teren(tianus) vet I Adiut 198-209 A.D. Brigetio

Pann Sup .............................III 4897

C. Iul(ius) T(erenti)anus ? IIII Fl Date? ad Haemum Moes

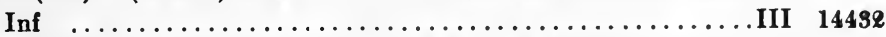

Terent(ius) $T$ spec legg III Antonin ( $=$ X Gem XIV Gem I Ad)

c212 Carnuntum Pann Sup.....................III 4452

Val(erius) Terentian(us) arm cust (III Aug) 200 A.D. Castra

Lambaesitana ........................... 1908:10

TERENTIUS

M. Aurelius T optio pr pr (III Aug) c253 Castra Lambaesitana ... VIII 18078

Iulius T bf cos X Gem Sever 224 A.D. Latobici Pann Sup..III 3899 (p1737)

TERMINALIS

Pap- T mil XIIII Gem post 100 Ager Ad Colapim Pann

Sup ...................................III 14048

TERTIANUS

Aur(elius) $\mathbf{T}$ mil II Ital \&-3s? Virunum Noricum..........III 4836a

Calpurn(ius) $\mathrm{T}$ mil XI Cl 155 A.D. Almus Moes Inf...........III 7449

TERTINUS

Aur(elius) T 7 leg XXX \&s? Ausci Aquitania............. XIII 448

L. Sep(timius T)ertinu(s) (7) II Ital p f 3s Ager Celeianus Nori-

cum ....................................III $\mathbf{5 8 0 0}$ 


\section{TERTIOLUS}

C. Ael(ius) $T$ bf VI Vict Date? Thamugadi Numidia..........VIII 8401 TERTIUS

L. Antest(1)us M. f. Anl. T Cremon(a) mil leg ? Date? Ager Mogontiacensis ................................. 7898 (Aurelius T)ertius natione Pann mil in leg? (Cl) 3s Rome .... VI 2673 L. Aurelius L. filius T Aurelia Lambaese vet (III Aug?) Date?

Kesur-El-Ghennaia ......................... VIII 4306

C. Betuscius $\mathbf{T}$ mil leg? Date? Poetovio Pann Sup...........III 4055

L. Calpur(nius) Terti(us) vet ex aquil IIII Fl firm Date? Singi-

dunum Moes Sup..........................II 1663

Ti. Claudius $\mathrm{T}$ mil bf $\cos \mathrm{X}$ Gem $\mathrm{p}$ f Date? Fl Raab Noricum....III 5510

C. Coccius C. f. Vetur. (T)ertius Plac(entia) mil XI Cl p f 42-

Vespas Burnum Dalmatia......................III 14997

L. C- L. f. Cla. Viru(ni) (T)ertius $7 \mathrm{XI} \mathrm{Cl}$ p f Vespas-

Traian Castellum Mattiacorum .................... XIII 7287

Fadienus T sig XIIII Gem Date? Iader Dalmatia...........III 2915

(?F)1(avius) $\mathrm{T}$ mil XI Cl 155 A.D. Almus Moes Inf.......... III 7449

C. Iunius $\mathbf{T}$ arm cust III Aug Date? Lambaesis............ VIII $\mathbf{2 9 2 7}$

G. Mansueti(us) $T$ vet XXII $(\operatorname{Pr} p$ f) Date? Lyons .........XIII 1868

Numitor(ius) T (mil? III Aug) ce18? Castra Lambaesitana

Bull Archeol 1904 p 206

Publ(icius) Tertiu(s) vet (V Mac) c134 Troesmis............III 6178 M. Terentius M. f. Ult. T Deci (mil?) XXII Prim 1s? Mainz.. XIII 6974 Ulpius T mil XXX Ulp vict Date? Lyons................ 1904:177 Valerius $T$ mil II $\mathrm{Tr}$ fort 151 A.D. Arsinoe Egypt........E.E. VII p459 Val(erius) T mil leg M(o)esiaca inter Dioclet et Constantinum Rome VI 8759 Vale(rius) $T$ bf trib XXII Pr p f Date? Mainz...........E. 1907:106 C. Valerius L. f. Poll. T Hasta mil IIII Mac ante Vespas Mainz. . XIII 6875

C. Val(erius) Tertiu(s) (bf cos) Date? Col Ulpia Traiana Germ Inf ..................................... 8621 (T)ertius mil (XXII Pr p f) strator 283? A.D. Tilena

Germ Sup............................... 5 5685 TERTULLIANUS

Iulius Tertullia(nus) 7 II Aug post Claud Petrianae? Eng. ...... VII 899 TERTULLINUS

Aur(elius Te)rtullinus mil XI Cl 155 A.D. Almus Moes Inf.....III 7449 tius C. f. Pup. T Paraetonio vet II Tr fort 194 A.D.

Alexandria Egypt........................... $\quad 6580$ TERTULLUS

M. Blesius $\mathrm{T}$ mil XI Cl p f 4q-Vespas Salonae Dalmatia........III 2013 Creperius $\mathrm{T}$ dup III Aug $\mathrm{p}$ v Antonin 218 A.D. Castra Lambaesi-

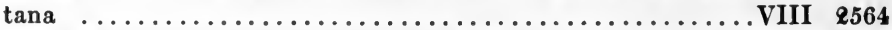

Q. Sollonius T mil leg XVI ante Vespas Milan.............. 5830

P. Timinius P. f. Pal. T Roma p p III Aug 144 A.D. Castra Lambaesitana ...................................... 2535

L. Valerius L. f. Pup. T Laude mil XXII Prim 1s? Mainz.... XIII 6978 
(T)ertu(llu)s Novar(ia) mil XI Cl 4q-Vespas Burnum

Dalmatia ...............................III 9906

TEURNICUS

G. Ces(tius) $T$ mil XX $\vee \vee$ Date? Chester Eng..........E.E. VII 891 TEVESTINUS

Calpurnius T spec (III Aug) Date? Lambaesis............ VIII 2833 THALAMUS

P. Saltienius P. f. Maecia T Hadria praef II Aug 3s Isca Eng. . VII 100-101 THAMARCUS

M. Aur(elius) T Rat(iaria) vet VII Cl 195 A.D. Viminacium Moes Sup................................III 14507 THEODORUS

P. Aelius T Cas mil? (III Aug) aet Antonini Pii Castra Lambaesitana .................................. VIII 18085

M. Aur(elius) Theodor(us) quaest? III Cyr Date? Palestine..III 13604 - (Th)eodorus Cirt(a) vet? (III Aug) aet Hadriani Castra

Lambaesitana .............................. VIII 18084 THEOMOLPUS

Aur(elius) T mil II Parth post Sept Sever Rome............VI 3405 THEOPOMPUS

M. Livius T Sidon(ia) vet? (III Aug) aet Hadriani Castra Lambaesitana .................................VIII 18084 THEVESTINUS

Pescenn(ius) T arm cust (III Aug) 200 A.D. Castra Lambaesitana THITHI

A.E. 1902:10

T. Aur(elius) T Rat(iaria) vet VII Cl 195 A.D. Viminacium Moes

Sup ..................................... 14507 THIUMPUS

Valerius T mil XI Cl pref II Hercul 3s exe-4s init Troesmis....... III 6194 THREPTUS

C. Antistius T bf cos Date? Latobici Pann Sup............III 3900 THROPHIMIANUS

C. Val(erius) Throphimian(us) Phil(ippis) vet VII Cl 195 A.D.

Viminacium Moes Sup........................III 14507 THRUPO

- Thrupo? 7 (leg?) Date? Proclitia Eng....VII 631a of VII 332 THUBUNIUS

Lucret(ius) T (mil? III Aug) c£18? Castra Lambaesitana Bull Archeol 1904 p 206

TIBEPIANO $\Sigma$

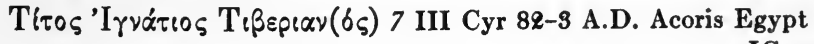

TIBERINUS

Aurel(ius) $\mathrm{T}$ mil XI Cl 155 A.D. Almus Moes Inf...........III 7449 
Aurel(lus) Tiberin(us) sig (III Aug) Date? Castra Lambaesitana .................................... VIII 18073 TIBEPPINOS

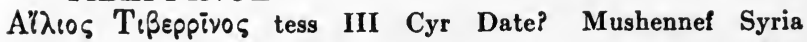
Prentice Gr \& Lat Insc 384

\section{TIMENS}

M. Aur(elius) T vet VII Cl 195 A.D. Viminacium Moes Sup.....III 14507 TIMON

M. Aurel(ius) T 7 III Gall Sever Alexand c225 Viminacium Moes

Sup A.E. $1905: 157$

TIMOTHEUS

M. Aur(elius) T Nic(opoli) vet VII Cl 195 A.D. Viminacium Moes

Sup III 14507

TIRO

Laellus T 7 leg III ante 108 Nicopoli Egypt .III 6602

C. Lusattus T (mil? III Aug) c\&00 Castra Lambaesitana

Bull Archeol 1905 p 240

L. Vafer- T 7 XXII Prim 86 A.D. Rome..............VI 38881 TITIANUS

Ael(ius) $\mathbf{T}$ vet (XIII Gem) post Traian Recka Dacia...........III 159\&a Aurelius T 7 VIII An(to)nin ex corn \&13-17 A.D. Mainz....... XIII 6803 M. Aur(elius) T bf cos VII Cl 800 A.D. Blatsche Moes Sup......III 8237 L. Iulius T ? (III Aug) Date? Castra Lambaesitana.......... VIII 2570 Tib. Iustinius Ael. Augusta T bf leg leg XXII 210 A.D. Mainz.. XIII 6741 L. Titius L. fil. Flav. Solva T 7 I Adiut Date? Hasta.........V 7560 Valerius Titian(us) 7 III Aug coh V 162 A.D. Castra Lambaesi-

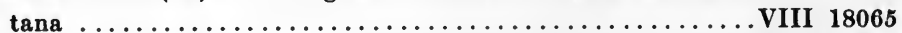

L. Veturius $T$ bf cos Date? Carnuntum Pann Sup.........III 1519q:3 Titus - (Ti)tianus? XIIII Gem post 100 Carnuntum Pann

Sup $\ldots \ldots \ldots \ldots \ldots \ldots \ldots \ldots \ldots \ldots \ldots \ldots$ III 11837

TITULLUS

T. Flavius T. f. Ste. T ? leg XX ante Claud Beneventum.......IX 1608

T. Terentius 7 XXII $p$ f Date? Rome................ VI 3634

TITUS

Aur(elius) $\mathrm{T}$ bf (I Min?) Date? Lucus Augusti Gall Narb...... XII 1576 Turran(ius) T spec legg III Antonin ( $=$ X Gem XIV Gem I Ad) c\&1\& Carnuntum Pann Sup.....................III 4452

M. Ulp(ius) T Sirmi(o) ? I Adi p f legia VGMVG? leg V M \&s?

Cusum Pann Inf...........................III $\mathbf{3 8 5 9}$

C. Valer(ius) Quirina T 7 leg ex corn cos c 800 Miltenberg XIII 6598 cf 654\&-3 - T 7 (leg?) coh X Date? Coccium Eng............... VII 288

TORQUATUS

M. Seius T ? (III Aug) Date? Castra Lambaesitana.......... VIII 2570 TREBONIANUS

M. Stertinius T ? (III Aug) Date? Castra Lambaesitana...... VIII 2562 
TRIBUNUS

L. Baebius T mil XXII Pr $p$ f post 89 Mainz.............XIII 6813 TRINIUS

- T 7 leg VII ante 42 Salonae Dalmatia............. III 8783 TROFIMAS

Aurel(ius) $\mathrm{T}$ tess XIIII $\mathrm{G} \mathrm{m} \mathbf{v}$ post 100 Carnuntum Pann Sup....III 13456 TROILUS

- illanius $\operatorname{Tr}(\mathbf{0})$ ilus bf $\cos$ I Ital Date? Almus Moes Inf.....III 7447 TUCCO

Q. Valerius T mil II Adi p f Date? Duraton Tarraconensis......II 2763 TULLIUS

Priminius T vet XXX Ulp vict Date? Geldern Germ Inf..... XIII 8601 TULLUS

T. Flavius T ? (III Aug) 809-211 A.D. Castra Lambaesitana.... VIII 2556

C. Valerius C. (f.) Vol. T Vian(na) mil XX V v Date? Magnae Eng VII 794 TURBO

M. — T 7 II Adiut 2 -3s Aquincum Pann Inf......... III 14349:\& TUSCUS

Ar- T mil? leg VII 42-70 A.D. Tragurium Dalmatia......III 9711

C. Vettius L. f. Vel. T aquil IIII Mac ante Vespas Montesampie-

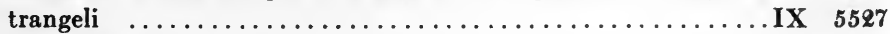
TUTIANUS

M. Septimius T Kart bf $\cos$ III Aug c225 Lambaesis......... VIII 2586 TUTOR

Restitutius (T)utor bf cos II Ital Antonin 215 A.D. Unterhoerl Noricum ..............................III 11488 TUTTIUS

T. Iulius T T. f. Claudia Viruna mil XXII Prim Date? Col Agrippinensium ........................... 8289 TYCHIANUS

P. Acilius T 7 II Tr fort Ger Sever c\&25 Alexandria Egypt. ....... III 12052 TYRANNUS

Aemilius T dup III Aug p v Antonin 218 A.D. Castra Lambaesi-

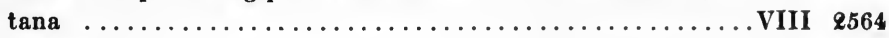
ULFUS

T. F1(avius) U sig XXX Ulp vict Sever Alexand ce25 Lyons. ... . XIII 1839 ULPIANUS

Tib. Claudius Tib. f. Quirina U dom Laod(icea) Syriae 7 X Gem IIII Fl XII Fulm III Cyr X Fr II Adiut V Mac ante M. Aurel Troesmis...............................III 6186 Marius U (mil? III Aug) ce18? Castra Lambaesitana ULPRO Bull Archeol 1904 p 206

T. Fl(avius) Ulpro? $7 \mathrm{XX} \mathrm{V} \mathrm{v} \mathrm{Date?} \mathrm{Chester} \mathrm{Eng.......E.E.} \mathrm{IX} 1060$ 


\section{UMBRIANUS}

Aur(elius) U vet ex dec (V Mac?) ante M. Aurel Napoca Dacia... III 7663 URBANUS

Aelius U dup III Aug p v Antonin 218 A.D. Castra Lambaesitana. VIII 2564 Ael(ius) U spec I et II Adi p f Sever 228 A.D. Aquincum Pann Inf. . III 3524 L. Alfidius $U$ spec VII Gem c200 Tarraco................ II 4122 Aurelius U vet (leg?) Date? Bu Atfan................. VIII 16912 Caecilius U optio val III Aug p v 209-11 A.D. Castra Lambaesitana ................... 2III 2563=Bull Archeol 1905 p235

C. Cesellius U Cas mil? (III Aug) Date? Castra Lambaesitana VIII 2568 L. Cornelius U mil XXI Rap 70-Hadrian Bonn .............XIII 8032 M. Flavius U Cirt(a) vet III Aug p v c198 Castra Lambaesitana . . VIII 18068 Gargilius U dup III Aug p v Antonin 218 A.D. Castra Lambaesi-

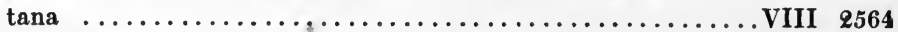

L. Hervinius U vet (III Aug) Date? Lambaesis............. VIII 3124

Iulius U 7 III Aug coh IX 162 A.D. Castra Lambaesitana... . . . VIII 18065 Iulius U dup III Aug p v Antonin 218 A.D. Castra Lambaesitana. . VIII 2564 C. Iulius U ? (III Aug) Date? Castra Lambaesitana........... VIII 2562 C. Iul(ius) U prin vex VII Gem $p$ f Date? Dianium...........II 5960 Q. Modius U Cir(ta) mil? (III Aug) Date? Castra Lambaesi-

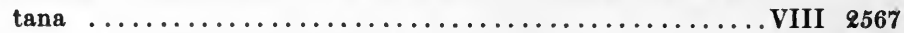

Q. Octavius U vet (III Aug) Date? Lambaesis............. VIII 3212 C. Ofellius U ? (III Aug) 209-211 A.D. Castra Lambaesitana . . . VIII 2556 Post(um)ius U tub III Aug p v 202 A.D. Castra Lambaesitana A.E. 1907:184 Servilius U Cas mil? (III Aug) Date? Castra Lambaesitana.. VIII 2568 M. Silius U (mil? III Aug) c200 Castra Lambaesitana

Bull Archeol 1905pe04 Urb(anus?) bf trib? III Aug c200 Castra Lambaesitana. . VIII 18078 URBICINUS

P. Aelius U frum II Aug Date? Rome................. VI 3337 URBICUS

D. Capienius U Voltinia Vienna sig (leg?) Date? Chester Eng E.E. IX 1078 Coc(ceius) Urb(icus?) corn (I Ital) \&s exe-3s Almus Moes Inf . ... III 14409:1 Gargilius U(rb)icus arm cust (III Aug) Date? Lambaesis. .... VIII 3668 Sextus Gellius U nat Cilix mil I Adiut Date? Carnuntum Pann Sup $\ldots \ldots \ldots \ldots \ldots \ldots \ldots \ldots \ldots \ldots \ldots \ldots \ldots \ldots \ldots \ldots \ldots \ldots$ III 11221

\section{URBIQUS}

C. Vetieni(us) C. f. Pupinia U tub exs leg I 1s? Col Agrippinen-

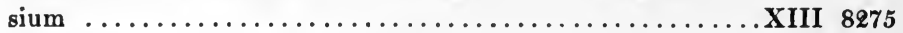

\section{URSARIS}

- U Tarnalis f. Sard(o) vet I Adiut 68 A.D. Stabiae........ X 7891

URSIANUS

Val(erius) U civis Aquileiesis prob(a)tus in leg X Gem Date?

Rome .............................. 1912:89

\section{URSINIANUS}

Aurelius U imm II Ital $2-3$ s Fafiana Noricum............. III 11816 


\section{URSINUS}

Aqu(ilius) U dup (XIIII Gem?) ante 178 Carnuntum Pann Sup..III 11180 Pervincius $U$ mil arm cust XXII (Pr) p f post 89 Mainz ........ XIII 6968 Resp(ectius Ur) sinus comm cos VIII Antonin 213-217 A.D. Mainz XIII 6803 URSIO

Aurel(ius) U mil leg VIII Date? Sabini

. $\mathrm{V} 4894$

M. Verinius U vet ex leg XXX Ulp vict Date? Lyons..........XIII 1901 URSULUS

Aelius U mil? X Gem Date? Vienna..................III 4568 M. Appianius Ursu(1)us Acr (fortasse Agrippinensium) 7 leg V

pf (7) leg I(II Au)g? Date? Scarbantia Pann Sup..III 10940 M. Aurelius U bf $\cos 225$ A.D. Col Agrippinensium ......... XIII 8205 Cocl_U U spec legg III Antonin ( = X Gem XIV Gem I Ad) c212

Carnuntum Pann Sup ............................ 4II 4452

L. Sper- U bf leg XX Date? Vevey Alpes Poeninae.......XII 164

L. Tere(ntius Ur)sulus mil? XIIII Gem post 100 Carnuntum

Pann Sup........................... 11236

URSUS

Amian(us) Urs(us?) (7 XXII Pr p f) 204 A.D. Mainz......... XIII 6801 Iul(ius) U dup (XIIII Gem?) ante 178 Carnuntum Pann Sup.... III 11180 Maefili(us)? U 7 (leg?) coh X Date? Chesters Eng............ VII 602 M(arcius) U mil III Ital Date? Sopianae Pann Inf ........... III 3309 G. Victor(ius) U vet I Adiut $\&$ s Carnuntum Pann Sup . . . . . . . . . . III 4489 - U actar II Aug 224 A.D. Isca Eng.................. VII 103 VALA

P. Tettius P. f. Cor. V mil leg XI — Vespas-Traian Vindonissa XIII 5212 VALENS

Aelius Valen(s) 7? XIII Gem post Traian Alba Dacia........ III 1629:6 Aelius $V$ vet II Ital $2-3$ s Fafiana Noricum...............II 11816 P. Ael(ius) V Rat(iaria) optio vet VII Cl 195 A.D. Viminacium

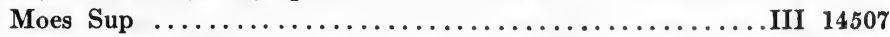
Ae(lius) Val(ens?) eq XX(II Pr p f) 230 A.D. Tilena Germ Sup.. XIII 5624

C. Aemilius Vale(ns) (mil III Cyr aut XXII Deiot) 90 A.D.

Egypt............................................ 1 (Am)monius V Sid(onia) vet? (III Aug) aet Hadriani Castra

Lambaesitana ............................ VIII 18084

C. Annius V Capito(lia) vet? (III Aug) aet Hadriani Castra

Lambaesitana.............................. VIII 18084

C. Annius V vet ex num frum IIII Fl Date? Rome............ VI 3341

M. Annius V 7 III Aug aet Antonini Pii Bescera Numidia..... . VIII 2486

C. Antistius Vale(ns) Ancyr(a) (vet) V Mac ante M. Aurel?

Troesmis ...............................III 6184

Anton(iu)s V mil XI Cl 155 A.D. Almus Moes Inf........... III 7449

Anto(nius) V mil XI Cl 155 A.D. Almus Moes Inf ............ III 7449

Antonius V 7 III Aug coh VIII 162 A.D. Castra Lambaesitana... VIII 18065 Antoni(u)s Val(en)s mil XI Cl post Hadrian Almus Moes Inf.... III 7453 C. Antonius V (vet II Tr fort?) 140 A.D. Fayoum Egypt... . . . . BGU 610 
C. Ant(onius) V Rat(iaria) vet VII Cl 195 A.D. Viminacium

Moes Sup..............................III 14507

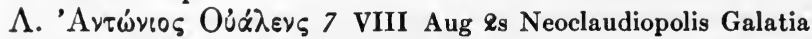

IG a RR III 141

M. Ant(onius) V R(emesiana?) vet VII Cl 195 A.D. Viminacium

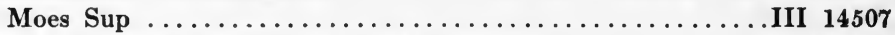

Atis(ius) Valen(s) vet $(\mathrm{V}$ Mac) c134 Troesmis.............III 6178

Avidius V ? VII Gem post 170 Mauretania Caesariensis . . . . . . . VIII 20994

Aufon(ius) Valen(s) vet (V Mac) c134 Troesmis.............III 6178

Aur(elius) Vale(ns?) vet VII Cl 135 A.D. Viminacium Moes Sup. III 8110

Aur(elius) V mil I Ital Date? Ad Haemum Moes Inf..........III 12442

Aur(elius) Val(ens?) mil II Adiut Date? Pann Inf incerta.......III 3678

Aur(elius) V (vet? V Mac?) Date? Potaissa Dacia...........III 7688

Aur(elius) V (vet? V Mac?) Date? Potaissa Dacia...........III 7688

M. Aur(elius) q(uondam) V 7 I Adiut post 114 Brigetio Pann Sup III 4315

L. Aur(elius) V Rat(iaria) arm cust vet VII Cl 195 A.D. Vimin-

acium Moes Sup.........................III 14507

M. Aur(elius) V Sc(upis) vet VII Cl 195 A.D. Viminacium Moes

Sup ................................. 14507

M. Aur(elius) V R(atiaria) vet VII Cl 195 A.D. Viminacium Moes Sup...........................III 14507

M. Aur(elius) V Sc(upis) vet VII Cl 195 A.D. Viminacium Moes Sup...............................III 14507

M. Aur(elius) V vet II Adiut 219 A.D. Aquincum Pann Inf ...... III 3484

C(laudius Va)lens sig I Min 190 A.D. Iversheim Germ Inf . . . . XIII 7946

Cl(audius) V mil II Adi $p$ f Antonin c215 Aquincum Pann Inf .... III 14342

$\mathrm{C}$ (laudius) Va(lens) vet VI Vict $\mathrm{p} f$ Date? Vianna Tarraconen-

sis .................................. 2465 add

Tib. Cl(audius) $\mathrm{V}$ vet $\mathrm{VI}(\mathrm{I} \mathrm{Cl})$ Date? Rama prope Lederatam

Moes Sup............................III 8100

L. Cominius Val(ens) vet V Mac 139-161 A.D. Troesmis....... III 6162

Did(ius) V R(emesiana?) vet VII Cl 195 A.D. Viminacium Moes

Sup $\ldots \ldots \ldots \ldots \ldots \ldots \ldots \ldots \ldots \ldots \ldots \ldots \ldots \ldots \ldots \ldots \ldots \ldots \ldots$ III 14507

(D)omitius V Cas ? (III Aug) Date? Castra Lambaesitana. ... VIII 2566

G. Domitius V tub III Aug p v 202 A.D. Castra Lambaesitana A.E. 1907:184

M. Domitius V Helio(poli) vet? (III Aug) aet Hadriani Castra

Lambaesitana ............................. VIII 18084

C. E(g)natius G. (f.) Fab. V Ancyra vet (leg?) Date? Troesmis III 6188

C. Egnatius V leg? Date? Troesmis..............III 6188

Fl(avius) $V$ vet $(V$ Mac) $c 134$ Troesmis................ 6178

Fla(vius) V mil XI Cl 155 A.D. Almus Moes Inf.............. III 7449

Flavius V corn III Gall aet M. Aurelii Perinthus Thrace........ III 7394

Fl(avius) $V$ vet ex bf leg (V Mac) Date? Troesmis...........III 6179

L. Flavius L. f. Fab. V Heraclea mil XI Cl p f 4\&-Vespas Burnum

Dalmatia ..............................III 14999

M. Fl(avius) V 7 III Aug 253 A.D. Gemellae Numidia........ VIII 2482

T. Flavius V (mil III Cyr aut XXII Deiot) 90 A.D. Fayoum

Egypt................................. Gen 1 
T. Fl(avius) T. f. Terentin. Val(ens) Amast(ri) vet $\mathrm{V}$ Mac ante $M$. Aurel Troesmis........................ 7501

T. Fl(avius) V Tolom(aida) vet? (III Aug) aet Hadriani Castra Lambaesitana ...............................VIII 18084

Gigennaus V p p III Aug 162 A.D. Castra Lambaesitana ........ VIII 18065

M. Herrennius Tromentina V Salona evoc XI Cl 7 XI Cl 7 I Ad 7 II Ad 7 XV Apol 7 IIII Fl c100? Cibalis Pann Inf ..... III 13360 Iuli(us) Valen(s) vet (V Mac) c134 Troesmis..............III 6178 Iullus $\mathrm{V}$ vet $(\mathrm{V}$ Mac) c134 Troesmis....................III 6178 Iullus $\mathrm{V}$ vet $(\mathrm{V}$ Mac) $\mathrm{c} 134$ Troesmis..................... III 6178 Iul(Ius) $V$ vet $(V$ Mac) c134 Troesmis.................. III 6178 Iul(ius) $\mathrm{V}$ mil XI $\mathrm{Cl} 155$ A.D. Almus Moes Inf............III 7449 Iul(ius) $\mathrm{V}$ mensor VII Cl Sever eq8 A.D. Viminacium Moes Sup..III 8112 Iul(ius) V mil str II Parth Date? Rome...............VI 32878 Iulius V mil IIII FI Date? Portus Magnus............... VIII 976\& Iul(ius) $V$ vet II Aug Date? Isca Eng.................. VII 183 Iul(ius) V 7 leg? Date? Rome................... VI 3816 C. Iul(ius) C. fil. V dom Amasia 7 V Mac ante M. Aurel Tropaeum Moes Inf ...........................III 14214:10

C. Iul(ius) V R(emesiana?) vet VII Cl 195 A.D. Viminacium Moes Sup.............................III 14507

G. Iul(Ius) V vet natio Sur(Us) prob in III Gall missus de leg III Aug 3s init Kesur-el-Ghennaia.................. VIII 4310

C. Iul(ius) V vet I Adiut Date? Carnuntum Pann Sup.........III 112ę

G. Iulius V Cas can (III Aug) Date? Castra Lambaesitana..... VIII 2568

C. Iu(lius) Val(ens) vet ex bf cos VII Cl Date? Viminacium Moes Sup.............................III 14217:4

C. Iulius V mil VII CI bf proc Date? Viminacium Moes Sup.A.E. 1913:39

C. Iu(li) us Val(en)s (mil III Cyr aut XXII Deiot) 90 A.D.

Fayoum Egypt.................................... Gen Lat 1

(L?) Iul(ius) V mil V Mac ante M. Aurel Chersonesus Taurica Latychev IV 181 M. Iul(ius) V Tr(imontio) vet VII Cl 195 A.D. Viminacium Moes Sup ................................ 14507

(T)1. Iulius Va(lens?) ? XIII Gem 70-84 A.D. Poetovio Pann Sup III 14355:3

T. Iulius $V$ vet ex eq $V$ Mac Date? Tarquinii.............XI 3369

L. Licinius L. (f) Ter. V Are(late) vet XX V v Date? Chester

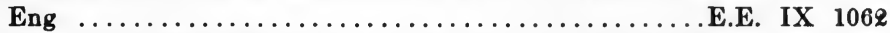

L? Licinius V The(veste) vet? (III Aug) \&s? Castra Lambaesitana ................................. VIII 18087

Mess(ius) $V$ vet (V Mac) c134 Troesmis.................III 6178

Nem- $V$ vet $(\mathrm{V}$ Mac) c134 Troesmis...............III 6178

C. Octavius C. f. Cla. V mil corn leg XXII ante Hadrian Alexandria Egypt............................. 6608

M. Octavius N. f. Aemil. V Stobis mil V Mac Date? Scupi

Moes Sup............................ 1910:173

Petro(nius) V mil XI Cl 155 A.D. Almus Moes Inf...........III 7449

Petronius V (eq? III Aug) 222-35 A.D. Castra Lambaesitana 
Q. Petronius V mil VII Gem p f Date? Riditae Dalmatia......III 2772 $\mathrm{Pe}-\mathrm{V}$ vet $(\mathrm{V}$ Mac) $\mathbf{c 1 3 4}$ Troesmis................... $617 \mathrm{II}$ M. Plaetorius $V$ vet II Adi $p$ f Date? Ravenna..............XI 23

Q. Pomp(onius?) V 7 XXII Prim Date? Mainz............XIII 6720

C. Porcius V 7 I Adiut 70-100 A.D. Mainz...............XIII 6836 Postumi(us) V 7 II Adiut $2-3$ s Aquincum Pann Inf........... III 14349:9 Publilius V 7 II Adiut $8-3$ s Aquincum Pann Inf .............. III 14349:4

Sempronius $V$ vet ex architect (V Mac) c134 Troesmis..........III 6178 L. Trebonius V mil VII Cl p f 42-70 A.D. Salonae Dalmatia. .... III 8760 Tri- Valen(8) mil XI Cl 155 A.D. Almus Moes Inf......... III 7449 M. Ulp(ius) V Rat(laria) vet VII Cl 195 A.D. Viminacium Moes

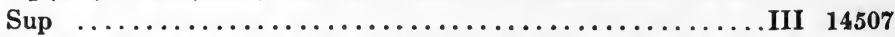

M. Ulp(ius) V Rat(iaria) vet VII Cl 195 A.D. Viminacium Moes

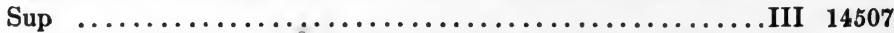

(M) Ulp(ius) V R(emesiana?) vet VII Cl 195 A.D. Viminacium Moes Sup................................ 14507

Valerius $V$ vet $(\mathrm{V}$ Mac) $c 134$ Troesmis.................III 6178 (V)al(erius) $\mathrm{V}$ vet ex imag (V Mac) c134 Troesmis.............III 6178 Val(erius) Vale(ns?) vet VII Cl 135 A.D. Viminacium Moes Sup. . III 8110 Val(erius) V mil XI Cl 155 A.D. Almus Moes Inf..............III 7449 Val(erius) $V$ mil XI Cl 155 A.D. Almus Moes Inf............ III 7449 Val(erius) V mil XI Cl 155 A.D. Almus Moes Inf.............III 7449 Val(erius) V (mil?) XIII Gem 160 A.D. Verespataki Dacia........III p959 Valerius Vale(ns?) mil V Mac aet Caracall? Troesmis..........III 6189 Val(erius) V (vet? V Mac?) Date? Potaissa Dacia...........III 7688 Valer(ius) $V$ sig XIII Gem c215? Aquileia................ V 808 Valeri(us) V (mil? II Parth?) Date? Rome................. 2410 Val(erius) Val(ens?) tess (II Adiut) 2-3s? Aquincum Pann Inf. . III 10520 C. Val(erius) V Rat(iaria) vet VII Cl 195 A.D. Viminacium Moes Sup .............................III 14507

C. Val(erius) V R(atiaria) vet VII Cl 195 A.D. Viminacium Moes Sup .................................. 14507

C. Val(erius) V R(emesiana?) interpres vet VII Cl 195 A.D. Viminacium Moes Sup......................... 14I 14507

C. Val(erius) V R(emesiana?) bf trib vet VII Cl 195 A.D. Viminacium Moes Sup...........................III 14507

(C) Val(erius) V R(emesiana?) optio vet VII Cl 195 A.D. Viminacium Moes Sup........................... 14507

C. Val(erius) V bf leg XI Cl post Traian Axiopolis Moes Inf ...... III 14439

L. Valerius $V$ vet leg VIIII aet Vespasiani Reate............IX 4689

M. Val(erius) V Sc(upis) vet VII $\mathrm{Cl} 195$ A.D. Viminacium Moes Sup $\ldots \ldots \ldots \ldots \ldots \ldots \ldots \ldots \ldots \ldots \ldots \ldots \ldots \ldots \ldots \ldots \ldots \ldots$ III 14507

M. Val(erius) V Fab. Eracl(ea) vet (VII Cl p f) Date? Viminacium Moes Sup........................ 1910:88

M. Varenus M.f. Vol. V vet VII $\mathrm{Cl}$ p f 42-70 A.D. Aequum Dalmatia ............................III 9761

L. V(ibi) us V vet I Ital Date? Aquileia........... Arch epigr Mitt VI p79 -immius V 7 III Aug \&s Thamugadi................. 1908:237 
(V)alens Cyr(enis) vet? (III Aug) aet Hadriani Castra

Lambaesitana .............................VIII 18084

V Hippo can (III Aug) aet Hadriani Castra Lambaesitana . . VIII 18084 (V)alens Sido(nia) vet? (III Aug) aet Hadriani Castra

Lambaesitana ............................ VIII 18084

-ius V vet? (III Aug) aet Hadriani Castra Lambaesitana. . VIII 18084 (Val)ens 7 XI Cl post Hadrian Durostorum Moes Inf.....III 12458 us V Thev(este) mil? III Aug c200 Castra Lambaesitana

Bull Archeol 1905 p239

us Val(ens?) mil? III Ital Date? Castra Regina Raetia.. III 11970 V 7 (leg?) Date? Cambriae oppida Eng.. VII 146 add E.E. VII 855 us Val(ens?) vet ex bf proc (V Mac) Date? Troesmis.....III 6180 us $V$ vet (V Mac) Date? Troesmis................III 6179 $\mathbf{V}$ vet (V Mac) Date? Troesmis................... 6179 V mil leg VII Date? Aleppi Syria................. 19I 182 VALENTIANUS

Aur(elius) V (mil? II) Adi p f 2-3s Ager Aquincensis Pann Inf.. III 10344 VALENTINUS

C. Antonius V vet XIIII Gem 211 A.D. Carnuntum Pann Sup... III 4441

L. Arbustius L. fil. Ann. V Grem(ona) p p IIII Fl fel 7 VII Gem

bis Date? Ficula.............................. 4007 Aur(elius) V mil XIIII Gem post 100 Carnuntum Pann Sup..... III 4459 Aur(elius) V (vet) ex tub? (V Mac?) Date? Potaissa Dacia....III 7688 M. Aur(elius) V bf cos XIIII Gem c182? Latobici Pann Sup.... III 3905 Barb(ius) V bf cos Date? Scarbantia Pann Sup..III 14068 add p2328:31 Caecilius Vale(n)tinus optio spei leg XIII Date? Ticinum......V 6423 P. Claudius Valentin(us) Had(rumeto) bf cos III Aug c225

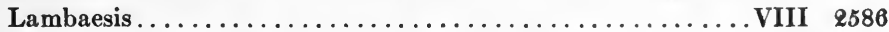

T. Cl(audius) $V$ corn X Gem p f 294 A.D. Vienna........... III 4558

Tib. Cl(audius) V vet ex arm cust I Adiut post 114 Adiaum Pann

Sup................................ III 4275

Flavius V (7?) XIII Gem post Traian Carnuntum Pann Sup.. III 14360:5

C. Germanius C. (f.) Collin. V mil XV Apol post 98 Nola.......X 1263

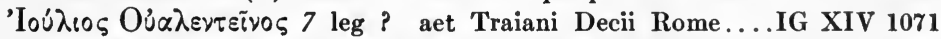
C. Iulius V Cirt(a) can (III Aug) Date? Castra Lambaesitana . . VIII 18086 (C.) Iul(ius) Valentin(us) $\mathrm{S}-$ vet VII Cl 195 A.D. Viminacium Moes $\operatorname{Sup} \ldots \ldots \ldots \ldots \ldots \ldots \ldots \ldots \ldots \ldots \ldots \ldots \ldots$ III 14507

Metilius V quondam imag I Adiut post 114 Adiaum Pann Sup..III 10965 M. Mociuncius V lib leg leg XIII Gem post Traian Apulum Dacia.................................III 1194

L. Philocalus L. f. Col. Valen(tinus) Gadara mil X Fr Date?

Byblus Syria...................... 6697

Salvinius V natus Carnunto mil X Gem optio Date? Rome..VI 3625 L. Sergius L. f. Sabati(na) Valenti(nus) leg XXII 1s Mainz.. XIII 6971 Sulp(icius) Valenti(nus) vet (V Mac) c134 Troesmis.......III 6178 Sulp(icius) V arm cust III Aug c225 Castra Lambaesitana..A.E. 1902:11 Ulp(ius) $V$ vet $X$ Gem Date? Vienna..............III 4553 
Val(erius) Valent(inus) vet (V Mac) c134 Troesmis.........III 6178 Iul. Val(erius) Valent(inus) vet (V Mac) c134 Troesmis....III 6178 M. Val(erius) Valen(tin)us bf cos XIII Gem Gordian 239 A.D.

Also-Kosaly Dacia........................... 8 III 8

T. Val(erius) Valentin(us) $R$ (atiaria) vet VII Cl 195 A.D.

Viminacium Moes Sup........................III 14507

Varius V 7 III Aug coh IV 168 A.D. Castra Lambaesitana.... VIII 18065

C. Vibulius C. f. Ofent. V Mediola(ni) mil leg XXII 1s?

Mainz................................. 6988

V centurio (legi)o secondi Flavie post Diocletianum Thel-

epte................................. 1890:187

VALERIANUS

Ael(ius) $\mathbf{V}$ bf trib I Adiut 243 A.D. Syria incerta............ III 196 (A)el(ius) $V$ spec (III Aug) Date? Lambaesis............. VIII 8793 Ael(ius) $V$ vet ex dup (XIII Gem) post Traian Recka Dacia.... III 1598a Aur(elius) V spec XI Cl aet Gordian III Josephsthal Dalmatia.. III 3021 Aur(elius) V mil Parth post Sept Sever Ager Albanus.........XIV 4009 Aur(elius) Valeria(nus) (vet? V Mac?) Date? Potaissa Dacia..III 7688 M. Aur(elius) Valer(ius) V 7 III Cyr Antonin 212 A.D. Canatha

Syria.................................... 181

Tib. Cl(audius) V 7 XIII Gem et I (Adiut) post 114 Apulum

Dacia ................................... III 981

L. Domitius V domo Kapitoliade mil VI Ferr $f$ c 208 A.D. Rome.. VI 210 Egna(tius) Valer(ianus) vet (V Mac) c134 Troesmis.........III 6178

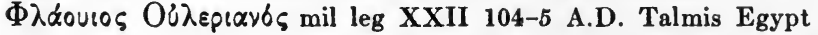

IG a RR I 1343

F1(avius) V spec (III Aug) Date? Lambaesis.............VIII 18300

T. Fl(avius) Pap. V Oesco frum V Mac ante Caracall Rome...... VI 3348

Q. Haterius $V$ frum VIII Aug c\&\&5 Rome............... VI 230

(Iu)1(ius?) V mil XX Britannic Date? Nemausus.........XII 3182

C. Iulius Valeri(anus) 7 III Aug Date? Lambaesis.........VIII 2997

C. Iulius V 7 III Aug XVI Fl firm bis IIII Scyth bis Date?

Lambaesis.............................. VIII 2627

Livius V spec legg III Antonin ( $=$ X Gem XIV Gem I Ad) c\&1£

Carnuntum Pann Sup.........................III 445\&

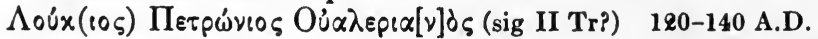

Fayoum Egypt ............................... 600

Q. Pompon(i)us V bf cos VII Cl Date? Viminacium Moes Sup..III 13807

L. Sentius $V$ vet ex adiutore princ III Aug Date? Casae......VIII 4332

Ulp(ius) V 7 X Gem 198-209 A.D. Celeia Noricum...........III 5156a

Ulp(ius) $\mathrm{V}$ bf leg ? ? Date? Viminacium Moes Sup........III 14589

(Va)leri(us V)alerianus mil XI Cl p f 4q-Vespas Burnum Dal-

matia.................................III 14321:19

Val(erius) V tess I Adiut post 114 Brigetio Pann Sup........... III 11037

Val(erius) V 7 leg ? Date? Aquincum Pann Inf...........III 3539

D. Val(erius) D. (f.) Volt. Va(leri)anus Vie(nna) mil leg?

Date? Bonn...............................XIII 8086 
M. Val(erius) V 7 IIII Fl Date? Brigetio Pann Sup...........III 4387 Val. Vib(ius) V bf cos XIII Gem post Traian Also-Kosaly Dacia.... III 823 Oن̉ $\alpha \lambda \varepsilon p \iota \alpha v^{\prime} \varsigma 7$ (II Tr?) 180-140 A.D. Fayoum Egypt .. BGU 600 V 7 XI Cl p f Vespas-Traian Vindonissa.............XIII 5213 -onius L. f. Col. V Antioch(ia) tub vet II Tr fort 194 A.D.

Alexandria Egypt........................... 6580 - V spec IIII Fl Sever Alexand 226 A.D. Ulpiana Moes Sup ... III 8173 V bf cos 282 A.D.? Ad Lacum Pelsonem Pann Sup......III 4147 VALERINUS

P. Caius V imm? X Fr Date? Bilak Dacia..............III 7625 VALERIO

Iovinius V vet ex leg I Min 3s? Lyons................. XIII 1861 VALERIUS

(A)el(ius) V corn V Mac? 197-809 A.D. Apulum Dacia....... III 14479 Ael(ius) V (vet) ex arm cust (V Mac?) Date? Potaissa Dacia..III 7688 P. Ael(ius) V spec II Adiut \&-3s Aquincum Pann Inf ......... III 14347:3 Aur(elius) V (vet? V Mac?) Date? Potaissa Dacia.......... III 7688 M. Aurel(ius) V sig V Mac Date? Concordia .............. 1881 Fl(avius) $\mathrm{V}$ imm ven XI Cl 155 A.D. Almus Moes Inf ........III 7449 T. Fl(avius) V Am(pelo?) vet VII Cl 195 A.D. Viminacium

Moes Sup..............................III 14507

I(u)I(ius) Va(l)eriu(s) vet II Adiut 161 A.D. Aquincum Pann

Inf..................................... III 13969

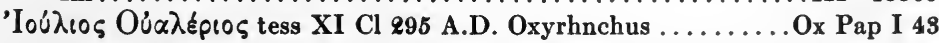

C. Iul(ius) $V$ vet ex bf $\cos$ XIII Gem post Traian Apulum Dacia...III 7748

C. Iulius V vet X Gem Date? Wiener Neustadt Pann Sup....III 11305

G. Iul(ius) $\mathbf{V}$ mil II Tr Date? Alexandria Egypt.............III 6604 Servius V 7 (leg ?) Date? Lancaster Eng.............E.E. VII 945 Siscius V 7 XIII Gem $211-\&$ A.D. Sarmizegetusa.............III 1464 Ulpius V mil V Mac p Antonin 218-22 A.D. Potaissa Dacia......III 908 Ulpius V spec leg primae Nor(icae) post Dioclet Virunum Noricum. III 4803

\section{VALES}

Antonius V mil III Cyr ante 108 Egypt.............Wessely Lat Pal 8

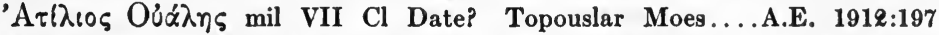
Aur(elius) V mil Adi p f Sever c\&28 Campona Pann Inf........III 3993

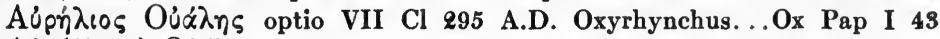

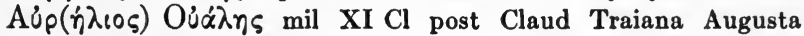

Moes Inf.............................IG a RR I 1491

M. A(u)r(elius) Va(1)es mil leg IIII str cos Date? Naissus

Moes $\operatorname{Sup} \ldots \ldots \ldots \ldots \ldots \ldots \ldots \ldots \ldots \ldots \ldots \ldots \ldots \ldots \ldots \ldots \ldots$ III 1675

C. Carminius V mil VII Gem fel Date? Lambaesis.........VIII 3075

Cassi(us) V vet (V Mac) c134 Troesmis..................III 6178

Domitius V mil III Aug Date? Lambaesis................VIII 3108

C. Iulius V vet V Mac ante M. Aurel? Cius Moes Inf........ III 18479

L. Longin(i)us V Cl. Ar(a) mil XV Apol 1s Carnuntum Pann

Sup ..................................... $4 \mathbf{4 4 7 5}$

Memi(us) V vet (V Mac) c134 Troesmis................III 6178 
Papi(rius) Vale(s) tub (I Ital) \&s exe-3s Almus Moes Inf....III 14409:1 Sal(vius) $V$ corn I Ital is exe-3s Almus Moes Inf.........III 14409:1 Septimius $V$ can $X$ Gem Date? Rome................VI 3625 M. Sulpicius M. f. Sabati(na) V Mantua mil XXII Prim 1s?

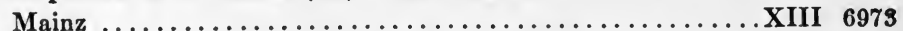

Val(erius) V mil IIII Fl Date? Ulpiana Moes Sup...........III 1690

nius Vales medicus IIII Mac ante Vespas Mainz........XIII 6700 - $\mathrm{V}$ vet $(\mathrm{V}$ Mac) c134 Troesmis.................III 6178

VALETINUS

Aur(elius) $\mathbf{V}$ sig leg XX Date? Arelate.............XII 678 VALIUS

Iul(ius) $\mathbf{V}$ mil XX V $v$ Date? London................ VII 27

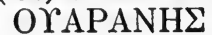

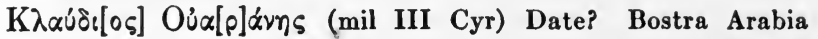

\section{VARIANUS}

- V vet $(\mathrm{V}$ Mac) Date? Troesmis.................III 6179 VARIO

Val(erius) $\mathbf{V}$ optio II Ital divit Date? Spoletium..........XI 4787 VARRO

Elionius V hast XIII Gem post 100 Brouse Bithynia....A.E. 1902:154 Menonius V 7 III Aug coh VI 162 A.D. Castra Lambaesitana.. VIII 18065 VARUS

Tit. Aur(elius) Var(us) 7 XV Apol aet M. Aurel Vagarchepat

Galatia................................ 1910:161

L. Gellius Ouf. V vet XIII Gem Date? infra Lacus Verbanum. . V 5586

Pamphilius V mil VII Gem p f Date? Tarraco.............II 4171

P. Scribon(i)us P. f. Col. Epheso V vet V Mac Date? Oescus

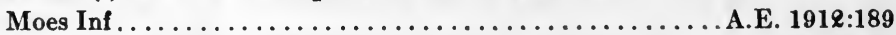

- V 7 (leg XXII aut III Cyr) aet Augusti Coptos Egypt....III 6627 VEGETUS

M. Marius M. f. Tro. V Aeq(uo) mil I Adiut 70-100 A.D. Mainz................................. 6831

—us (Ve)getus mil XI Cl p f Vespas-Traian Vindonissa...XIII 5209 VELOX

Valius $V$ mil VII Gem $p$ Date? Tarraco...............II 4171

L. Val(erius) $V$ mil XIIII $G \mathrm{~m} v$ Date? Cemenelum......... V 7873 VENUSTUS

Aemilius $\mathrm{V}$ mil XXX Ulp $\mathrm{p} f$ 3s? Lyons................XIII 1828

M. Iscantius V Cas mil? (III Aug) Date? Castra Lambaesi-

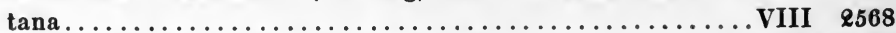

Iunius $\mathrm{V}$ aquil III Aug Date? Lambaesis............... VIII 2928

Q. Sal(vius?) V vet (III Aug) Date? Lambaesis...........VIII 3234

P. Tamudius V Ar. Car discens armaturae (III Aug) 211-\& A.D.

Lambaesis.................................. 2618

- lius V tub III Aug p v 202 A.D. Castra Lambaesitana.. A.E. 1907:184 


\section{VEPITTA}

Marcus Sulpicius V mil XIIII G m v post 100 Carnuntum

Pann Sup................................II 11234

VERANUS

C. Iul(ius) G. f. Vol. Luco Vocontiorum V vet XIIII Gem

post 100 Carnuntum Pann Sup...................III 11283

Sep(timius) V optio XIIII Gem post 100 Carnuntum Pann Sup..III 11232

L. Sep(timius) V vet II Adi p f 218 A.D. Stuhlweissenburg Pann

Inf..................................... 3344

VERATIUS

M. Aur(elius) Aelia Mog V bf trib I Adiut post 114 Scarbantia

Pann Sup..............................III 15188:4

VERAX

Iulius V 7 leg VI? Date? South Shields Eng........E.E. IX 1139 VERECUNDUS

$\mathrm{Ca}$ (ecilius) V 7 XI Cl p f 4q-Vespas Burnum Dalmatia......... III 9906

L. Campanius L. f. Pol. V vet IIII Scyt Date? Rovigno....... V 8185

T. Flavius V Gl. Savaria 7 XIIII G m v post 100 Carnuntum

Pann Sup.............................. 4416

T. Flavius Verecun(dus) frum II Aug Date? Rome.........VI 3338

Iulius V (eq? III Aug) 222-35 A.D. Castra Lambaesitana

MAH $1897 \mathrm{p} 447$

Iulius V 7 (I Ital) Date? Moes Inf incerta.............III 6232

C. Iulius C. f. Papiria V Trai(anensis) mil (I Min?) c100

Bonn ................................... 1908:63

G. Iul(ius) Vere(cundus) vet? ? Date? Carnuntum Pann

Sup ..................................... 14087

D. Iunius V 7 I Adiut 70-100 A.D. Mainz.............. XIII 6840

P. Ius(tidius?) Verec(u)nd(us) Sarmizegetusa mil (XI)II

Gem post Traian Apulum Dacia...................III 1189

L. Marcius Ae onis f. $\mathbf{V}$ mil I Min $p$ f Date? Zuelpich ........ XIII 7923

G. Mettius C. f. Cam. V Alba 7 X Gem p f Date? Hasta..... V 7553

D. Miscenius V vet XV Apol 1s Carnuntum Pann Sup...... III 14358:ฉ1

Q. Moneius V Narbonensis vet VII Gem fel Date? Tarraco..II 4161

M. Nonius V Syri(a) mil III Aug Date? Lambaesis..........VIII 3207

G. Rauconi(us) G. f. Scaptia V vet ex sig VII $\mathrm{Cl}$ p f Date?

Scupi Moes Sup............................III 8800

Romani(us) V (mil? II Parth?) Date? Rome............. 2410

Seionius Vere(cundus?) 7 I Adiut 70-100 A.D. Mainz...... XIII 6841

C. Terentius V 7 leg XXI ante Hadrian Heliopolis Syria........III 140

L. Valerius C. f. Vol. V Ve- vet XIII G m v 70-100 Mainz... XIII 6912

C. Viselius Verecund(us) vet XI Cl p f Vespas-Traian Vindonissa

JDAI 1913 Beibl p318

Ani. Verecun(dus) domo Vercel(lis) sig et vet XXI Rap

1s? Germ incerta........................XIII 8849 VEREIANUS

Q. Vereius V exactus III Aug p v c£0\& Castra Lambaesitana . . A.E. 1898:109 


\section{VERINUS}

Ael(ius) Verin(us) architectus (leg ?) Date? Mainz.......XIII 6680 P. Aelius V bf cos 213 A.D. Celeia Noricum..............III 5154 Aur(elius) $V$ vet (II Ital) $2-3$ s Celeia Noricum.............III 5218 L. Gratius L. f. Clau. V Cemeneli frum II Aug Date? Rome. VI 3339 Lu(ci)lius L. f. V vet VI Vict Date? Seprium............V 5610 Pompeius V mil II Tr fort Ger post 214 Alexandria Egypt...... III 6609 Sacron(ius) V vet II Ital arm cust 3 s? inter Ivennam et Celeiam

Noricum............................III 5106

Titiconius $\mathbf{V}$ mil leg XXX Date? Lyons..............XIII 1904

C. Verecundinius $V$ vet XXII Pr $p$ f post 89 Lyons ......... XIII 1902 VERISSIMUS

M. Minuc(ius) Verissim(us) $\mathrm{R}$ (atiaria) vet VII Cl 195 A.D.

Viminacium Moes Sup........................II 14507

Ver(atius) V spec I et II Adi $p$ S Sever 228 A.D. Aquincum Pann

Inf.

III 3524

VERNA

Caelius V dup III Aug p v Antonin 218 A.D. Castra Lambaesi-

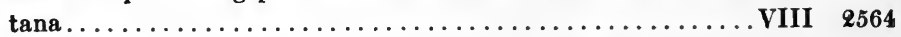

Hortensius $\mathrm{V}$ dup III Aug p $v$ Antonin 218 A.D. Castra Lam-

baesitana............................... 2564

VERNULEUS

C. Avon(ius) V vet XIII Gem post Traian Apulum Dacia......III 1037 VERUS

M. Aebutius $\mathrm{V}$ mil $\operatorname{leg} \mathrm{XV}$ 1s? Milan................ V 5817 Atilius V 7 V Mac post M. Aurel Oescus Moes Inf ........E. 1912:188 Aufidius $V$ eq III Aug Date? Lambaesis............... VIII 3047 Aurelius V mil XI Cl p f 4q-Vespas Pituntium Dalmatia.......III 12815a Aur(elius) V (vet? V Mac?) Date? Potaissa Dacia........III 7688 Au(relius) V (vet) ex eq (V Mac?) Date? Potaissa Dacia....III 7688 (Aurel?)ius V 7 leg - Antonin c215 Ager ad Colapim Pann

Sup ............................... III 10888

L. Caeci(1)ius L. f. Quirina V(e)rus Admedera (mil) I Adiut

Date? Aquincum Pann Inf...................III 13372

L. Cassius V mil I Min Date? Cartenna Mauretania Caesariensis................................ VIII 9654

M. Cingonius V Cirt(a) vet III Aug p v c198 Castra Lambaesi-

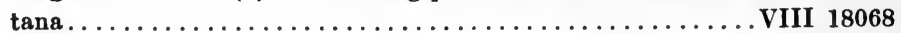

Cominius V mil XIII Gem 1s Tergeste............... 540

C. Cornelius C. f. Pom. Dert(ona) V vet bf $\cos$ II Adiut 2-3s?

Poetovio Pann Sup..........................III 4057

Fabricius V 7 XI Cl p f 42-Vespas Burnum Dalmatia........E. 1903:376

Q. Flaccinius $\mathbf{V}$ frum XXX Ulp vict Date? Rome..........VI 3361

Flavius V dup III Aug p v Antonin 218 A.D. Castra Lambaesitana. VIII 2564

C. Iulius V Ammeder(a) bf cos III Aug c225 Lambaesis.... VIII 2586

C. Iulius V Ammedara bf cos (III Aug) c225? Lambaesis.. VIII 2911

Iunius V 7 III Aug coh I 162 A.D. Castra Lambaesitana...... VIII 18065 
Licinius V 7 (leg XXII aut III Cyr) aet Augusti Coptos Egypt...III 6627

L. Lictavius L. f. An. V Foro Iuli mil IIII Mac ante Vespas Mainz............................... 6868

Q. Manlius Pap. V vet ex sig leg XV 1s? Sarmizegetusa......III 1478

C. Memmius V Cas tess (III Aug) Date? Castra Lambaesitana. VIII 2567

C. Statius V 7 leg XIII ante 84? Scarbantia Pann Sup........III 4246

L. Tanicius L. f. Vol. V Vienna 7 III Cyr 80-1 A.D. Thebes Egypt. . III 34

C. Tauricius V bf cos Date? Germania incerta............ XIII 8841 Ulpius $\mathrm{V}$ vet XXX Ulp vict Date? Lyons..............XIII 1858 Valeri(us) V 7 (leg?) Date? Magnae Eng............. VII $790=738$ L. Val(eri)us L. f. Vo(lt. V)erus $\operatorname{dom}(\mathbf{L u})$ co $\mathrm{Au}(\mathrm{g})$ mil VII Cl

p f 42-70 A.D. Burnum Dalmatia................. III 13251 Vind(ius) $\mathrm{V}$ bf cos II Ital $\mathrm{p} f$ Sever 226 A.D. Bedaium Noricum... III 5575 (L?) Virius L. f. Pob. - ovico V mil XI Cl p f 42-Vespas Bur-

num Dalmatia......................... 15005:1

Volusius V 7 XXII Pr p f 204 A.D. Mainz................XIII 6686

Volus(ius) Ver(us) (7 XXII Pr p f) 204 A.D. Mainz. . . . . . . . .XIII 6801

— V 7 (leg?) Date? Borcovicium Eng.............. VII 686 VESTALIS

C. Iulius V vet (III Aug) Date? Lambaesis............. VIII 3168 VETERANUS

Aurel(ius) V bf lat XIIII Gem Date? Dertona............. 7366 VETTIANUS

T. Fl(avius) V bf leg (III Aug) Date? Lambaesis............. 1913:12 VETTIUS

C. Iulius V Aug Vindelicum frum VIII Aug Date? Rome.....VI 3353 VETULENUS

F1(avius) V 7 III Ital Date? Abusina Raetia.............II 5937 VETUS

Antistius $\mathbf{V}$ vet $(\mathrm{V}$ Mac) c134 Troesmis................ III 6178

L. Blattius L. f. Ro(m). V 7 I(V) Mac Date? Fregose Venetia. .

A.E. $1893: 119$

Septimius V (mil II Parth Sever) c225? Fabrateria.......... 5652 VETUSTIANUS

C. Iulius V Mil(evo) mil? (III Aug) Date? Castra Lambaesitana ................................... 2567 VETUSTINUS

P. Aelius V mil XIII Gem post Traian Apulum Dacia.........III 1186

C. Geminius V Kar vet ex bf trib III Aug p v c198 Castra Lambaesitana ............................ 18068 VIATOR

Aur(elius) V mensor VII Cl Sever 228 A.D. Viminacium Moes Sup III 8112 Aurel(ius) V vet ex librario (III Aug) 270-275 A.D. Lambaesis... VIII 2626 M. Calventius V 7 IIII Fl firm Date? Sarmizegetusa..........III 7904 C. Cusonius V nation Pann mil I Adiut c150 Caesarea Mauretania Caesariensis.......................VIII 9376 
Geminius V dup III Aug p v Antonin 218 A.D. Castra Lambaesi-

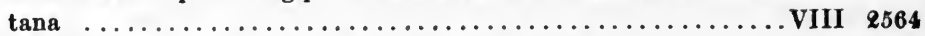

C. Iulius $\mathbf{V}$ arm cust III Aug Date? Lambaesis............ VIII 2925

M. Lucretius V vet (III Aug) Date? Lambaesis............. VIII 3183

Q. Lutatius Q. f. Quir. V Aut(rico) mil III Aug 1s? Theveste A.E. 1897:29

- V 7 leg XVI aet Tiberii Mainz..............XIII 6942

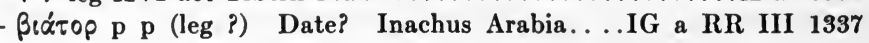
VIATORINUS

Aur(ellus) V (vet? V Mac?) Date? Potaissa Dacia...........III 7688 VIBIANUS

Aur(elius) V vet leg — Date? Aquincum Pann Inf ........III 14348 M. Aurelius V mil? II Adiut $2-3$ s? Aquincum Pann Inf ........ III 10458 Tib. Cl(audius) V 7 frum XIII Gem p post Hadrian Augustopolis

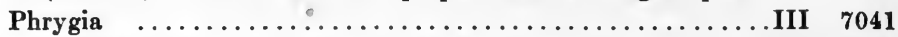

Iul(ius) Vibia(nus) vet (V Mac) Date? Troesmis..........III 6179

- V 7 X Gem ante Traian Aquincum Pann Inf...........III 10517 V optio III Aug \&s exe Kasr-Ghelane............... 1900:127 VIBIUS

Aelius V 7 XX V v Date? Condercum Eng................ VII 503

T. Aurelius T. f. Aelia V Acuinci 7 III Aug p v 3s? Lambaesis. VIII 2826

C. Maccenius $V$ mil X Gem Date? Rome............... VI $\mathbf{2 4 3 7}$

\section{VICANUS}

C. Mellonius V frum VIII Aug p c Commodae aet Commodi Rome VI 3354

Q. Servilius V vet XII Fulm Date? Capua............... $\mathbf{3 8 9 5}$

Q. Varius V Kar imm (III Aug) \&s? Castra Lambaesitana... . . VIII 18087

VICTION

Aur(elius) V 7 ? XIII Gem post Traian Apulum Dacia III 1029:18 = 8065:24

VICTOR

(A)ebutius V (eq? III Aug) 222-35 A.D. Castra Lambaesitana

MAH 1897 p447

Ae(lius) Vict(or) bf VIII Aug Date? Treveri Belgica.........XIII 3645

C. Aelius V ls (III Aug) Date? Castra Lambaesitana...........VIII 2568

L. Aelius Vic(t)or sig III Aug Date? Lambaesis . . . . . . . . . . VIII 18280

P. Aelius $V$ vet (III Aug) Date? Lambaesis............... VIII 3021 Ael(ius) V Trim(ontio) vet VII Cl 195 A.D. Viminacium Moes

Sup $\ldots \ldots \ldots \ldots \ldots \ldots \ldots \ldots \ldots \ldots \ldots \ldots \ldots \ldots \ldots \ldots \ldots \ldots \ldots \ldots \ldots$ III 14507

Aemilius V dup III Aug p v Antonin 218 A.D. Castra Lambaesi-

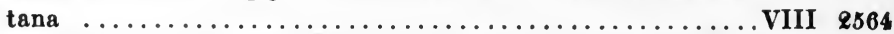

(A)em(llius) V ? (III Aug) 253-268 A.D. Castra Lambaesitana. . VIII 18061

C. Aemilius V vet I Min p \& \&s? Augustodunum prov Lugudun. . XIII 2666

C. Aemilius V vet (III Aug) Date? Lambaesis ............ VIII 3024-§

A. Aemilius V Tac(ape) mil? (III Aug) Date? Castra Lambae-

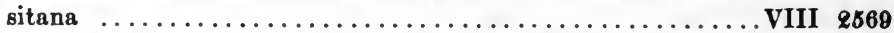

T. Aemilius V Kart quaest III Aug c225 Lambaesis.......... VIII 2586

P. Allienus P. f. V 7 IIII Fl Date? Rome.............. VI 3900 \&

(Anneiu)s Vi(ctor?) bf XX V v Date? prope Thevestem Numidia VIII 2080 
Annlus V arm cust (III Aug) 200 A.D. Castra Lambaesitana.. A.E. 1802:10 Annius $V$ mensor III Aug p v Antonin 218 A.D. Castra Lambae-

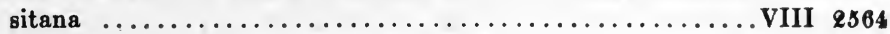
Annius V 7 leg(?) Date? Bewcastle Eng............E.E. III 113 M. Annius V Cas mil? (III Aug) Date? Castra Lambaesitana... VIII 2587 (Ant)istius V Kas eq (III Aug) Date? Castra Lambaesitana... VIII \&565 Antonius V sig (III Aug) Date? Lambaesis.............. VIII 2811 C. Antonius V Thev(este) mil? (III Aug) Date? Castra Lambaesitana ................................ 2567

L. Antonius V Scytopol(1) vet? (III Aug) aet Hadriani Castra

Lambaesitana ............................. VIII 18084

P. Antonlus V mil frum VI Vict Date? Sarmizegetusa.........III 1474

M. Areus Victor? vet (III Aug) $211-2$ A.D. Lambaesis...... . VIII 2618 Arius V arm cust III Aug c\&25 Castra Lambaesitana............ 1902:11 C. $\mathbf{A}(t) \mathbf{i}(1 \mathrm{i})$ us V The(veste) vet? (III Aug) \&s? Castra Lambaesitana .............................. VIII 18087 Auflinius V(ic)tor 7 VII Cl Date? Viminacium Moes Sup.... III 8104 Aufld(ius) V vet ex actar (III Aug) $270-275$ A.D. Lambaesis... VIII 2626 Aurelius V dup III Aug p v Antonin 218 A.D. Castra Lambaesitana. VIII 2564 Aurelius V lib V Mac M. Aurel-274 Potaissa Dacia............ III 909 Aur(elius) V mil II Ital 3s? Celeia Noricum..............III 11700 Aur(elius) V mil I Ital Date? Chersonesus Taurica Moes Inf . . . . III 13751a Aurel(ius) V sig (III Aug) Date? Castra Lambaesitana........ VIII 18073 Aur(elius) Vict(or) (vet? V Mac?) Date? Potaissa Dacia.....III 7688 M. Aurelius V mil III Aug Date? Lambiridi............. VIII 18567 M. Aur(elius) V vet leg I Date? Col Agrippinensium........ XIII 8279 Q. Aurel(ius) V mil III Aug Date? Lambaesis............. VIII 3059 Caecilius V vet (III Aug) 1s? Thamugadi Numidia. Bull Archeol 1911 p124 Caecilius V Hadr(umeto) bf $\cos$ III Aug c225 Lambaesis...... VIII 2586 C. Caecilius V Cas vet III Aug 166 A.D. Castra Lambaesitana ... VIII 18067 C. Calvisius V vet (III Aug) Date? Lambaesis............. VIII 3073

C. Campanius V mil I Min p f Date? Rovenich............ XIII 7939

C. Cantinius V Calam(a) vet III Aug p v c198 Castra Lambaesi$\tan a \ldots \ldots \ldots \ldots \ldots \ldots \ldots \ldots \ldots \ldots \ldots \ldots \ldots \ldots \ldots \ldots \ldots$ VIII 18068

Sex. Carminius V Utic(a) vet III Aug 166 A.D. Castra Lambaesitana ................................. 18067

(C)assius Vi(c)tor bf I Min Date? Novaesium Germ Inf.......XIII 8566 C. Castricius C. Off. V Como mil II Adiut Date? Aquincum

Pann Inf........................... 14849:2

Clodius V exactus III Aug p v c202 Castra Lambaesitana . . . A.E. 1898:109 Clodius Vic(tor) mil III Aug Date? Lambaesis. ............. VIII 3085 Cornelius V dup III Aug p v Antonin 218 A.D. Castra Lambaesi$\tan a \ldots \ldots \ldots \ldots \ldots \ldots \ldots \ldots \ldots \ldots \ldots \ldots \ldots \ldots \ldots \ldots \ldots \ldots \ldots$ VIII 2564 Cornelius V ? (III Aug) 253-268 A.D. Castra Lambaesitana. . . . VIII 18061 Cornel(ius) V tub III Aug Date? Verecunda..............VIII 18513 Cornelius $v$ vet leg XXII Date? Lyons...............XIII 1851 P. Cornelius V Cuicul(o) bf cos III Aug c225 Lambaesis....... VIII 2586

Q. Cornel(ius) V nat Afer vet II Tr Date? Puteoli..........X 1778 
Q. Domitius V Cas str (III Aug) Date? Castra Lambaesitana. VIII 2568 Q. (D)onatius Vic(tor) Col. Utica vet? (III Aug) Date? Castra Lambaesitana .......................... VIII 18086

Elius V mensor (III Aug) 3s? Castra Lambaesitana....... A.E. 1904:72 Etereus V arm cust III Aug ceq5 Castra Lambaesitana...... A.E. 1902:11 C. Fabuleius V vet III Aug 1s? Simitthus.........VIII $10590=14602$ Fl(avius) V 7 I Adiut 173 A.D. Ljubuski Dalmatia........... III 8484 Flavius V tub III Aug $p$ v Antonin 218 A.D. Castra Lambaesitana VIII 2564 Fla(vius) $\mathbf{V}$ mil leg I post 114 Brigetio Pann Sup.............III 10994 Flavius $V$ frum XXX Ulp Date? Rome................VI 3962 T. Flavius V K(arthagine) vet III Aug 166 A.D. Castra Lambaesitana ............................... VIII 18067 Fulvius V dup III Aug p v Antonin 218 A.D. Castra Lambaesitana VIII 2564 Gargilius V dup III Aug p v Antonin 218 A.D. Castra Lambaesitana .................................... 2584

C. Geminius V optio III Aug 253 A.D. Gemellae Numidia.... . . VIII 2482 C. Gentilius V vet XXII Pr $p$ a et Commodi Mainz.........XIII 6677 Glicius V dup III Aug p v Antonin 218 A.D. Castra Lambaesitana VIII 2564 Grunius V (mil? III Aug) c218? Castra Lambaesitana

Bull Archeol 1904 pe06 Iulius V vet ex tess (III Aug) 158 A.D. Casae......... VIII 4330 cf 4332 Iulius $V$ arm cust (III Aug) 200 A.D. Castra Lambaesitana A.E. 1908:10 Iulius V dup III Aug $p$ v Antonin 218 A.D. Castra Lambaesitana. . VIII 2564 Iulius V dup III Aug $p$ v Antonin 218 A.D. Castra Lambaesitana. . VIII 2564 Iulius V dup III Aug p v Antonin 218 A.D. Castra Lambaesitana. . VIII 2564 Iulius V seq dup III Aug p v Antonin 218 A.D. Castra Lambaesi-

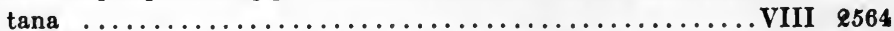

Iulius V arm cust III Aug ce25 Castra Lambaesitana.........E. 1902:11 Iulius $\mathbf{V}$ vet ex librario (III Aug) $270-275$ Lambaesis........... VIII 2626 Iul(ius) Vict(or) 7 VIII Aug Date? Boeckingen...........XIII 6473 (I) uliu(s) V vet (III Aug) Date? Lambaesis.............. VIII 18307 Iulius V ? (III Aug) Date? Castra Lambaesitana............VIII 2562 C. Iul(ius) Ser. Vic(t)or His(pa)li mil X Gem ante 70? Iria Tarraconensis ........................... 2545

C. Iulius V Tha(mugadi) vet III Aug 166 A.D. Castra Lambaesitana ................................ 18067

C. Iulius V Cirt(a) vet III Aug p v c198 Castra Lambaesitana... VIII 18068

C. Iulius Victo(r) Cirt(a) vet III Aug p v c198 Castra Lambaesitana ............................... VIII 18068

C. Iulius V armatura (III Aug) 193-211 A.D. Castra Lambaesi-

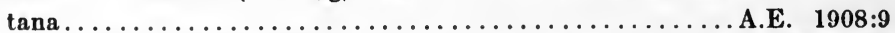

C. Iulius V Cilio dup? (III Aug) Date? Castra Lambaesitana. . VIII 2569

C. Iul(ius) Victo(r) tub III Aug Date? Lambaesis........... VIII 2926

C. Iulius V vet (III Aug) Date? Lambaesis.............. VIII 18306

C. Iulius $V$ vet (III Aug) Date? Lambaesis........VIII $3170=\mathbf{3 1 6 9}$ ?

C. Iulius $V$ mil III Aug Date? Lambaesis......... VIII $3171=3172$

C. Iulius V Utic(a) mil? (III Aug) Date? Castra Lambaesitana VIII 2567 (C? I) ulius V tub III Aug p v 208 A.D. Castra Lambaesitana A.E. 1907:184 
L? (Iu)1(ius) V vet ex sig leg XXX 210 A.D. Vetera Germ Inf... XIII 8654 M. Iulius Vict(or) (mil? III Aug) Date? Castra Lambaesitana

A.E. $1899: \theta 1$

M. Iulius $\mathbf{V}$ mil IIII Fl fel Date? Altinum.............. 2159

Q. Iulius V Thel(epte) b s III Aug c825 Lambaesis ........... VIII 2586

T. Iu(li)us V Am(maedara) vet? (III Aug) \&s? Castra Lambae-

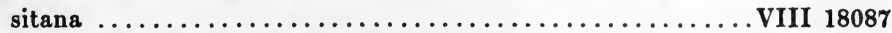

Iunius V 7 VII Gem fel 8 s exe Emporia.................II 6183

C. Iunius V 7 III Aug Date? Mascula Numidia............ VIII 2224

Q. Laelius V ? (III Aug) Date? Castra Lambaesitana......... VIII 2565

Licinius $\mathrm{V}$ dup III Aug $\mathrm{p} v$ Antonin 218 A.D. Castra Lambaesi-

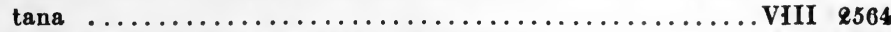

T. Licinius V mil III Aug Date? Lambaesis............... VIII 3178

Lollius V librator III Aug Date? Lambaesis............... VIII 2934

P. Lo(ngeius) V Gisira n can (III Aug) Date? Castra Lambaesitana ................................ 2568

L. L- V vet leg XXII 215 A.D. Castellum Mattiacorum.... XIII 7261 Manilius V arm cust III Aug c225 Castra Lambaesitana....A.E. 1902:11 Q. Manlius V 7 III Aug Date? Lambaesis............... VIII 2650 Marcius V Kar mil? (III Aug) Date? Castra Lambaesitana... VIII 2568 Martius V sig XXX Ulp vict Sever Alexand p 230 A.D. Vetera

Germ Inf........................... 8616

C. Memmius V 7 III Aug cers Lambaesis............... VIII 2586

Minucius V vet (III Aug) Date? Lambaesis..............VIII 3196

Modius V eq (III Aug) Date? Lambaesis............... VIII 8197

C. Modius V (eq? III Aug) \&22-35 A.D. Castra Lambaesitana

Q. Munius V Tuburb(o) mil? (III Aug) Date? Castra Lambae-

MAH $1897 \quad \mathrm{p447}$

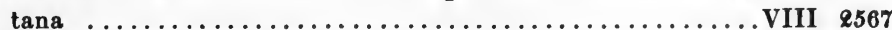

Numerius V dup III Aug p v Antonin 218 A.D. Castra Lambaesitana .................................... 2564

L. Oc(ta)vius Vi(ct)or $7 \mathrm{XV}$ Apol post Traian Ancyra.........III 268

Q. Papirius Vi(ctor?) mil? (III Aug) Date? Castra Lambaesi-

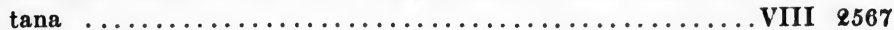

Pescenius $V$ mil III Aug Date? Lambaesis............... VIII $\$ 216$

Q. Pescennius V Tam(ugadi) can (III Aug) Date? Castra

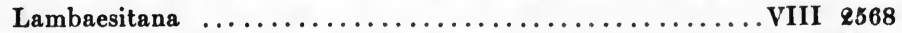

Pettius V mil (III Aug) Date? Lambaesis................ VIII 9219

Pomponius V dup III Aug p v Antonin 218 A.D. Castra Lambaesitana ................................... 2564

M. Pontennius V vet ex marso (III Aug) $211-q$ A.D. Lambaesis. . VIII 2618 Potentinius V optio XXII Pr p f post 89 Mainz...........XIII 6985

L. Propertius V ? (III Aug) Date? Castra Lambaesitana...... VIII 2565

M. Ptolomeus V cor (III Aug) Date? Lambaesis ............ VIII 2965

Sallustius V arm cust (III Aug) 200 A.D. Castra Lambaesitana A.E. 1902:10 Sallustius V dup III Aug p v Antonin 218 A.D. Castra Lambaesi-

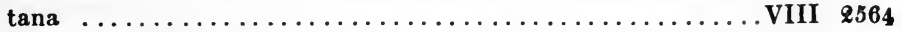

Sal(lustius) V arm cust III Aug ce25 Castra Lambaesitana..A.E. 1902:11 
C. Saltius V Cast vet III Aug p v c198 Castra Lambaesitana . . . VIII 18068

L. Sempro(nlus) V optio (III Aug) 198-211 A.D. Castra Lambae-

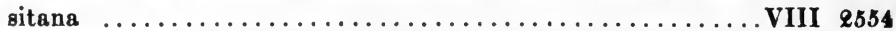

L. Sempronius V Ammed(ara) mil? (III Aug) Date? Castra Lambaesitana...................................... 2568

Sep(timius) V bf cos (leg?) Date? Apulum Dacia............III 1189 C. Septimius V mil III Aug Date? Lambaesis............. VIII 3237-8

C. Sertorius V Kart vet III Aug c198 p v Castra Lambaesitana . . VIII 18068 Servil(lus) V vet ex actario (III Aug) 270-275 A.D. Lambaesis... VIII 2626 Servius V ? (III Aug) Date? Castra Lambaesitana............ VIII e562 L. Sextilius V dup III Aug p v Antonin 218 A.D. Castra Lambae-

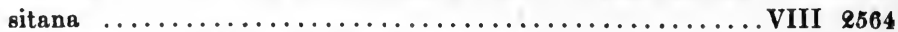

Simplicinius V 7 I Min et III Parth 3s Bonn............. XIII 8065 Sittlus V (eq? III Aug) $2 \& 2-35$ A.D. Castra Lambaesitana MAH 1897 p447 C. Sittius V ? (III Aug) 809-11 A.D. Castra Lambaesitana..... . VIII 2556 Tadius $\mathbf{V}$ vet II Ital $\boldsymbol{\ell}-\mathbf{s} s ?$ Virunum Noricum.............. III 4853 Tannoniue $\mathrm{V}$ arm cust (III Aug) 200 A.D. Castra Lambaesitana

A.E. 1902:10

Marcus Terentius V vet (leg?) Date? Bu Atfan............ VIII 16913 Ulpius V 7 XI Cl aet Antonini Pii Portus Magnus...........VIII 9761 Ulp(ius) $V$ imag leg VII \&-3s? Cyrrhus Syria...............III 195 M. Ulp(ius) V buc XIIII Gem post 100 Brigetio Pann Sup. . . . . . III 11029 Umbrius V dup III Aug p v Antonin 218 A.D. Castra Lambaesi-

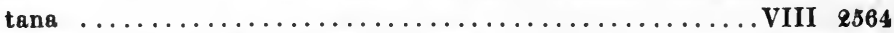

Val(erius) $V$ vet $(V$ Mac) $c 134$ Troesmis................ III 6178

Valerius $\mathrm{V}$ vet ex 1 c (III Aug) $270-275$ A.D. Lambaesis. ....... . VIII 2626

Valer(lus) Vict(or) ? XV Apol Date? Rome............... VI 32908

A. Valerius (V)Ictor yet (III Aug) Date? Verecunda......... VIII 4247

C. Valerius C. f. Galeria V Luguduni sig II Aug Date? Isca Eng. VII 125

Lucius Valerius $V$ mil leg XXII 1s? Mainz..............XIII 6980

L. Valerius V Cas mil? (III Aug) Date? Castra Lambaesitana. . VIII 2568

C. Vatinius V vet (III Aug?) Date? Casae. . . . . . . . . . . . VIII 18539

C. Vatinius V Cas mil? (III Aug) Date? Castra Lambaesitana VIII 2569

C. Vibsanius V Cast vet III Aug p v c198 Castra Lambaesitana. . VIII 18068

M. Volusienius V vet II Adiut Date? Ticinum........Pais Suppl $\mathbf{n} 869$ Oủlx $\tau \omega p 7$ (II Tr?) 120-140 A.D. Fayoum Egypt......... BGU 600 V? (7) V Mac et XI Cl aet Hadriani Palestine..........III 14155:\& tius V Thev(este) (mil? III Aug) ce00 Castra Lambaesi-

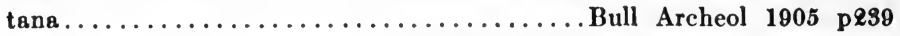
- (?Vi)ctor dup III Aug p v Antonin 218 A.D. Castra Lambaesitana $\ldots \ldots \ldots \ldots \ldots \ldots \ldots \ldots \ldots \ldots \ldots \ldots \ldots \ldots \ldots \ldots \ldots \ldots \ldots$.III 2564 (V)ictor ? (III Aug) 253-268 A.D. Castra Lambaesitana.. VIII 18061 -lius V H(adrumeto) optio (III Aug) Date? Castra Lambaesitana ..................................... 2565 vinius Victo(r) sig (III Aug) Date? Castra Lambaesitana.. VIII 18073 - Ser. V Iad(ere) eq XIII Gem post Traian Apulum Dacia.. III 1200 VICTORIANUS

C. Atilius Liv(lu)s Victoria(nus) vet III Aug Date? Lambaesis VIII 3041 


\section{VICTORINUS}

Abinneus V exactus III Aug p v c202 Castra Lambaesitana A.E. 1898:109 M. Aebutius M. f. Ulp. Papir. Troiana V Poetovio mil X Gem 7 XI Cl 7 XIIII Gem 7 I Min 7 XXII Pr 7 XIII Gem 7 VII

Cl.7 XV (Apol) post Traian Ancyra............... III $260=6761$ Ael(ius) $V$ mil XI Cl 155 A.D. Almus Moes Inf. ............III 7449 P. Aelius V dup I Adi Antonin c215 Intercisa? Pann Inf..A.E. 1909:146 P. Ael(ius) V opt VII Cl p f Philipp 244-49? A.D. Dacia incerta. .III 8047 P. Aelius V ? (III Aug) Date? Castra Lambaesitana.......... VIII 2562 T. Aelius V Siscia bf $\cos$ III Aug c225 Lambaesis.... . . . . . . . . VIII 2586

P. Ancharius $V$ vet (III Aug) Date? Lambaesis............ VIII 2804 Aurelius V mil II Parth p f a atern c225 Rome.............. VI 3404 A(u)rel(ius) V mil XXII Prim 226 A.D. Tilena Germ Sup...... XIII 5621 Aur(elius) V 7 II Adiut 2-3s? Ager Aquincensis Pann Inf ...... III 10360 Aur(elius) V natione Dacisca regione Sardic(a) mil in leg?

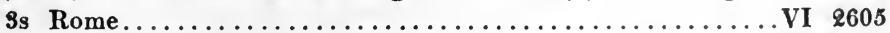

Aur(elius) V (vet) ex eq (V Mac?) Date? Potaissa Dacia.......III 7688 Aurel(ius) V mil III Ital Date? Castra Regina Raetia.........III 11966 C. Caecilius Victorin(us) Cas peq (III Aug) Date? Castra Lambaesitana ............................ VIII 2569

Q? Caecillus V vet ex librario? (III Aug) 270-275 A.D. Lam-

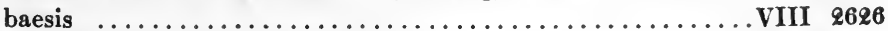

Vib. Cassius V bf $\cos$ II Ital p f Antonin 215 A.D. Celeia Noricum III 5185 P. Cornelius $V$ mil III Aug Date? Lambaesis.............. VIII 3092 T. Devillius T. fil. Aurelia V imm arm cust XXII Pr p f 205 A.D. Mainz .............................XIII 6710

T. Flavius V Damasc(o) vet? (III Aug) aet Hadriani Castra

Lambaesitana ..............................VIII 18084

T. F1(avius) V 7 XXX Ulp vict Date? Col Agrippinensium XIII 8219 et 8233 Herennius $V$ disc eqq III Aug Date? Lambaesis........... VIII 2882 Herennius V vet leg XXII — Date? Castellum Mattiacorum XIII 7290 Iul(ius) Victorin(us) dup (XIIII Gem?) ante 178 Carnuntum Pann

Sup ................................. 11180

Iulius $V$ arm cust III Aug c225 Castra Lambaesitana..........E. 1902:11 Iulius V (eq? III Aug) 22\&-35 A.D. Castra Lambaesitana MAH 1897 p447 I(ulius) V 7 (leg?) Date? Papcastle Eng.................. III 95 Iul(ius) $V$ bf cos Date? Campona Pann Inf................III 3397 C. Iul(ius) V R(emesiana?) vet VII Cl 195 A.D. Viminacium Moes Sup .................................. 14507

M. Iulius V 7 IIII Fl Date? Aquincum Pann Inf........... III 3555

Li(cinius) $V$ mil leg II Date? Bosna Dalmatia..............II 12764 L. Privat(i)us V Trai(a)n(opoli) 7? III Aug Date? Lambaesis. VIII 2964 Severinius $V$ vet ex sig VIII Aug Antonin c215 Lauterburg Germ Sup ............................... 6076

Sittius V arm cust III Aug c225 Castra Lambaesitana......A.E. 1902:11 L. Titennius L. f. Lemonia V. Bono(nia) mil XI Cl p f Vespas-

Traian Vindonissa........................ 5213 P. Titi(us) V corn II Adiut 2 -3s? Brigetio Pann Sup......... III 10987 
Val(erius) V spec legg III Antonin ( = X Gem XIV Gem I Ad) ce12 Carnuntum Pann Sup...................... 4452

Val(erius) V optio X Gem Date? Carnuntum Pann Sup.........III 4419

(Valerius) Victo(rin)us mil (VII) Cl Date? Horreum Margi

Moes Sup............................III 12667

C. Val(erius) V vet ex bf trib V Mac Date? Drobeta Dacia.....III 1584

Q. Val(erius?) Vic(to)rinus mil (leg?) Date? Lincoln Eng....E.E. IX 1112

Sex. Vettius V Cast vet III Aug p v c198 Castra Lambaesitana. . VIII 18068

C. Vitalinius $\mathbf{V}$ mil leg XXII Date? Genava.............. XII 5878

T. Voccius V arm cust (XIIII Gem?) 188 A.D. Carnuntum Pann

Sup $\ldots \ldots \ldots \ldots \ldots \ldots \ldots \ldots \ldots \ldots \ldots \ldots \ldots \ldots \ldots \ldots \ldots \ldots \ldots \ldots$.E. $1905: 287$

-li(us) V 7 VI Vict p f D(omitianae) aet Domitiani Bürgel

Germ Inf............................ 8538

V 7 (leg?) Date? Greatchesters Eng. .............E. VII 1051

(Vi)ctorin(us) mil dup I Min Date? Bonn...........XIII 8078

- V \& XIII Gem post Traian Apulum Dacia............ III 1058

VICTORIUS

Camer(ius) V vet ex actar (III Aug) $270-275$ A.D. Lambaesis... VIII 2626

M. Manilius V Uti(ca) vet? (III Aug) Date? Castra Lambae-

$\operatorname{tana} . \ldots \ldots \ldots \ldots \ldots \ldots \ldots \ldots \ldots \ldots \ldots \ldots$. . . . . . . . . 18086

Pom - V vet ex dup XIII Gem post Traian Apulum Dacia.. III 1067

VINCENTIUS

Aurelius $\mathrm{V}$ mil in leg $\mathrm{XI} \mathrm{Cl}$ ss exe-4s init Caesarea Mauretania

Caesariensis ................................ 21021

Aurelius V ex praepositis X Gem Date? Canossa............XI 1016

Cornelius V arm cust III Aug c225 Castra Lambaesitana.... A.E. 1902:11

\section{VINDEX}

Aur(elius) $\mathrm{V}$ mil XI Cl 155 A.D. Almus Moes Inf............III 7449

Aur(elius) $V$ mil VII Cl Date? Cyrrhus Syria............... III 194

Aur(elius) V dup II Adiut Date? Aquincum Pann Inf.........III 3458

T. Domit(ius) V 7 XX(X?) V v Date? Roermond Germ Inf ....XIII 8707

Sex. Donnius V 7 X Gem p f D(omitianae) aet Domitiani Brohl. XIII 7717

M. Valerius Sp. f. (V)index mil leg XII Date? Brixia.........V 4377

Vibi(us) Vind(ex?) ? (III Aug) 253-268 A.D. Castra Lambaesitana VIII 18061

- V 7 XI Cl f aet Traiani Carnuntum Pann Sup...........III 11239

V bf cos Date? Apulum Dacia...................II 1059

\section{VINDILUS}

Aelius $V$ mil III Aug Date? Lambaesis................ VIII 2783

VINITOR

Sempronius V dup III Aug p v Antonin 218 A.D. Castra Lambae-

sitana

VIII 2564

\section{VIOLANUS}

Ulp(ius) V spec legg III Antonin (=X Gem XIV Gem I Ad)

c212 Carnuntum Pann Sup..................... 4452 


\section{VIRIANUS}

Aurel(ius) V spec legg III Antonin ( $=$ X Gem XIV Gem I Ad)

ce1e Carnuntum Pann Sup....................III 445\&

VIRILIO

Q. Valerius Q. f. Ofe. V Me(diolani) mil XXII Prim 1s? Mainz XIII 6975

C. Vibius C. f. Volt. V eq leg XV ante Vespas Worms Germ Sup. . XIII 6241

\section{VIRILIS}

T. Fl(avius) V 7 II Aug 7 XX V v 7 VI Vict 7 III Aug 7 III Parth

Sever 3s Lambaesis......................... VIII 2877

Iulius V Thubur(bo) sig (III Aug) Date? Castra Lambaesitana VIII 2568

\section{VITALES}

(Ti)b(erius) V vet ex $-\mathrm{V}$ Mac ante M. Aurel? Troesmis....III 7506

\section{VITALIANUS}

L. Firm(i)us V mil leg VII Date? Rome................ VI 3593

\section{VITALIS}

Ael(ius) Vi(talis?) vet (XIIII Gem?) Antonin c215 Carnuntum

Pann Sup ..............................III 14358:13

C. Aelius V Cas str (III Aug) Date? Castra Lambaesitana.....VIII 2567

M. Ael(ius) V Kast vet VII Cl 195 A.D. Viminacium Moes Sup..III 14507

P. Ael(lus) V C(astris) eq polio vet VII Cl 195 A.D. Viminacium

Moes Sup..............................III 14507

P. Ael(ius) V R(atiaria) vet VII Cl 195 A.D. Viminacium Moes Sup III 14507

P. (A)elius $V$ aquil III Aug Date? Lambaesis.............VIII 2794

T. Aelius V Cas mil? (III Aug) Date? Castra Lambaesitana.. VIII 2567

Alba(ni) us V(ita?)lis 7 XXX Ulp vict Date? Ulpia Noviomagus XIII 8730

Ananius Vit(alis) ? III (Aug) Date? Lambaesis.............VIII 18282 Ancari(us) V arm cust (III Aug) 800 A.D. Castra Lambaesitana

A.E. 1902:10

L. Annius V (spec VII Gem fel) Date? Tarraco.............II 4143

M. Antonius V K(arthagine) vet III Aug 166 A.D. Castra Lam-

baesitana ................................. VIII 18067

C. Aponius V exactus III Aug p v ce0\& Castra Lambaesitana A.E. 1898:109

C. Aponius V Tipas(a) exactus (III Aug) Date? Castra Lam-

baesitana ..................................... 2567

Arrius V dup III Aug p v Antonin 218 A.D. Castra Lambaesitana. . VIII 2564

Aur(elius) $V$ vet ex mensore tritici leg VII 48-70 A.D. Viminacium

Moes Sup..............................E. 1907:41

Aur(elius) V mil IIII Fl c\&13? Noviomagus Germ Sup........XIII 6104 Aurel(ius) V (mil? III Aug) c\&18? Castra Lambaesitana

Bull Archeol 1904 p 206

Aurelius V 7 IIII Fl Date? Eporedia................. V 6782 Aur(elius) V 7 V Mac Date? Salonae Dalmatia.............III 2046 Aur(elius Vital(is) (vet? V Mac?) Date? Potaissa Dacia..... III 7688 L. Barbius V mil (leg?) Date? Carnuntum Pann Sup....... III 4400 Q. Caelius V mil (III Aug) Date? Lambaesis.............VIII 3069 L. Celerin(i) us V corn VIIII Hisp ante Vespas? York Eng...E.E. VII 928 
Ti. Claudius Ti. f. (C)a(1) V 7 V Mac I Ital I Min XX V v IX Hisp VII $\mathrm{Cl} p \mathrm{f}$ aet Domitiani Rome................. VI 3584

T1. Claudius V domo Interammi Praetuttis p p (III Aug)

Date? Castra Lambaesitana............cf CIL IX 5068 A. E. 1904:70

Comodius V bf trib (III Aug) Date? Lambaesis........... VIII 2846-7

L. Cornelius V ? (III Aug) Date? Castra Lambaesitana........ VIII 2562

Q. Cornelius V Cas eq (III Aug) Date? Castra Lambaesitana.. VIII 2567

L. Ecimius Bellicianus V vet XX V v Date? Chester Eng. .....E.E. VII 893

T. Fl(avius) V Ael(ia) Aug(usta) mil bf cos XXII Pr p \& 186 A.D.

Iagesthausen............................... XIII 6558

Fla(vius) V 7 ? XIII Gem post Traian Apulum Dacia........III 8065:27

G. Gabinius V bf trib lat III Aug p v 198 A.D. Castra Lambaesi-

tana ......................................... 2551

Iulius $V$ natione Belga fabriciesis XX V v post 43 Bath Eng...... VII 49

Iul(ius) $V$ arm cust (III Aug) 200 A.D. Castra Lambaesitana A.E. 1902:10

Iulius V arm cust III Aug c225 Castra Lambaesitana. . . . . . . A.E. 1902:11

Iulius V vet (III Aug) Date? Lambaesis. ................ VIII 18308

Iulius V (vet?) XXII (Pr) p \& Date? Ambarri prov Lugudun.... XIII 2526

Iul(ius) $V$ vet leg XXX Date? Vetera Germ Inf...........XIII 8622

Iul(ius) Vitalis? 7 (leg?) coh IIII Date? Stanwix Eng........VII 918

C. Iulius V Thev(este) vet III Aug p v c198 Castra Lambaesitana VIII 18068

M. Iul(ius) V optio hastati I Adiut post 114 Brigetio Pann Sup....III 4328

M. (I) ulius V bf cos Date? Neviodunum Pann Sup..........III 3927

Sex. Iul(ius) $\cdot V 7$ leg? Date? Aquincum Pann Inf............III 10526

Q. Lartidius V Am(maedara) bf leg leg III Aug 166 A.D. Castra

Lambaesitana .................................. III 18067

Liberalinius V eq I Min Date? Bonn...............XIII 8070

L(icinius) V str leg leg XIIII Gem Sever c225 Carnuntum Pann

Sup $\ldots \ldots \ldots \ldots \ldots \ldots \ldots \ldots \ldots \ldots \ldots \ldots \ldots \ldots \ldots \ldots$ III 11108

M. Massonius V bf $\cos 218$ A.D. Nettersheim............E. 1911:155

L. Mummius V Cas mil? (III Aug) Date? Castra Lambaesi-

tana ................................. VIII 2568

C. Octavius C. f. Fabia V domo Brixiae vet VII $\mathrm{Cl}$ p f 4q-70

A.D. Aequum Dalmatia..........................III 14946

Passenius Vital(is) arm cust III Aug c225 Castra Lambaesitana

A.E. 1902:11

L. Plotius V exactus III Aug p v c\&0\& Castra Lambaesitana . . . A.E. 1898:109

C. Pomponius V Ammed(ara) vet III Aug p v c198 Castra Lam-

baesitana ................................. VIII 18068

Sattonius V lib (XXII Pr p f?) 250-1 A.D. Tilena Germ Sup....XIII 5622

Sextilius $\mathrm{V}$ vet (III Aug) $270-275$ A.D. Lambaesis........... VIII 2626

Tertinius V mil XXX Ulp vict 232 A.D. Vetera Germ Inf ...... XIII 8619

C. (T)illius M. f. Pol. Vital(is) Ast vet (leg?) bf trib lat Date?

Hasta .................................. 75

M. Trebi(us) Vitali(s) bf cos Date? Mursella Pann Sup...... III 10957

Ulp(ius) V 7 III Ital Date? Apulum Dacia................III 7785

M. Ulp(ius) V bf cos X Gem Date? Domavianum Dalmatia.... III 14219

C. Valerius V ? (III Aug) Date? Castra Lambaesitana.........VIII 2562 
Q. Varius V bf $\cos 191$ A.D. Thornborough Eng............. VII 271

C. Velcacius V Sim(Ithu) corn (III Aug) Date? Castra Lambaesitana ................................ VIII 2568

Vettius Vita(lis) mil II Ital \&-3s Inter Iuva vum et Ovilava Noricum III 5614

Veturius V Lamb bf cos III Aug ce25 Lambaesis............. VIII 2586 Blaera V 7 III Aug Date? Rome................ VI 3645 nq $V$ vet $(\mathrm{V}$ Mac) Date? Troesmis............... III 6179 merasius L. f. d Ticin(o) Vital(is) (mil) IIII Fl fel Date?

Pann Sup incerta............................III 4593 VI(t)ali(s) mil I Min Date? Bonn............. XIII 8073 VITEALIS

C. Severinius V vet ex bf $\cos \mathrm{XXX}$ Ulp vict Date? Col Agrippinensium .............................. 82893 VITHANNUS

T. Flavius V vet XXX Ulp vict Date? Lyons............. XIII 1858 VITULLUS

Victorinius V civis Sumelocennesis vet leg VIII 2-3s Ambarri prov Lugudun ............................. 2506 VITULUS

Iul(ius) Vitul(us) vet (V Mac) c134 Troesmis III 6178

Q? Voconius V (7) XXII Pr pf 2s exe-3s init Frauenstein Germ Sup $\ldots \ldots \ldots \ldots \ldots \ldots \ldots \ldots \ldots \ldots \ldots \ldots \ldots \ldots \ldots \ldots \ldots \ldots \ldots$ XIII 7608 VOCCO

P. Ael(ius) V mil XXII Pr p f post 89 Sumelocenna Germ Sup .... XIII 6362 VOLUSIUS

Sfi? V (vet? V Mac?) Date? Potaissa Dacia..............III 7688 VULTILIANUS

L. Lartidius V dup leg Date? Carnuntum Pann Sup.... III 11226 ZENON

Cla(u)dius Z mil III Cyr ante 108 Egypt........... Wessely Lat Pal 8 ZENOPHILUS

(C) Iu(lius) $Z$ mil III Cyr Date? Gerasa Syria............III 13603 ZENOSTRATUS

Septimius Z mil II Parth Sever p f Aeternae post 193 Apamea

Syria .III 187 add 
0 


CS

2351

D43

\section{Dean, Lindley Richard \\ A study of the cognom of soldiers in the Roman legions}

PLEASE DO NOT REMOVE CARDS OR SLIPS FROM THIS POCKET

UNIVERSITY OF TORONTO LIBRARY 
